UNIVERSIDADE DE SÃO PAULO

INSTITUTO DE GEOCIÊNCIAS

\title{
Avaliação da aplicação de consolidantes no Arenito Itararé, constituinte da fachada do Teatro Municipal de São Paulo
}

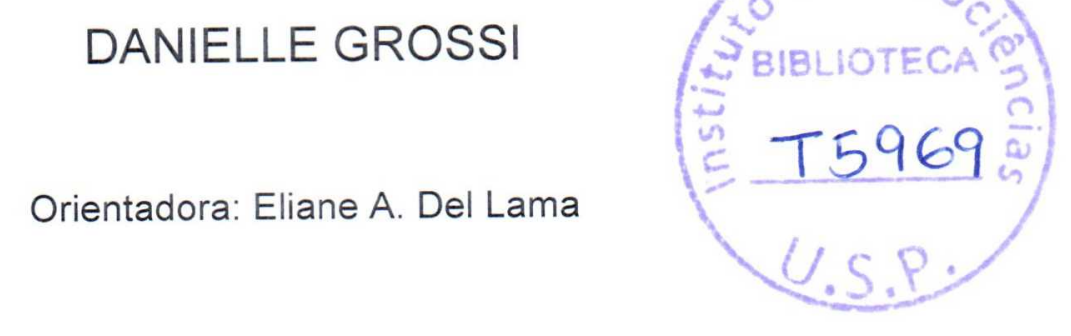

TESE DE DOUTORAMENTO

Programa de Pós-Graduação em Geociências (Mineralogia e Petrologia)

IGc-Instituto de Geociências

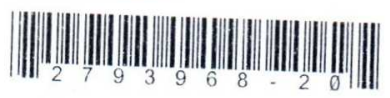

Avaliação da aplicação de consolidantes no arenito Itara constituinte da fachada do Teatro $M$ T5969 
Avaliação da aplicação de consolidantes no Arenito Itararé, constituinte da fachada do Teatro Municipal de São Paulo

Tese apresentada ao Instituto de Geociências da Universidade de São Paulo para obtenção do título de Doutora em Ciências

Área de concentração: Mineralogia e Petrologia

Orientadora: Profa. Dra. Eliane A. Del Lama 
Autorizo a reprodução e divulgação total ou parcial deste trabalho, por qualquer meio convencional ou eletrônico, para fins de estudo e pesquisa, desde que citada a fonte.

Ficha catalográfica preparada pelo Serviço de Biblioteca e Documentação do Instituto de Geociências da Universidade de São Paulo

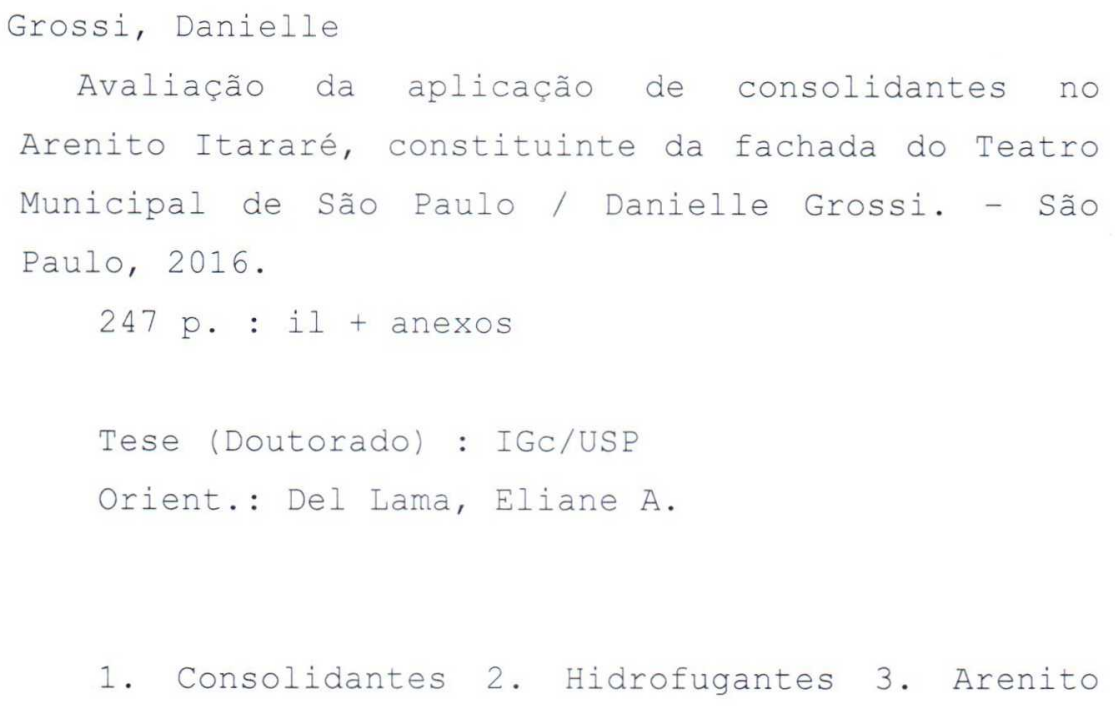




\section{Agradecimentos}

À FAPESP pelo apoio financeiro a esta pesquisa (2012/24067-4 e 2015/108588).

Ao Leandro Moraes do Instituto de Geociências pelo enorme auxílio na realização do projeto da máquina de saturação e secagem.

Ao NAP (Núcleo de Apoio à Pesquisa) Geohereditas - Patrimônio Geológico e Geoturismo pelo apoio logístico.

Ao Alexander Gimenez da Silveira pelo auxílio para cortar as amostras.

Ao Marcelo Afonso pelo auxílio em coletar amostras, na ajuda com a autorização do ICMBio e com informações sobre a Floresta Nacional de Ipanema.

Ao Prof. Dr. George W. Scherer pela imensa atenção ao me receber na Universidade de Princeton e no auxílio com os procedimentos lá realizados.

A Universidade de Princeton pela oportunidade de estar em um dos maiores centros tecnológicos do mundo para realização de parte dos testes aqui apresentados.

À Lucia Shibata pelo auxílio com a língua inglesa e com as traduções.

Às empresas Quantiq (importadora da Wacker), Evonik, Bellizoni e $\mathrm{NanoBr}$ pelo fornecimento de amostras de produtos químicos para tratamento das rochas.

À Sandra Andrade do Laboratório de Química do Instituto de Geociências da Universidade de São Paulo pelo auxilio e disponibilização das dependências e equipamento do laboratório e, também, a toda a sua equipe.

À Zelaine Callegaro, proprietária da antiga pedreira na Fazenda da Laje, localizada no município de São Miguel das Missões, pelo acesso às amostras de arenito.

Ao Sr. Ângelo da antiga pedreira de Arenito Itararé, nas cercanias da FLONA de Ipanema pela disponibilidade em nos permitir a coleta de amostras.

Ao Eduardo Brandau Quitete e Fábio Conrado de Queiroz do IPT pelo auxílio com o corte de amostras.

À Mariolis Della Torre pela doação da polpa e celulose.

Ao Roberto Carlos do CETEM-RJ pela disponibilização da câmara de intemperismo artificial de $\mathrm{SO}_{2}$.

À Luana do CETEM- RJ, por ajudar com os testes.

E, principalmente, à minha orientadora, Eliane Del Lama, pelo auxílio, direcionamento e conselhos. 
Tese de Doutorado - Danielle Grossi - 2016 


\section{Lista de abreviações}

$A G$ - Antigraffiti - Evonik

ABNT - Associação Brasileira de Normas Técnicas

$\mathrm{CaOH}$ - Hidróxido de cálcio

CNRC - Centro Nacional de Referência Cultural

CONDEPHAAT - Conselho de Defesa do Patrimônio Histórico, Arqueológico, Artístico e Turístico do Estado de São Paulo

CONPRESP - Conselho Municipal de Preservação do Patrimônio Histórico, Cultural e Ambiental da Cidade de São Paulo

A - Pré-tratamento consecutivo com $\mathrm{A} 2 \rightarrow \mathrm{A} 3 \rightarrow \mathrm{A} 6$

A2 - Etilenodiamina anidro

A3 - 1,3 diaminopropano

A6 - 1,6 diaminohexano

$A P$ - Pré-tratamento com A e tratamento com $P$

ATC - Pré-tratamento com A e tratamento com TC

ATW - Pré-tratamento com A e tratamento com TW

A630 - Pré-tratamento com A e tratamento com 630

BEPE - Bolsa Estágio e Pesquisa no Exterior

DIN - Deutsches Institut fur Normung

DPH - Departamento de Patrimônio Histórico

DPHAN - Departamento do Patrimônio Histórico e Artístico Nacional

$D R X$ - Difratometria de raios $X$

EDS - Espectroscopia de raios $X$ de energia dispersiva

EMBRATUR - Instituto Brasileiro de Turismo

FAPESP - Fundação de Amparo a Pesquisa no Estado de São Paulo

FRX - Fluorescência de Raios $X$

GeoHereditas - Núcleo de Apoio à Pesquisa em Patrimônio Geológico e Geoturismo

ICOM - Conselho Internacional de Museus (International Council of Museums)

ICOMOS - Conselho Internacional de Monumentos e Sítios (International Council of Monuments and Sites)

IGEPAC - SP - Inventário Geral do Patrimônio Ambiental e Cultural Urbano do Estado de São Paulo

IPHAN - Instituto do Patrimônio Histórico e Artístico Nacional

IPT - Instituto de Pesquisas Tecnológicas

MEK - Metiletilcetona 
MTEOS - Metiltrietoxisilano

MEV - Microscópio Eletrônico de Varredura

OEA - Organização dos Estados Americanos

ONU - Organização das Nações Unidas

P - Fosfato de amônio dibásico

$\mathrm{PCH}$ - Programa de Reconstrução das Cidades Históricas

POLI - Escola Politécnica

PVA - Acetato de polivinila

SEPLAN - Secretaria do Planejamento

SPHAN - Serviço de Patrimônio Histórico e Artístico Nacional

TC - Conservare ${ }^{\circledR} \mathrm{OH} 100-$ ProSoCo

TEOS - Ortossilicato de tetraetila

TW - Silres ${ }^{\circledR}$ BS OH 100 - Wacker

UNESCO - Organização das Nações Unidas para a Educação, a Ciência e a Cultura

VOC - Compostos orgânicos voláteis

630 - Protectosil ${ }^{\circledR}$ WS 630 - Evonik

808 - Protectosil ${ }^{\circledR} 808$ - Evonik 


\section{Sumário}

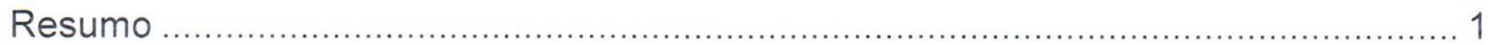

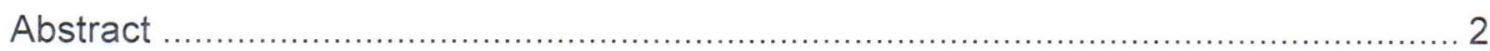

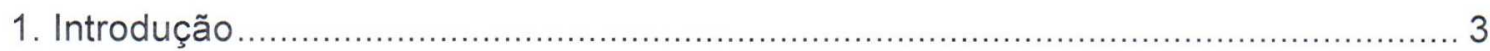

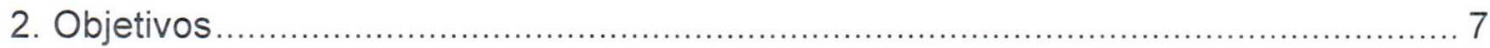

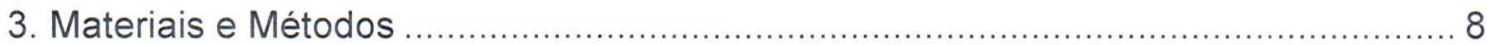

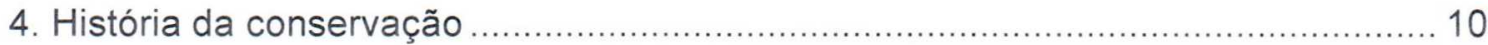

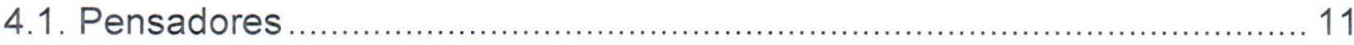

4.1.1. Viollet-le-Duc.................................................................. 12

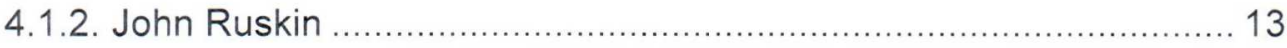

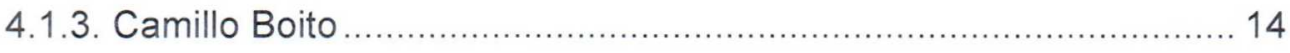

4.1.4. Alois Riegl ....................................................................... 15

4.1.5. Max Dvořák ........................................................................... 15

4.1.6. Cesare Brandi ....................................................................... 16

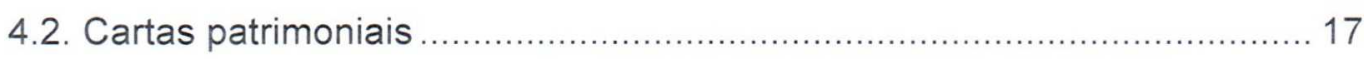

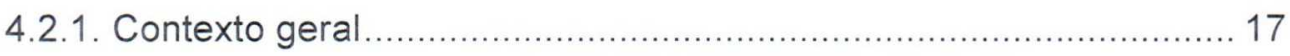

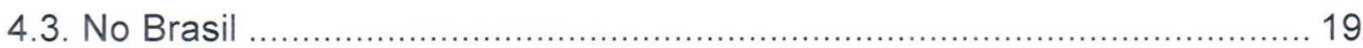

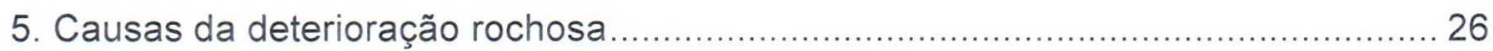

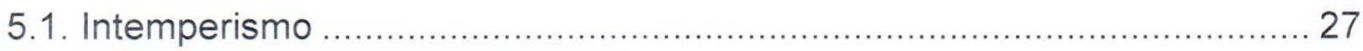

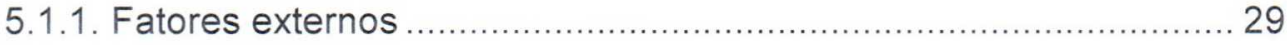

5.1.2. Fatores intrínsecos ............................................................... 38

6. Objeto de estudo: Teatro Municipal de São Paulo .............................................. 42

6.1. Rochas utilizadas no Teatro Municipal de São Paulo ............................ 44

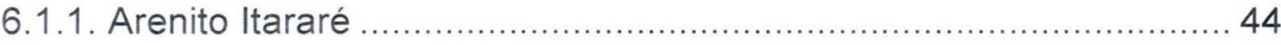

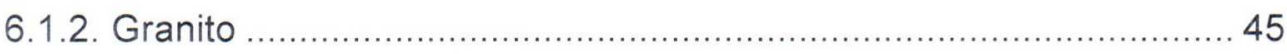

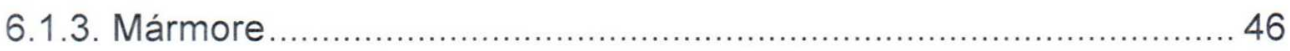

6.1.4. Outros Materiais .................................................................... 47

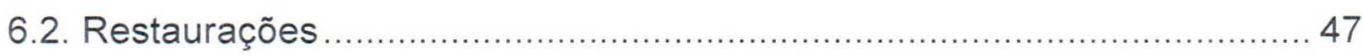

6.2.1. $1^{a}$ Restauração: 1952-1955 ................................................. 47

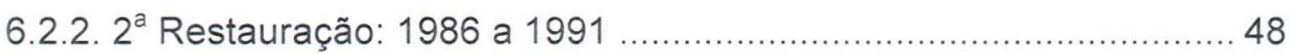

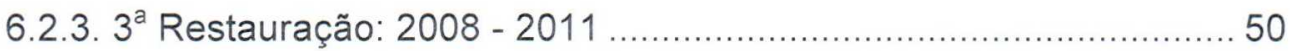

6.3. Outros prédios construídos em arenito ............................................ 53

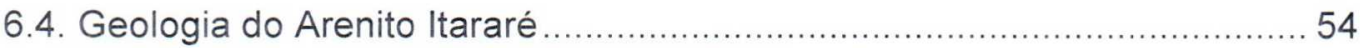

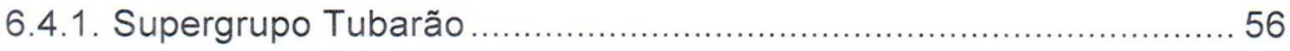

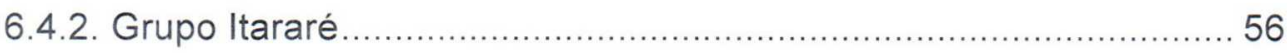

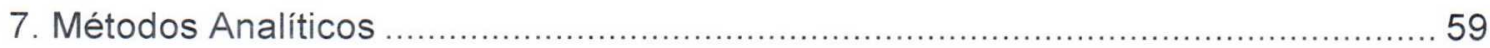




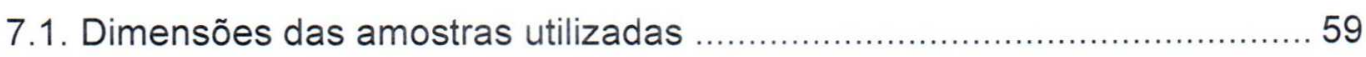

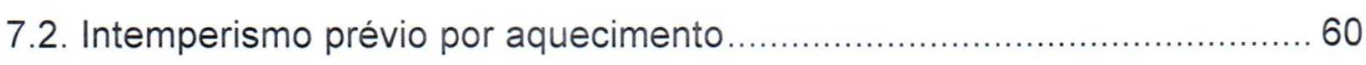

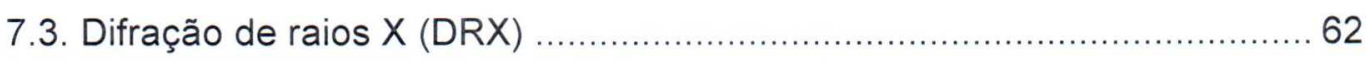

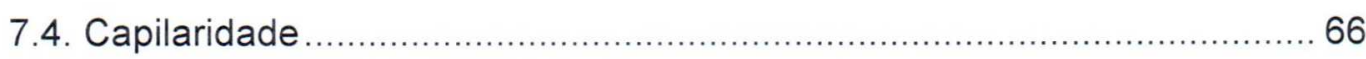

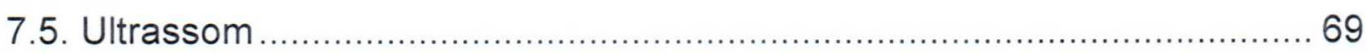

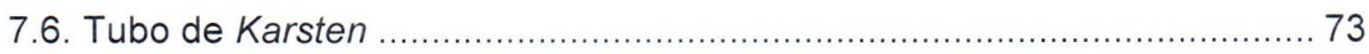

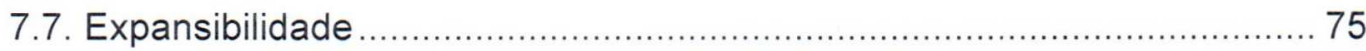

7.8. Microscópio Eletrônico de Varredura (MEV) ....................................... 76

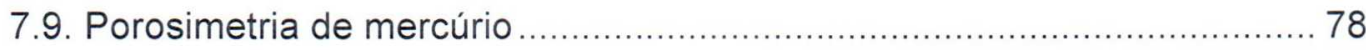

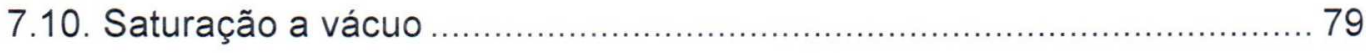

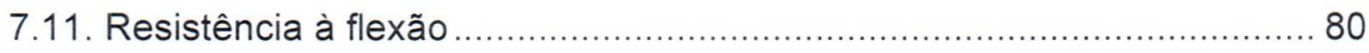

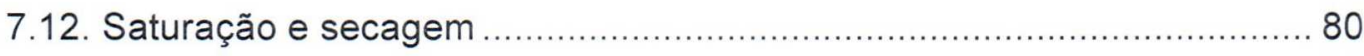

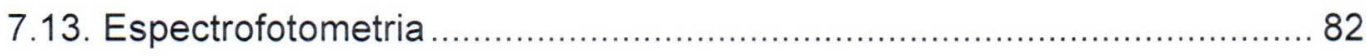

7.14. Profundidade de Penetração ........................................................ 83

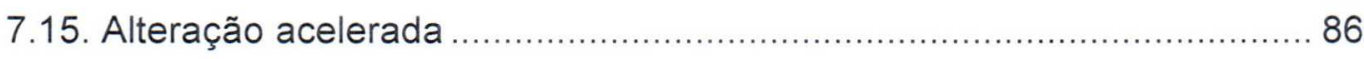

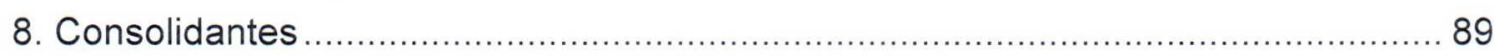

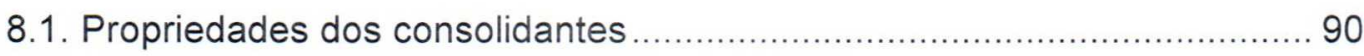

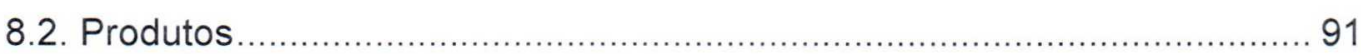

8.2.1. Consolidantes orgânicos ...................................................... 91

8.2.2. Consolidantes inorgânicos .................................................. 96

8.3. Fatores que influenciam a ação dos produtos ...................................... 98

8.4. Modificações após aplicação do produto ................................................. 99

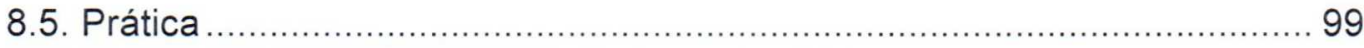

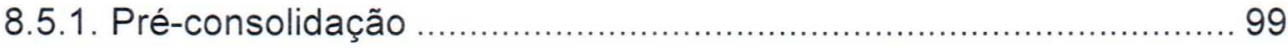

8.5.2. Técnicas de aplicação ......................................................... 100

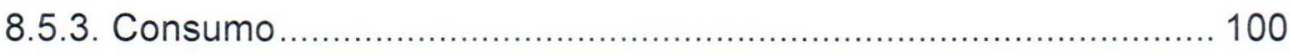

8.5.4. Agenda de aplicação …...................................................... 102

8.6. Métodos de avaliação da consolidação ............................................. 102

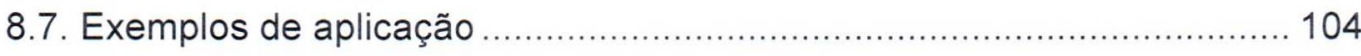

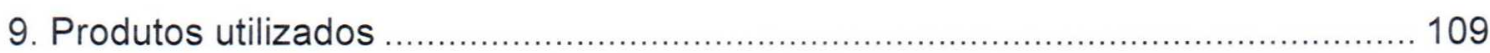

9.1. Universidade de Princeton .............................................................. 109

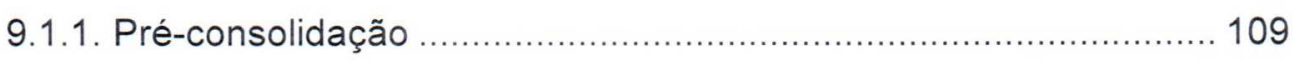

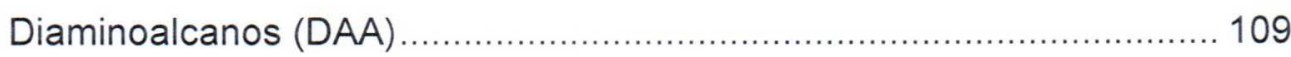

Etilenodiamina anidro (A2) ........................................................ 110

1,3 diaminopropano 99\% (A3) .................................................... 111

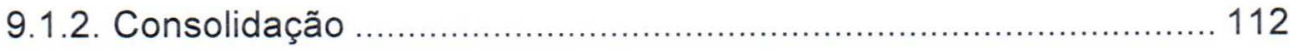

Fosfato de amônio dibásico (DAP) ............................................ 112 


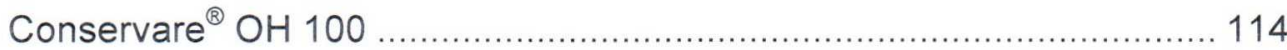

9.2. Produtos utilizados no Brasil.............................................................. 115

9.2.1. Pré-consolidantes ........................................................ 116

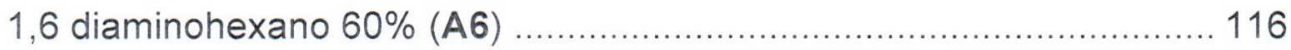

9.2.2. Protetor de superfície/ hidrofugantes ..................................... 117

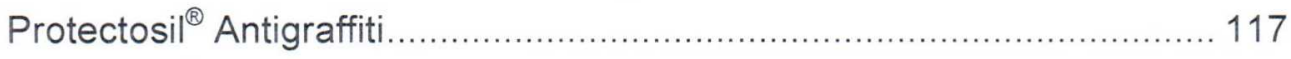

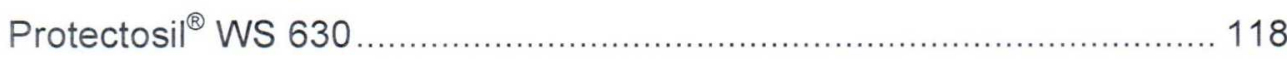

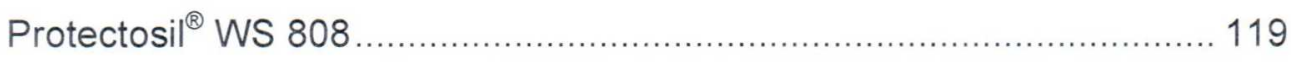

9.2.3. Consolidantes ........................................................................ 120

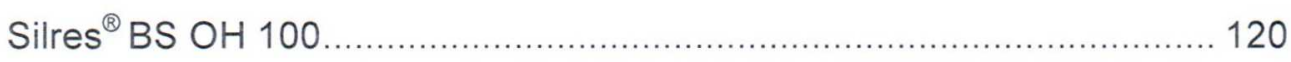

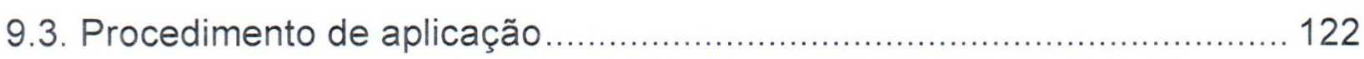

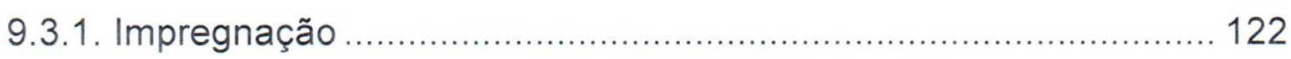

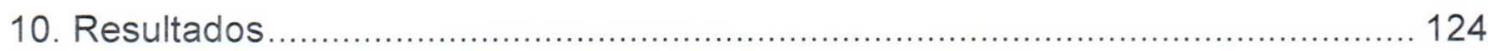

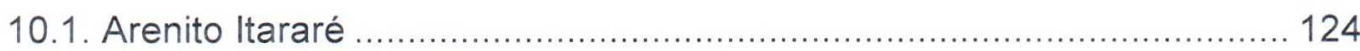

10.1.1. Mineralogia do Arenito Itararé ................................................ 124

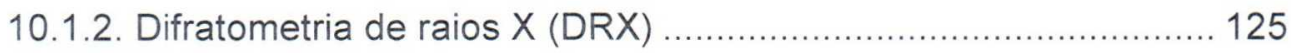

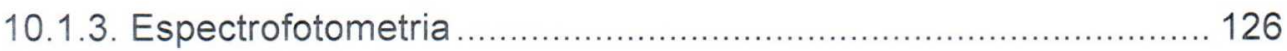

10.1.4. Intemperismo prévio por aquecimento ................................ 131

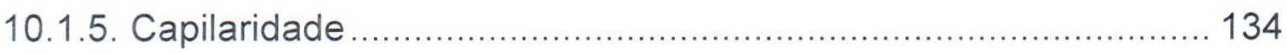

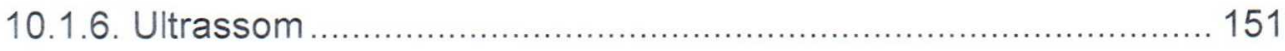

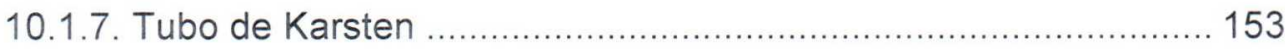

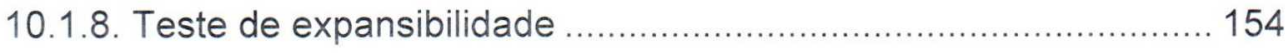

10.1.9. Microscopia Eletrônica de Varredura (MEV) ............................... 154

10.1.10. Porosimetria de mercúrio ................................................... 174

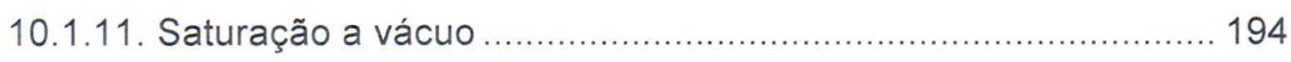

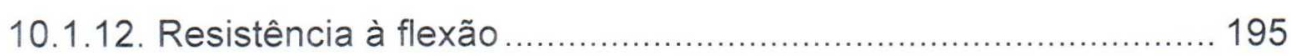

10.1.13. Ciclos de saturação e secagem ............................................ 195

10.1.14. Profundidade de Penetração .................................................. 203

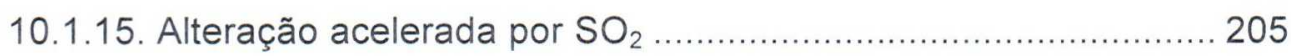

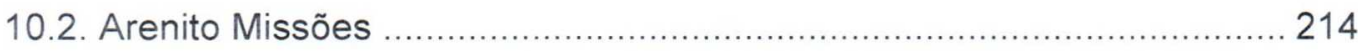

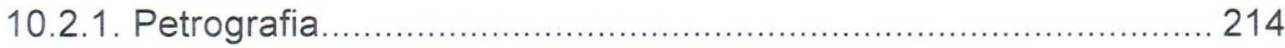

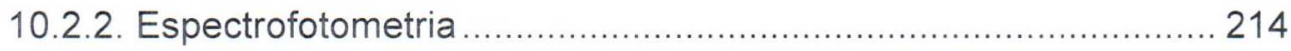

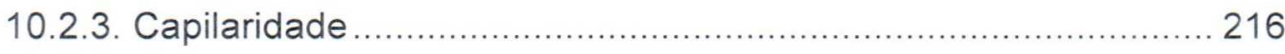

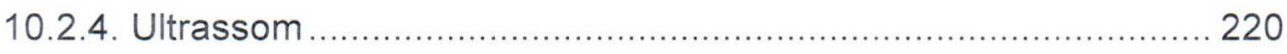

10.2.5. Teste de expansibilidade .................................................. 222

10.2.6. Porosimetria de mercúrio ................................................... 222

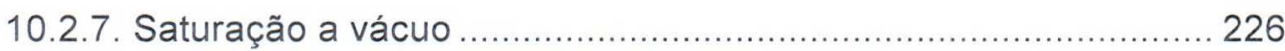


10.2.8. Resistência à flexão 226

11. Discussão 228

12. Conclusões 233

13. Referências bibliográficas 236 ANEXO I

ANEXO ॥ 


\section{Resumo}

Grossi, D. (2016). Avaliação da aplicação de consolidantes no Arenito Itararé, constituinte da fachada do Teatro Municipal de São Paulo. Tese de Doutorado, Instituto de Geociências, Universidade de São Paulo, São Paulo.

Esta tese tem por objetivo avaliar o comportamento da aplicação de préconsolidantes, consolidantes, hidrofugantes e protetor de superfície aplicados no Arenito Itararé, utilizado na fachada frontal do Teatro Municipal de São Paulo. Esta rocha possui caracteristicas intrínsecas que a desqualificam para uso em revestimentos, fachadas ou qualquer lugar em que fique sujeita às intempéries, uma vez que apresenta comportamento bastante friável e principalmente por possuir minerais expansiveis em sua constituição. Os consolidantes utilizados no tratamento dos arenitos foram o fosfato de amônio dibásico $(P)$ e o ortossilicato de tetraetila (TC e TW). Para auxiliar a efetividade do tratamento foram utilizados pré-consolidantes: etilenodiamina anidro (A2), 1,3 diaminopropano 99\% (A3) e 1,6 diaminohexano 60\% (A6). Foram testados ainda dois hidrofugantes (siloxano organofuncional - 630 e propil siliconato - 808) e um protetor de superfície (fluorosilano - AG). Para analisar sua durabilidade e efetividade, foram realizados os testes de velocidade de ondas ultrassônicas, saturação a vácuo, capilaridade, porosimetria de mercúrio, saturação e secagem, espectrofotometria, tubo de Karsten, profundidade de penetração, difração de raios $X(D R X)$, microscopia eletrônica de varredura (MEV), e ensaio de intemperismo acelerado por $\mathrm{SO}_{2}$. Uma primeira etapa de aplicação de produtos $\mathrm{e}$ verificação de efetividade do tratamento foi realizada na Princeton University (E.U.A.). Para esta parte da pesquisa foram testados o Arenito Itararé e ○ Arenito Missões. Na segunda etapa, os tratamentos e ensaios foram realizados no Brasil, utilizando apenas - Arenito Itararé e os produtos disponíveis para venda no país. Para levar esta pesquisa o mais próximo da realidade vivenciada nas restaurações, diferentes técnicas de aplicação foram testadas para verificar a profundidade de penetração.

Após a realização de todos os testes, concluiu-se que, dentre os tratamentos realizados na Universidade de Princeton, os mais efetivos para o Arenito Itararé, em ordem decrescente, foram: AP (pré-tratado com A e consolidado com P) e ATC (prétratado com A e consolidado com TC). Para o Arenito Missões, o melhor tratamento foi AP (pré-tratado com A e consolidado com P).

Dos produtos utilizados no Brasil, o que melhor funcionou para consolidar o Arenito Itararé foi AP. 


\section{Abstract}

Grossi, D. (2016). Evaluation of the consolidants application in Itararé Sandstone, constituent of the façade of the São Paulo Municipal Theater. PhD thesis, Instituto de Geociências, Universidade de São Paulo, São Paulo.

This thesis aims to evaluate the behavior of the pre-consolidants, consolidants, water repellents and surface protector applied in Itararé Sandstone, used on the front facade of the São Paulo Municipal Theater. This stone shows intrinsic characteristics that disqualify its use in coatings, facades or wherever it is subjected to the weather, as it presents quite friable behavior and especially for having clay swelling in its constitution. The consolidants utilized in sandstone treatments were ammonium phosphate dibasic (P) and ethyl silicate (TC and TW). To assist the effectiveness of the treatment pre-treatments with ethylenediamine anhydrous (A2), 1,3 diaminepropane $99 \%$ (A3) and 1,6 diaminohexane 60\% (A6) were used. Two water repellents (siloxane organofunctional - 630 and propyl siliconate - 808) and one surface protector (fluorosilane - AG) were tested. To analyze their durability and effectiveness, many analyses were performed, such as, ultrasonic wave velocity, vacuum saturation, capillarity, mercury porosimetry, wet and dry cycles, spectrophotometry, Karsten tube, penetration depth, $X$ ray diffraction (XRD), scanning electron microscope (SEM) and accelerated weathering by $\mathrm{SO}_{2}$. The first stage of product application and verification of effectiveness of the treatment was carried out at Princeton University (USA). In this university Itararé Sandstone and Missões Sandstone were tested. On the second stage, treatments and tests were carried out in Brazil, utilizing only Itararé Sandstone and the products avaliable in the country. To bring theory and practice closer, different application techniques were carried out when verifying the depth of penetration.

The tests at Princeton University showed that the best treatments for the Itarare Sandstone were: AP (pre-treated with diaminoalcanes and treated with ammonium phosphate dibasic) and ATC (pre-treated with diaminoalcanes and treated with ethyl silicate). For the Missões Sandstone the best treatment was AP (pre-treated with diaminoalcanes and treated with ammonium phosphate dibasic).

The best treatment for the Itararé Sandstone carried out in Brazil was AP. 


\section{Introdução}

Desde o período colonial, sabe-se da utilização no Brasil de mármores italianos e portugueses como revestimento. Este consumo aumentou a partir da segunda metade do século XIX (Frascá 2003a).

A Associação Brasileira de Normas Técnicas NBR 15012 (2003), define rocha de revestimento como "rocha natural, que submetida a processos diversos e graus variados de desdobramento e beneficiamento, é utilizada no acabamento de superfícies, especialmente pisos e fachadas, em obras de construção civil". A norma ASTM C119: 2014 define rocha ornamental como "pedra natural que foi selecionada e aparelhada ou cortada para tamanhos ou formas específicas, com ou sem uma ou mais superfícies mecanicamente acabadas".

A rocha ornamental é produto de um desmonte, que terá seu uso direcionado pelo modo de seu beneficiamento. Esta pode ser utilizada tanto na parte estrutural (blocos grandes), quanto em revestimento (chapas polidas ou não).

As rochas ornamentais são utilizadas para arte funerária, estatuária, construção de pias, tampos de mesa, dentre outras peças decorativas. Este é o seu uso mais nobre. Já na construção civil podem ser atribuídos diversos usos a elas como elementos estruturais, tendo como exemplo pilares e colunas, em revestimentos de paredes e pisos que podem ser assentados em áreas externas ou internas.

Rochas de revestimento são definidas por Frascá (2003a) como "produtos obtidos do desmonte de materiais rochosos em blocos e de seu subsequente desdobramento em chapas, posteriormente polidas e cortadas em placas ou ladrilhos [...] uma importante propriedade das rochas para revestimento é sua durabilidade, que se refletirá em maior e mais efetiva proteção das estruturas, por sua vez colaborando para o prolongamento da durabilidade destas. A interação da rocha com agentes externos torna, porém, a sua durabilidade comprometida, devido às variações de temperatura, ataque ácido de poluentes e outros".

A beleza das rochas se dá pela sua cor, textura e estrutura. Estes parâmetros, intrínsecos à rocha, são um reflexo do seu processo de formação, composição e orientação do mineral, além de deformações impostas por processos geológicos. No entanto, observar apenas os fatores estéticos, implica em não saber se o material resistirá bem às solicitações derivadas de seu emprego. É importante que antes de escolher uma rocha ornamental, seja realizado estudo sobre a tipologia do jazimento, que é definida pela presença de tensões confinantes, intensidade e tipo de alteração que a rocha foi submetida, heterogeneidade textural e estrutural, dentre outros. É importante observar também propriedades físicas, mecânicas e petrográficas, que vão 
condicionar comportamentos como contração e expansão térmica, resistência às intempéries, desgaste abrasivo, presença de sais solúveis na composição da rocha, porosidade, dentre outros. A deterioração, pode ainda, ser efeito da escolha de rochas com defeitos inerentes, de defeitos resultantes da extração na pedreira, ou de técnicas de acabamento inapropriadas. Esses defeitos, podem ser "invisiveis" até que a rocha seja instalada.

Para prolongar a beleza original das rochas é necessário que haja manutenção periódica. E aqui começam as diferenças quanto ao tempo, técnica, produtos aplicados e outras variáveis envolvidas.

Prevenção e conservação são dois tipos de intervenção que estão intimamente ligados, mas são diferentes, sendo interessante fazer a distinção entre eles. O primeiro está ligado à ideia de intervir hoje para evitar problemas futuros, prevenindo processos de deterioração. Já a conservação, visa consertar algo que ocorreu no passado. Tem como objetivo aumentar a resistência da rocha principalmente aos ataques intempéricos. A consolidação faz parte da prevenção, mas nem todo processo de prevenção utiliza a consolidação (Price 2006). Contudo, na prática, a consolidação é realizada durante conservação, contrariando a afirmação de Price.

As rochas esculpidas, são as que mais necessitam de intervenção, pois qualquer perda da camada superficial, mesmo que seja pequena, incorre em grande e irreparável perda estética (Price 2006). Apesar dos enormes esforços dos arquitetos e conservadores, por meio do uso dos métodos e produtos disponíveis para evitar a perda de material cultural e histórico, estes não têm sido suficientes para a manutenção das obras (Honsinger e Sasse 1991).

Há cerca de 30 anos, o interesse em consolidantes atingiu seu ponto máximo na Europa. Desde então, têm sido intensamente estudadas a dinâmica e a deterioração das rochas e sua relação com o meio ambiente, bem como a ação e duração dos consolidantes. Estes estudos levaram à melhor compreensão e desmistificação dos tratamentos sintéticos, chegando-se à conclusão que estes produtos não substituem a limpeza rotineira e o bom senso (Price 2006).

Segundo o mesmo autor, a maioria dos processos de deterioração é devido à presença de água. Portanto, a manutenção preventiva como preenchimento de fissuras e fraturas, fixação de blocos soltos e proteção de locais expostos, para que a água não penetre no interior da rocha, são medidas que previnem sua deterioração. $O$ controle da temperatura e da umidade, também são medidas importantes. Em alguns casos é necessário que a escultura seja removida do local aberto e levada para local abrigado. 
Os processos de deterioração ocorrem devido à interação entre as características físicas, petrográficas e mecânicas da rocha, do ambiente onde se encontra e dos processos de fixação e manutenção. Essa deterioração leva tanto à perda estética como brilho, cor, manchamento, quanto mecânica, ou seja, as características físicas e químicas são alteradas. As deteriorações do tipo inchamento, desprendimento de minerais ou fragmentos e escamação podem ser decorrentes da presença de minerais expansivos como os do grupo da esmectita. Pode-se citar ainda, a formação de eflorescências e subeflorescências provenientes de sais da rocha, quando em contato com água, pela percolação de sais da argamassa ou pelo seu assentamento inadequado.

Com a ação da água, principalmente no estado líquido, o intemperismo ocorre a partir de mudanças microestruturais (Honsinger e Sasse 1991).

O tipo de deterioração mais comum em arenitos é o face bedding, que ocorre em rochas onde o plano de acamamento é colocado paralelo à parede. Com essa configuração, camadas inteiras podem se despregar, devido à esfoliação em larga escala. Quando o plano de acamamento é posicionado perpendicular à parede, pode ocorrer edge bedding. A melhor posição de assentamento do arenito é com o acamamento na horizontal (Searls e Thomasen 1991), ou seja, na mesma orientação de formação.

A maioria dos diagnósticos mostra que os problemas advêm da falta de conhecimento sobre os resultados da interação das rochas com o ambiente externo (poluição) e clima agressivo, com o processo de beneficiamento, processos de aplicação da rocha e ações antrópicas. Vale ressaltar, que a rocha é um material que se altera naturalmente com o passar do tempo, pela interação com as condições atmosféricas da superfície terrestre. Mas, existem meios de evitar que esta deterioração seja acelerada e, ainda melhor, aumentar a sua durabilidade em relação à velocidade de seu intemperismo natural. Quando em contato com as condições atmosféricas das grandes cidades ou regiões industrializadas, que são mais poluídas, a deterioração é acelerada. Os ventos podem carregar esses poluentes e contaminar regiões rurais. Em áreas marinhas, a deterioração é acelerada pela ação dos aerossóis salinos (Frascá 2003a).

Algumas rochas sedimentares possuem argilas expansivas em sua composição, o que causa expansão de áreas expostas à umidade, resultando em pressões internas que as deterioram. Para predizer a probabilidade de dano por este mecanismo, é necessário caracterizar a magnitude da expansão e as propriedades mecânicas da rocha. Rochas que se expandem, também exibem comportamento viscoelástico, provavelmente devido ao escorregamento das lâminas de argila 
(Scherer e Jiménez González 2005). Estes autores introduziram um novo método de medir a expansão. A deformação de uma placa de rocha é produzida pela saturação de um dos lados. Este método é mais rápido que a medição tradicional direta da pressão de expansão, rendendo também informação sobre a absorção de água e a influência da umidade no módulo elástico. Este método é descrito no item dedicado aos estudos de caso.

Neste contexto, devido à grande importância do prédio do Teatro Municipal para a história da cidade de São Paulo e para os acontecimentos culturais da atualidade, julga-se necessário verificar qual o consolidante que melhor se comporta no Arenito Itararé que o constitui e que provoca menor variação colorimétrica, pois a cor da fachada é um dos aspectos mais importantes que afeta a aparência geral das construções. 


\section{Objetivos}

O Arenito Itararé, constituinte do Teatro Municipal de São Paulo, é uma rocha com problemas de durabilidade devido à sua mineralogia (presença de argilominerais expansivos). A sua utilização em construções importantes histórica e culturalmente, como o citado teatro, faz com que seja necessário o estudo de produtos e técnicas que possam diminuir a sua velocidade de deterioração, prolongando a vida destes prédios e a obra dos artistas que a executaram.

Assim, o objetivo principal é testar alguns produtos para a pré-consolidação e consolidação do Arenito Itararé e verificar qual deles possui maior durabilidade frente ao intemperismo, além de observar qual deles causa menor alteração de cor na rocha após sua aplicação. Adicionalmente, foram testados dois hidrofugantes e um protetor de superfície.

Para fins de comparação, foi ensaiado o Arenito Missões. Esta é uma rocha que foi bastante utilizada nas construções da cidade de São Miguel das Missões, no RS. Este arenito, que é bastante resistente, apresenta as seguintes alterações: erosão, colonização biológica, fraturas e desplacamentos locais. Esta rocha foi tratada e ensaiada com os produtos e testes disponíveis na Universidade de Princeton.

Esta pesquisa visa aumentar o número de trabalhos realizados na conservação das rochas de monumentos, disponibilizando métodos e materiais aplicáveis, evitando que trabalhos inadequados sejam feitos durante as restaurações do patrimônio brasileiro. 


\section{Materiais e Métodos}

Durante este trabalho, foram realizados pesquisa bibliográfica, trabalhos de campo no Teatro, coleta de amostras em pedreiras, estágio no exterior com apoio da Bolsa Estágio e Pesquisa no Exterior (BEPE) da Fundação de Amparo a Pesquisa no Estado de São Paulo (FAPESP), petrografia, DRX, intemperismo por aquecimento, capilaridade, velocidade de ondas ultrassônicas, tubo de Karsten, expansibilidade, microscopia eletrônica de varredura, porosimetria de mercúrio, saturação a vácuo, resistência à flexão, saturação e secagem, espectrofotometria, profundidade de penetração e alteração acelerada por $\mathrm{SO}_{2}$. A descrição destas técnicas encontra-se no item 7 .

Para a coleta de amostras foram seguidas as sugestões da norma ABNT NBR 6490 NB 28 (1985).

A pedreira do Arenito Itararé (Figura 3.1) está localizada na Floresta Nacional de Ipanema (Flona), município de Iperó, interior do estado de São Paulo. Atualmente a pedreira não está mais em funcionamento e todo o local é uma área de preservação ambiental. Para a retirada de material é necessária a autorização do ICMBio (Instituto Chico Mendes de Conservação da Biodiversidade). A autorização para a coleta de amostras para este trabalho está no Anexo I.

As coordenadas dos locais de coleta foram: Local 1 - Zona UTM 23K, 234.361,131/7.406.781,536. Local 2 - Zona UTM 23K, 235.209,607/7.407.491,781.

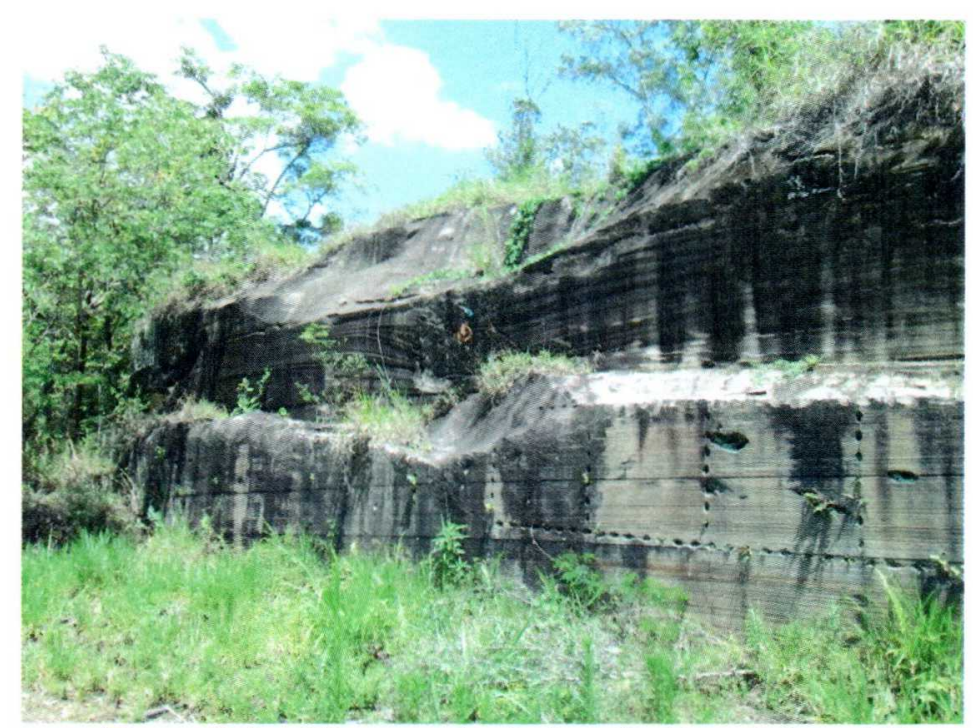

Figura 3.1 - Afloramento do Arenito Itararé (Local 1).

O Arenito Missões foi coletado na Fazenda da Laje (Figura 3.2), na localidade de Santa Bárbara, município de São Miguel das Missões - RS. É uma pedreira local, onde acredita-se que foram retiradas as pedras utilizadas pelos indígenas nas 
construções missioneiras. As coordenadas GPS obtidas do local de coleta foram Zona UTM 21J, 724.512,31/6.836.008,89.

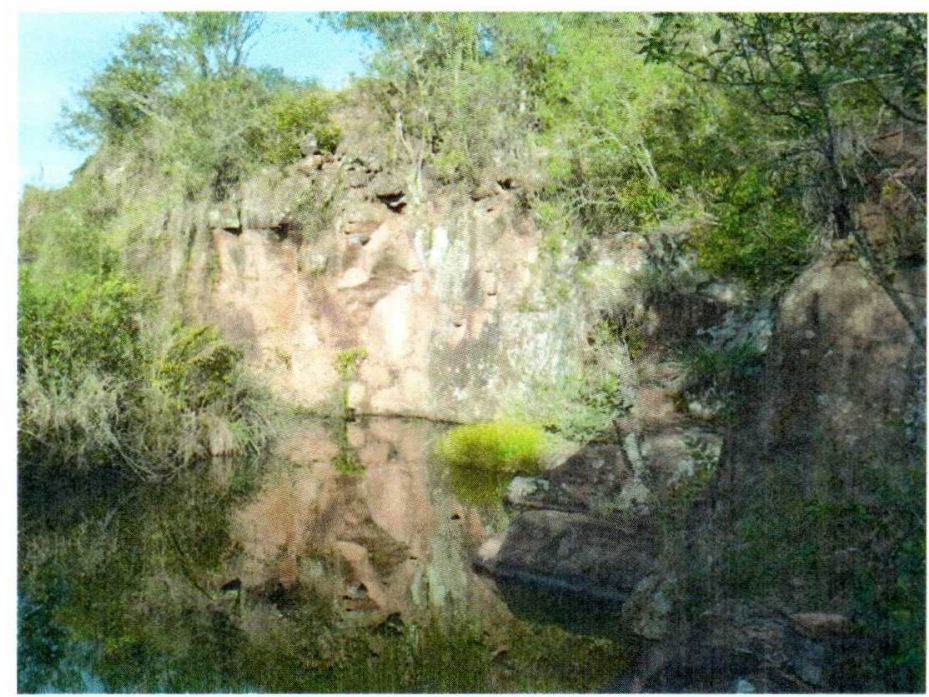

Figura 3.2 - Afloramento do Arenito Missões

Foram feitas sessões delgadas das amostras tratadas. Estas, foram observadas por meio de lupa e analisada sua petrografia. Todavia, não foi possível observar nenhuma modificação e nem a deposição do produto. Portanto, este método mostrou-se inadequado para observação de tratamentos em rochas. 


\section{História da conservação}

Alguns lugares memória, como descritos por Nora (1993), possuem importante papel por fazer parte da memória e do sentimento de pertencimento de um determinado grupo. Segundo Pensavento (2002), a memória é a "presentificação" do passado.

Quando observamos um espaço de relevância histórica, ele nos transporta ao passado, fazendo-nos reviver sentimentos e sensações que a ele se referem e que em muito fundamentam e explicam o momento presente. Portanto, uma edificação de valor histórico, carrega consigo os materiais de que é composta e coisas intangíveis, como significados e lembranças de vivências.

A memória coletiva, além de definir um local, uma população, uma nação; os une. Segundo Pollak (1989), juntando e reorganizando os fragmentos, uma cidade pode escrever ou até reescrever seu passado.

Essa história em comum, é levada às gerações futuras e as construções, são um testemunho dela. Pensavento (2002) afirma que "as lembranças se apoiam nas pedras da cidade".

O patrimônio histórico era entendido pelo mundo ocidental dentro do conceito de materialidade; focado no monumento. Este conceito vem sendo substituído pelo termo patrimônio cultural, que é mais abrangente e se refere aos bens culturais e identidades coletivas; o que enriquece a noção de patrimônio, que passa a englobar paisagens, culturas, gastronomia, documentos, expressões de arte, arquitetura e sítios arqueológicos. A noção de preservação do patrimônio no Brasil, é geralmente citada como tendo início no ano de 1920 , devido à elaboração dos primeiros projetos de lei relativos a ela.

O estudo do patrimônio cultural valoriza-se, por conseguinte, realizando o mesmo com a população que com ele se identifica. O patrimônio cultural compreende - meio ambiente, a paisagem, o saber fazer e, por fim o patrimônio histórico que engloba desde artefatos até construções. Segundo Choay (2001) a noção de patrimônio deve ir além de objetos, edificações e documentos, pois está embasada em processos sociais mais generalizados que envolvem desde a história até a antropologia. Kersten (2000) define patrimônio como "dinâmicas da experiência coletiva, sobre a qual cada grupo social manifesta o que deseja como perene e eterno".

O Brasil levou muito tempo para se desligar da colônia, Portugal. A inconfidência mineira, que ocorreu em 1789 em Ouro Preto, é tida como um movimento de autonomia política que afirmou a identidade nacional. Quase na mesma 
época, a Europa se mostrava muito mais avançada que o Brasil (como ainda o é), e já manifestava preocupação com seu patrimônio. Esse descompasso entre Brasil e países europeus permaneceu durante o século XIX, quando o Brasil estava aberto à cultura europeia, principalmente a francesa. Este descompasso continua presente até hoje. Tal fato é evidenciado pelo patrocínio oficial à Missão Francesa. Juntamente com a chegada desses artistas trazendo a cultura da Europa, algumas cidades brasileiras entraram no mercado internacional por meio da exportação de matérias-primas, como o café, a borracha e o algodão, fortalecendo o intercâmbio de informações (Pinheiro 2006). Segundo esta autora, na cidade de São Paulo, devido à economia do café, foram realizadas mudanças de fachadas, largos e praças com estilo inglês para a modernização do velho burgo comercial. Algumas igrejas foram demolidas para o alargamento de ruas e avenidas, ou para construção de outras mais modernas, como a Catedral Metropolitana. Outras, como a Igreja Jesuítica do Pátio do Colégio, foram reconstruídas, em detrimento da demolição do Palácio do Governo.

O Teatro Municipal de São Paulo é uma construção emblemática, que evidencia o gosto da burguesia daquela época (início do século $X X$ ) pelos valores e pela cultura da Europa, que exaltavam modernidade e civilização. Esta necessidade de intercâmbio cultural, mostra a tentativa de esquecer 0 passado retrógrado e primitivo da cidade.

\subsection{Pensadores}

Quando se trata de restauração, alguns conceitos, geralmente conflitantes, são interessantes de serem definidos, dentre eles: conservação, restauração e renovação. Os pensadores aqui apresentados foram parte importante do processo de definição de conceitos, além de terem feito sugestões para balizar a atuação dos restauradores e conservadores.

Snethlage e Sterflinger (2011) definem conservação como preservar o monumento no seu estado presente, dentro das definições históricas que nós o recebemos. Isso evita, quando possível, o complemento de partes faltantes, exceto casos onde tal atitude se faz absolutamente necessária para sua preservação futura, por exemplo, para evitar a penetração de água. A deterioração existente deve ser reparada e para a preservação a longo prazo a resistência do material pode ser aumentada. A Conservação de Reparo não aborda fatores ativos de deterioração que afetam o objeto. Em contrapartida a Conservação Preventiva aborda fatores ambientais que causam deterioração. Em condições externas, o fator ambiental pode 
ser minimizado com a construção de uma cobertura. Em ambientes internos, a instalação de um aparelho para controlar a umidade e a temperatura do ar é bastante eficiente. Segundo estes autores, restauração e renovação são definidos como:

Restauração objetiva a preservação sustentável do monumento. Em casos onde a deterioração está muito avançada, o conceito de restauração aceita a colocação de partes faltantes ou preenchimento de lacunas com rochas novas ou a reparação com argamassas. Em casos como a destruição da face de um objeto religioso, a restauração permite sua reconstrução de maneira adequada para que ele possa cumprir a sua função.

Renovação objetiva recriar a aparência original por excesso de trabalho na superfície ou pela complementação de todas as partes faltantes. Todavia, este tipo de trabalho não é bem visto pelos conservadores.

Alguns termos, ainda, são substituídos com o tempo, acompanhando o pensamento corrente e os novos conhecimentos, como é o caso do termo reversibilidade, que após 30 anos de sua criação, é substituído por retratabilidade. Apesar da mudança, o termo é muito discutido entre os anos de 1999 e 2003, mas finalmente é aceita a substituição do termo. Uma postura científica é necessária quando o assunto é retratabilidade e compatibilidade. É necessário estudar o estado da superfície a ser tratada, seu comportamento e efetividade dos consolidantes compatíveis, já que produtos que são ideais na teoria, não se comportam da mesma maneira na prática. Para isso, são necessárias pesquisas de laboratório e monitoramento do local tratado. Tudo isso deve ser documentado para produzir conhecimento acerca dos tratamentos a longo prazo.

A complexidade da conservação da longa história das estruturas em pedra, como as catedrais, mostra a necessidade de manutenção e reparos, regularmente. Para verificar qual o melhor meio de realizar uma intervenção e quais os produtos que devem ser utilizados, faz-se necessário conhecer e compreender a história e a evolução das teorias que conceituaram e, algumas, ainda conceituam esta prática, além de fazer recomendações. Estas visam evitar os erros, muitos deles fatais, cometidos no passado, como as tão polêmicas e debatidas intervenções de Viollet-leDuc.

\subsubsection{Viollet-le-Duc}

Arquiteto francês ligado à arquitetura revivalista do século XIX, Eugène Emmanuel Viollet-le-Duc foi um dos primeiros estudiosos da conservação. Nasceu em 
1814 e morreu em 1879, vivendo durante este período em um meio que cultivava as artes e a cultura. Ele deixou sua marca pessoal no âmbito da restauração. A primeira restauração realizada por Viollet-le-Duc foi a Igreja de Vézelay, no ano de 1840 (Kühl 2000).

Considerava um perigo tanto restaurar buscando reproduzir perfeitamente tudo - que se encontrava no edifício, quanto a pretensão de substituí-las por formas posteriores. Pois, o primeiro pode dar a falsa impressão de originalidade e o segundo pode fazer com que se pense que não foi um restauro e sim uma vontade do artista (Viollet-le-Duc 1854).

Em sua publicação Dictionnaire, ele expõe sua definição de restauração, que em muito mostra o trabalho feito por ele em alguns prédios medievais (Kühl 2000):

"A palavra e o assunto são modernos. Restaurar um edifício não é mantê-lo, repará-lo ou refazê-lo, é restabelecê-lo em um estado completo que pode não ter existido nunca em um dado momento."

Esta frase exprime exatamente o modo como intervinha. Se forem comparadas fotos do antes e depois de algumas das edificações restauradas por Viollet, fica bastante difícil acreditar que sejam a mesma, tamanha a diferença entre uma e outra.

Como práticas que anda estão em voga na atualidade, pode-se citar sua recomendação de restaurar não só a fachada como também a estrutura do edifício, procurar seguir a concepção original para solucionar problemas estruturais, a importância de realizar um levantamento minucioso sobre o estado do edifício antes de determinar uma intervenção, olhar cada caso isoladamente e a importância da restauração para a sobrevivência de uma obra, documentar a intervenção, utilizar materiais mais resistentes do que os empregados na construção (Kühl 2000).

Atualmente Viollet-le-Duc é visto por alguns como um ícone, que tinha aspectos inovadores em sua prática e formulações teóricas coerentes, e por outros como um grande destruidor da história humana, desrespeitador do valor da matéria e das configurações originais.

\subsubsection{John Ruskin}

John Ruskin foi escritor, crítico, poeta e desenhista. Ele é considerado o principal teórico do século XIX na Inglaterra. Nasceu em 1819 e faleceu em 1900. Era contrário à industrialização, de tal modo que dizia-se que seus livros eram proibidos de serem transportados por ferrovias (Pinheiro 2008). Defendia a manutenção da pátina, por mostrar a passagem do tempo, o respeito ao antigo, a sustentabilidade, o que 
mostrava que suas ideias eram bastante avançadas para a época. Argumentava pela utilização de materiais e técnicas duráveis para a construção de edifícios, valorizava a estrutura em detrimento a aparência, era contra a restauração e a considerava como destruição do original e da história, como pode-se verificar na seguinte passagem:

Restauração é "[...] a mais total destruição que um edifício pode sofrer [...] é impossível, tão impossível como ressuscitar os mortos, restaurar qualquer coisa que já tenha sido grandiosa ou bela em arquitetura." Considera-a uma "mentira do começo ao fim" (Ruskin 1849).

No contexto brasileiro, as ideias de Ruskin sobre conservação dos edifícios antigos ressoavam nos escritos de Euclides da Cunha, que também defendia a manutenção da pátina. Dentre estes escritos pode-se citar o relatório intitulado "Os Reparos nos Fortes de Bertioga" e o artigo "Chafarizes do Rio de Janeiro". Lucio Costa condenava a tentativa de deixar tudo com aparência de novo, mas também não concordava com todas as ideias de Ruskin. Outro escritor que repercutia as ideias Ruskinianas, era o médico pernambucano José Mariano Filho, que também era a favor da não intervenção e da manutenção das características arquitetônicas, constatado em seu artigo sobre a demolição do Solar do Megaípe. Manuel Bandeira, também pernambucano, concordava com José Mariano, o que é evidenciado em seu alerta, em 1928, para a preservação da cidade de Ouro Preto (Pinheiro 2008).

\subsubsection{Camillo Boito}

Nascido em 1836 e falecido em 1914, este italiano era arquiteto, restaurador, crítico, historiador, professor, teórico e literato. Ficou conhecido por elaborar princípios que formaram a base da teoria de restauração contemporânea. Dentre eles pode-se citar: valorizar a documentação da obra, manter unidade de estilo, documentar reparos e restauros, utilizar materiais distintos para a reposição, unificar esteticamente, respeitar todas as fases do monumento (sendo admitida a retirada de partes de qualidade inferior), indicar os locais de intervenção, intervir minimamente, intervir periodicamente para evitar a restauração, restaurar só para preservar a memória, nas substituições diferir em estilo para saber o que é novo e o que é velho e expor partes removidas. No entanto, o percurso de Boito não foi homogêneo e são verificadas várias incoerências e resultados de qualidade desigual em sua obra.

Boito classifica a restauração arquitetônica em três tipos distintos: arquitetônica, arqueológica e pictórica. Elas diferem quanto ao período que pretendem conservar. Para a arquitetônica seria conservada a beleza dos edifícios do 
Renascimento em diante. Na restauração arqueológica são conservadas as construções que são importantes para a antiguidade. E na pictórica são conservados os edifícios medievais (Kühl 2002).

\subsubsection{Alois Riegl}

Nascido em 1858 e falecido em 1905 na Áustria, Alois Riegl foi um historiador que trabalhou na reorganização da legislação de conservação dos monumentos austríacos. Estabeleceu os princípios para a preservação dos monumentos baseados nos seguintes valores: histórico, de antiguidade, de rememoração internacional, relativo, de uso e de novidade. Riegl segue pelo caminho do valor dado ao monumento e não intrínseco a ele. Divide os monumentos em intencionais e não intencionais. Os monumentos intencionais são construídos desde épocas remotas. Defende que o monumento histórico é uma criação da sociedade que é delimitada por um dado tempo e espaço. Estes princípios foram estabelecidos em "O Culto Moderno dos Monumentos" sendo este um conjunto de reflexões que direcionam tomadas de decisão, a política e a prática da conservação de monumentos.

Destaca que esta valorização do novo em detrimento do velho é uma atitude milenar, que está arraigada na sociedade e se preserva até hoje, e será muito difícil modificá-la. Esta atitude é mais visível nas camadas mais baixas da sociedade. De outro lado, os pensadores modernos valorizam as ruínas como parte de um ciclo natural da obra humana, que deve ser protegidas de um fim prematuro. Apenas esta intervenção é permitida por ele. Todas as outras para cobrir a nova forma esculpida pelo passar do tempo são rejeitadas. Valoriza o que o aspecto de tempo transcorrido causa no observador. Defende que toda obra deve passar pelo ciclo de criação e destruição (Cunha 2006).

\subsubsection{Max Dvořák}

Max Dvořák foi um historiador da arte que nasceu em 1874 na Boêmia e faleceu em 1921.

Em seu texto intitulado Catecismo da Preservação dos Monumentos, publicado em 1916, baseado nas ideias de Riegl, Dvořák defende a relação entre as artes e o desenvolvimento espiritual da humanidade e tem como objetivo orientar os trabalhos de restauração com conselhos práticos, identificando erros e atitudes prejudiciais, do 
ponto de vista de quem conviveu com esses problemas no dia-a-dia. Inicia o debate sobre a importância de preservar o entorno dos monumentos.

Dentre suas ideias, pode-se citar a impossibilidade de recriar o passado, necessidade de haver funcionário qualificado trabalhando nos órgãos de preservação do patrimônio, a preservação de um monumento seria justificada pelo valor atribuído a ele pelas pessoas, todos os monumentos antigos devem ser conservados, respeito pelas camadas da mesma obra, preservação do entorno dos monumentos, conservação e proteção ao invés de renovação e condena a unidade de estilo.

Segundo Dvořak, preservar significa respeitar a diversidade, a pluralidade, e assegurar que várias formas de manifestação, inclusive as do presente possam coexistir, permitindo que os monumentos históricos atuem como efetivos e fidedignos suportes materiais da memória coletiva, sendo impossível devolver o estilo original a uma construção, mesmo o mais bem intencionado restaurador, pois não se sabe como era a forma original (Dvořák 1916).

\subsubsection{Cesare Brandi}

Cesare Brandi nasceu em 1906 e faleceu em 1988 na Itália. Em seu livro Teoria da Conservação, escrito no ano de 1963 e traduzido para o português no ano de 2008 (terceira edição), Brandi (1963) define restauração como:

"qualquer intervenção voltada a dar novamente a eficiência a um produto da atividade humana" [...] "a restauração constitui o momento metodológico do reconhecimento da obra de arte, na sua consistência física e na sua dúplice polaridade estética e histórica, com vistas a sua transmissão para o futuro".

Dentre suas ideias pode-se citar:

- o que se restaura é apenas a matéria e não a obra de arte;

- cuidado para que na restauração não ocorra um falso artístico ou histórico;

- devem ser mantidos os traços da passagem do tempo;

- a importância do conhecimento sobre o material que será trabalhado no momento do restauro;

- a reposição de uma peça ou cópia não é justificada constituindo assim um falso histórico, tendo apenas função didática;

- a integração deve ser facilmente identificável, mantendo-se a unidade à distância;

- não realizar substituições para fins estruturais;

- intervenção atual deve facilitar as futuras; 
- não se deve remover adições nem a pátina;

- cada caso deve ser estudado individualmente; não existe uma receita única e imutável;

- a conservação e a restauração devem sempre olhar para os dois vieses da arte: a historicidade e a esteticidade;

- manutenção das adições é perfeitamente factível do ponto de vista histórico. Pelo ponto de vista artístico estas devem ser retiradas (salvo casos em que foi alcançada nova unidade estética);

- a escavação de sepultamentos devem ser considerados parte da restauração e não anteriores a ela;

- estudar exaustivamente o material que será trabalhado e os produtos e processos utilizados e a interação desta interface para que os resultados sejam o máximo previsíveis.

\subsection{Cartas patrimoniais}

\subsubsection{Contexto geral}

A problemática do patrimônio é histórica e sociológica, pois nada possui valor em si; o homem é que lhe atribui este valor (Meneses 1992). As cartas patrimoniais foram e continuam sendo importantes objetos para orientar, balizar e aumentar 0 comprometimento de empresas, nações e países na direção da escolha e proteção de patrimônios relevantes, que são partes significativas de uma história, evento, cidade e/ou cultura. Algumas são nacionais, outras internacionais. Os vários tipos de documento indicam o nivel de compromisso dos paises que os seguem. Nas convenções, as obrigações são entre os países contratantes, já as recomendações são instrumentos de cooperação internacional. Estas cartas, advém da necessidade encontrada pela sociedade, que passou a ser discutida e avaliada pelos pensadores, gerando documentos (cartas patrimoniais) para a proteção dos bens de valor histórico, artístico e cultural.

Na década de 1970, muitos projetos envolvendo a preservação surgiram na cidade de São Paulo. Com eles, inicia-se a preocupação com a preservação não só dos bens materiais, mas também com o ambiente e a qualidade de vida. A importância da sociedade nos processo de decisão é reconhecida, mas como se vê até hoje, essa importância é dada somente no papel. Na prática, cada órgão faz o que mais lhe convém e a sociedade não é consultada nem direta e nem indiretamente. 
Babelon e Chastel (1994 apud Prata 2009) consideram que o conceito de patrimônio para ser bem compreendido, deve ser estudado em suas várias camadas. $\mathrm{Na}$ França, a noção de patrimônio ocorreu em momentos distintos: religioso, monárquico, familiar, nacional, administrativo e científico. Em cada momento, o foco da preservação era diferente. Mas de modo geral, o conceito de patrimônio é fundado em cima da ideia de veneração, sendo um vínculo entre a população e um objeto "sagrado", com valor cívico.

Alois Riegl, reconhecido tardiamente como um dos principais teóricos do estudo dos monumentos históricos, é o primeiro a fazer a distinção entre os monumentos intencionais e não intencionais. Em 1903, Riegl apresenta a obra "O Culto Moderno dos Monumentos", que é resultado do pedido feito a ele da proposição de uma nova legislação para a conservação dos monumentos na Áustria, pela Comissão de Monumentos Históricos da Áustria, da qual era presidente. Nesta obra, apresenta valores atuais, como por exemplo, o valor documental de uma obra e respeito pelas várias fases pelas quais passou o monumento, e relaciona o tipo de conservação necessária a cada monumento de acordo com o valor a ele atribuído, que pode ser um valor de rememoração (que é subdividido em valor histórico ou rememoração intencional) ou de contemporaneidade (subdividido em valor de uso ou de arte) (Prata 2009).

Em relação à prática da preservação na Europa, a bibliografia mostra três fases. A primeira, monumentalista, inicia-se na metade do século XIX e estende-se até a Segunda Guerra Mundial. Nesta fase, o importante eram edifícios emblemáticos como monumentos históricos e artísticos, com valor pela beleza ou antiguidade. 0 entorno não era contemplado. Com o advento da Segunda Guerra e a destruição das cidades, os conceitos começam a mudar e os centros históricos passam a ser valorados. Essa é a segunda fase, a centro historicista, que apesar de ampliar o objeto, acaba tratando todo o centro do mesmo modo como tratava um monumento. Ela dura até metade da década de 1970, findando com o Ano do Patrimônio Arquitetônico Europeu. Inicia-se então a terceira fase, a da cidade contemporânea, onde a preservação não se restringe aos centros históricos, contemplando então a conservação urbanística da cidade contemporânea. Nesta fase, a conservação é inserida nos planos diretores e no planejamento urbano. $O$ italiano Gustavo Giovannoni é considerado um dos precursores do pensamento sobre urbanismo e conservação e contribuiu com o desenvolvimento de um modo de conservar os prédios antigos e integrá-los à cidade da era industrial (Choay 2001). Antes de Giovannoni, houve três abordagens sobre o patrimônio urbano: a primeira foi a memorial, da qual John Ruskin (1849) é o maior representante; a segunda, conhecida 
como histórica ou propedêutica, tem como representantes Viollet-le-Duc (1854) e Camillo Sitte (1992) e a terceira, que é chamada de histórica ou museal dos viajantes, estetas e cientistas. Todavia, nenhum deles realizou algo para a integração dos espaços antigos e modernos da época (Prata 2009).

No Brasil, comparando com as fases acima citadas, a primeira seria de 1937, com a criação do SPHAN (Serviço de Patrimônio Histórico e Artístico Nacional) e terminaria no final dos anos 1960. A segunda fase, centro historicista, aconteceu entre 60 e 70. A partir dos anos 70, iniciou a terceira fase, onde há o reconhecimento da importância da cidade contemporânea (Prata 2009). Na década de 1970 estava em voga o conceito de Conservação Integrada, sobre âmbito social, como áreas verdes e de recreação, equipamentos de uso coletivo e espaços públicos. Nas décadas de 1980 e 1990, o conceito passou a abranger também as áreas centrais, devido ao aumento do valor dos imóveis dessa área, que aconteceu pelo aumento de serviços e do turismo.

\subsection{No Brasil}

No Brasil, a preocupação com a preservação do patrimônio histórico, principalmente arquitetônico, inicia-se em 1920, pois a falta de conservação estava comprometendo o patrimônio e dilapidando bens nacionais.

$\mathrm{Na}$ constituição de 1934, o artigo 10 diz:

Art. 10 - Compete concorrentemente à União e aos Estados:

III - proteger as belezas naturais e os monumentos de valor histórico e artístico, podendo impedir a evasão de obras de arte.

Esta é a primeira noção de Patrimônio Histórico e Artístico Nacional no Brasil.

Prata (2009) considera que o início da preservação no Brasil ocorre em 1923, com a criação da Inspetoria de Monumentos Históricos, tendo seu ponto alto em 30 de novembro de 1937, com a criação do Decreto-Lei n 25.

No Decreto-Lei $n^{\circ} 25$, o então presidente Getúlio Vargas cria o SPHAN (Serviço do Patrimônio Histórico e Artístico Nacional), que foi estruturado por intelectuais e artistas da época para organizar a proteção ao Patrimônio Histórico e Artístico Brasileiro (mais tarde, originaria o Instituto do Patrimônio Histórico e Artístico Nacional - IPHAN). A partir daí ocorre uma proteção regulamentada dos bens culturais brasileiros.

Nos 30 primeiros anos, o SPHAN teve como foco o patrimônio (monumentos), juntamente com a arquitetura moderna, devido à participação de vários arquitetos 
modernistas em suas decisões. Nesta época existia uma forte ligação entre patrimônio e memória nacional onde estava sendo desenvolvido um projeto para a construção da identidade brasileira.

Com o Estado empoderado da tarefa de cuidar do patrimônio cultural brasileiro, começam as discussões sobre nação, povo, elite, imigrante, trabalho, indústria nacional, mundo civilizado, progresso, história do Brasil e quais seriam os monumentos que representariam bem o nosso passado (Prata 2009).

O SPHAN tem seu nome alterado para Departamento do Patrimônio Histórico e Artístico Nacional (DPHAN) em 1946 e para Instituto do Patrimônio Histórico e Artístico Nacional (IPHAN) em 1970.

O mesmo Decreto-Lei $n^{0} 25$, regulamenta o processo de tombamento e organiza a proteção ao patrimônio histórico, artístico e nacional. A preocupação com a vizinhança do bem tombado, encontra-se descrita no artigo 18, o qual regulamenta que nada pode ser construído sem a autorização prévia do órgão preservacionista, garantindo assim, a visibilidade do bem tombado.

O CONDEPHAAT, um órgão paulista, foi criado em 1968 pelo artigo 128 da Constituição do Estado de São Paulo de 1967. A Lei 10.247, que organiza o órgão e Ihe atribui competências, foi promulgada no mesmo ano. A sua criação foi realizada dentro do contexto internacional, que discutia os aspectos urbanos, ambientais e sociais do patrimônio. O Decreto-Lei $n^{0} 149$ foi proclamado em 1969 e trata do tombamento de bens para que o patrimônio histórico e artístico regional seja protegido. No mesmo ano, foi editado do Decreto Estadual que regulamenta a Lei 10.247/1968, o Decreto $n^{\circ} 149 / 1969$ e também o processo de tombamento. Nele, o objetivo é promover o turismo devido a um sentimento cívico, sem mudar a proteção ao patrimônio.

Nos Encontros de Governadores que aconteceram em Brasília e Salvador nos anos de 1970 e 1971, respectivamente, o patrimônio cultural e ambiental é tratado pelos poderes federados como elemento básico para a formação da consciência nacional. Nestes encontros, também é discutida a descentralização da tarefa de preservar, sendo estimulada a criação de órgãos preservacionistas em âmbito municipal e estadual (Prata 2009).

O Compromisso de Salvador ratifica o de Brasília e acrescenta 24 recomendações que têm como objetivo relacionar a preservação com outras áreas, valorizando assim a troca de conhecimento para melhor preservar. Recomenda o conceito de ambiência, para que ocorra a proteção mais eficiente dos conjuntos paisagísticos de valor. 
Seguindo essas ideias, em 1975 é criado o Departamento de Patrimônio Histórico (DPH), da Secretaria Municipal de Cultura. No ano de 1985, é criado o Conselho Municipal de Preservação do Patrimônio Histórico, Cultural e Ambiental da Cidade de São Paulo (CONPRESP), que fica encarregado da parte de deliberar os tombamentos. No entanto, o CONPRESP só é instalado em 1988.

Nos anos de 1973 e 1975 são criados o Programa de Reconstrução das Cidades Históricas $(\mathrm{PCH})$ e o Centro Nacional de Referência Cultural (CNRC), respectivamente. Ambos, como alternativas ao IPHAN. O PCH tinha como objetivo conciliar desenvolvimento, turismo e preservação do patrimônio. Ele possuía um conjunto amplo de metas, como formação e capacitação de mão de obra, edição de roteiros turísticos, financiamento para empreendimento, para fins turísticos e instituição de leis de preservação nos Planos Diretores de Desenvolvimento Urbano dos Municípios, que eram acompanhadas pelo IPHAN, EMBRATUR, e SEPLAN. O CNRC foi criado a partir de um convênio entre órgãos federais, como a Secretaria de Planejamento da Presidência da República, Ministérios da Educação e Cultura, tanto do Interior quanto das Relações Exteriores, dentre outros. O CNRC foi coordenado por Aloísio de Magalhães (designer, artista plástico e secretário de cultura do Ministério da Educação e da Cultura em 1981) e procurou se contrapor à política de "pedra e cal" do IPHAN, contratando técnicos de formação variada, em especial os com formação em ciências sociais, em contraposição ao mar de arquitetos do IPHAN. Esta política de "pedra e cal", foi assim chamada por privilegiar a preservação de bens materiais em detrimento aos bens imateriais, como festas, danças e gastronomia. Todo o trabalho foi fundamentado na diversidade, no fazer popular e na dinâmica cotidiana, ou seja, uma visão antropológica em contraposição à cultura patrimonial tradicional, que valorizava o caráter estilista, culto e excepcional.

Em 1979, o IPHAN, o PCH e o CNRC se fundem.

Em 1987, em Petrópolis, ocorre uma discussão nacional, que reitera a necessidade de uma visão integrada do processo social em suas vertentes cultural e ambiental, para a compreensão dos centros históricos.

O IPHAN publicou, em 2009, a portaria $n^{0} 127$, que é a primeira chancela brasileira de Paisagem Cultural Brasileira, na qual discorre sobre um novo instrumento de proteção e promoção, que diz em seu artigo $1^{0}$ :

"Paisagem Cultural Brasileira é uma porção peculiar do território nacional, representativa do processo de interação do homem com o meio natural, à qual a vida e a ciência humana imprimiram marcas ou atribuíram valores".

Desde a década de 80 , muitas pesquisas foram realizadas em torno da atuação do IPHAN e concluem sobre o importante trabalho de institucionalização do 
patrimônio, que foi articulado por este órgão. Porém, essa prática preservacionista é alterada nos anos de 1980, devido às discussões que aconteciam tanto nacional quanto internacionalmente. Ocorre a descentralização do IPHAN para a ampliação da rede institucional. Como resultado da ampliação da rede, aumenta o número de bens passíveis de tombamento, passando a incluir bens de religiões não católicas e de etnias negras e testemunhos da industrialização e da imigração. São ampliadas também, as discussões sobre patrimônio dentro de órgãos relativos ao planejamento e ao desenvolvimento. Nos anos de 1970 e 80 ocorreu grande abertura temática em relação à questão ambiental e às áreas envoltórias (Prata 2009).

A Secretaria Municipal de Cultura inicia, em 1983, o Inventário Geral do Patrimônio Ambiental e Cultural Urbano do Estado de São Paulo (IGEPAC-SP). Neste inventário, foi utilizado um conceito amplo de patrimônio. Como exemplo de sua ação, pode-se citar o tombamento do bairro da Bela Vista, em São Paulo, que foi baseado nos estudos do IGEPAC (Lima e Maleque 2007).

É necessário que a preservação acompanhe as mudanças e a dinâmica da sociedade, para que o patrimônio esteja sempre inserido na sociedade para salvaguardar a memória de um fato ou grupo social.

$\mathrm{Na}$ Tabela 4.1 é apresentada uma breve descrição, ano e local do evento de todas as cartas patrimoniais relacionadas ao patrimônio arquitetônico.

Tabela 4.1 - Relação de cartas patrimoniais (Fonte:

http://portal.iphan.gov.br/pagina/detalhes/226, Instituto do Patrimônio Histórico, e Artístico Nacional 1995).

\begin{tabular}{|c|c|l|l|}
\hline Ano & Nome & \multicolumn{1}{c|}{ Descrição/ Evento } \\
\hline 1931 & Carta de Atenas & $\begin{array}{l}\text { Foco para o reconhecimento de uma ação interdisciplinar na conservação } \\
\text { dos monumentos. Responsabilidade dos Estados de inventariar os seus } \\
\text { bens (documentação internacional). Trata do entorno, publicidade, ruídos e } \\
\text { uso dos bens, além dos limites para a intervenção. Conclusões Gerais e } \\
\text { Deliberações da Sociedade das Nações, do Escritório Internacional } \\
\text { dos Museus. }\end{array}$ \\
\hline 1933 & Carta de Atenas \\
\hline 1964 & $\begin{array}{l}\text { Generalidades, diagnósticos e conclusões sobre os problemas urbanísticos } \\
\text { das principais e grandes cidades do mundo, baseadas nas 4 funções do } \\
\text { urbanismo: habitar, trabalhar, recrear e circular. Congresso Internacional } \\
\text { de Arquitetura Moderna, em Atenas. }\end{array}$ \\
\hline Carta de Veneza
\end{tabular}




\begin{tabular}{|c|c|c|}
\hline Ano & Nome & Descrição/ Evento \\
\hline 1967 & Normas de Quito & $\begin{array}{l}\text { Alerta sobre a situação de urgência dos bens e responsabilidades dos } \\
\text { governos da América. Ampliação do conceito de monumento ao espaço - } \\
\text { função social. Exposição do perigo da perda dos monumentos da região } \\
\text { Íbero-Americana por falta de "politica oficial" que alie a valorização do } \\
\text { patrimônio ao beneficio econômico. Solução: "política de planejamento } \\
\text { urbano" que valorize o patrimônio. Apresentação dos monumentos como } \\
\text { recursos econômicos - turismo. Reunião sobre Conservação e Utilização } \\
\text { de Monumentos e Lugares de Interesse Histórico e Artístico. }\end{array}$ \\
\hline 1968 & $\begin{array}{c}\text { Recomendação } \\
\text { de Paris }\end{array}$ & 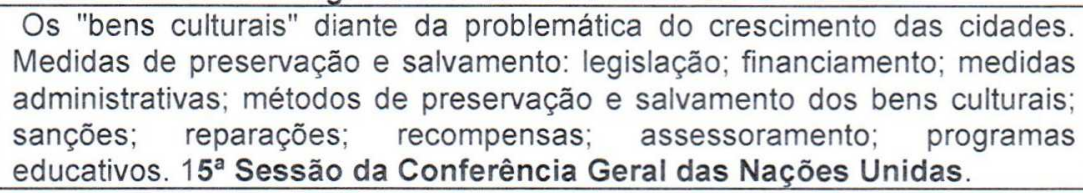 \\
\hline 1970 & $\begin{array}{c}\text { Compromisso de } \\
\text { Brasilia }\end{array}$ & $\begin{array}{l}\text { Ministro Jarbas Passarinho. Resumo de recomendações expostas em } \\
\text { cartas patrimoniais anteriores. Enfatizando a responsabilidade de governos } \\
\text { e secretarias (estados e municípios) com a conservação, preservação, } \\
\text { catalogação e políticas educativas dos bens culturais. Determina criar } \\
\text { órgãos de defesa onde ainda não existam, em conformidade com os } \\
\text { Conselhos Estaduais de Cultura. Especificações educativas como inclusão } \\
\text { no currículo escolar de História da Arte no Brasil. Encaminhamento para a } \\
\text { criação do Ministério da Cultura. Carta anexa assinada por Lucio Costa. I } \\
\text { Encontro de Governadores de Estado, Secretários Estaduais da Área } \\
\text { Cultural, Prefeitos de Municípios Interessados e Presidentes e } \\
\text { Representantes de Instituições Culturais. }\end{array}$ \\
\hline 1971 & $\begin{array}{l}\text { Compromisso de } \\
\text { Salvador }\end{array}$ & $\begin{array}{l}\text { Realizado pelo Ministério da Educação e Cultura e pelo IPHAN - Instituto } \\
\text { do Patrimônio Histórico e Artístico Nacional. Recomenda-se a criação do } \\
\text { Ministério da Cultura e secretarias ou fundações estaduais. Outras } \\
\text { recomendações sobre o plano urbanístico com valorização dos sitios } \\
\text { históricos; solicitada a parceria entre Estado e universidades. II Encontro } \\
\text { de Governadores para a Preservação do Patrimônio Histórico, Artístico } \\
\text { e Arqueológico e Natural do Brasil. }\end{array}$ \\
\hline 1972 & $\begin{array}{l}\text { Carta do } \\
\text { Restauro }\end{array}$ & $\begin{array}{l}\text { Orientações técnicas sobre o processo de restauro em diferentes } \\
\text { suportes/categorias: objetos arqueológicos, arquitetônicos, pictóricos e } \\
\text { escultóricos; instruções para a tutela dos centros históricos (reestruturação } \\
\text { urbanística, reordenamento viário e revisão dos equipamentos urbanos). } \\
\text { Carta do Restauro, do Ministério da Instrução Pública do Governo da } \\
\text { Itália. }\end{array}$ \\
\hline 1972 & $\begin{array}{l}\text { Declaração de } \\
\text { Estocolmo }\end{array}$ & $\begin{array}{l}\text { Recomendações para a melhoria da qualidade de vida e meio ambiente, } \\
\text { indica a necessidade da criação de principios e critérios que sejam comuns } \\
\text { a todos os povos do mundo e que os encoraje a proteger seu próprio meio } \\
\text { ambiente. Culminou na criação do Programa das Nações Unidas para o } \\
\text { Meio Ambiente (UNEP) e o destaque foi a relação entre desenvolvimento e } \\
\text { preservação. Assembleia Geral das Nações Unidas. }\end{array}$ \\
\hline 1972 & $\begin{array}{c}\text { Recomendação } \\
\text { de Paris }\end{array}$ & $\begin{array}{l}\text { Definições do patrimônio cultural e natural e sua proteção nacional e } \\
\text { internacional. Criação de um comitê intergovernamental. Criação do "Fundo } \\
\text { do Patrimônio Mundial". Definição para as condições para assistência } \\
\text { internacional. Programas Educativos. Convenção sobre a Proteção do } \\
\text { Patrimônio Mundial, Cultural e Natural. }\end{array}$ \\
\hline 1974 & $\begin{array}{l}\text { Resolução de } \\
\text { São Domingos }\end{array}$ & $\begin{array}{l}\text { Recomendações no plano social e econômico e proposta operacionais: } \\
\text { resgate de informações nos arquivos; plano educacional; valorização do } \\
\text { turismo; criação de uma Associação Interamericana de Arquitetos e } \\
\text { Especialistas na Proteção do Patrimônio Monumental; criação de um fundo } \\
\text { de emergência. Seminário Interamericano sobre Experiências na } \\
\text { Conservação e Restauração do Patrimônio Monumental dos Periodos } \\
\text { Colonial e Republicano, pela OEA. }\end{array}$ \\
\hline 1975 & $\begin{array}{c}\text { Declaração de } \\
\text { Amsterdã }\end{array}$ & $\begin{array}{l}\text { Firma o patrimônio arquitetônico europeu como patrimônio mundial } \\
\text { (construções isoladas, conjuntos, bairros, cidades e aldeias). Necessidade } \\
\text { de incentivo financeiro e programas de educação. Políticas para } \\
\text { conservação integrada. Congresso do Patrimônio Arquitetônico } \\
\text { Europeu. }\end{array}$ \\
\hline 1975 & $\begin{array}{c}\text { Manifesto de } \\
\text { Amsterdã }\end{array}$ & $\begin{array}{l}\text { Em referência ao "Ano europeu do patrimônio arquitetônico". Promoção de } \\
\text { uma política de conservação integrada, entre pesquisas, técnicas de } \\
\text { restauração apropriadas, recursos jurídicos, financeiros e administrativos, } \\
\text { juntamente com a participação da população. Carta Europeia do }\end{array}$ \\
\hline
\end{tabular}




\begin{tabular}{|c|c|c|}
\hline Ano & Nome & Descrição/ Evento \\
\hline & & Patrimônio Arquitetônico - Ano do Patrimônio Europeu. \\
\hline 1976 & $\begin{array}{l}\text { Recomendações } \\
\text { de Nairóbi }\end{array}$ & $\begin{array}{l}\text { Definição de conjunto histórico ou tradicional, sua importância como } \\
\text { "patrimônio universal insubstituível" e medidas de salvaguarda. Coloca em } \\
\text { voga o problema das supressões do entorno de um patrimônio sob a vista } \\
\text { da ambiência. Recomendações para pesquisa, ensino, informação e } \\
\text { cooperação internacional. } 19^{a} \text { Sessão da UNESCO. }\end{array}$ \\
\hline 1977 & $\begin{array}{l}\text { Carta de Machu } \\
\text { Picchu }\end{array}$ & $\begin{array}{l}\text { Revisão da Carta de Atenas, revisão e ampliação de conceitos e } \\
\text { recomendações: cidade-região, crescimento urbano, conceito de setor, } \\
\text { moradia, transportes na cidades, disponibilidade do solo urbano, recursos } \\
\text { naturais, preservação, tecnologia, projeto urbanístico e arquitetônico. } \\
\text { Encontro Internacional de Arquitetos. }\end{array}$ \\
\hline 1980 & Carta de Burra & $\begin{array}{l}\text { Conselho internacional de monumentos e sítios. Definições do documento: } \\
\text { bem, significado cultural, substância, conservação, manutenção, } \\
\text { preservação, restauração, reconstrução, adaptação, uso compativel. } \\
\text { Recomendações quanto a: conservação, preservação, restauração, } \\
\text { reconstrução, adaptação e procedimentos. Conselho Internacional de } \\
\text { Monumentos e Sítios, na Austrália. }\end{array}$ \\
\hline 1982 & $\begin{array}{c}\text { Declaração de } \\
\text { Nairóbi }\end{array}$ & $\begin{array}{l}\text { Organização das Nações Unidas para o Meio Ambiente. Revisão da } \\
\text { conferência de Estocolmo. Recomendações para proteção e melhoramento } \\
\text { do meio ambiente. Assembleia Mundial dos Estados, no Quênia. }\end{array}$ \\
\hline 1982 & $\begin{array}{l}\text { Declaração de } \\
\text { Tlaxcala }\end{array}$ & $\begin{array}{l}\text { Sobre os perigos e ameaças do patrimônio arquitetônico na América. } \\
\text { Recomendações: revitalização com pesquisa e prática interdisciplinar; } \\
\text { responsabilidades do serviço público quanto aos prejuízos causados; } \\
\text { comunicação das experiências de preservação; valorização das soluções } \\
\text { tradicionais; responsabilidade das escolas de arquitetura em criar } \\
\text { mestrados e doutorados em restauração. } 3^{\circ} \text { Colóquio Interamericano } \\
\text { sobre a Conservação do Patrimônio Monumental. }\end{array}$ \\
\hline 1985 & $\begin{array}{l}\text { Declaração do } \\
\text { México }\end{array}$ & $\begin{array}{l}\text { Conceito de cultura, identidade cultural e patrimônio cultural. Discussão } \\
\text { sobre a "Dimensão cultural do desenvolvimento", cultura e democracia; } \\
\text { relação entre cultura, educação, ciência e comunicação. Recomendações } \\
\text { para a cooperação cultural internacional. Conferência Mundial sobre as } \\
\text { Políticas Culturais. }\end{array}$ \\
\hline 1986 & $\begin{array}{c}\text { Carta de } \\
\text { Washington }\end{array}$ & $\begin{array}{l}\text { Definição de cidade histórica. Princípios e objetivos da salvaguarda de } \\
\text { bairros e cidades históricas. Métodos e instrumentos: estudo multidisciplinar } \\
\text { com observância à Carta de Veneza. Carta Internacional para a } \\
\text { Salvaguarda das Cidades Históricas. }\end{array}$ \\
\hline 1987 & $\begin{array}{l}\text { Carta de } \\
\text { Petrópolis }\end{array}$ & $\begin{array}{l}\text { Definição de "sítio histórico" e recomendações para ações de preservação. } \\
\text { Proteção legal a partir instrumentos: tombament, inventário, normas } \\
\text { urbanísticas, isenções e incentivos, declaração de interesse cultural e } \\
\text { desapropriação. "Valor social" considerado maior que o valor de } \\
\text { mercadoria. } 1^{\circ} \text { Seminário Brasileiro para Preservação e Revitalização } \\
\text { de Centros Históricos. }\end{array}$ \\
\hline 1987 & $\begin{array}{c}\text { Carta de } \\
\text { Washington }\end{array}$ & $\begin{array}{l}\text { A salvaguarda das cidades e bairros históricos deve estar inserida no } \\
\text { planejamento territorial e urbano, com politica apropriada de } \\
\text { desenvolvimento economico e social. Carta Internacional para a } \\
\text { Salvaguarda das Cidades Históricas. }\end{array}$ \\
\hline 1989 & $\begin{array}{l}\text { Declaração de } \\
\text { São Paulo }\end{array}$ & $\begin{array}{l}\text { Declara a necessidade de incorporar as tecnologias como sensoriamento } \\
\text { remoto, aerofotogrametria, reprodução a laser, microscopia eletrônica e } \\
\text { outros meios para a conservação de sítios históricos e no estudo territorial } \\
\text { e fundiário dos espaços urbanos. Jornada Comemorativa do } 25^{\circ} \\
\text { aniversário da Carta de Veneza. }\end{array}$ \\
\hline 1990 & $\begin{array}{l}\text { Carta de } \\
\text { Lausanne }\end{array}$ & $\begin{array}{l}\text { Continuação da Carta de Veneza. Definição de patrimônio arqueológico. } \\
\text { Políticas de conservação integrada; Legislação e economia; Inventário; } \\
\text { Intervenções no sítio; Preservação e conservação; Qualificações } \\
\text { profissionais. Carta para Gestão e Proteção de Patrimônio } \\
\text { Arqueológico. }\end{array}$ \\
\hline 1994 & $\begin{array}{c}\text { Conferência de } \\
\text { Nara }\end{array}$ & $\begin{array}{l}\text { Considera a diversidade cultural e de patrimônio. Discussão sobre "valores } \\
\text { e autenticidade", amparados na Carta de Veneza. Conferência sobre a } \\
\text { autenticidade em relação à Convenção do Patrimônio Mundial. }\end{array}$ \\
\hline 1995 & Carta de Brasilia & $\begin{array}{l}\text { A necessidade de discutir a questão da "autenticidade", diante da realidade } \\
\text { regional "de uma cultura sincretista e de uma cultura de resistência". } \\
\text { Autenticidade e identidade; Autenticidade e mensagem; Autenticidade e } \\
\text { contexto; Autenticidade e materialidade; Graduação da autenticidade; }\end{array}$ \\
\hline
\end{tabular}




\begin{tabular}{|c|c|c|}
\hline Ano & Nome & Descrição/ Evento \\
\hline & & $\begin{array}{l}\text { Conservação da autenticidade. Documento Regional do Cone Sul sobre } \\
\text { Autenticidade. }\end{array}$ \\
\hline 1995 & $\begin{array}{c}\text { Recomendação } \\
\text { da Europa }\end{array}$ & $\begin{array}{l}\text { Faz referência a outros documentos patrimoniais. Traz em anexo: definição } \\
\text { de paisagem e paisagem cultural. Recomendação sobre a conservação } \\
\text { integrada das áreas de paisagens culturais com as políticas paisagísticas, } \\
\text { adotada pelo Comitê de Ministros. } 543^{\circ} \text { encontro de vice-ministros. }\end{array}$ \\
\hline 2010 & Carta de Brasília & $\begin{array}{l}\text { Propõe a participação dos jovens no Comitê do Patrimônio Mundial da } \\
\text { UNESCO, inserção da educação patrimonial no conteúdo escolar, inclusão } \\
\text { social patrimonial, identificação e registro de bens culturais. Fórum Juvenil } \\
\text { de Patrimônio Mundial acerca da proteção e promoção do Patrimônio } \\
\text { Mundial. }\end{array}$ \\
\hline
\end{tabular}




\section{Causas da deterioração rochosa}

A durabilidade está diretamente relacionada ao desempenho satisfatório de um material, em relação ao objetivo que este foi utilizado ou projetado. Este desempenho satisfatório refere-se à manutenção de suas condições normais de resistência para o qual foi empregado (Neville 2001). Ou seja, é a capacidade do material de se comportar da forma requerida, isto é, semelhante à inicial, sem comprometimento de suas características, em um determinado período de tempo. Este período de tempo mostra o seu estado limite, ou seja, sua vida útil. Medeiros et al. (2011) definem vida útil como o "período efetivo de tempo durante o qual uma estrutura ou qualquer de seus componentes satisfazem os requisitos de desempenho do projeto, sem ações imprevistas de manutenção ou reparo".

Na norma ASTM C 119-14, a durabilidade também é baseada no fator tempo, para verificar a manutenção das características originais da rocha, ou seja, as mesmas encontradas quando a rocha é extraída de uma pedreira. Nesta norma, a durabilidade é definida como um conceito dinâmico que trata da capacidade da rocha manter suas características essenciais de aparência e resistência.

De maneira geral, a durabilidade da rocha está condicionada a fatores intrínsecos e extrínsecos. Dos intrínsecos, o considerado mais importante deles, por muitos autores, é a porosidade; sendo que a configuração e ligação entre estes poros também é bastante importante, pois caso eles estejam interligados e diminuam de diâmetro para o interior da rocha, a capilaridade agirá fortemente, levando líquidos rapidamente para seu interior. Uma vez em seu interior, esses líquidos podem cristalizar sais ou reagir quimicamente com a rocha, dissolver minerais ou gerar minerais secundários, o que é chamado de intemperismo químico.

A alterabilidade $(\mathrm{M})$, que é o grau de propensão à deterioração da rocha em função do tempo, é definida por Aires-Barros (1991 apud Frascá 2003a) como um conceito dinâmico (Eq. 1). Este tempo não é o tempo geológico, geralmente utilizado quando o assunto são as rochas; ele é o tempo na escala de vida humana e depende do uso e das intempéries a que esta rocha é submetida.

$$
M=f(i, e, t)
$$

Eq. 1

Onde:

$i=$ fatores intrínsecos dependentes do tipo de rocha como grau de fissuramento, porosidade e natureza do material exposto às intempéries; 
e $=$ fatores extrínsecos, relativos ao meio em que ocorre a alteração como temperatura, $\mathrm{pH}$, Eh, quantidade de água e forças bióticas;

$\mathrm{t}=$ tempo.

Para avaliar a alterabilidade, os parâmetros citados acima devem ser acompanhados ao longo do tempo.

Processos mecânicos e químicos, controlados em sua intensidade pelo clima, são responsáveis pela alteração das rochas (Tucker 2014).

\subsection{Intemperismo}

A norma ABNT NBR 15012 (2013), da Associação Brasileira de Normas Técnicas, define intemperismo como "conjunto dos processos de natureza física, química ou biológica que atuam na superfície terrestre e que levam à desintegração e decomposição química das rochas e minerais". Segundo Neves (2011), o intemperismo é "a alteração das rochas, através de processos físicos e químicos, que produzem minerais em equilíbrio com as condições ambientais, ou seja, é a transformação de minerais primários das rochas (ígneas, sedimentares e metamórficas) em novos minerais, mais estáveis sob condições de superfície".

Os fatores que controlam o intemperismo são:

- clima: variação sazonal da temperatura, umidade e precipitação;

- rocha parental: diferentes resistências aos agentes intempéricos;

- flora e fauna: matéria orgânica para as reações químicas, além de movimentar materiais;

- relevo;

- tempo.

Quanto aos tipos de intemperismo, temos o químico e o físico. Estes dois, apesar de agir de forma diferente, sempre atuam conjuntamente. O físico aumenta a superficie de contato da rocha com ar e com a água, por meio de fraturas. A velocidade com que eles atuam depende do clima, do local e do grau de empacotamento cristalino. As condições atmosféricas das grandes cidades fazem com que o intemperismo aja mais rapidamente.

O intemperismo físico causa a fragmentação e desagregação das rochas, separando os grão minerais. Suas causas são a variação de temperatura durante a noite, o congelamento de água nas fissuras e fraturas, o crescimento de raízes de plantas, entre outras. 
O intemperismo químico ocorre principalmente devido à formação dos minerais que compõem a rocha terem ocorrido em outras condições de pressão e temperatura, o que os tornam instáveis na superficie terrestre. Estes minerais sofrem transformações químicas, principalmente oxidação e hidrólise, para que se tornem estáveis novamente.

O principal agente do intemperismo químico é a água das chuvas, que carrega poluentes, como por exemplo o gás carbônico $\left(\mathrm{CO}_{2}\right)$, que torna a água ácida $\left(\mathrm{H}_{2} \mathrm{CO}_{3}-\right.$ ácido carbônico). $\mathrm{O}$ íon $\mathrm{H}^{+}$fica livre e reage com os minerais, liberando em solução cátions alcalinos, como $\circ \mathrm{K}^{+}$e $\mathrm{Na}^{+}$e alcalino-terrosos, como $\mathrm{Ca}^{2+} \mathrm{e} \mathrm{Mg}^{2+}$. $\mathrm{Na}$ interface mineral x solução, ocorre o rompimento estrutural, culminando na liberação de $\mathrm{Al}$ e Si, como íns ou polimerizados, para a solução. Estes elementos podem se recombinar, formando minerais secundários ou ser lixiviados (Toledo et al. 2009). Esta deterioração, com o passar do tempo, leva à falência dos materiais, afetando a estrutura de uma edificação.

Em relação ao clima, quando este é árido, o intemperismo físico predomina sobre o químico. Já quando o clima é úmido, ou seja, com alta disponibilidade de água, há predominância do químico sobre o físico. Outro fator importante é o tipo de rocha, pois o intemperismo físico tende a predominar quando se trata de rochas ígneas e o químico em rochas sedimentares e metamórficas (Gusmão Filho 2008).

Portanto, conclui-se que a alteração das rochas é um processo natural, que pode ser acelerado pela ação antrópica.

Como modo de diminuir a taxa de deterioração, são utilizadas as técnicas de reduzir a entrada de água por meio de tratamentos químicos na superfície, implementação de programa de manutenção periódica e reparação de áreas danificadas.

Assim, a deterioração das rochas ocorre devido aos seguintes fatores:

- Ambientais: poluição, umidade do ar, temperatura e ozônio;

- Biológicos: presença de plantas, microrganismos e animais;

- Arquitetônicos: posição geográfica da obra, orientação de assentamento das rochas com camadas ou estratificações e utilização de produtos incompatíveis para 0 assentamento ou fixação;

- Geológicos: propriedades intrínsecas da rocha, formação de minerais secundários, expansão e contração de minerais e desastres naturais;

- Manutenção: técnicas e produtos inadequados;

- Fatores antrópicos: incivilidade e intervenção inadequada. 
Esses fatores, geralmente ocorrem conjuntamente, com a predominância de um deles, o que faz com que a alteração seja mais intensa. Os fatores ambientais agem quimicamente e a rocha responde fisicamente.

\subsubsection{Fatores externos}

\section{- Poluentes}

A atmosfera é formada por uma mistura gasosa a partir da superfície terrestre e seu término não é um consenso. A parte dela que é interessante para este trabalho, a troposfera, possui uma espessura que varia de 16 a $19 \mathrm{~km}$. Sua composição básica na parte mais próxima da superfície é constituída por $78 \%$ de $\mathrm{N}_{2}, 21 \%$ de $\mathrm{O}_{2}$ e partes menores de argônio, dióxido de carbono e outros gases como elementos traço. A alteração destas proporções ou desta composição, seja ela por elementos naturais ou sintéticos, é chamada de poluição (Frascá 2003a).

Este é um tema importante para esta pesquisa, pois os poluentes, sejam eles gasosos, líquidos, na forma de aerossóis ou mesmo particulados, que podem ser lançados ou formados na atmosfera pela interação de dois ou mais elementos, afetam de maneira direta e irreversível os materiais pétreos. Como consequência, as rochas que ficam expostas a este tipo de agressão, passam por mudanças estéticas como perda de brilho e de cor, bem como por mudanças estruturais como a dissolução, fraturas e quebras. Portanto, conhecer a atuação dos poluentes pode auxiliar na escolha de medidas preventivas para proteger a rocha deste tipo de deterioração (Amoroso e Fassina 1985).

Os poluentes sozinhos geralmente não causam danos estruturais às rochas, alterando apenas a estética. Quando esses poluentes estão associados à água, ela os leva para dentro da rocha ou se mistura com eles e forma substâncias mais danosas. A alteração das rochas por este meio, é lenta e gradual, tornando o material menos competente e visualmente diferente. A mistura da água com os poluentes é responsável por $85 \%$ da formação de $\mathrm{SO}_{2}$ e $\mathrm{NO}_{3}$ na atmosfera. Mas a água também pode ter ação benéfica, lavando os poluentes da superfície.

Quando um poluente é depositado na superfície rochosa sem a interação com a água, é chamado de deposição seca. Este evento ocorre continuamente. Quando há interação com a água, seja para formar substâncias ou apenas para transporte, é chamado de deposição úmida. Este tipo de deposição está condicionada com a precipitação ou com o aumento da umidade relativa do ar. 
A deposição seca de gases ácidos, depende da umidade higroscópica, que é proveniente da umidade do ar. Este tipo de deposição depende da natureza do material, do tamanho dos poros e da superfície específica (Frascá 2003a).

Segundo esta autora, todos os poluentes têm caráter ácido e, em poucos dias, juntamente com as partículas de água da atmosfera, sob influência do oxigênio, raios solares e temperatura, podem formar aerossóis, névoa, chuva ácida, chegando a pH entre 3 e 4,5 .

As características mais comuns dos poluentes são mostradas na Tabela 5.1.

Dentre os poluentes atmosféricos, os que mais afetam as rochas expostas às intempéries são:

- Óxidos de enxofre: $0 \mathrm{SO}_{2}$ (dióxido de enxofre) é considerado o poluente atmosférico mais degradador de rochas, sendo formado quando o enxofre $\left(S^{2-}\right)$ reage com o oxigênio $\left(\mathrm{O}_{2}\right)$ (Eq. 2).

$$
\mathrm{S}+\mathrm{O}_{2} \rightarrow \mathrm{SO}_{2}
$$

Eq. 2

Quando $\circ \mathrm{SO}_{2}$ reage com a água, pode formar ácido sulfuroso $\left(\mathrm{HSO}_{3}\right)$ (Eq. 3).

$$
\mathrm{SO}_{2}+\mathrm{H}_{2} \mathrm{O} \rightarrow \mathrm{H}_{2} \mathrm{SO}_{3}
$$

Eq. 3

$\mathrm{O} \mathrm{SO}_{2}$ pode reagir com gás ozônio $\left(\mathrm{O}_{3}\right)$, e formar $\circ \mathrm{SO}_{3}$ gasoso (Eq. 4), que quando em contato com o vapor d'água e outras substâncias presentes na atmosfera, forma o ácido sulfúrico $\left(\mathrm{H}_{2} \mathrm{SO}_{4}\right)$ (Eq. 5). O ácido sulfuroso e o ácido sulfúrico são os maiores contribuintes da chuva ácida (Amoroso e Fassina 1985).

$$
\begin{aligned}
& \mathrm{SO}_{2}+\mathrm{O}_{3} \rightarrow \mathrm{SO}_{3}+\mathrm{O}_{2} \\
& \mathrm{SO}_{3}+\mathrm{H}_{2} \mathrm{O} \rightarrow \mathrm{H}_{2} \mathrm{SO}_{4}
\end{aligned}
$$

$\mathrm{Na}$ cidade de São Paulo, desde o ano de 2003 até o ano de 2013, a média anual de $\mathrm{SO}_{2}$ caiu para menos da metade (Figura 5.1), o que é benéfico à maior durabilidade das rochas tratadas e sem tratamento. 
Tabela 5.1 - Características dos principais poluentes atmosféricos (adaptado de Frascá 2003a).

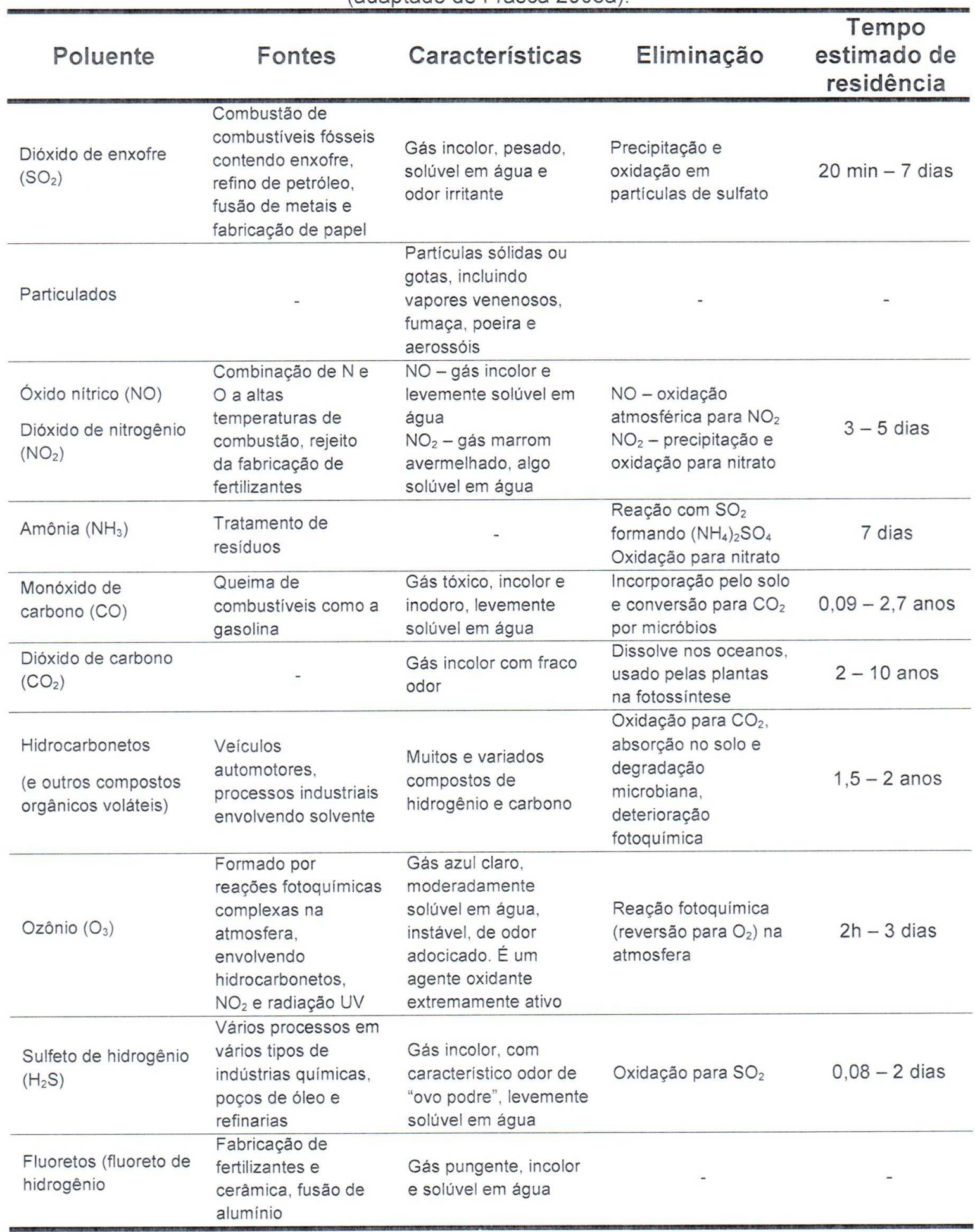




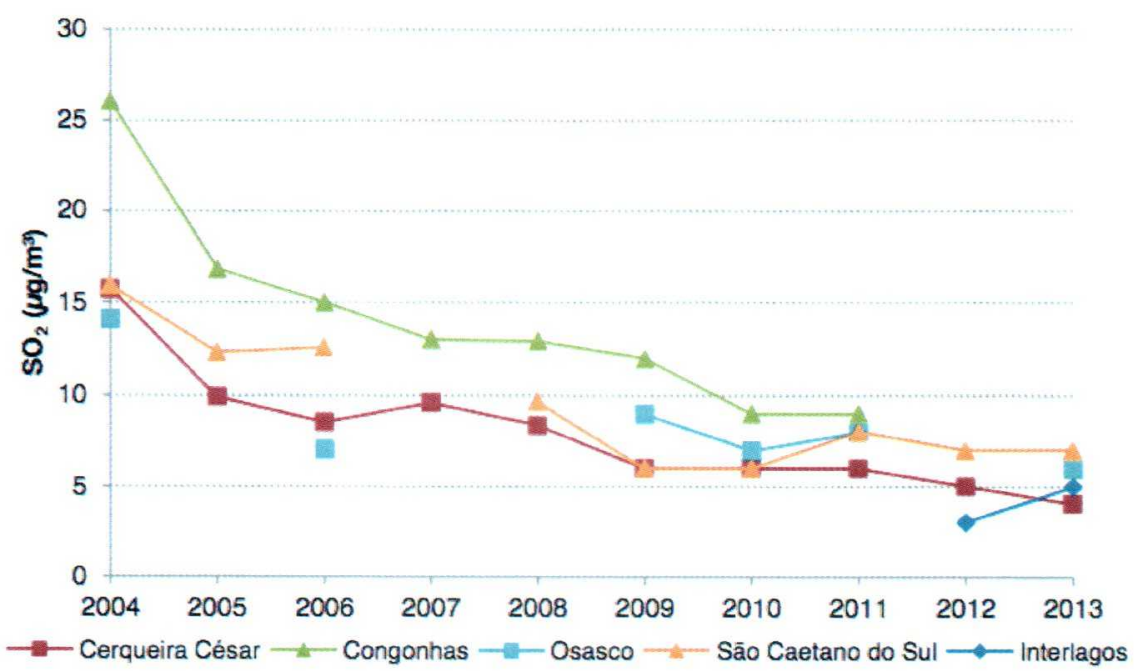

Figura 5.1 - Média anual da concentração de $\mathrm{SO}_{2}$ atmosférico na cidade de São Paulo (Fonte: Relatório anual CETESB 2013).

- Óxidos de nitrogênio: o óxido nítrico (NO) não é muito perigoso ou danoso, pois não é solúvel em água. Porém, quando afetado pelos raios ultravioleta e pelo ozônio, se transforma em dióxido de nitrogênio $\left(\mathrm{NO}_{2}\right)$ (Eq. 6), que possui impacto considerável sobre as rochas. Os $\mathrm{NO}_{x}$ ocupam parte importante na formação das chuvas ácidas.

$\mathrm{O} \mathrm{NO}_{2}$ também pode ser produzido pela queima do carvão, óleo e gás natural ou quando a temperatura é alta o bastante, o que leva o oxigênio e o nitrogênio a se associarem (Kupchella e Hyland 1992).

$$
\mathrm{N}_{2}+2 \mathrm{O}_{2} \rightarrow 2 \mathrm{NO}_{2}
$$

Eq. 6

Por sua vez, $0 \mathrm{NO}_{2}$ pode reagir com água e formar ácido nitroso $\left(\mathrm{HNO}_{2}\right)$ e ácido nítrico $\left(\mathrm{HNO}_{3}\right)$ (Eq. 7).

$$
2 \mathrm{NO}_{2}+\mathrm{H}_{2} \mathrm{O} \rightarrow \mathrm{HNO}_{2}+\mathrm{HNO}_{3}
$$

A ação dos nitratos em patrimônio pétreo pode ser correlacionada à ação de sais solúveis, o que, no entanto, não é muito evidente (Amoroso e Fassina 1985).

A concentração média anual de $\mathrm{NO}_{2}$ nas diversas estações de monitoramento da Grande São Paulo é mostrada na Figura 5.2. Pode-se verificar que entre 2007 e 2011 houve declínio dos valores medidos em diversas estações. 


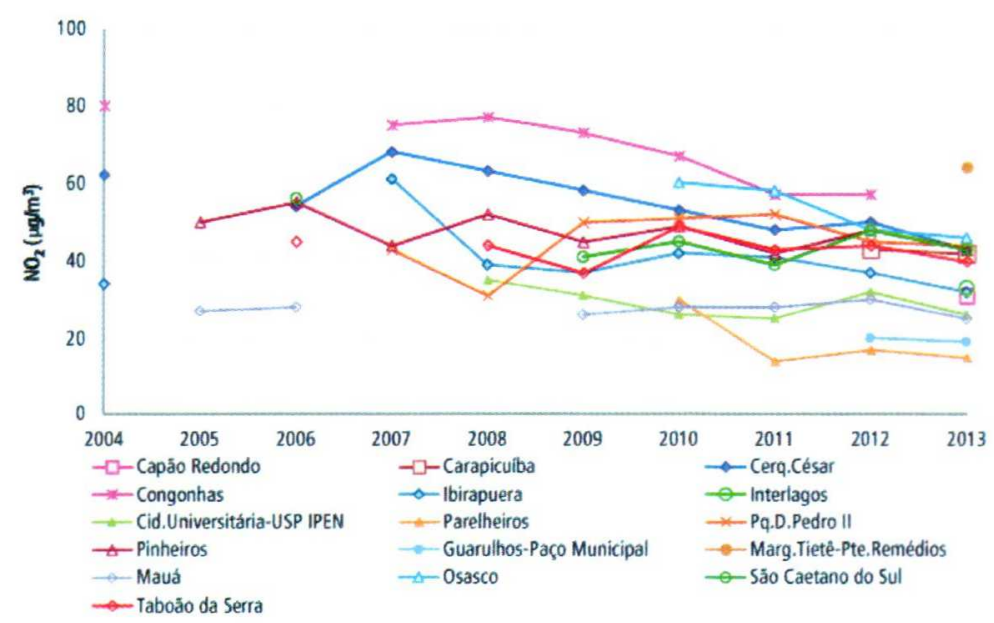

Figura 5.2 - Média anual da concentração de $\mathrm{NO}_{2}$ na Grande São Paulo (Fonte: Relatório anual CETESB 2013).

- Monóxido de carbono: formado, principalmente, pela queima incompleta de combustíveis ricos em carbono como os derivados do petróleo ou carvão, mas também gerado naturalmente (aparecendo misturado com outros gases como o metano) pelo decaimento de materiais, expelido por vulcões e gerado por reações químicas na atmosfera superior (Kupchella e Hyland 1992). Este poluente interfere muito pouco quando o assunto é a deterioração de rochas. A evolução anual das médias da concentração de monóxido de carbono (CO) na Grande São Paulo é mostrada na Figura 5.3. De 2007 a 2013 nota-se leve declínio na emissão deste gás.

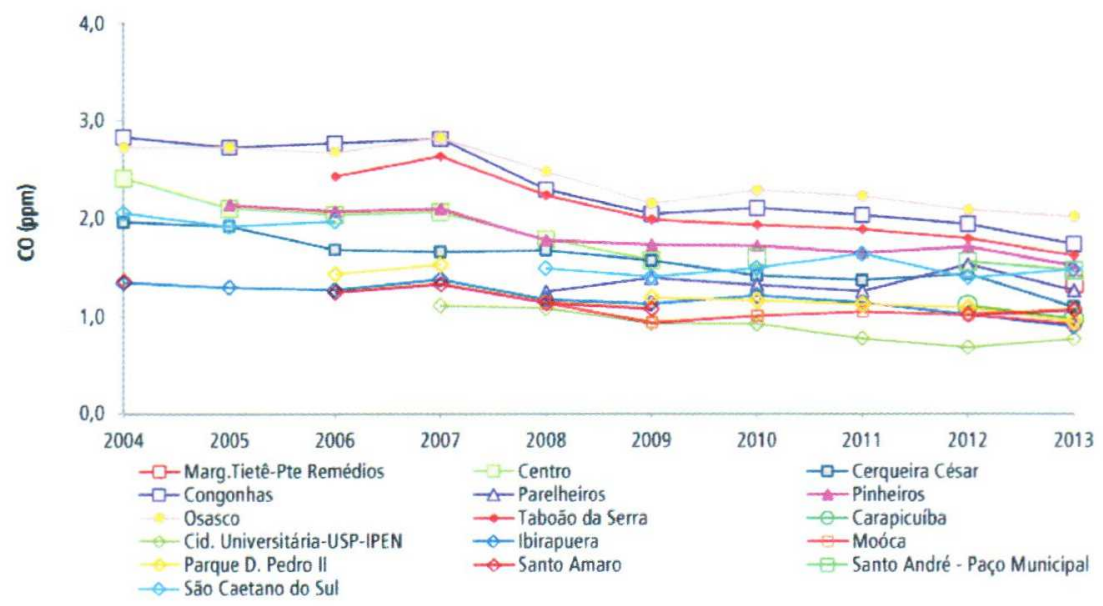

Figura 5.3 - Média anual da concentração de CO na Grande São Paulo (Fonte: Relatório anual CETESB 2013).

- Dióxido de carbono: gás incolor de odor fraco, também conhecido como gás carbônico. É formado pela respiração, fermentação de açúcares e outras comidas, 
queima de carvão, madeira, tabaco e outros materiais que contém átomos de carbono em sua composição. Representa $0,03 \%$ da atmosfera, sendo um componente menor. É relativamente inócuo e retém calor proveniente dos raios infravermelhos. Quando solubilizado em água, forma ácido carbônico (Kupchella e Hyland 1992), provocando a dissolução dos carbonatos de rochas calcíticas e dolomíticas como o calcário e o mármore, formando bicarbonatos de cálcio e magnésio; podendo ainda dissolver alguns ions metálicos em silicatos como micas e feldspatos (Amoroso e Fassina 1985). O dióxido de carbono $\left(\mathrm{CO}_{2}\right)$ não é um parâmetro medido pelas estações de monitoramento da Grande São Paulo.

- Particulados ou aerossóis: são partículas suspensas no ar, provenientes de substâncias sólidas (particulados) ou líquidas (aerossóis), respondendo por $5 \%$ dos poluentes. Fumaças são suspensões de particulados em uma fase gasosa, geradas da queima incompleta de combustíveis.

Eles representam $5 \%$ dos poluentes atmosféricos e são constituídos de ácido sulfúrico, sais de sulfato, sais de metais tais como chumbo e óxidos de ferro, névoas e garoas líquidas, poeiras de carbono e sílica finamente divididas, dentre outros que não são catalogados (Amoroso e Fassina 1985). As partículas apresentam dimensões entre $0,005 \mu \mathrm{m}$ e $100 \mu \mathrm{m}$. A chuva não consegue remover partículas menores que 2 $\mu \mathrm{m}$. Portanto estas permanecem suspensas no ar, podendo ser transportadas por longas distâncias (Kupchella e Hyland 1992).

A média anual da emissão de materiais particulados finos na região da Grande São Paulo pode ser verificada na Figura 5.4.

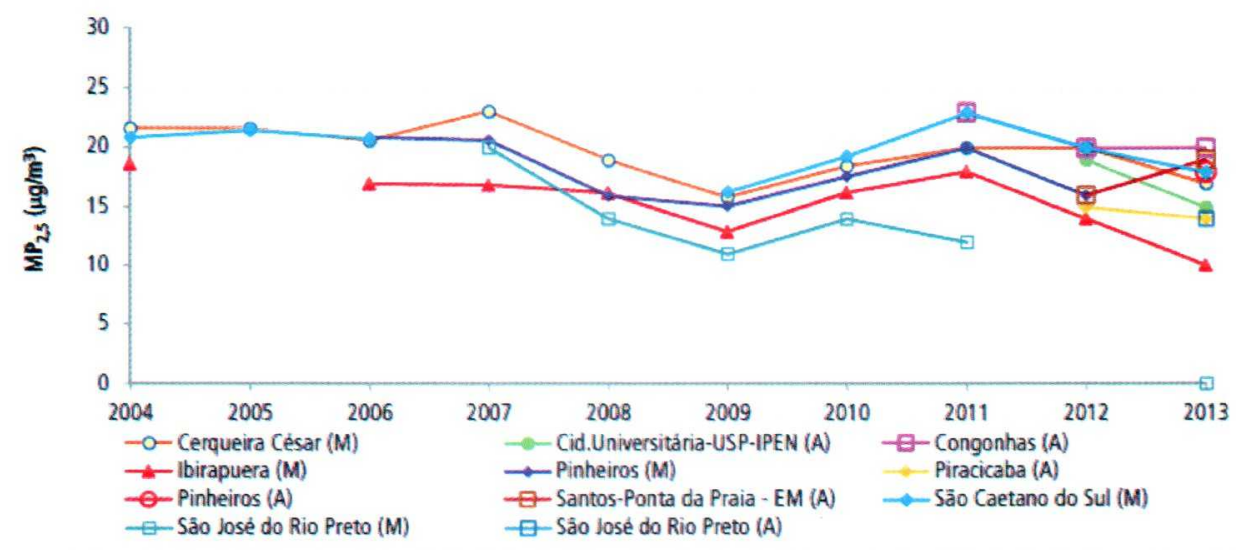

Figura 5.4 - Média anual dos materiais particulados finos na Grande São Paulo (Fonte: Relatório anual CETESB 2013). 
As chuvas são caracterizadas como ácidas quando seu $\mathrm{pH}$ é $<5,6$. Nos grandes centros urbanos, ela apresenta $\mathrm{pH}$ perto de 4. Neste $\mathrm{pH}$, a ação do ácido é muito maior do que no $\mathrm{pH} 5,6$, afetando todos os tipos de materiais construtivos, desde concretos, cimentos e rochas, inclusive arenitos e granitos. (Frascá 2003b).

\section{- Umidade}

Antes do tratamento é importante verificar se a rocha está seca ou se não apresenta umidade excessiva. Se a rocha não está visivelmente molhada, é importante verificar se há umidade pela presença de sais. Alguns sais são higroscópicos, atraindo umidade e eventualmente podem deliquescer se a umidade estiver acima da taxa de equilíbrio do sal. A existência de colonização biológica pode favorecer a retenção de umidade, dificultando o tratamento. A umidade proveniente das chuvas pode ser minimizada consultando a previsão do tempo, agendando o trabalho em períodos mais secos e protegendo a área com plásticos ou alguma outra cobertura temporária. Em locais como o Egito o problema é a baixa umidade e a alta temperatura, que faz com que os alcoxisilanos evaporem antes de alcançarem o estado de gel. No entanto, esta baixa umidade faz com que a deterioração rochosa seja muito mais lenta do que em lugares úmidos, haja visto a idade das pirâmides, que passaram por todos estes anos sem os tratamentos tecnológicos a que se tem acesso atualmente.

Em pequenas áreas, o problema da umidade no interior da rocha pode ser resolvido com a aplicação de solventes de baixa evaporação e que sejam misciveis em água. Estes formarão uma solução quando o alcoxisilano, que é um consolidante à base de silano, for aplicado. O produto utilizará a água capilar para compor o consolidante. Em grande escala, esta técnica é impraticável. Utiliza-se então secador de cabelos, aquecedor e desumidificador de ar. Devido à inflamabilidade dos consolidantes, os aquecedores devem ser desligados no momento da aplicação do produto (Wheeler 2005).

\section{- Colonização biológica}

O crescimento biológico está intrinsicamente relacionado com fatores ambientais como, temperatura, umidade relativa, chuvas, nutrientes disponíveis, formando padrões de escorrimento que produzem umidade persistente.

Existem vários tipos de organismos que colonizam as rochas, como algas, bactérias, fungos, musgos, árvores, videiras e trepadeiras. Fungos e bactérias não 
interferem na aplicação de consolidantes devido a seu pequeno tamanho. Todavia, as algas são visíveis e formam filmes verdes e marrons que mantém a umidade na rocha. Os mais problemáticos são os liquens, que possuem grandes corpos de frutificação, cobrindo a superfície de maneira dramática. Devido a esta poderosa cobertura, eles também mantém a umidade na superfície e dificultam a evaporação da água do interior da rocha. Dependendo do tipo de líquen, esses corpos de frutificação aderemse a rocha. Musgos geralmente não são bem aderidos à rocha e formam uma camada fina que carrega água. Videiras e trepadeiras cobrem e sombreiam as superfícies, deixando-as sujas ou inacessíveis para o tratamento (Wheeler 2005).

A remoção desses organismos depende do estado da rocha e quão presos estão a ela. Algas e musgos podem ser removidos mecanicamente. A remoção das algas pode ser realizada por meio de sua secagem e seus resíduos removidos com escova. Os musgos fracamente presos também podem ser removidos com escova. Secar e remover mecanicamente musgos e liquens sem um pré-condicionamento, leva ao risco da perda de grãos ou até de grandes pedaços de rocha. Secar os liquens pode dificultar sua remoção, pois eles tornam-se mais duros. Molhar os liquens com água, solvente ou com uma mistura dos dois deixa-os mais fácil para serem removidos manualmente sem causar danos à rocha. Aplicar misturas diluídas em água e solventes como etanol e acetona, leva a condições necessárias para que a maioria dos liquens possa ser removida após a evaporação da água. Em qualquer caso, há sempre o risco de manchar a rocha pelo umedecimento de liquens escuros ou profundos. Em videiras e trepadeiras, a única solução é a remoção mecânica. Outro modo de remover a colonização biológica é pela aplicação de biocidas, que são agentes químicos que visam inativar bactérias, fungos, musgos e até árvores. Estes produtos não são prejudiciais às pessoas e causam poucos danos ao ambiente. É necessário tomar algumas precauções quanto aos efeitos sobre as rochas e quando de seu contato com os alcoxisilanos. Alguns biocidas com estanho em sua composição diminuem o tempo da formação do gel de alguns produtos (Wheeler 2005).

Os alcoxisilanos, que serão descritos mais a frente, têm apresentado diminuição ou supressão do crescimento biológico, o que pode ser atribuído à toxicidade de alguns catalisadores, como o dibutiltindilurato, ou pela supressão de água no momento da reação com os alcoxisilanos.

Muitas vezes, acredita-se que com a remoção dos musgos, liquens ou ainda organismos superiores, o problema está acabado. Isto não é real, pois os esporos de alguns destes organismos podem viver por muito tempo, mesmo após a aplicação de produtos bastante fortes e destrutivos a eles. A melhor maneira de acabar com estes 
organismos é eliminar sua fonte de vida: a água. Mas como na maioria dos casos isto não é possível, o indicado é que seja feita a manutenção periódica impedindo que os organismos que crescem entrem em seu estágio reprodutivo; o que pioraria 0 problema. A manutenção periódica minimiza os estragos causados por estes organismos, visto que ela retirará as sementes e esporos que foram carregados pelo vento. Há de se ter em mente que nenhuma destas soluções é definitiva; sempre haverá a necessidade de manutenção.

\section{- Sais solúveis}

Apesar de geralmente ser considerado um fator externo, algumas rochas possuem sais solúveis em sua composição química, que quando solubilizados, oferecem os mesmos riscos do enriquecimento externo por sais.

Rochas que contém sais, geralmente, necessitam de consolidação, pois estes, além de comuns, são um poderoso modo de deterioração, gerando formas como desintegração granular, descamação e esfoliação, dependendo da concentração local e tipo dos sais. Tais tipos de alteração são causados pelo aumento de tensão causado pela cristalização dos sais nos poros e fraturas. Se a rocha permanecer seca, os sais não causarão problemas. Contudo, como já citado anteriormente, alguns sais apresentam deliquescência, o que aumenta a umidade da rocha, dificultando o tratamento com alcoxisilanos. A presença de sais higroscópicos influencia na umidade das rochas, pois atraem umidade. Quanto mais porosa a rocha, mais espaço existe para ser ocupado por estes sais e maior o favorecimento a entrada de umidade. Todavia, se a rocha possuir poros grandes o suficiente para acomodar os sais cristalizados sem a criação de nenhuma tensão interna, os sais não serão danosos a ela. Portanto, rochas de poros grandes não são facilmente degradadas pela ação dos sais. Rochas nesta situação devem ser dessalinizadas e secas vagarosamente para evitar problemas de cristalização (Wheeler 2005).

Um dos objetivos da consolidação é reduzir os danos durante a remoção de sais. Bradley (2000 apud Wheeler 2005) verificou que a cristalização dos sais quebra as pontes silicáticas formadas pela aplicação de produtos $\mathrm{OH}$, diminuindo a durabilidade do mesmo.

Produtos que possuem a catálise ativada pela umidade relativa, como o Silres ${ }^{\circledR}$ $\mathrm{OH}$ (Wacker), não devem ser utilizados em rochas com sais. O Brethane, que utiliza o naftaleno como catalisador, é desestabilizado na presença de sais, fazendo com que o tempo do ponto de gel não possa ser previsto (Wheeler 2005). 


\section{- Temperatura}

Os materiais utilizados em construções, sejam eles naturais ou artificiais, dilatam quando calor é aplicado sobre eles. Essa variação volumétrica, que pode ser somente unidimensional, leva a produção de pequenas fissuras que diminuem a resistência do material. Quando o calor é causado pela radiação solar, a temperatura gerada vai depender do ângulo de incidência destes raios, da espessura do material, de sua condutividade e de sua cor.

\subsubsection{Fatores intrínsecos}

Porosidade, estrutura e mineralogia são as características intrínsecas da rocha que mais afetam a velocidade de seu intemperismo.

\section{- Porosidade}

Conhecer tamanho e configuração dos poros da rocha é importante, pois esta característica física é responsável pelo transporte de água. Conforme diminui o diâmetro dos poros, o poder de sucção aumenta e a água penetra mais profundamente. Nos poros com diâmetro inferior a $1 \mu \mathrm{m}$, o poder de sucção é muito grande (Frascá 2003a). Este fato é causado pela atração da água na direção das paredes dos poros que ocorre devido a uma das forças fundamentais da capilaridade, a adesão ou adsorção. Devido à tensão superficial, que é a força de atração entre as moléculas de água, juntamente com a atração entre as moléculas de água e as paredes, forma-se uma superfície curva na interface água $x$ ar. Isto pode ser demonstrado colocando um tubo de vidro transparente e fino dentro da água. Quanto menor o raio interno do tubo (capilar), mais a água subirá (Figura 5.5). Esta superfície é chamada de hidrofilica. A altura de elevação da água é inversamente proporcional ao raio interno do tubo e à densidade do líquido. Se for considerada a água a $20^{\circ} \mathrm{C}$, pode-se utilizar a equação 8 para determinar a altura da água (Brady e Weil 2012). 


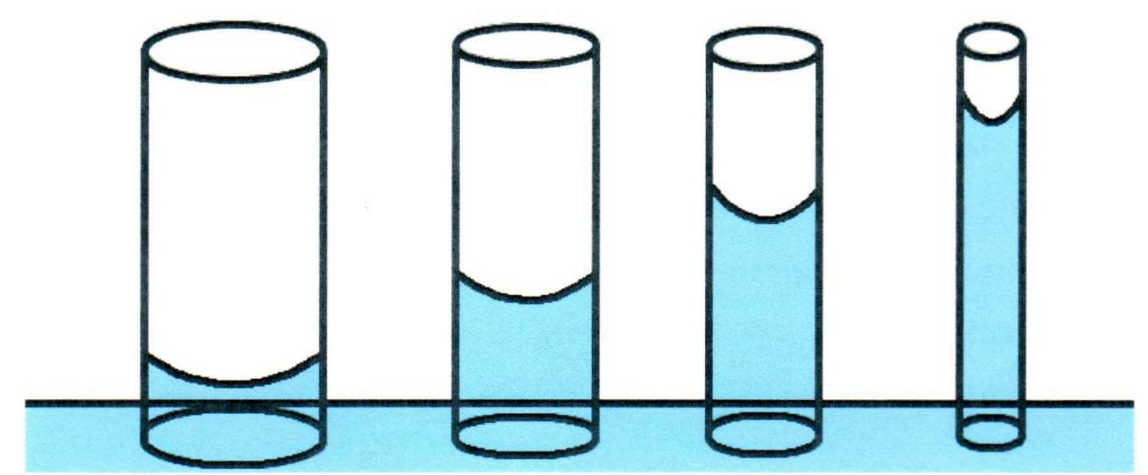

Figura 5.5 - Comportamento capilar da água em tubos com diferentes tamanhos de raio.

$$
h=\frac{0,15 \mathrm{~cm}^{2}}{r}
$$

Onde:

$\mathrm{h}=$ altura de ascensão $(\mathrm{cm})$;

$r=$ raio do tubo $(\mathrm{cm})$.

Quando se trata de capilaridade, costuma-se pensar somente na ascensão da água. No entanto, este movimento ocorre tridimensionalmente (Brady e Weil 2012).

\section{- Mineralogia}

A mineralogia também é um fator extremamente condicionante, pois as rochas compostas de minerais com baixo grau de alterabilidade, como o quartzo, e que possuem baixa porosidade, não são alteradas facilmente.

Quando as rochas se formam elas são estáveis mineralógica e estruturalmente, naquelas condições de pressão e temperatura. Quando são expostas à superfície, os minerais são modificados pelas novas condições climáticas, até que um ponto de estabilidade seja novamente alcançado. Este processo de modificação é chamado de intemperismo. Goldich (1938) propôs uma tabela que mostra a estabilidade mineral de quatro rochas estudadas (um anfibolito, um gnaisse granítico e dois diabásios) à medida que ocorrem as perdas dos elementos químicos (Figura 5.6). Esta tabela é o inverso da série de Bowen, o que indica que os minerais formados em temperaturas mais baixas são mais estáveis na superfície terrestre. 

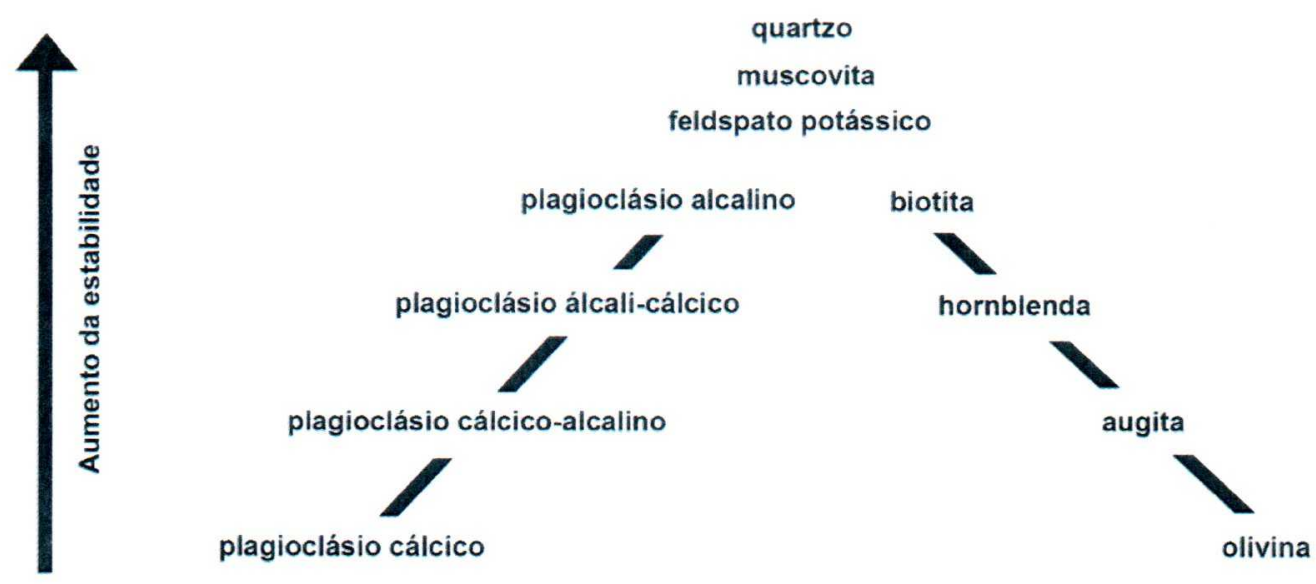

Figura 5.6 - Série de Goldich - série de estabilidade mineral (adaptado de Goldich 1938).

Quando esta estabilidade se perde, novos minerais são formados, para alcançar novamente a estabilidade. Aires-Barros (1991 apud Frascá 2003a) propõe uma relação entre os minerais, os produtos resultantes e as principais alterações provocadas pelo intemperismo (Figura 5.7).

Winkler (1997) aponta que feldspatos e silicatos ferromagnesianos se transformam em minerais mais estáveis, como os argilominerais, por hidratação e as micas, por rápida perda de ferro. Entretanto, a oxidação é um fenômeno que ocorre mais rapidamente do que a perda de ferro. Minerais carbonáticos e sulfatos dissolvem, e o quartzo, que por sua vez é muito estável, não se altera. O enriquecimento residual em $\mathrm{Al}^{3+}$ ocorre por lixiviação do $\mathrm{Si}^{4+}$, o que leva à diminuição da resistência da rocha.

Toledo et al. (2009) mostram que quando a totalidade do potássio dos Kfeldspatos é eliminada em solução, há a formação de caulinita. Quando parte do potássio não é eliminada em solução, forma-se esmectita, que é um argilomineral expansivo. Neste caso, ocorreu eliminação de $87 \%$ do potássio, $46 \%$ da sílica e todo o alumínio permaneceu.

A transformação do feldspato em caulinita foi observada nas análises feitas pelo IPT, com o arenito proveniente da fachada do Teatro Municipal.

Com os produtos e técnicas atualmente disponíveis, é possivel apenas retardar ou minimizar os efeitos causados pelo intemperismo, mas não revertê-lo. Para aplicar essas técnicas e produtos, é indispensável que se conheça a rocha, o produto utilizado, a interação entre eles e os possiveis resultados da aplicação do produto na rocha com o passar do tempo. Um grande problema é a simulação da passagem do tempo, pois não há nenhum equipamento que imite o ambiente exato em que a rocha está exposta. Vale ressaltar que este ambiente tende a mudar com o passar do tempo devido à urbanização que aumenta, à emissão de poluentes e a modificação da insolação (prédios altos próximos a um monumento, podem mudar a quantidade de luz 
solar recebida). Para simular a exposição aos agentes mais nocivos, existem câmaras de intemperismo como a de saturação e secagem, umidade, congelamento $e$ descongelamento, névoa salina e de $\mathrm{SO}_{2}$. Os estudos intempéricos (alteração acelerada) iniciaram-se na década de 1930 por iniciativa de engenheiros e arquitetos, no intuito de prever a durabilidade e a resistência de rochas e concretos utilizados na construção civil. Os ensaios de caracterização tecnológica procuram representar diversas solicitações pelas quais poderá passar a rocha desde seu processamento até seu uso final. Com estes estudos, consegue-se determinar para quais tipos de uso é indicada uma dada rocha, ou seja, busca-se determinar as propriedades relevantes da rocha e que também constituem parâmetros de controle dos fatores de alteração.

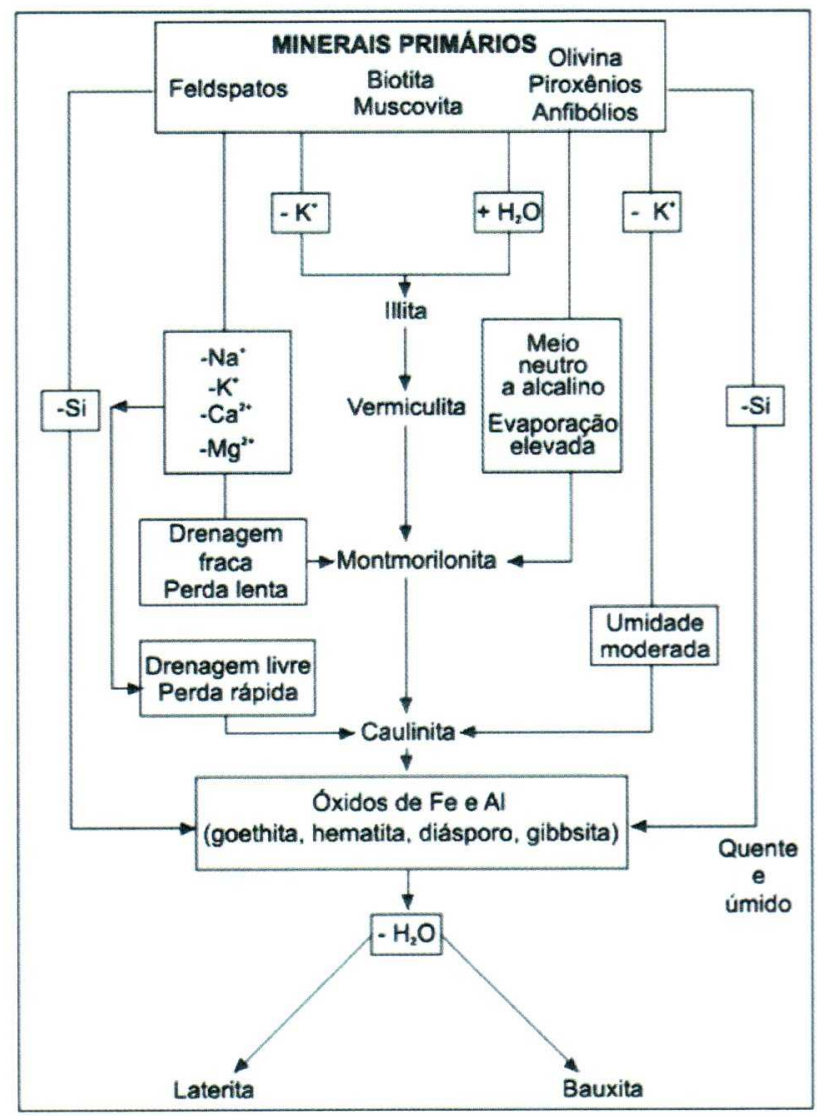

Figura 5.7 - Representação esquemática dos processos intempéricos (Aires-Barros 1991 apud Frascá 2003b). 


\section{Objeto de estudo: Teatro Municipal de São Paulo}

Segundo Santos (2007), no fim do século XIX, a população da cidade de São Paulo sentia a necessidade de possuir um teatro grandioso para receber as estrelas, principalmente europeias, que aqui vinham se apresentar. Alguns artistas até se negaram a se apresentar na cidade, devido à falta de estrutura. Nesta época, existia 0 Teatro São José, porém este não suportava as necessidades de uma cidade em rápido crescimento como São Paulo.

Em maio de 1895, Carlos Garcia apresentou um projeto na Câmara Municipal oferecendo 3 anos de isenção de impostos a quem realizasse a obra. Como não apareceram candidatos e em 1896 o Teatro São José foi destruído por um incêndio, a Prefeitura ofereceu 20 anos e depois 50 anos de isenção de impostos, aparecendo então os primeiros projetos. Mas a grande dificuldade corria em torno do apoio financeiro para a realização da obra. Algumas pessoas tentaram, mas não conseguiram a quantia necessária para a realização de uma construção de tão grandioso vulto (Brandão 1993).

Segundo este autor, em 1900, São Paulo necessitava urgentemente do teatro, pois outras cidades com população menor já tinham construído seus teatros, como por exemplo, Recife, Salvador e Maranhão. Na época, São Paulo contava com 85 mil habitantes. Iniciou-se então, o debate que nos é próximo até a presente data. Deveria - Estado financiar tal tipo de obra? Pela primeira vez, nota-se a ação conjunta entre a iniciativa privada e o Estado, com objetivo cultural. Mas havia muitos opositores que diziam que o dinheiro público não deveria servir para patrocinar o divertimento para uma única classe da sociedade.

A associação entre prefeitura, que cede o terreno, e Estado, que injeta capital (2,3 mil contos de réis), as obras do teatro tiveram início no dia 05 de junho de 1903 com projeto de Claudio Rossi e Domiziano Rossi e execução do Escritório Técnico de Ramos de Azevedo (Secretaria Municipal de Cultura de São Paulo). Cabe destacar que 0 arquiteto Ramos de Azevedo foi o responsável pela modernização da cidade de São Paulo. O projeto ficou bastante parecido com a Ópera de Paris, desenhado por Charles Garnier, mostrando claramente sua inspiração (Santos 2007).

As obras foram concluídas após oito anos e três meses, o que deu início à vinda de grandes nomes da Europa para realizar apresentação em São Paulo. A grandiosidade desta obra competia com a do Teatro de Buenos Aires. Sua construção seguiu o estilo renascentista barroco e teve um custo que foi o dobro do previsto $(4,5$ mil contos de réis). Alguns citam o estilo como eclético, uma mistura do barroco do setecentos, art noveau e renascentista (Martini 2010). Era o prédio mais alto da cidade 
na época e tinha $3.600 \mathrm{~m}^{2}$ de construção e jardins com $12.000 \mathrm{~m}^{2}$. Apenas 40 anos após sua construção, o teatro já estava esmagado pelos altos prédios, com 10 ou 15 andares, que foram construídos em seu entorno.

No dia da inauguração do teatro, foi distribuída uma monografia, na qual constavam todos os fornecedores, inclusive o do arenito, comprovando que o mesmo foi extraído da Floresta Nacional (Flona) de Ipanema. Neste mesmo documento, estavam listados os fornecedores dos Granitos Itaquera e de Lageado, bem como do granito porfiróide de Itupararanga (Severo 1911).

Onze anos após sua inauguração, o teatro foi utilizado para a Realização da Semana de Arte de 1922, colocando-o mais uma vez na história brasileira. Com o passar dos anos o teatro, que era administrado pelo município, foi entrando em processo acelerado de decadência e passou a ser usado para convenções, festas de formatura e bailes de carnaval, o que causou problemas em algumas estruturas.

Em 1981, o prédio foi tombado pelo Conselho de Defesa do Patrimônio Histórico, Arqueológico, Artístico e Turístico do Estado de São Paulo (CONDEPHAAT).

No ano de 1983 o teatro ganhou seu museu, que guarda quase todos os programas de tudo que ali foi encenado (Brandão 1993).

O Teatro passou por três restaurações. A primeira foi realizada por Tito Raucht, que teve início em 1952 e durou 3 anos, e foi a que mais causou modificações em sua arquitetura interna (Santos 2011), o que foi confirmado por Fábio Almeida, assistente de Lilian Jaha (Arquiteta da Secretaria Municipal de Cultura de São Paulo) em comunicação pessoal, realizada em 19/10/2011.

A segunda grande restauração datou de 1986 a 1991 e foi coordenada por Lilian Jaha. Nesta obra, toda a infraestrutura foi modernizada e recuperada, a elétrica e a hidráulica foram substituídas, a ala nobre e a sala de espetáculos foram restauradas. O subsolo foi totalmente escavado para a criação do salão dos arcos. Esta foi a reforma que realizou mais intervenções no prédio (Santos 2011).

$\mathrm{Na}$ terceira intervenção, que foi de 2008 a 2011, as arquitetas Lilian Jaha e Rafaela Bernardes estiveram a frente das obras. Grande parte do teatro foi contemplada nesta reforma, tais como o bar, a plateia, o palco e os vitrais. A parte mais difícil deste trabalho foi a recuperação do arenito da fachada principal, que se encontrava muito degradado. As colunas e a parte inferior em granito também foram limpas e tratadas.

Santos (2007) propõe a reformulação da visita monitorada e criação de material de apoio trilíngue do Teatro Municipal. 


\subsection{Rochas utilizadas no Teatro Municipal de São Paulo}

\subsubsection{Arenito Itararé}

Esta rocha é o objeto de estudo deste trabalho.

O arenito é proveniente da Floresta Nacional de Ipanema (Flona de Ipanema), localizada na cidade de Iperó, Estado de São Paulo, que foi a Real Fábrica de Ferro de Ipanema e marcou o início da indústria siderúrgica no país. A área, que funcionou de 1811 a 1895, foi utilizada inicialmente para extração de minério de ferro, utilizado principalmente para produção de armas para a Guerra do Paraguai, além de produzir outros artigos como panelas, grades e compassos. Em um segundo momento, foi explorada na área a apatita, que era utilizada para produção de superfosfato (adubo inorgânico). Atualmente, esta área é tombada pelo IPHAN, cadastrado no livro do Tombo Arqueológico, Etnográfico e Paisagístico, constituindo patrimônio histórico, artístico e natural.

O arenito, que também é conhecido como Arenito Itararé, foi utilizado em toda a fachada frontal do teatro, nos balcões laterais e, originalmente, na balaustrada, que foi substituída por argamassa. Ele também foi utilizado para revestimento de construções, além dos próprios fornos da fábrica de ferro.

O afloramento desta rocha está localizado dentro da área denominada geologicamente de Formação Itararé, na Bacia do Paraná, que é caracterizada por rochas sedimentares e efusivas a subefusivas formadas entre as eras paleozoica e mesozoica. Por sua vez, a Formação Itararé, que pertence ao Grupo Tubarão (Carbonífero Superior a EoPermiano), é formado por rochas sedimentares que se depositaram em regime glacial (não observável na pedreira da Flona), em ambientes variados como costeiro e continental, sendo este último deltaico e fluvial (Del Lama et al. 2008).

Arenitos são considerados mais complexos que mármores e granitos quando o assunto é consolidação, pois possuem porosidade multifásica (Sassoni et al. 2013); isto é, os arenitos possuem poros de diversos tamanhos em uma mesma amostra.

Se na época da construção do teatro, houvesse tecnologia disponível para que fosse realizada uma pesquisa petrográfica deste arenito, a conclusão seria de que era uma rocha imprópria para ser utilizada em área externa devido a sua mineralogia. Vale ainda ressaltar, que a fachada composta por este arenito está voltada para a direção sul, o que insere mais um fator, que auxilia na sua rápida deterioração devido à menor insolação, que favorece a retenção da água que provém principalmente das chuvas e o crescimento de algas, bactérias e fungos. 


\subsubsection{Granito}

Foram utilizados dois tipos de granito: um de coloração vermelha (Granito Itupeva) e outro de coloração cinza (Granito Itaquera).

A rocha de coloração vermelha, foi utilizada na confecção das colunas que estão localizadas sob os arcos do Salão Nobre, nas duas varandas laterais e na fachada principal. Já foi classificada erroneamente como sendo um sienito (Método Engenharia 1991). No entanto, por meio de análise visual, é possível verificar que se trata de um granito, muito semelhante ao Granito Itupeva (Figuras 6.1 a 6.3) descrito no Catálogo de Rochas Ornamentais do Estado de São Paulo (IPT 1990) (Figura 6.4).

Este granito pode ser encontrado em outros monumentos da capital, tais como, $1^{\circ}$ Tribunal de Alçada Civil, Centro Cultural Banco do Brasil, Mosteiro São Bento, Mercado Municipal e Palácio da Justiça (Del Lama et al. 2015).

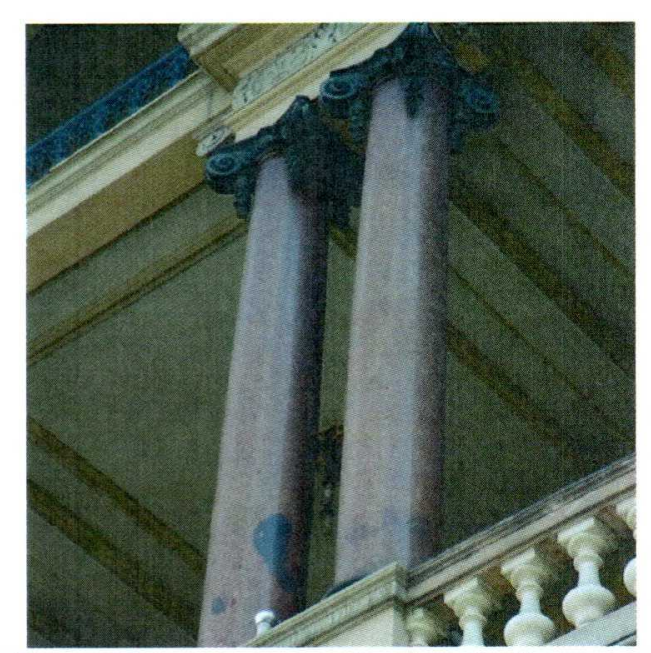

Figura 6.1 - Colunas de Granito Itupeva.

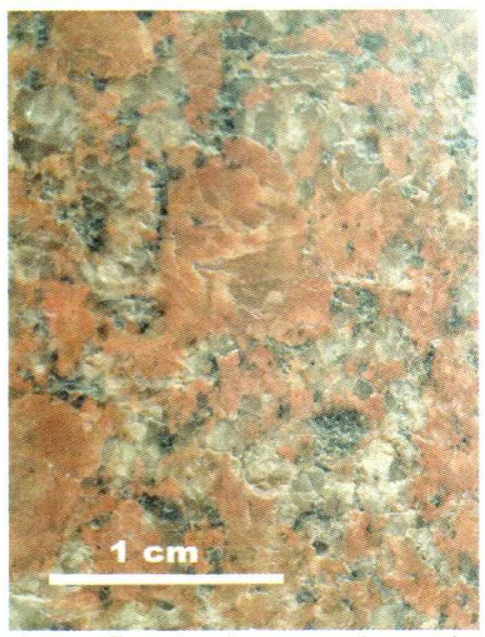

Figura 6.3 - Granito Itupeva das colunas do Teatro Municipal - em detalhe.

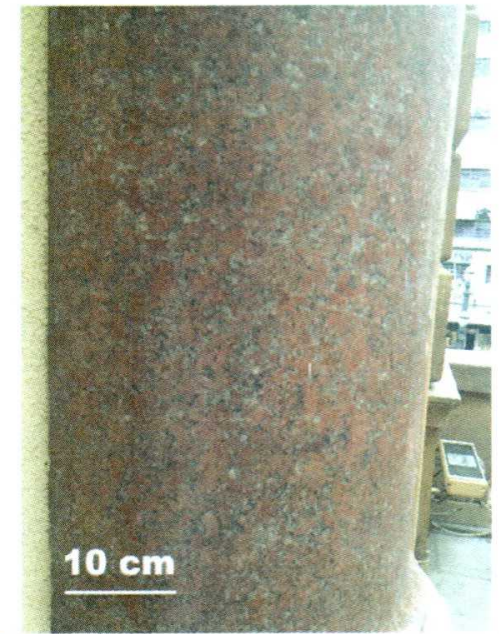

Figura 6.2 - Granito Itupeva em detalhe.

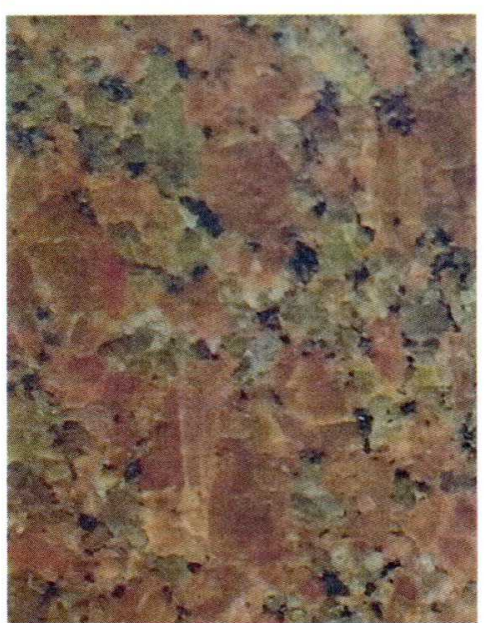

Figura 6.4 - Granito Itupeva (IPT, 1990). 
O Granito Itaquera (Figura 6.5), está presente nas quatro fachadas, uma faixa de granito cinza recobre a parte superior do subsolo, sendo utilizado também na base dos pilares (Método Engenharia 1991). Ele também está presente em colunas estruturais, no saguão de entrada. Esse granito foi reconhecido por Stern et al. (2006) e Del Lama et al. (2009) como sendo o Granito Itaquera.

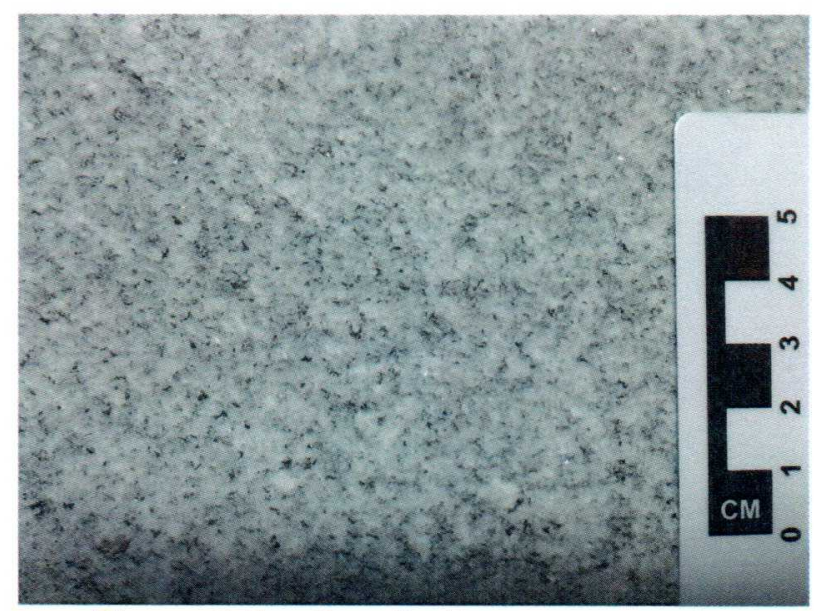

Figura 6.5 - Granito Itaquera serrado.

\subsubsection{Mármore}

Estas rochas estão localizadas na área nobre, na entrada, na escadaria e no foyer. Elas possuem diferentes colorações, como branco, cinza e amarelado (Método Engenharia 1991). Pelas diferentes colorações e características mineralógicas e petrográficas, elas são diferenciadas. Nas diferentes áreas do teatro pode-se encontrar: Mármore de Verona e Mármore de Carrara (Figura 6.6). Porém, mármore é o nome comercial de algumas rochas que, na realidade, são calcários; como é o caso do Rosso di Verona e Giallo di Verona (Figura 6.7). 


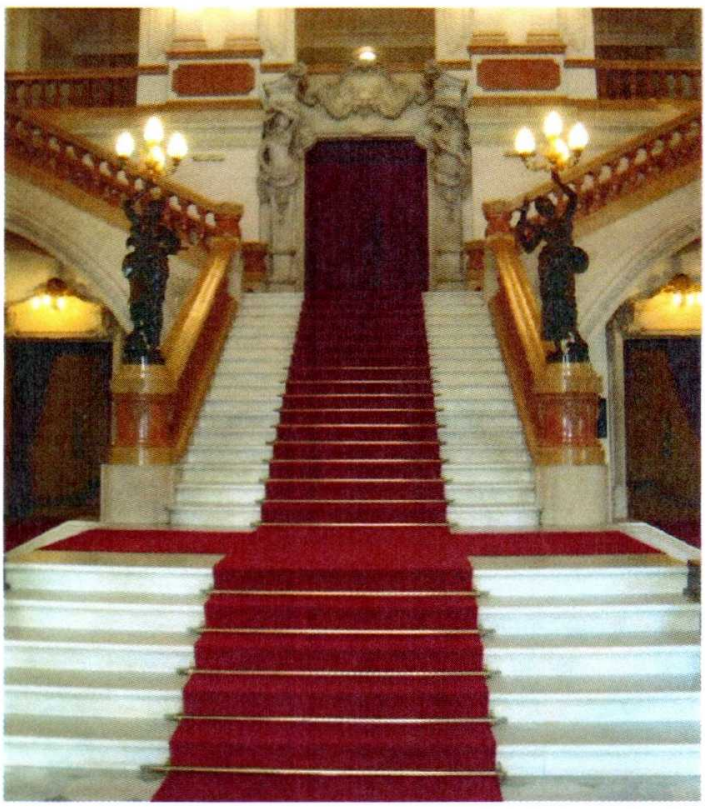

Figura 6.6 - Mármore de Carrara na escadaria.

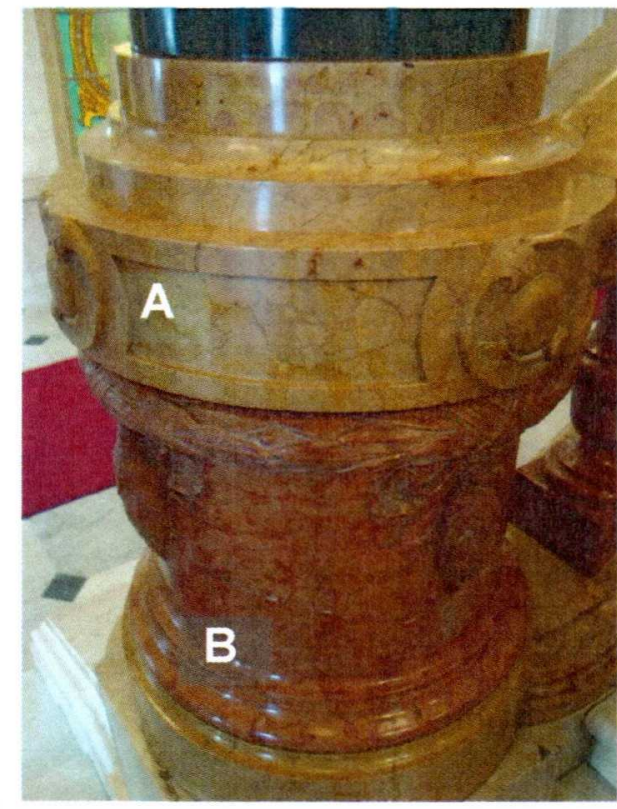

Figura 6.7 - Calcários: (a) Giallo di Verona e (b) Rosso di Verona.

\subsubsection{Outros Materiais}

Os capitéis e as bases das colunas de granito vermelho são em bronze ou em argamassa. Esses elementos, seguem o estilo jônico ou coríntio.

Máscaras, molduras, esquadrias, balaústres, capitéis, pedestais de colunas e algumas partes das alegorias foram realizadas em argamassa (Método Engenharia 1991).

\subsection{Restaurações}

Devido ao objetivo deste trabalho, não serão relatadas as modificações ocorridas na parte interna, acústica, soalhos, revestimentos, pinturas, tecidos, vitrais, dentre outros; concentrando as informações na parte pétrea do prédio.

\subsection{1. $1^{\text {a }}$ Restauração: $1952-1955$}

Em 1952, quando o Municipal entrou em reforma, o prédio encontrava-se em situação calamitosa com madeiramento apodrecido e fiação desfazendo-se.

Nesta reforma, foram realizadas as primeiras e maiores modificações estruturais. No teatro foram encontrados quinhentos e quarenta pontos de onde nada 
se via e vários outros pontos aonde só chegava som residual. Chegou-se a cogitar a demolição do prédio. Nesta intervenção buscou-se deixar o teatro mais parecido com o que era originalmente, seja nas cores das paredes, tecidos das poltronas, bordados das cortinas ou mesmo nos corrimãos folhados a ouro (Brandão 1993). Com exceção das obras estruturais, que tinham como objetivo resolver problemas graves, todas as outras intervenções seguiam a corrente de restauração que estava em voga na época, que era a de intervir buscando levar o prédio ao seu estado original, como se o tempo não houvesse passado.

Na parte rochosa não foi realizada nenhuma intervenção.

\subsection{2. $2^{\mathrm{a}}$ Restauração: 1986 a 1991}

Em 1985, foi realizado o levantamento dos problemas da fachada causados pelas intempéries, poluição e pela constante vibração produzida pela passagem dos automóveis, ônibus e metrô. Ao mesmo tempo, houve avaliação do estado dos soalhos de madeira da plateia, palco e teto, que estavam danificados e tomados por cupins de três espécies. A parte externa que é feita de arenito estava bastante avariada.

O laudo feito pelo Instituto de Pesquisas Tecnológicas (IPT), mostrava que o teatro estava prestes a virar uma ruína de luxo. Após todo o levantamento das necessidades do prédio, iniciou-se a batalha para levantar os recursos necessários para a obra.

Para a restauração da fachada foi necessário pesquisar a origem dos arenitos nela utilizados. Como resultado soube-se que os arenitos eram provenientes da Fazenda de Ipanema, que foi comprovado por meio de uma monografia distribuída no dia da inauguração, bem como na edição especial do semanário "Ilustração Paulista" $n^{\circ} 35$ de 12 de setembro de 1911. Apesar da pedreira possuir quantidade suficiente do material, foi necessária a autorização do Governo Federal para extraí-lo, pois a Flona já era tombada e a pedreira há muito estava fechada. Além de ter sido necessário encontrar mão de obra que soubesse como os blocos eram extraídos naquela época.

0 arenito estava bastante degradado devido às mudanças de temperatura, poluição urbana e às chuvas, pois é uma rocha porosa, de baixa resistência e com a presença de argilominerais expansíveis (Del Lama et al. 2008). No serviço de cantaria houve substituição, enxertos, obturação e consolidação. Para essas restaurações, foi utilizada rocha da mesma pedreira da Fazenda, hoje Flona, de Ipanema. Geólogos do 
IPT acompanharam o trabalho de extração e determinaram os melhores locais para sua obtenção. Nesta intervenção, o peitoril da balaustrada foi substituído.

Nos blocos substituídos, a adesão se deu pelo uso de uma mistura de massa e cola plástica, também chamada de Iberê. Em alguns lugares, foram utilizados pinos de aço para sustentação do peso. As obturações foram realizadas com resina de poliéster, pó xadrez e arenito triturado, que também foi chamada de argamassa. $\mathrm{Na}$ grande maioria das vezes as rochas foram lavadas com Detertec 7 (detergente neutro) e escova de cerdas macias e depois enxaguadas com água (Método Engenharia 1991, Brandão 1993).

Elementos em arenito que estavam bastante degradados foram consolidados com Paraloid B72 ${ }^{\circledR}$ (resina acrílica - copolímero de etil metacrilato). Nas rachaduras a coesão entre as peças foi recobrada com a aplicação de Primal AC (copolímero acrílico, obtido pela junção de etil acrilato e metil metacrilato) por meio de seringas. Todo o arenito do prédio foi pulverizado com uma camada impermeabilizante de verniz à base de silicone (Concremat 2010). Atualmente sabe-se por meio de estudos, que a consolidação em alguns arenitos não surte bons efeitos devido às mudanças na capilaridade da água e a cristalização de sais nas partes mais profundas provocarem o destacamento de superfície, devido à diminuição da permeabilidade à água em vapor (Poupeleer 2007, Scherer e Wheeler 2009).

O granito cinza da fachada apresentava grande sujidade (poeira, graxa e cimento) e pichações. Ele foi limpo com Detertec 7 , e as pichações foram removidas com uma solução composta por Pintoff, ácido acético e ácido cítrico. Todas as superfícies receberam jateamento com areia fina, que está proibida atualmente. Para finalizar o restauro, foi aplicado verniz impermeabilizante à base de silicone, o mesmo do arenito, com intuito de facilitar a remoção de pichações futuras. Atualmente sabe-se que, muitas vezes, um mesmo produto não serve para rochas tão distintas. Busca-se realizar testes para verificar sua ação sobre a superfície rochosa mas, antigamente, os paradigmas da restauração eram outros, bem como as normas para sua realização.

As colunas de granito rosa, que estavam com sujidade orgânica e inorgânica de origem externa, foram limpas com Detertec 7 e escova de cerdas macias. Ao final da limpeza foi aplicado o mesmo verniz impermeabilizante que foi utilizado no granito cinza e no arenito.

Nas seis alegorias feitas em bronze, localizadas no lado externo, foi realizada apenas a limpeza para a remoção de poeira com Detertec 7. A pátina formada pela reação de elementos do bronze foi mantida. Esta prática de não retirar a pátina formada pelo tempo é utilizada até hoje para que a restauração não fique artificial e para mostrar um pouco da história pela qual aquele objeto passou. Todos os conjuntos 
escultóricos receberam polimento com cera microcristalina. As peças traseiras de fixação do Drama e da Música foram tratadas com ácido fosfórico e cromato de zinco para interromper o processo de oxidação dos elementos fixadores em ferro.

O mármore do Salão Nobre estava em bom estado de conservação sendo realizada apenas sua limpeza para retirada da cera utilizada na manutenção diária com utilização de produto com toluol e Detertec 7 , bem como posterior aplicação de verniz Paraloid $B 72^{\circledR}$. As manchas mais resistentes foram retiradas com hidróxido de amônio.

Em 1988, o teatro foi reaberto, mas sua parte externa ainda estava em obras, inclusive com a presença de andaimes. No ano de 1991, quando completou 80 anos, o teatro foi entregue a São Paulo com aparência semelhante a que tinha, quando inaugurado. Grande parte da restauração foi baseada em fotos, filmes, relatórios, depoimentos, plantas antigas, pesquisas sobre materiais, além de descobertas acidentais, que foram fundamentais para reencontrar a pedreira do arenito bege, pesquisar, restaurar e reinventar fechaduras europeias (Brandão 1993).

O Patrimônio Histórico do Município foi responsável por esta obra (Martini 2010).

\subsection{3. $3^{\mathrm{a}}$ Restauração: $2008-2011$}

Nesta obra, que contou com a participação de mais de 60 profissionais, foi possível realizar o restauro completo das fachadas e da ala nobre. As intervenções foram pautadas na conservação e limpeza. As esculturas de bronze, os elementos de pedra, as esquadrias de madeira e ferro, os vitrais e a cobertura de cobre foram restaurados. A fachada, área de circulação do público, restaurante e área nobre foram limpos, retocados e protegidos (Folha de São Paulo 2008, Santos 2011).

O granito utilizado no embasamento do prédio encontrava-se em bom estado, apenas sujo em alguns locais e outros com escamação, que são devido a sais solúveis como $\mathrm{KNO}_{3}$, bastante comum neste local, devido à presença de ureia.

O granito das colunas estava em bom estado, possuindo apenas sujeira, fezes de pombos e pequenas fissuras (Concremat 2010).

A maior dificuldade desta obra foi a fachada de arenito, devido à porosidade intrínseca do material. Nas áreas onde a deterioração era profunda, foram colocadas próteses da mesma rocha e as áreas menores foram obturadas com uma mistura de arenito em pó e resina. Para a limpeza foi utilizado jateamento com microesferas de vidro. Os locais mais alterados eram onde foram realizadas reintegrações na última 
restauração. Tal fato pode ser relativo ao material retirado da pedreira ser da parte mais superficial do corpo, sendo este, mais intemperizado ou devido ao posicionamento das camadas de deposição ter sido colocado no sentido vertical. Em todo o arenito foi encontrada uma camada de biofilme de cianobactérias devido à porosidade do substrato e as argilas (montmorilonitas) que armazenam água. Outro problema encontrado no arenito é a cristalização de sais, principalmente nas cornijas. Devido à sua constituição e aliando a isso a exposição a chuvas e poluição, o intemperismo desta rocha acaba sendo acelerado.

Para toda a restauração foi necessária extensa pesquisa de materiais, para que a aparência ficasse mais próxima possível da original e para isso trabalharam conjuntamente engenheiros químicos, civis, mecânicos e elétricos e especialistas nos materiais utilizados na reforma: metais, argamassa, pedra, vitrais e madeira. Em 2007 , foram realizados testes laboratoriais para definir a técnica de limpeza ideal para as rochas (água, jateamento, microesferas de vidro ou detergentes), bem como testados emplastros para a limpeza mais profunda. O custo total da obra foi de 28 milhões (estavam previstos 18 milhões na época do edital, que inicialmente eram 5,8 milhões). Nas obras de restauração de conservação foram gastos 7,1 milhões provenientes da Prefeitura de São Paulo (15\%) e do financiamento pelo BID (Banco Interamericano de Desenvolvimento) (85\%) (Folha de São Paulo 2008, Folha de São Paulo 2010, Sacramento 2010, Santos 2011).

Conforme informado por Fernanda Lapo (comunicação pessoal com a Arquiteta da Concremat - empresa responsável por esta obra de restauro), após todo 0 processo de restauração, o arenito foi protegido com Paraloid $B 72^{\circledR}$ diluído em xilol e no granito foi utilizado Vedacil-Max. Como citado anteriormente, pode-se observar que após estudos pormenorizados e detalhados não foi possivel utilizar o mesmo produto para proteger duas rochas tão distintas como arenito e granito. Para tratar as áreas afetadas por bactérias, foi utilizado um algicida antes da aplicação do verniz. Foram excluídas todas as técnicas que necessitavam da aplicação de água.

Nesta restauração, foram tomados os devidos cuidados para que nem tudo ficasse idêntico, tendo como objetivo datar a restauração. A pintura do restaurante $e$ do bar, por exemplo, ganhou um tom diferente, evitando gerar falsos históricos. Buscou-se utilizar métodos reversíveis, apesar de já saber de antemão que nem todos o são.

As Figuras 6.8 e 6.9 mostram o aspecto do arenito da fachada antes e depois deste processo de restauro, respectivamente. A Figura 6.10 mostra alguns detalhes da fachada após o restauro. 


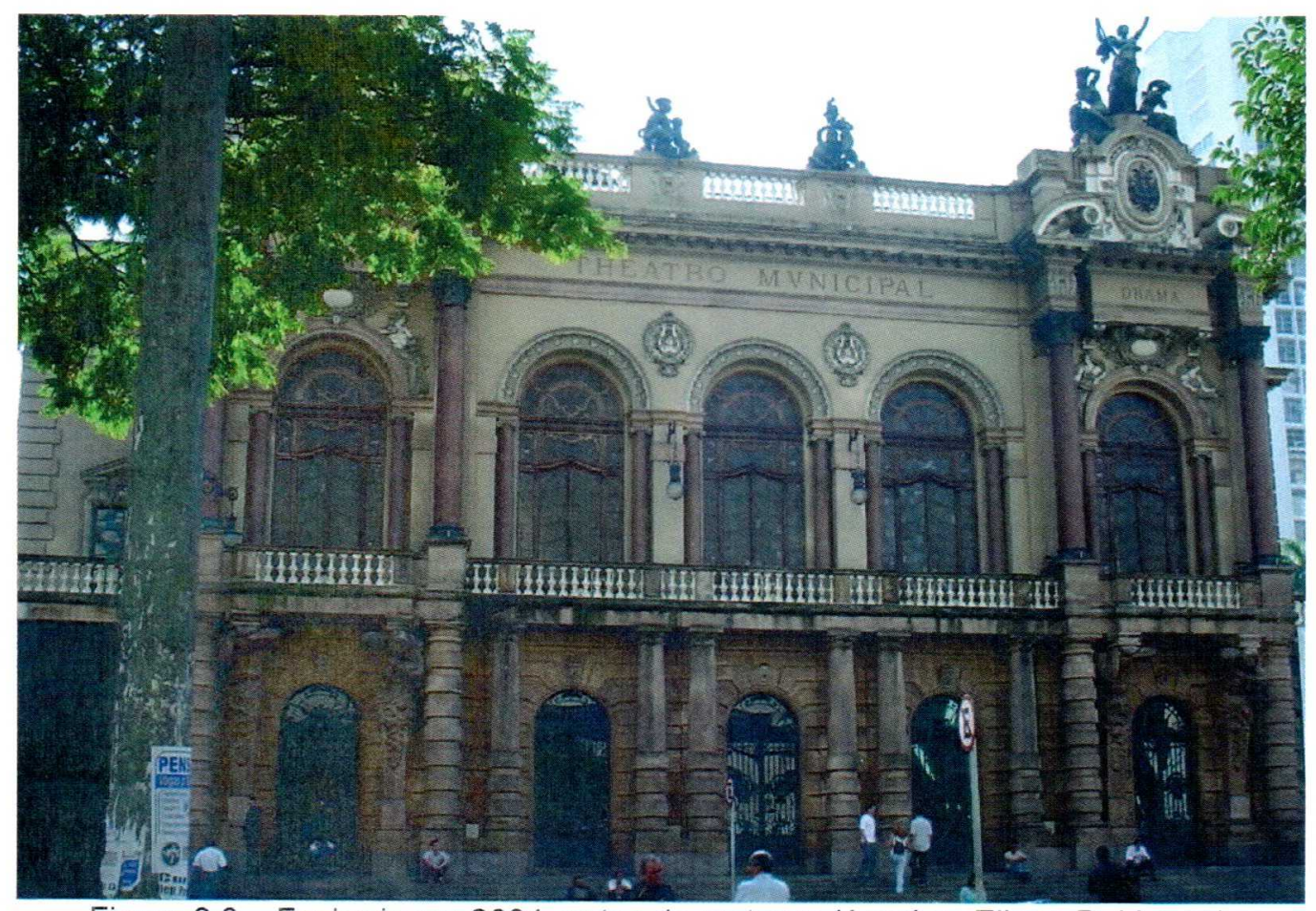

Figura 6.8 - Fachada em 2004, antes do restauro (Arquivo: Eliane Del Lama)

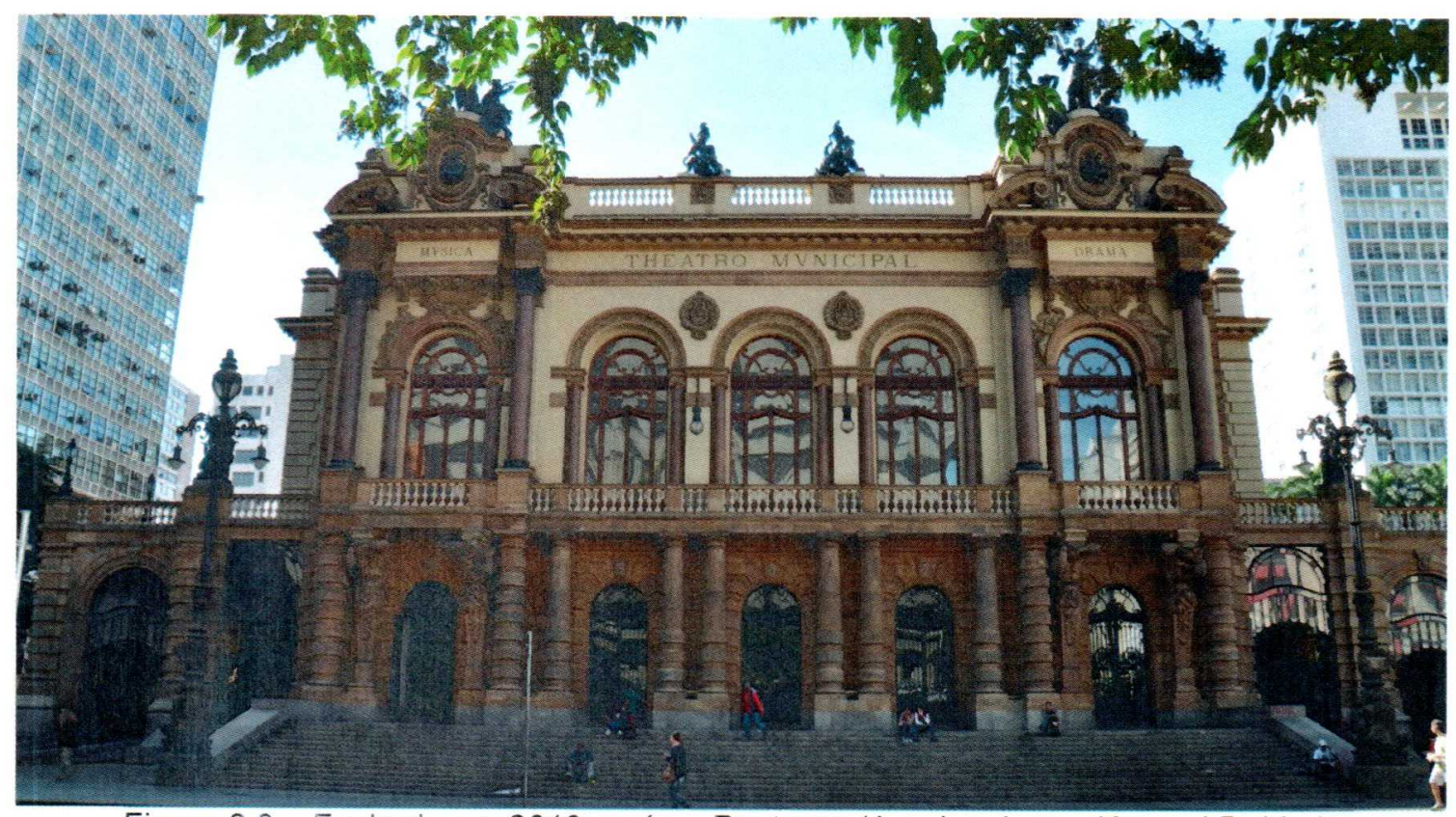

Figura 6.9 - Fachada em 2013, após o Restauro (Arquivo: Lauro Kazumi Dehira). 

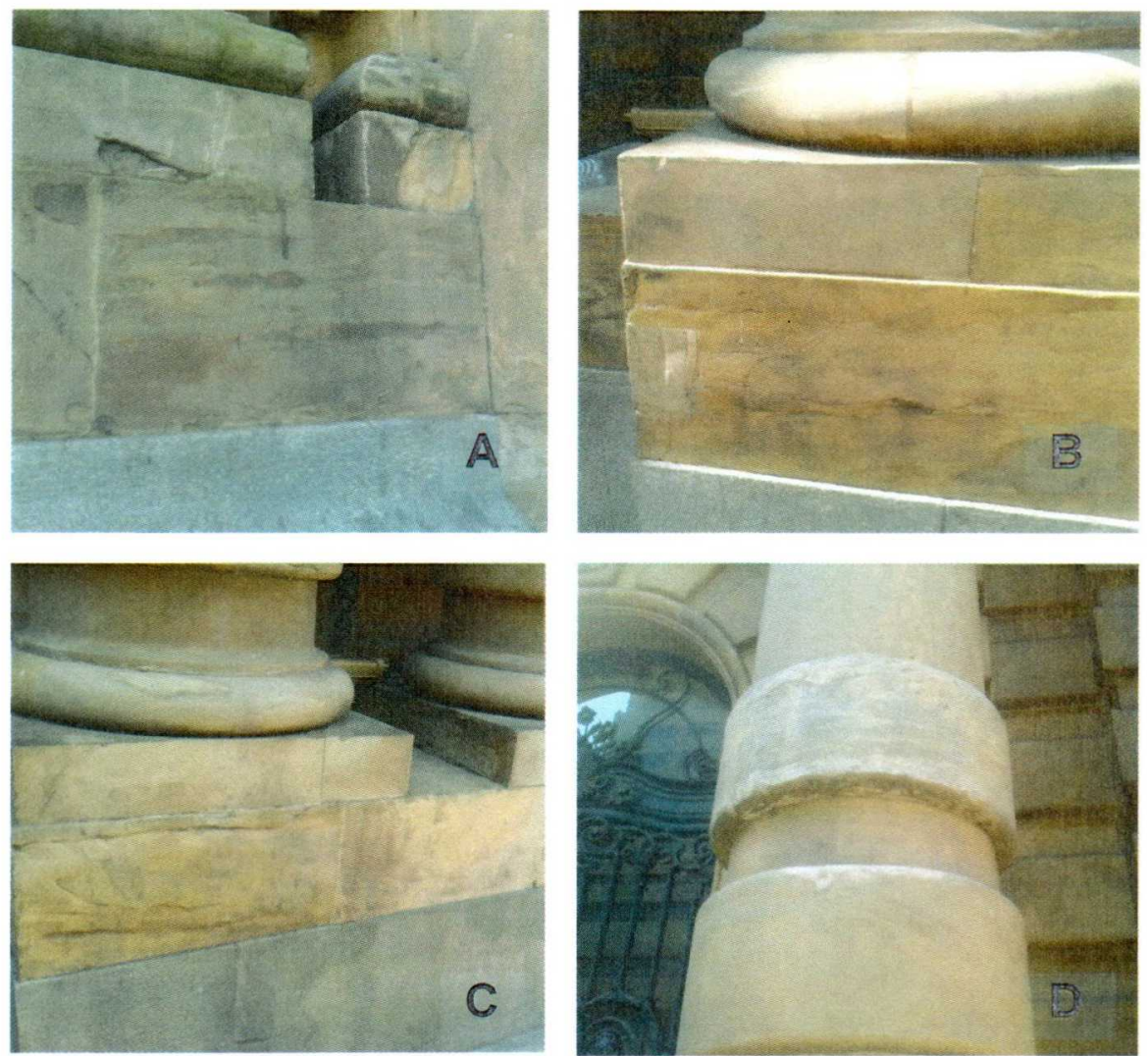

Figura 6.10 - Detalhes da fachada: (a) Interface coluna-parede, (b) Obturação na base da coluna, (c) Blocos abaixo da coluna e (d) Coluna.

\subsection{Outros prédios construídos em arenito}

Dentre as construções realizadas totalmente ou em parte com o Arenito Itararé, além do Teatro Municipal de São Paulo, pode-se citar o Palácio do Itamaraty, no Rio de Janeiro (Luiz Chieregati, comunicação pessoal).

Segundo Luciano Bonatti Regalado, coordenador do Centro de Memória da Flona de Ipanema, além do alto forno Varnhagen, construído em 1818 e da Casa das Armas Brancas, construída em 1886, existem muitos outros prédios construídos com Arenito Itararé, como por exemplo: o alto forno Mursa, o prédio da estribaria, a serraria, a casa da guarda, o forno de ustulação (no interior da mata no Morro Araçoiaba), a oficina de refino, dentre outros. O Arenito de Ipanema foi praticamente utilizado em todas as obras da Real Fábrica de Ferro, localizada na Flona de Ipanema. $\mathrm{O}$ arenito para estas construções era retirado dos terrenos da própria fábrica. Não há relatos de que o mesmo fosse comercializado pela fábrica.

Outros arenitos foram utilizados na construção do patrimônio brasileiro. Alguns exemplos são listados a seguir. 
A Catedral Metropolitana de Santo Ângelo e as Ruínas de São Miguel Arcanjo na cidade de São Miguel das Missões, RS são constituídas pelo Arenito Botucatu. Esse arenito é composto por grãos de quartzo cimentados por calcedônia. O que the confere a coloração vermelha é o óxido de ferro presente em sua composição.

Muitas igrejas do nordeste foram construídas com arenito, tais como:

- Igreja da Ordem Terceira de São Francisco, localizada no Pelourinho em Salvador e considerada uma das sete maravilhas da colonização portuguesa no mundo, sendo também Patrimônio da Humanidade;

- Igreja de Santo Antônio, localizada em Natal, é também conhecida como Igreja do Galo e tem seus detalhes em beachrocks, que é um arenito de cimentação carbonática;

- Igrejas dos Prazeres (Jaboatão dos Guararapes), São Pedro dos Clérigos (Recife), Nossa Senhora do Rosário dos Pretos (Recife), Basílica do Carmo (Recife) e Convento de Santo Antônio (Igarassú) são algumas das construções em beachrocks de Pernambuco.

\subsection{Geologia do Arenito Itararé}

A Formação Itararé pertence ao Supergrupo Tubarão (definição de Morengui 2007), que na área de estudo ocorre no morro de Araçoiaba, e possui a seguinte sequência estratigráfica da base para o topo: Complexo Embu, Grupo São Roque, Fácies Cantareira, Grupo Tubarão e Suites Alcalinas (Oliveira et al. 2005). A litoestratigrafia do Grupo Itararé é mostrada na Figura 6.11. Vale ressaltar que na Figura, o Grupo Itararé está como Formação; divisão mais aceita na época da elaboração da litoestratigrafia. 


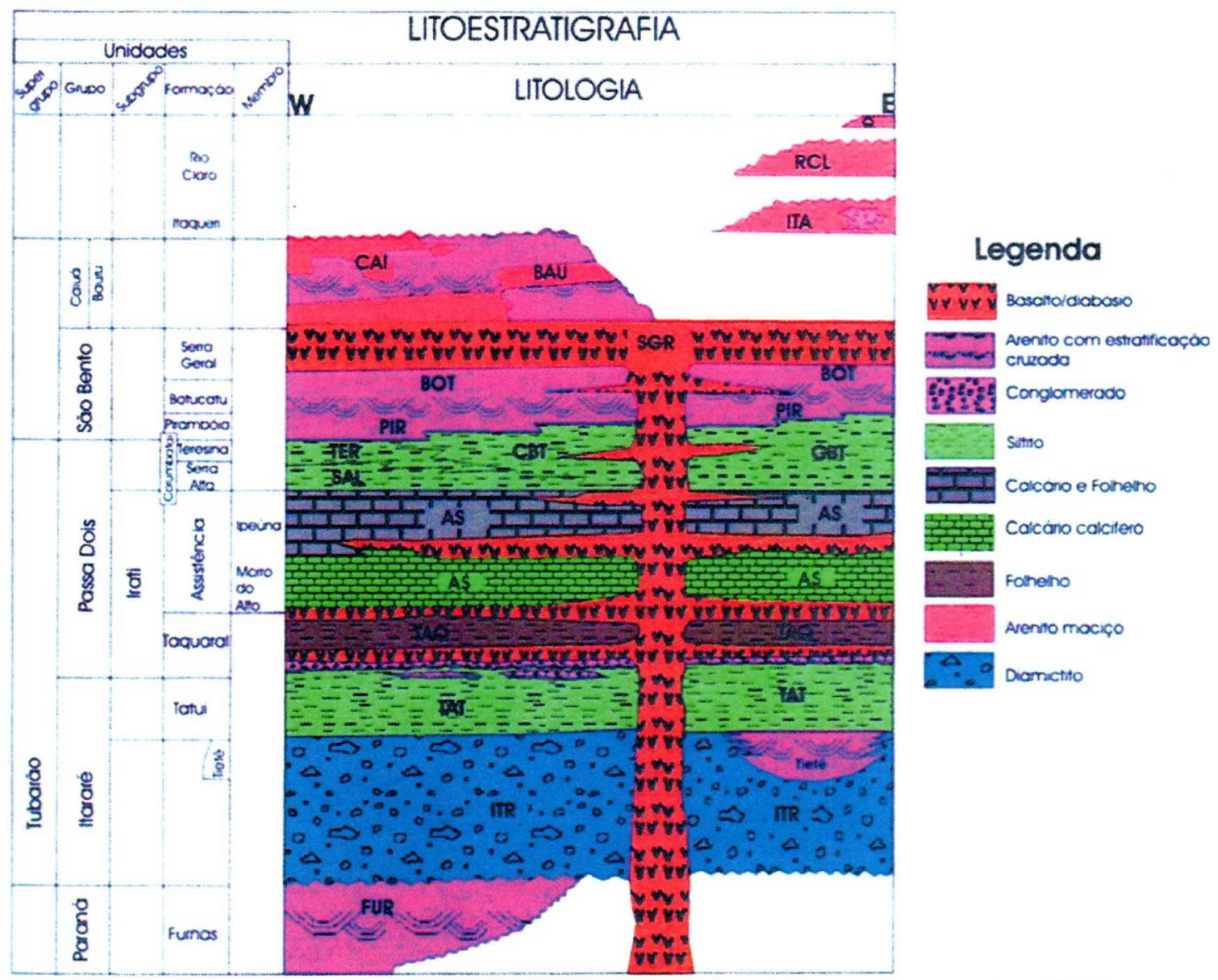

Figura 6.11 - Litoestratigrafia da Formação Itararé (adaptado Montanheiro 1999).

O mapa geológico da região de Ipanema, que é onde fica a antiga pedreira, pode ser observado na Figura 6.12. Na Figura 6.13 pode-se verificar um recorte do Mapa Geológico, que possui em destaque a região da Flona de Ipanema. 

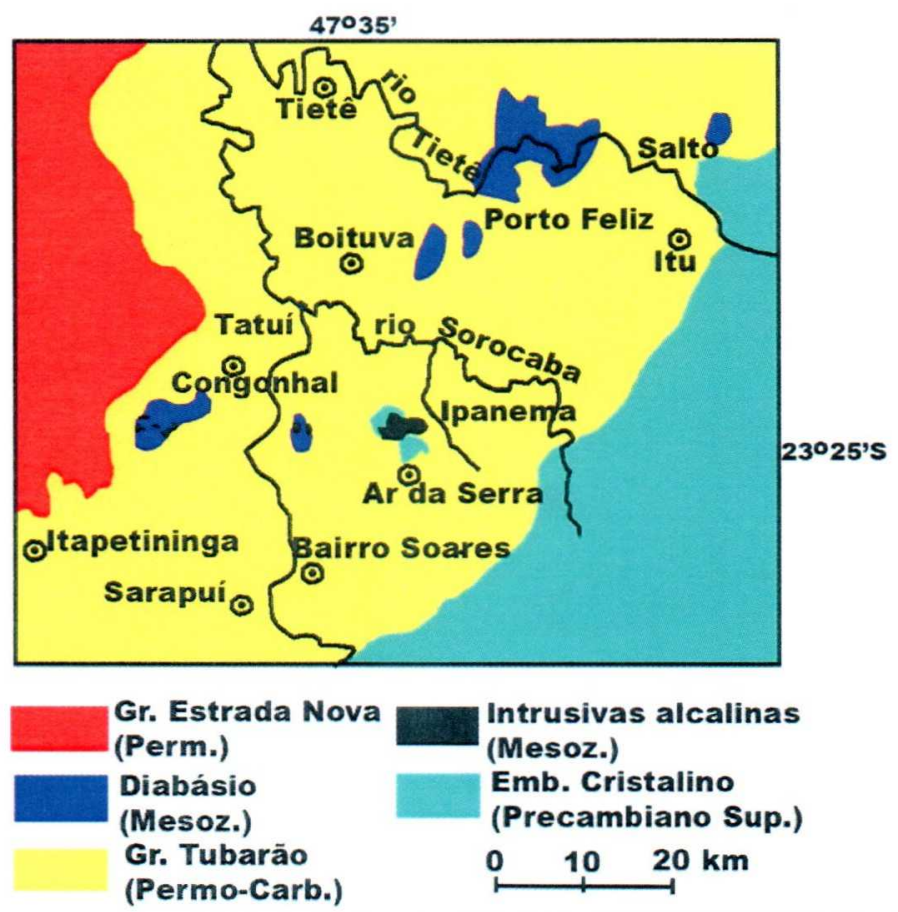

Figura 6.12 - Mapa Geológico da Região de Ipanema (Adaptado - Davino 1975).

\subsubsection{Supergrupo Tubarão}

Este supergrupo da Bacia do Paraná é subdividido nos grupos Itararé e Aquidauana, e Formação Tatuí (Morenghi 2007).

\subsubsection{Grupo Itararé}

Salvetti (2005) defende que a deposição do Grupo Itararé, por ele chamado de subgrupo, iniciou durante o Carbonífero Médio e terminou no Permiano Médio, sendo uma das mais expressivas unidades da Bacia do Paraná, com espessura superior a $1000 \mathrm{~m}$. No Estado de São Paulo, essa unidade aflora em toda a extensão da borda leste da bacia. Havia um mar epicontinental no interior da bacia durante o Carbonífero Médio.

Em Milani (2004), baseado em Almeida et al. (1980), podemos encontrar uma descrição geral do que ocorreu na Bacia do Paraná, incluindo o Grupo Itararé. Profundas mudanças tectônicas e climáticas ocorriam no Gondwana enquanto acontecia a sedimentação na Bacia do Paraná. Dentre estes eventos pode-se citar glaciações continentais $e$ ingressões marinhas. Além disso, ocorria atividade tectônica nos arcos marginais e movimentos verticais em diversos locais, que acabaram por compartimentar a Bacia do Paraná. A subsidência ocorrida no Carbonífero foi importante para a porção setentrional da Bacia do Paraná, onde está localizado o Grupo Itararé. 

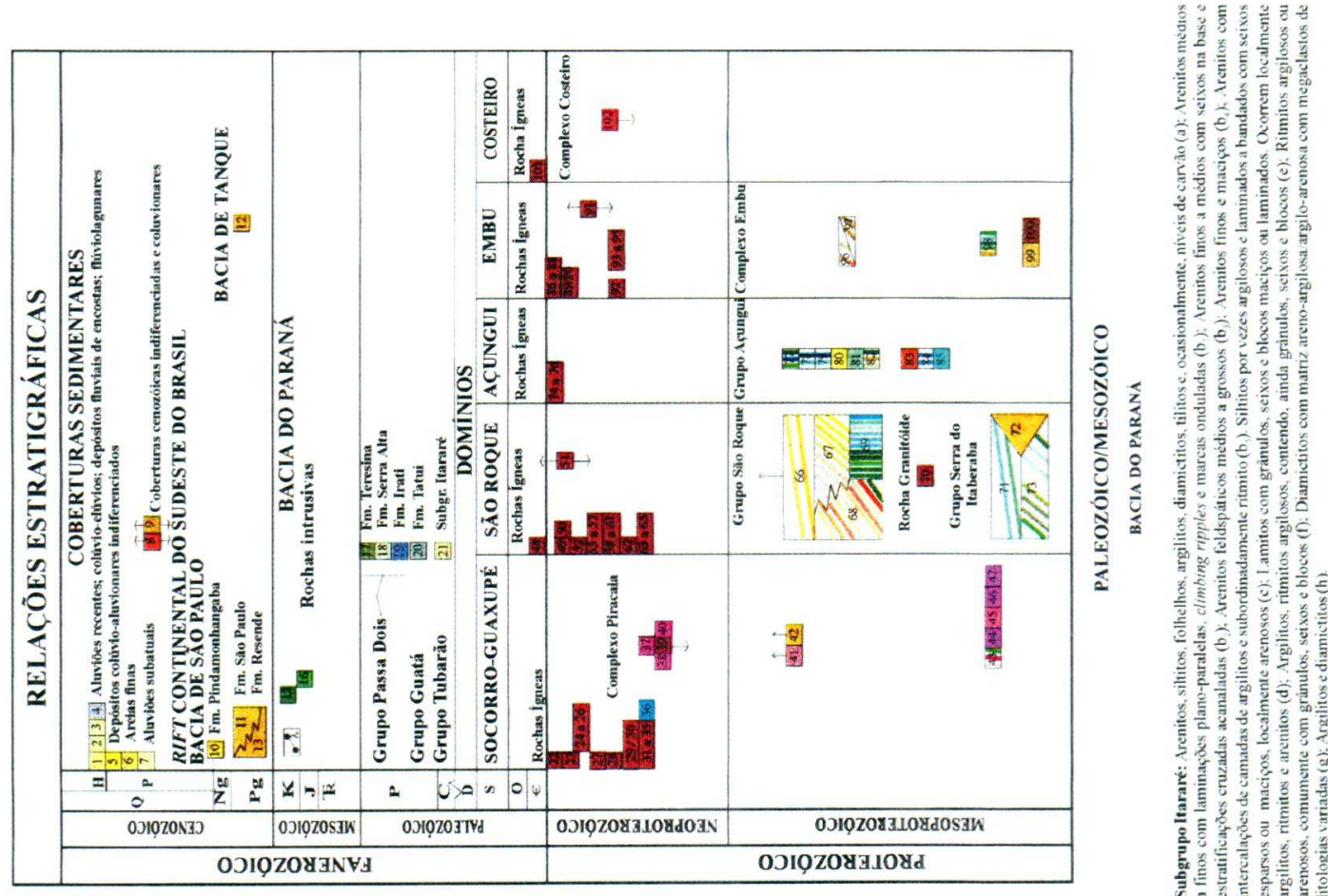

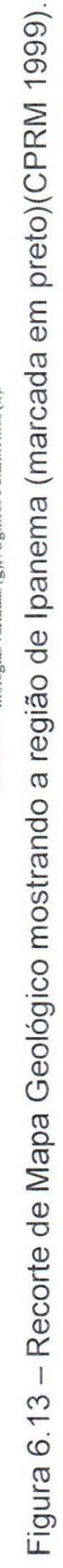


Rocha-Campos e Santos (1981) descrevem este grupo como formado por diamictitos com diversos tipos de matriz, que pode ser: pelítica a arenosa, maciça ou estratificada. Estes diamictitos ocorrem ao longo de todo o perfil exposto, sendo que em alguns locais, aparecem intercalados com litologias predominantemente pelíticas e, em outros, conjuntamente com sedimentos areno-conglomeráticos.

Morenghi (2007) descreve Grupo Itararé, contendo depósitos gláciocontinentais na base e depósitos glácio-marinhos no topo.

Petri e Souza (1993) estudaram o Grupo Itararé, na região do médio Tietê e dividiram o Grupo nas Formações Itu (sistemas fluvio-deltáico) e Capivari (depósitos marinhos transgressivos)

O Grupo Itararé apresenta complexa associação de litofácies que são de origem lacustre, glacial marinho, fluvial, deltaico, praiano, eólicos e terrestres. Estas duas últimas origens, ocorrem mais raramente (Oliveira et al. 2005).

Estes autores definem o Grupo Itararé como sendo constituído de sedimentos clásticos de granulação heterogênea, mineralogicamente imaturos, passando a arenitos feldspáticos. Estes arenitos apresentam estratificação plano-paralela à cruzada com ocorrência de marcas de ondas e acamamento gradacional. Ocorrem também diamictitos, que são ligados ao processo glacial, sendo este o termo litológico mais característico do Grupo. Arenitos finos, siltitos e folhelhos também ocorrem ritmicamente com estratificação plano-paralela. Possuem grande destaque arenitos conglomeráticos e conglomerados.

No morro de Araiçoiaba podem ser encontrados quase todos os litotipos do Grupo Itararé, predominando o arenito de granulação fina a média. Nos pacotes de arenito são observadas lentes de conglomerado que vão desde centímetros até mais de um metro de espessura, sendo mal selecionado e imaturo. Podem ser observadas intercalações de sedimentos siltosos e argilosos, além da presença de diamictitos. Em alguns locais o arenito apresenta-se endurecido devido ao metamorfismo de contato, gerado pelas intrusões alcalinas ocorridas no Cretáceo Inferior (Oliveira et al. 2005).

A divisão estratigráfica do Itararé não é consenso na bibliografia, pois há enorme variação tanto lateral quanto vertical dentro da unidade, o que se deve a variações nos ambientes de sedimentação (Morenghi 2007). Salvetti (2005), mostra ainda, que a literatura sobre o Grupo Itararé é bastante fragmentada, sendo difícil encontrar bibliografia que trate do grupo como um todo. Em sua maioria, tratam de pequenas áreas. Provavelmente isso se deva à sua grande extensão. 


\section{Métodos Analíticos}

As metodologias aqui apresentadas, em alguns casos, apresentarão duas formas ou equipamentos diferentes pois em primeira instância foram realizadas na Universidade de Princeton (Nova Jersey) nos Estados Unidos e em segunda instância foram realizadas com os equipamentos ou técnicas disponiveis no Brasil.

\subsection{Dimensões das amostras utilizadas}

Foram utilizados seis tamanhos de amostra:

Tamanho 1: $2,5 \times 2,5 \times 8,5 \mathrm{~cm}$ - utilizadas no teste de velocidade de ondas ultrassônicas e no de capilaridade (Figura 7.1);

Tamanho 2: $1,0 \times 1,0 \times 1,5 \mathrm{~cm}$, com a mesma orientação das amostras maiores - utilizadas nos testes de expansibilidade, porosimetria de mercúrio e capilaridade (Universidade de Princeton) (Figura 7.2);

Tamanho 3: 5,0 × 4,0 × 1,5 cm - utilizadas na saturação a vácuo (Figura 7.3);

Tamanho 4: 1,25 × 1,25 x 8,5 cm - utilizadas nos testes de resistência à flexão, saturação e secagem e capilaridade (Universidade de São Paulo) (Figura 7.4);

Tamanho 5: 2,0 × 2,0 x 0,2 cm - utilizadas para observação ao Microscópio Eletrônico de Varredura (MEV) e confecção de lâmina petrográfica;

Antes de ser cortada para que fossem realizados os testes, a amostra foi virtualmente dividida em 3 eixos (Figura 7.5). O eixo X é paralelo ao acamamento. A orientação utilizada nos testes foi: acamamento paralelo (horizontal) e perpendicular (vertical) ao maior lado (eixo X);

Tamanho 6: 5,0 × 5,0 × 5,0 - utilizadas para os testes de tubo de Karsten e profundidade de penetração (Figura 7.6). O acamamento foi posicionado horizontalmente, assim como é encontrado na pedreira e na mesma posição de deposição. 


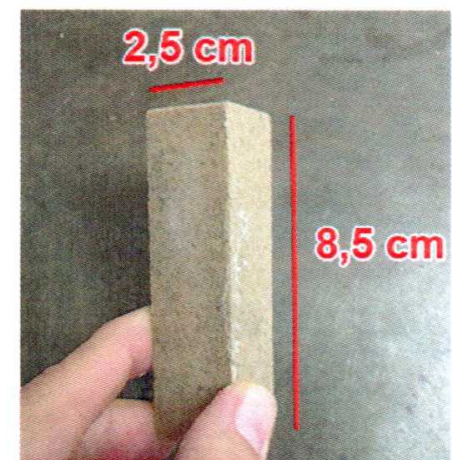

Figura 7.1 - Amostra tamanho 1.

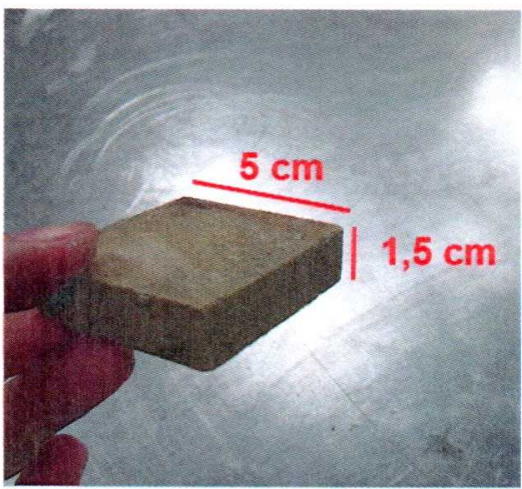

Figura 7.3 - Amostra tamanho 3.

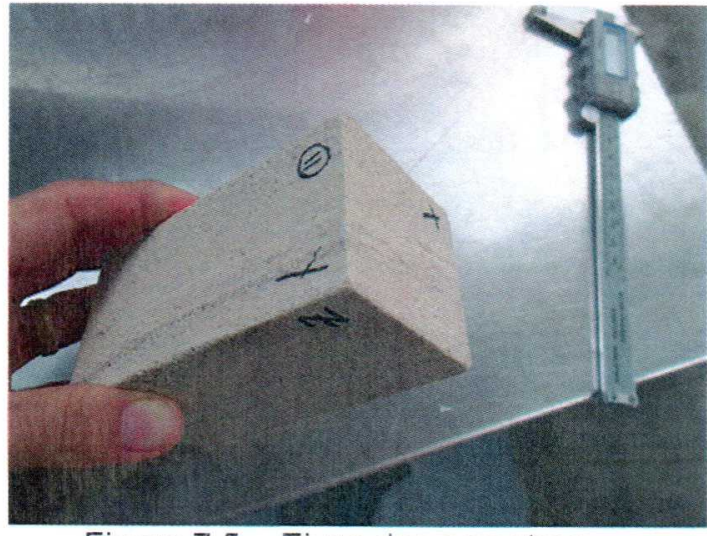

Figura 7.5 - Eixos das amostras.

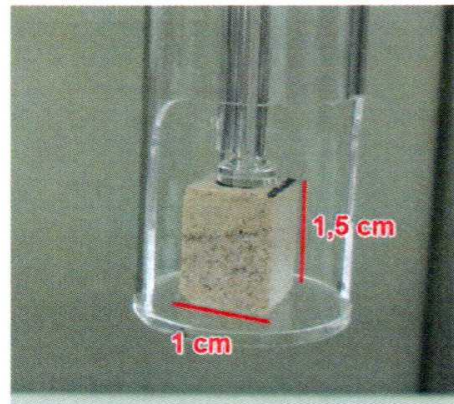

Figura 7.2 - Amostra tamanho 2

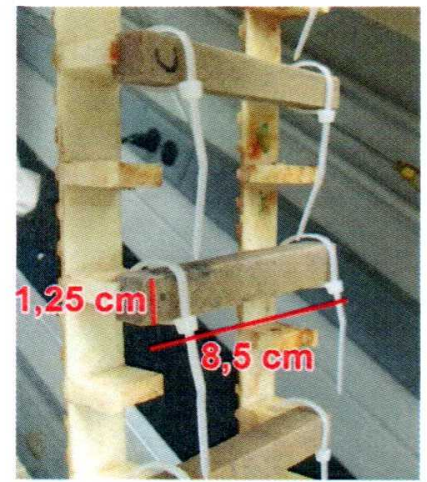

Figura 7.4 - Amostra tamanho 4

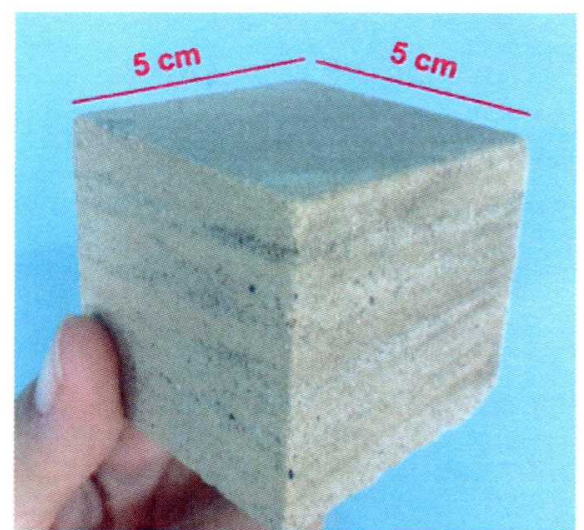

Figura 7.6 - Amostra tamanho 6

\subsection{Intemperismo prévio por aquecimento}

As amostras utilizadas em laboratório para testar técnicas e produtos geralmente são recolhidas da pedreira e, portanto, frescas. Esta condição não é coerente com a encontrada nos monumentos, que já estão com suas rochas alteradas química e fisicamente pelo tempo. Sassoni et al. (2011 e 2012) e Franzoni et al. (2013 e 2014) realizaram testes e verificaram a efetividade do aquecimento para simular os valores encontrados nos testes realizados em monumentos. Sassoni et al. (2011) aqueceram as rochas de $100^{\circ} \mathrm{C}$ a $500^{\circ} \mathrm{C}$ de 1 até 16 horas e verificaram que 0 
aquecimento a mesma temperatura apresentava resultados similares independentemente do tempo. O melhor resultado foi encontrado em rochas aquecidas a $300^{\circ} \mathrm{C}$, que apresentaram redução de $43,4 \%$ no módulo dinâmico e $27,1 \%$ na resistência à flexão. Franzoni et al. (2013) utilizaram diferentes temperaturas de aquecimento em rochas secas e saturadas com água. Verificaram que o aquecimento é benéfico para a abertura de nanofissuras e geram condições mecânicas mais comparáveis com a rocha alterada naturalmente. No entanto, dependendo do tipo de rocha e de suas características microestruturais, o grau de efetividade do aquecimento varia significativamente. Sassoni et al. (2012) consideram que o intemperismo artificial por aquecimento é bem sucedido para tornar a amostra fresca semelhante à alterada naturalmente, podendo assim, simular em laboratório, as condições mais factíveis para o campo. Com o auxílio desta técnica, os resultados se tornam mais representativos com os que são observados em campo. Naidu et al. (2015) aqueceram as amostras a $300^{\circ} \mathrm{C}$ por uma hora para intemperizar artificialmente as amostras antes de tratá-las. O aquecimento produz uma rocha homogeneamente alterada e não deixa resíduos que possam interagir com os consolidantes.

\section{Metodologia utilizada}

As amostras do Arenito Itararé, antes de serem tratadas, foram aquecidas a $300^{\circ} \mathrm{C}$ por 24 horas para gerar danos microestruturais e simular os valores encontrados nos testes realizados em rochas alteradas. A temperatura e o tempo de exposição foram determinados de acordo com a literatura consultada.

Contudo, as amostras submetidas a este processo tiveram sua cor bastante modificada e, apesar de terem sido avaliadas ao microscópio ótico, e não terem sido encontradas mudanças mineralógicas, este procedimento foi utilizado apenas para as amostras utilizadas no teste de capilaridade e para os ciclos de saturação e secagem.

Após o processo de aquecimento, as amostras ficaram avermelhadas (Figura 7.7), o que aconteceu principalmente nas de grãos mais finos. 


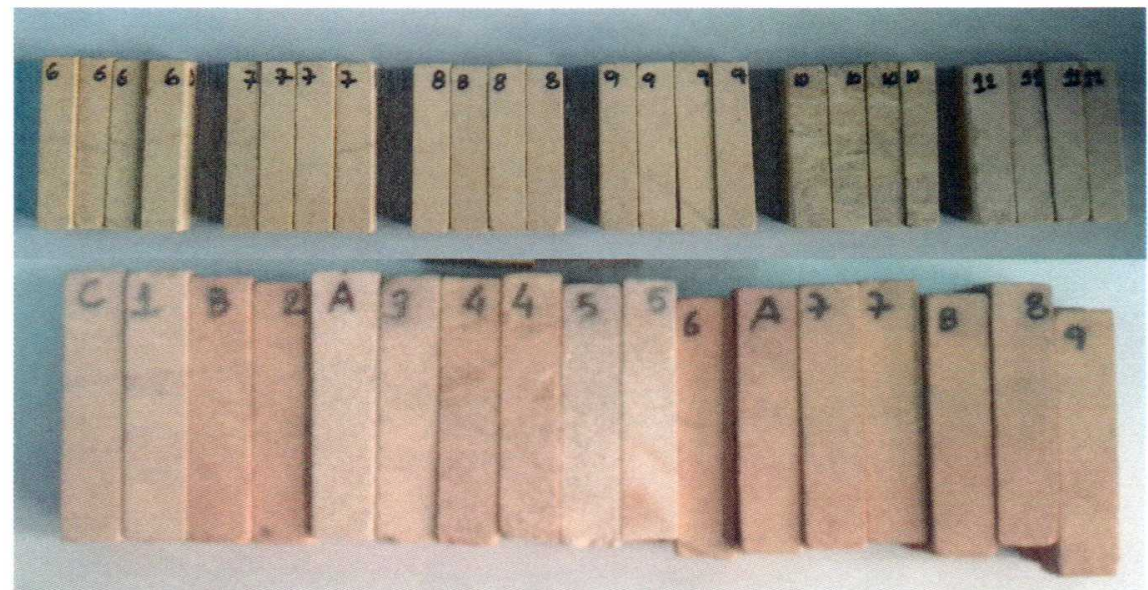

Figura 7.7 - Amostras antes (acima) e após o aquecimento (abaixo)

\subsection{Difração de raios $X(D R X)$}

Esta é uma técnica utilizada para caracterizar materiais cristalinos microestruturalmente.

Um feixe monocromático de raios $\mathrm{X}$, incide sobre uma amostra cristalina. Este feixe será difratado (Figura 7.8) obedecendo a Lei de Bragg (Eq. 9).

$$
\mathrm{n} \lambda=2 \mathrm{~d} \operatorname{sen} \Theta
$$

Eq. 9

Onde:

$\mathrm{n}=$ número inteiro;

$\lambda=$ comprimento de onda;

$\mathrm{d}=$ distância interplanar;

$\Theta=$ ângulo de incidência dos raios $x$. 


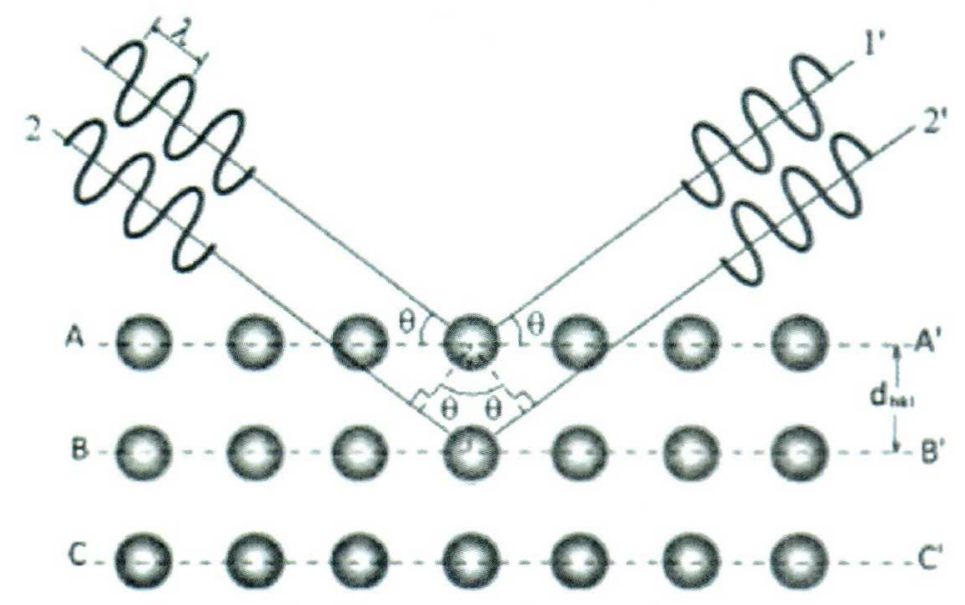

Figura 7.8 - Planos de difração (Souza 2012).

No momento em que as ondas incidentes e difratadas estão em fase, isto é, quando a diferença de caminho é igual a um número inteiro de comprimento de onda, o ângulo $\theta$ e sua intensidade são auferidos. Cada cristal possui uma distância interplanar característica. Foi desenvolvido o método do pó para que fosse possivel obter várias partículas aleatoriamente ordenadas. No entanto, este arranjo aleatório não pode ser obtido com todos os minerais. Os que são placóides, tendem a se posicionar perpendicular ao eixo cristalográfico c.

Os argilominerais são reunidos em grupos de acordo com a distância interplanar: 12 a $15 \AA=$ grupo da clorita, vermiculita e grupo da esmectita, $10 \AA=$ grupo das micas, $9 \AA=$ talco e pirofilita e $7 \AA=$ grupo da caulinita.

Existem dois processos que podem ser utilizados para diferenciar os grupos. Um deles é a saturação com etilenoglicol, que faz com que a distância interplanar do grupo das esmectitas seja deslocado, diferenciando-as do grupo das cloritas. Outro processo é 0 aquecimento a $500^{\circ} \mathrm{C}$ por $4 \mathrm{~h}$, que faz com que a vermiculita perca sua hidratação e seja diferenciada da clorita.

\section{Metodologia utilizada}

O equipamento utilizado foi um D8 Advance da Bruker (Figura 7.9) com tubo de cobre ( $\mathrm{Cu} \mathrm{Ka}$ ) e filtro de níquel para eliminar $\mathrm{KY}$ e $\mathrm{K} \beta$ e que absorve comprimentos de onda abaixo de 1,4869. Com isso, o $K_{a 1}$, que tem comprimento de onda $(\lambda)$ de 1,3922, é eliminado e fica apenas $K_{\alpha 2}$ que tem $\lambda$ igual a 1,5418. Para análise dos dados, foi utilizado o DIFRAC.EVA 4.1. O objetivo foi o de identificar argilominerais expansivos (grupo das esmectitas). 
Uma pequena amostra do Arenito Itararé fresco foi moída com martelo e triturada em almofariz de ágata, até ficar bem fina, de modo que os grãos não fossem sentidos quando o pó fosse passado entre os dedos.

Este pó foi colocado no porta-amostra, bem pressionado, para compactar os grãos. Iniciaram-se as medições, que finalizaram em cerca de 15 minutos.

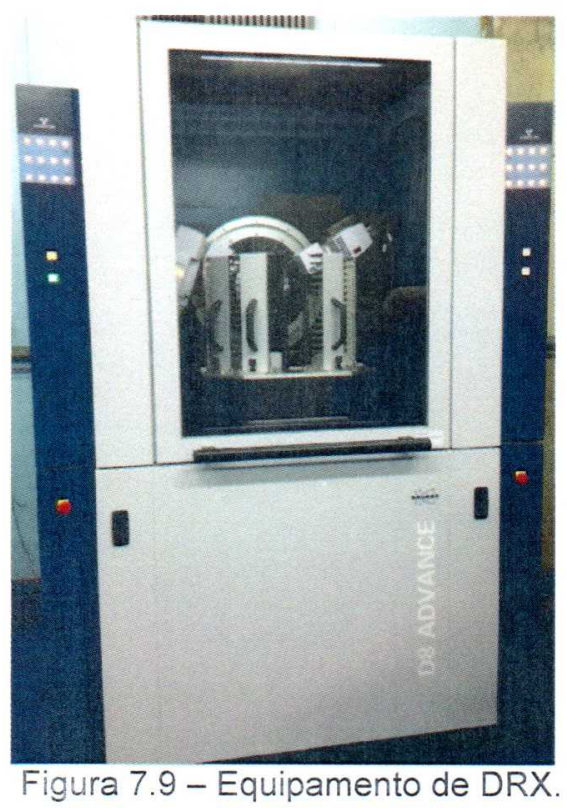

\section{Separação da fração argila}

Após esta primeira etapa, uma outra fração de amostra moída foi submetida ao procedimento de separação de argilominerais. Este procedimento consiste em colocar $30 \mathrm{~g}$ de rocha moída em $200 \mathrm{~mL}$ de água deionizada. Esta mistura foi submetida ao agitador mecânico (Figura 7.10) por cerca de 5 minutos, para ficar o mais homogênea possível. Após este período, ela foi despejada em uma proveta (Figura 7.11) e a água foi completada até $250 \mathrm{~mL}$. Utilizou-se um agitador manual para misturar tudo e aguardou-se o tempo de 2 horas e 03 minutos. Passado o tempo de descanso, uma pipeta volumétrica foi colocada $10 \mathrm{~cm}$ submersa e a mistura foi coletada até alcançar a marca de $20 \mathrm{~cm}$. O conteúdo dela foi despejado em uma placa de vidro de $2 \times 2 \mathrm{~cm}$, que fica acondicionada dentro de uma placa de Petri (Figuras 7.12 e 7.13). Assim que a água evaporou totalmente, a fração argila estava pronta para ser colocada novamente no Difratômetro de Raios $X$ e realizar nova medição. 


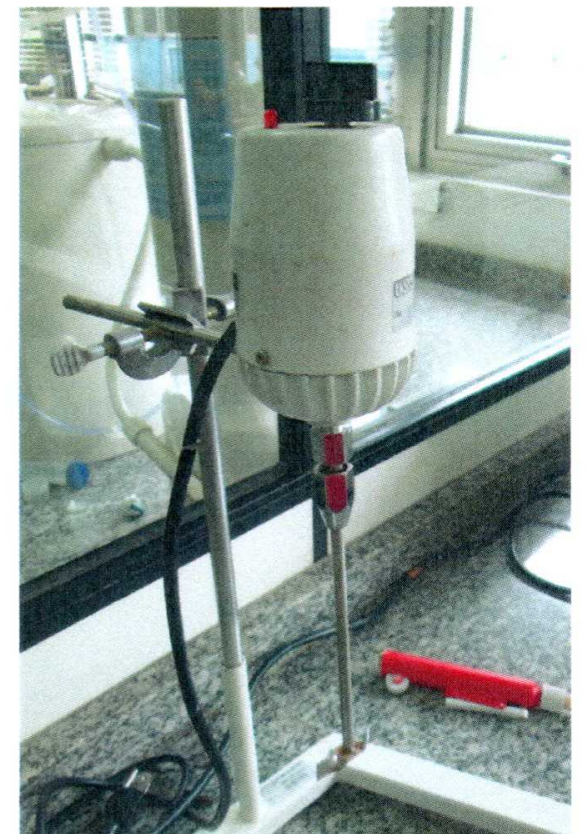

Figura 7.10 - Agitador mecânico.

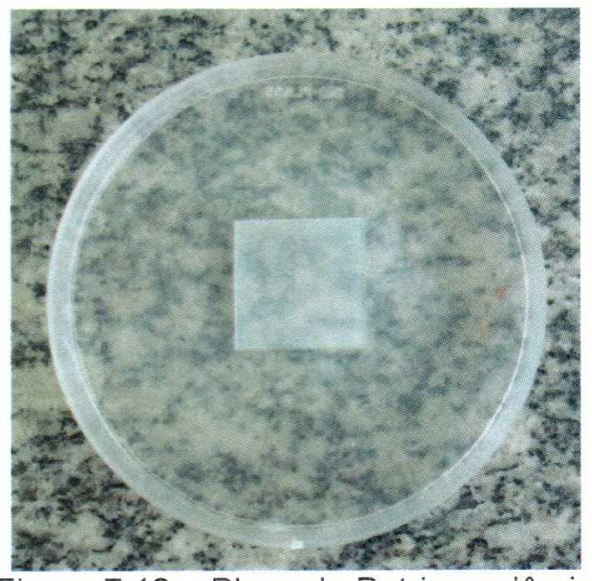

Figura 7.12 - Placa de Petri com lâmina.

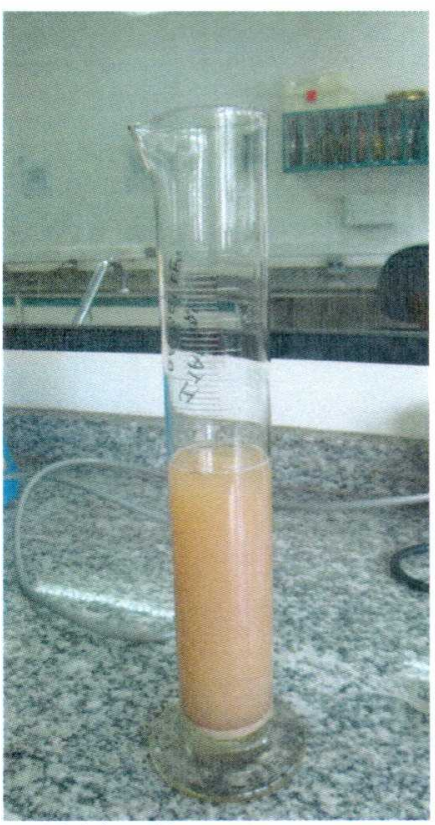

Figura 7.11 - Proveta com amostra.

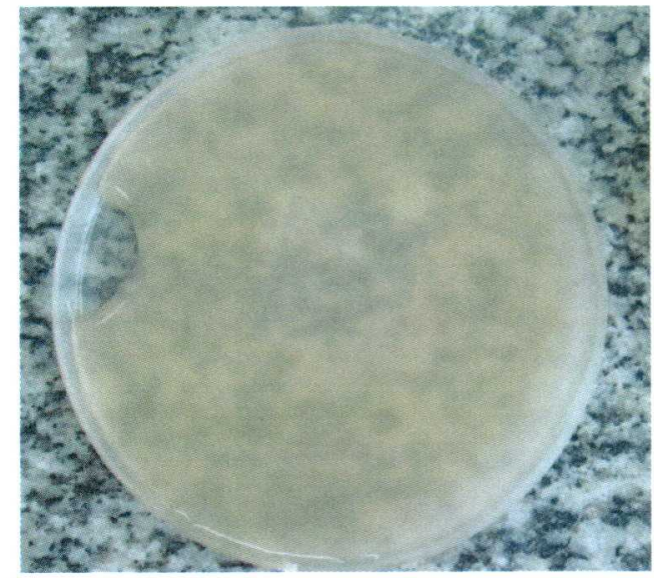

Figura 7.13 - Placa de Petri com a fração argila em solução.

Como existem alguns argilominerais que possuem o mesmo espaço basal, a glicolagem é feita para verificar qual delas está presente. Este procedimento foi realizado colocando-se a placa que foi preparada no procedimento anterior dentro de um dessecador de vidro, contendo etilenoglicol, por 24 horas. O etilenoglicol é conhecido por aumentar o espaço basal de argilominerais expansivos. Se isto ocorrer, sabe-se que se trata de um argilomineral do grupo da esmectita.

$\mathrm{O}$ ensaio foi realizado em três amostras diferentes. Aqui é mostrado apenas o gráfico que apresentou menor quantidade de quartzo e, portanto, resultados mais significativos. Os outros dois, encontram-se na seção ANEXO II. 


\subsection{Capilaridade}

Este teste visa medir o aumento de peso da amostra, conforme ela absorve água. A importância dele deve-se ao fato de que um bom consolidante não deve afetar - comportamento capilar da amostra de maneira significativa. Caso contrário, pode ocorrer a aceleração da deterioração pelo aumento da pressão interna devido ao acúmulo de água, que fica aprisionada atrás da camada tratada. Este fato pode levar ao desplacamento de grandes superfícies.

O teste consiste em colocar a base da amostra em contato com a água e verificar o aumento de peso com o tempo. A altura da ascensão $(h)$ pode ser calculada pelo ganho de peso $(\Delta \mathrm{m})$ usando a equação 10 (Scherer e Jiménez González 2005):

$$
h=\frac{\Delta \mathrm{m}}{\varnothing \rho_{L} A}
$$

Onde:

$A=$ área da amostra em contato com o líquido $\left(\mathrm{cm}^{2}\right)$;

$\emptyset=$ porosidade da rocha $(\%)$;

$\rho_{L}=$ densidade do líquido $\left(1,0 \mathrm{~g} / \mathrm{cm}^{3}\right)$.

Para termos de comparação é interessante lembrar que a capilaridade está relacionada à permeabilidade $(k)$, calculada pela equação 11 (Scherer e Jiménez González 2005). O k é a velocidade com que a água invade os poros. O movimento da água dentro dos poros ocorre de acordo com a Lei de Darcy.

$$
Q=\mathrm{k} \frac{h}{\mathrm{~L}} \mathrm{~A}
$$

Onde:

$Q=$ fluxo $\left(\mathrm{m}^{3} / \mathrm{s}\right)$;

$\mathrm{k}=$ coeficiente de permeabilidade $(\mathrm{m} / \mathrm{s})$;

$\mathrm{h}=$ carga hidráulica que dissipa na percolação $(\mathrm{m})$;

$\mathrm{L}=$ distância a percorrer $(\mathrm{m})$;

$A=$ área $\left(m^{2}\right)$.

\section{Metodologia utilizada}

Este teste foi realizado com duas metodologias diferentes: uma na Universidade de Princeton e outra na Universidade de São Paulo. 


\section{- Universidade de Princeton}

Este equipamento foi desenvolvido pela equipe do laboratório do Prof. Dr. George W. Scherer e utilizada por Scherer e Jimenez Gonzalez (2005), cujos procedimentos são descritos. A amostra seca foi suspensa e presa à base da balança eletrônica. Aguardou-se alguns segundos até o peso inicial estabilizar. O software que registra os dados, DASYlab, foi ligado. Este programa registrou o peso medido uma vez por segundo. Colocou-se a base da amostra em contato com a água, que estava em um recipiente logo baixo dela. A balança marca o aumento que ocorreu pela invasão da água nos poros da amostra. O aumento da massa deve formar uma curva que se estabilizará em algum momento, mostrando uma reta. A parte mais reta da porção ascensional da curva é selecionada (Figura 7.14).

A partir da inclinação deste pedaço da curva, a capilaridade (S) é calculada usando-se a equação 20.

$$
S=\frac{\Delta m}{(A \sqrt{t})}
$$

Onde:

$\mathrm{m}=$ massa $(\mathrm{g})$;

$A=$ área $\left(\mathrm{cm}^{2}\right)$;

$\mathrm{t}=$ tempo $(\mathrm{s})$.

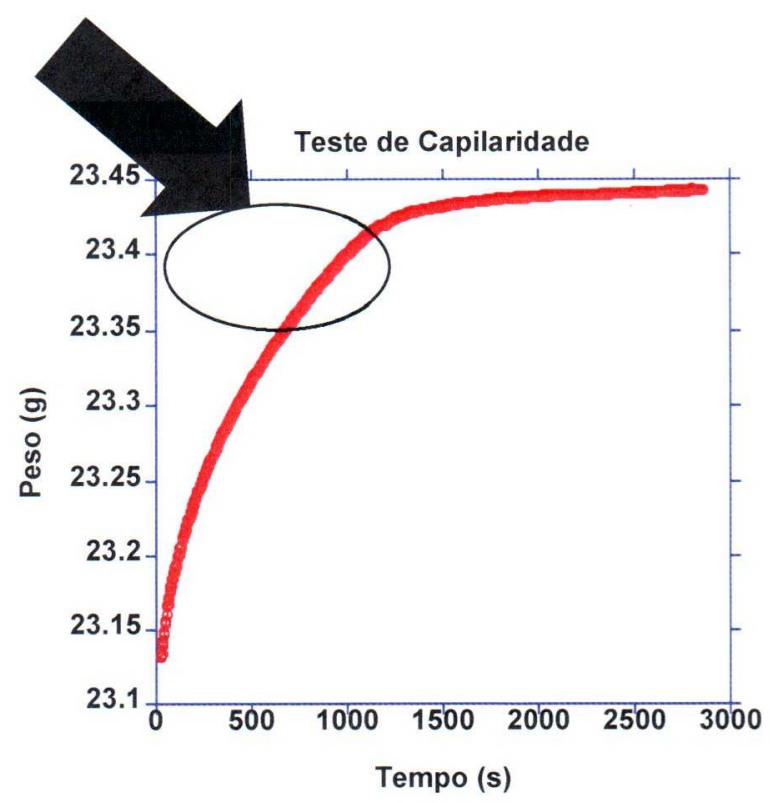

Figura 7.14 - Método de seleção dos dados da curva do teste de capilaridade. 
O equipamento é mostrado na Figura 7.15.

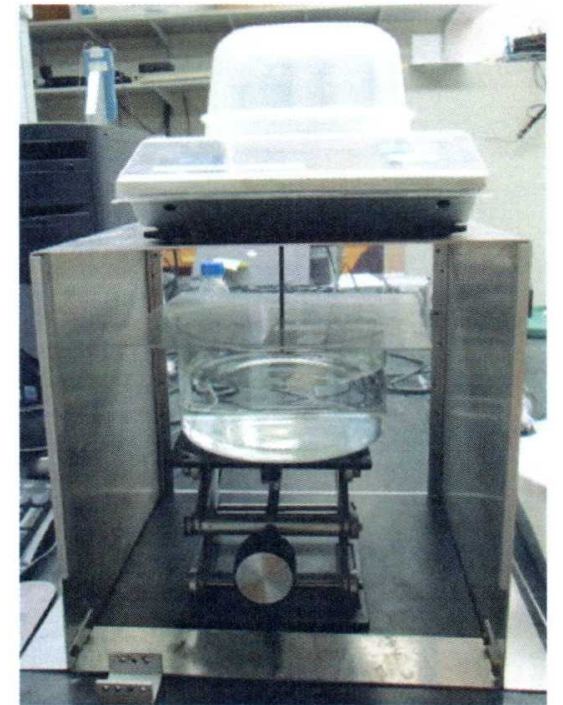

Figura 7.15 - Equipamento de capilaridade.

Para identificar a direção do fluxo de água em relação às camadas deposicionais da rocha, admitiu-se sempre as camadas horizontas, já que elas não ocorrem verticalmente (a não ser em dunas) e denominou-se o fluxo de água como paralelo ou perpendicular às camadas, conforme mostra a Figura 7.16. Esta identificação serve para os ensaios em ambas as Universidades.

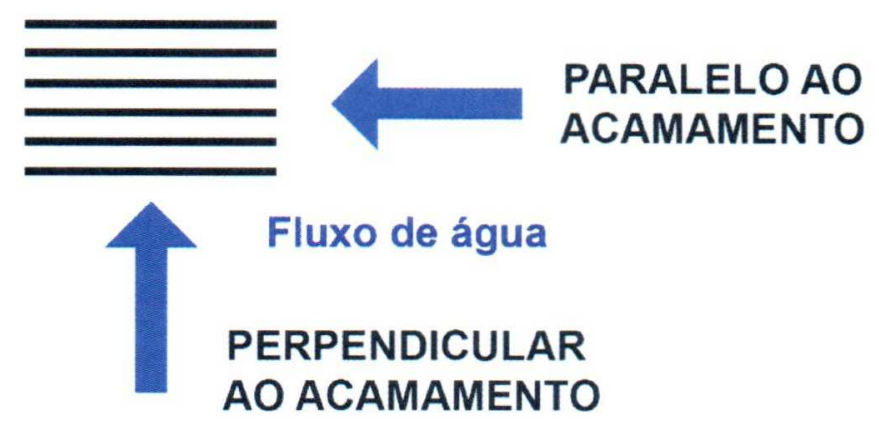

Figura 7.16 - Direção do fluxo em água em relação ao acamamento.

\section{- Universidade de São Paulo}

Esta metodologia difere da descrita anteriormente devido à indisponibilidade de equipamento semelhante. Foi desenvolvida uma nova metodologia para realizar o ensaio, baseada nas normas EN 1925 (1999) e NBR 9779 (2012).

As amostras foram cortadas e colocadas no forno a $300^{\circ} \mathrm{C}$ por 24 horas para simular o intemperismo que ocorre naturalmente, conforme descrito anteriormente. Foram tratadas três amostras com cada produto. Após os produtos estarem 
completamente prontos e secos, as amostras, foram colocadas sobre um estante para tubos de ensaio, para garantir que elas ficassem posicionadas verticalmente e a água pudesse penetrar o mais livremente possível. Esta estante foi colocada sobre suportes para que a água permeasse sem obstáculos. Este conjunto foi colocado dentro de um container plástico com tampa, para evitar a evaporação. As amostras foram pesadas e colocadas dentro da estante. A água foi colocada dentro do container até que atingisse cerca de $3 \mathrm{~mm}$ acima da base da rocha. O nível de água foi mantido e acompanhado durante todo o experimento. As amostras foram retiradas do contato com a água em intervalos definidos, o excesso de água foi retirado com um papel umedecido e, então pesadas. Os intervalos foram de $0,30,60,90,120,180,240,300$ minutos.

A parte de cálculos seguiu os procedimentos descritos anteriormente.

Neste ensaio, foi realizado apenas o teste com a água percolando perpendicularmente ao acamamento. Vale ressaltar que a metodologia e o tamanho das amostras foi diferente e, portanto, o número de medidas, alterado. As amostras utilizadas, eram bem maiores que as do ensaio realizado na Universidade de Princeton. Tanto que, não houve saturação total da amostra, mesmo após 24 horas. Contudo, isso não influenciou os resultados, pois, como explicado anteriormente, apenas a parte ascensional da curva é utilizada para calcular a capilaridade.

\subsection{Ultrassom}

Um dos modos de avaliar a deterioração rochosa é o ultrassom. Esta é uma técnica não destrutiva, que pode ser aplicada em materiais de vários tamanhos. Nesta metodologia, foi medido o tempo de propagação das ondas $P$, que são mais precisas que as ondas $\mathrm{S}$, em um determinado percurso. Com estes dados, foi possível calcular o valor da velocidade (Eq. 12), que geralmente é mostrada em $\mathrm{m} / \mathrm{s}$, porém para este estudo será mostrada em $\mathrm{km} / \mathrm{s}$ devido ao número de algarismos significativos ser mais adequado (Grossi 2013).

$$
V=\frac{\mathrm{d}}{\mathrm{t}}
$$

Onde:

$V$ = velocidade de propagação $(\mathrm{m} / \mathrm{s})$;

$\mathrm{d}=$ distância $(\mathrm{m})$;

$\mathrm{t}=$ tempo $(\mathrm{s})$. 
Os valores da velocidade de onda ultrassônica, dependem das características físicas das rochas como homogeneidade, densidade, porosidade e saturação por água. A diminuição do valor da velocidade ultrassônica provém de descontinuidades ou obstáculos no caminho de sua propagação (Papida et al. 2000, Kahraman 2002). Portanto, comparar os dados obtidos em rocha fresca com os obtidos em rochas alteradas fisicamente por temperatura ou tratadas por pré-consolidantes e consolidantes é útil para mostrar o aumento da coesão entre os grãos.

Tanto em condições laboratoriais quanto em campo, este equipamento é de fácil manuseio. Alguns equipamentos oferecem um botão no transdutor, que permite ao operador gravar o teste sem tirar as mãos da posição de ensaio.

Para realizar o teste foi necessário colocar os dois transdutores em contato com a superfície do objeto a ser analisado: um transdutor emissor e um receptor. Para melhorar o contato entre o transdutor e a superfície foi utilizada graxa. Para evitar que a graxa entrasse em contato com o material, uma camada de filme plástico cobriu esta peça. Existem três modos de posicionamentos dos transdutores (Figura 7.17): transmissão direta, semidireta e indireta. Para este estudo, foi utilizado apenas 0 posicionamento direto.

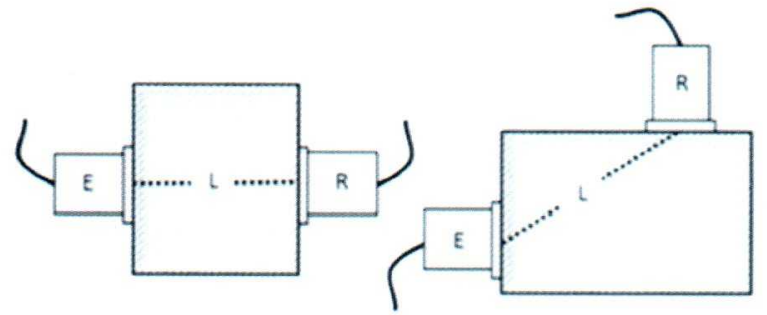

A

B

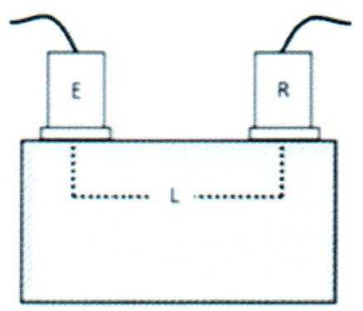

C

Figura 7.17 - Posicionamento dos transdutores. (a) direto, (b) semidireto, (c) indireto. E: emissor, R: receptor, L: distância entre os centros dos transdutores (Gimenez e Del Lama 2014).

Foi calculado também o módulo de elasticidade dinâmico $\left(E_{d y n}\right)$ a partir da equação 13.

$$
E_{d y n=}=\rho x V^{2}
$$

Onde:

$\rho=$ densidade $\left(\mathrm{kg} / \mathrm{m}^{3}\right)$;

$\mathrm{V}=$ velocidade $(\mathrm{m} / \mathrm{s})$. 
O tamanho da amostra deve ser sempre medido, pois a partir deste método é possível calcular o módulo de Young (Kolsky 1963 apud Scherer e Jiménez González 2005). Mas o efeito mais importante é o módulo de elasticidade (dinâmico ou estático), porque o método acústico impõe tensão muito pequena, que é inversamente proporcional ao módulo. A frequência também é algo que afeta muito o módulo, principalmente se a amostra for seca. O módulo dinâmico em rocha seca é menor. No entanto o módulo estático em amostra seca é maior do que nas saturadas com água (Scherer e Jiménez González 2005).

\section{Metodologia utilizada}

\section{- Universidade de Princeton}

Nos testes realizados na Universidade de Princeton para medir a velocidade de propagação das ondas ultrassônicas foi utilizado o equipamento PUNDIT (CNS Farnell) (Figura 7.18) com transdutores de $54 \mathrm{kHz}$. O equipamento foi calibrado e, como acoplante, foi utilizada uma pequena folha de borracha ou graxa coberta por um pequeno pedaço de filme plástico. Tudo isso, para que não fossem deixados resíduos na rocha, pois estes, atrapalhariam o resultado dos testes pela obstrução dos poros, gerando valores falsos. O tempo que a onda levou para percorrer a borracha, quando esta foi utilizada, foi descontado. Para que a pressão entre os transdutores e a amostra não variasse, e consequentemente o valor medido fosse impreciso (Gimenez e Del Lama 2014), um equipamento foi desenvolvido pelo laboratório do Prof. Dr. George W. Scherer (Figura 7.19). Este equipamento fixa os transdutores, que por sua vez deslizam sobre uma base para se adaptar ao tamanho da amostra. $\mathrm{Na}$ extremidade que se movimenta, é acoplado um equipamento para medir a pressão que a amostra está recebendo. A força foi sempre a mesma, $100 \mathrm{~N}$.

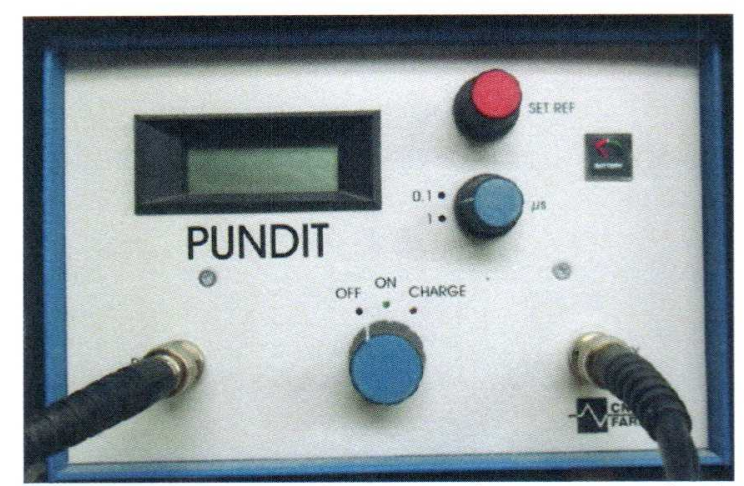

Figura 7.18 - Equipamento para medir tempo de propagação das ondas de ultrassom. 


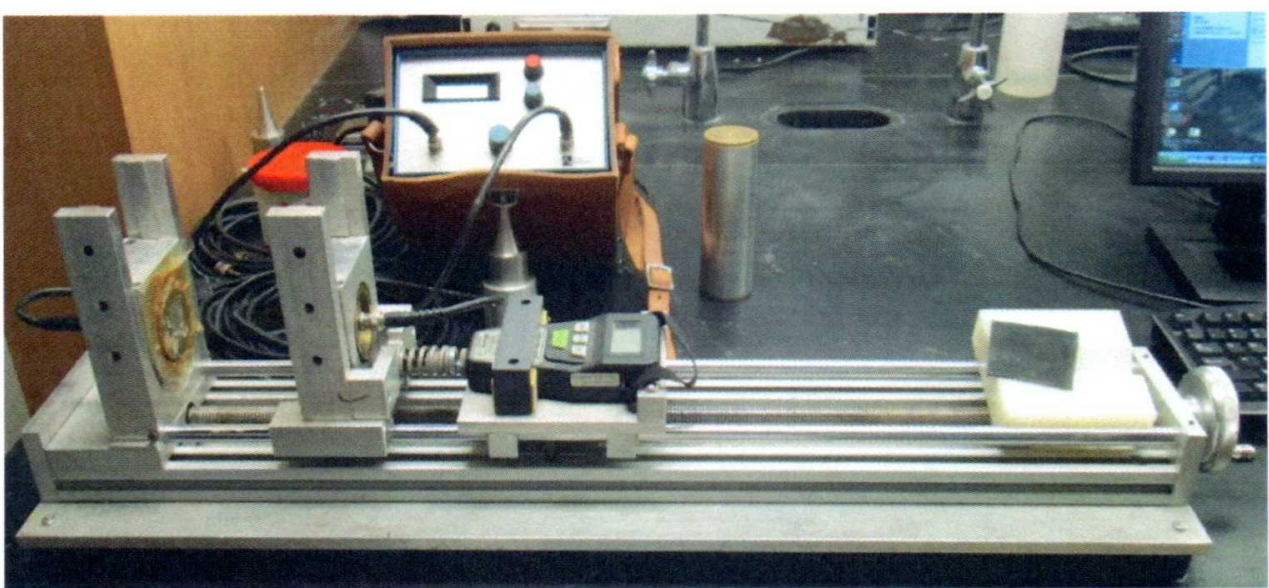

Figura 7.19 - Base para acoplar os transdutores e medir a pressão exercida sobre a amostra.

\section{- Universidade de São Paulo}

Para medir o tempo de propagação das ondas ultrassônicas, foi utilizado o VMeter Mark III (NDT James Instruments Inc.) (Figura 7.20). Foram realizadas medidas apenas de ondas $\mathrm{P}$, com método direto de posicionamento de transdutores de $54 \mathrm{kHz}$ (Figura 7.21), ganho de $500 \mathrm{kHz}$. Cada valor é obtido por meio da média de 3 pulsos em 2 segundos, que o próprio aparelho calcula. As medidas foram repetidas 3 vezes em cada amostra e escolhido o valor mais constante.

A orientação das camadas ficou perpendicular às ondas ultrassônicas; ou seja, paralela com a face onde se encontra os transdutores.

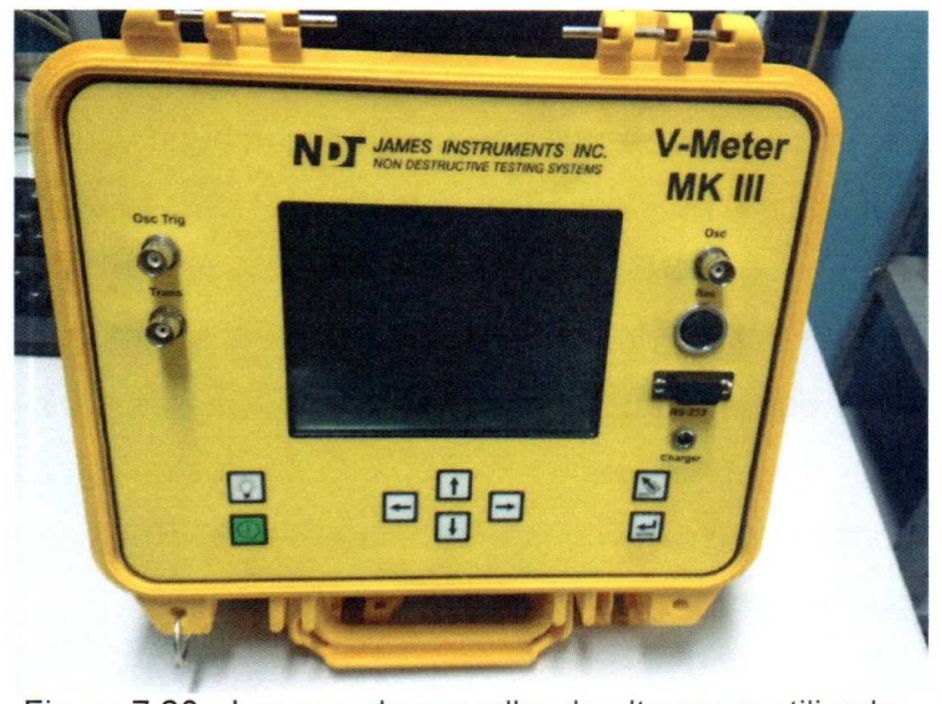

Figura 7.20 - Imagem do aparelho de ultrassom utilizado.

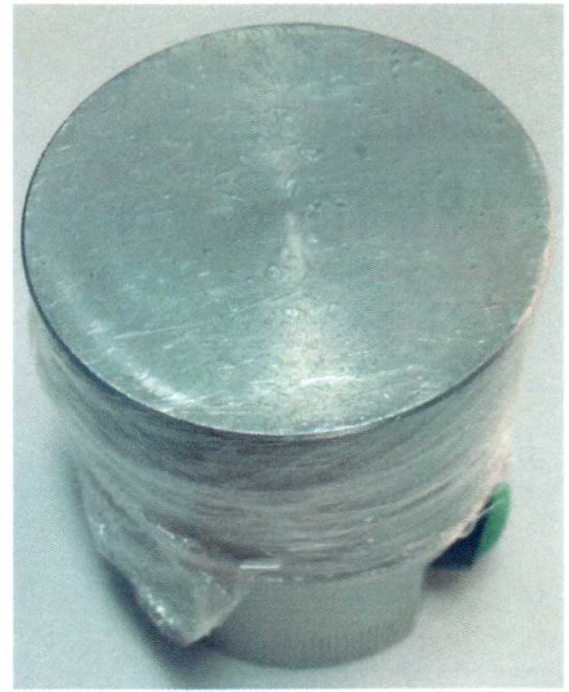

Figura 7.21 - Transdutor de 54 $\mathrm{kHz}$ com graxa e cobertura de filme pástico.

A teoria do ensaio de ultrassom encontra-se descrita em Grossi (2013) e Gimenez e Del Lama (2014). 
O teste de velocidade de ondas ultrassônicas, foi realizado com os produtos encontrados e utilizados no Brasil. Todas as amostras utilizadas para os testes foram cortadas de modo que os ensaios sejam sempre perpendiculares ao acamamento da rocha, pois, os testes realizados na Universidade de Princeton, mostraram que não há uma relação direta entre os resultados encontrados com os dois posicionamentos de acamamento testados. Esse posicionamento, também segue a forma ideal de assentamento de rochas com acamamentos ou bandas: com as faixas paralelas ao solo.

\subsection{Tubo de Karsten}

A propriedade do material ser percolado por água, sob um determinado gradiente de pressão, é chamada de permeabilidade. Esses dados podem ser utilizados para prever a velocidade de deterioração de uma superfície em boas condições e sem tratamento. Pode ainda, ser utilizado para comparar a diferença de velocidade de absorção de água entre uma rocha fresca e uma tratada, para determinar se o tratamento mudou a dinâmica interna da rocha quando em contato com água líquida. Além de tratamentos de limpeza, protetivos ou consolidantes, a sujidade atmosférica, a presença de colonização biológica e de sais higroscópicos, sejam originais da rocha ou provenientes do spray (em áreas costeiras), também podem alterar este parâmetro.

O tubo de Karsten é composto de um corpo de vidro cilíndrico graduado e aberto (Figura 7.22), que é fixado a uma superfície que pode ser horizontal ou vertical, existindo um tubo específico para cada uma dessas orientações. Para realizar o ensaio, o tubo é fixado na superfície e preenchido com água destilada. A absorção de água, é determinada de acordo com o tempo pela leitura do abaixamento do nível da água. Existem diversos materiais que são utilizados para fixar o tubo. Soares (2010) utilizou durepox®, massa de modelar e silicone, enquanto Apps (2011) testou alguns materiais para fixação do tubo e concluiu que o silicone é o mais eficiente. Rodrigues (2012) optou pelo alginato na fixação do cachimbo. 


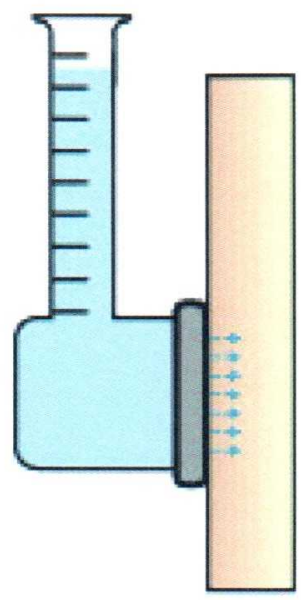

Figura 7.22 - Desenho esquemático do cachimbo para superfície vertical (adaptado de Apps 2011).

A absorção de água é calculada pela quantidade absorvida $(\mathrm{mL})$. Medindo a absorção em intervalos de tempo regulares, são realizados gráficos do volume de água absorvida em função do tempo. O coeficiente de absorção de água é dado pela inclinação da reta obtida (Scartezini et al. 2002).

\section{Metodologia utilizada}

A aplicação dos consolidantes por capilaridade foi dificultada devido às dimensões da amostra. O produto foi aplicado paulatinamente para que ele conseguisse atingir a maior altura possivel. Os produtos hidrofugantes $(630,808 \mathrm{e}$ TW) não apresentam este comportamento. Portanto, a amostra foi imersa de uma só vez, devido ao fato de que se o produto secar, a superfície torna-se hidrofóbica e impede que o produto possa penetrar profundamente.

Foi ensaiado apenas o cachimbo para superfícies verticais. Os tubos foram fixados na rocha com bentonita em pó (Figura 7.23) misturada com água até obter uma pasta consistente e homogênea. Esta é uma nova metodologia, que foi desenvolvida especialmente para este trabalho; pois, tanto a argilinha (Grossi 2013), quanto o alginato (Rodrigues 2012), possuem aditivos químicos, que poderiam reagir com os produtos aplicados nas rochas e gerar resultados errôneos. O objetivo era inserir o mínimo possível de elementos para que o teste fosse o mais fiel possível. A bentonita foi escolhida por ser um produto extraído da rocha e não possuir aditivos químicos. Os aditivos de materiais como argilinha e alginato, poderiam reagir com os produtos aplicados e alterar os resultados. Os tubos foram preenchidos com água deionizada. A absorção foi auferida nos intervalos de 5, 10, 15, 20, 25, 30, 60 minutos. Um tubo foi fixado sobre uma superfície de vidro para medir a perda de água para 0 ar. 


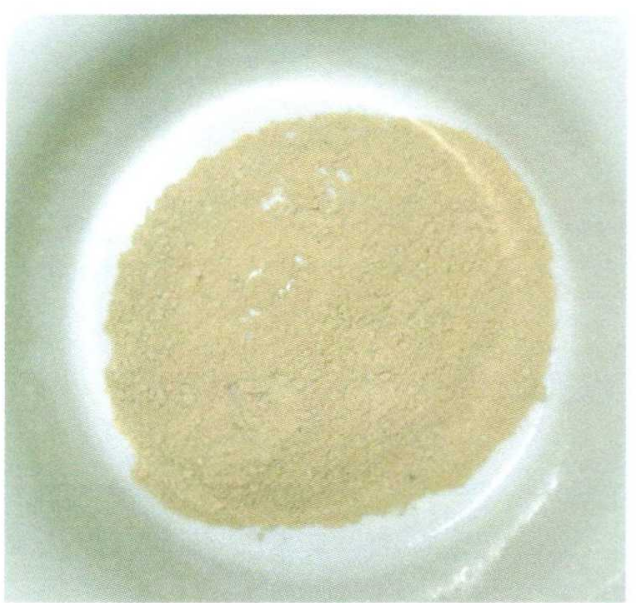

Figura 7.23 - Bentonita em pó.

Este teste foi realizado apenas na Universidade de São Paulo.

\subsection{Expansibilidade}

Muitas rochas sedimentares possuem argilominerais que causam expansão quando em contato com a umidade. Isto resulta em forças internas que geram sua deterioração. Este é um fato preocupante, principalmente quando esse tipo de rocha é parte de prédios ou monumentos. Para prever o comportamento da rocha, é necessário que a magnitude da expansão seja caracterizada. Na Universidade de Princeton, o laboratório do Prof. Dr. George W. Scherer utiliza um Analisador Mecânico Diferencial (DMA). Este teste consiste em colocar a amostra submersa em água e medir o quanto ela expande com o tempo.

A teoria é amplamente discutida em Scherer e Jiménez González (2005).

\section{Metodologia utilizada}

A expansão da rocha foi medida utilizando o analisador mecânico diferencial (Figura 7.24) da marca Perkin-Elmer (modelo DMA7). As amostras possuíam $15 \mathrm{~mm}$ de altura. O experimento consistiu em medir a altura da amostra, erguer o recipiente com água, enquanto o equipamento continua medindo a altura do corpo de prova, uma vez por segundo. Após o final do teste, uma curva foi gerada e obteve-se a diferença entre a medida inicial e a final, verificando assim, o quanto a amostra expandiu em contato com a água. 


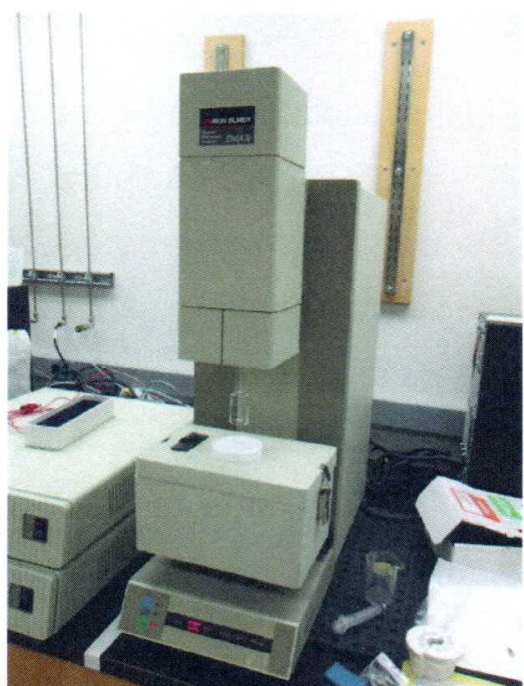

Figura 7.24 - Analisador mecânico diferencial.

\subsection{Microscópio Eletrônico de Varredura (MEV)}

O MEV obtém imagens de superfícies, com grande profundidade, alta resolução e aparência tridimensional. Por meio da interação entre elétrons, gerados pelo equipamento, e a matéria, o MEV permite visualizar informações como hábito, potencial elétrico e diferenciação entre elementos químicos. Utilizando os raios $\mathrm{X}$, é possível mapear a composição química de uma região ou um cristal (Mannheimer 2002).

Segundo este autor, existem dois tipos de obtenção de imagens. Com os elétrons secundários, que possuem baixa energia dispersiva, pode-se visualizar a topografia e a morfologia da superfície. Com elétrons retroespalhados, pode-se verificar, além das feições vistas nos elétrons secundários, o contraste de número atômico, que aparece como tonalidades diferentes na amostra. Quanto mais clara a imagem, mais pesado o elemento que a compõe.

Este autor cita que, para realizar o ensaio, as amostras são fixadas sobre a mesa de trabalho e todo o conjunto da coluna é mantido em vácuo. Os elétrons, emitidos através do aquecimento de um filamento, geralmente de tungstênio (pode ser de alumínio), que é chamado de cátodo, são acelerados e focalizados por uma lente, formando um feixe colimado de elétrons. Os elétrons primários incidem na amostra, se espalham e geram elétrons secundários, por uma modulação da intensidade do feixe de raios catódicos. Esses, são reconhecidos pelo detetor e a imagem é formada na tela. 


\section{Metodologia utilizada}

Para os ensaios no Microscópio Eletrônico de Varredura foram utilizados três equipamentos. O primeiro é um LEO 400I, equipado com espectrômetro de energia dispersiva de raios $X$ (EDS) Oxford, do Laboratório de Microscopia Eletrônica de Varredura do Instituto de Geociências (LabMev IGc), da Universidade de São Paulo. Para o ensaio, as amostras foram recobertas com carbono.

O segundo é um Quanta FEG 600 - FEI, equipado com sistema de microanálise por EDS Quantax-Bruker, (Detector 4030) e com silicon drift detector, do Laboratório de Caracterização Tecnológica, da Engenharia de Minas e de Petróleo (Escola Politécnica), da Universidade de São Paulo. Para o ensaio neste equipamento, as amostras foram recobertas com platina, que tem aproximadamente $15 \mathrm{~nm}$ de espessura.

O terceiro é um VPE SEM Quanta $250 \mathrm{FEI}$, do Laboratório de Microscopia Eletrônica de Varredura do Centro de Pesquisas Geocronológicas (LabMev CPGeo) do Instituto de Geociências da Universidade de São Paulo. Para o ensaio neste equipamento, as amostras não precisaram de nenhum recobrimento.

Os parâmetros utilizados em cada imageamento consta na legenda da respectiva figura.

Os equipamentos são mostrados na Figura 7.25.

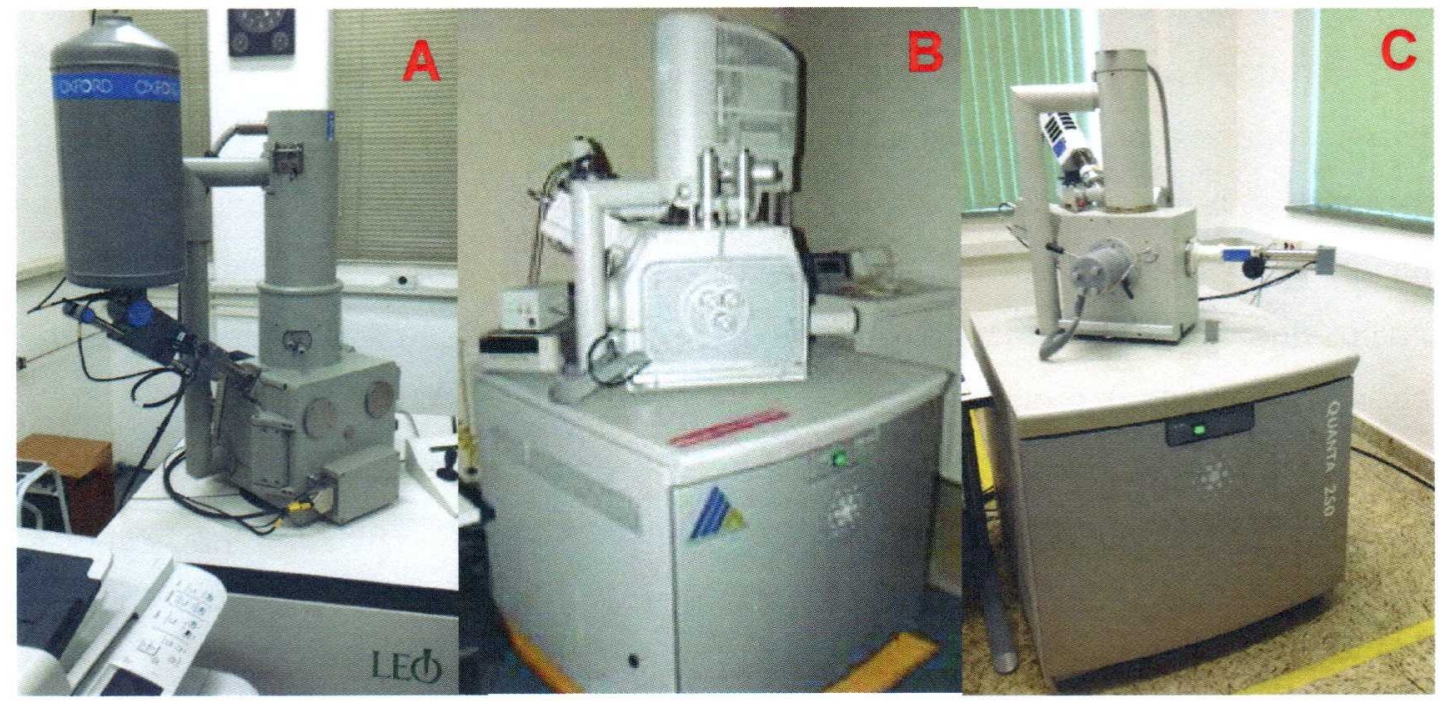

Figura 7.25 - Microscópio Eletrônico de Varredura (MEV). A= LEO 440I, B= Quanta FEG 600 $\mathrm{C}=$ VPE SEM Quanta 250 (MEV Ambiental). 


\subsection{Porosimetria de mercúrio}

O equipamento possui três câmaras para inserir a amostra e realizar o teste. Duas delas ficam em baixa pressão e medem o volume dos poros maiores e mais facilmente acessíveis. A terceira, é ensaiada em alta pressão e mede o volume dos poros menores. Esta técnica tem sido utilizada para caracterizar vários aspectos de materiais porosos, como volume dos poros e intrusão cumulativa. Ela foi proposta em 1921 por Washburn e consiste em medir a distribuição e tamanho dos poros, a partir de dados de pressão e volume, que são obtidos quando o mercúrio, que é uma substância não molhante, penetra os poros do material. O mercúrio, devido às suas características, só penetra nos poros quando é aplicada pressão. Quando inicia a pressão, a máquina registra este parâmetro, juntamente com a redução do nível de mercúrio nos capilares. Como resultado, é produzida uma curva porosimétrica, onde os picos mostram o volume dos poros do material.

O porosímetro usa a equação de Washburn (Eq. 14) para medir a distribuição e diâmetro dos poros.

$$
D=\frac{-4 \gamma \cos \theta}{P}
$$

Onde:

$\mathrm{D}=$ raio do poro $(\mu \mathrm{m})$;

$\gamma=$ tensão superficial do mercúrio (485 dynas $\left./ \mathrm{cm}^{2}\right)$;

$\theta=$ ângulo de contato $\left({ }^{\circ}\right)$;

$\mathrm{P}=$ pressão $(\mathrm{Pa})$.

Esta equação considera que todos os poros são cilíndricos e que todos se esvaziam quando a pressão chega a zero.

\section{Metodologia utilizada}

Para o ensaio realizado em ambas as Universidades, o procedimento foi 0 mesmo. Registrou-se o peso da amostra, do recipiente que a recebeu, e do conjunto pronto com recipiente, amostra, graxa e tampas. O conjunto montado foi colocado no local para rodar à baixa pressão. Os dados de peso são digitados no programa que calcula os dados. Com o término deste ciclo, coloca-se o conjunto no espaço para alta pressão.

O equipamento utilizado na Universidade de Princeton é mostrado na Figura 7.26 e o utilizado no Brasil (Pore Sizer 9320 da Micrometrics) é mostrado na Figura 7.27 . 


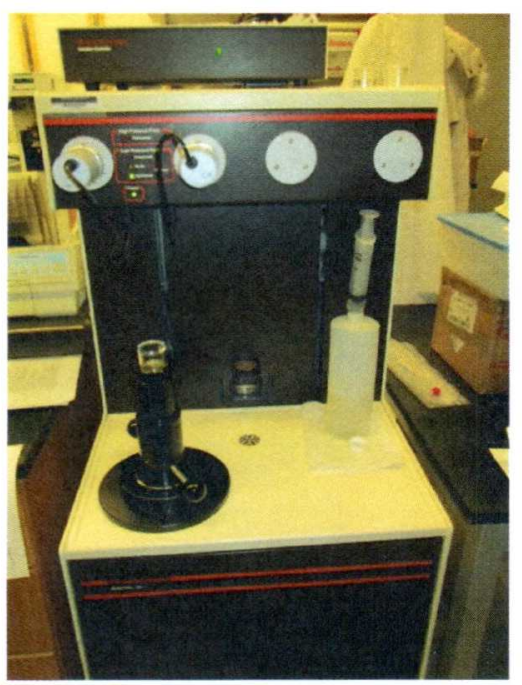

Figura 7.26 - Equipamento de porosimetria de mercúrio - Universidade de Princeton.

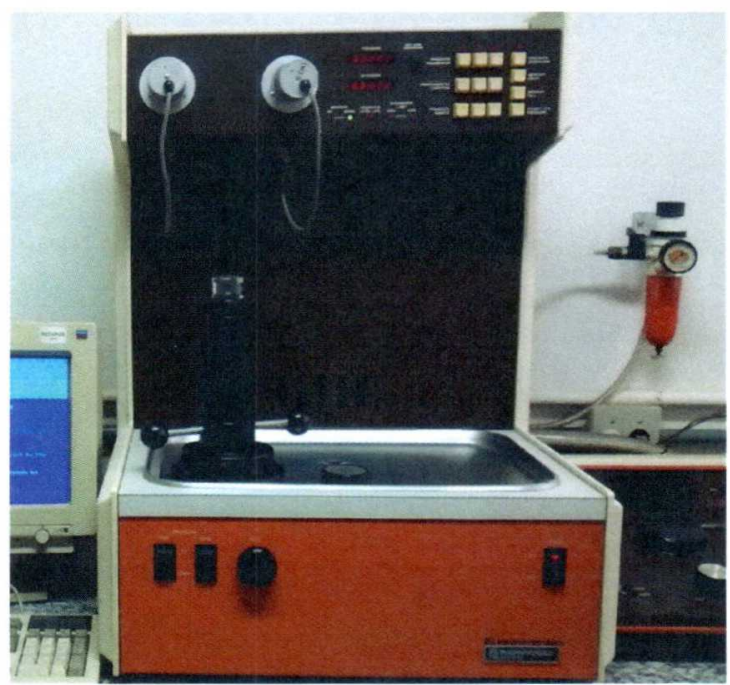

Figura 7.27 - Porosímetro utilizado na Universidade Federal de São Carlos.

\subsection{Saturação a vácuo}

Este teste é um método simples para medir a porosidade da rocha.

O ensaio consiste em pesar a amostra, colocá-la dentro do dessecador (Figura 7.28) e criar vácuo. Após 2 minutos produzindo vácuo, foi adicionada água até cobrir a amostra. Depois disso, deixou-se o ar entrar pela mangueira equalizando a pressão interna com a pressão atmosférica. Após 20 minutos a amostra foi pesada novamente. Dividindo-se o ganho de peso pelo peso inicial, a porosidade, em porcentagem, é obtida.

Este método não se adequa para comparar a porosidade com outros métodos como a porosimetria de mercúrio.

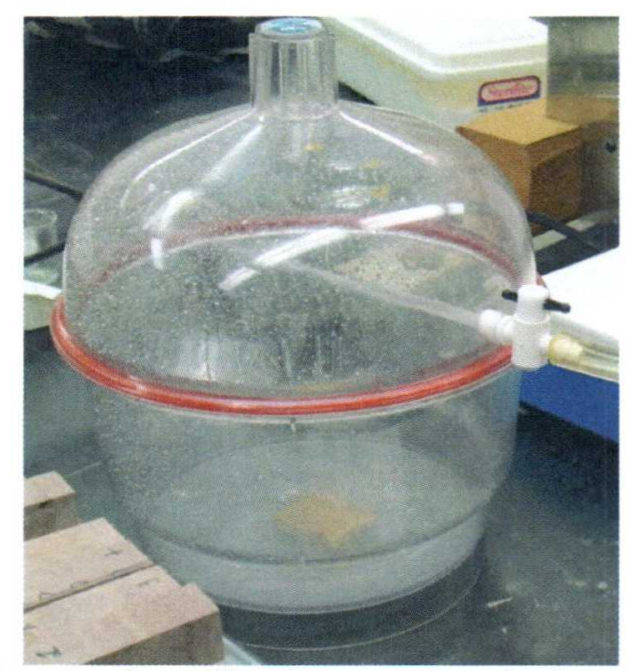

Figura 7.28 - Dessecador, utilizado para o ensaio de saturação a vácuo. 


\subsection{Resistência à flexão}

Quando uma placa de rocha saturada de água é submetida à flexão, o lado côncavo é comprimido e o convexo é tracionado, portanto um gradiente é criado nos poros com líquido. O líquido flui até que a pressão atmosférica seja restaurada. A força requerida para sustentar a flexão diminui com o tempo, o que é chamado de relaxação hidrodinâmica, pois resulta do fluxo do líquido nos poros (Scherer e Jiménez González 2005).

\section{Metodologia utilizada}

Para estes testes, foi utilizado um equipamento desenvolvido na Universidade de Princeton pela equipe do Prof. Dr. George W. Scherer, do Departamento de Engenharia Química e Biológica (Figura 7.29). As medidas foram extraídas durante a aplicação da força. O objetivo era obter uma reta utilizando os valores das medidas e calcular sua equação, para saber qual é a resistência da rocha. Neste teste, a rocha não deve ser destruída; deve-se diminuir a pressão antes disso.

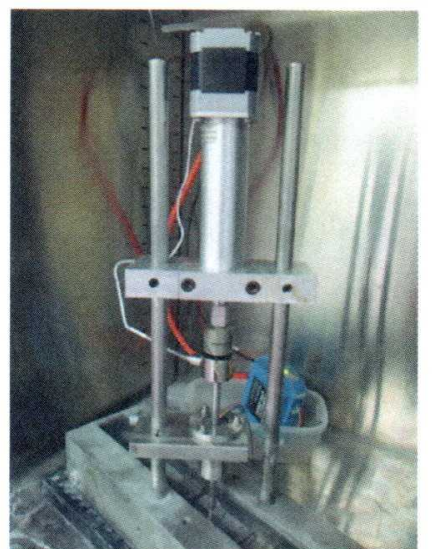

Figura 7.29 - Equipamento de teste de resistência à flexão.

\subsection{Saturação e secagem}

Um dos elementos mais nocivos à durabilidade das rochas é a água. Principalmente, quando se trata de uma rocha que possui argilominerais expansivos em sua composição. O umedecimento faz com que os argilominerais expandam e criem uma tensão interna entre os minerais. Quando a água evapora e a rocha seca, os minerais expansivos tendem a, gradualmente, voltar a um local bastante próximo do original. A água também pode lixiviar alguns elementos químicos, além de minerais. Estes dois processos fazem com que sejam criados espaços vazios, aumentando a 
porosidade da rocha e diminuindo a coesão entre os grãos, deixando-a, com o passar do tempo, mais friável.

Para simular a saturação por água e a secagem das rochas, a equipe do laboratório do Prof. George W. Scherer desenvolveu uma máquina que umedece e seca, constatemente, as amostras. Há ainda a possibilidade de aquecê-las, caso seja necessário. Com sua autorização, este equipamento foi construído no Brasil para realizar o teste novamente.

\section{Metodologia utilizada}

Para este ensaio, o procedimento utilizado em ambas as Universidades foi o mesmo, assim como o equipamento. O objetivo do equipamento (Figura 7.30) é saturar e secar as rochas, para simular as solicitações que elas sofrem quando expostas em locais abertos. Para isso, as rochas são presas nas correias, que giram e as colocam imersas em água em $1 / 3$ do tempo e $2 / 3$ do tempo permanecem fora da água sendo secas por um ventilador que fica na parte superior. Este procedimento completo corresponde a 1 ciclo. Pode-se modificar a velocidade de rotação e foi escolhido 1 ciclo por hora. Ao final do teste os valores de peso, velocidade de ondas ultrassônicas e de cor, são comparados tanto com os valores iniciais da mesma amostra, quanto com os valores iniciais e finais da amostra sem tratamento.

No total este experimento durou 550 ciclos. Este teste só foi realizado com o Arenito Itararé.

Foram acompanhados os valores de peso, velocidade de ondas ultrassônicas e cor, antes, durante a após os ciclos de saturação e secagem.

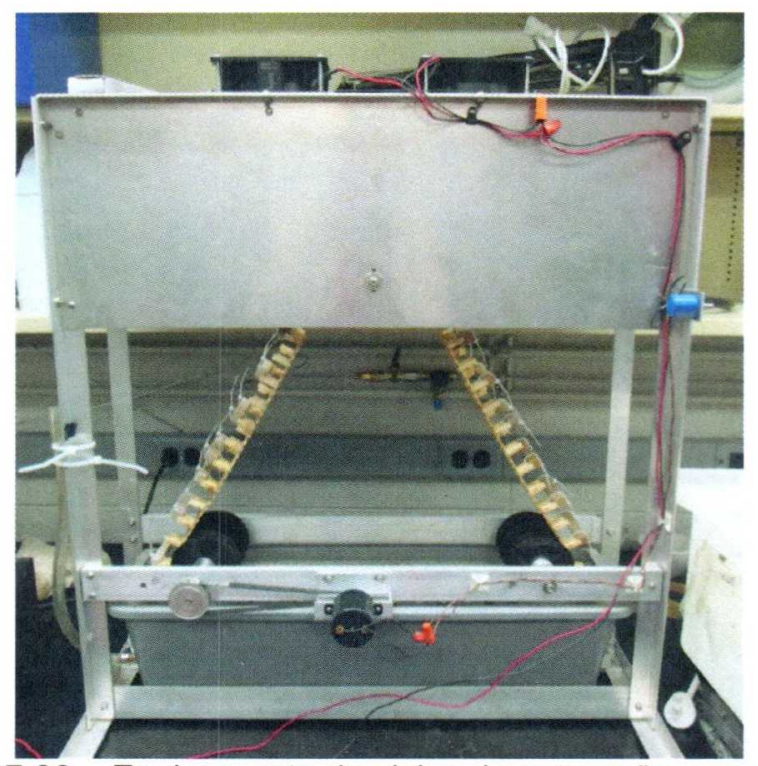

Figura 7.30 - Equipamento de ciclos de saturação e secagem. 


\subsection{Espectrofotometria}

Monumentos e prédios em pedra têm a cor de sua superfície alterada devido à poluição atmosférica, chuvas ácidas, oxidação e redução de minerais como $\circ \mathrm{Fe}$ (ferro), colonização biológica, excrementos de animais, urina, fogueiras e velas, eflorescências, dentre outros.

A percepção da cor depende de fatores como a idade, a acuidade visual, alterações genéticas como o daltonismo, parâmetros como cor do fundo, luminosidade e tamanho do objeto. Para eliminar a dependência destes fatores e transformar um parâmetro qualitativo em quantitativo, foi desenvolvido o espectrofotômetro.

Para interpretar os dados, foi desenvolvido o diagrama cromático da CIE (Commission Internacionale d'Eclairage) (Figura 7.31), que utiliza o os parâmetros de Luminosidade $(\mathbf{L})$, cromaticidade $\left(\mathbf{a}^{*}\right.$ e $\left.\mathbf{b}^{\star}\right)$, saturação $(\mathbf{C})$ e tonalidade $(\mathbf{h})$. Para a luminosidade o valor 100 identifica o branco e 0 o preto. Para a cromaticidade, $0 \mathbf{a}^{*}$ representa as cores verde (valores negativos) e vermelho (valores positivos) e $\mathbf{b}^{*}$ representa azul (valores negativos) e amarelo (valores positivos).

Quando é feita a manutenção de um monumento, tenta-se deixar a pedra com sua cor próxima da original, porém com a manutenção da pátina causada pelo tempo. É importante na visão atual, que não se limpe a pedra demasiadamente, evitando assim que o monumento fique com aspecto novo; o que atualmente, é considerado artificial. Para tal, o espectrofotômetro é imprescindivel. Ele também pode ser usado para acompanhar a aplicação e deterioração de um tratamento protetivo/consolidante, além de acompanhar manutenções de limpeza.

A teoria que embasa este método é discutida em Grossi (2013).

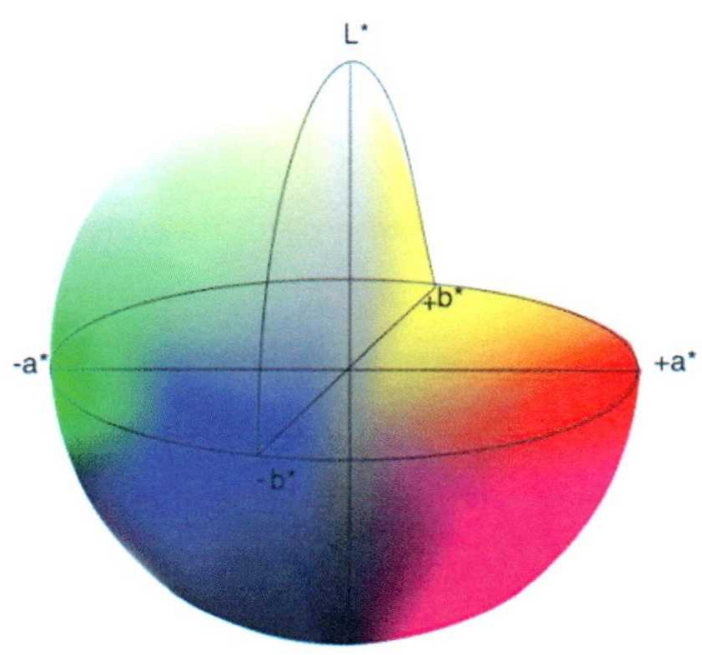

Figura 7.31 - Diagrama CIELab (http://www.flexoglobal.com/flexomag/08September/graphics/ploumidis7a.gif). 


\section{Metodologia utilizada}

Foram realizadas três campanhas de medidas no Teatro Municipal. Em todas, esperou-se pelo menos 5 dias sem chuvas para realizar o ensaio. Foram realizadas 15 medidas em cada área de aproximadamente $20 \times 30 \mathrm{~cm}$. As campanhas de medidas foram realizadas nos dias 20/01/2014, 13/04/2015 e 12/05/2016, e foram ensaiadas 27 áreas. Estas áreas foram cuidadosamente mapeadas, para que nas leituras subsequentes fossem medidas sempre nas mesmas áreas.

Para esta pesquisa, foi utilizado um espectrofotômetro Konica Minolta CM 2500d (Figura 7.32) com os seguintes parâmetros:

- iluminante D65 (utiliza a luz do dia para seus cálculos, incluindo o ultravioleta);

- componente especular incluso (SCI) e excluso (SCE);

- observador a um ângulo de $10^{\circ}$;

- abertura de $8 \mathrm{~mm}$.

O software On Color versão 5.4.5.1 foi utilizado para a análise dos dados.

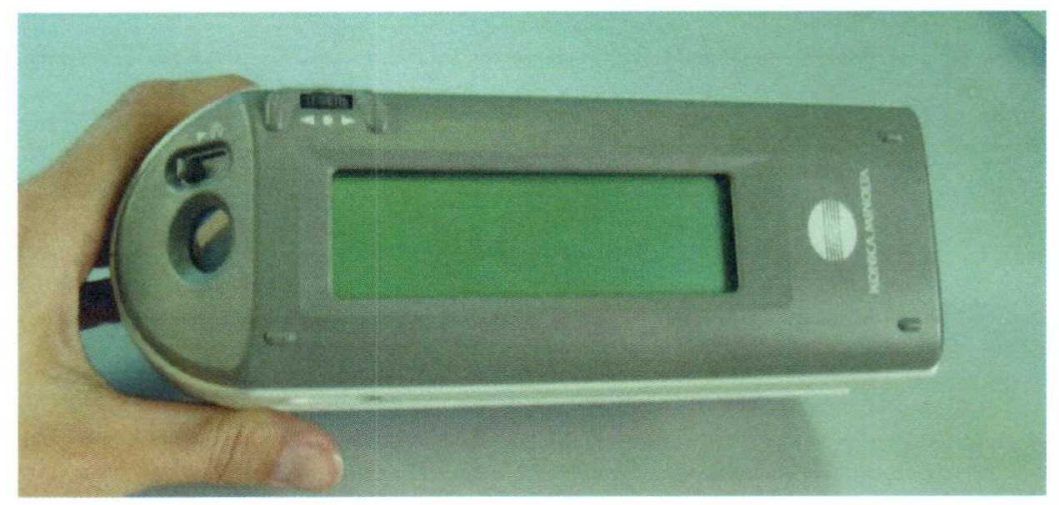

Figura 7.32 - Equipamento utilizado nos testes de espectrofotometria.

\subsection{Profundidade de Penetração}

Este experimento foi desenvolvido a partir de conversas realizadas com Enrico Sassoni e no artigo de Franzoni et al. (2014). A partir destas fontes, uma nova metodologia foi desenvolvida para que fosse utilizável em laboratório, mas também condizente com a realidade encontrada no momento de uma intervenção de conservação ou restauração.

\section{Metodologia utilizada}

As amostras de $5 \times 5 \times 5 \mathrm{~cm}$ foram cortadas e secas à temperatura ambiente. Após estarem completamente secas (quando o peso estabiliza), iniciou-se o processo 
de aplicação dos produtos. Os pré-tratamentos foram realizados pela técnica de impregnação, ou seja, a base da amostra foi colocada em contato com o produto para que esse atingisse o topo por capilaridade. Quando isto ocorreu, a amostra foi totalmente submersa no produto e só foi retirada após 24 horas. $O$ tratamento final foi realizado de acordo com as técnicas citadas abaixo. As amostra com pré-tratamentos anteriores ao produto, que seria avaliada a profundidade de penetração, tiveram os pré-tratamentos aplicados pelo método de imersão, para que toda a amostra estivesse impregnada.

Para testar a profundidade de penetração, três técnicas distintas foram avaliadas:

- pincel;

- spray;

- polpa;

- celulose;

- bentonita;

- estopa.

Para as técnicas do spray e do pincel, foram realizadas três camadas de aplicação, com intervalo de 5 minutos entre elas. Este intervalo foi escolhido para garantir que houvesse produto disponivel para que a rocha o absorvesse. $\mathrm{Na}$ bibliografia consultada, era indicado o intervalo de 10 minutos entre as aplicações e 10 camadas de aplicação do produto. No entanto, foi observado que este tempo de intervalo é ineficiente, pois os produtos secam, dificultando a penetração mais profunda. Uma nova metodologia foi desenvolvida, pois 10 aplicações são inviáveis em grandes áreas e o intuito deste trabalho é ser o mais factível possível na prática do conservador restaurador.

Foram feitas 3 aplicações com intervalos de 5 minutos entre elas, visando manter um filme de produto disponível para que a rocha pudesse absorver e sem que a superfície secasse e dificultasse a penetração da próxima camada. Essa metodologia foi utilizada tanto para a aplicação com o pincel quanto com o spray.

Para facilitar a técnica do spray e evitar a fadiga manual, foi utilizado um borrifador de pressão acumulada, que se mostrou bastante prático e postergou a fadiga.

$\mathrm{Na}$ aplicação do produto com polpa de celulose (Figuras 7.33 e 7.34), a polpa foi embebida no produto por uma hora para absorvê-lo, depois foi amassada em um almofariz de ágata e finalmente aplicada na rocha, formando uma camada de pouco mais de $0,5 \mathrm{~cm}$. Foi retirado o excesso de produto da polpa antes de aplicá-la na superfície, para minimizar o escorrimento. 


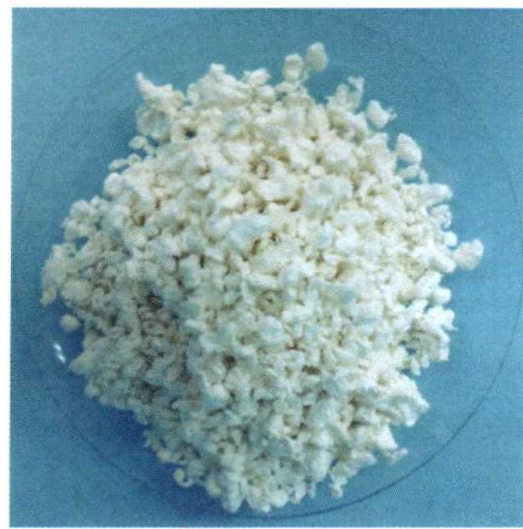

Figura 7.33 - Polpa de celulose seca.

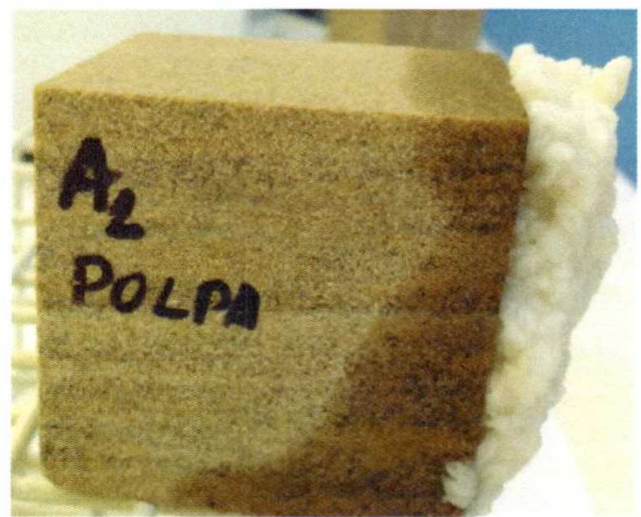

Figura 7.34 - Polpa de celulose aplicada.

O acamamento foi posicionado horizontalmente, assim como ocorre na pedreira e no momento da deposição, que é a posição ideal para a colocação das rochas no momento do assentamento. O produto foi aplicado na superfície vertical para simular a situação encontrada na fachada. Após a finalização da aplicação, as amostras foram quebradas ao meio (Figura 7.35). A medida do umedecimento foi coletada na parte mais central (Figura 7.36). Para medir a parte umedecida, foi utilizado um paquímetro digital (Figura 7.37) com precisão de dois algarismos. Para quebrar as amostras, foram utilizados martelo e ponteira (Figura 7.38).

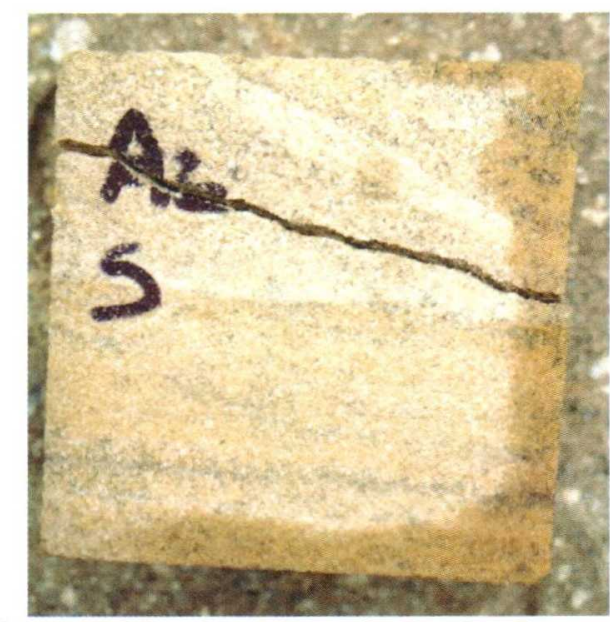

Figura 7.35 - Amostras de $5 \times 5 \times 5 \mathrm{~cm}$ para teste de profundidade de penetração.

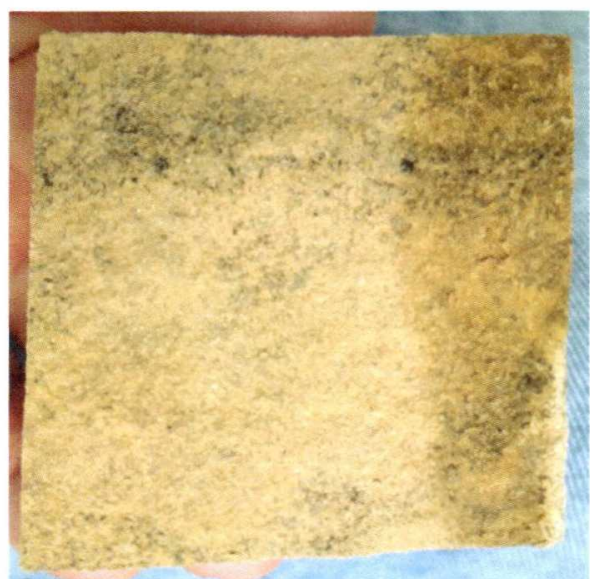

Figura 7.36 - Corte de amostra após teste de profundidade de penetração. 


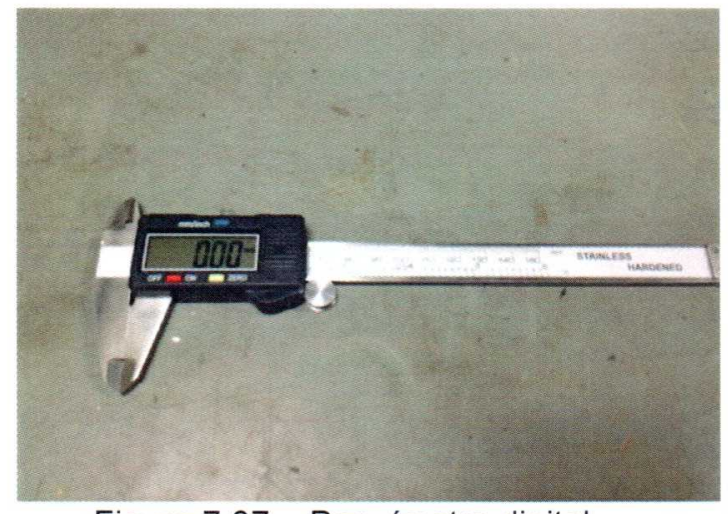

Figura 7.37 - Paquímetro digital.

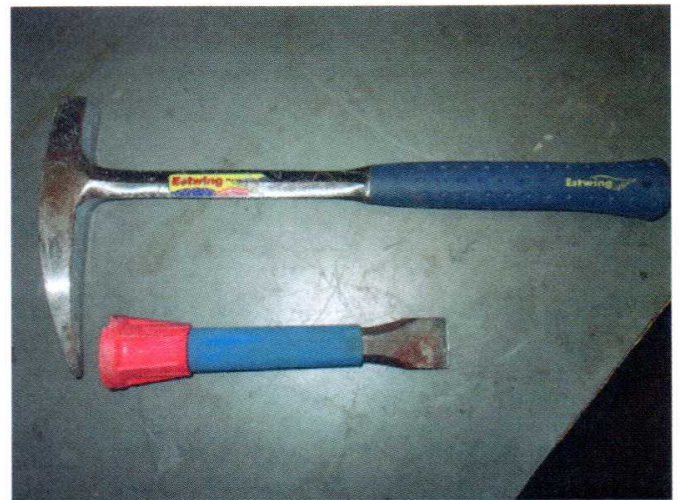

Figura 7.38 - Martelo e ponteira.

A técnica de aplicação de polpa pode ser realizada com diversos materiais. Neste caso, foram utilizadas a celulose (para a maioria dos casos), estopa e bentonita; sendo estas duas últimas utilizadas apenas quando necessário.

$\mathrm{Na}$ técnica de polpa de celulose, o TW não se mostrou adequado pois endureceu a polpa e esta não pôde ser triturada no almofariz e, portanto, não houve possibilidade de aderência com a superfície vertical. Duas outras técnicas foram testadas: estopa e bentonita. A estopa apresentou uma aderência muito fraca e a bentonita mostrou maior aderência, mas deixou resíduos.

$\mathrm{O} \mathrm{CaOH}$ e $\mathrm{PCaOH}$ não apresentaram resultados com o spray, pois entupiram o equipamento. Portanto, esta técnica não é recomendada quando se usa a solução de hidróxido de cálcio $(\mathrm{CaOH})$.

O tempo de intervalo entre as aplicações tanto do spray quanto do pincel foi de 2 minutos para 808 e 630 , pois eles secaram rápido e após secos, estes produtos impedem que mais uma camada seja aplicada devido à sua característica hidrofugante.

\subsection{Alteração acelerada}

Este ensaio visa simular situações encontradas no ambiente em que a rocha está exposta, como por exemplo, variações térmicas e ação de poluentes. O objetivo é avaliar seu comportamento e quais são os mecanismos de deterioração da mesma. Ou seja, verificar qual a resposta dos componentes intrínsecos da rocha às características extrínsecas (ambientes degradadores) a que estão expostas (Frascá 2003a). No caso desta pesquisa, também foi avaliado como os consolidantes e hidrofugantes utilizados reagem quando expostos a fatores ambientais. 
Estes ensaios são realizados em câmaras climáticas. Existem alguns tipos de câmaras, como as de $\mathrm{SO}_{2}$ (dióxido de enxofre), UV (ultravioleta) e de névoa salina. Para este trabalho foi utilizada a câmara de $\mathrm{SO}_{2}$.

A câmara de atmosfera rica em $\mathrm{SO}_{2}$, visa simular as intempéries causadas pela chuva ácida, oriundas deste tipo de contaminação atmosférica, presente em grandes centros urbanos.

\section{Metodologia utilizada}

O ensaio foi realizado de acordo com a norma estabelecida pelo CETEM - RJ, que é baseada na norma ABNT NBR 8096 - Material metálico revestido e nãorevestido - Corrosão por exposição ao dióxido de enxofre.

Foram medidos o peso, a velocidade de ondas ultrassônicas (com o equipamento disponível no Brasil - V-Meter Mark III) e cor, antes e depois do ensaio. O parâmetro massa foi utilizado para o cálculo do módulo dinâmico.

As amostras foram colocadas na câmara, de modo que estivessem pelo menos $10 \mathrm{~cm}$ distantes das paredes e $20 \mathrm{~cm}$ distantes do teto. Foram colocados três corpos de prova com cada tratamento e mais três sem tratamento, para que estes representassem o valor de controle; totalizando 33 amostras.

Foram colocados 2 litros de água destilada no interior da câmara, até que a placa de metal, que existe em seu fundo, estivesse completamente coberta. Iniciou-se o teste com temperatura de $40^{\circ} \mathrm{C}$. Após esta temperatura ser atingida, injetou-se $0,2 \mathrm{~L}$ de gás $\mathrm{SO}_{2}$. Ligou-se o circulador para homogeneizar a atmosfera no interior da câmara. Após 8 horas nestas condições, a câmara foi aberta por 16 horas e a água trocada. Este procedimento refere-se a 1 ciclo.

Pela norma do CETEM - RJ, a amostra deve ser submetida a 30 ciclos. No entanto, foram feitos apenas 15 ciclos, pois a intenção era alterar apenas o produto, que está presente na camada superficial e não alterar a rocha em profundidade.

A câmara de $\mathrm{SO}_{2}$ e as amostras posicionadas para o início do ensaio, encontram-se nas Figuras 7.39 e 7.40 . 


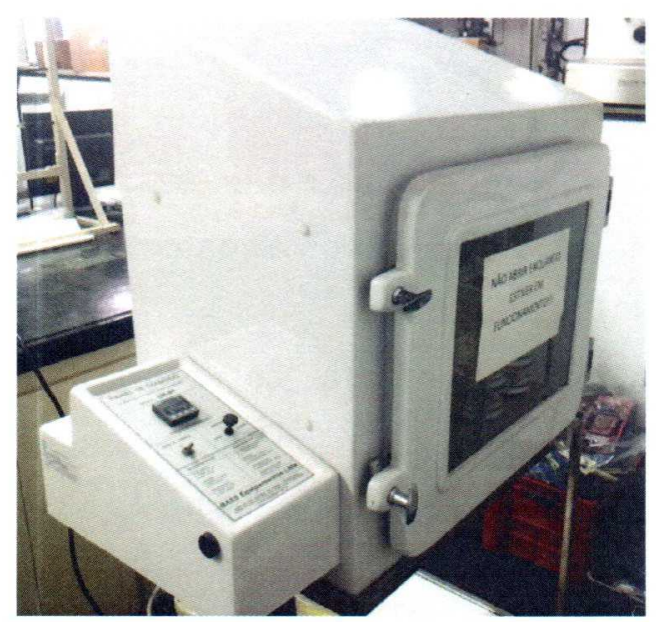

Figura 7.39 - Câmara de $\mathrm{SO}_{2}$.

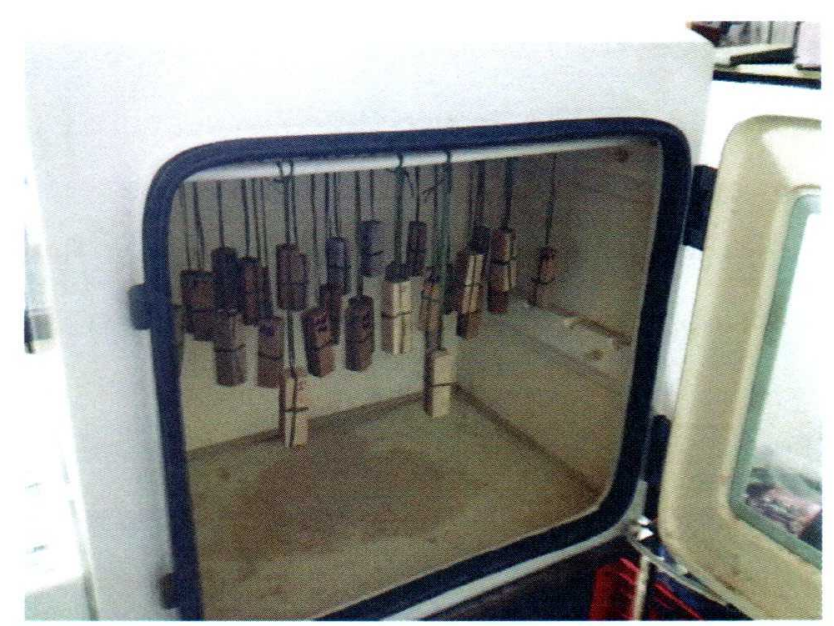

Figura 7.40 - Câmara com amostras erguidas. 


\section{Consolidantes}

A história do uso de consolidantes é longa e um pouco desanimadora. Muitos produtos que surgiram no mercado mostraram-se ineficientes, outros, que eram muito promissores, mostraram-se com pouca ou nenhuma eficiência. Outros ainda causaram mais danos do que se não tivessem sido aplicados (Price 2006).

No século XIX, os consolidantes eram de base mineral como silicatos, fluoretos, água de cal e barita (Borsoi et al. 2012). Todavia, estes não penetravam em profundidade, e visavam apenas agregar os grãos. No século $X X$, iniciaram-se as pesquisas para que estes produtos penetrassem em maior profundidade, com o intuito de proteger e consolidar a rocha, pois os tratamentos superficiais estavam gerando o desplacamento das superfícies nas quais eram aplicados (Price 2006). Iniciou-se a utilização de resinas acrílicas e epóxi, pois os produtos sintéticos apresentam melhor aderência, são mais flexíveis, de mais fácil aplicação e grande compatibilidade com o substrato (Borsoi et al. 2012). Este é exatamente o caso do Teatro Municipal de São Paulo: desplacamentos. Nas segunda e terceira restaurações foi utilizado o Paraloid $B 72^{\circledR}$ em baixa concentração, para não fechar os poros. Atualmente já são vistos desplacamentos de cerca de $2 \mathrm{~cm}$ de espessura, que podem ser devido à formação desta placa de dureza maior que a rocha.

No entanto, um dos problemas que poderia ser causado pela aplicação do consolidante era o encapsulamento e manutenção de sais dentro das rochas. Para isso os consolidantes foram aprimorados e atualmente permitem que sais que estão dentro da rocha, possam se cristalizar do lado de fora, evitando que a cristalização ocorra internamente e cause estufamentos e posterior desplacamento das superfícies tratadas. Para diminuir a deterioração do patrimônio em pedra, desde a antiguidade são realizados reparos e reposições de peças para que este permaneça do modo como foi construído. $\mathrm{Na}$ antiguidade, não havia tecnologia suficiente e a maioria das rochas utilizadas eram as que estavam expostas há muito tempo e devido a isso, com resistência reduzida, causada pela deterioração gerada pelos fatores intempéricos. Para retirar as rochas mais frescas, que estão em profundidade, foi necessário o advento da pólvora e das máquinas.

Durante o século XIX, os produtos químicos para consolidação apresentaram grande desenvolvimento, dentre eles os silicatos de sódio ou potássio (water glass), silicatos de etilo e fluorosilicatos, que foram desenvolvidos para agir como consolidantes. Consolidantes orgânicos foram desenvolvidos após século XX. Dentre eles é possível citar as resinas acrílicas e epóxi. Esses produtos eram, em geral, sintetizados para utilização industrial e recomendados para obras de conservação. 
Inicialmente, as práticas de preservação eram voltadas para obras de arte do acervo de museus, encontradas em escavações. Com o passar do tempo, passou a ser estendida para achados arqueológicos. Um dos primeiros exemplos de restauração foi a Grande Esfinge de Gizé (2700 - 2600 a.C.). Foi desenterrada da areia e restaurada pela primeira vez pelo Faraó Thutmosis IV (1400 a.C.). Blocos de rocha foram colocados em locais em que a original estava muito deteriorada (Snethlage e Sterflinger 2011).

Para balizar a utilização dos consolidantes, as diversas Cartas como as de Atenas e de Veneza, estabelecem alguns princípios, conceitos e práticas; o que facilita, harmoniza e restringe as obras.

\subsection{Propriedades dos consolidantes}

Os tratamentos de proteção e consolidação devem ser resistentes e repelentes de água, não restringir a difusão do vapor de água, resistente contra agentes químicos e biológicos e suportar ampla variação de temperatura. O consolidante deve ser compatível física (dimensão das partículas em relação a dos poros) e quimicamente com o substrato. Ele não deve bloquear os poros e nem impedir o movimento de umidade dentro da rocha. O produto deve ser invisível, não devendo causar mudanças na cor, textura e na refletividade da rocha, deve ser resistente aos raios ultravioletas e visíveis, à decomposição química, ou tornar-se frágil com o passar do tempo, além de não induzir o crescimento de algas e bactérias na superfície.

Custo, perigo de uso, impacto ambiental, facilidade e tempo de aplicação, sensibilidade à temperatura e à umidade durante a aplicação, são alguns pontos que devem ser analisados no momento da escolha de um consolidante.

O principal fator que dita a performance do consolidante é a ligação que o produto faz com os minerais. Para ser um bom consolidante o produto deve ter a habilidade de formar ligações em todas as direções (tridimensionalmente) e deve ter no mínimo três grupos reativos. Estes requisitos eliminam polímeros lineares que possuem componentes bifuncionais. Componentes com grupos tri e tetrafuncionais geralmente são desqualificados como consolidantes por possuírem propriedades indesejáveis. Tri e tetrafuncionais cloro e fluorosilanos são voláteis e geram ácidos clorídrico e fluorídrico durante a hidrólise, danificando as rochas. Ele deve apresentar baixa pressão de vapor para que o produto tenha tempo de penetrar e realizar ligações entre os grãos antes que ele evapore (Wheeler 2005). A solidificação ocorre por reação química ou por evaporação do solvente e deve reestabelecer a coesão 
interna, aumentando a resistência a força compressiva, à abrasão, ao intemperismo químico e diminuir a taxa de decaimento.

Consolidantes poliméricos, incluindo resinas epóxi, poliacrilatos, polimetacrilatos, poliésteres e polivinis podem ser divididos em duas categorias:

- Polímeros termoplásticos: endurecem com a evaporação do consolidante, mas não forma cadeias.

- Polímeros termoendurecíveis: é formado com ligação entre as cadeias, formando uma estrutura tridimensional insolúvel.

As desvantagens de um consolidante baseado em polímero é sua pequena profundidade de penetração, sensibilidade aos raios UV e susceptibilidade ao ataque microbiano (Naidu et al. 2015).

\subsection{Produtos}

Os produtos utilizados para consolidação podem ser orgânicos ou inorgânicos.

\subsubsection{Consolidantes orgânicos}

Por muitos anos os únicos materiais disponíveis para realizar pequenos reparos e para conservação preventiva eram cal, gesso de Paris, óleo de linhaça, cera e colas animais e vegetais. Misturas caseiras com cal ou com colas vegetais e animais eram usadas para produzir argamassa, utilizada para preenchimento. Partes quebradas eram coladas com cola de osso ou goma laca. Se as peças eram muitas, estas eram fixadas com grampos ou pinos de ferro ou bronze. Para peças que ficavam em locais abrigados, era utilizada uma mistura de cola animal e gipsita. Esta mistura é praticamente igual à utilizada para fazer pintura que imita o mármore, conhecida como stucco lustro. Em locais expostos às intempéries, como lápides em mármore ou calcário, a cera de abelha era utilizada para produzir brilho e hidrofugação. A cera de abelha era a cera, refinada por branqueamento, utilizada devido ao seu $\mathrm{pH}$, por não se tornar quebradiça e por ser facilmente retirada pela aplicação de vapor de água quente com um pouco de detergente. Esses produtos em forma de cera, como o polietileno glicol, penetravam nas rochas por meio de aquecimento. No entanto, esse tipo de abordagem era difícil de ser usada em áreas externas e de grandes dimensões devido à dificuldade de aquecer a superfície. Em locais quentes, a superfície tratada com esses produtos tendia a tornar-se suja. As ceras utilizadas atualmente, como o ciclododecano, são sólidas, voláteis e servem para consolidações temporárias e revestimentos em tecido. Quando dissolvido em solventes apolares, em poucas 
semanas já quase não há mais produto precipitado. Gorduras animais tendem a ser ácidas e acabam reagindo quimicamente com a superfície. Um problema causado pela cera de abelhas é que ela retém a poeira na superfície. Para a aplicação, ela pode ser aquecida até atingir o estado líquido ou ser diluída em aguarrás. As ceras modernas são feitas pela mistura de parafina microcristalina, obtida pela destilação do petróleo. Sua temperatura de fusão é superior à da cera de abelhas e não adere à temperatura ambiente (Snethlage e Sterflinger 2011).

Solventes de baixa viscosidade facilitam a penetração. Este método é utilizado para resinas naturais, como a goma laca e óleo de linhaça, mais utilizados no século XIX, ou para epóxi e resinas sintéticas, com aplicações mais recentes. Apesar de possuir boa penetração, esse tipo de resina pode ser absorvida seletivamente e não penetrar homogeneamente, além de diminuir a profundidade de penetração com a evaporação dos solventes. Apesar de suas desvantagens, alguns pesquisadores conseguiram bons resultados variando a combinação e porcentagem entre resina $e$ solvente. A resina epóxi pode causar escurecimento imediato e possui baixa durabilidade.

Outro método de aplicar os consolidantes orgânicos consiste em saturar a rocha com um monômero e induzir a polimerização in situ. Estes produtos são moléculas relativamente pequenas, que reagem entre si formando polímeros, que são moléculas muito maiores.

Os principais consolidantes orgânicos são acrilatos e silanos (Price 2006).

Acrilatos são dissolvidos em solventes orgânicos ou dispersões aquosas (neste caso, principalmente para reparos ou aditivos em argamassas). Sua fórmula geral é $\mathrm{CXY}=\mathrm{CH}_{2}$, que pode ser derivada do ácido acrílico. As letras $X$ e $Y$ referem-se a grupos orgânicos que determinam as propriedades mecânicas e químicas da resina de polímero acrílico. A formação do polímero resulta da quebra da dupla ligação entre os átomos de carbono com formação de longas cadeias com ligação simples entre os átomos de carbono (Figura 8.1) (Snethlage e Sterflinger 2011). A temperatura de transição vítrea $(\mathrm{Tg})$ determina a adequação do produto aos propósitos da conservação, principalmente no que se refere às propriedades mecânicas. Quando o produto está abaixo da $\mathrm{Tg}$, o produto é rígido e vítreo; quando está acima é mole e flexível. 


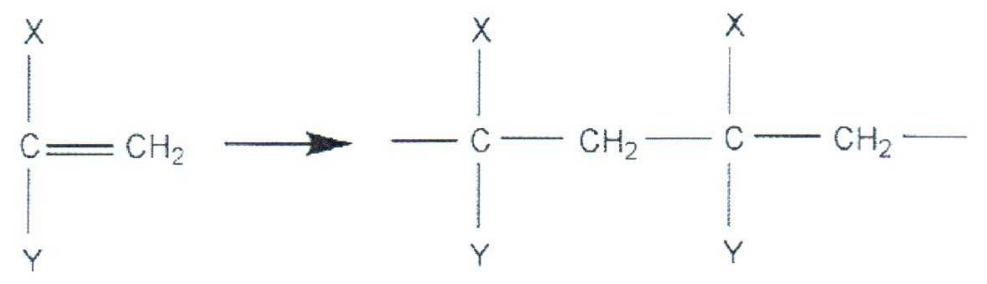

Figura 8.1 - Esquema da reação principal de formação do polímero acrílico (Snethlage e Sterflinger 2011).

Dentre os acrilatos, o mais conhecido é o Paraloid $B 72^{\circledR}$ produzido pela empresa Roehm \& Haas. Quimicamente, este produto é um copolímero de etil metacrilato e metil acrilato, com $\mathrm{Tg}=72^{\circ} \mathrm{C}$. Este produto é utilizado em rochas que estão se desagregando, cerâmicas, pinturas de parede, objetos arqueológicos metálicos, dentre outros. Ele é dissolvido em solventes orgânicos como o tolueno, acetona e butil acetato de butila em concentrações que vão de 2 a 10\%. Dependendo da volatilidade do solvente, mudam a área e o método de aplicação. Quanto menos volátil o solvente e maior o seu ponto de ebulição, maior a profundidade de penetração. Este produto não penetra profundamente em rochas porosas (Snethlage e Sterflinger 2011).

A profundidade de penetração pode chegar a $5 \mathrm{~mm}$ em mármores e arenitos muito alterados. Caso a profundidade de alteração seja maior, a aplicação deste produto pode causar desplacamento da superfície tratada.

No Teatro Municipal de São Paulo, na segunda e terceira intervenções, foi utilizado o Paraloid $B 72^{\circledR}$, que é um acrilato, para proteger a superfície do arenito.

O Paraloid B72 ${ }^{\circledR}$ (Figura 8.2) é comumente misturado com Dri-Film 104 da empresa General Electric para alcançar também o efeito hidrofugante. Essa mistura é conhecida como Coquetel de Bolonha, pois foi testado e aplicado em Bolonha por O. Nonfarmale e R. Rossi-Maranesi no ano de 1976 (Snethlage e Sterflinger 2011).<smiles>CCOC(=O)CC(C)(CC(C)(CC(C)(CC(C)(CC(C)(CC(C)(CC(C)(C)CC(C)(C)C(=O)OC)C(=O)OC)C(=O)OC)C(=O)OC)C(=O)OC)C(=O)OCC)C(=O)OCC</smiles>

Figura 8.2 - Estrutura química do Paraloid $B 72^{\circledR}$ (Snethlage e Sterflinger 2011). 
Silanos são compostos derivados do silício, que apresentam grande compatibilidade química com arenitos, pois formam pontes entre silício e oxigênio que são relativamente fortes, e possuem estabilidade termal e oxidativa. Apresentam bons resultados em rochas com deterioração média. Porém, resultam sem efeito em rochas muito degradadas (Price 2006), pois se depositam preferencialmente em pequenos poros ou matrizes de granulação fina e seu preenchimento causa escurecimento da rocha. Outra propriedade é ser resistente à radiação ultravioleta, o que torna esse produto ideal para ser utilizado em áreas expostas às intempéries. No entanto, tendem a descolorir quando as ligações colapsam ou se reconfiguram (Wheeler 2005). Estes produtos sofrem hidrólise, formando polímeros e dióxido de silício. Um álcool é formado durante a reação, sendo eliminado por evaporação. Uma vez formados os polímeros que unem os grãos, estes não podem ser desfeitos por solventes, tornando o tratamento irreversível. O tipo principal são os alcoxisilanos. Alguns deles possuem propriedades repelentes de água, devido à presença dos grupos metil e etil junto do elemento silício. Dentre os monômeros de silano, podemos citar os mais comuns como MTMOS (metiltrimetoxisilanos), ETEOS (etiltrietoxisilanos) e TEOS (tetraetoxisilano). Resinas acrílicas podem ser adicionadas aos silanos para deixar as superfícies mais duras (Price 2006).

O silano utilizado nesta pesquisa é o TEOS.

O TEOS, também conhecido como silicato de etila, é um dos produtos mais utilizados para consolidar rochas, principalmente arenitos e granitos. A deposição de gel de sílica pela aplicação do TEOS ocorre por duas reações que ocorrem simultaneamente. A primeira refere-se à hidrólise do grupo alcoxi, separando as moléculas de etanol. Esta reação pode ser melhorada pela catálise ácida ou alcalina, o que é feito na maioria dos produtos vendidos no mercado. O segundo passo é a condensação de silanóis (-Si-OH) instáveis para gel amorfo. No mercado são encontrados TEOS nas formas de monômero e oligômero, que têm a mesma ação. A única diferença é a presença de oligômeros na segunda forma apresentada (Snethlage e Sterflinger 2011). Uma grande vantagem do TEOS é que os produtos formados na reação resultam em etanol, que é completamente evaporado e não causa nenhum dano à rocha.

No processo de formação dos tetraalcoxisilanos (TMOS), quando em contato com a água líquida tornam-se menos hidrofóbicos, devido à hidrólise formar produtos menos solúveis como $\circ \mathrm{Si}(\mathrm{OH})_{4}$. Durante a hidrólise é produzido álcool. No processo de deposição do TEOS, a viscosidade permanece baixa até o momento da formação do gel. A formação do gel não é o fim da atividade química do produto. Após esta etapa, onde há partes sólidas e líquidas do produto, inicia a condensação (hidrólise). 
Nesta fase, o gel começa a encolher. Porém, ocorrem outras mudanças no gel além da contração. O engrossamento ou amadurecimento envolvem a dissolução e reprecipitação de partes do gel. A etapa posterior é a secagem, onde muitos problemas podem acontecer, como: evaporar, criar tensão superficial e rachar. As fraturas podem ocorrer por uma série de fatores, dentre eles a tensão superficial do líquido (Wheeler 2005). As etapas de formação do TEOS, tanto monomérico como oligomérico, são mostradas na Figura 8.3, onde é possível visualizar que a presença de água é essencial para a reação do TEOS e posterior formação de gel de sílica. Devido a esta característica, o TEOS não é efetivo em climas áridos, pois a água pode evaporar antes da formação do gel, isto é, existe a necessidade que haja um pouco de água nos poros para a formação do gel (Snethlage e Sterflinger 2011).

Os silanos são abordados em detalhe por Wheeler (2005). 


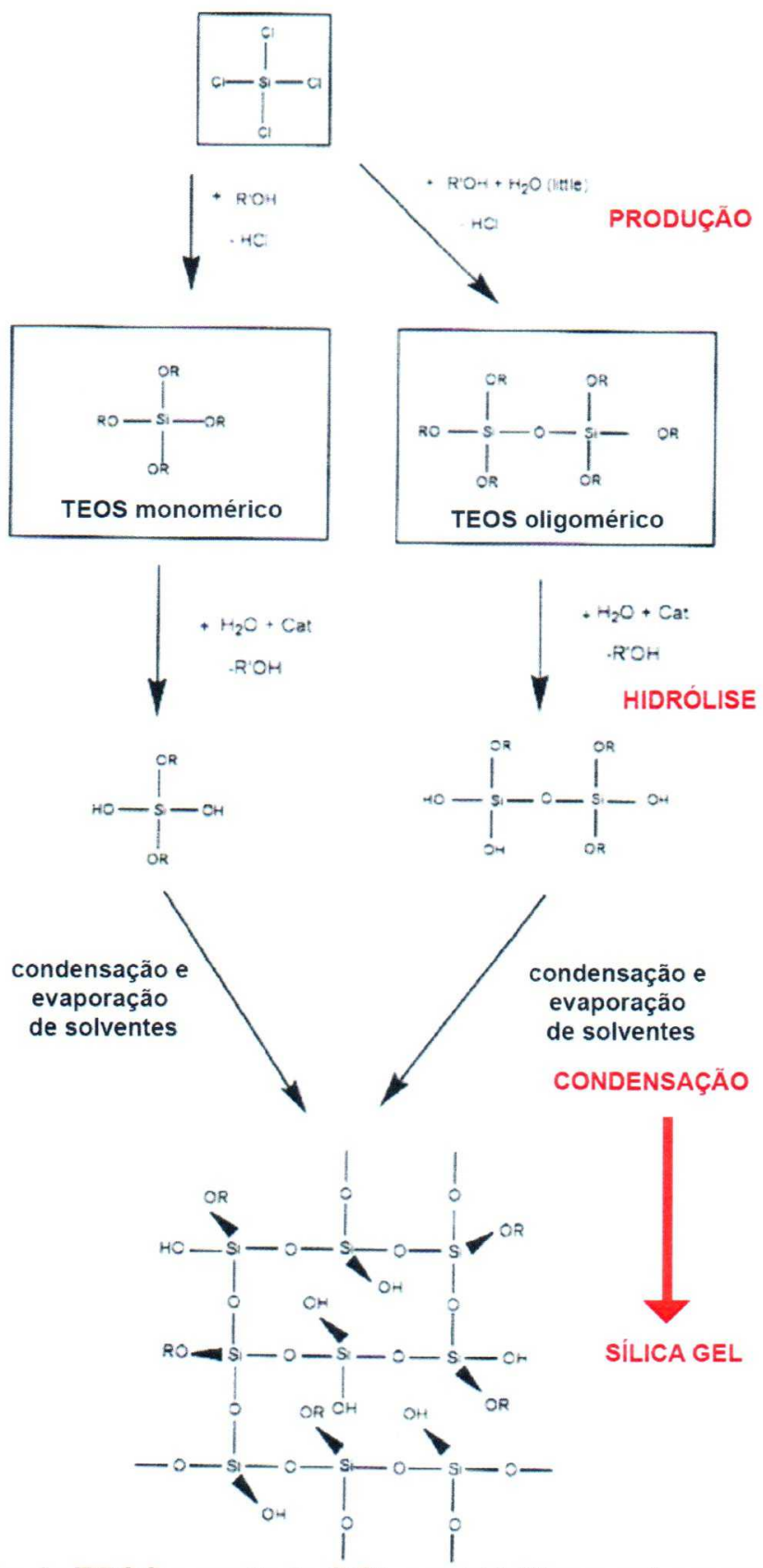

Figura 8.3 - Formação do TEOS a partir do $\mathrm{SiCl}_{4}$ por hidrólise e subsequente condensação (adaptado de Snethlage e Sterflinger 2011).

\subsubsection{Consolidantes inorgânicos}

Possuem origem mineral, incluindo soluções como hidróxido de bário e de cálcio. Em alguns casos, unem partículas desagregadas devido à reação com cálcio insolúvel e carbonato de bário, funcionando como os silanos (Price 2006).

A água de cal é uma solução saturada com $0,18 \mathrm{~g}$ de $\mathrm{Ca}(\mathrm{OH})_{2}$ por litro de água. Para consolidar rochas bastante degradadas, ela deve ser encharcada várias 
vezes com essa solução e, em geral, não funciona bem. Entre as aplicações, a rocha deve secar completamente. O princípio é a deposição de carbonato de cálcio nos poros. Mas este é um procedimento demorado e pode levar de semanas até um mês (Snethlage e Sterflinger 2011).

A reação química é mostrada na equação 15:

$$
\mathrm{Ca}(\mathrm{OH})_{2}+\mathrm{CO}_{2} \rightarrow \mathrm{CaCO}_{3}+\mathrm{H}_{2} \mathrm{O}
$$

Devido à sua baixa solubilidade, a deposição do $\mathrm{CaCO}_{3}$ (carbonato de cálcio) é muito pequena e a maioria dos cristais se forma muito próximo a superfície devido à maior facilidade em reagir com $0 \mathrm{CO}_{2}$ do ar. Hanser et al. (2003 apud Snethlage e Sterflinger 2011) revisaram este método e mostraram que há muitas contraindicações devido à grande quantidade de água aplicada sobre a rocha, que pode causar a cristalização de sais no seu interior.

A cristalização de sais no interior da rocha gera um aumento de pressão e posterior desplacamento de quantidade considerável de material, perdendo para sempre a superfície original.

Outros problemas causados por esse método são o branqueamento da superfície devido aos cristais de calcita e a alta alcalinidade da solução que fica por volta de $11 . \mathrm{O}$ pH alto leva à solubilização do ferro contido na rocha e a consequente perda de tons amarronzados. Também aumenta a taxa de deposição de poluentes do ar, como $\mathrm{SO}_{2}$ e $\mathrm{NO}_{x}$, o que acaba dissolvendo o carbonato de cálcio depositado (Snethlage e Sterflinger 2011).

O hidróxido de cálcio $\mathrm{Ca}(\mathrm{OH})_{2}$ é quimicamente compatível com rochas calcárias. Funciona como uma consolidação pela recristalização de gipsita (sulfato de cálcio) e de outros minerais solúveis. Muitos conservadores-restauradores preferem limpar a rocha com abrasivos a ar, laser, ou com emplastros antes de aplicar a água de cal.

Atualmente a deposição de calcita por bactérias tem sido utilizada em rochas carbonáticas degradadas. Porém esta técnica tem a limitação da profundidade de penetração.

A hidroxiapatita é um consolidante inovador para a consolidação de mármores e rochas carbonáticas (Sassoni et al. 2011, Sassoni et al. 2013, Graziani et al. 2015).

Outros consolidantes inorgânicos são hidróxido de bário, banho de cal, fluorosilicatos, silicatos de sódio ou potássio e sol de sílica. 


\subsection{Fatores que influenciam a ação dos produtos}

É importante observar a composição mineral, a porosidade total, porosidade acessível e distribuição dos poros e tamanho do grão, pois estas características influenciam o comportamento do consolidante.

É necessário que haja compatibilidade química e física entre a composição mineral da rocha e a composição química do produto. Caso contrário, pode ser que o produto não faça a ligação entre os grãos, apenas obstruindo os poros e não aumentando a resistência da rocha.

Uma técnica utilizada para examinar depósitos de silanos em rochas é a microscopia eletrônica de varredura (MEV). Este equipamento mostra a aparência do gel e sua relação com o substrato.

A consolidação das rochas é uma operação complexa, que pode ser dificultada pela presença de argilominerais.

Os argilominerais possuem muitos grupos $\mathrm{OH}$, que são receptivos aos alcoxisilanos. No entanto, Elfving e Jäglid's (1992 apud Wheeler 2005) demonstraram que a quantidade de TEOS depositado na muscovita foi menor do que a depositada no quartzo e no feldspato, que possuem poucas ligações Si-OH.

Sattler e Snethlage (1988) mostraram que os arenitos com cimentação argilosa, apresentam metade do incremento de resistência em relação aos arenitos com cimentação silicática. Felix e Furlan (1994 apud Wheeler 2005) compararam o comportamento da rocha Villarlod Molasse, que é constituinte de vários prédios suiços e contém argilominerais, frente à aplicação de silicatos de etilo, em relação a rochas que não contém estes minerais. O resultado foi que a Villarlod apresentou encolhimento de $1,5 \mathrm{~mm} / \mathrm{m}$, devido à deposição preferencial do produto entre as camadas argilosas e de sua compactação.

Snethlage e Wendler (1991 apud Wheeler 2005) alertam para os perigos de tratar arenitos de cimentação argilosa, pois o tratamento com alcoxisilanos aumenta a expansão que ocorre nas argilas quando em presença de água.

Mas quando os argilominerais estão presentes em calcários, eles melhoram o desempenho dos alcoxisilanos, o que foi comprovado pela maioria dos testes geomecânicos. Alguns calcários com argilominerais se contraem e em outros se expandem, aumentando o risco de deterioração por saturação e secagem depois da aplicação do alcoxisilano (Wheeler 2005).

Vale ressaltar que os argilominerais aqui mencionados não possuem a mesma estrutura, pertencem a diferentes grupos, e cada estrutura reage de modo diferente à consolidação. O desempenho de cada tipo de argilominerais não é descrito na 
literatura. Este tema precisa ser mais pesquisado para entender a influência dos argilominerais na consolidação.

\subsection{Modificações após aplicação do produto}

Um fator importante a ser considerado é a mudança de cor ou escurecimento da superfície após a aplicação do consolidante. Um dos fatores de mudança de cor são os minerais presentes. Mudanças de cor ocorrem em todos os materiais porosos, pois a interface mineral-ar é substituída pela interface mineral-consolidante. Devido a isso, a quantidade de luz refletida pelo mineral é menor, explicado pelo índice de refração do produto ser menor do que o da água. Esse fenômeno pode ser observado pelo escurecimento da rocha quando ela é molhada pela água da chuva, por exemplo.

\subsection{Prática}

Uma dúvida que existe é em que situações e condições deve-se utilizar os alcoxisilanos. Um dos condicionantes é a temperatura do ar. A literatura mostra que a temperatura do ar e da superfície deve estar entre $10^{\circ} \mathrm{C}$ e $32^{\circ} \mathrm{C}$. Rochas escuras chegam a alcançar $80^{\circ} \mathrm{C}$, necessitando que a rocha seja protegida do sol antes da aplicação, para que esta não chegue a temperaturas tão altas. O produto não deve ser aplicado em superfícies molhadas nem sujeitas a chuva. A umidade relativa deve estar entre $40 \%$ e $80 \%$ (Wheeler 2005).

\subsubsection{Pré-consolidação}

Quando a superfície apresenta danos severos como descamação, esfoliação ou desintegração granular forte, a aplicação direta de um consolidante pode ocasionar perda de grãos ou fragmentos, ou seja, é necessário manter os fragmentos no lugar enquanto o produto penetra. Nestes casos, é indicada uma estabilização da rocha antes da aplicação do consolidante, que é chamada de pré-consolidação. Esta prática também é adotada antes da limpeza ou da remoção de sais.

Uma ampla gama de resinas pode ser utilizada junto com produtos $\mathrm{OH}$ e $\mathrm{H}$ para pré-consolidar, porque acrílicos, PVAs e resinas de celulose são insolúveis ou parcialmente solúveis nestes produtos. Recentemente, foram utilizadas soluções de 
hidrógeno tartarato de amônio em $\mathrm{HCT}^{\circledR}$ (vendido pela ProSoCo) para consolidar mármores com desagregação granular, e calcários e arenitos carbonáticos que apresentavam menor grau de intemperismo (Wheeler 2005).

\subsubsection{Técnicas de aplicação}

Para superfícies grandes, a técnica mais comum é a pulverização, existindo uma grande variedade de pulverizadores. Contudo, é necessário que eles possuam uma cobertura interna de latão, aço inoxidável, polipropileno ou teflon. Pulverizadores de bomba ejetam muito líquido e causam grande desperdício. Alguns produtos tendem a escorrer pela superfície devido a sua baixa viscosidade. Se aplicação for realizada em pequenas áreas, o escorrimento é mais fácil de ser controlado. Um bom controle de escorrimento é alcançado com a utilização de pequenos borrifadores de mão, embora eles criem bolhas que impedem a penetração, induzem a evaporação e causam rápida fadiga por necessitarem de bombeamento manual constante. Garrafas de apertar eliminam as bolhas de ar, diminuem a evaporação e despejam quantidade moderada de líquido, evitando o escorrimento. O controle não é tão bom quanto nos borrifadores e nebulizadores e algumas garrafas de apertar levam à fadiga manual. Pipetas de Nalgene ${ }^{\circledR}$ ou de vidro ou conta-gotas, podem ser utilizadas para pequenos objetos ou áreas. As escovas de cerdas naturais permitem ótimo controle, induzem algumas bolhas, limitam a evaporação e o escorrimento, levam à pequena fadiga manual e transferem o mínimo de consolidante em determinado período de tempo.

Outras técnicas foram utilizadas para melhorar a penetração e diminuir a evaporação, como impregnação a vácuo (Hempel 1976 apud Wheeler 2005) e chumaço de algodão embebido em consolidante (Rossi-Maranesi 1995 apud Wheeler 2005). O chumaço de algodão pode ser substituído por pasta de celulose para evitar que fiapos fiquem na superfície.

\subsubsection{Consumo}

O melhor meio para calcular a quantidade de produto necessária é fazer uma área modelo que será tratada para calcular seu consumo. Esse valor é extrapolado para a área total. Um fator importante que determina o escorrimento é a geometria e orientação da superfície. Sem este método, é impossível saber quanto produto será necessário, pois depende da superfície, do método de aplicação e do escorrimento, já 
que este último pode gerar perda de produto. Alguns métodos para controlar o escorrimento são: utilizar uma técnica de aplicação que o minimize, evitar a utilização de solventes como acetona e metiletilcetona, que também limitam o acesso do consolidante pelo preenchimento dos poros ou alcançam áreas indesejadas, enxugando as áreas com toalhas de papel ou pedaços de pano e direcionar com aparatos apropriados o escorrimento do produto para que este não alcance áreas indesejadas. Em locais que possuem juntas, um pequeno pedaço de madeira embrulhado em plástico pode ser utilizado como pingador, para que o material que escorrer possa ser recolhido (Figura 8.4) (Wheeler 2005).

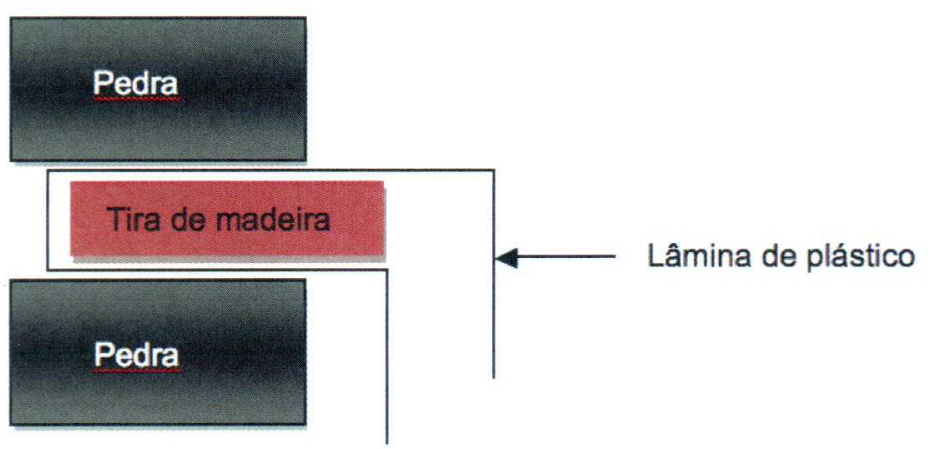

Figura 8.4 - Esquema para o método de controle de escorrimento do produto (Wheeler 2005 adaptado).

Outro fator que interfere no consumo do consolidante é a porosidade e permeabilidade da rocha. Realizando testes de permeabilidade, como com o tubo de Karsten, é possivel estimar quanto produto a rocha absorverá, utilizando a equação 16:

Área de superfície $\mathrm{x}$ porosidade $\mathrm{x}$ profundidade de penetração $=$ volume de consolidante

Esta equação não considera a permeabilidade. Rochas com baixa permeabilidade absorvem $\circ$ líquido mais vagarosamente $e$, consequentemente apresentam maior escorrimento se a quantidade de produto aplicado não for reduzida. Escorrimento e porosidade são os dois fatores que mais afetam o consumo.

Em granitos e mármores, que possuem baixa porosidade, uma boa média de consumo para se trabalhar é de $5 \mathrm{~L} / \mathrm{m}^{2}$ (Arnold 1978, Price 1981 apud Wheeler 2005). 


\subsubsection{Agenda de aplicação}

O número de aplicações influencia o consumo, mas a agenda de aplicação também é importante. As aplicações podem ocorrer em intervalos de horas ou de dias, chegando até a semanas. O número de aplicações pode chegar a 15.

$\mathrm{Na}$ literatura da ProSoCo, são indicados grupos de 3 aplicações com intervalos de 5 a 15 minutos entre cada aplicação e de 20 a 60 minutos entre cada grupo, que é chamado de ciclo. Entre as aplicações é necessário alisar a superfície com toalhas de papel ou pedaços de tecido para remover o excesso de consolidante. Solventes voláteis como acetona, auxiliam nessa remoção. Essa etapa de remoção é importante para que a superfície não fique com aspecto brilhante. Depois que o consolidante já tornou-se gel, a remoção é difícil. Estas recomendações não são difíceis de serem executadas em objetos pequenos, mas em grandes áreas, o trabalho torna-se difícil. Tratar duas áreas pequenas concomitantemente pode gerar confusão e tratar uma área grande de uma só vez pode criar problemas devido ao tempo de pausa entre as aplicações.

O tratamento é realizado de baixo para cima e cada operador deve trabalhar em no máximo $10 \mathrm{~m}^{2}$ por vez. Um programa de 9 aplicações (3 ciclos de 3 aplicações) demora cerca de três horas, incluindo instalação e limpeza. Um único operador deve planejar tratar duas áreas em um dia. A intenção das aplicações é prover um fluxo contínuo de líquido na superfície e ao mesmo tempo prover tempo suficiente para que a rocha absorva o líquido. Quando o líquido é aplicado em grandes quantidades, isso leva ao escorrimento e à perda de produto. Quando aplicado devagar demais, gera bolhas de ar entre as camadas aplicadas. Outro modo de aplicar é em dias sucessivos que reduz a perda por escorrimento e garante uma agenda mais tranquila.

Depois que a aplicação é concluída, incluindo lavagem com solvente, alisamento com papel ou tecido para evitar o efeito de brilho, colocação de proteção do sol e da chuva com plástico ou papel alumínio, o período de espera se inicia.

\subsection{Métodos de avaliação da consolidação}

É importante caracterizar a rocha, verificar a interface produto-rocha e por fim analisar se o tratamento foi efetivo ou não. Para isso existem os seguintes procedimentos:

- Petrografia antes e após o tratamento; 
- MEV (Microscopia Eletrônica de Varredura) para avaliar quantitativamente a deterioração, verificar se o consolidante uniu os grãos da rocha e controlar o efeito dos tratamentos;

- Caracterização da composição química para compreender os mecanismos de deterioração, bem como saber sobre produtos aplicados anteriormente;

- Teor de sais solúveis;

- Testes de durabilidade como câmaras de intemperismo $\left(\mathrm{SO}_{2}\right.$, névoa salina, UV, umidade, congelamento e degelo);

- Porosidade e permeabilidade para verificar se o tratamento não mudou muito a dinâmica interna dos poros;

- Profundidade de penetração;

- Ultrassom.

Honsinger e Sasse (1991) sugerem a seguinte metodologia para avalição do comportamento do consolidante:

- Teste de profundidade de penetração, para observar que o produto penetra de forma diferente nos diferentes climas;

- Sucção de água e comportamento de secagem - capilaridade ou forças de adsorção. Neste teste, a face tratada deve ser imersa em água e pesada por quatro semanas. Após este tempo a amostra deve ser deixada secando e ser pesada nos mesmos intervalos de tempo;

- Ângulo de contato e intemperismo em laboratório - para ângulo de contato, gotas são colocadas com a rocha na horizontal, medindo-se o ângulo de contato entre as gotas e a rocha. Se este está acima de $90^{\circ}$ a superfície é definida como hidrofóbica. Já os testes de intemperismo em laboratório, servem para comparar a durabilidade de diferentes produtos de tratamento;

- Difusão de água em vapor - é esperado que o tratamento da rocha não impeça o fluxo de vapor de água, pois este processo é importante para rochas que estão expostas às condições atmosféricas. Amostras de $5 \times 5 \times 1 \mathrm{~cm}$ devem ser cortadas e ensaiadas segundo a norma DIN 52615 (1987) e pelo método do "copo molhado" (wet cup method) EN 12524 (2000);

- Adsorção de vapor de água - este teste deve ser realizado com amostras do mesmo tamanho do anterior e as umidades relativas à temperatura de $23^{\circ} \mathrm{C}$, medidas;

- Investigação da estrutura dos poros por microscópio eletrônico (MEV) antes e após o tratamento;

- Porosimetria de mercúrio: para dar suporte ao teste anterior por meio do estudo das mudanças na distribuição dos poros como resultado do tratamento. 


\subsection{Exemplos de aplicação}

Nishiura et al. (1984 apud Wheeler 2005) realizaram ensaios de intemperismo acelerado e ciclos de congelamento e degelo, em tufos tratados com SS-101 ${ }^{\circledR}$ (MTEOS), um produto japonês semelhante ao Wacker $\mathrm{H}^{\circledR}$. Os testes de laboratório simularam as condições do campo. A avaliação foi realizada observando o comportamento das ondas ultrassônicas em 0,5 e 10 ciclos de congelamento e degelo. Depois de 10 ciclos, a velocidade ultrassônica caiu $67 \%$ na amostra não tratada e $4 \%$ na tratada.

Honsinger e Sasse (1991) testaram 150 produtos poliméricos de cura a frio em arenitos. Eles são baseados em solventes, dos quais pode-se citar: poliuretanos (que endurecem com a umidade do ambiente e com adição de componentes especiais), resinas epóxi, resinas acrílicas modificadas, compostos orgânicos de silício, silanos e polisiloxanos, sílica éster modificado, fluoroetileno e poliésteres insaturados. Os substratos foram diferentes arenitos que são representativos dos monumentos alemães, como: Arenito Ebenheider, Arenito Obernkirchener e "Sander" Schilfsandstone. As amostras foram submetidas a três diferentes condições climáticas até alcançarem umidade constante: $8^{\circ} \mathrm{C}$ e $60 \%$ de umidade relativa (UR), $23^{\circ} \mathrm{C}$ e $50 \%$ UR, $28^{\circ} \mathrm{C}$ e $95 \%$ UR. Os produtos foram aplicados por absorção capilar. Os testes para avaliar a efetividade do produto foram: profundidade de penetração, sucção por água e comportamento de secagem, ângulo de contato, intemperismo acelerado em laboratório, difusão de vapor de água e adsorção de vapor de água. Alguns epóxis e poliuretanos apresentaram boa penetração e não fecharam os poros para a capilaridade, fecharam apenas os microporos e não provocam mudanças drásticas de cor. Eles tornaram a rocha mais coesa e com repelência a água.

Ginell et al. (1995) realizaram testes em laboratório para simular as condições de campo. Eles monitoraram as condições ambientais em Mayan, cidade de Xunantunich, em Belize. A partir destes dados, definiram ciclos diários de $21^{\circ} \mathrm{C}$ e $85 \%$ de umidade relativa e $44^{\circ} \mathrm{C}$ e $25 \%$ UR em amostras de calcário sem tratamento e tratadas com Conservare ${ }^{\circledR} \mathrm{OH}$. Esta rocha, de granulação fina $(1-10 \mu \mathrm{m})$, tem porosidade de $27 \%$ a $56 \%$. O meio para avaliar a performance do consolidante foi a microabrasão, que foi realizada antes dos ciclos de umidade e temperatura, depois do consolidante curar, depois de 30 dias de ciclos e depois de 180 dias de ciclos. Antes dos ciclos, a perda por abrasão de rocha tratada foi de apenas $9 \%$ do valor da perda da rocha fresca. Depois de 30 dias, esse percentual aumentou para $15 \%$ e depois de 180 dias passou a $47 \%$. 
Delgado-Rodrigues e Costa (1996) expuseram granitos tratados e sem tratamento a ciclos de temperatura e umidade e longo tempo em imersão em água. $A$ avaliação foi feita por meio de observação da alteração das ondas ultrassônicas e resistência à flexão. A velocidade ultrassônica aumentou de $2,2 \mathrm{~km} / \mathrm{s}$ para $3,8 \mathrm{~km} / \mathrm{s}$ na rocha tratada com um etil silicato. Após 120 ciclos caiu para $2,8 \mathrm{~km} / \mathrm{s}$. A resistência à flexão mostrou mudanças semelhantes, passando de 3,2 MPa na amostra não tratada para 9,1 MPa na tratada e para 6,3 MPa após 120 ciclos. Depois de quarenta dias imersa em água, a amostra não tratada teve uma queda na velocidade ultrassônica de $3,8 \mathrm{~km} / \mathrm{s}$ para $2,8 \mathrm{~km} / \mathrm{s}$, que é semelhante à queda observada nos ciclos de umidade $e$ temperatura. A amostra tratada apresentou pequena ou nenhuma mudança de velocidade após a imersão. Observando e comparando os resultados de laboratório e de campo pode-se saber: testes mecânicos em laboratórios fornecem os maiores valores alcançáveis em campo. Por meio da comparação dos valores de campo e de laboratório, pode-se acessar a qualidade do tratamento em campo. Avaliando a performance de consolidantes por meio de testes mecânicos, é importante olhar para o aumento da força relativa e absoluta em amostras tratadas. A força relativa tende a aumentar mais em rochas silicáticas do que em carbonáticas. A força absoluta deve ser similar. Experimentos de intemperismo artificial tentam simular as condições de campo como saturação e secagem, ciclos de congelamento e degelo e levam à perda de propriedades mecânicas em poucos ciclos. Esses resultados mostram que são necessárias visitas constantes ao local tratado para verificar quando será necessária nova intervenção, pois as condições ambientais e a rocha podem trabalhar contra a estabilização do alcoxisilano, enfraquecendo o tratamento.

Jiménez González e Scherer (2004) descreveram novos métodos para determinar a magnitude das tensões que ocorrem em ciclos saturado/seco e a taxa na qual essas tensões aumentam e diminuem. Também discutiram a influência dos inibidores de intumescimento sobre a magnitude da expansão e a taxa de relaxamento de tensão das pedras: Portland Brownstone - EUA, Villarlod Molasse - Suíça e Arenito Tarifa - Espanha. Eles verificaram que a consolidação no Portland Browstone é mais efetiva pela aplicação do DAA.

Scherer e Jiménez González (2006) estudaram o Portland Brownstone com o objetivo de apresentar análises de experimentos de expansão para avaliar o risco de dano causado pelo stress provocado pela expansão dos argilominerais. Como as medidas diretas de expansão possuem algumas desvantagens, um novo método de avaliar o stress pela expansão foi proposto. Este novo método avalia o empenamento de uma fina placa de rocha quando água é colocada em contato em um dos lados, rendendo também informações sobre a permeabilidade e a influência da umidade no 
módulo elástico. Este estudo mostra que algumas rochas passam por stress destrutivo devido ao esforço diferencial produzido durante a secagem.

Jiménez González e Scherer (2006) desenvolveram um equipamento para automatizar e acelerar os ciclos de saturação e secagem de rochas. A medição direta da expansão indica que seu aumento é diretamente proporcional ao aumento do número de ciclos, indicando dano progressivo. Eles desenvolveram uma nova técnica para analisar o comportamento de expansão de pedras, que consiste em medir o empenamento de uma placa de rocha fina colocada entre dois apoios e que era umedecida por cima. A deformação e o relaxamento da placa podem ser analisados para medir a expansão livre, a taxa do módulo saturado e seco e a absorção da pedra. $O$ tratamento com DAA (diaminoalcanos) também foi bastante estável no que diz respeito à lavagem, mas todas as tentativas de eliminar totalmente a expansão foram infrutíferas.

Wangler e Scherer (2008) identificaram dois tipos principais de expansão em argilominerais: de curto alcance, com aumento de volume nos espaços intracristalinos e de longo alcance, com expansão osmótica contínua. Mostram que a identificação do tipo de expansão é importante para a compreensão e, finalmente, a prevenção de danos por expansão. Eles acompanharam por DRX (Difração de Raios X), ensaios de expansão em três rochas (Portland Brownstone, Bluestone e Arenito Asteca), com prétratamentos catiônicos e solventes orgânicos, que demonstram que a expansão intracristalina é o principal modo de expansão presente nas três pedras. Os resultados do DRX mostraram a importância do cátion de compensação no processo de expansão. Durante a pesquisa foi desenvolvido um método para a caracterização da expansão intracristalina em arenitos.

Wangler e Scherer (2009) objetivaram descobrir os mecanismos pelos quais os DAA agem para reduzir expansão de argilominerais do Portland Brownstone. As hipóteses apontavam que o mecanismo fosse a troca iônica entre as camadas de argilominerais. Para tal utilizaram diaminoalcanos diferentes, com 2, 3, 4 e 6 átomos de carbono, preparados a 0,31 M. O comportamento hidrofóbico encontrado nos resultados comprova a hipótese da troca catiônica. A resistência à retirada do produto pela lavagem mostra que o que acontece é a troca catiônica, e não a complexação dos grupos amina ou da superfície das camadas de argilominerais estarem carregadas negativamente. O tratamento aumenta o módulo dinâmico e a taxa de relaxamento viscoelástico da pedra, de modo que qualquer redução imediata na expansão nas rochas tratadas pode ser compensado por um aumento do módulo de elasticidade, embora a tensão possa relaxar mais rápido. Tudo isso indica que o DAA se intercala com as camadas de argilominerais. No entanto, a expansão residual continua sem ser 
compreendida, mas é possível que o DAA continue se hidratando quando molhado. Adicionalmente, o argilomineral foi separado, tratado, observado ao difratômetro de raios $X$, seco e molhado, e o espaço basal foi observado. A maioria dos DAA aumentou o espaço basal em $13 \AA$. Os argilominerais tratados com etilenodiamina apresentaram a menor abertura basal, provavelmente devido ao tamanho da molécula. O diaminobutano e diaminohexano não apresentaram picos neste teste.

Sassoni et al. (2011) apresentaram um trabalho sobre a formação de hidroxiapatita para consolidação do calcário, que é gerada a partir da reação entre hidrogenofosfato de amônio e a calcita, presente na rocha. A eficácia da hidroxiapatita como um consolidante para três litotipos, com diferentes porosidades e conteúdos de calcita, foi investigada e comparada com a do consolidante TEOS (ortossilicato de tetraetila). Os três litotipos selecionados foram: Globigerina Calcário (uma pedra calcária altamente porosa, normalmente utilizada em Malta), Giallo Siena (um arenito calcário altamente poroso, utilizado na Toscana) e Pietra Serena (um arenito quartzítico moderadamente poroso, normalmente usado em arquitetura de Florença). As amostras apresentaram aumento das propriedades mecânicas, o que foi atribuído à diminuição de microfissuras e preenchimento dos poros por fosfato de cálcio, confirmado por MEV. Houve pequena redução dos poros grandes, o que foi observado em testes de intrusão de mercúrio e capilaridade. No entanto, esta redução não altera significativamente as trocas de vapor com o ambiente.

Sassoni et al. (2013) testaram o DAP (fosfato de amônio dibásico) em arenitos devido à sua vantagem de não alterar substancialmente as propriedades de transporte das rochas e o comparam com o TEOS. Para os experimentos, as rochas foram alteradas artificialmente e após este processo foram aplicados os produtos. Tanto o DAP, quanto o TEOS, propiciaram sensivel aumento tanto do módulo elástico dinâmico, quanto da resistência à tração. Diferente do TEOS, as amostras tratadas com DAP apresentaram pouca variação no tamanho e distribuição dos poros pouquíssima variação na taxa de capilaridade e pequena alteração na troca de água de vapor. A melhoria das propriedades mecânicas pela aplicação do DAP foi 70 a $80 \%$ da encontrada pela aplicação do TEOS. Acreditam que a troca do solvente do TEOS de White Spirit por álcool isopropílico, com objetivo de diminuir a toxicidade, pode ter diminuído a efetividade da consolidação. Na Pietra Serena, que é um arenito quartzítico com porções de rocha calcária, o TEOS só penetrou 3 a $4 \mathrm{~mm}$ devido à pequena dimensão dos poros. A profundidade de penetração do produto foi verificada com o uso de martelo, em amostras cilíndricas após a saturação. O DAP foi considerado um consolidante promissor por ser solúvel em água, não ser perigoso para as pessoas que o aplicam e por não modificar muito as características da rocha. 
Naidu et al. (2015) discutiram a eficácia da hidroxiapatita (HAP), a partir da utilização do fosfato de amônio dibásico (DAP), como um consolidante inorgânico e o comparam com um consolidante à base de silicato (TEOS), disponível comercialmente (Conservare ${ }^{\circledR} \mathrm{OH} 100$ ), seguido de uma lavagem com etanol-água para acelerar a reação de hidrólise. O Calcário Indiana foi alterado artificialmente, imitando no laboratório o dano visualizado na natureza. Foram avaliados o módulo dinâmico de elasticidade (uma medida da rigidez) e sorvidade de água das pedras tratadas. O HAP mostrou-se um consolidante melhor do que o TEOS para este caso. A formação dos consolidantes nos poros e nos contornos de grão foi confirmada por microscopia eletrônica de varredura (MEV) e espectroscopia de raios $X$ de energia dispersiva (EDS).

Murta (2015) estudou a aplicação de sol gel hídrido (alcóxidos com polidemetilsiloxano) em esteatito, objetivando dar melhor trabalhabilidade no produto. O consolidante aplicado preencheu fraturas, diminuiu a porosidade e a absorção de água da rocha, podendo tornar-se um produto viável, após mais pesquisas, na consolidação de rochas. 


\section{Produtos utilizados}

A aplicação dos produtos foi realizada em dois momentos e com produtos distintos. Inicialmente, serão descritos os produtos utilizados na Universidade de Princeton e, no tópico seguinte, os produtos utilizados no Brasil. Vale ressaltar que alguns dos produtos que foram utilizados em Princeton, foram encontrados no Brasil, e portanto permaneceram os mesmos. Outros, que não foram encontrados, foram substituídos por produtos similares, disponíveis no país.

\subsection{Universidade de Princeton}

\subsubsection{Pré-consolidação}

Diaminoalcanos (DAA)

Diaminoalcanos são alcanos de cadeia linear, que contêm grupos amina em cada uma de suas extremidades. Acredita-se que esses surfactantes substituam os íons alcalinos entre as camadas de argilominerais, ligando-as e impedindo que a água entre. Outro benefício do uso destes produtos é que eles melhoram a performance e a durabilidade dos consolidantes de silicato. Sua fórmula geral é $\mathrm{NH}_{2}\left(\mathrm{CH}_{2}\right)_{n} \mathrm{NH}_{2}$ (Wangler e Scherer 2009).

Os DAA de cadeia mais curta (com 2, 3 e 4 átomos de carbono) são enviados como sais com ácido hidroclorídrico, formando os sais de amina. A solubilidade destes produtos decresce conforme aumenta o número de átomos de carbono. Para indicar o número de átomos de carbono é utilizada a notação DAAn, onde $\mathrm{n}$ é o número de átomos de carbono. A concentração indicada para $n \leq 10$ é $0,5 \mathrm{~mol} / \mathrm{L}$ (Wangler et al. 2006).

Scherer e Jiménez González (2008) utilizaram TEOS (ortosilicato de tetraetila) e aplicaram, em algumas amostras, inibidor de expansão (dihidrocloridrato de 1,3 diaminopropano) antes da consolidação para reduzir a expansão das argilominerais expansivos. Os resultados com a utilização do pré-consolidante foram melhores do que os encontrados em amostras onde foi aplicado apenas o TEOS, que perdeu a eficácia após alguns ciclos de saturação e secagem.

Pré-consolidação usando diaminoalcanos (DAA) com 2, 3, 4, 6 e 8 carbonos e uma solução com um complexo de etilenodiamina cobre (II) foram utilizadas por Wangler e Scherer (2009) para controlar a expansão dos argilominerais no Portland Brownstone. O último se mostrou o mais efetivo deles. 
Para o presente trabalho, foram utilizadas duas pré-consolidações consecutivas, por ser mais efetivo, como comprovado pela literatura (Wangler et al. 2006), pois assim a rocha é exposta a mais grupos amina.

Os pré-consolidantes utilizados nesta pesquisa, foram o etilenodiamina anidro E479-500, que possui 2 átomos de carbono e o 1,3 diaminopropano 99\%, que possui 3 átomos de carbono. Os dois produtos são descritos a seguir.

\section{Etilenodiamina anidro (A2)}

- $1^{\text {a }}$ pré consolidação:

O produto utilizado foi o etilenodiamina anidro E479-500 da Fisher Scientific, que é um diaminoalcano (DAA). Também é conhecido como 1,2 diaminoetano. Sua fórmula química é $\mathrm{C}_{2} \mathrm{H}_{8} \mathrm{~N}_{2}$, ou seja, é um produto orgânico que possui 2 átomos de carbono. As propriedades físicas deste produto encontram-se descritas na Tabela 9.1.

Tabela 9.1 - Propriedades físicas do A2 E479-500.

\begin{tabular}{lc}
\hline Ponto de ebulição & $118^{\circ} \mathrm{C} @ 760 \mathrm{mmHg}$ \\
Densidade & $0,9 \mathrm{~g} / \mathrm{mL}$ \\
Ponto de inflamação & $35^{\circ} \mathrm{C}$ \\
Ponto de fusão & $8,5^{\circ} \mathrm{C}$ \\
\hline
\end{tabular}

Quando totalmente seco, o produto se apresenta na forma de cristais, que são difíceis de serem retirados com água e força manual.

O produto foi preparado a $0,25 \mathrm{~mol} / \mathrm{L}$, concentração recomendada pela literatura (Wangler et al. 2006). No total, foram preparados $1000 \mathrm{~mL}$, que foi estimado de acordo com a quantidade de produto absorvido pela rocha e o tamanho do vasilhame onde seria realizada a aplicação.

Para calcular a quantidade de produto absorvido pela amostra, foi utilizada a equação 17:

$$
\text { Vprod }=\frac{\text { Vamostra } * \Phi}{100}
$$


Onde:

$\mathrm{V}_{\text {prod }}=$ Volume do produto $(\mathrm{mL})$;

$V_{\text {amostra }}=$ volume da amostra $\left(\mathrm{mm}^{3}\right)$;

$\Phi=$ porosidade da rocha (\%).

O resultado obtido, foi multiplicado pelo número de amostras para saber o volume que as amostras absorveriam e, com isso, conhecer quanto produto seria necessário preparar e garantir que houvesse produto disponível durante 0 tempo em que a amostra ficaria imersa.

Para calcular a quantidade de produto necessária para produzir $1000 \mathrm{~mL}$ de solução, foi utilizada a equação 18 .

$$
\mathrm{Q}_{\text {prod }}=\frac{\mathrm{M} \times \mathrm{V} \times 0,25 \mathrm{~mol} / \mathrm{L}}{\rho}
$$

Onde:

$Q_{\text {prod }}=$ quantidade de produto $(\mathrm{mL})$;

$\mathrm{M}=$ peso molecular $(\mathrm{g} / \mathrm{mol})$;

$\mathrm{V}=$ volume $(\mathrm{L})$;

$\rho=$ densidade $(0,9)$.

Portanto, para produzir $1000 \mathrm{~mL}$, foram colocados $16,7 \mathrm{~mL}$ de etilenodiamina anidro E479-500 em um balão volumétrico e completado com água deionizada até atingir a marca de $1000 \mathrm{ml}$.

Após as rochas serem submetidas a este primeiro pré-tratamento, foi aplicado o 1,3 diaminopropano $99 \%$, como descrito a seguir. As amostras submetidas ao prétratamento apenas com este produto foram nomeadas de $\mathbf{A} 2$.

\section{1,3 diaminopropano $99 \%$ (A3)}

- $2^{a}$ pré consolidação

Foi preparado o 1,3 diaminopropano $99 \%$ da ACROS Organics, que é um diaminoalcano (A3). Sua fórmula química é $\mathrm{C}_{3} \mathrm{H}_{10} \mathrm{~N}_{2}$, ou seja, é um produto orgânico com 3 átomos de carbono em sua cadeia. Este produto é solúvel em água e na maioria dos solventes orgânicos. As propriedades físicas deste produto encontram-se descritas na Tabela 9.2. 
As amostras submetidas ao pré-tratamento apenas com este produto foram nomeadas de $\mathbf{A} 3$.

Tabela 9.2 - Propriedades físicas do 1,3 diaminopropano $99 \%$.

\begin{tabular}{lc}
\hline Ponto de ebulição & $140,0^{\circ} \mathrm{C}$ \\
Densidade & $0,8800 \mathrm{~g} / \mathrm{mL}$ \\
Ponto de Inflamação & $48^{\circ} \mathrm{C}$ \\
Ponto de fusão & $-12,0^{\circ} \mathrm{C}$ \\
Solubilidade em água & Solúvel \\
Outras solubilidades & $\begin{array}{l}\text { Miscivel com quase todos os } \\
\text { solventes orgânicos comuns }\end{array}$ \\
\hline
\end{tabular}

Para se conhecer a quantidade de produto que as amostras absorveriam e garantir que houvesse produto suficiente durante todo o periodo que elas passaram embebidas, foi utilizada a equação 17.

Foram preparados $1000 \mathrm{~mL}$ de solução a $0,25 \mathrm{~mol} / \mathrm{L}$. Para calcular a quantidade de produto necessária, utilizou-se a equação 18 , que também está descrita no item anterior. Portanto, foram colocados $84,1 \mathrm{~mL}$ do $\mathrm{A} 3 \mathrm{em}$ um balão volumétrico, que foi completado com água deionizada até atingir a marca de $1000 \mathrm{~mL}$.

Após dois dias secando, depois da aplicação dos dois pré-consolidantes, parte das amostras foi submetida ao primeiro consolidante (fosfato de amônio dibásico - P inorgânico), e parte foi reservada para ser tratada com o segundo consolidante (TC orgânico).

\subsubsection{Consolidação}

\section{Fosfato de amônio dibásico (DAP)}

O produto utilizado para a consolidação foi o fosfato de amônio dibásico, também conhecido como fosfato dibásico de amônio ou ainda fosfato diamônio. Ele é um sal inorgânico, que quando reage com o cálcio, forma hidroxiapatita (equação 19), que é um mineral insolúvel em água com pH 7 e relativamente solúvel em soluções ácidas; com pH abaixo de 5,5. Sua estrutura cristalina é hexagonal. Este mineral, constituinte dos ossos, já era bastante utilizado na medicina. Mas só recentemente começou a ser utilizado para consolidação de rochas que contenham cálcio, como o 
mármore. Sassoni et al. (2011) utilizaram DAP para consolidar rochas carbonáticas alteradas. Sassoni et al. (2013) utilizaram DAP para consolidar arenitos silicosos e carbonáticos, ambas as rochas apresentavam certas quantidades de calcita. Naidu et al. (2015) utilizaram DAP para consolidar calcários.

A efetividade do DAP em arenito depende da quantidade de frações carbonáticas nele existente (Sassoni et al. 2013).

$$
\begin{gathered}
10 \mathrm{CaCO}_{3}+5\left(\mathrm{NH}_{4}\right)_{2} \mathrm{HPO}_{4} \rightarrow \\
\mathrm{Ca}_{10}\left(\mathrm{PO}_{4}, \mathrm{CO}_{3}\right)_{6}\left(\mathrm{OH}, \mathrm{CO}_{3}\right)_{2}+5\left(\mathrm{NH}_{4}\right)_{2} \mathrm{CO}_{3}+3 \mathrm{CO}_{2}+2 \mathrm{H}_{2} \mathrm{O}
\end{gathered}
$$

No entanto, esta é a primeira vez que o DAP é utilizado em uma rocha sem carbonato; o qual é introduzido artificialmente por imersão em água de cal.

Para a aplicação do DAP, os procedimentos utilizados foram os mesmos indicados por Sassoni et al. (2011), os quais encontram-se descritos abaixo.

Para a consolidação, foi preparado o fosfato de amônio dibásico (DAP) da Fluka Analytical na concentração de $1 \mathrm{~mol}$. Sua fórmula química é $\left(\mathrm{NH}_{4}\right)_{2} \mathrm{HPO}_{4}$, sendo solúvel em água a $20^{\circ} \mathrm{C}$. Em temperatura ambiente este produto é um pó branco (Tabela 9.3).

\begin{tabular}{|c|c|}
\hline Pureza & $\geq 99,0 \%(\mathrm{~T})$ \\
\hline Impurezas & $\begin{array}{c}\text { matéria insolúvel, passa no } \\
\text { teste de filtro }\end{array}$ \\
\hline $\mathrm{pH}$ & $7,5-9,0\left(25^{\circ} \mathrm{C}, 1 \mathrm{M} \mathrm{em} \mathrm{H}_{2} \mathrm{O}\right)$ \\
\hline $\begin{array}{l}\text { Ponto de } \\
\text { fusão }\end{array}$ & $155^{\circ} \mathrm{C}$ (dec.)(lit.) \\
\hline Solubilidade & $\begin{array}{c}\mathrm{H}_{2} \mathrm{O} \text { : solúvel a } 20^{\circ} \mathrm{C} \text {, clara, } \\
\text { incolor }\end{array}$ \\
\hline $\begin{array}{l}\text { Traços de } \\
\text { ânions }\end{array}$ & cloreto $\left(\mathrm{Cl}^{-}\right): \leq 5 \mathrm{mg} / \mathrm{kg}$ \\
\hline
\end{tabular}

Tabela 9.3 - Propriedades físicas do fosfato de amônio dibásico.

Como seu peso molecular é $132,06 \mathrm{~g} / \mathrm{mol}$, misturou-se essa mesma quantidade em gramas, ou seja, $1 \mathrm{~mol}$, em $1000 \mathrm{~mL}$ de solução aquosa com água deionizada, com a utilização de um agitador magnético.

Para aumentar a quantidade de cálcio disponível, as amostras foram colocadas em um banho de água de cal por 24 horas, após a aplicação do DAP. A água de cal 
visou introduzir a cal $\left(\mathrm{Ca}(\mathrm{OH})_{2}\right)$ nos poros da rocha, para reagir com o dióxido de carbono $\left(\mathrm{CO}_{2}\right)$ presente no ar, produzindo então carbonato de cálcio $\left(\mathrm{CaCO}_{3}\right)$. Em rochas carbonáticas, o carbonato de cálcio age como consolidante, devido à sua compatibilidade química com os minerais da rocha, formando ligações entre eles. Mas no caso do Arenito Itararé, ele não possui esta compatibilidade e o intuito de produzir $\mathrm{CaCO}_{3}$ nos poros é apenas para que haja a reação com o DAP.

Metade das amostras foram pré-tratadas antes da aplicação do DAP e a outra metade apenas foi aplicado o DAP.

As amostras submetidas a esse tratamento foram nomeadas de $\mathbf{P}$.

\section{Conservare ${ }^{\circledR} \mathrm{OH} 100$}

O segundo tipo de consolidação foi realizado com o Conservare ${ }^{\circledR} \mathrm{OH} 100$, fabricado pela empresa ProSoCo. Este é um ortossilicato de tetraetila (TEOS) de fórmula $\left(\mathrm{Si}\left(\mathrm{OC}_{2} \mathrm{H}_{5}\right)_{4}\right)$ n. Suas propriedades encontram-se descritas na Tabela 9.4. Com o passar do tempo, a água atmosférica reage com os grupos $-\mathrm{OC}_{2} \mathrm{H}_{5}$, processo esse conhecido como hidrólise e que demora semanas para se completar. Durante a hidrólise, os oligômeros se condensam e o resultado final deste processo é formação de gel de sílica.

O produto foi diluído na proporção de $1: 3$ em etanol a $99,5 \%$, como indicado pelo fabricante, pois o produto puro tende a trincar após sua secagem. No total foram preparados $600 \mathrm{~mL}$.

As amostras tratadas com este produto seguiram a nomenclatura TC

Tabela 9.4 - Propriedades físicas do Conservare ${ }^{\circledR} \mathrm{OH} 100$ (ProSoCo).

\begin{tabular}{ccc}
\hline Forma & $\begin{array}{c}\text { Sem cor a levemente } \\
\text { amarelo } \\
\text { Densidade }\end{array}$ \\
Conteúdo embalagem & $1 \mathrm{~L}$ \\
Conteúdo ativo & $100 \%$ \\
Sólidos totais & $43 \%$ ASTM D5095 \\
Conteúdo deVOC & $>400 \mathrm{~g} / \mathrm{L}$ \\
Ponto de inflamação & $40^{\circ} \mathrm{C}$ \\
Ponto de congelamento & $<-30^{\circ} \mathrm{C}$ \\
Validade & 1 ano selado, lacrado \\
\hline
\end{tabular}


As amostras foram cobertas pelo produto até a metade devido à sua densidade ser maior do que a dos outros três produtos já descritos. Quando o produto atingiu o topo, elas foram totalmente submersas e deixadas por 24 horas em recipiente hermeticamente fechado. Após este período elas foram retiradas da solução e deixadas para secar e hidrolisar naturalmente, dentro da capela. $O$ fabricante indica que o tempo de hidrólise é de três semanas.

Após três semanas, as amostras foram colocadas em banho de álcool, diluído na proporção $1: 4 \mathrm{em}$ água destilada, pois a água ajuda a completar a hidrólise. O álcool serve para ajudar a entrada da água, já que o produto é hidrofóbico nos primeiros meses. As amostras foram cobertas até o topo pela solução, pois devido à hidrofobicidade, não há o comportamento de transporte por capilaridade. Elas foram deixadas nesta solução por 24 horas. Os recipientes do banho foram tampados com filme plástico e tampa para evitar a evaporação. Após este período, as amostras foram deixadas para secar naturalmente, em capela. O motivo do banho foi devido à pesagem e o acompanhamento por meio de medição das ondas ultrassônicas indicarem que o produto não estava completamente pronto; diferente do que indicado pelo fabricante.

O produto foi aplicado em amostras com e sem pré-tratamento.

\subsection{Produtos utilizados no Brasil}

Buscando repetir alguns testes e realizar outros, buscou-se no Brasil os produtos utilizados anteriormente. No entanto, o TEOS da ProSoCo não foi encontrado, pois esta empresa não possui distribuidor no país. Em seu lugar foi testado o Silres $\mathrm{OH} 100^{\circledR}$ da Wacker. Também foram testados os produtos Protectosil WS $808^{\circledR}$ e Protectosil WS $630^{\circledR}$, indicados por Renato Stoicov, da Evonik. Infelizmente esta empresa não possuía nenhum TEOS disponível para teste.

Os pré-consolidantes utilizados anteriormente são distribuídos no Brasil e continuaram a ser testados. Adicionalmente foi inserido o diaminohexano, que possui 6 átomos de carbono, devido a Wangler e Scherer (2009) terem demonstrado em seus testes, que quanto maior o número de carbonos a que a rocha é submetida, melhor o resultado final. 


\subsubsection{Pré-consolidantes}

\section{1,6 diaminohexano $60 \%(\mathbf{A} 6)$}

Foi utilizado o 1,6 diaminohexano $60 \%$ da ACROS Organics, que é um diaminoalcano (A6). Sua fórmula química é $\mathrm{C}_{6} \mathrm{H}_{16} \mathrm{~N}_{2}$, ou seja, é um produto orgânico com 6 átomos de carbono em sua cadeia. Este produto é solúvel em água e na maioria dos solventes orgânicos. As propriedades físicas deste produto encontram-se descritas na Tabela 9.5.

As amostras que foram tratadas apenas com este produto foram nomeadas de A6. As que foram submetidas ao tratamento com os três diaminoalcanos (A2, A3 e A6), tiveram nomenclatura $\mathrm{A}$

Tabela 9.5 - Propriedades físicas do 1,6 diaminohexano $60 \%$.

\begin{tabular}{lc|}
\hline Ponto de ebulição & $205^{\circ} \mathrm{C}$ \\
Densidade & $0,93 \mathrm{~g} / \mathrm{mL}$ \\
Ponto de inflamação & $160^{\circ} \mathrm{C}$ \\
Ponto de fusão & $42^{\circ} \mathrm{C}$ \\
Solubilidade em água & Solúvel \\
Outras solubilidades & Éter e benzeno \\
\hline
\end{tabular}

A solução foi preparada a $0,25 \mathrm{~mol} / \mathrm{L}$, ou seja, para se produzir $1 \mathrm{~L}$ foram colocados $54 \mathrm{~mL}$ do 1,6 diaminohexano $60 \%$ em um balão volumétrico, que foi completado com água deionizada até a marca de $1000 \mathrm{~mL}$.

O procedimento para aplicação do produto foi o de impregnação, que foi descrito anteriormente. As amostras que foram tratadas com pré-consolidantes, foram deixadas secar até que fosse atingido o peso constante, antes da aplicação do consolidante.

O produto puro foi deixado para secar em uma placa de petri e o que foi observado após sua secagem foi um material branco espesso (Figura 9.1), que não foi facilmente retirado em água. Foi necessária certa força para despregar o produto da placa. 


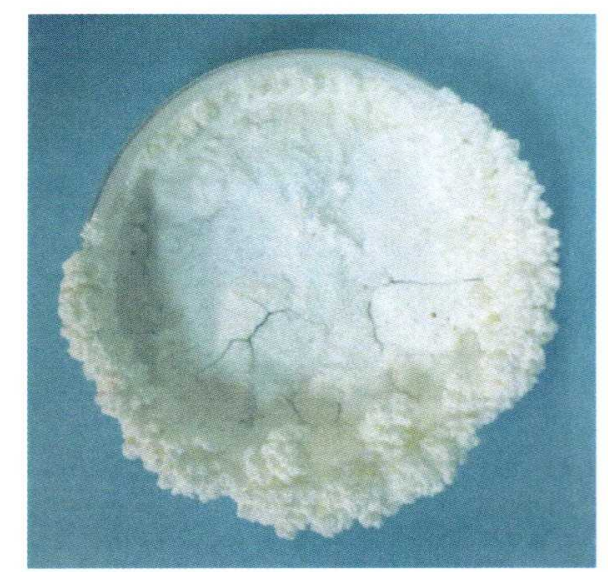

Figura 9.1 - A6 puro após secagem em capela.

\subsubsection{Protetor de superfície/ hidrofugantes}

\section{Protectosil $^{\circledR}$ Antigraffiti}

Segundo o fabricante, este é um fluorosilano à base de água, que não obstrui os poros (respirável), que serve para proteger a rocha e facilitar a limpeza em locais em que são comuns atos de vandalismo com a utilização de diversos produtos para grafitar, como: caneta hidrográfica, tintas betuminosas, asfalto e outras tintas solventes ou à base de água. Ele é produzido pela Evonik Industries, que possui representante no Brasil. Não altera a aparência do substrato. Sua ação é a partir de ligações químicas com o substrato como realizado por outros silanos. Isso faz com que o produto possa ser submetido a algumas limpezas antes de que seja necessário o retratamento. Eduardo Spagnuolo da $\mathrm{NanoBr}$ informou que o produto suporta 10 limpezas em um mesmo local.

Os principais benefícios do produto, segundo o fabricante, são: ausência de compostos orgânicos voláteis, respirável, excelente resistência aos raios UV, resistência ao ataque alcalino, não descama e não amarelece. Suas propriedades estão descritas na Tabela 9.6.

Este produto foi aplicado puro, como indicado pelo representante. As amostras tratadas com este produto foram denominadas AG.

Quando deixado para secar em placa de petri (puro), foi observada a formação de uma camada bege-esbranquiçada e fraturada, que aderiu firmemente à placa (Figura 9.2). 
Tabela 9.6 - Propriedades físicas do Protectosil $^{\circledR}$ Antigraffiti.

\begin{tabular}{lc}
\hline Cor & Amarelo claro \\
Solvente & Água \\
Ponto de inflamação & - \\
Densidade & $1,06 \mathrm{~g} / \mathrm{cm}^{3}$ \\
VOC (Compostos orgânicos voláteis) & $<25 \mathrm{~g} / \mathrm{L}$ \\
& $>90 \%$ respirável \\
\hline
\end{tabular}

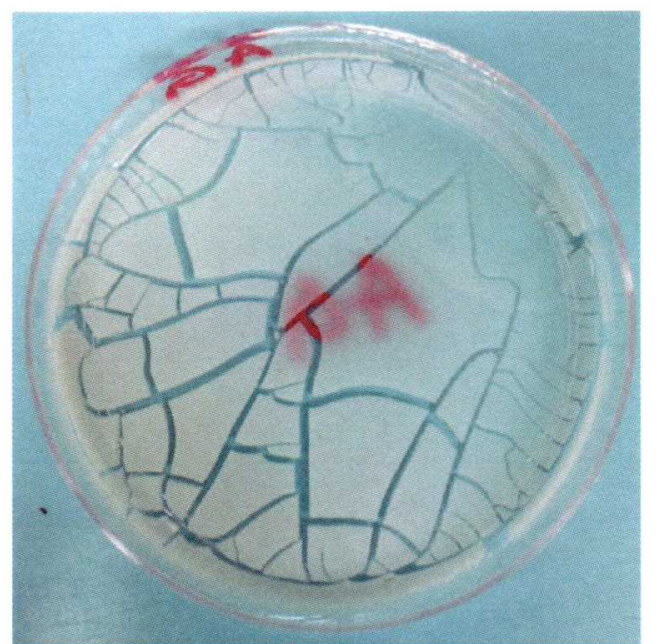

Figura 9.2 - Protectosil $^{(}$Antigrafiti puro, seco em capela.

\section{Protectosil $^{\circledR}$ WS 630}

Este produto é descrito pelo fabricante como uma emulsão repelente de água baseada em siloxanos organofuncionais, produzido pela Evonik Industries. É adequado para a repelência de água em substratos minerais porosos. Este produto reduz significativamente a absorção de água, repele os poluentes solúveis na água, não forma películas adesivas de silicone, mostra muito boa penetração em materiais minerais, é permeável ao vapor de água, é incolor, é eficaz em microfissuras de até 0,3 milímetros, e pode ser aplicado puro ou diluído em água deionizada. A diluição utilizada foi a indicada pelo fabricante para arenitos: 1 parte do produto para 9 partes de água. O produto puro, após 3 semanas exposto em capela, não secou completamente, formando um gel (Figura 9.3). As propriedades deste produto encontram-se descritas na Tabela 9.7.

As amostras submetidas ao tratamento com este hidrofugante, receberam a sigla 630 . 
Tabela 9.7 - Propriedades do Protectosil ${ }^{\circledR}$ WS 630.

Densidade

Aparência

Ponto de inflamação

Ingrediente ativo

$\mathrm{pH}\left(20^{\circ} \mathrm{C}\right)$ $\sim 1 \mathrm{~g} / \mathrm{cm}^{3}$

Líquido branco

$>85^{\circ} \mathrm{C}$

$50 \%$

$6,5-8,5$

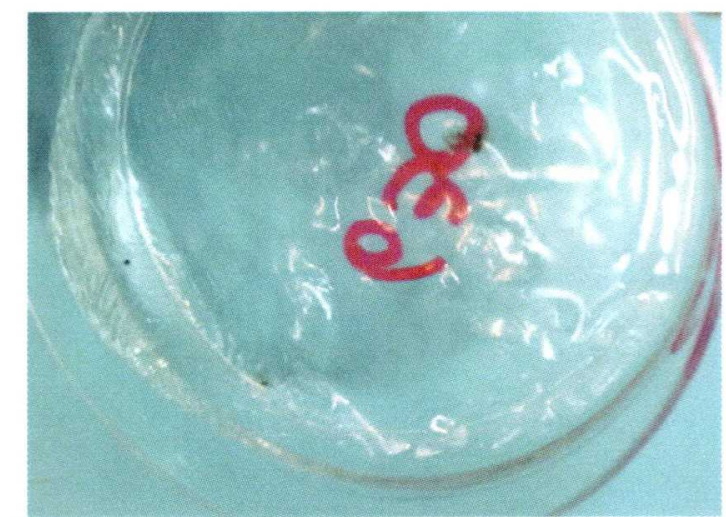

Figura 9.3 - Protectosil $^{\circledR}$ WS 630 deixado para secar em capela.

\section{Protectosil ${ }^{\circledR}$ WS 808}

Este produto é um propil siliconato oligomérico/concentrado de silicato, repelente de água e consolidante para substratos minerais. Foi especialmente desenvolvido para ser consolidante e repelente de água para produtos de argila de baixa temperatura de cozimento (por exemplo, telhas, tijolos comuns, pisos, terracota), bem como várias pedras naturais, tais como, arenitos e calcários. Este produto é adequado para a recuperação de pedras naturais. Apresenta alta profundidade de penetração, cura rápida, alta durabilidade, é permeável ao vapor de água, é incolor, reduz consideravelmente a absorção de água e sais solúveis (por exemplo cloretos) e é resistente contra ambiente alcalino. O produto é concentrado e pode ser diluído em água deionizada desde 1:10 até 1:100. Após 3 semanas em capela, o produto puro não secou completamente (Figura 9.4). Suas propriedades são descritas na Tabela 9.8 .

As amostras que receberam o tratamento com este produto foram nomeadas 808. 


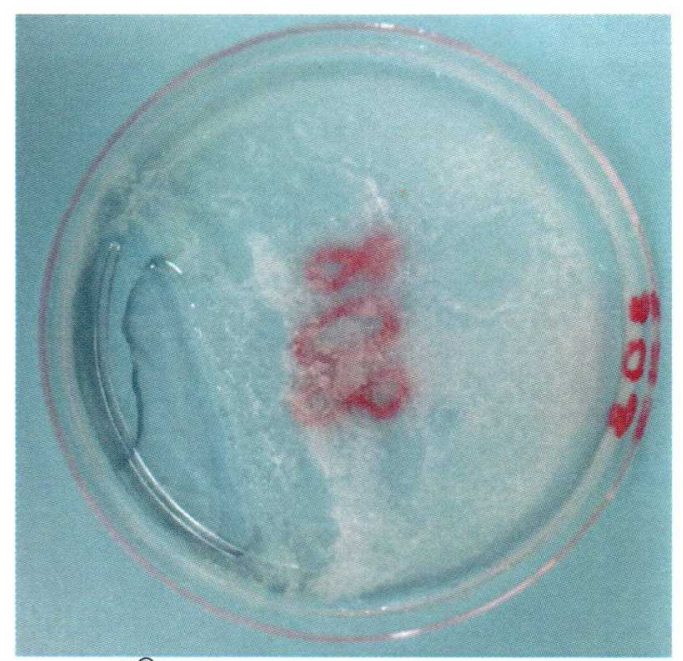

Figura 9.4 - Protectosil $^{\circledR}$ WS 808 após 3 semanas secando em capela.

Tabela 9.8 - Propriedades do Protectosil ${ }^{\circledR}$ WS808.

\begin{tabular}{lc}
\hline Cor & Claro, incolor a levemente amarelado \\
Ingrediente ativo & $55 \%$ \\
Diluição & Água deionizada \\
$\mathrm{pH}$ & $>13$ \\
\hline
\end{tabular}

\subsubsection{Consolidantes}

\section{Silres ${ }^{\circledR}$ BS OH 100}

É um silicato de etila, livre de solvente, pronto para uso, para consolidar rochas. Seu catalisador neutro, promove a reação entre o silicato de etila e a água do ar ou do interior da rocha, formando um gel de sílica. O etanol, formado na reação, evapora e a formação total do produto ocorre dentro de dois meses. O produto não possui quaisquer aditivos hidrofóbicos como silanos ou siloxanos. Antes da total formação do produto, a superfície pode ficar levemente perolizada, com a aparência de hidrofóbica, mas este efeito desaparece tão logo o produto esteja completamente hidrolisado. Seu baixo peso molecular garante alta penetração, forma um filme que não atrai sujeira, forma um aglutinante mineral compatível com o material de construção, resistente ao ataque ácido e permeável ao vapor d'água.

Este produto é bastante irritante para as vias aéreas e possui um cheiro forte. Após 3 semanas secando em uma placa de perti, o produto puro formou uma película bastante fraturada e friável (Figura 9.5). Suas propriedades são listadas na Tabela 9.9.

As amostras tratadas com este produto foram nomeadas como TW. 


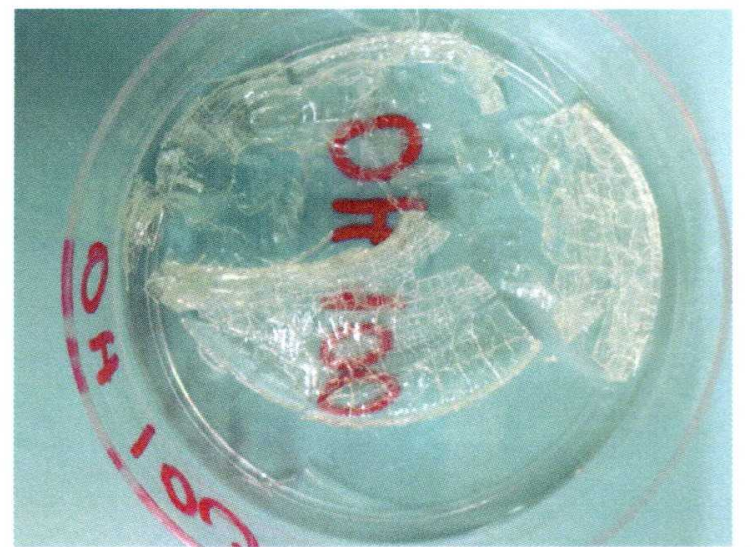

Figura 9.5 - Silres ${ }^{\circledR}$ BS OH 100 após 3 semanas secando.

Tabela 9.9 - Propriedades do Silres ${ }^{\circledR} \mathrm{BS} \mathrm{OH} 100$.

\begin{tabular}{lcl}
\hline Densidade a $25^{\circ} \mathrm{C}$ & $0,997 \mathrm{~g} / \mathrm{cm}^{3}$ \\
Ponto de inflamação & $40^{\circ} \mathrm{C}$ \\
Temperatura de ignição & $230^{\circ} \mathrm{C}$ \\
Conteúdo de etil silicato & $100 \%$ \\
\hline
\end{tabular}

Para ficar mais compreensível, a Tabela 9.10 resume as siglas, os produtos e a sequência utilizada. 
Tabela 9.10 - Siglas dos tratamentos e suas respectivas sequências.

\begin{tabular}{|c|c|}
\hline Sigla do tratamento & Sequência do tratamento realizado \\
\hline \multicolumn{2}{|c|}{ Tratamentos realizados na Universidade de Princeton } \\
\hline A & $\mathrm{A} 2 \rightarrow \mathrm{A} 3$ \\
\hline $\mathrm{P}$ & $\mathrm{P} \rightarrow \mathrm{CaOH}$ \\
\hline AP & $\mathrm{A} 2 \rightarrow \mathrm{A} 3 \rightarrow \mathrm{DAP}$ \\
\hline $\mathrm{TC}$ & TEOS ProSoCo \\
\hline ATC & $\mathrm{A} 2 \rightarrow \mathrm{A} 3 \rightarrow \mathrm{TC}$ \\
\hline AP E & $\mathrm{A} 2 \rightarrow \mathrm{A} 3 \rightarrow$ enxágue $^{*} \rightarrow \mathrm{P}+\mathrm{CaOH}$ \\
\hline ATC E & $\mathrm{A} 2 \rightarrow \mathrm{A} 3 \rightarrow$ enxágue $^{*} \rightarrow \mathrm{TC}$ \\
\hline \multicolumn{2}{|c|}{ Tratamentos realizados na Universidade de São Paulo } \\
\hline A & $\mathrm{A} 2 \rightarrow \mathrm{A} 3 \rightarrow \mathrm{A} 6$ \\
\hline $\mathrm{CaOH}$ & $\mathrm{CaOH}$ \\
\hline $\mathrm{PCaOH}$ & $\mathrm{P}+\mathrm{CaOH}$ \\
\hline $\mathrm{P}$ & $P$ \\
\hline AP & $\mathrm{A} 2 \rightarrow \mathrm{A} 3 \rightarrow \mathrm{A} 6 \rightarrow \mathrm{DAP}$ \\
\hline TW & Silres ${ }^{\circledR}$ BS OH100 \\
\hline ATW & $\mathrm{A} 2 \rightarrow \mathrm{A} 3 \rightarrow \mathrm{A} 6 \rightarrow \mathrm{TW}$ \\
\hline 630 & Protectosil囚 WS630 \\
\hline A630 & $\mathrm{A} 2 \rightarrow \mathrm{A} 3 \rightarrow \mathrm{A} 6 \rightarrow 630$ \\
\hline 808 & Protectosil@ WS808 \\
\hline A808 & $\mathrm{A} 2 \rightarrow \mathrm{A} 3 \rightarrow \mathrm{A} 6 \rightarrow 808$ \\
\hline$A G$ & Protectosil $\circledast$ Antigraffiti \\
\hline
\end{tabular}

+ Produtos misturados antes da aplicação.

$\rightarrow$ O produto secou antes do próximo ser aplicado.

\subsection{Procedimento de aplicação}

\subsubsection{Impregnação}

Os produtos foram aplicados por capilaridade, para evitar que bolhas de ar fossem aprisionadas dentro da rocha. Para isto, a base maior das amostras foi colocada em contato com uma pequena camada do produto e aguardou-se até que ele percolasse até o topo (Figura 9.6). Após esta fase, as amostras foram cobertas pelos produtos e deixadas imersas por 24 horas. Depois deste período, foram deixadas para secar naturalmente. Foram consideradas secas, quando o peso delas se estabilizou. 
Os produtos que são hidrofugantes, não apresentam comportamento capilar. E quando secam, impedem que mais produto penetre. Portanto, as amostras foram completamente imersas de uma só vez para os produtos 630 e 808 .

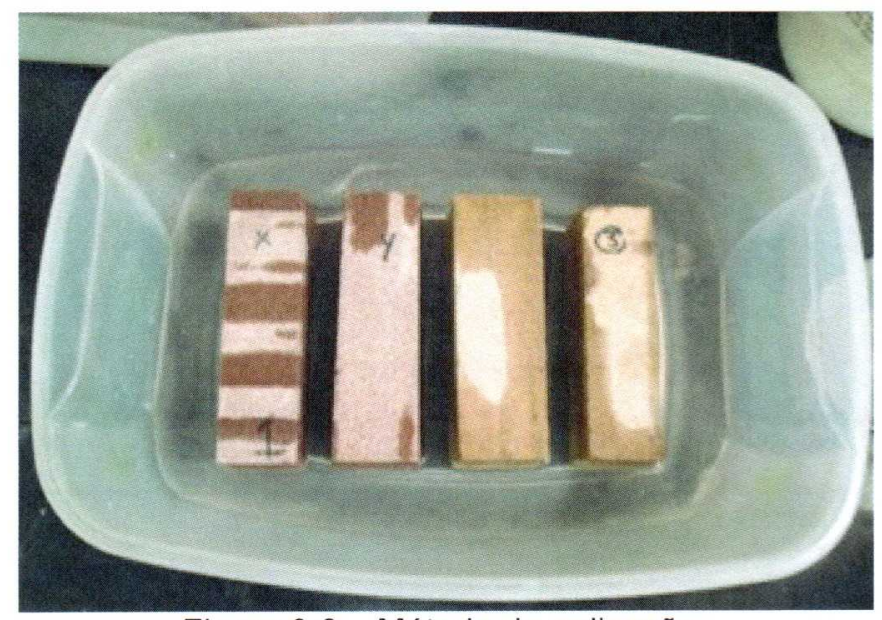

Figura 9.6 - Método de aplicação.

- Segundo método de aplicação

Este segundo método foi apenas utilizado nas amostras tratadas na Universidade de Princeton. Os resultados da aplicação do pré-consolidante seguido do consolidante não foram satisfatórios no teste de capilaridade, isto é, não foi formada a curva ascensional esperada. Devido a isto, um novo método foi testado. Levantou-se a hipótese de que havia reatividade entre os produtos no estado líquido (antes de secar completamente), o que foi confirmado, pois, quando os produtos puros foram misturados houve liberação de calor. No entanto, misturando na mesma concentração usada para a aplicação, nenhuma reação visível foi observada.

A aplicação foi realizada em novas amostras frescas. Desta vez, as amostras foram secas em forno a $60^{\circ} \mathrm{C}$ por 24 horas entre as duas aplicações dos A, para garantir que o produto estivesse totalmente seco. Para testar a hipótese de um possível excesso de pré-consolidante (o que poderia ser a causa dos resultados inesperados), metade das amostras pré-tratadas foi imersa por $24 \mathrm{~h}$ em água deionizada e secas durante $24 \mathrm{~h}$ em forno a $60^{\circ} \mathrm{C}$. Este procedimento foi chamado de enxágue $(E)$. Antes da aplicação dos consolidantes, mesmo as amostras que não receberam enxágue, também foram secas por $24 \mathrm{~h}$ em forno a $60^{\circ} \mathrm{C}$. 


\section{Resultados}

Alguns dos presentes resultados foram obtidos em dois laboratórios distintos: um, durante o estágio sanduíche, realizado na Universidade de Princeton, sob a orientação do Prof. Dr. George W. Scherer, e outro, na Universidade de São Paulo. Alguns experimentos foram realizados apenas na primeira instituição e outros, realizados apenas na segunda.

Serão apresentados e discutidos os dados obtidos na petrografia, difração de raios $\mathrm{X}$, intemperismo por aquecimento, capilaridade, velocidade de ondas ultrassônicas, tubo de Karsten, expansibilidade, microscopia eletrônica de varredura, porosimetria de mercúrio, saturação a vácuo, resistência à flexão, saturação e secagem, espectrofotometria, profundidade de penetração e alteração acelerada.

Foram ensaiadas duas rochas: Arenito Itararé e Arenito Missões.

\subsection{Arenito Itararé}

\subsubsection{Mineralogia do Arenito Itararé}

O Arenito Itararé apresenta coloração de bege a amarelo pálido, levemente estratificado, composto basicamente por quartzo, com granulação que varia de fina a grossa.

Observando sessões delgadas, verifica-se que a estratificação e a variação granulométrica mudam paulatinamente. No entanto, duas regiões de granulação distintas podem ser identificadas.

$\mathrm{Na}$ região de granulação mais fina, os grãos variam de $0,11 \mathrm{~mm}$ a $0,36 \mathrm{~mm}$ (areia fina) (Figura 10.1), enquanto na de grãos mais grossos, variam de 0,18 mm a $1,1 \mathrm{~mm}$ (areia grossa). Para ambas as regiões, os grãos são bem selecionados, de arredondados a sub-angulosos. A matriz é argilosa. Os minerais encontrados, em ordem decrescente, são quartzo, feldspato sódico, feldspato potássico, muscovita e biotita. A titanita, a turmalina e o zircão aparecem como minerais acessórios. A Figura 10.2 mostra os minerais em maior aumento. 


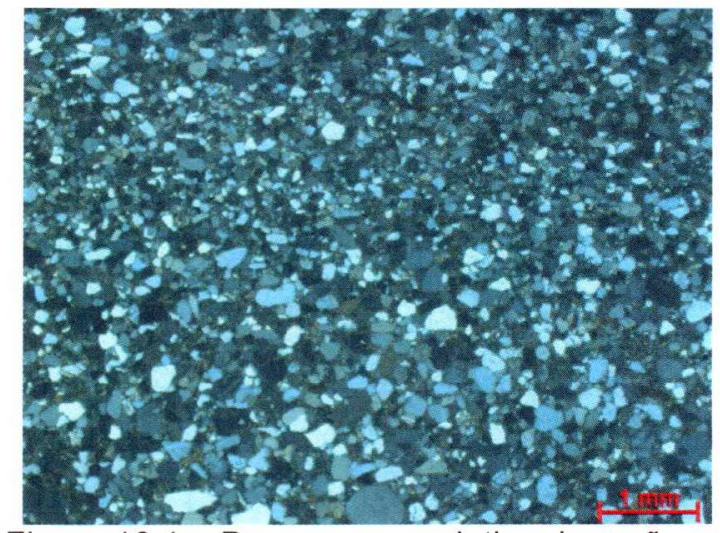

Figura 10.1 - Passagem gradativa dos grãos tamanho areia fina para o tamanho areia grossa.

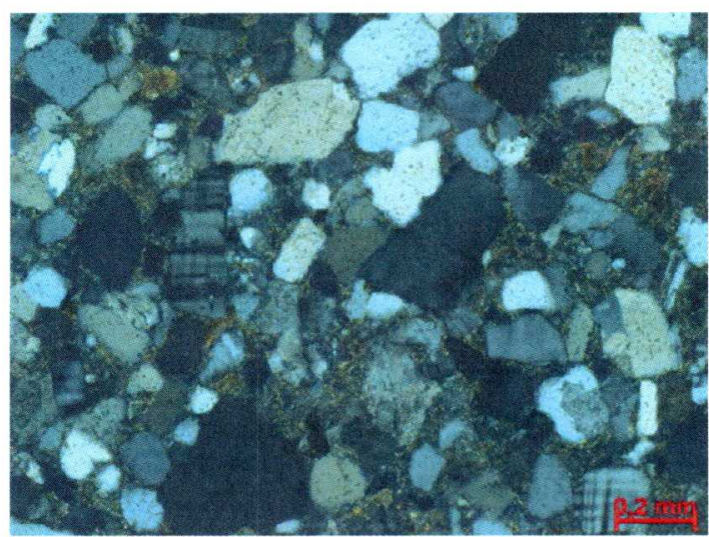

Figura 10.2 - Mineralogia do Arenito Itararé nicóis cruzados.

Segundo análise petrográfica realizada por equipe técnica composta por: Atelier Lumière, Eduardo Cerqueira, Estúdio Sarasá, Imagem \& Texto, IPT, Mário M. Oliveira, Poli-USP, Pool, Studio Argolo e disponibilizada por Fernanda Lapo (Arquiteta da Concremat - empresa responsável pela última obra de restauro), o arenito da fachada foi classificado como:

"... arenito impuro com matriz esmectítica pouco recristalizada. Os minerais instáveis (neste caso, feldspatos) encontram-se fortemente argilizados, alterados para caulinita, em toda a rocha. Na parte interna, a matriz encontra-se lixiviada, os grãos de feldspatos corroídos e os vazios alongados, evidenciando alteração por água pluvial. Por outro lado, próximo à porção externa, os vazios são alongados e a matriz não se encontra removida." A transformação dos feldspatos em caulinita mostra que houve intemperismo químico e, portanto, a rocha já encontra-se deteriorada.

A rocha foi descrita por Del Lama et al. (2008) como sendo um arenito estratificado com granulações que variam de fina a grossa, formado em ambiente deltaico. Apresenta em suas camadas o registro da direção das correntes fluviais, estratificações cavalgantes, estruturas de corte e preenchimento de canais. Petrograficamente, o Arenito Itararé é feldspático com matriz argilosa em proporção variável, que provoca estufamentos e fazem com que ele se deteriore rapidamente. Analisando a rocha por difração de raios $X$, verifica-se que a matriz argilosa é constituída por argilominerais do grupo da esmectita, contendo clorita e illita.

\subsubsection{Difratometria de raios $X(D R X)$}

O Arenito Itararé foi analisado via difração de raios $X$, apresentando pico de 14 $\AA$. Quando este pico, que indica argilominerais como esmectita, vermiculita, clorita ou 
argilominerais de camadas interestratificadas, é submetido a glicolagem (saturação em etilenoglicol), e passa para $16 \AA$, como foi o caso (Figura 10.3), mostra a presença de argilas expansivas do grupo das esmectitas. Este dado corrobora com Bocardi et al. (2006), Morenghi (2007) e Del Lama et al. (2008).

Os argilominerais expansivos são as grandes responsáveis pela rápida deterioração deste arenito.

Além dos argilominerais, foram encontrados quartzo, gipsita, caulinita, microclínio, muscovita e albita.

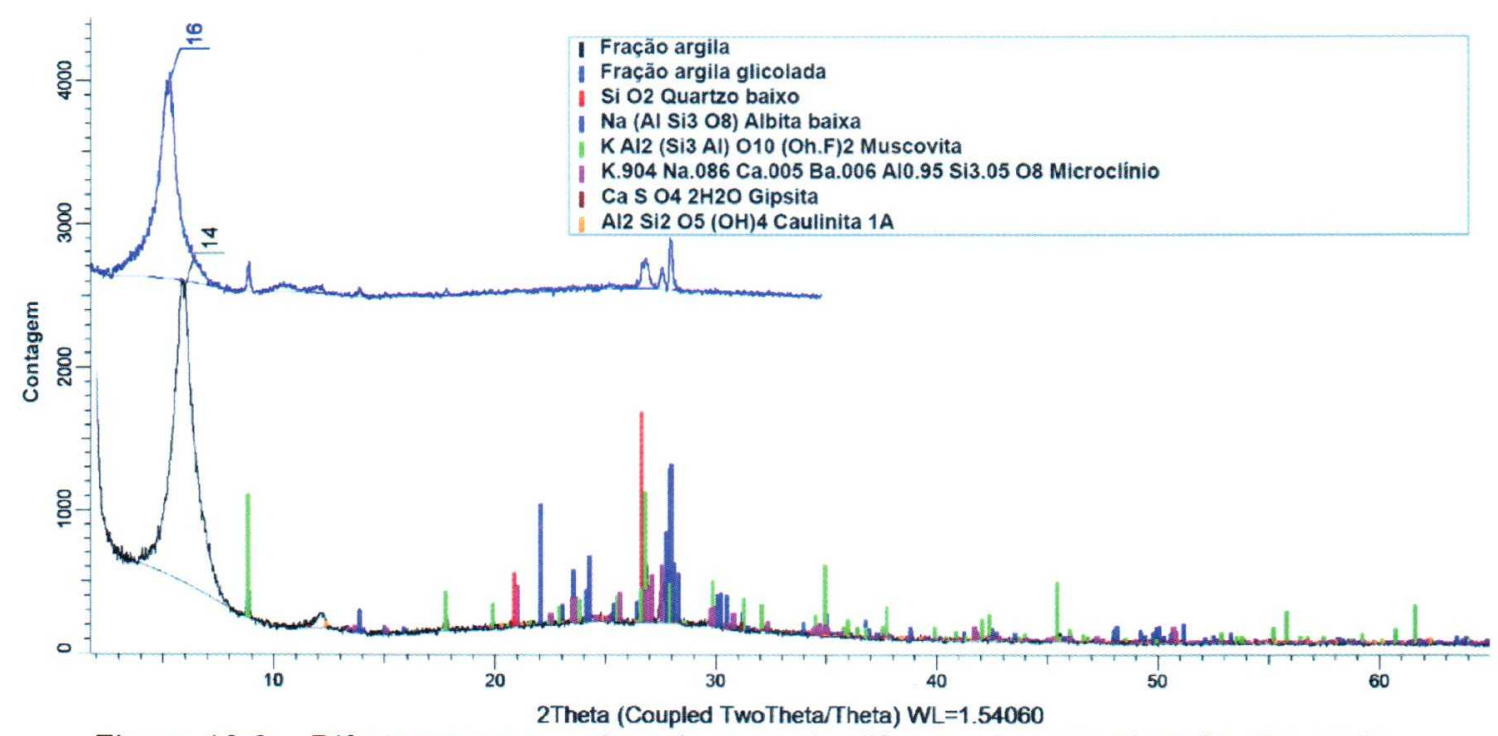

Figura 10.3 - Difratograma gerado pelo teste de difração de raios $X$ da fração argila.

\subsubsection{Espectrofotometria}

As medidas com o espectrofotômetro foram realizadas por toda a fachada, nos pontos indicados na Figura 10.4 .

Os valores para rocha fresca correspondem a média de 45 medidas, realizadas em 4 amostras diferentes; sendo $L=71, a^{*}=4,3$ e $b^{*}=19$.

Os valores do parâmetro de luminosidade ( $L$ ) para as três campanhas de medidas, inclusive para a rocha fresca são mostrados na Figura 10.5. Vale lembrar que quanto mais próximo de 100 , mais claras são as superfícies. Observando a mesma Figura, é possível notar que a rocha da fachada do teatro está mais escura do que a rocha fresca, o que pode ser devido à deterioração da rocha, à sujidade, à colonização biológica e/ou devido ao produto aplicado na intervenção de 2011. Podese observar, ainda, que de maneira geral os valores estão bem próximos nas três campanhas. 
Comparando os valores da campanha de 2014 (traço azul) e 2015 (traço vermelho), com exceção ao ponto 1 , que ficou mais escuro em 2015, os pontos 10 , $13,14,15,17,25$ e 27 ficaram mais claros, neste mesmo ano.

No ano de 2016 (traço verde) houve diminuição na luminosidade de alguns pontos como 10, 14, 15, 17, 22 e 23. No entanto, os pontos 2 e 3 mostraram aumento da luminosidade.

O desvio padrão foi: fresca $=3,2,2014=4,1,2015=4,0$ e $2016=3,4$. Isso mostra que os dados estão ficando mais homogêneos, com o passar dos anos.

De forma geral, observando-se a olho nu, percebe-se que há muita poeira depositada, principalmente nas superfícies horizontais. 


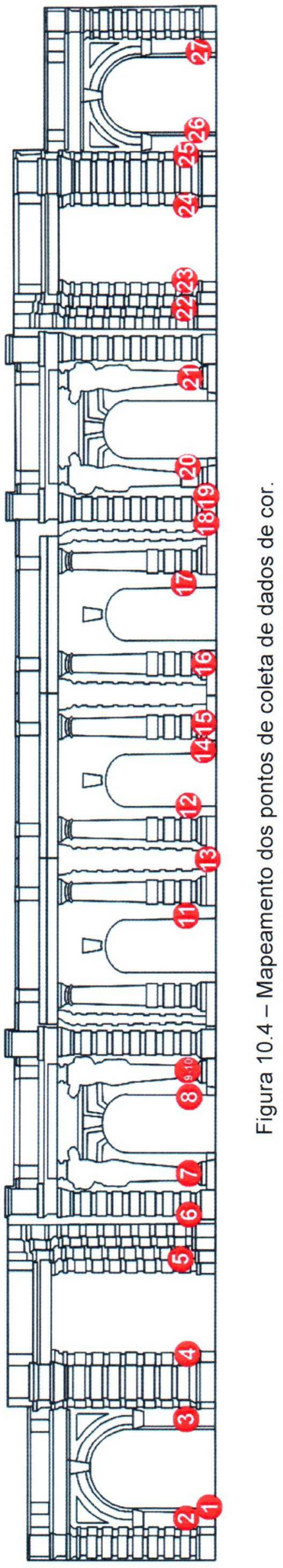


Observando-se os valores médios de cada ano e da rocha fresca, tem-se: fresca $=71,2014=47,2015=48$ e 2016 $=47$. A variação destes três anos, em relação a rocha fresca, é de $-33 \%,-32 \%$ e $-34 \%$. Portanto, há uma diminuição média de $33 \%$ na luminosidade em relação a rocha fresca, que não variou substancialmente durante os três anos de medidas.

\section{Parâmetro L}

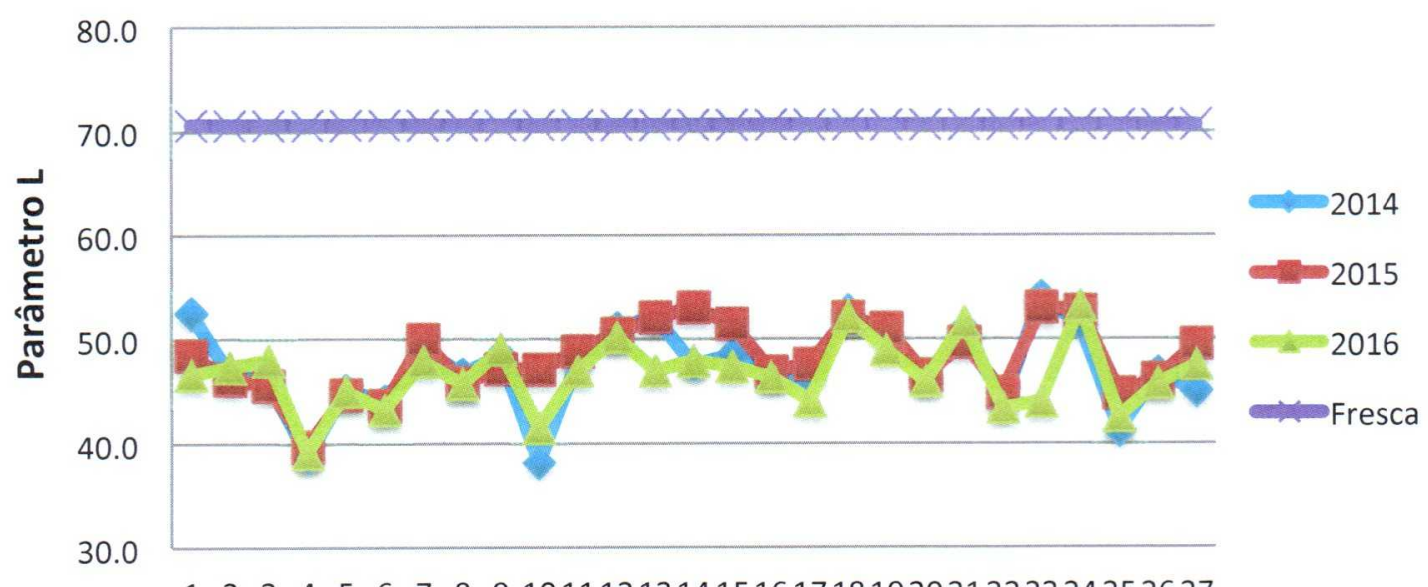

1223045567889101112131415161718192021222324252627

Figura 10.5 - Variação da luminosidade em rocha fresca e nas três campanhas.

Com relação ao parâmetro a*, do ano de 2014 (traço azul) para 2015 (traço vermelho) (Figura 10.6), nota-se uma tendência de diminuição da tonalidade vermelha (valores positivos), que está ficando mais próxima ao valor encontrado em rocha fresca. Isso pode ser devido à deterioração do produto aplicado na fachada na intervenção de 2011.

Na campanha de 2016 (traço verde), os valores estão bem próximos aos da campanha de 2015. No entanto, os pontos 1, 2, 11, 24 e 25 apresentaram diminuição da tonalidade vermelha, enquanto os pontos 12, 17 e 23 mostraram ligeiro aumento.

O desvio padrão foi: fresca $=0,5,2014=1,9,2015=1,5$, e $2016=1,6$, mostrando a homogeneidade dos valores nas três campanhas e menor variação na rocha fresca.

Em linhas gerais, se for comparada a média dos três anos e da rocha fresca, que são: fresca $=4,2,2014=5,6,2015=5,3$ e $2016=5,1$, obtém-se uma variação de $31 \%, 24 \%$ e $20 \%$. Nota-se, portanto, uma tendência ao aumento da tonalidade vermelha. 


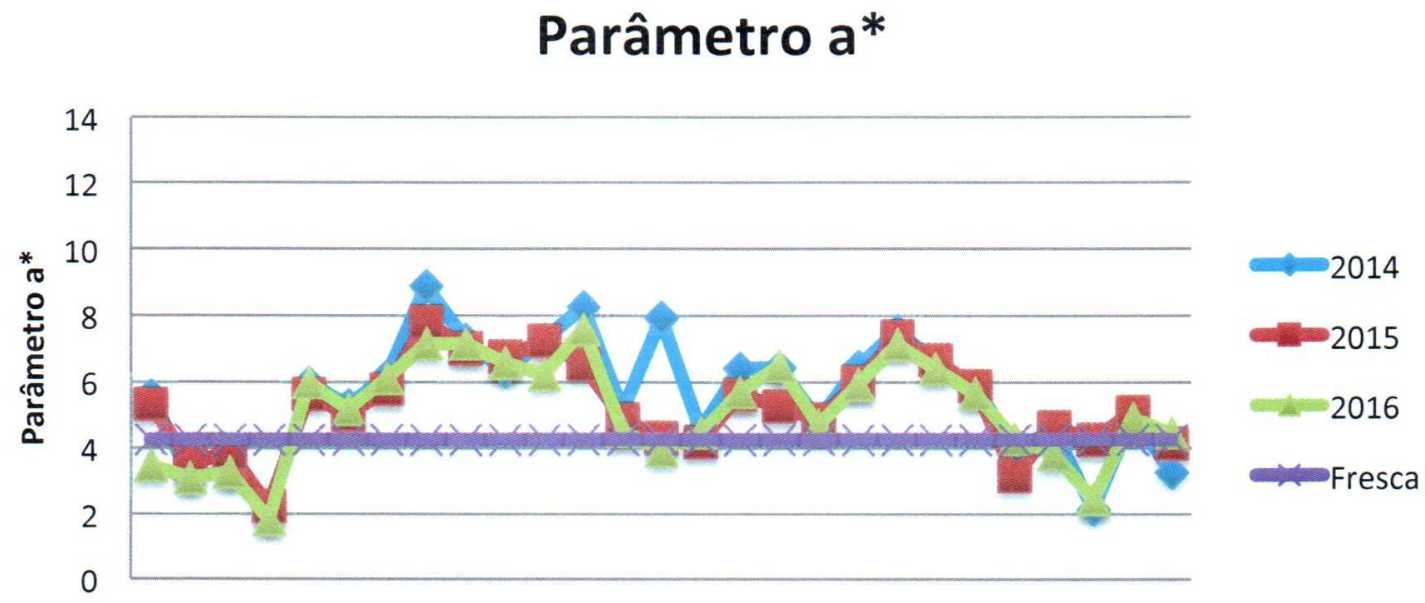

1223445667889101112131415161718192021222324252627

Figura 10.6 - Variação da cor vermelha (valores positivos).

Com relação ao parâmetro b* (amarelo para valores positivos) (Figura 10.7), pode-se verificar uma diminuição nas rochas do teatro com relação à rocha fresca. Ou seja, esta é mais amarela.

Na campanha de 2014 (traço azul), os valores encontram-se distribuídos pelo gráfico, sendo que a maioria mostra uma diminuição da cor amarela em relação à rocha fresca e três pontos $(8,12$ e 14) mostram aumento desta cor.

Nota-se a tendência de diminuição da tonalidade amarela da campanha de 2014 (traço azul) para a de 2015 (traço vermelho), distanciando do valor da rocha fresca.

A campanha de 2016 (traço verde), de forma geral, apresentou valores bem próximos aos da campanha de 2015, com exceção aos pontos 1, 2, 13, e 14, que apresentaram diminuição da cor amarela e dos pontos 17, 18 e 21, que apresentaram pequeno aumento desta tonalidade, ficando mais próximos da tonalidade média da rocha fresca.

O desvio padrão foi: fresca $=0,1,2014=3,5,2015=2,9,2016=2,7$, mostrando, que, os dados das rochas do teatro são bem menos homogêneos que os dados da rocha fresca.

Comparando o valor médio das três campanhas com a média da rocha fresca, que são: fresca $=19,2014=16,2015=16$ e $2016=15$, obtém-se uma variação de $-16 \%,-16 \%$ e $-18 \%$, respectivamente. Isso mostra uma tendência de diminuição da tonalidade amarela.

Atualmente, comparando as tendências dos três parâmetros, verifica-se aumento do vermelho, diminuição do amarelo e da luminosidade das rochas do teatro quando comparado à rocha fresca. 


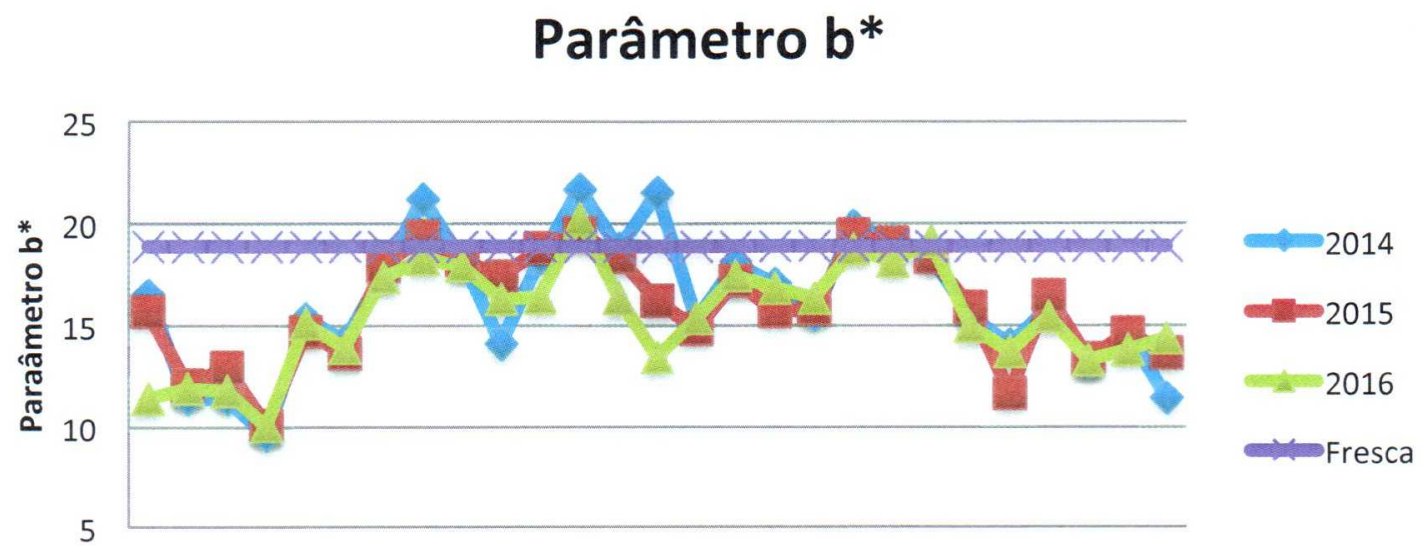

1234567899101112131415161718192021222324252627

Figura 10.7 - Variação da cor amarela (valores positivos).

10.1.4. Intemperismo prévio por aquecimento

- Espectrofotometria das amostras aquecidas

Observando-se a Figura 10.8, nota-se que a luminosidade (L) ficou levemente diminuída nas amostras aquecidas. Na Figura 10.9, observa-se que houve aumento nos valores e na dispersão dos dados para a tonalidade vermelha (a*). Na Figura 10.10 , verifica-se que praticamente não houve mudança na tonalidade amarela $\left(b^{*}\right)$. Estes dados confirmam o avermelhamento observado a olho nu e traz informações adicionais sobre a tonalidade amarela e a luminosidade.

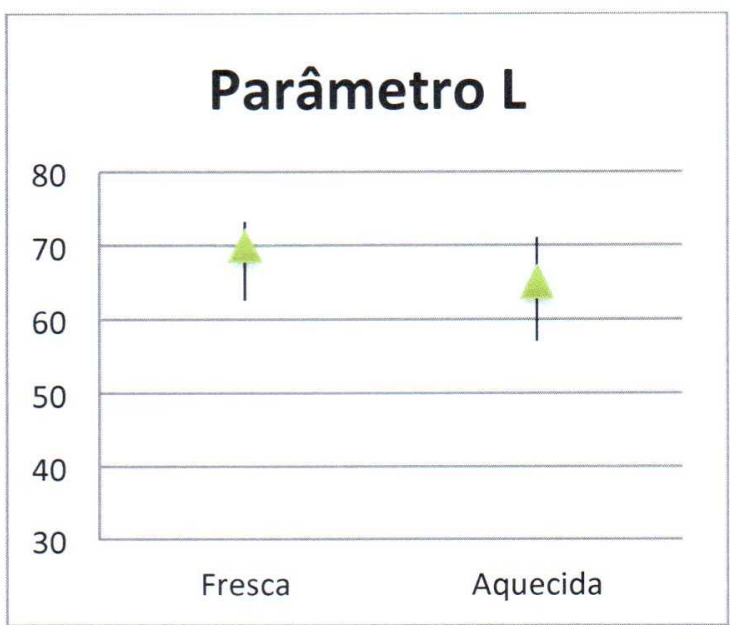

Figura 10.8 - Variação do parâmetro L em amostra fresca e aquecida.

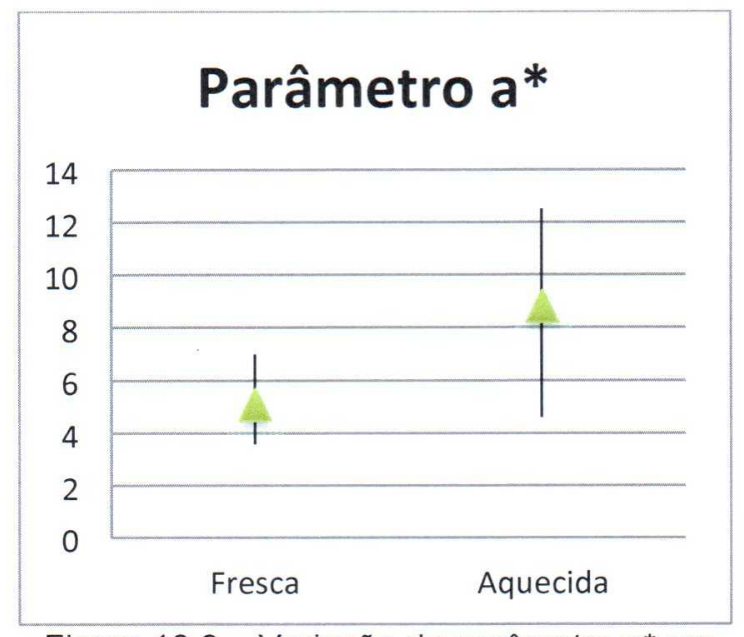

Figura 10.9 - Variação do parâmetro $a^{*}$ em amostra fresca e aquecida. 


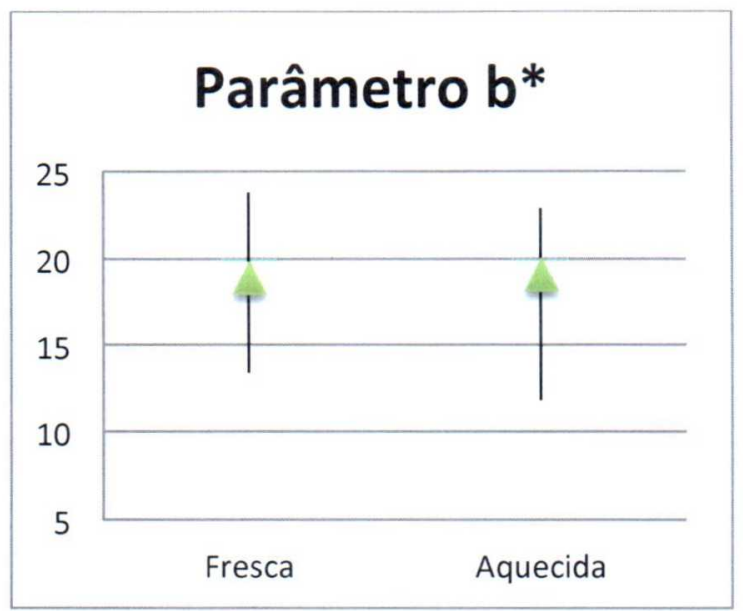

Figura 10.10 - Variação do parâmetro b* em amostra fresca e aquecida.

\section{- Sessões delgadas das amostras aquecidas}

A variação na cor sugeriu que poderia ter ocorrido alteração mineral (oxidação do ferro) pelo calor, principalmente de minerais com ferro. Para avaliar essa possibilidade, foi analisada a sessão delgada de uma amostra aquecida, e nenhuma feição diferente foi observada (Figura 10.11).

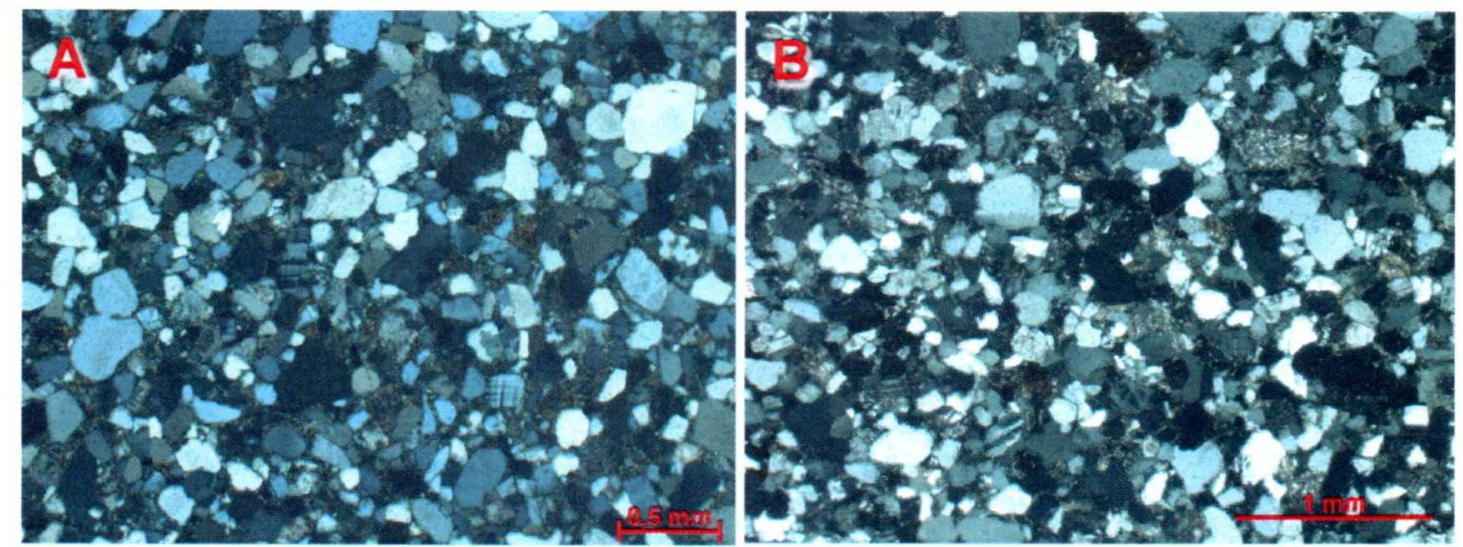

Figura 10.11 - Lâmina do Arenito Itararé antes (a) e após aquecimento (b).

\section{- Velocidade de ondas ultrassônicas das amostras aquecidas}

Foi realizado o ensaio de velocidade de ondas ultrassônicas, e seus resultados foram comparados com os encontrados nas amostras frescas. $O$ valor médio das ondas ultrassônicas de 33 amostras frescas foi de $2,5 \mathrm{~km} / \mathrm{s}$. Quando essas amostras foram submetidas ao aquecimento, o valor médio diminuiu para $1,9 \mathrm{~km} / \mathrm{s}$; uma diminuição de $26 \%$. O módulo dinâmico também diminuiu de 13,5 na fresca, para 7,5 
na aquecida; uma diminuição de 44\%. Portanto, com relação à velocidade ultrassônica, o aquecimento conseguiu simular os efeitos do intemperismo natural.

\section{- Porosimetria de mercúrio das amostras aquecidas}

Foi realizado também o teste de porosimetria de mercúrio, e este foi comparado com os valores mostrados pela rocha fresca, mostrando que a amostra que foi submetida ao aquecimento, apresentou seus poros menores $(0,01 \mu \mathrm{m}$ e $1 \mu \mathrm{m})$ diminuídos (Figura 10.12). No entanto, os poros maiores foram mais numerosos. Apesar da abertura dos poros maiores, a porosidade total ficou em $4,28 \%$, ou seja, um pouco menor que a apresentada pela amostra fresca $(5,80 \%)$. A intrusão cumulativa também foi um pouco diminuída e passou de $0,025 \mathrm{~mL} / \mathrm{g}$ (fresca) para $0,02 \mathrm{~mL} / \mathrm{g}$ (aquecida). Esperava-se que o aquecimento aumentasse a porosidade da rocha e não a diminuísse. Contudo, como a porosimetria de mercúrio é um teste que não pode ser repetido na mesma amostra, a peça que foi ensaiada fresca, não é a mesma que foi ensaiada aquecida. Portanto, pode ser apenas uma diferença de porosidade de uma amostra para outra, considerando a heterogeneidade do Arenito Itararé. Seria necessário realizar o teste mais vezes para ter certeza que o aquecimento está diminuindo os poros. Essa diminuição da porosidade pode ser, também, devido à recristalização dos grãos.

Os gráficos relativos a rocha fresca são mostrados a seguir e no tópico reservado à porosimetria de mercúrio, para facilitar a leitura.
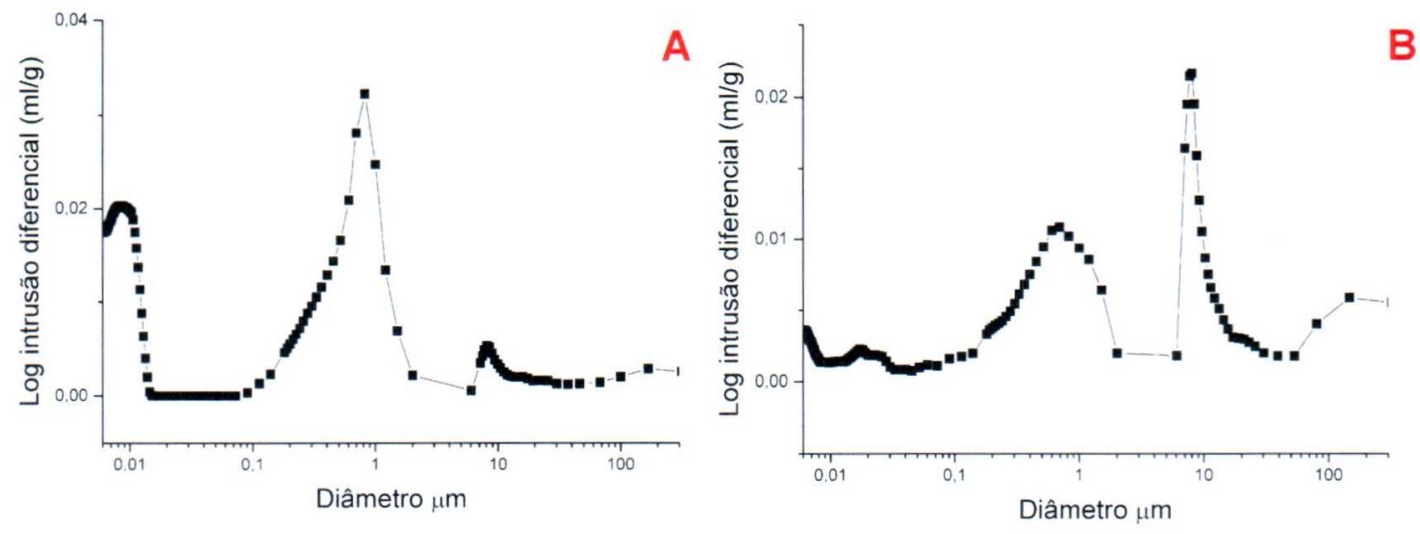

Figura 10.12 - Tamanho dos poros de amostra de Arenito Itararé Fresco (A) e aquecido a $300^{\circ} \mathrm{C}(\mathrm{B})$. 


\subsubsection{Capilaridade}

\section{- Amostra fresca}

O ensaio de capilaridade em amostra fresca não apresentou nenhuma variação significativa quanto à direção de fluxo de água em relação às camadas, sendo o seu resultado médio $0,004 \mathrm{~g} / \mathrm{cm}^{2} \cdot \mathrm{s}$ (Figura 10.13). Vale ressaltar que a reta mostrada, é apenas uma parte da curva ascensional formada pelo aumento de peso, devido à absorção de água, como já explicado anteriormente.

Algumas amostras foram testadas mais de uma vez e mostraram resultados levemente diferentes como é o caso das amostras 10 e 11. No caso da amostra 2, a reta formada em 2-2 não pode ser observada pois está completamente coberta pelos resultados do seu primeiro teste (amostra 2).

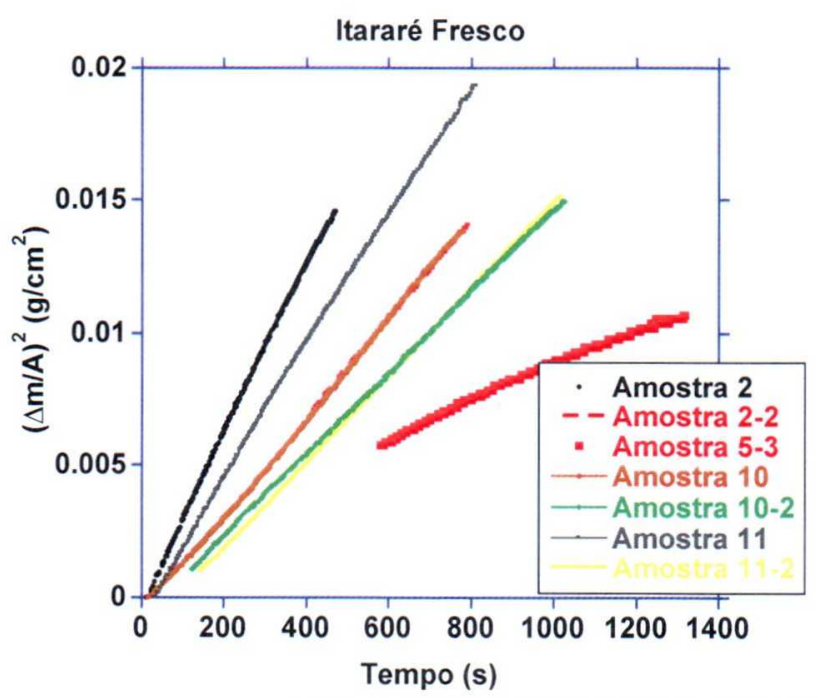

Figura 10.13 - Ensaio de capilaridade em amostra do Arenito Itararé fresco.

\section{$-\mathrm{A}$}

Com a aplicação do A, a quantidade de água absorvida aumentou levemente, passando de $0,0038 \mathrm{~g} / \mathrm{cm}^{2} \cdot \mathrm{s}$ (rocha fresca - perpendicular) e $0,0043 \mathrm{~g} / \mathrm{cm}^{2} \cdot \mathrm{s}$ (fresca paralelo), para $0,0060 \mathrm{~g} / \mathrm{cm}^{2} \cdot \mathrm{s}$ (fluxo perpendicular) e $0,0051 \mathrm{~g} / \mathrm{cm}^{2} \cdot \mathrm{s}$ (fluxo paralelo ao acamamento), o que pode ser observado pela inclinação das retas mostradas na Figura 10.14 . 


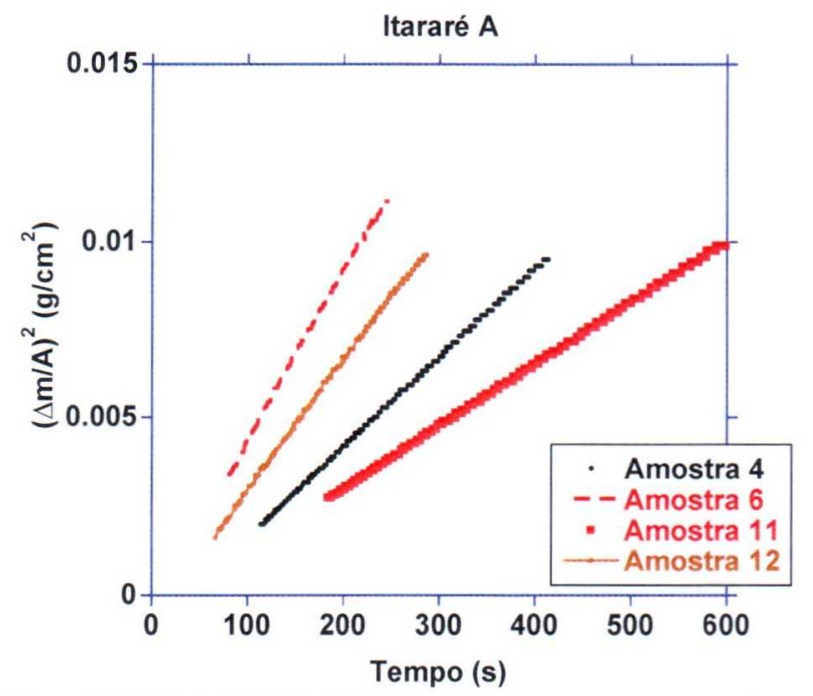

Figura 10.14 - Capilaridade em amostras do Arenito tratado com A.

\section{$-P$}

Já com a aplicação do $\mathbf{P}$, houve uma sensível diferença entre os resultados no teste de capilaridade, obtidos nas diferentes direções de acamamento, sendo 0,0027 $\mathrm{g} / \mathrm{cm}^{2} \cdot \mathrm{s}$ para o fluxo perpendicular e $0,0053 \mathrm{~g} / \mathrm{cm}^{2} \cdot \mathrm{s}$ para o fluxo paralelo ao acamamento. A média geral ficou em $0,004 \mathrm{~g} / \mathrm{cm}^{2} \cdot \mathrm{s}$ (Figura 10.15).

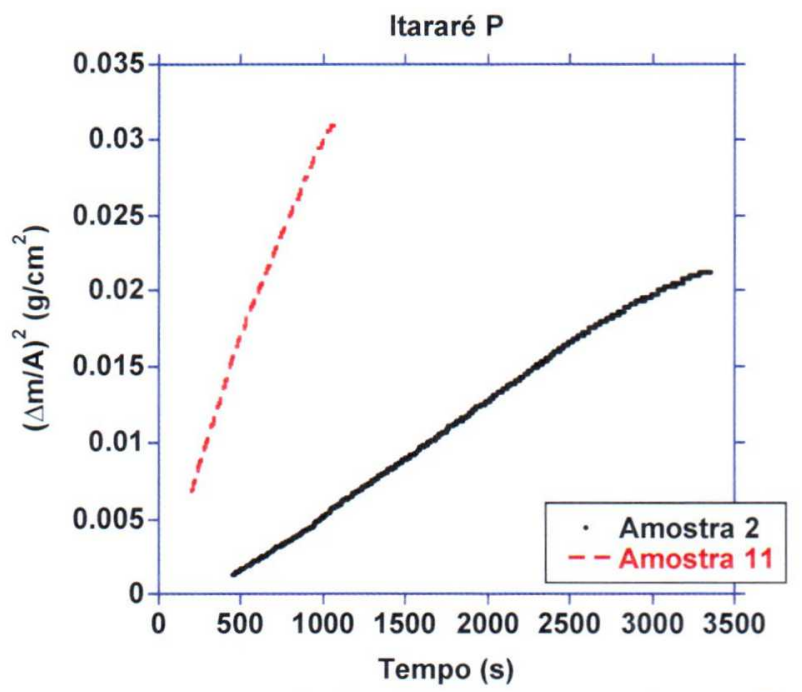

Figura 10.15 - Capilaridade em amostra do Arenito Itararé tratado com P. Amostra 2: fluxo perpendicular, Amostra 11: fluxo paralelo ao acamamento.

\section{- AP}

Comparando os dados obtidos em amostra fresca, verificou-se que a aplicação sequencial de $A$ e $P$ não mostrou bons resultados, pois na maioria dos testes não houve a formação de curva ascensional (amostras 1 e 2), por meio da qual é medida a 
capilaridade e a única amostra que o permitiu apresentou o valor de $0,00043 \mathrm{~g} / \mathrm{cm}^{2} \cdot \mathrm{s}$ (Figura 10.16), que é muito menor do que o observado em rocha fresca. Este resultado sugere que os produtos reagiram dentro da amostra. Provavelmente o A não havia secado completamente quando o $\mathbf{P}$ foi aplicado. Para testar a hipótese, 0 procedimento foi repetido e maior atenção foi dada à secagem do A. Para isso, foi desenvolvido um segundo procedimento (capítulo 9.3.1), e seus resultados serão apresentados posteriormente à finalização dos resultados do primeiro procedimento.

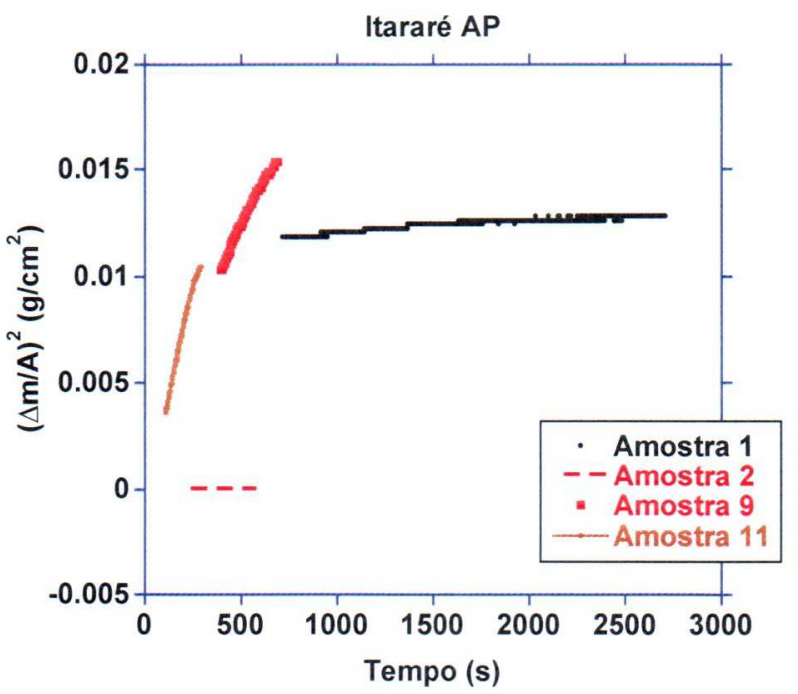

Figura 10.16 - Capilaridade em amostras do Arenito Itararé tratadas com AP. Amostras 1 e 2: fluxo perpendicular, Amostras 9 e 11: fluxo paralelo.

- TC

Em amostras tratadas com TC, a quantidade de água absorvida na direção perpendicular ao acamamento diminuiu bastante, ficando em $0,0017 \mathrm{~g} / \mathrm{cm}^{2} \cdot \mathrm{s}$. Já para o fluxo paralelo, não houve tanta diminuição, ficando com a média de $0,0033 \mathrm{~g} / \mathrm{cm}^{2} \cdot \mathrm{s}$. No entanto, houve grande diferença de valores (Figura 10.17) para as duas amostras de fluxo paralelo $\left(0,0115 \mathrm{~g} / \mathrm{cm}^{2} \cdot \mathrm{s}\right.$ e $\left.0,0039 \mathrm{~g} / \mathrm{cm}^{2} \cdot \mathrm{s}\right)$. 


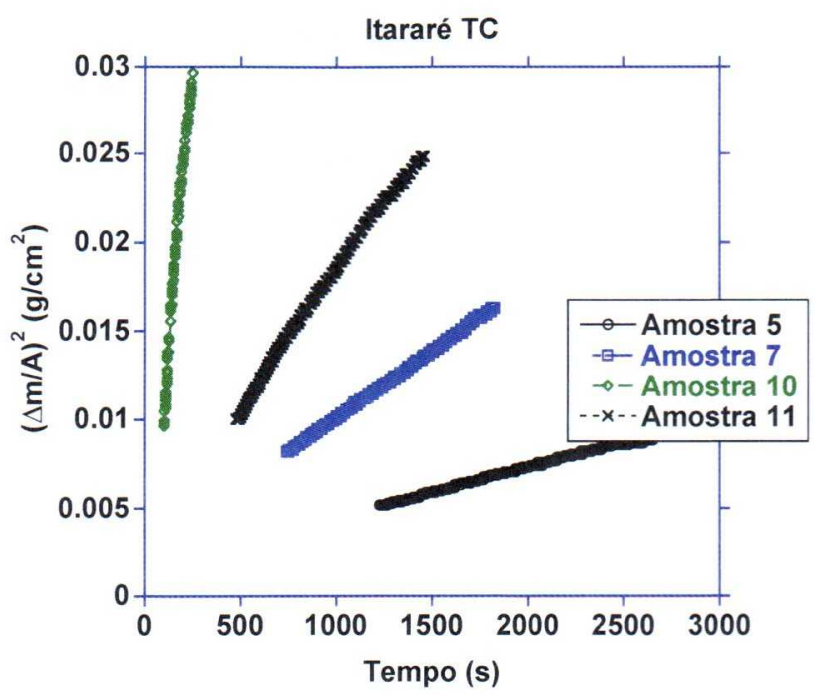

Figura 10.17 - Teste de capilaridade em amostra com fluxo perpendicular ( 5 e 7$)$ e paralelo (10 e 11) do Arenito Itararé tratado com TC.

\section{- ATC}

O resultado médio para o fluxo perpendicular ao acamamento foi de 0,0019 $\mathrm{g} / \mathrm{cm}^{2} \cdot \mathrm{s}$ e de $0,0055 \mathrm{~g} / \mathrm{cm}^{2} \cdot \mathrm{s}$ para o fluxo paralelo. A média geral ficou em 0,0037 $\mathrm{g} / \mathrm{cm}^{2} \cdot \mathrm{s}$, não sendo muito inferior ao da amostra fresca. Como a capilaridade foi muito diminuída para as rochas ensaiadas com fluxo perpendicular ao acamamento (Figura 10.18) e verificou-se a reatividade entre A e TC, decidiu-se repetir a aplicação em outras amostras e garantir que o A estava seco para que não houvesse reação. Também foi testada a hipótese dos poros terem sido muito reduzidos pelo excesso de A nestes locais. Para tal, novas amostras foram tratadas com um segundo procedimento.

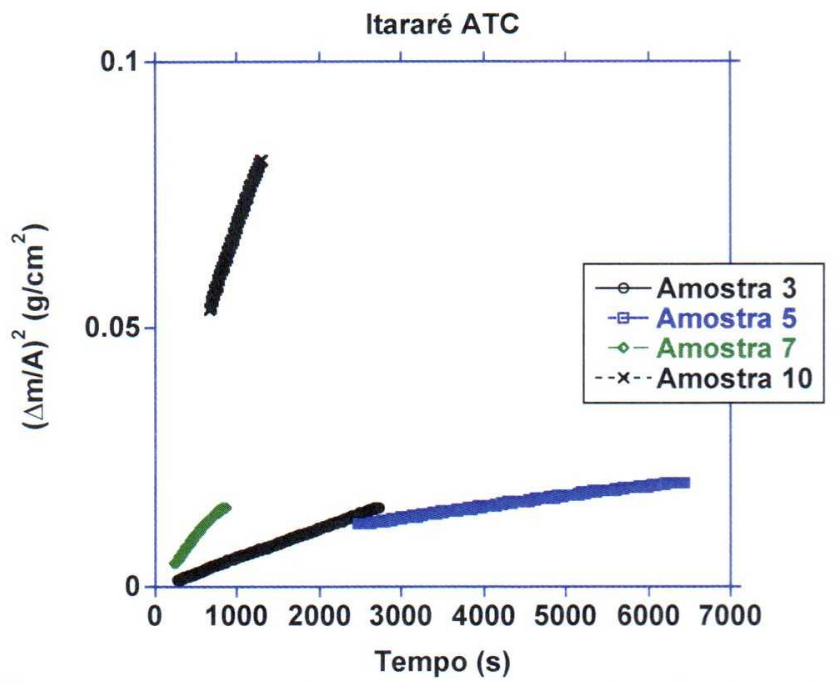

Figura 10.18 - Teste de capilaridade em amostras do Arenito Itararé tratadas com ATC. Amostras 3 e $5 \mathrm{com}$ fluxo perpendicular e amostras 7 e $10 \mathrm{com}$ fluxo paralelo ao acamamento. 
Observando-se todos os resultados reunidos (Tabela 10.1), pode-se verificar que houve grande variação nos resultados da rocha fresca na direção de fluxo perpendicular $\left(0,0025\right.$ a $\left.0,0057 \mathrm{~g} / \mathrm{cm}^{2} \cdot \mathrm{s}\right)$. Na direção de fluxo paralelo, a variação foi menor $\left(0,0039\right.$ a $\left.0,0050 \mathrm{~g} / \mathrm{cm}^{2} \cdot \mathrm{s}\right)$. De maneira geral, os resultados estão dentro do intervalo encontrado nas amostras frescas, ou bem próximo a eles, com exceção do AP, que apenas uma das amostras formou a curva ascensional e o valor obtido foi bem mais baixo. TC e ATC na direção de fluxo perpendicular diminuíram um pouco a capilaridade. Portanto, apenas o AP apresentou resultados ruins e foi testado com um segundo procedimento, descrito a seguir, para verificar se estes resultados eram devido à reatividade dos produtos em estado líquido.

Tabela 10.1 - Capilaridade no Arenito Itararé.

\begin{tabular}{|c|c|c|c|}
\hline Tratamento & $\begin{array}{l}\text { Direção do } \\
\text { fluxo da água }\end{array}$ & $\begin{array}{c}\text { Capilaridade } \\
\left(\mathrm{g} / \mathrm{cm}^{2} \cdot \mathrm{s}\right)\end{array}$ & $\begin{array}{c}\text { Média } \\
\left(\mathrm{g} / \mathrm{cm}^{2} \cdot \mathrm{s}\right)\end{array}$ \\
\hline \multirow{7}{*}{ Fresca } & \multirow{3}{*}{ Perpendicular } & $\begin{array}{l}0,0057 \\
0,0043\end{array}$ & \multirow{3}{*}{0,0038} \\
\hline & & 0,0026 & \\
\hline & & 0,0025 & \\
\hline & \multirow{4}{*}{ Paralelo } & 0,0043 & \multirow{4}{*}{0,0043} \\
\hline & & 0,0039 & \\
\hline & & 0,0050 & \\
\hline & & 0,0040 & \\
\hline \multirow{3}{*}{ A } & Perpendicular & $\begin{array}{l}0,0050 \\
0,0069\end{array}$ & 0,0060 \\
\hline & \multirow{2}{*}{ Paralelo } & 0,0042 & \multirow{2}{*}{0,0051} \\
\hline & & 0,0060 & \\
\hline \multirow[t]{2}{*}{$\mathbf{P}$} & Perpendicular & 0,0027 & 0,0027 \\
\hline & Paralelo & 0,0053 & 0,0053 \\
\hline AP & Perpendicular & 0,0004 & 0,0004 \\
\hline \multirow[t]{3}{*}{ TC } & Perpendicular & $\begin{array}{l}0,0017 \\
0,0027\end{array}$ & 0,0022 \\
\hline & Paralelo & 0,0039 & 0.0077 \\
\hline & & 0,0115 & \\
\hline \multirow{4}{*}{ ATC } & Perpendicular & 0,0024 & 0,0019 \\
\hline & & 0,0014 & \\
\hline & \multirow[t]{2}{*}{ Paralelo } & 0,0043 & \multirow[t]{2}{*}{0,0055} \\
\hline & & 0,0067 & \\
\hline
\end{tabular}

\section{- Aplicação com $2^{\circ}$ procedimento}

Como os resultados da aplicação do AP não foram satisfatórios, um novo procedimento foi testado para verificar se havia algum problema com o modo de 
aplicação utilizado. A hipótese era de que havia reatividade entre os dois produtos em solução ( $\mathrm{A}$ e P, A e TC), o que foi confirmado, pois, quando os produtos puros foram misturados, a reação entre eles foi notada pela liberação de calor. No entanto, misturando na mesma concentração usada para a aplicação, nenhuma reação visível foi observada.

O segundo procedimento consiste em assegurar que o produto aplicado anteriormente, estava completamente seco. Para tal, amostras foram secas em estufa a $60^{\circ} \mathrm{C}$ por 24 horas entre as duas aplicações de $\mathrm{A}$ e antes da aplicação do consolidante (P ou TC). Isso, para garantir que o A estava totalmente seco; já que foi confirmada a reatividade entre estes dois produtos em solução.

Para testar se havia um excesso de $\mathbf{A}$ que reagiu quando o consolidante foi aplicado e isso poderia ser a causa dos maus resultados, algumas amostras foram deixadas $24 \mathrm{~h}$ de molho em água destilada e secas durante $24 \mathrm{~h}$ em forno a $60^{\circ} \mathrm{C}$. Isso foi chamado de enxágue $(E)$.

Os consolidantes foram preparados na mesma concentração. No entanto, 0 óxido de cálcio foi misturado diretamente no $\mathbf{P}$ (solução aquosa), formando $\mathrm{CaOH}$ (hidróxido de cálcio). Portanto, a aplicação foi realizada concomitantemente, proporcionando cálcio disponível para que o $\mathbf{P}$ reagisse.

No segundo procedimento, foram utilizadas outras amostras frescas. Nestas amostras, também foi realizado o ensaio de velocidade de ondas ultrassônicas, que será discutido, posteriormente.

\section{- AP 2 (sem enxágue)}

O valor médio para o fluxo perpendicular foi de $0,0040 \mathrm{~g} / \mathrm{cm}^{2} \cdot \mathrm{s}$, para o fluxo paralelo ao acamamento foi de $0,0056 \mathrm{~g} / \mathrm{cm}^{2} \cdot \mathrm{s}$ e média geral de $0,0048 \mathrm{~g} / \mathrm{cm}^{2} \cdot \mathrm{s}$ (Figura 10.19). Esse valores são bem próximos aos encontrados na amostra fresca ensaiada. 


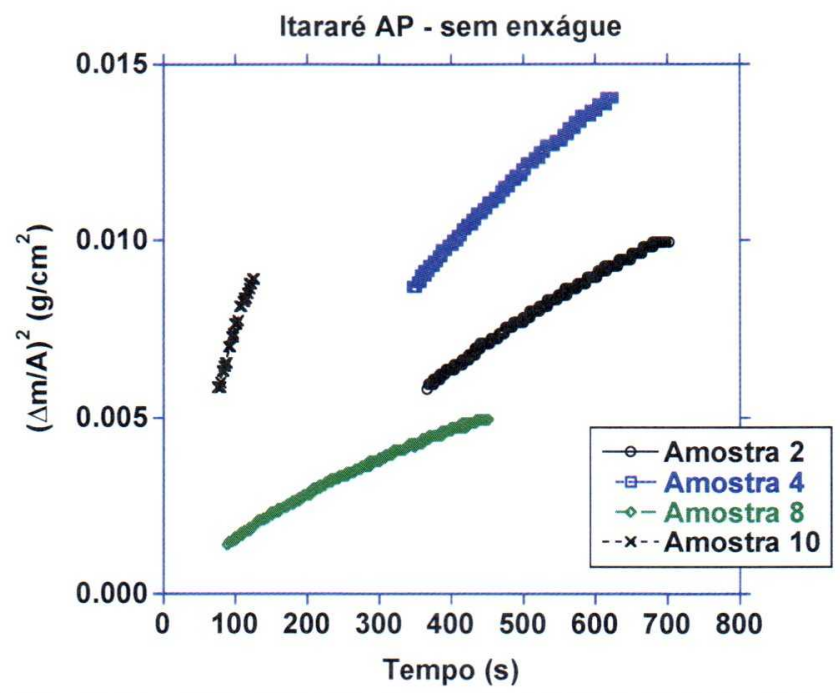

Figura 10.19 - Teste de capilaridade em amostras do Arenito Itararé tratado com AP (sem enxágue). Amostras 2 e $4 \mathrm{com}$ fluxo perpendicular e amostras 8 e 10, fluxo paralelo ao acamamento.

\section{- AP 2E (com enxágue)}

O valor médio para o fluxo perpendicular ao acamamento foi de $0,0047 \mathrm{~g} / \mathrm{cm}^{2} \cdot \mathrm{s}$ e para o fluxo paralelo foi de $0,0016 \mathrm{~g} / \mathrm{cm}^{2} \cdot \mathrm{min}^{1 / 2}$ (Figura 10.20). Nas amostras de fluxo paralelo, o comportamento inesperado foi mantido, sendo mais acentuado nas que foram enxaguadas com água após a aplicação do pré-consolidante, mostrando que não é o excesso de $\mathbf{A}$ que reagiu com o $\mathbf{P}$, e sim a incompatibilidade química entre os dois produtos.

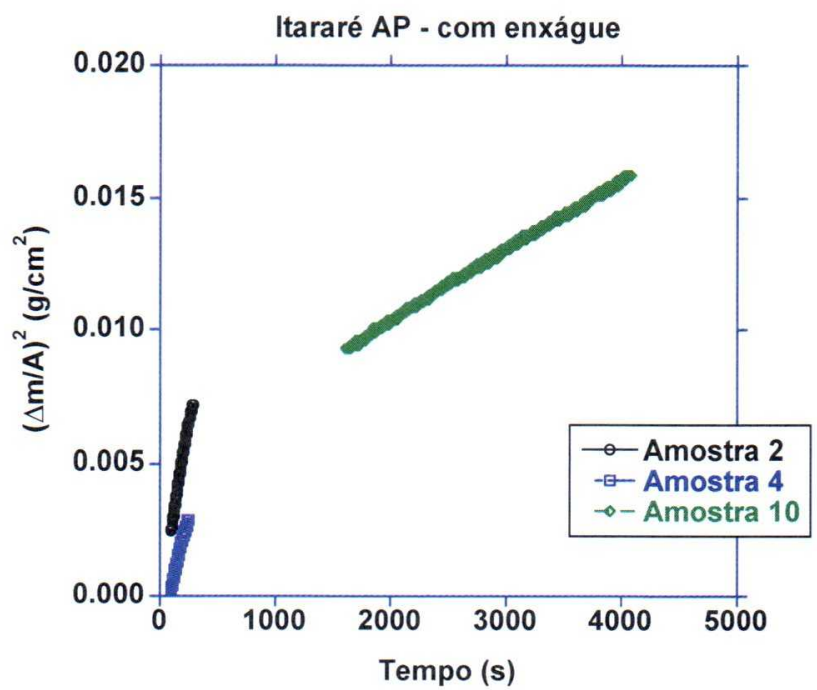

Figura 10.20 - Teste de capilaridade em amostra de Arenito Itararé tratado com AP com enxágue. Amostra 2 e $4 \mathrm{com}$ fluxo perpendicular ao acamamento e a 10, paralelo. 


\section{- ATC 2 (sem enxágue)}

O resultado médio foi de $0,0034 \mathrm{~g} / \mathrm{cm}^{2} \cdot \mathrm{s}$ para amostras com fluxo perpendicular (Figura 10.21) e média de $0,0043 \mathrm{~g} / \mathrm{cm}^{2} \cdot \mathrm{s}$ para as com fluxo paralelo; bem próximo ao valor da amostra fresca. Na média geral o valor foi de $0,0038 \mathrm{~g} / \mathrm{cm}^{2} \cdot \mathrm{s}$. Aqui mais uma vez a amostra com acamamento direcionado verticalmente apresentou dois valores bem distintos. No procedimento utilizado anteriormente, o resultado encontrado foi de $0,002 \mathrm{~g} / \mathrm{cm}^{2} \cdot \mathrm{s}$, o que mostra que esse segundo procedimento é mais adequado.

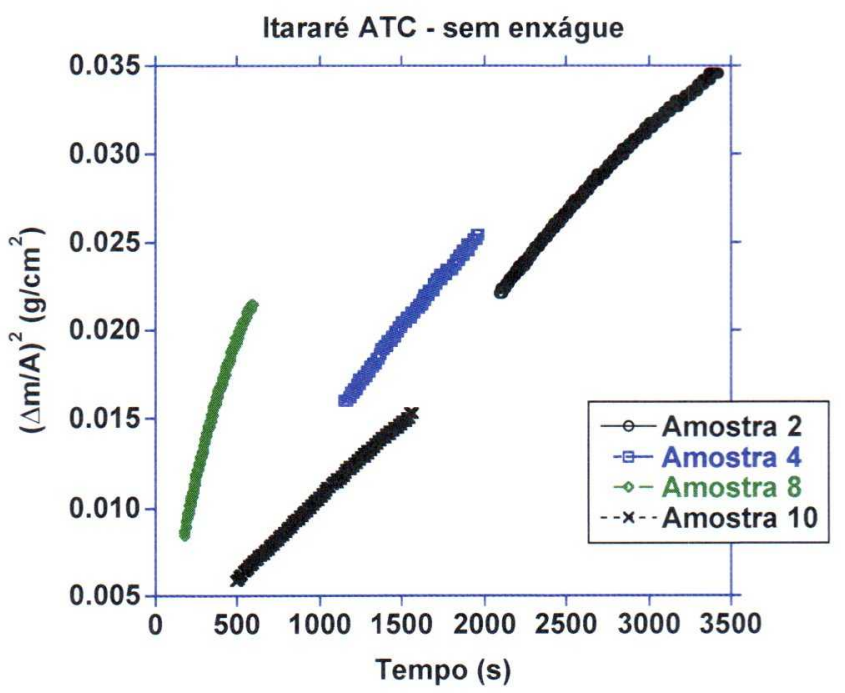

Figura 10.21 - Teste de capilaridade em amostra de Arenito Itararé tratado com ATC 2 (sem enxágue). Amostras 2 e $4 \mathrm{com}$ fluxo perpendicular ao acamamento e 8 e $10 \mathrm{com}$ fluxo paralelo.

\section{- ATC 2E (com enxágue)}

As amostras posicionadas com fluxo perpendicular ao acamamento, apresentaram diminuição na quantidade de água absorvida $\left(0,0030 \mathrm{~g} / \mathrm{cm}^{2} \cdot s\right)$, enquanto as com fluxo paralelo, ficaram com média bem próxima das amostras frescas $\left(0,0046 \mathrm{~g} / \mathrm{cm}^{2} \cdot \mathrm{s}\right)$. A média geral ficou em $0,0039 \mathrm{~g} / \mathrm{cm}^{2} \cdot \mathrm{s}$ (Figura 10.22). 


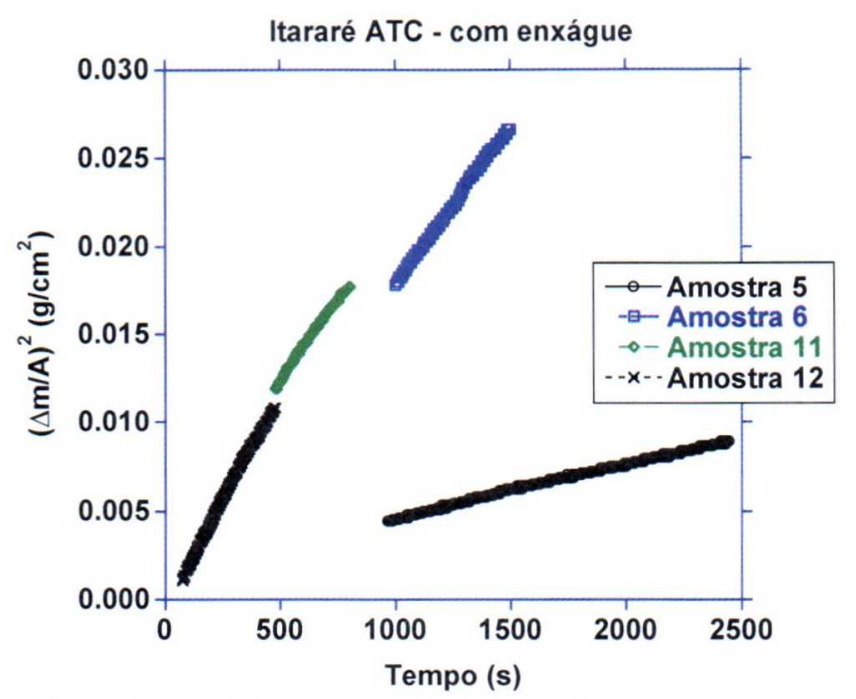

Figura 10.22 - Teste de capilaridade em amostra de Arenito Itararé tratado com ATC $2 \mathrm{E}$ (com enxágue). Amostras 5 e $6 \mathrm{com}$ fluxo perpendicular e 11 e $12 \mathrm{com}$ fluxo paralelo ao acamamento.

Analisando os resultados obtidos com o segundo procedimento de aplicação (Tabela 10.2), verifica-se que não há grandes diferenças entre a média deles; com exceção ao AP com enxágue (paralelo), que mostrou diminuição da capilaridade.

Nota-se que o enxágue não fez diferença nos resultados, portanto não era o excesso de A que estava reagindo com os consolidantes.

No entanto, se compararmos os resultados da primeira e da segunda aplicações do AP, tanto com ou sem enxágue, a segunda apresentou-se muito melhor. O ATC aumentou a quantidade de água absorvida nas rochas com fluxo perpendicular, mas diminuiu bastante nas com fluxo paralelo. Apesar da diminuição, os valores estão bem próximos da rocha fresca. Devido à grande variação dos valores para um mesmo tratamento, esse teste não auxilia muito na avaliação dos produtos. 
Tabela 10.2 - Capilaridade no Arenito Itararé: segundo procedimento.

\begin{tabular}{lccc}
\hline Tratamento & $\begin{array}{c}\text { Direção fluxo } \\
\text { de água }\end{array}$ & $\begin{array}{c}\text { Capilaridade } \\
\left(\mathbf{g} / \mathbf{c m}^{2} \cdot \mathbf{s}\right)\end{array}$ & $\begin{array}{c}\text { Média } \\
\left(\mathbf{g} / \mathbf{c m}^{2} \cdot \mathbf{s}\right)\end{array}$ \\
\hline AP 2 & Perpendicular & $\begin{array}{c}0,0035 \\
0,0044\end{array}$ & 0,0040 \\
\cline { 2 - 4 } sem enxágue & Paralelo & 0,0031 & 0,0031 \\
\hline \multirow{2}{*}{$\begin{array}{l}\text { AP 2E } \\
\text { com enxágue }\end{array}$} & Perpendicular & 0,0051 & 0,0047 \\
\hline \multirow{2}{*}{$\begin{array}{l}\text { ATC 2 } \\
\text { sem enxágue }\end{array}$} & Paralelo & 0,0042 & 0,0016 \\
\cline { 2 - 4 } & Perpendicular & 0,0031 & 0,0033 \\
\hline \multirow{2}{*}{ ATC 2E } & Paralelo & 0,0034 & 0,0043 \\
com enxágue & Perpendicular & 0,0055 & 0,0033 \\
\cline { 2 - 4 } & Paralelo & 0,0017 & 0,0030 \\
\hline
\end{tabular}

\section{- Universidade de São Paulo}

\section{- Fresca}

Para as amostras frescas, a capilaridade média encontrada foi de 0,0221 $\mathrm{g} / \mathrm{cm}^{2} \cdot \mathrm{s}$ e o desvio padrão de 0,003. Comparando-se este resultado com o encontrado na Universidade de Princeton, verifica-se que a diferença no procedimento, levou a valores muito distintos. A parte que mostra a inclinação das curvas de absorção de água é mostrada na Figura 10.23 .

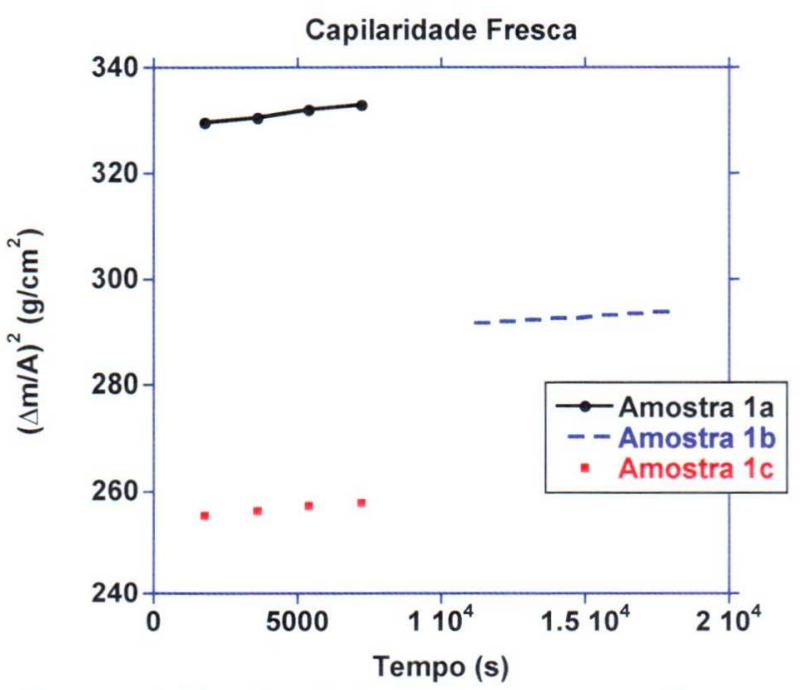

Figura 10.23 - Capilaridade em amostras frescas. 


\section{$-\mathrm{A}$}

As amostras que foram tratadas com uma sequência de $\mathbf{A}(\mathbf{A} 2 \rightarrow \mathrm{A} 3 \rightarrow \mathrm{A6}$ ), apresentaram média de absorção de água de $0,0286 \mathrm{~g} / \mathrm{cm}^{2} \cdot \mathrm{s}$; que é um pouco maior do que a média das rochas frescas. O desvio padrão foi de 0,011. As retas, a partir das quais foi calculada a capilaridade, são mostradas na Figura 10.24.

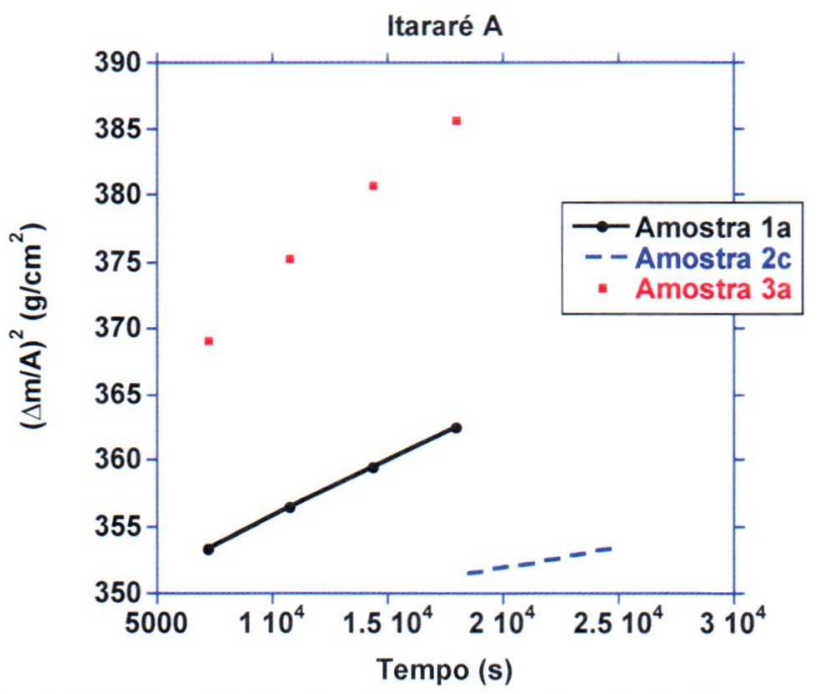

Figura 10.24-Capilaridade em amostras tratadas com A.

\section{$-\mathrm{P}$}

Os resultados de capilaridade para as amostras tratadas apenas com $\mathbf{P}$, foi de $0,0213 \mathrm{~g} / \mathrm{cm}^{2} \cdot \mathrm{s}$ e o desvio padrão foi de 0,002 . A inclinação das curvas é mostrada na Figura 10.25 .

Quando foi misturado hidróxido de cálcio $(\mathrm{CaOH})$ junto com o $\mathbf{P}$, para aumentar a quantidade de cálcio disponível e melhorar a performance do produto, a quantidade de água absorvida aumentou para $0,0316 \mathrm{~g} / \mathrm{cm}^{2} \cdot \mathrm{s}$ e o desvio padrão também aumentou, para 0,01. A inclinação da parte ascensional das curvas é mostrada na Figura 10.26 . 


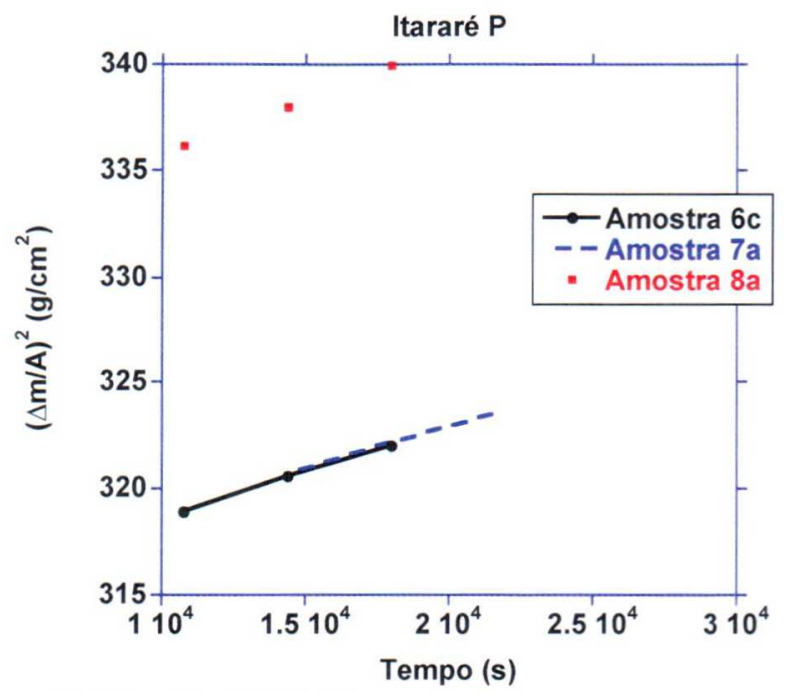

Figura 10.25 - Capilaridade em amostras tratadas com P.

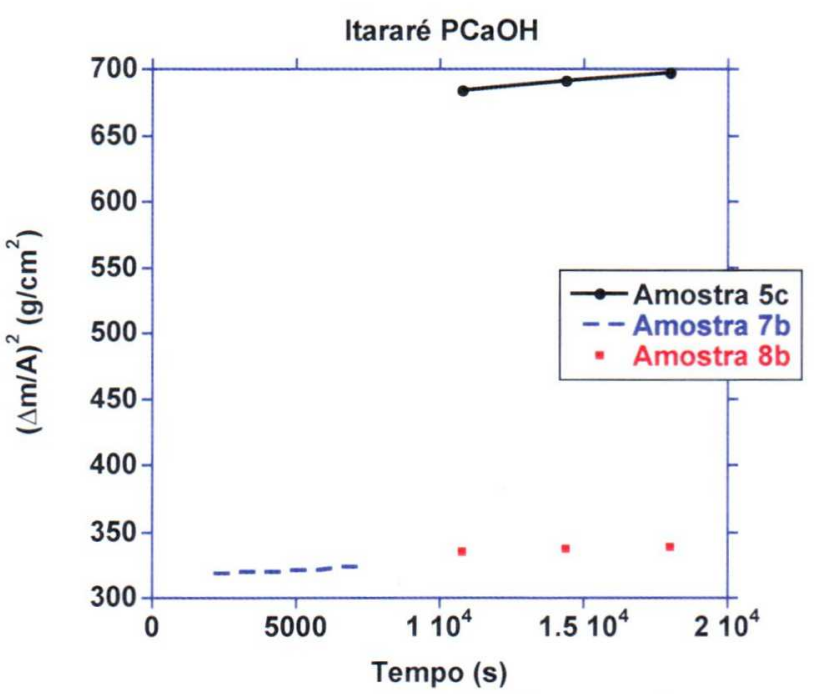

Figura 10.26 - Capilaridade em amostras tratadas com P misturado com $\mathrm{CaOH}$.

\section{- AP}

Quando a sequência de A foi aplicada antes do P, o valor de água absorvida $\left(0,0268 \mathrm{~g} / \mathrm{cm}^{2} \cdot \mathrm{s}\right)$ não foi muito diferente do encontrado com a aplicação do $P$ sozinho. Mostrando que o A não é efetivo para diminuir a quantidade de água que penetra na rocha. O desvio padrão foi de 0,007 e a inclinação das curvas é mostrada na Figura 10.27 . 


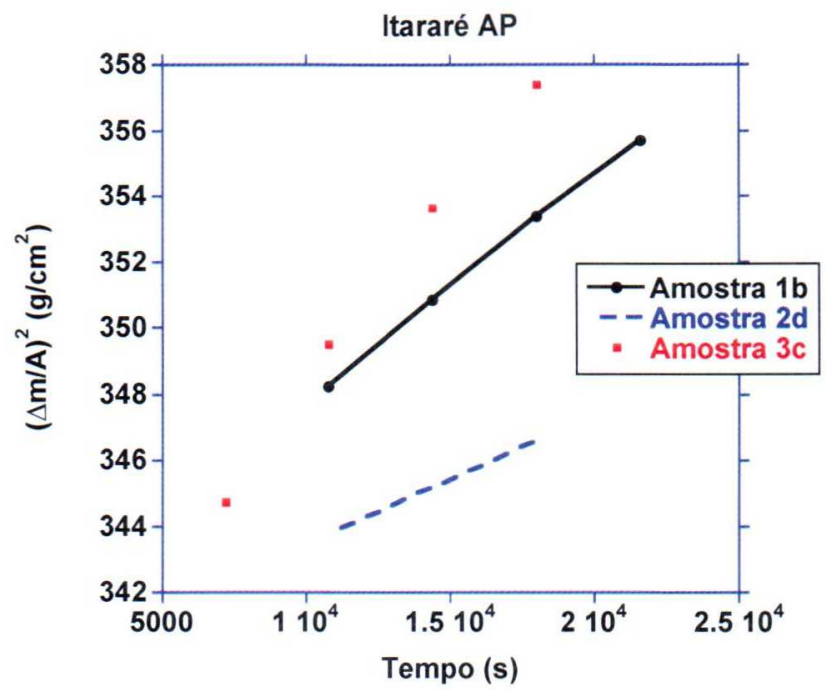

Figura 10.27 - Capilaridade em amostras pré-tratadas com A e tratadas com P.

\section{$-\mathrm{CaOH}$}

As amostras tratadas com a solução de hidróxido de cálcio ( $\mathrm{CaOH})$, apresentaram a absorção média de água de $0,0212 \mathrm{~g} / \mathrm{cm}^{2} \cdot \mathrm{s}$ e desvio padrão de 0,001 . O valor da quantidade de água absorvida foi calculado a partir da inclinação das retas apresentada na Figura 10.28.

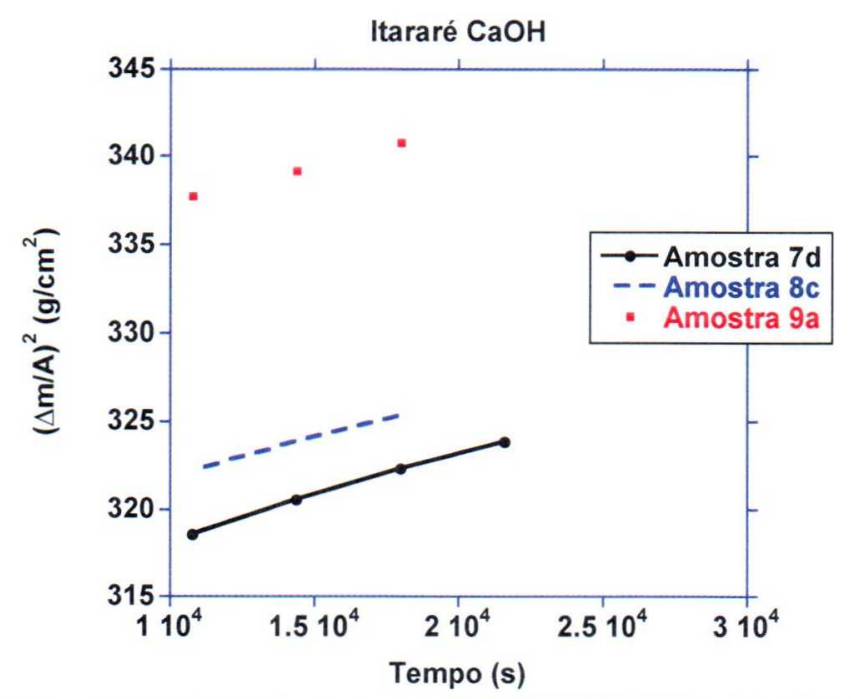

Figura 10.28 - Capilaridade em amostras tratadas com solução de $\mathrm{CaOH}$.

\section{- TW}

A quantidade média de água absorvida pelas amostras tratadas com TW foi de $0,0210 \mathrm{~g} / \mathrm{cm}^{2} \cdot \mathrm{s}$ e o desvio padrão foi de 0,007 . As retas que geraram o cálculo da quantidade de água absorvida são mostradas na Figura 10.29. 


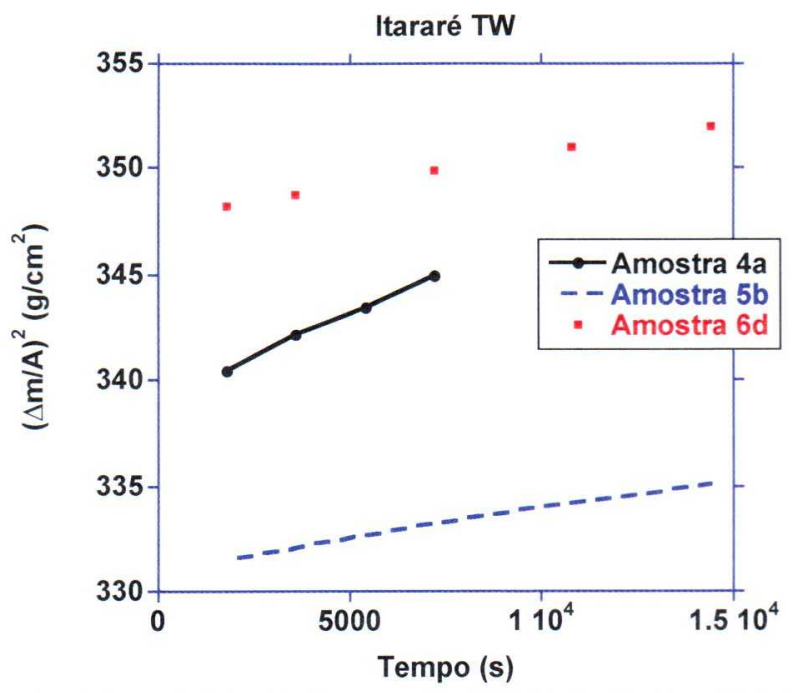

Figura 10.29 - Capilaridade em amostras tratadas com TW.

\section{- ATW}

A média da quantidade de água absorvida pelas amostras tratadas com $\mathrm{A} e$ consecutivamente por TW, foi de $0,0114 \mathrm{~g} / \mathrm{cm}^{2} \cdot \mathrm{s}$. O desvio padrão foi de 0,006 . A inclinação das curvas de capilaridade é mostrada na Figura 10.30.

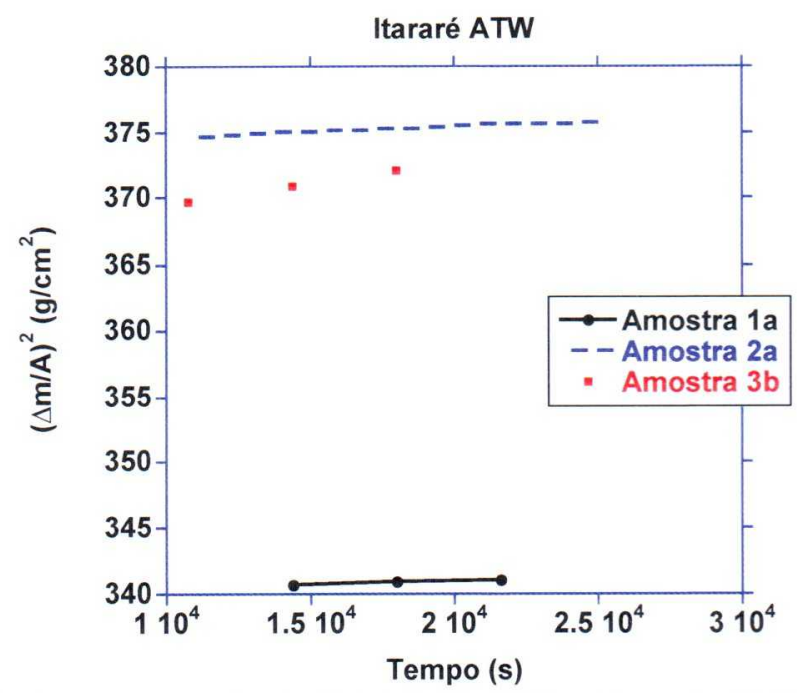

Figura 10.30 - Capilaridade em amostras pré-tratadas com A e tratadas com TW.

\section{$-630$}

Nas amostras em que foi aplicado o hidrofugante 630, a quantidade média de água absorvida foi de $0,0088 \mathrm{~g} / \mathrm{cm}^{2} \cdot \mathrm{s}$. Na Figura 10.31 são observadas apenas duas retas, pois uma das amostras foi perdida durante o processo de manipulação. $O$ desvio padrão foi de 0,002 . 


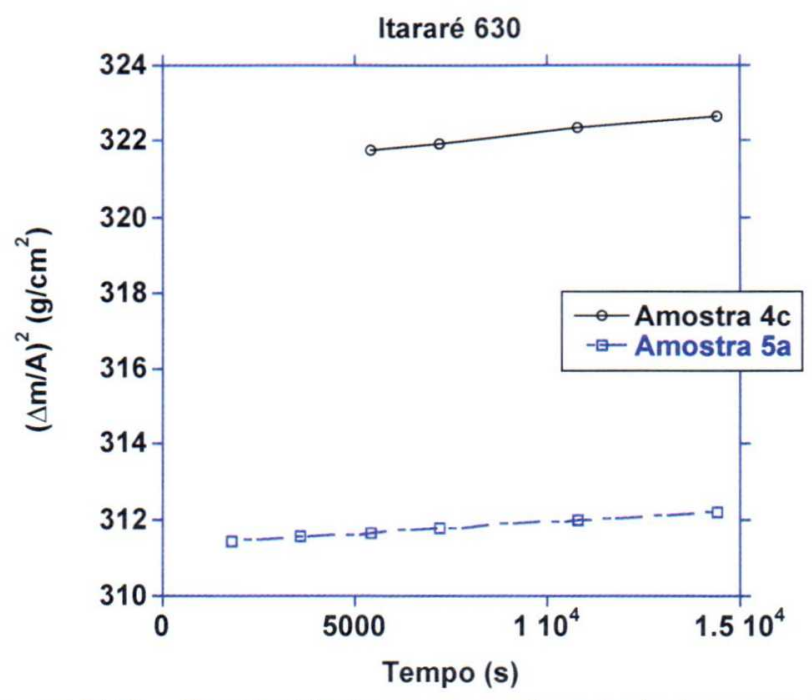

Figura 10.31 - Capilaridade em amostras tratadas com 630 .

\section{$-\mathrm{A} 630$}

Nas amostras em que foi aplicado o $\mathrm{A}$ antes do 630 , a quantidade de água absorvida, foi de $0,0094 \mathrm{~g} / \mathrm{cm}^{2} \cdot \mathrm{s}$. Um pouco a mais do que quando o hidrofugante foi aplicado na superfície sem pré-tratamento. O desvio padrão foi de 0,001. A quantidade de água absorvida, foi calculada à partir da inclinação das retas, retiradas da curva de capilaridade (Figura 10.32).

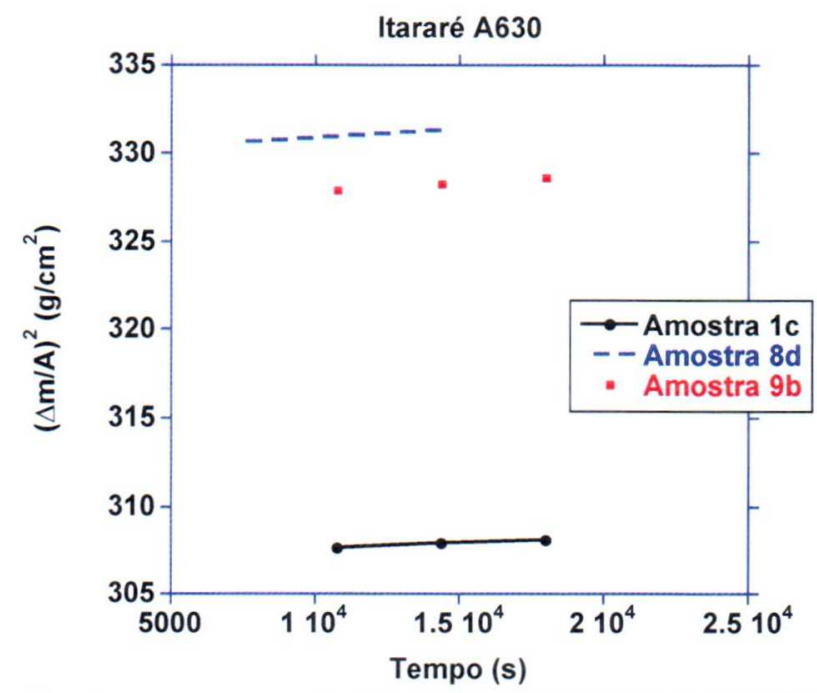

Figura 10.32 - Capilaridade em amostras pré-tratadas A e tratadas com 630.

\section{$-808$}

O teste de capilaridade nas amostras tratadas com 808, apresentou valor médio de $0,0132 \mathrm{~g} / \mathrm{cm}^{2} \cdot \mathrm{s}$ (Figura 10.33) e o desvio padrão de 0,005 . 


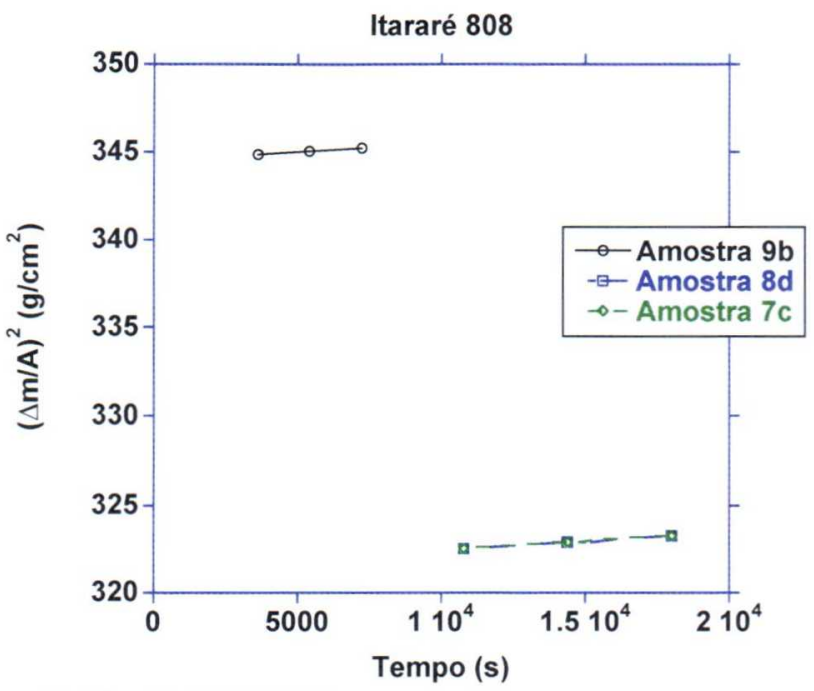

Figura 10.33 - Capilaridade em amostras tratadas com 808 .

\section{- AG}

Nas amostras em que foi aplicado o AG, a quantidade média de água absorvida por capilaridade foi de $0,0089 \mathrm{~g} / \mathrm{cm}^{2} \cdot \mathrm{s}$, que foi o segundo menor resultado; ficando atrás apenas do 630. O desvio padrão foi baixo $(0,001)$, mostrando a homogeneidade dos valores. As retas utilizadas para calcular a capilaridade são mostradas na Figura 10.34.

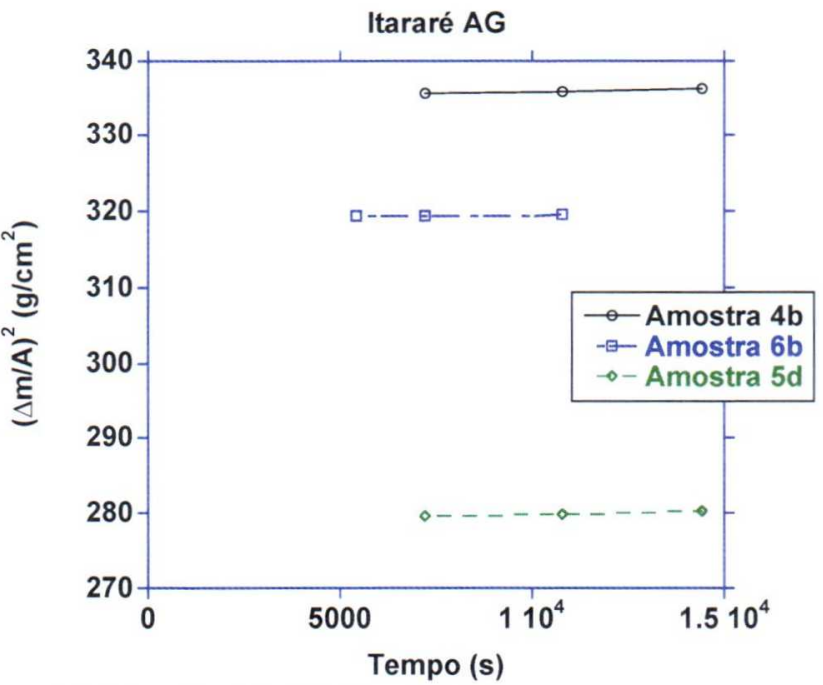

Figura 10.34 - Capilaridade em amostras tratadas com AG.

Todos os resultados encontrados neste teste e as médias ponderadas são encontrados na Tabela 10.3. Vale ressaltar, que os tratamentos estão organizados em ordem crescente de capilaridade média. Observando os valores todos reunidos e organizados em ordem crescente, pode-se dizer que os hidrofugantes e o protetor de superfície (AG), foram os que apresentaram a menor quantidade de água absorvida. 
Vale ressaltar que o TW, além de consolidar, possui ação hidrofugante nos primeiros meses após a aplicação. No caso deste produto, a aplicação do $\mathbf{A}$ antes dele, aumentou seu poder hidrofugante.

Dos produtos que não são hidrofugantes, $\mathrm{O} \mathrm{CaOH}$ e $\circ \mathrm{P}$ foram os que apresentaram melhor comportamento, com valores levemente menores que o da rocha fresca e sem tratamento.

Tabela 10.3 - Resultados do teste de capilaridade.

\begin{tabular}{|c|c|c|}
\hline Tratamento & $\begin{array}{c}\text { Capilaridade } \\
\left(\mathrm{g} / \mathrm{cm}^{2} \cdot \mathrm{s}\right)\end{array}$ & $\begin{array}{c}\text { Média } \\
\left(\mathrm{g} / \mathrm{cm}^{2} \cdot \mathrm{s}\right) \\
\end{array}$ \\
\hline Fresca 1a & 0,0252 & \\
\hline Fresca 1b & 0,0189 & 0,0221 \\
\hline Fresca 1c & 0,0221 & \\
\hline $\begin{array}{l}6304 \mathrm{c} \\
6305 \mathrm{a}\end{array}$ & $\begin{array}{l}0,0099 \\
0,0076\end{array}$ & 0,0088 \\
\hline AG 4b & 0,0090 & \\
\hline AG $6 b$ & 0,0102 & 0,0089 \\
\hline AG 5d & 0,0076 & \\
\hline$A 6301 c$ & 0,0079 & \\
\hline$A 6302 b$ & 0,0098 & 0,0094 \\
\hline $\mathrm{A} 630 \mathrm{3d}$ & 0,0104 & \\
\hline $\begin{array}{l}\text { ATW 1d } \\
\text { ATW 2a } \\
\text { ATW 6d }\end{array}$ & $\begin{array}{l}0,00741 \\
0,00891 \\
0,01803 \\
\end{array}$ & 0,0114 \\
\hline $\begin{array}{l}8087 c \\
8088 d \\
8089 b \\
\end{array}$ & $\begin{array}{l}0,0188 \\
0,0097 \\
0,0110 \\
\end{array}$ & 0,0132 \\
\hline TW 4a & 0,0288 & \\
\hline TW 5b & 0,0167 & 0,0210 \\
\hline TW 6d & 0,0174 & \\
\hline $\mathrm{CaOH} 7 \mathrm{~d}$ & 0,0222 & \\
\hline $\mathrm{CaOH} 8 \mathrm{c}$ & 0,0207 & 0,0212 \\
\hline $\mathrm{CaOH} 9 \mathrm{a}$ & 0,0207 & \\
\hline$P 6 c$ & 0,0207 & \\
\hline P 7a & 0,0202 & 0,0213 \\
\hline P 8a & 0,0230 & \\
\hline AP 1b & 0,0263 & \\
\hline AP 2d & 0,0199 & 0,0268 \\
\hline AP $3 c$ & 0,0342 & \\
\hline $\begin{array}{l}\text { A 1a } \\
\text { A 2c } \\
\text { A 3a }\end{array}$ & $\begin{array}{l}0,0291 \\
0,0177 \\
0,0389\end{array}$ & 0,0286 \\
\hline $\begin{array}{l}\mathrm{PCaOH} 5 \mathrm{c} \\
\mathrm{PCaOH} 7 \mathrm{~b} \\
\mathrm{PCaOH} 8 \mathrm{~b}\end{array}$ & $\begin{array}{l}0,0421 \\
0,0299 \\
0,0228\end{array}$ & 0,0316 \\
\hline
\end{tabular}


10.1.6. Ultrassom

\section{- Universidade de Princeton}

Observando todos os valores encontrados com a utilização do equipamento de ultrassom (Tabela 10.4) e o módulo dinâmico, é possível verificar que os produtos que mais aumentaram a coesão entre os grãos (em ordem decrescente), fato este comprovado pelo aumento de velocidade das ondas ultrassônicas em comparação com a rocha não tratada, foram: A (perpendicular), AP (paralelo), A (paralelo), AP (perpendicular) juntamente com ATC (paralelo), ATC (perpendicular), TC (paralelo), P (paralelo), $\mathbf{P}$ (perpendicular) e, por último, TC (perpendicular).

Para o cálculo do módulo dinâmico, foi utilizado o valor da densidade de cada amostra. O valor médio de densidade encontrado foi de $2119\left(\mathrm{~g} / \mathrm{cm}^{3}\right)$, sendo o desvio padrão de 36 .

\section{- Segundo procedimento de aplicação}

Aplicando AP 2 e ATC 2 em outras amostras, porém com o segundo procedimento, os resultados encontrados, são bem mais altos do que os resultados do primeiro procedimento. Organizando decrescentemente pelo aumento da velocidade das ondas ultrassônicas, tem-se: ATC $2 \mathrm{E}$ (paralelo e com enxágue), AP 2 (perpendicular sem enxágue), ATC 2 (paralelo sem enxágue), ATC 2E (perpendicular com enxágue), e, com resultados praticamente iguais, AP 2 (paralelo sem enxágue), AP 2E (paralelo e perpendicular - ambos com enxágue) e, por fim, ATC 2 (perpendicular sem enxágue).

Na Tabela 10.4, encontram-se, também, todos os resultados de velocidade de ondas ultrassônicas e módulo dinâmico.

O aumento de todas as medidas do segundo procedimento em comparação com o primeiro, mostra que este segundo método gera maior coesão entre os cristais, sendo portanto, mais adequado para esta rocha. $O$ enxague não mostrou uma diferença sistemática nos valores, portanto não interfere no resultado.

\section{- Universidade de São Paulo}

O ensaio de velocidade de ondas ultrassônicas, foi parte integrante dos ensaios de ciclos de saturação e secagem e de alteração acelerada por $\mathrm{SO}_{2}$. Portanto, seus resultados, serão mostrados e discutidos nos tópicos relativos a estes ensaios. 
Tabela 10.4 - Velocidade de ondas ultrassônicas e módulo dinâmico no Arenito Itararé e direção dos transdutores em relação ao acamamento.

\begin{tabular}{|c|c|c|c|c|c|c|}
\hline Tratamento & $\begin{array}{l}\text { Direção dos } \\
\text { transdutores }\end{array}$ & $\begin{array}{l}\text { Densidade } \\
\left(\mathrm{g} / \mathrm{cm}^{3}\right)\end{array}$ & $\begin{array}{c}\text { Velocidade } \\
\text { fresca } \\
(\mathrm{km} / \mathrm{s})\end{array}$ & $\begin{array}{c}\text { Velocidade } \\
\text { tratada } \\
(\mathrm{km} / \mathrm{s})\end{array}$ & $\begin{array}{l}E_{\text {dyn }} \\
\text { fresca } \\
\text { (Gpa) }\end{array}$ & $\begin{array}{c}E_{\text {dyn }} \\
\text { tratada } \\
\text { (Gpa) }\end{array}$ \\
\hline \multirow{2}{*}{ Fresco } & Perpendicular & 2104 & $2,6^{*}$ & - & $14,2^{*}$ & - \\
\hline & Paralelo & 2125 & $2,5^{*}$ & - & $11,8^{*}$ & - \\
\hline \multirow{2}{*}{ A } & Perpendicular & $2129^{*}$ & $2,6^{*}$ & $3,8^{*}$ & $13,9^{*}$ & 30,2 \\
\hline & Paralelo & $2047^{*}$ & $2,6^{*}$ & $3,7^{*}$ & $14,0^{*}$ & 27,5 \\
\hline \multirow{2}{*}{$\mathbf{P}$} & Perpendicular & 2138 & 2,4 & 2,9 & 12,7 & 17,7 \\
\hline & Paralelo & 2099 & 2,4 & 3,1 & 12,2 & 20,7 \\
\hline \multirow{2}{*}{ AP } & Perpendicular & 2108 & 2,6 & 3,6 & 14,1 & 27,2 \\
\hline & Paralelo & 2071 & 2,2 & 3,2 & 10,3 & 21,2 \\
\hline \multirow{2}{*}{ TC } & Perpendicular & 2089 & 2,6 & 3,1 & 13,8 & 20,6 \\
\hline & Paralelo & 2015 & 2,6 & 3,5 & 13,7 & 24,5 \\
\hline \multirow[b]{2}{*}{ ATC } & Perpendicular & 2120 & 2,7 & 3,7 & 15,0 & 28,7 \\
\hline & Paralelo & 2143 & 2,6 & 3,6 & 14,8 & 27,9 \\
\hline \multirow{4}{*}{ AP 2} & Perpendicular & 2058 & 2,2 & 3,8 & 9,6 & 31,4 \\
\hline & Perpendicular & 2086 & 2,2 & 3,7 & 9,8 & 28,8 \\
\hline & Paralelo & 2036 & 2,1 & 3,6 & 8,9 & 25,2 \\
\hline & Paralelo & 1973 & 2,7 & 4,1 & 14,5 & 33,0 \\
\hline \multirow{4}{*}{ AP $2 E^{\star *}$} & Perpendicular & 2090 & 2,3 & 3,9 & 11,1 & 30,2 \\
\hline & Perpendicular & 2078 & 2,4 & 3,7 & 11,6 & 28,9 \\
\hline & Paralelo & 2066 & 2,0 & 3,5 & 7,9 & 26,1 \\
\hline & Paralelo & 2127 & 2,7 & 4,0 & 15,2 & 33,8 \\
\hline \multirow{4}{*}{ ATC 2} & Perpendicular & 2118 & 2,5 & 3,9 & 13,5 & 32,5 \\
\hline & Perpendicular & 2265 & 2,3 & 3,8 & 11,7 & 32,8 \\
\hline & Paralelo & 2067 & 2,1 & 3,8 & 9,1 & 29,0 \\
\hline & Paralelo & 2109 & 2,7 & 4,2 & 15,4 & 36,7 \\
\hline \multirow{4}{*}{ ATC $2 E^{* *}$} & Perpendicular & 2183 & 2,5 & 4,0 & 13,5 & 34,2 \\
\hline & Perpendicular & 2086 & 2,3 & 3,9 & 10,8 & 31,0 \\
\hline & Paralelo & 2143 & 2,1 & 3,7 & 9,2 & 29,8 \\
\hline & Paralelo & 2061 & 1,8 & 3,2 & 6,9 & 20,8 \\
\hline
\end{tabular}

${ }^{*}$ média

** pré-tratado com $\mathbf{A}$, imerso em água para evitar o possível excesso de $\mathbf{A}$ e tratado com consolidante.

$E=$ com enxágue. 


\subsubsection{Tubo de Karsten}

Pode-se verificar, observando a Figura 10.35, que os tratamentos A, A2, A23 e $\mathrm{CaOH}$ aumentaram a quantidade de água absorvida, quando comparados à amostra fresca. A linha preta mais grossa (fresca), foi destacada intencionalmente, para dividir o gráfico e facilitar a visualização dos tratamentos que absorvem mais e menos água do que a rocha fresca.

Todos os outros produtos mostraram redução na quantidade de água absorvida. Os que diminuíram menos este parâmetro foram $\mathrm{PCaOH}$ e AP.

A aplicação de A, nos três casos (A2, A23 e A236), aumentou a absorção de água, assim como a aplicação do $\mathbf{C a O H}$. No caso do $\mathrm{A2}$ e A23, a absorção total da água observável do cachimbo, ocorreu antes dos 60 minutos. De modo geral, é possivel observar que a aplicação do $\mathbf{A}$ antes dos consolidantes não melhorou sua performance em relação à absorção de água. $\mathrm{O}$ aumento da absorção de $\mathrm{A}$ favorece $a$ maior penetração dos consolidantes. No caso do $\mathbf{P}$, a aplicação dos $\mathbf{A}$ antes do produto, aumentou levemente a quantidade de água absorvida. Após a aplicação dos produtos $\mathrm{P}, \mathrm{TW}, \mathrm{ATW}, \mathbf{8 0 8}$, A808 e $\mathbf{6 3 0}$, a amostra praticamente não absorveu água.

\section{Absorção de água vs tempo}

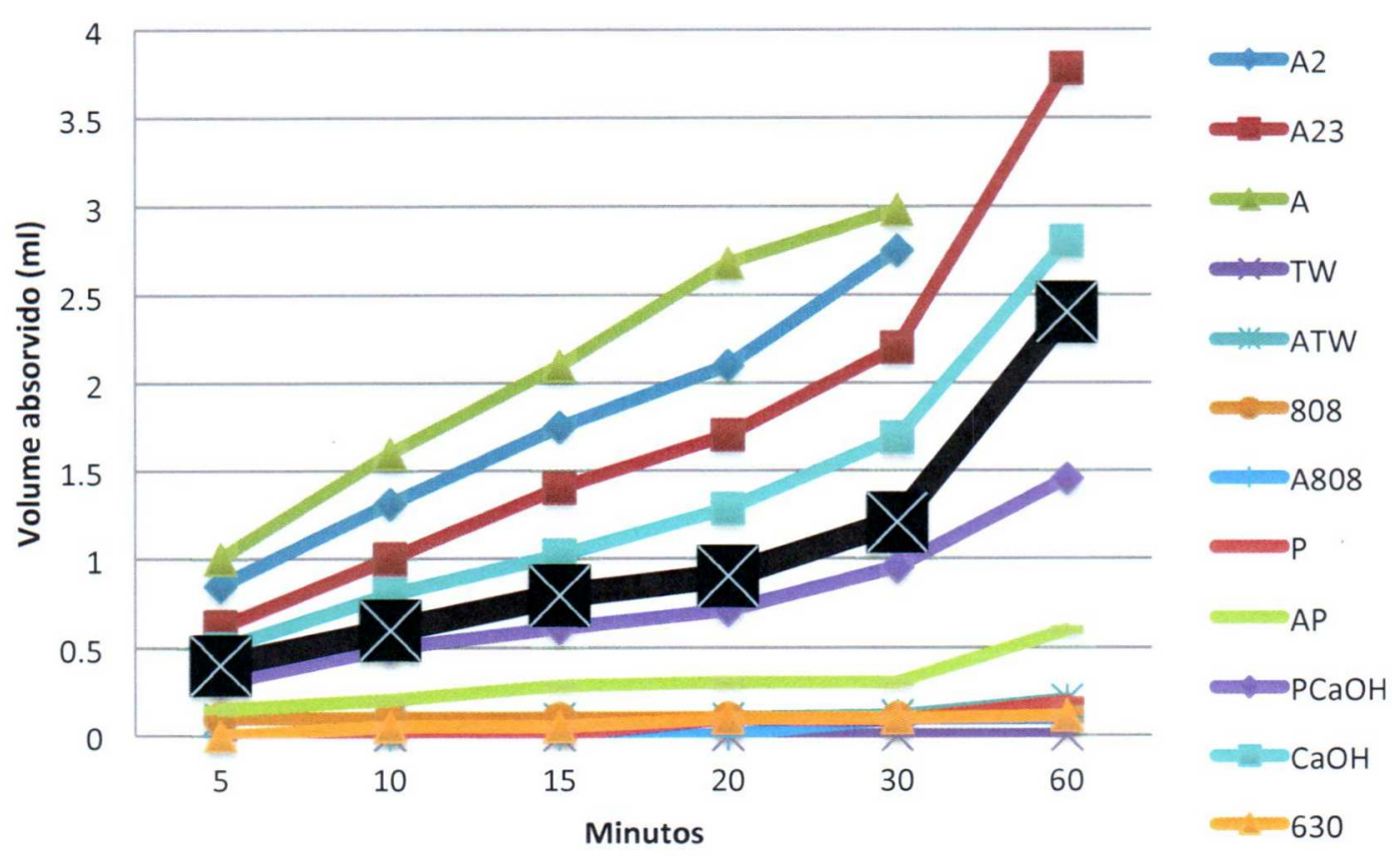

Figura 10.35 - Resultados do teste com o tubo de Karsten em amostras tratadas e fresca. 


\subsubsection{Teste de expansibilidade}

Os resultados do teste de expansibilidade não foram satisfatórios. A mesma amostra foi testada diversas vezes e o resultado foi diferente a cada teste. Em alguns casos, os resultados variaram de positivos a negativos. Inclusive, uma amostra de quartzo foi testada duas vezes para verificar se havia algum problema com a máquina e este teste também mostrou-se inconsistente. Portanto, os resultados deste teste não foram incluídos nas análises. No entanto, todos os resultados encontrados estão no Anexo II.

No Brasil, buscou-se algum equipamento disponível para que o teste fosse realizado. Tentou-se adaptar a técnica de expansibilidade de solos e utilizar a máquina de adensamento, disponível no Laboratório de Solos da Faculdade de Engenharia Civil. No entanto, nenhuma expansão foi observada.

\subsubsection{Microscopia Eletrônica de Varredura (MEV)}

\section{- Amostra fresca}

A amostra fresca foi avaliada no MEV para verificar quais são as feições originais dos poros e grãos. Foi realizado EDS para fazer o mapeamento geral da amostra (Figura 10.36). Os elementos químicos encontrados foram ferro, titânio, potássio, silício, alumínio, magnésio, sódio e oxigênio (Figura 10.37). Por meio das imagens de MEV foi possível verificar o diâmetro dos poros (Figura 10.38). O EDS foi utilizado também para caracterizar os argilominerais do grupo da esmectita (Figuras 10.39 e 10.40) e identificar minerais não visualizados em lâmina petrográfica, por exemplo, calcopirita, rutilo e ilmenita.

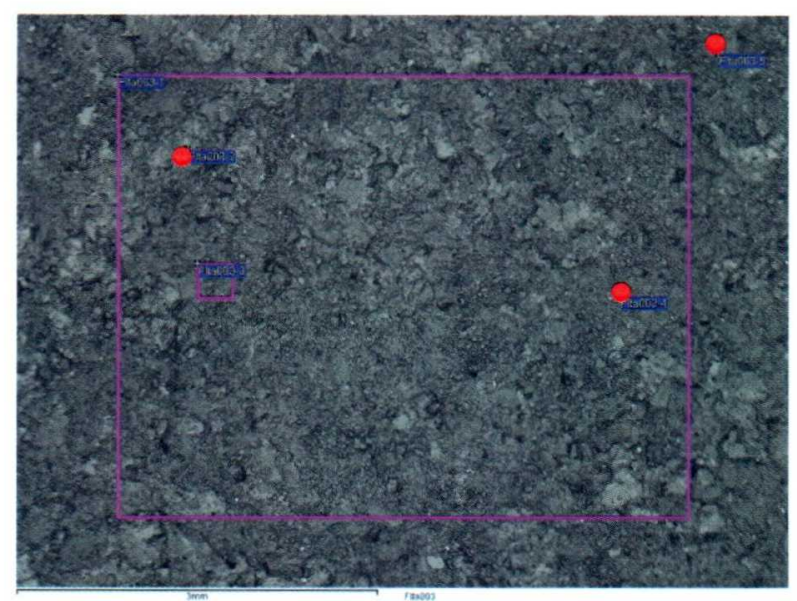

Figura 10.36 - Localização de área e pontos de EDS. 


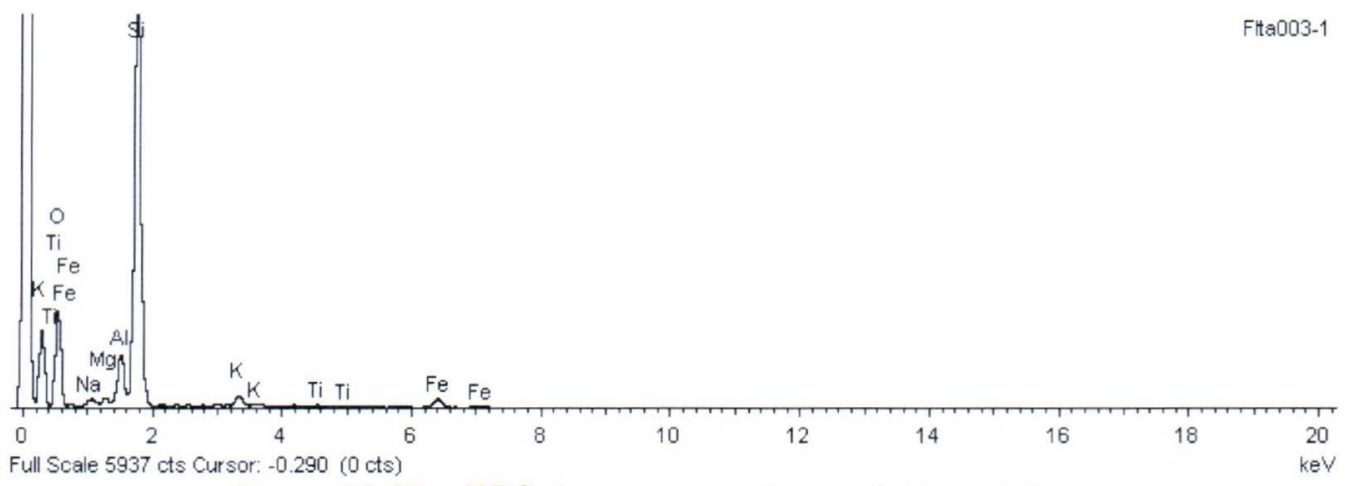

Figura 10.37 - EDS do mapeamento geral da amostra.

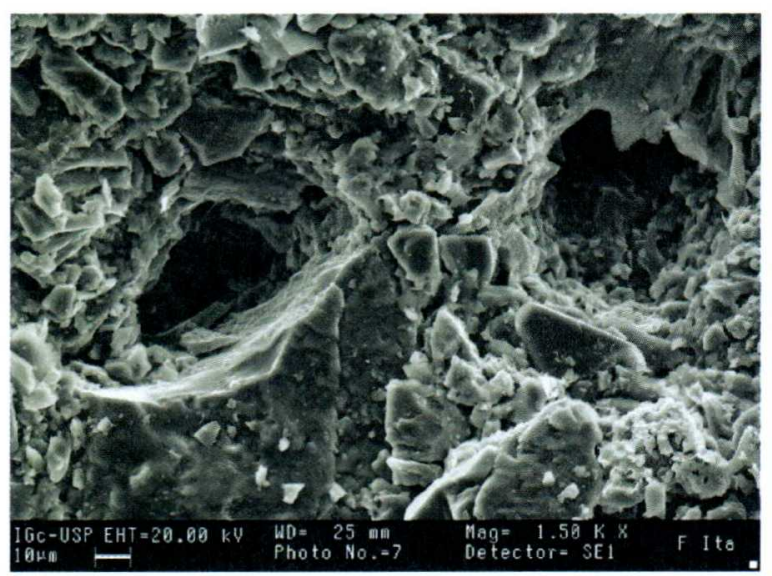

Figura 10.38 - Poros com diâmetro entre 20 e $30 \mu \mathrm{m}$.

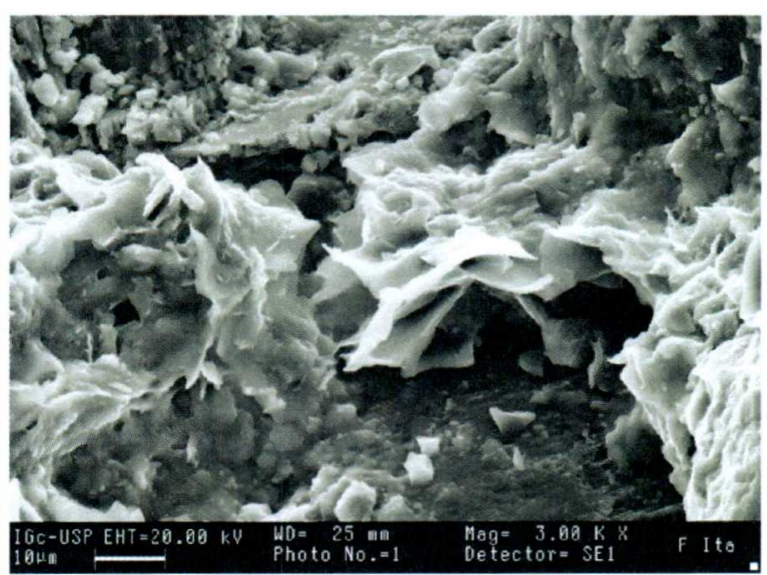

Figura 10.39 - Esmectitas.

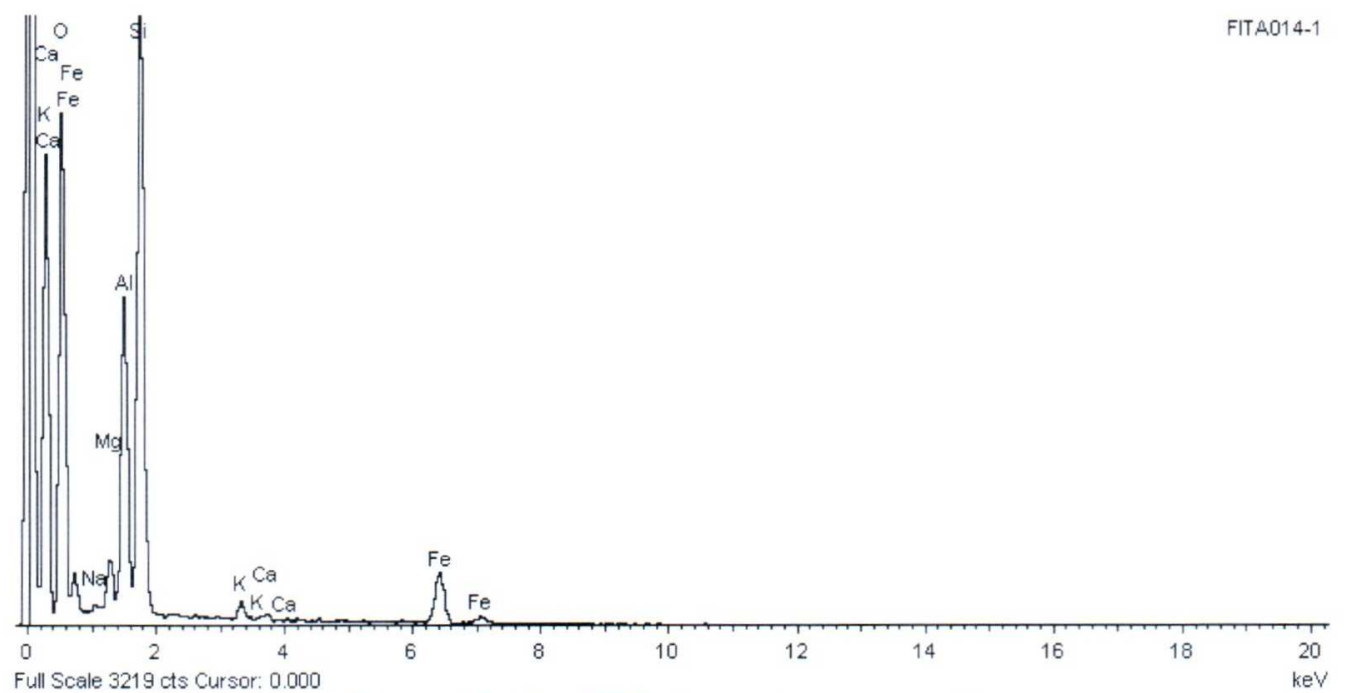

Figura 10.40 - EDS das argilas esmectíticas.

- A

Quando observada ao MEV, a amostra de Arenito Itararé tratada com A (A2 $\rightarrow$ A3 $\rightarrow$ A6), apresentou a formação de estruturas em forma de flor e estruturas esferoidais (Figuras 10.41 e 10.42). Foi realizado o mapeamento qualitativo para obter a composição das estruturas em forma de flor, onde foi verificado que são formadas 
por carbono (Figura 10.43). O mapeamento das estruturas esferoidais mostra que são formadas por cálcio (Figuras 10.44 e 10.45). A Figura 10.46 mostra as estruturas esferoidais em maior aumento. No entanto, o cálcio não é um dos elementos químicos da composição indicada pelo fabricante dos produtos.

Para verificar a proveniência do cálcio, foi realizada análise de fluorescência de raios X (FRX) nos produtos aplicados. Foi encontrado cálcio no A2 e no A6. Portanto, ele é proveniente dos produtos utilizados

Vale ressaltar, que o hidrogênio e o nitrogênio, também constituintes de $A$ $\left(\mathrm{NH}_{2}\left(\mathrm{CH}_{2}\right) \mathrm{nNH}_{2}\right)$, não são detectados pelo $\mathrm{MEV}$.

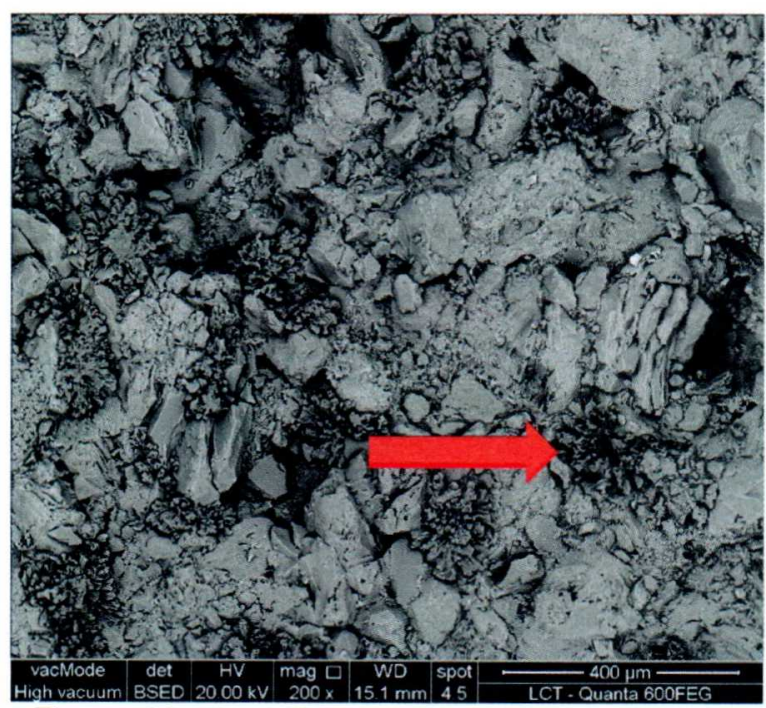

Figura 10.41 - Vista geral da amostra tratada com A (detalhe para as estruturas formadas em forma de flor) - MEV Poli.

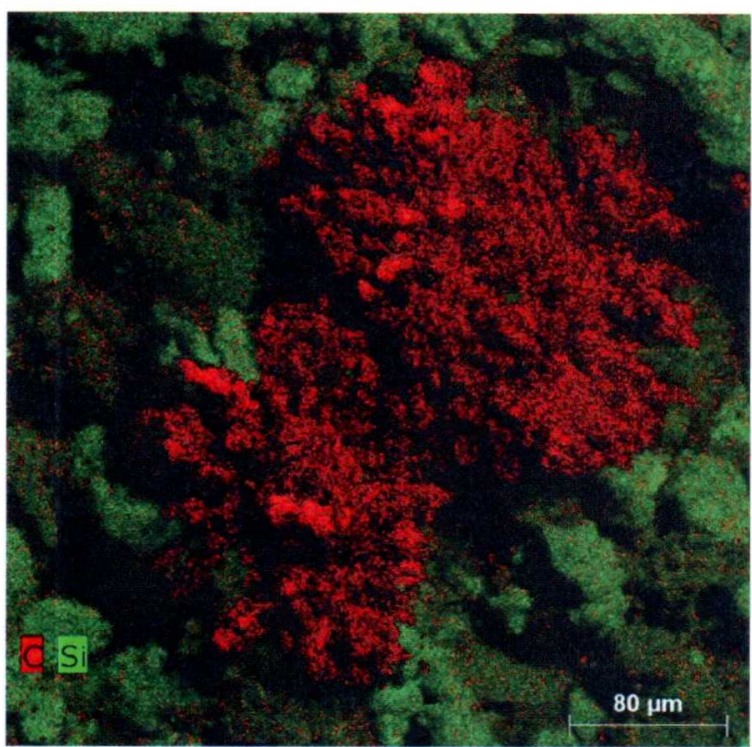

Figura 10.43 - Estruturas em forma de flor compostas por carbono - MEV Poli

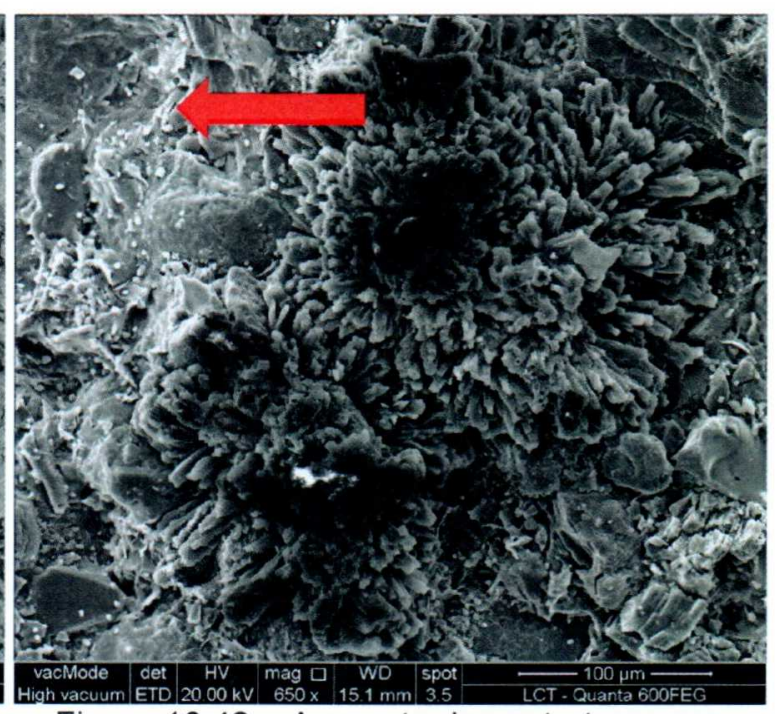

Figura 10.42 - Aumento das estruturas em forma de flor. Detalhe para as estruturas esferoidas sobre os minerais - MEV Poli.

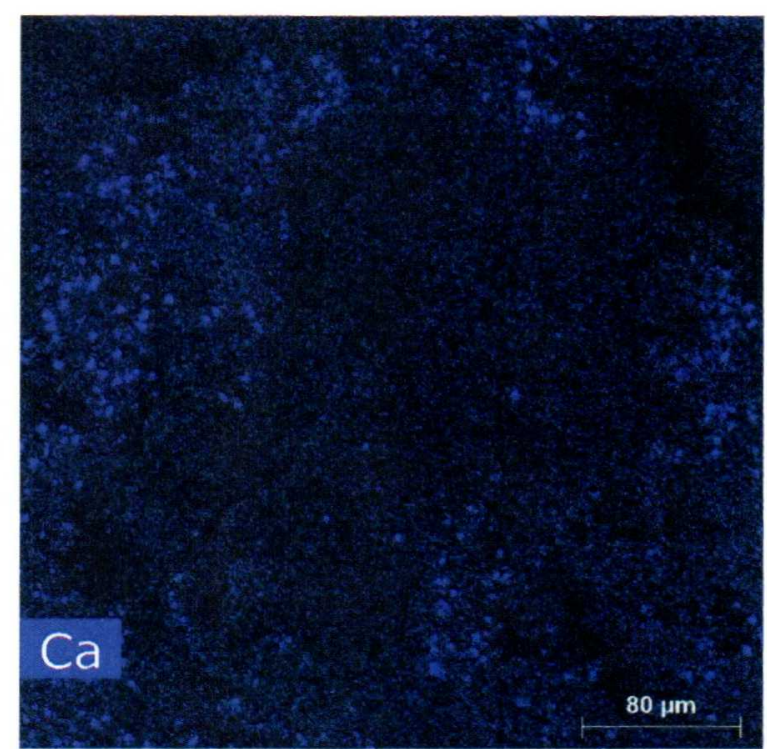

Figura 10.44 - Estruturas esferoidais compostas por cálcio - MEV Poli. 


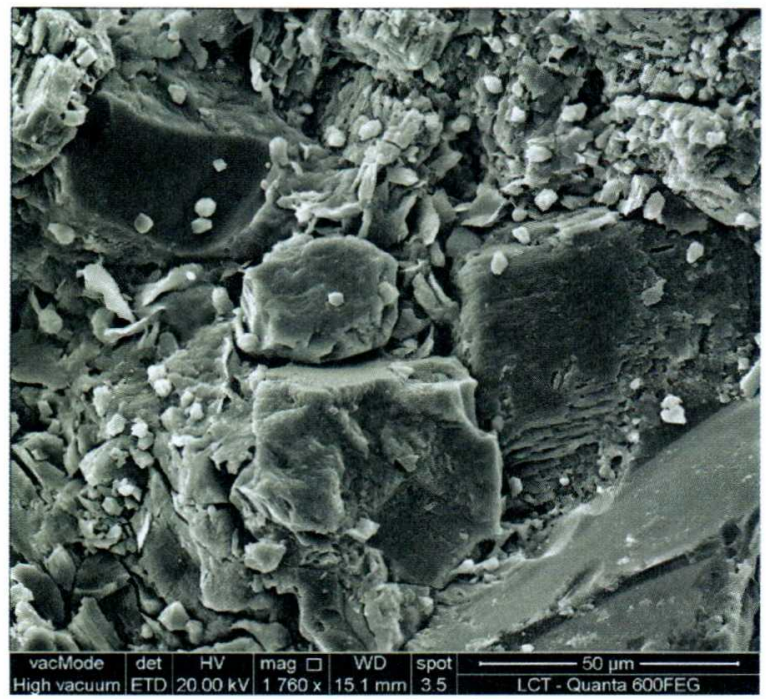

Figura 10.45 - Detalhe das estruturas esferoidais - MEV Poli.

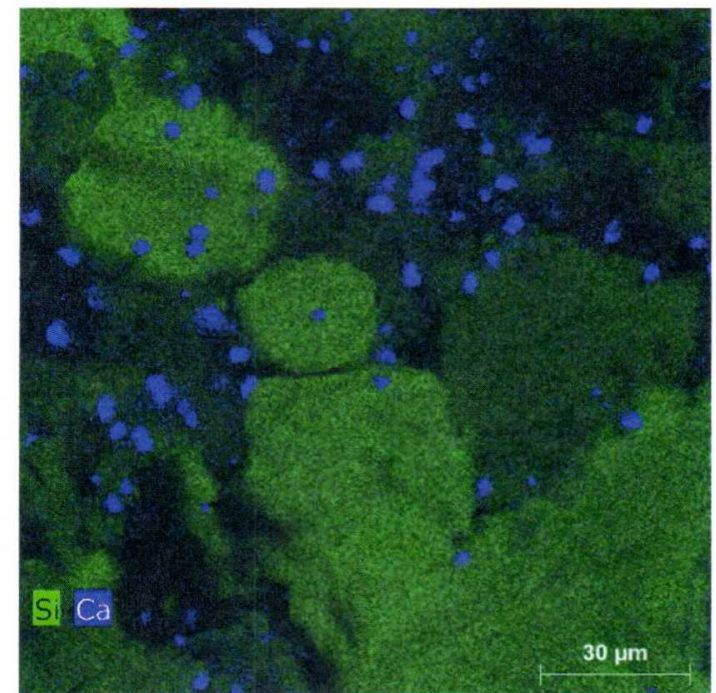

Figura 10.46 - Mapeamento das estrutras esferoidais formadas por cálcio - MEV Poli.

$-P$

Inicialmente, foi realizado EDS, para um mapeamento geral da amostra (Figura 10.47). Por meio deste teste, verificou-se a presença de todos os elementos citados para a rocha fresca e mais o fósforo (Figura 10.48). O fósforo encontrado é proveniente do produto utilizado. Mas, não há a presença de cálcio, que seria o desejado para a formação de hidroxiapatita. Portanto, houve a deposição do produto sem a formação de hidroxiapatita.

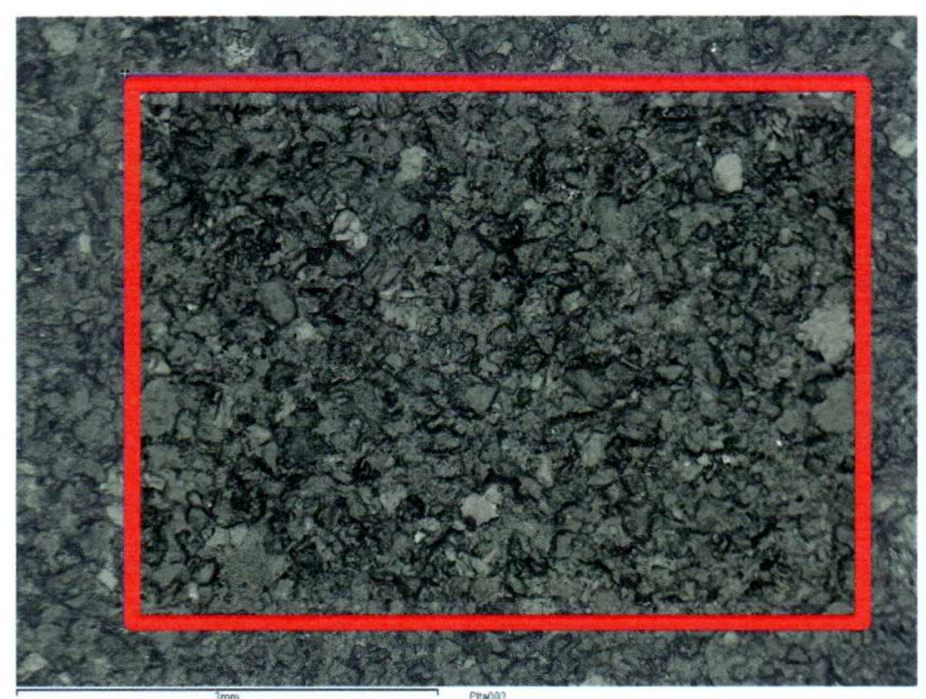

Figura 10.47 - Área de mapeamento por EDS. 


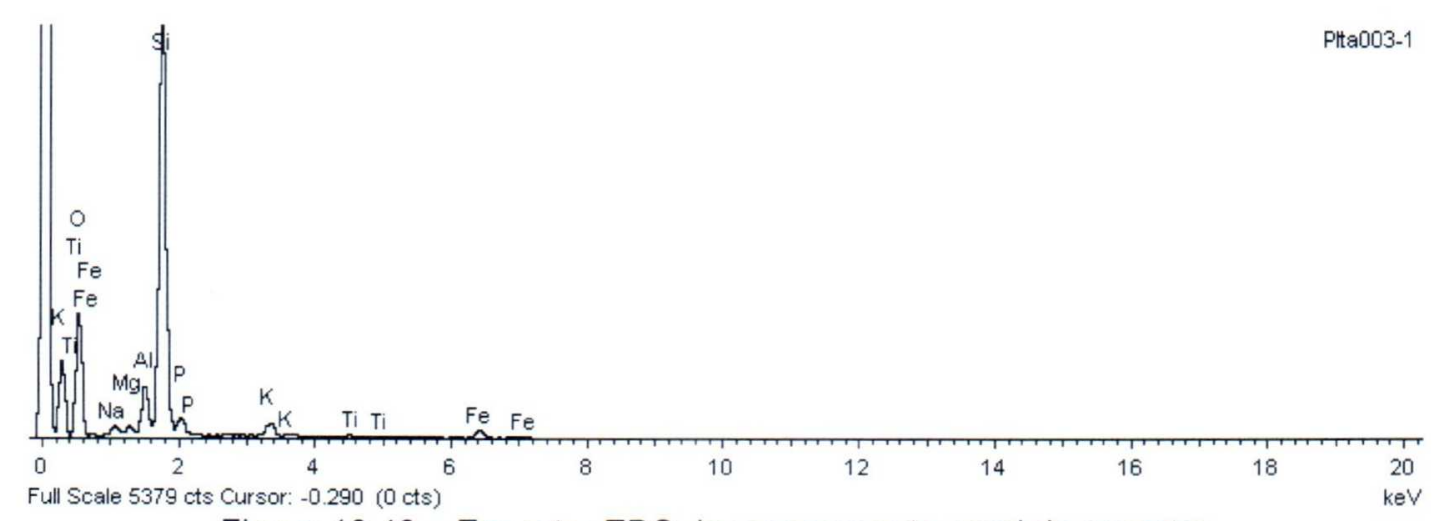

Figura 10.48 - Espectro EDS do mapeamento geral da amostra.

Foi realizado EDS nas esmectitas (Figura 10.49) para verificar se o produto estava presente nestes minerais. Verificou-se no EDS que há a presença de fósforo nestes minerais (Figura 10.50).

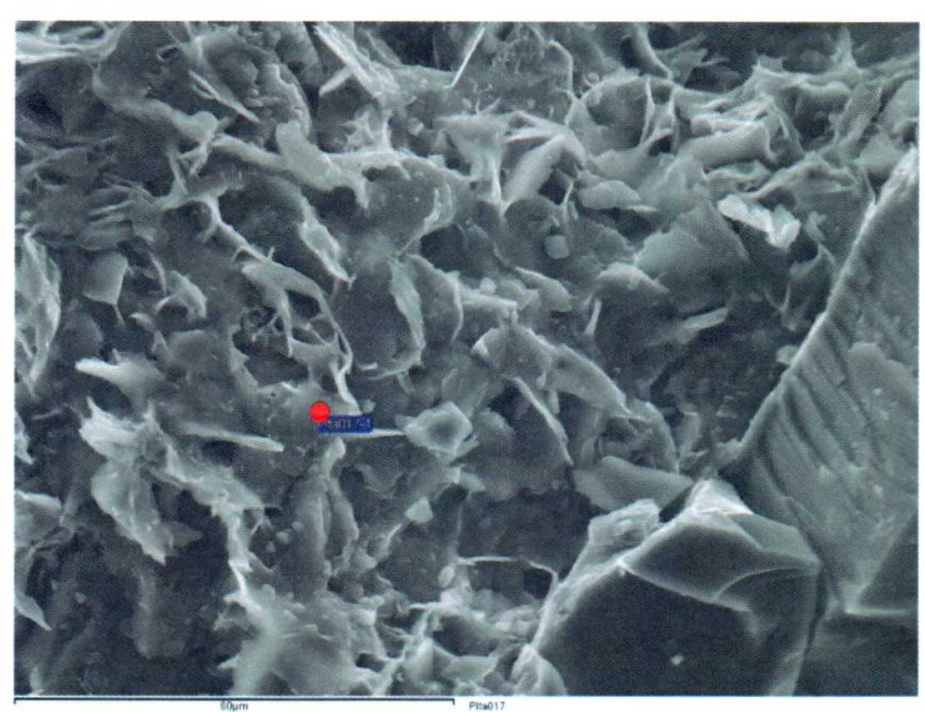

Figura 10.49 - Esmectitas com indicação do ponto de EDS (marcado em vermelho).

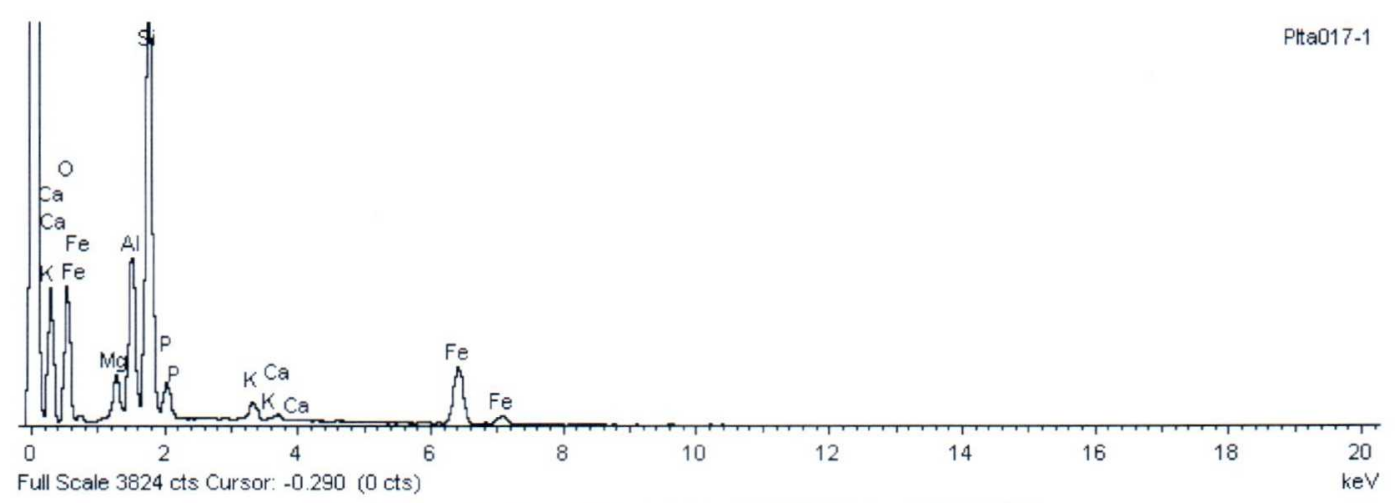

Figura 10.50 - Espectro de EDS na esmectita.

A Figura 10.51 mostra que o produto formado aderiu aos grãos deste agregado, formando ligações entre eles. Foram realizados seis pontos de EDS neste 
agregado e todos apresentaram o mesmo espectro, com pequenas variações na quantidade dos elementos (Figura 10.52).

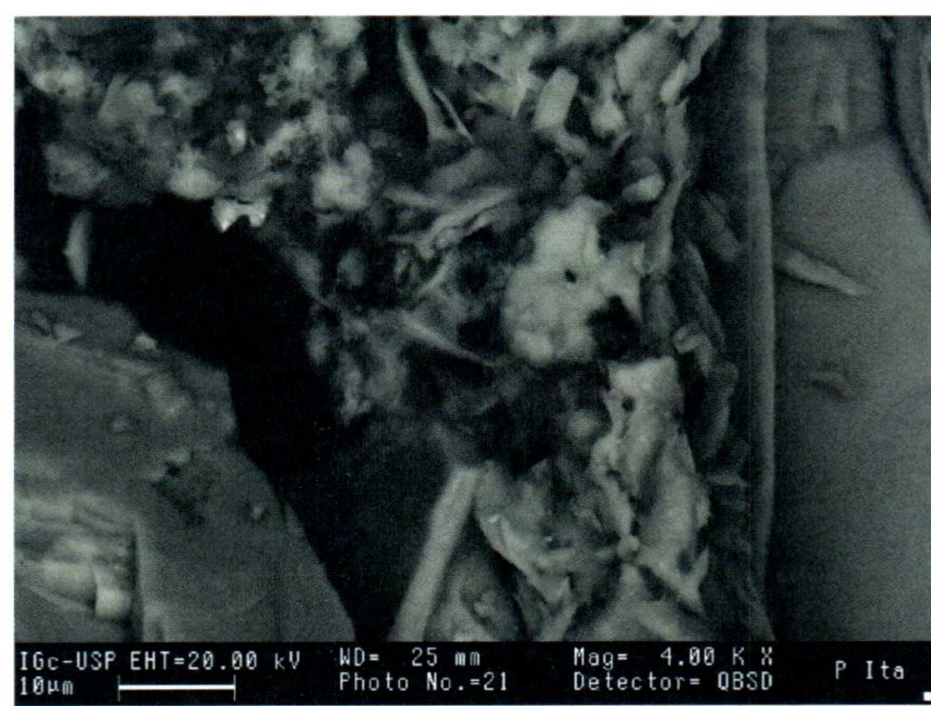

Figura 10.51 - Imagem de elétrons retroespalhados: agregado de minerais consolidados por $P$.

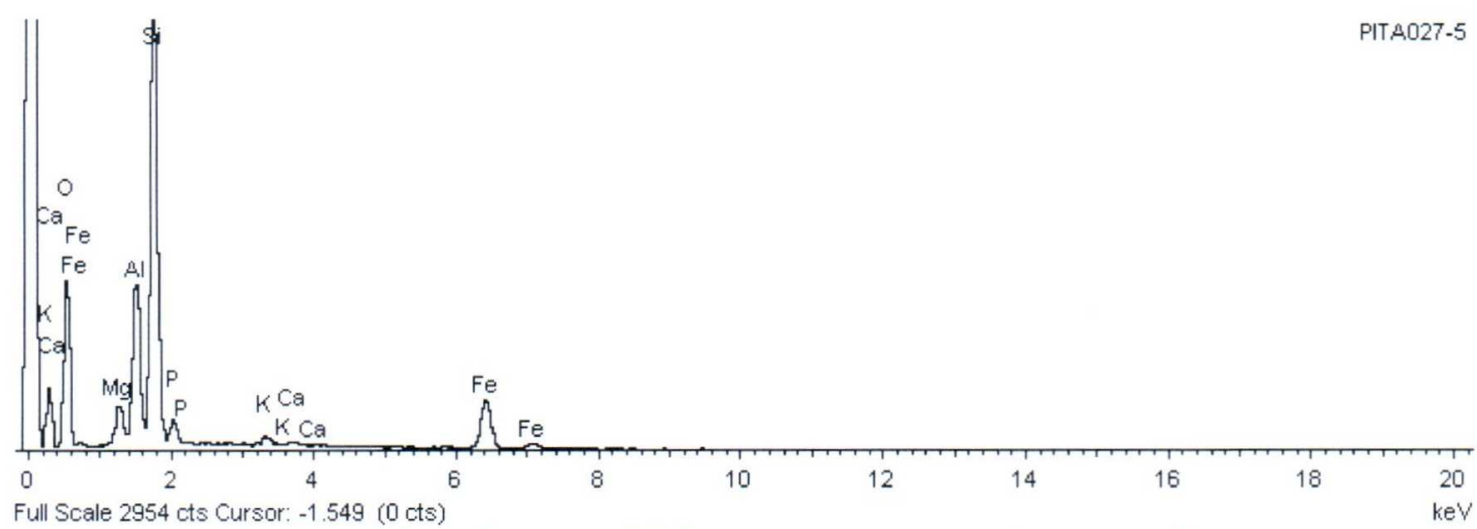

Figura 10.52 - Espectro EDS em agregado consolidado por P

Foi encontrada uma camada irregular cobrindo os grãos (Figura 10.53). No EDS, verificou-se a presença de fósforo, magnésio e manganês, provavelmente formando fosfato de magnésio sobre os minerais (Figura 10.54). 


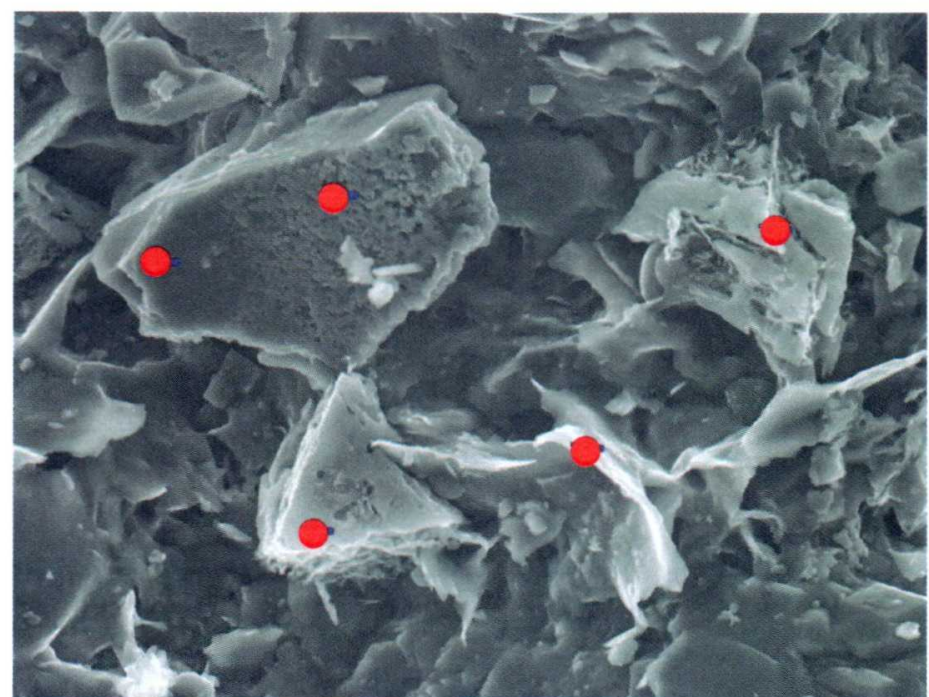

Figura 10.53 - Camada irregular cobrindo os grãos - pontos de EDS em vermelho.

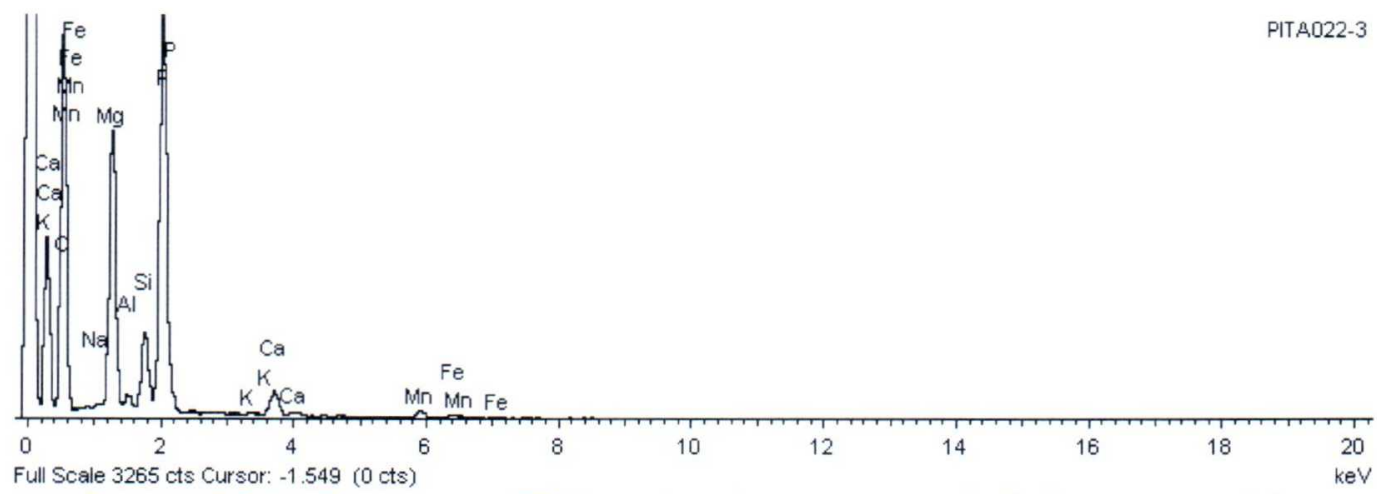

Figura 10.54 - Espectro de EDS mostrando a presença de fósforo e magnésio.

Foi realizado o EDS em áreas com minerais menores, com feições subeuhedrais (Figura 10.55), que confirmaram a presença de fosfato de magnésio (Figura 10.56).

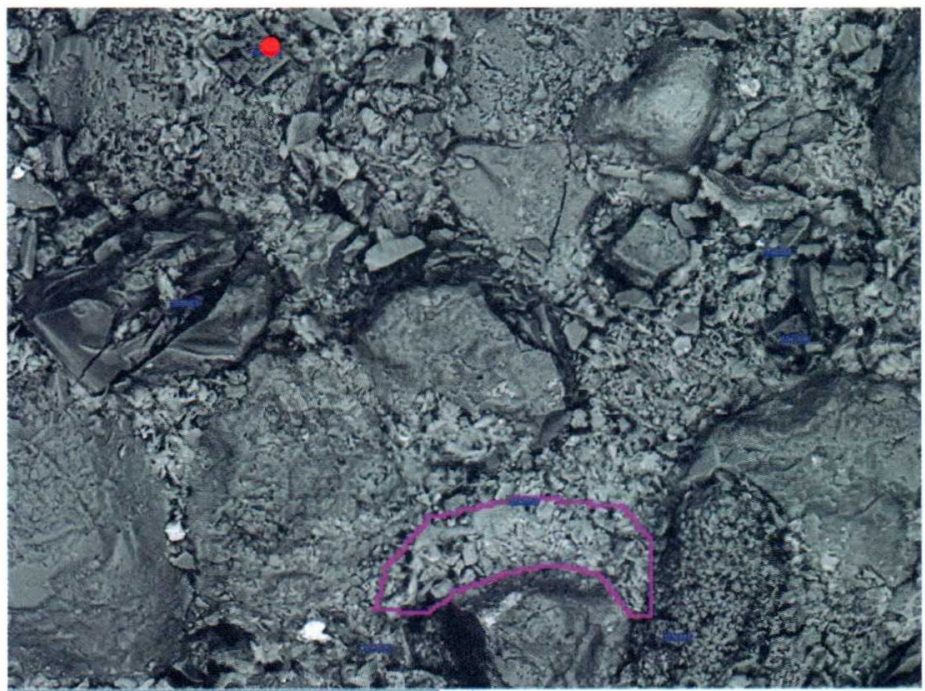

Figura 10.55 - Fosfato de magnésio (ponto vermelho) marcado no local de espectro de EDS. 


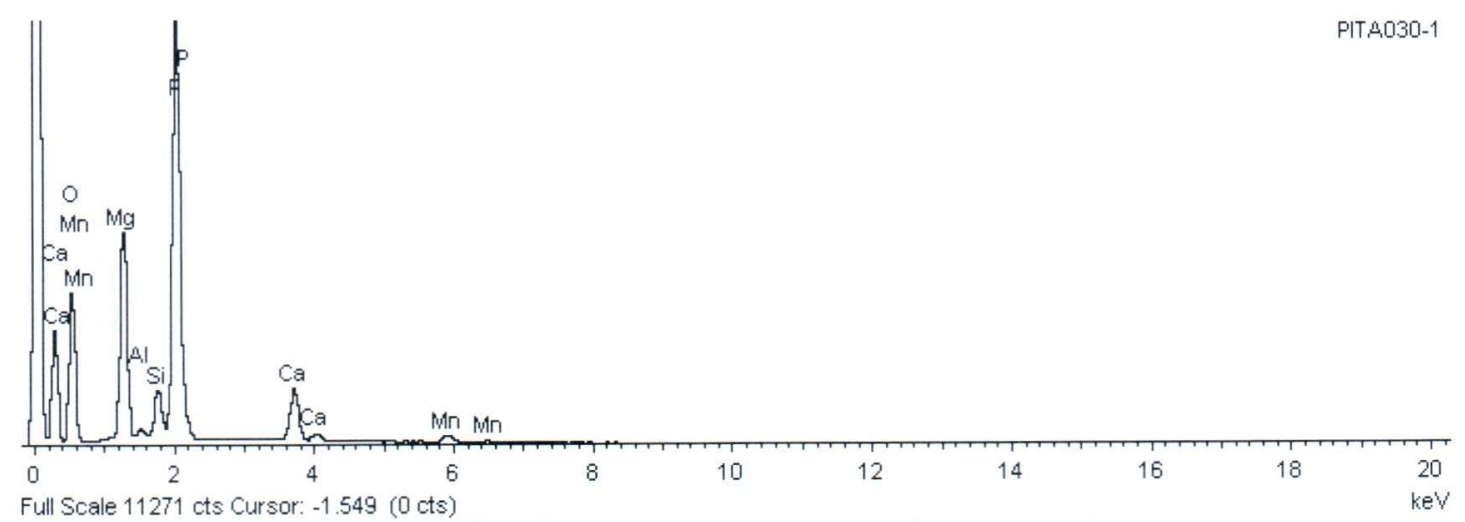

Figura 10.56 - Espectro de EDS do fosfato de magnésio.

A presença de $\mathbf{P}$ foi confirmada por mapeamento (Figura 10.57 e 10.58). Este elemento está concentrado nas regiões mais profundas da amostra.

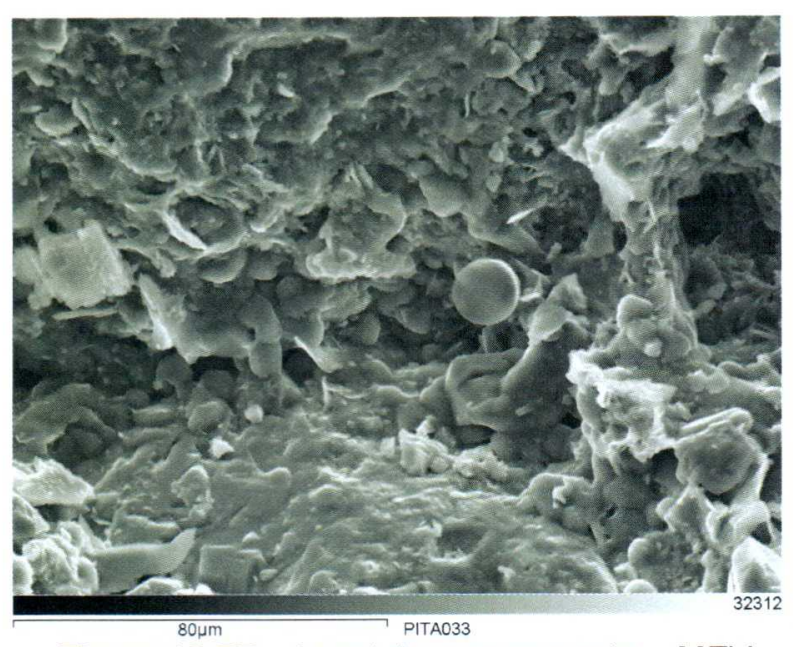

Figura 10.57 - Local de mapeamento - MEV Poli.

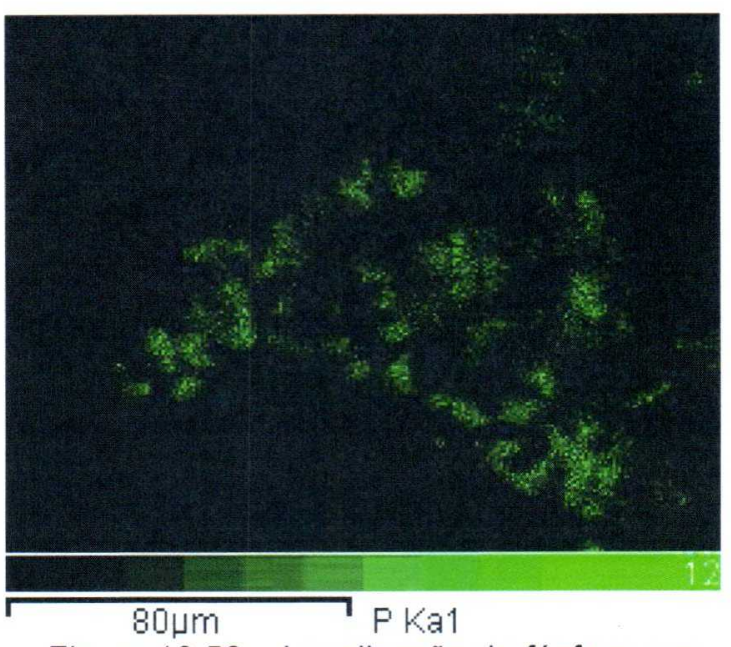

Figura 10.58 - Localização do fósforo, em verde - MEV Poli.

\section{- AP}

Nas amostras tratadas com AP, observou-se as estruturas esferoidais características do A, que são formadas por cálcio (Figura 10.59). O P formou uma camada de aspecto alveolar na superfície dos grãos (Figura 10.60). Foram realizados cinco pontos de EDS, onde a composição foi bem semelhante, com pequenas alterações de quantidade e de elementos químicos. Neste último caso, a alteração ocorria quando o mineral, sobre o qual o produto se depositou, era diferente do anterior. O espectro de EDS com a composição superficial da rocha tratada é mostrado na Figura 10.61. 


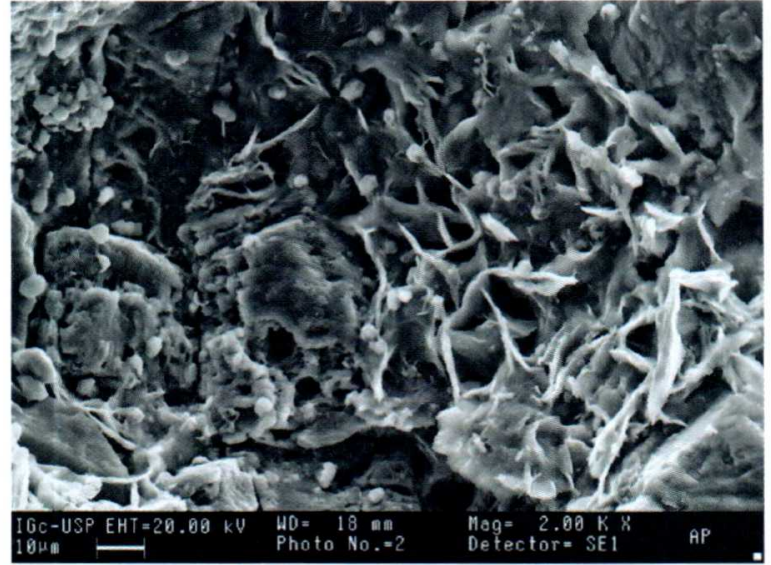

Figura 10.59 - Estruturas esferoidais provenientes do A.

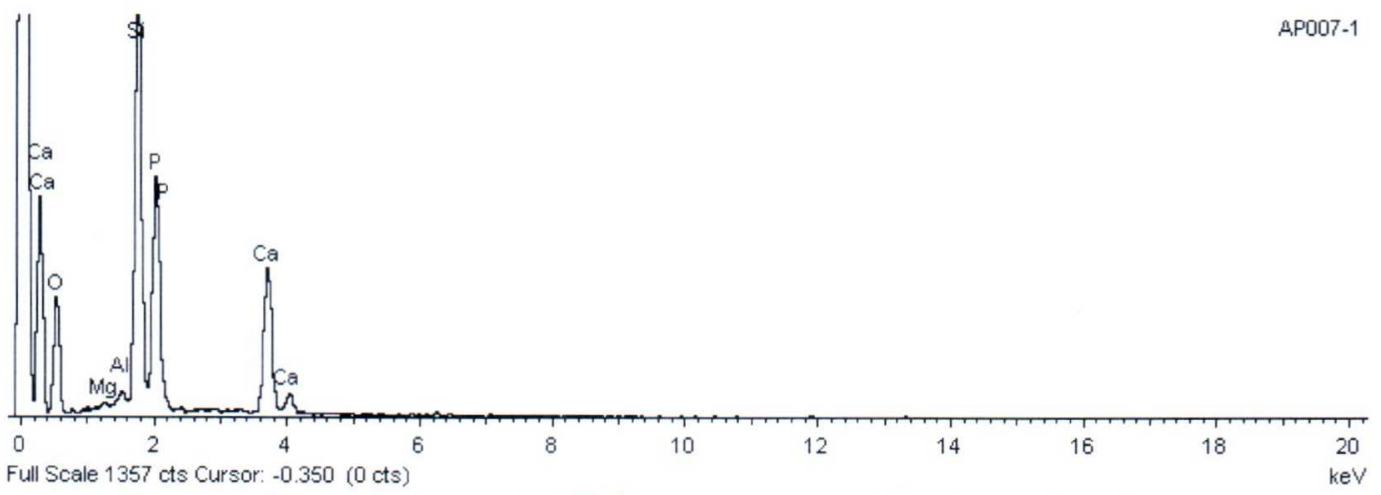

Figuras 10.61 - Espectro de EDS com a composição do produto formado.

\section{- $\mathrm{PCaOH}$}

Quando o P foi misturado com $\mathrm{CaOH}$ (solução) antes de ser aplicado nas amostras, o resultado observado, após o produto secar, foi a formação de estruturas esferoidais fosfatadas (Figuras 10.62 e 10.63).

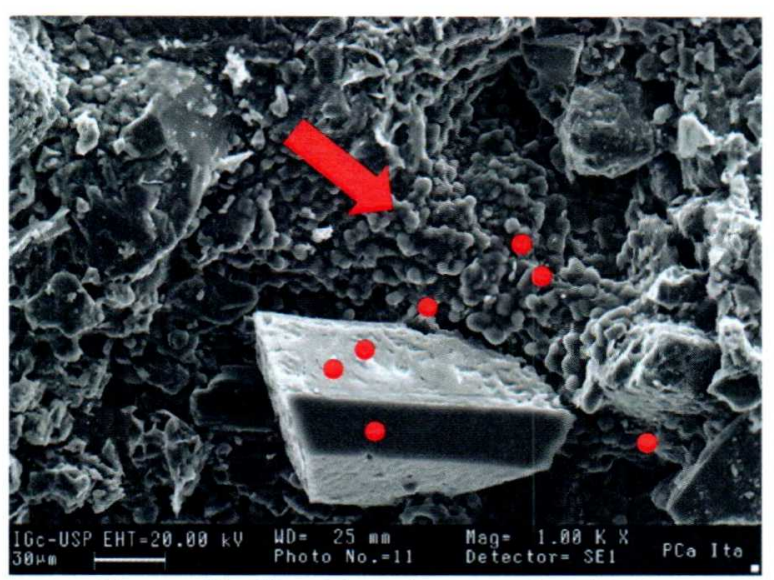

Figura 10.62 - Estruturas esferoidais deposição do consolidante - pontos EDS marcados em vermelho.

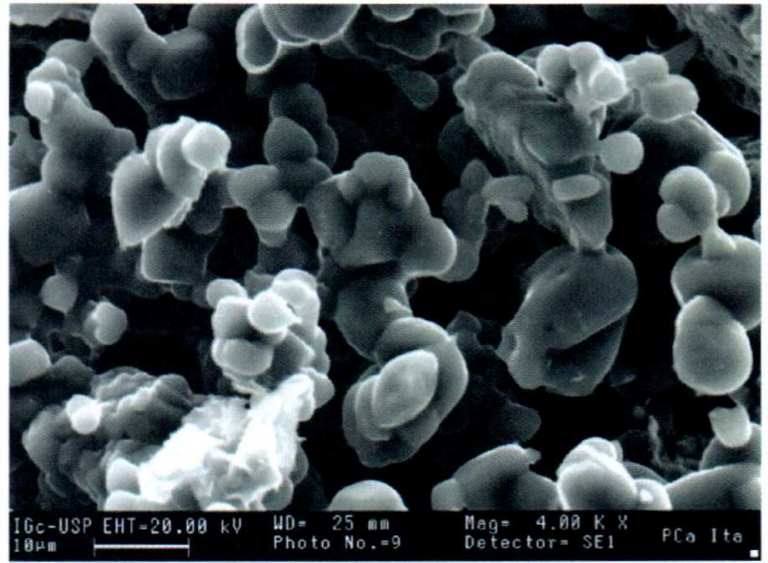

Figura 10.63 - Detalhe das estruturas formadas pelo consolidante. 
Quando foi realizado o mapeamento por elemento químico (Figura 10.64), verificou-se que as estruturas esferoidais são ricas em fósforo (Figura 10.65), comprovando que são formadas pela deposição do consolidante.

Nos seis pontos de EDS realizados (Figura 10.64), a grande maioria não apresentou cálcio e quatro deles apresentaram pequenas quantidades de estrôncio (Figura 10.66) e manganês (Figura 10.67).

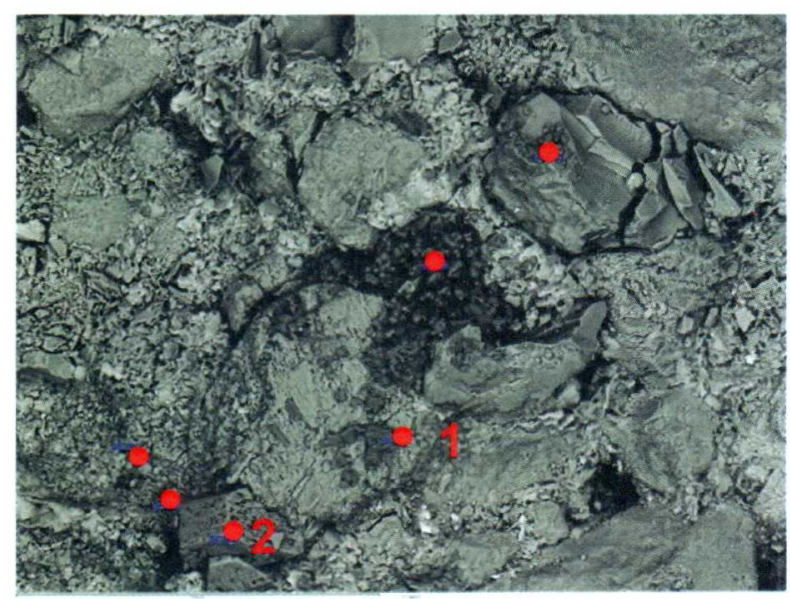

Figura 10.64 - Localização dos EDSs, pontos em vermelho - MEV Poli.

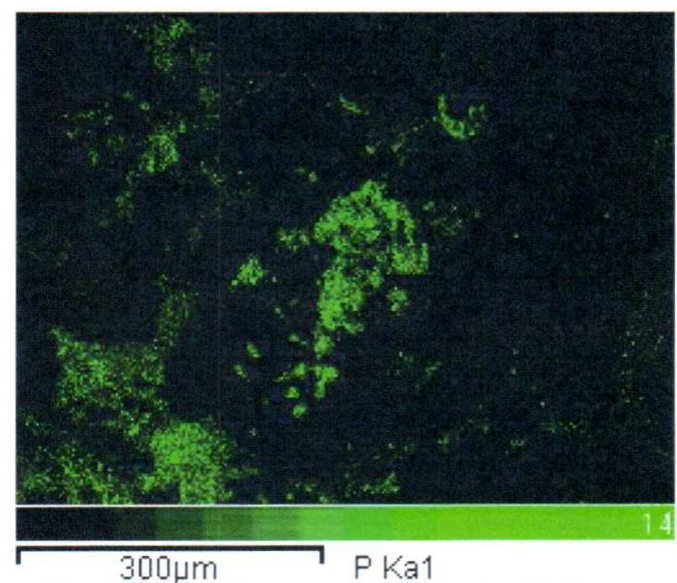

Figura 10.65 - Localização do fósforo MEV Poli.

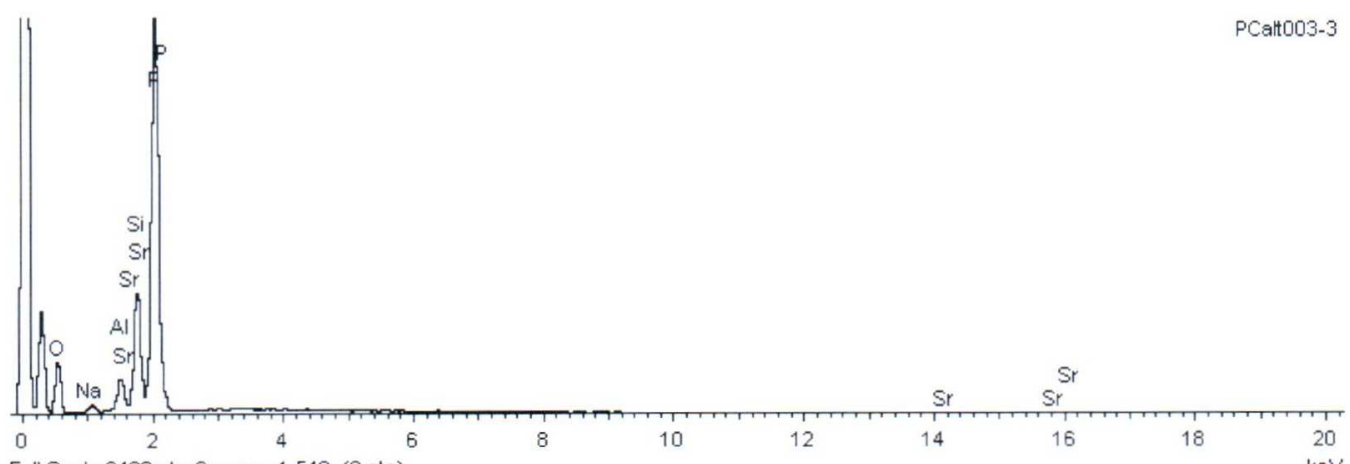

Full Scale $8493 \mathrm{cts}$ Cursor: -1.549 (0 cts)

Figura 10.66 - Espectro EDS (1 da Figura 10.81) das estruturas esferoidais.

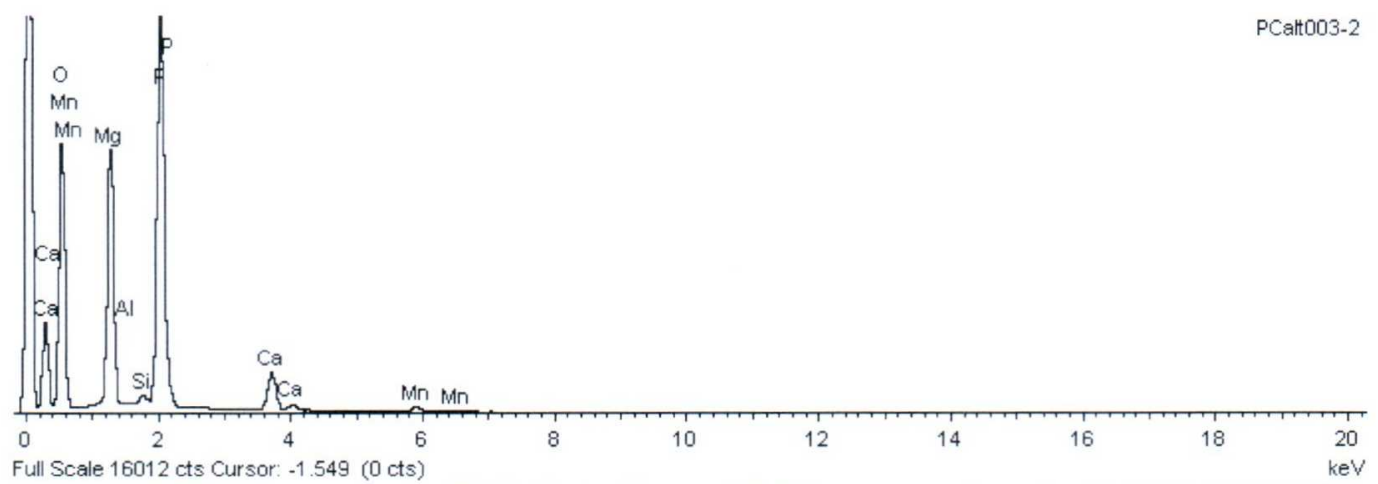

Figura 10.67 - Espectro de EDS (2 da Figura 10.64) mostrando o fosfato de magnésio. 


\section{$-\mathrm{CaOH}$}

Quando a solução de $\mathrm{CaOH}$ foi aplicado no Arenito Itararé, observou-se estruturas em forma de bastonetes (Figuras 10.68 e 10.69). Foi realizado EDS destas estruturas (Figura 10.70), no qual foi confirmado, que são formadas por cálcio.

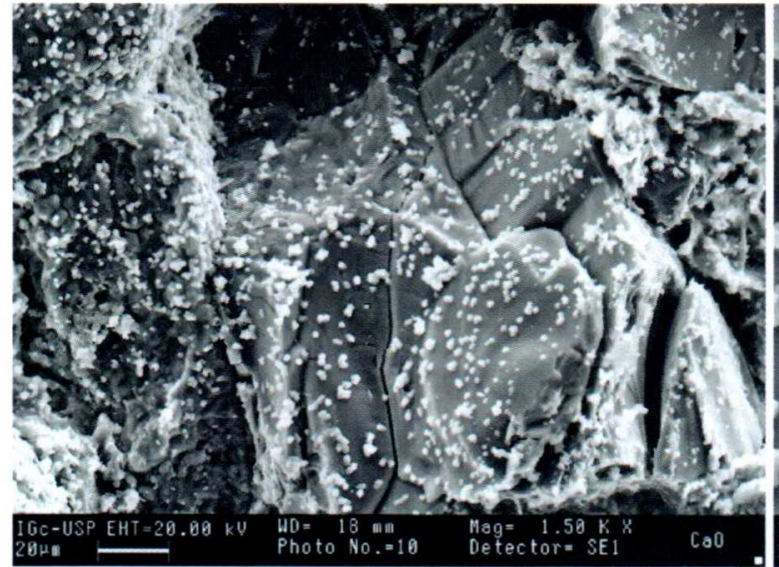

Figura 10.68 - Visão geral da amostra.

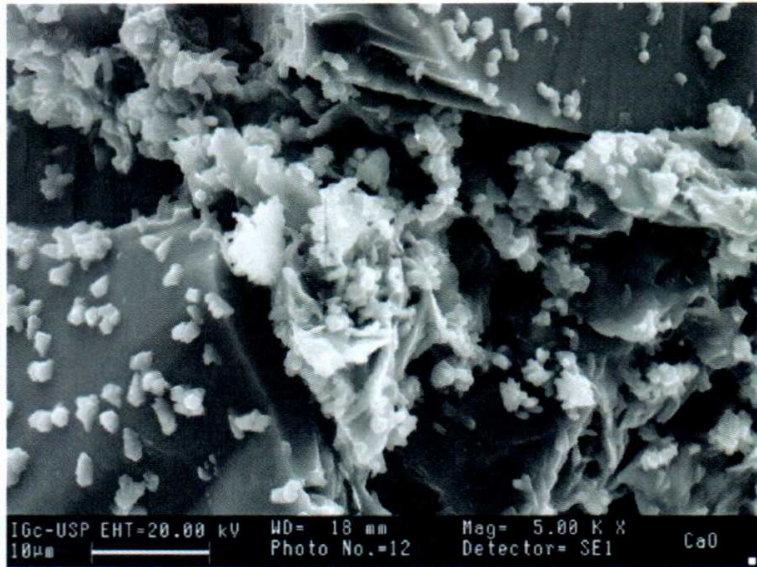

Figura 10.69 - aumento e visualização das estruturas em forma de bastonetes.

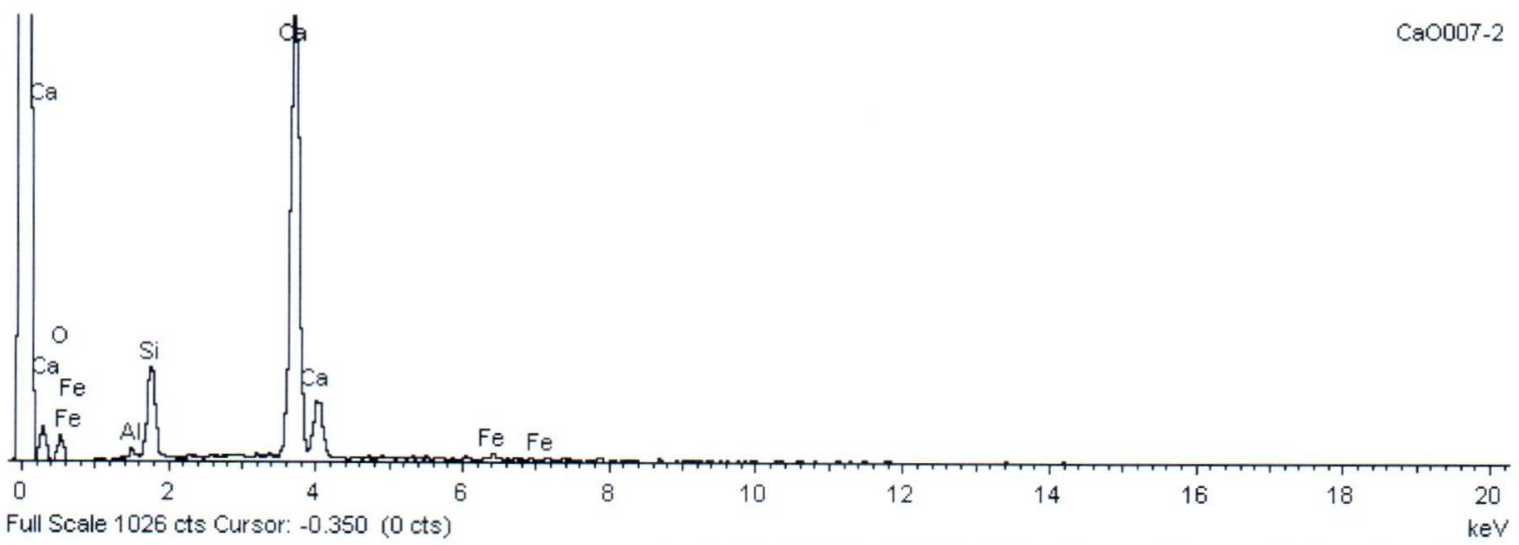

Figura 10.70 - Espectro EDS mostrando a composição das estruturas em forma de bastonetes.

Foi observada a formação de uma camada com aspecto de crosta sobre alguns grãos (Figura 10.71). O espectro de EDS desta crosta também mostrou que é composta por cálcio. 


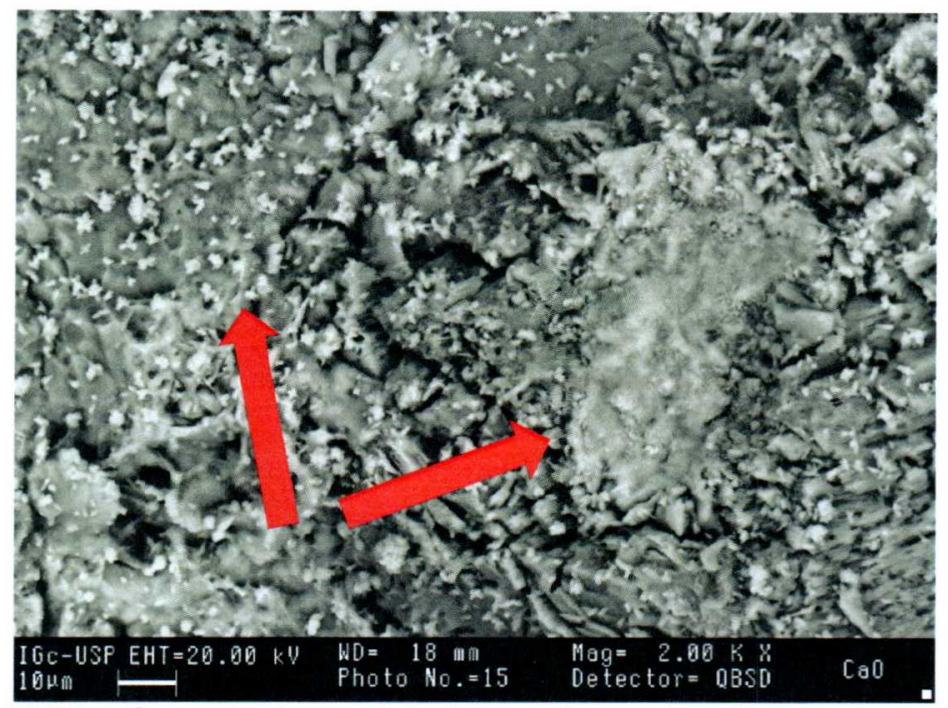

Figura 10.71 - Camada de produto formando crostas. Detalhe para crostas

\section{- TW}

O TW foi avaliado em dois equipamentos diferentes. Para o primeiro, a amostra foi recoberta por carbono, que requer uma espessura mais fina. No segundo equipamento (Poli), o recobrimento foi de platina, que necessita de uma espessura maior (aproximadamente $15 \mathrm{~nm}$ ).

Observando a amostra no primeiro equipamento, notou-se um filme de aspecto de "pele de sapo" (Figuras 10.72). Este filme foi encontrado em vários minerais, como feldspato (Figura 10.73), argilominerais (Figura 10.74) e poros (Figura 10.75), mostrando que o produto cobriu todos os grãos e poros.

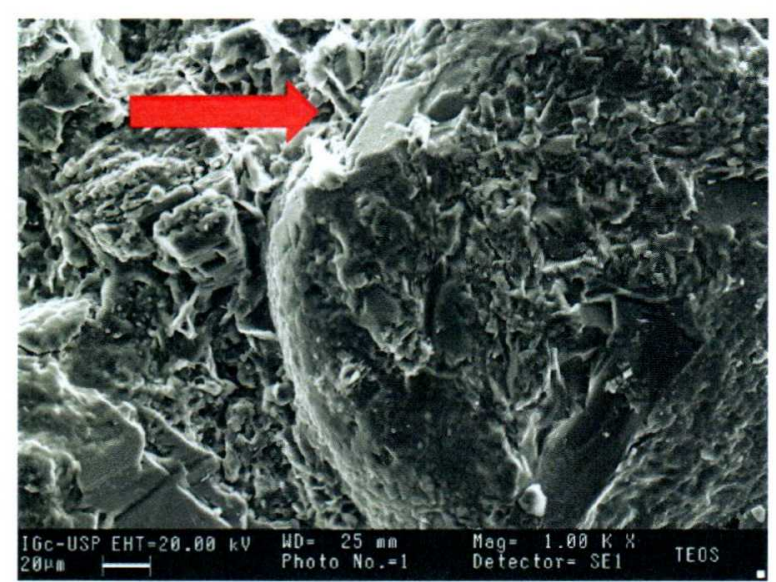

Figura 10.72 - Visão geral da amostra. Detalhe para aspecto "pele de sapo".

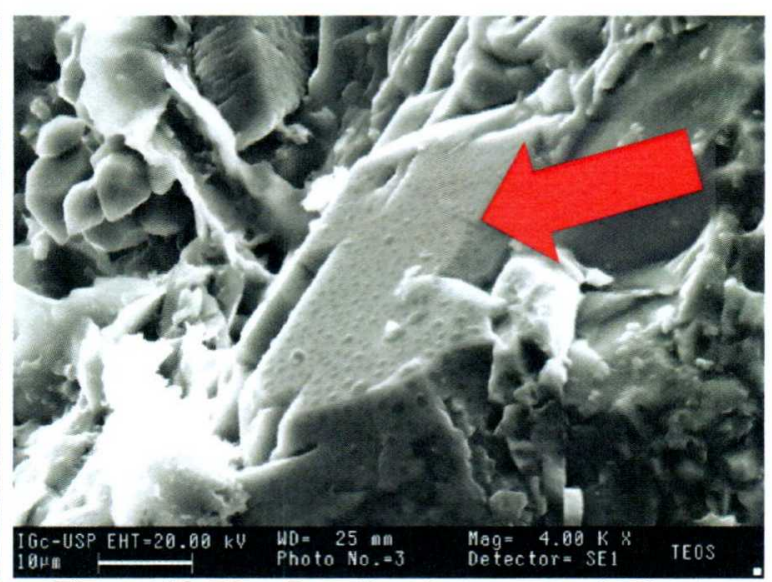

Figura 10.73 - Detalhe do aspecto "pele de sapo no feldspato. 


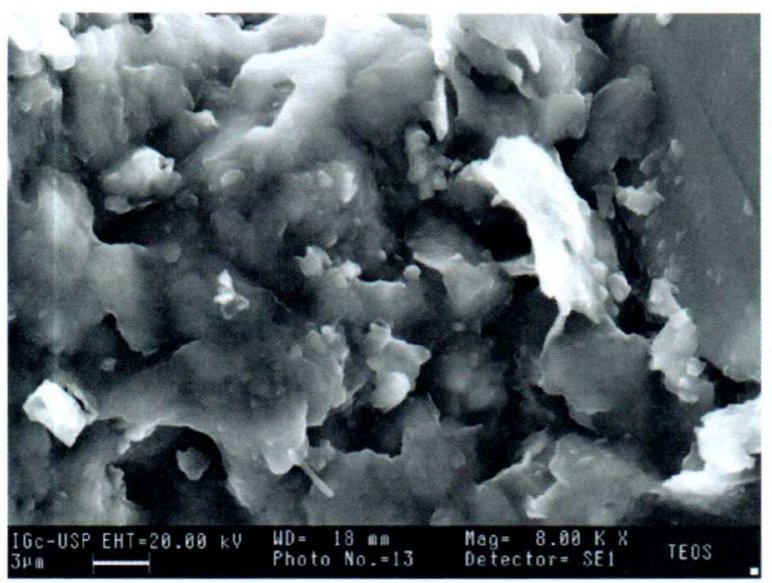

Figura 10.74 - Filme de TW recobrindo argilas

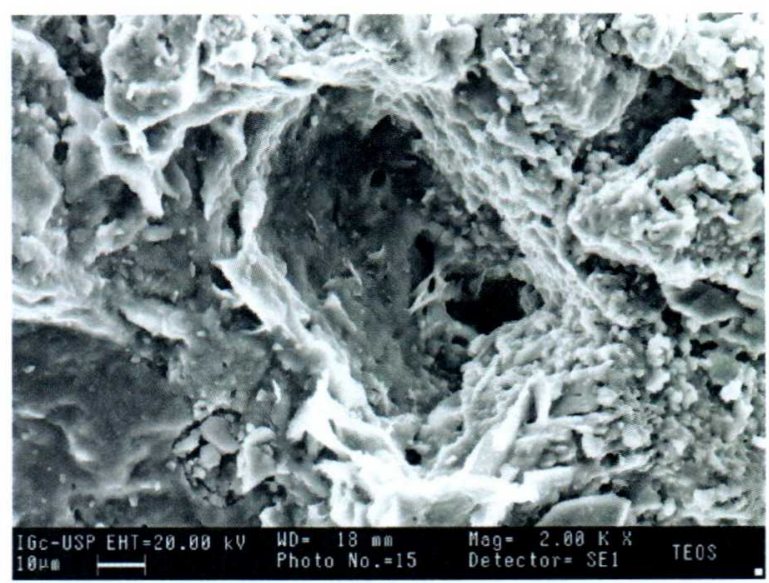

Figura 10.75 - Poro recoberto pelo produto.

Utilizando o MEV no laboratório da Poli, a cobertura com aspecto "pele de sapo", não pôde ser observada. Isto se deve, provavelmente, à espessura do recobrimento de platina. No entanto, foi possível visualizar outras feições que não puderam ser observadas no equipamento anterior, como o ressecamento do filme de gel de sílica (Figura 10.76). Foi possível também, inferir a espessura aproximada do filme (Figura 10.77). Elevando o aumento para 30.000x, foi possível observar minúsculas gretas de contração na superfície do filme, que antes parecia lisa (Figura 10.78).

Foi realizado mapeamento para verificar se havia produto sem polimerizar, o que pode ser observado pela presença de carbono. No entanto, o mapeamento mostrou que quase não há carbono (Figura 10.79).

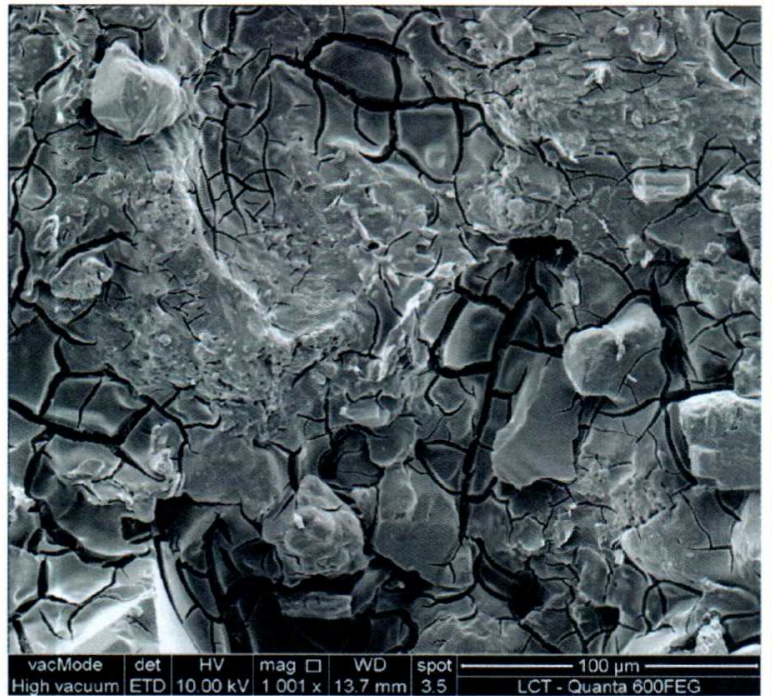

Figura 10.76 - Fraturas - MEV Poli.

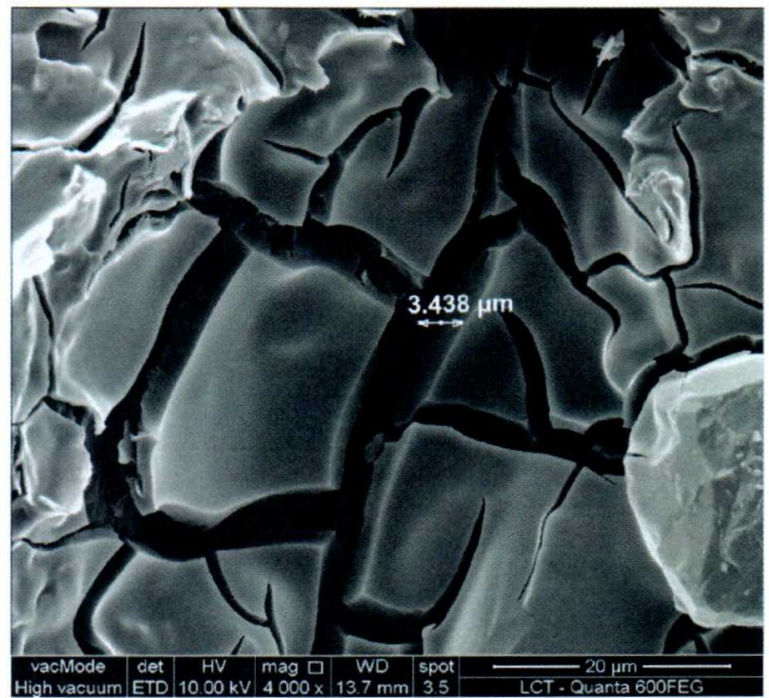

Figura 10.77 - Espessura aproximada do filme - MEV Poli. 


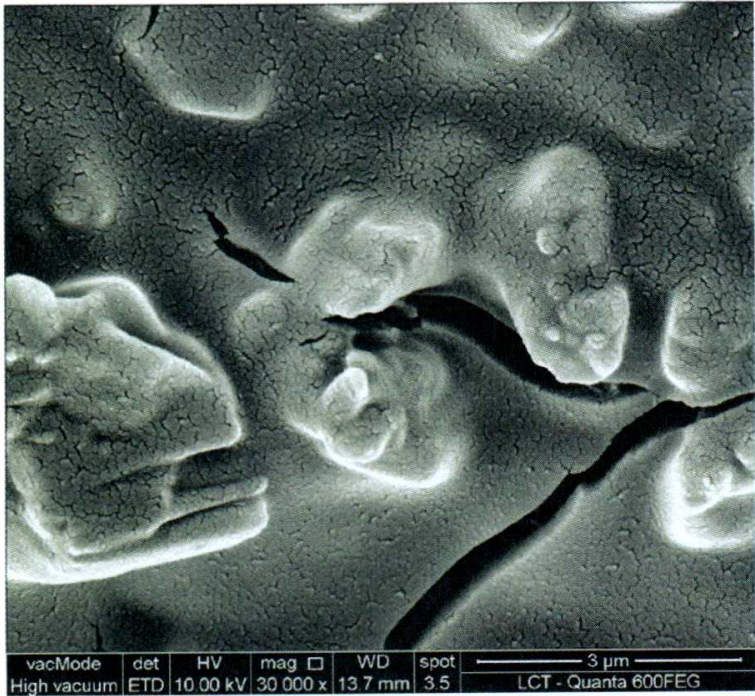

Figura 10.78 - Nano fraturas na superfície do filme de TW - MEV Poli.

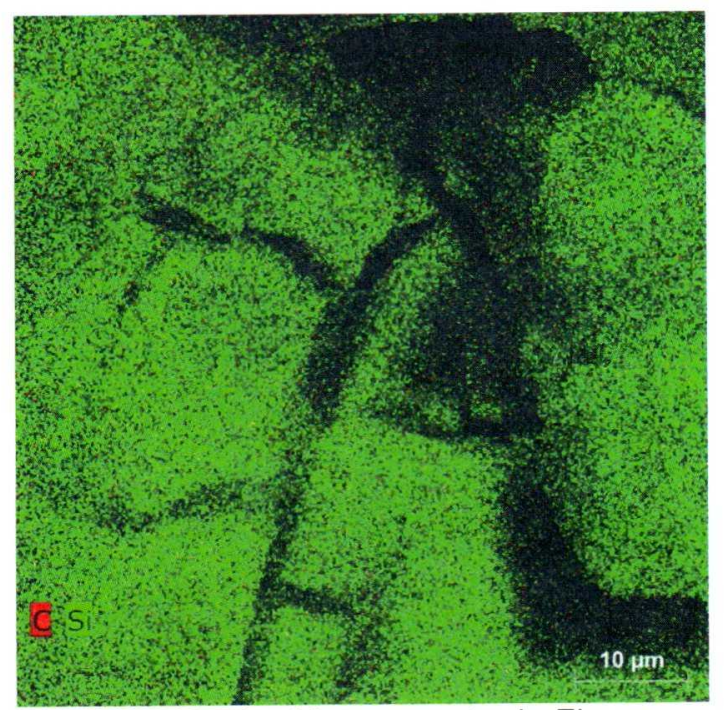

Figura 10.79 - Mapeamento da Figura anterior - MEV Poli

\section{- ATW}

Quando o A foi aplicado antes do TW, foram observadas as estruturas esferoidais características do A (Figuras 10.80 e 10.81).

Nas Figuras 10.82 e 10.83, é possível observar as gretas de contração características do TW. No entanto, elas parecem ser menores e menos abundantes.

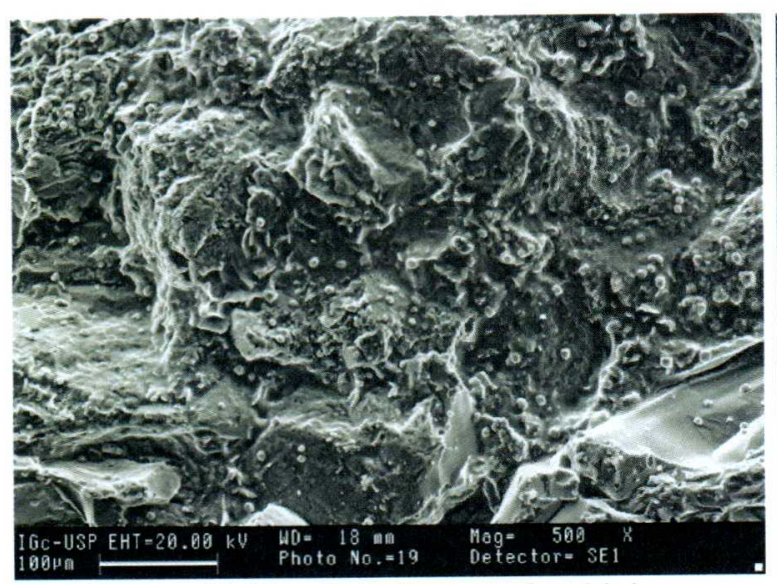

Figura 10.80 - Estruturas esferoidais na superfície dos minerais

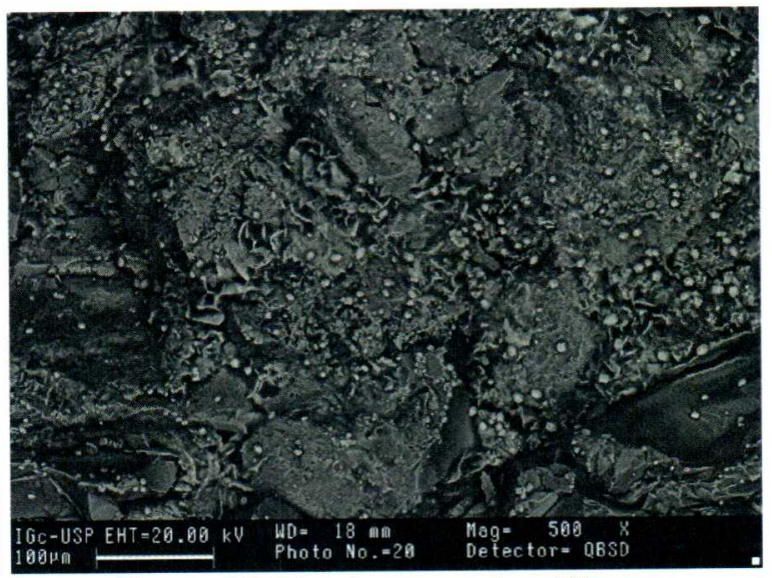

Figura 10.81 - Imagem de elétrons retroespalhados. 


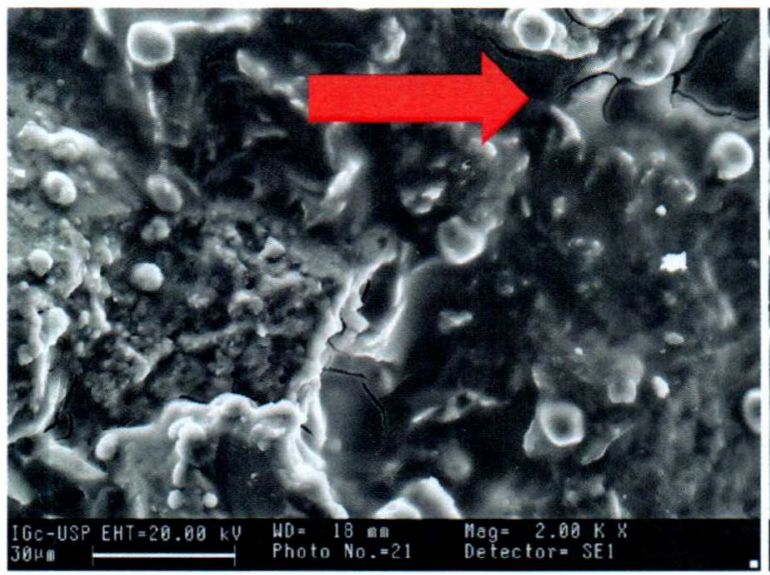

Figura 10.82 - Filme recobrindo os minerais Detalhe para fraturas.

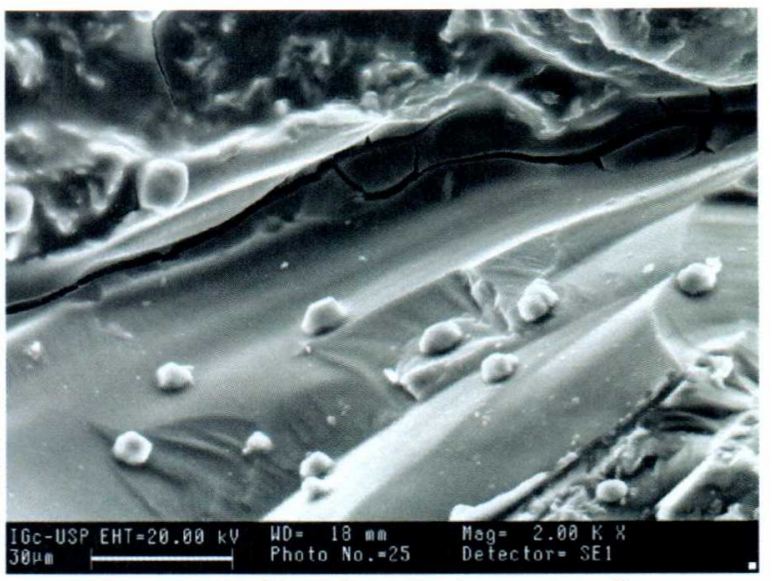

Figura 10.83 - Gretas de contração e estruturas esferoidais.

O espectro de EDS, realizado nas estruturas esferoidais, mostra que elas são compostas por cálcio, como nas amostras tratadas por A (Figuras 10.84 e 10.85 ambas no MEV Poli).

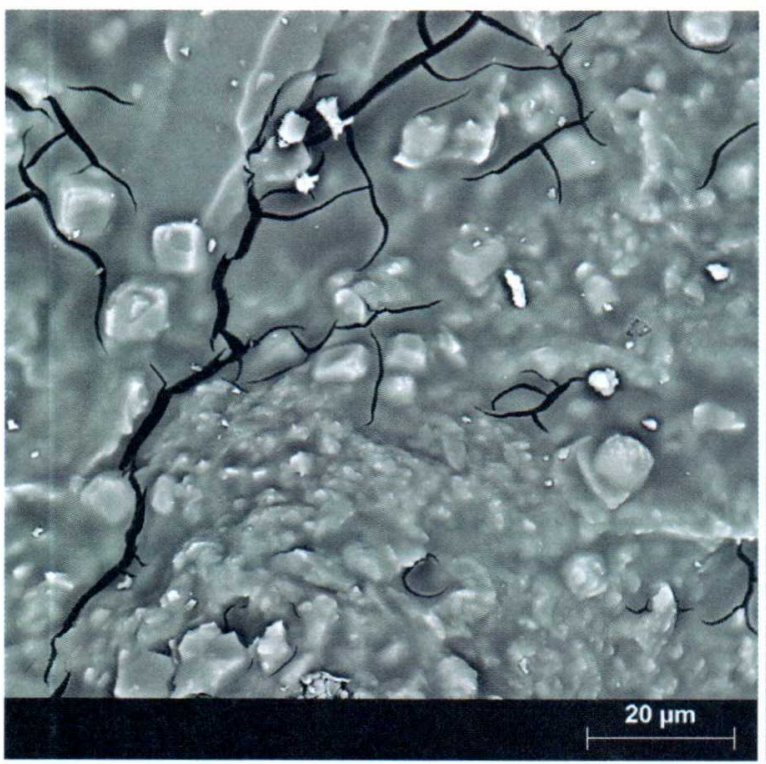

Figura 10.84 - Localização do mapeamento

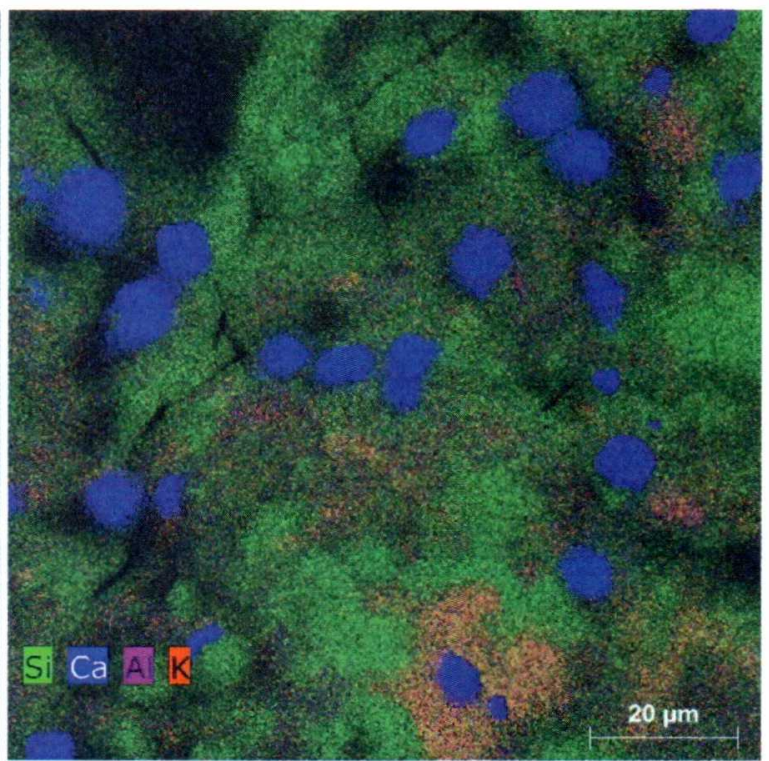

Figura 10.85 - Mapeamento mostrando estruturas esferoidais de cálcio.

\section{$-630$}

Após a aplicação e total secagem do 630 , observando as amostras ao MEV em menor aumento, verificou-se um aspecto mais folicular (Figura 10.86). No mapeamento desta mesma figura, encontrou-se carbono, que é proveniente da polimerização incompleta do produto (Figura 10.87). Em maior aumento, verificou-se a formação de um filme fibroso sobre os minerais (Figura 10.88 e 10.89). 


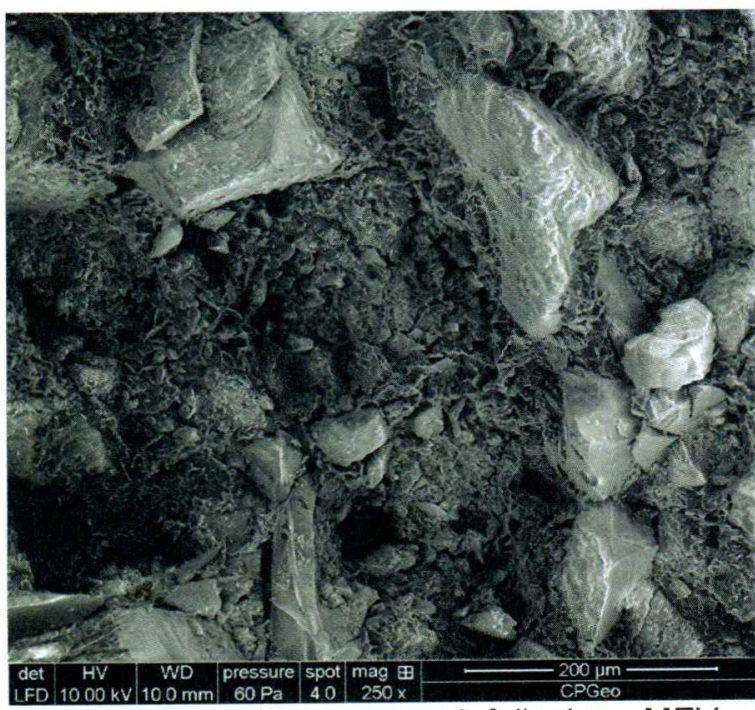

Figura 10.86 - Aspecto geral, folicular - MEV ambiental.

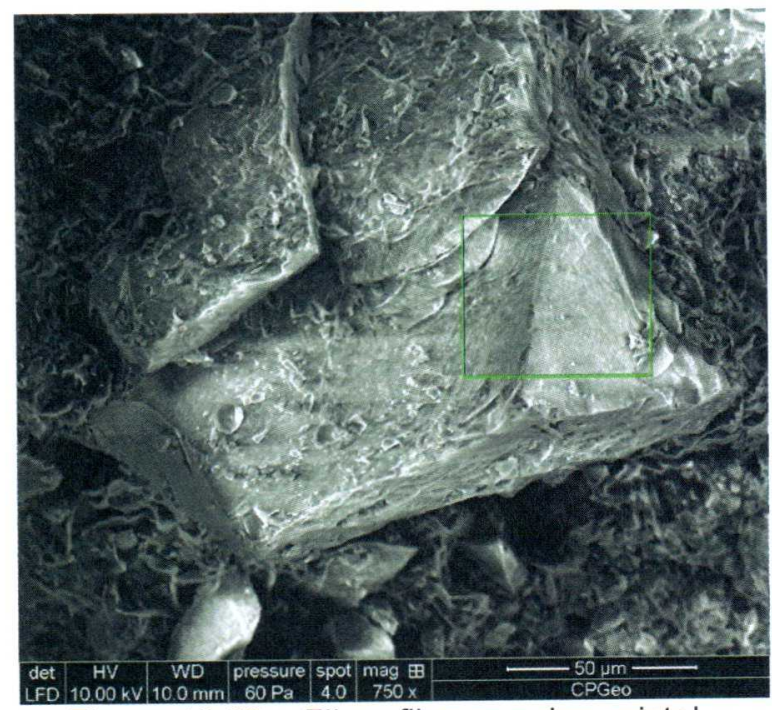

Figura 10.88 - Filme fibroso sobre cristal MEV ambiental.

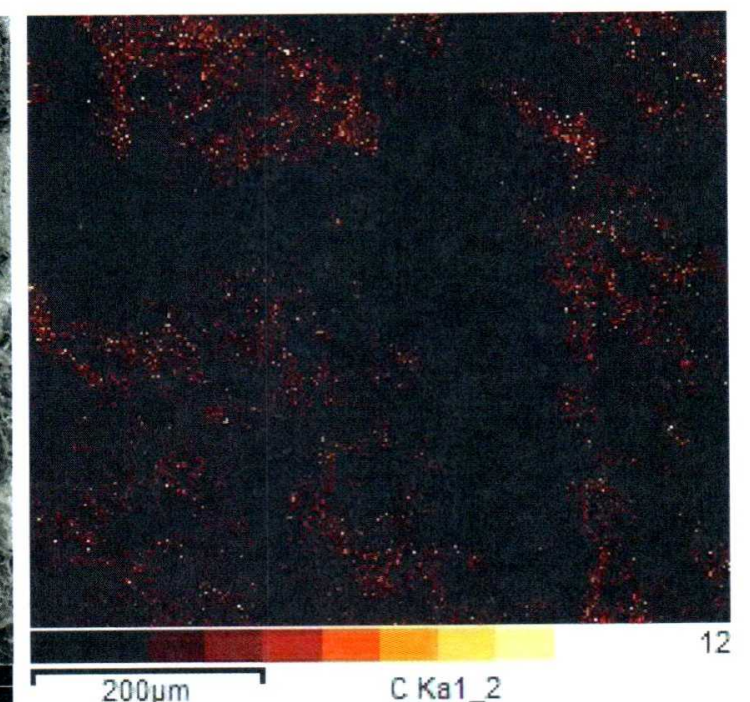

Figura 10.87 - Carbono detectado no mapeamento - MEV ambiental.

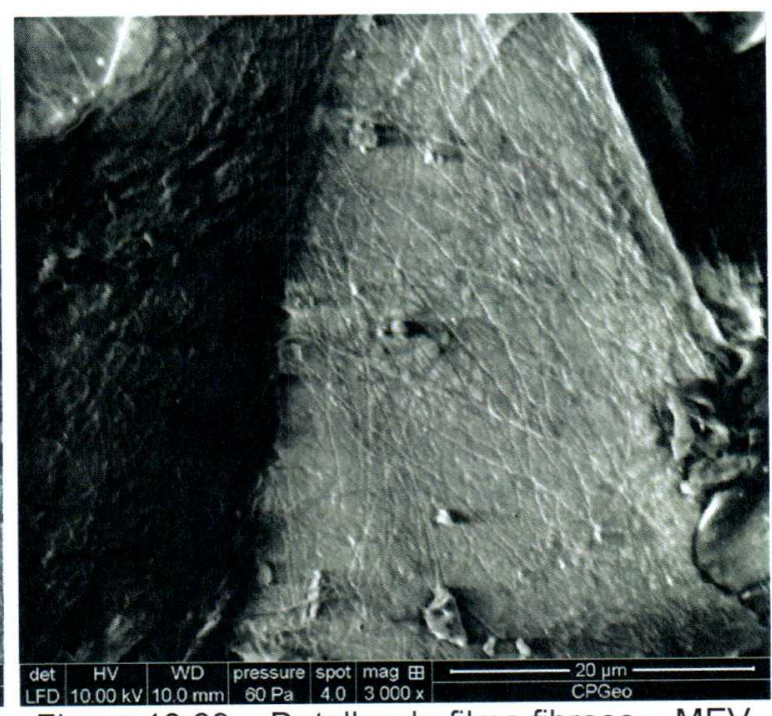

Figura 10.89 - Detalhe do filme fibroso - MEV ambiental.

\section{- A630}

Nas amostras em que foi aplicado $A$ e depois 630 , houve a formação de uma camada amorfa sobre os grãos (Figura 10.90 e 10.91). 


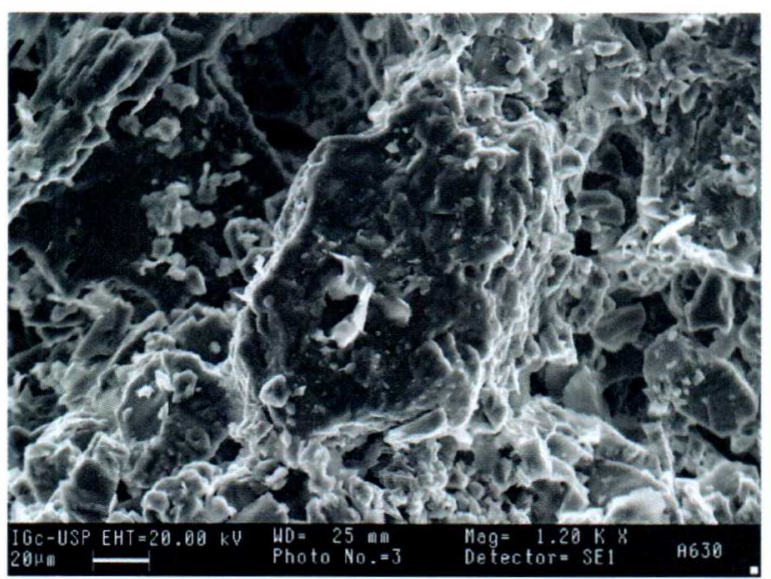

Figura 10.90 - Camada amorfa formada sobre os grãos.

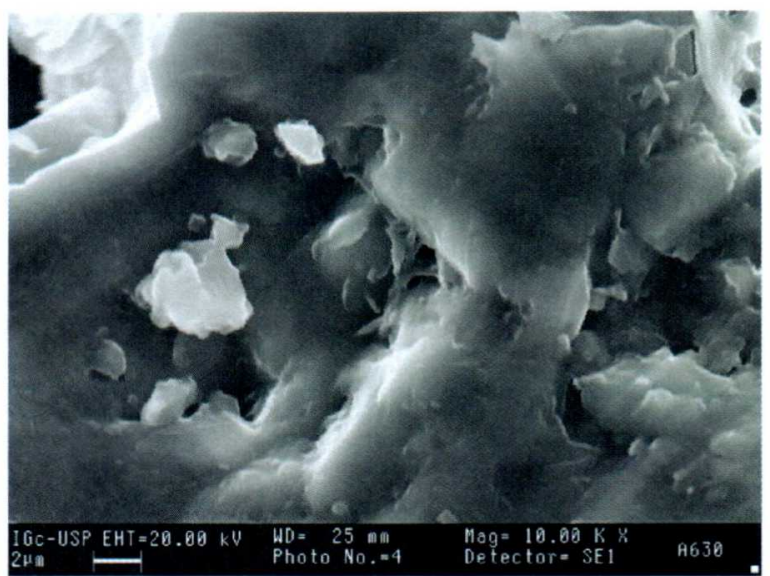

Figura 10.91 - Imagem anterior com maior detalhe

Por se tratar de um produto comercial, os elementos químicos constantes de sua fórmula não são divulgados. O que se sabe é que o produto é uma emulsão de silanos. Portanto, deverá depositar silício, que faz parte da composição da rocha, sendo difícil de identificá-lo quimicamente. No entanto, quando realizado EDS (Figura 10.92), grandes quantidades de cálcio (Figura 10.93) foram encontradas sobre os grãos de diversos minerais, devido à aplicação do $\mathbf{A}$.

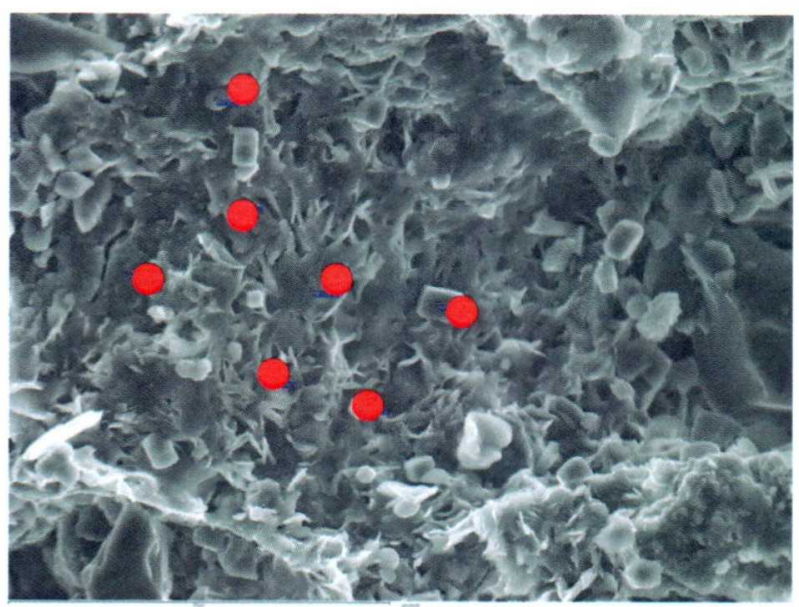

Figura 10.92 - Camada amorfa recobrindo minerais e localização dos pontos de EDS (pontos em vermelho). 


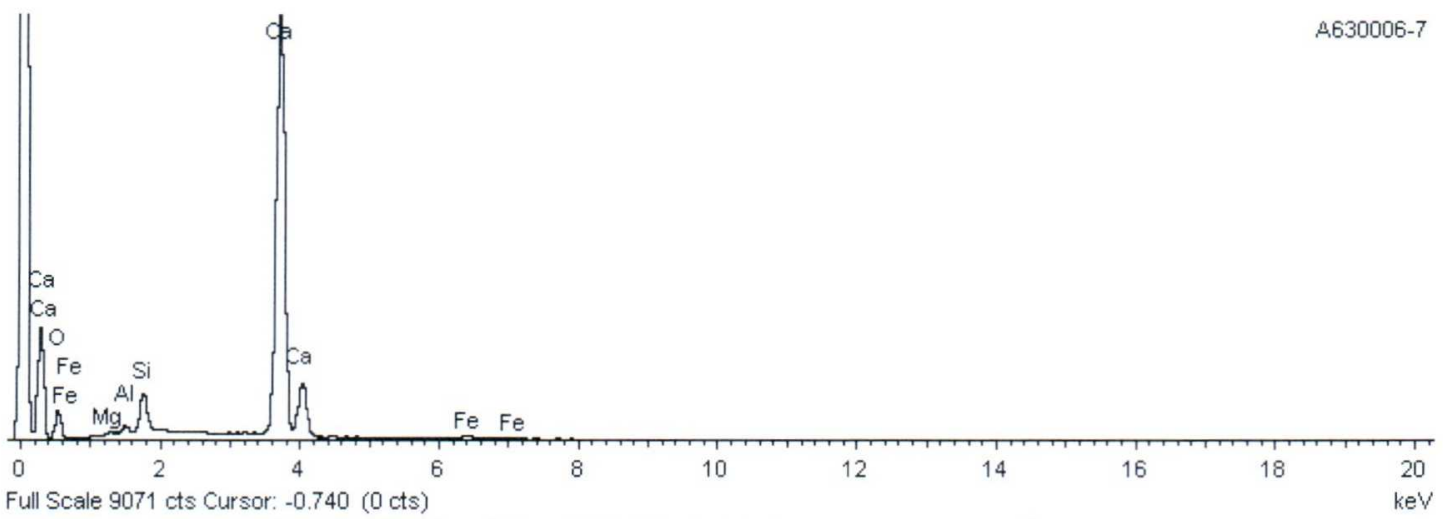

Figura 10.93 - Espectro EDS da camada de hidrofugante.

$-808$

Observando a feição geral da amostra (Figura 10.94), nota-se uma camada irregular recobrindo todos os grãos, de modo que fica dificil determinar, visualmente, quais são os minerais abaixo do tratamento. Em maior aumento, verifica-se que a superfície do tratamento apresenta aspecto áspero (Figuras 10.95 e 10.96)

A Figura 10.97, mostra a localização do mapeamento, realizado para determinar quimicamente a deposição do produto. No entanto, este é um produto comercial e sua composição é declarada como um propil siliconato. Portanto, será depositada sílica, que faz parte da composição da rocha, sendo muito difícil identificar o produto quimicamente. O EDS mostrou grande quantidade de silício e oxigênio (Figura 10.98), que devem ser do mineral (quartzo) subjacente.

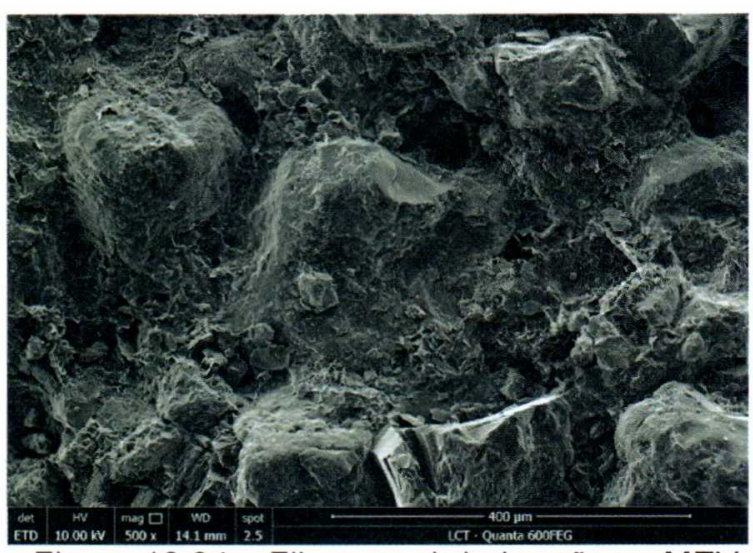

Figura 10.94 - Filme recobrindo grãos - MEV Poli.

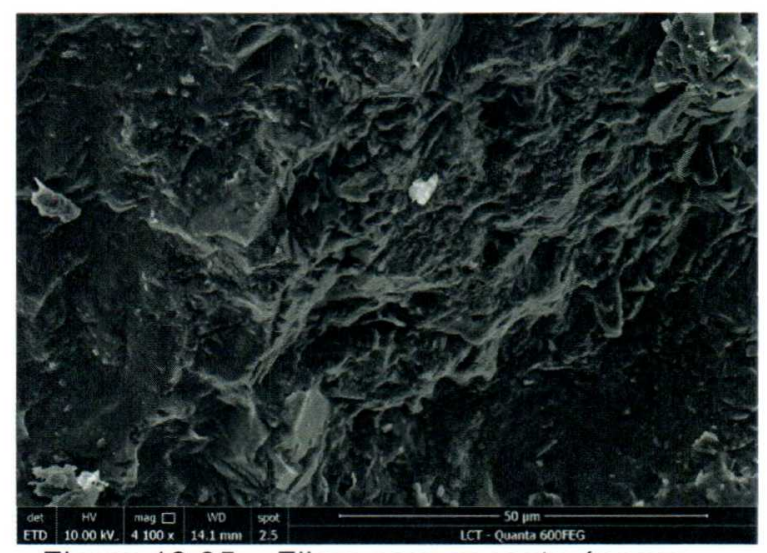

Figura 10.95 - Filme com aspecto áspero MEV Poli. 


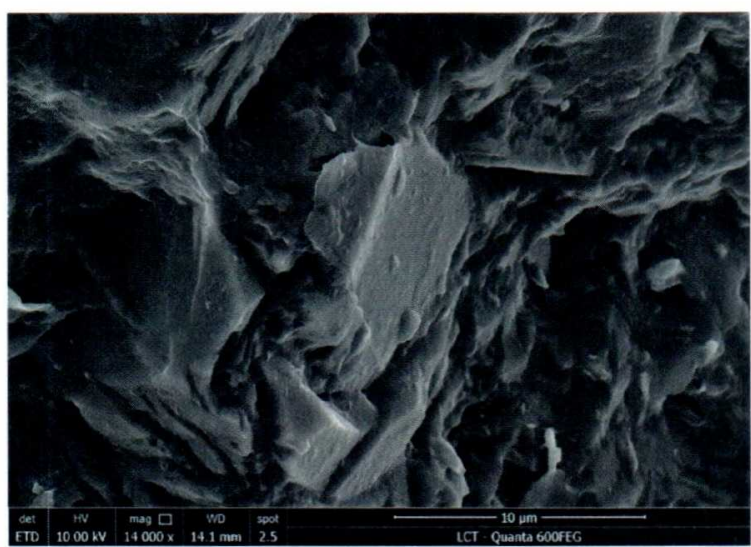

Figura 10.96 - Aspecto áspero em maior aumento - MEV Poli.

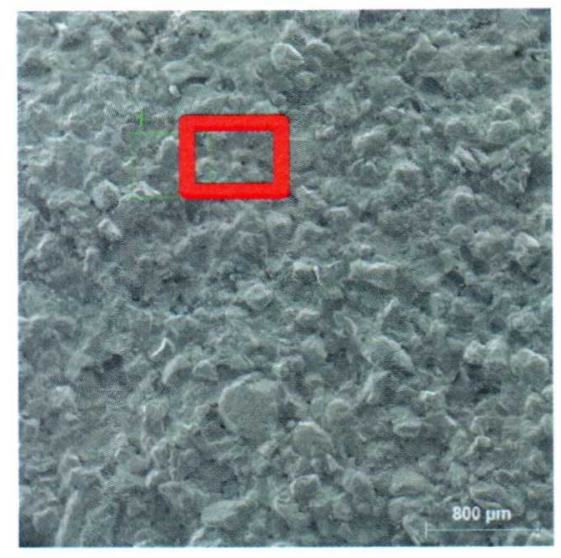

Figura 10.97 - Localização do EDS - elétrons reroespalhados (MEV Poli).

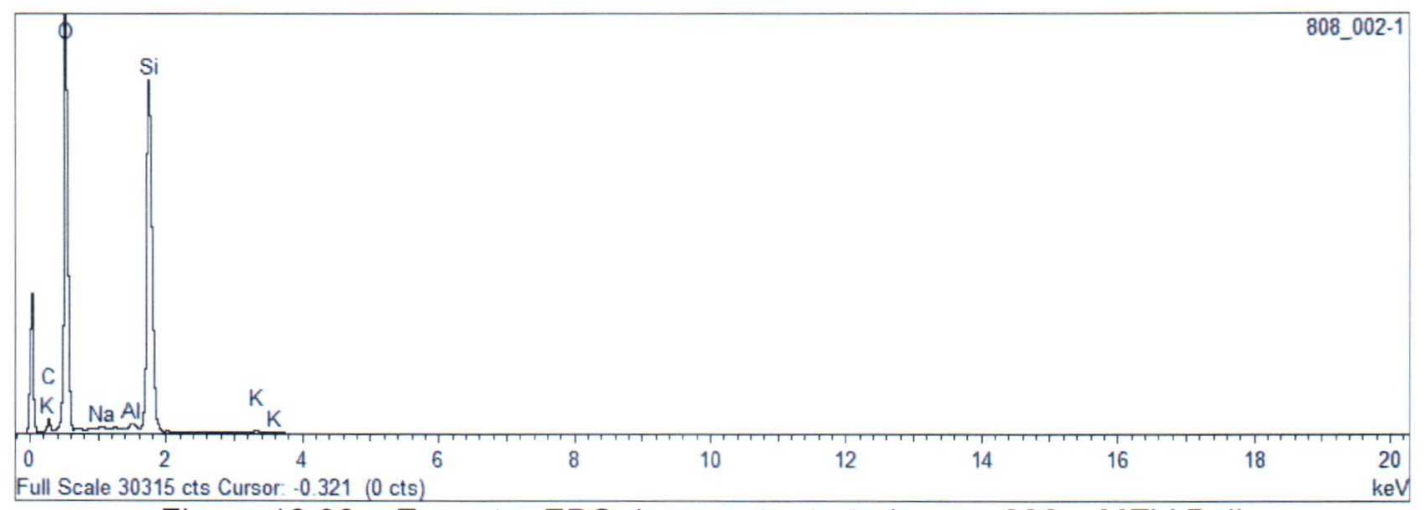

Figura 10.98 - Espectro EDS da amostra tratada com 808 - MEV Poli.

- AG

É possível visualizar que o produto não forma filme (Figura 10.99), mas cobre os locais onde estão presentes os poros menores. Após sua secagem, visualiza-se marca de bolhas (Figuras 10.100 e 10.101). Este é um produto comercial e sua fórmula não é divulgada. Para saber se o produto está cobrindo todos os grãos, foi realizado o mapeamento. Na Figura 10.102 é possível observar 3 áreas que foram ensaiadas. Os resultados para estas áreas foram os mesmos, diferindo apenas na composição química do grão sob o produto. Foi escolhido o EDS com menos elementos químicos para facilitar a visualização. Observando a Figura 10.103 é possível ver que, além da composição da rocha (silício) e do recobrimento (platina), temos flúor e oxigênio, que podem ser provenientes do produto ou dos minerais subjacentes. 


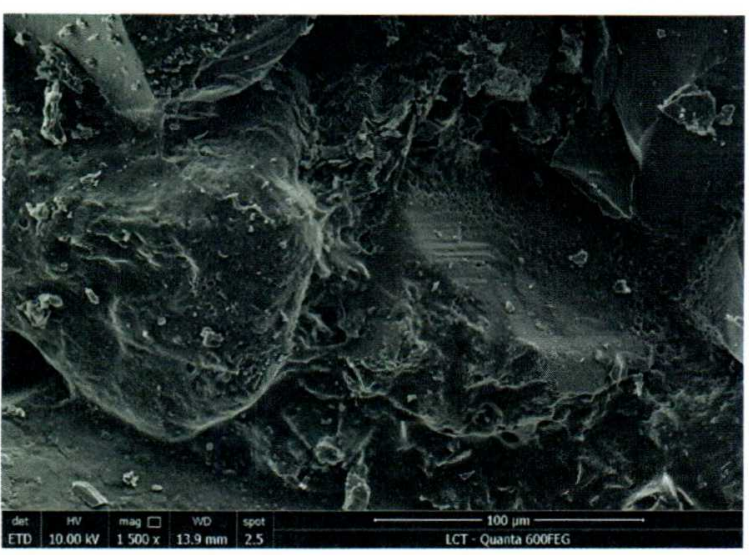

Figura 10.99 - Produto cobrindo grãos - MEV Poli.

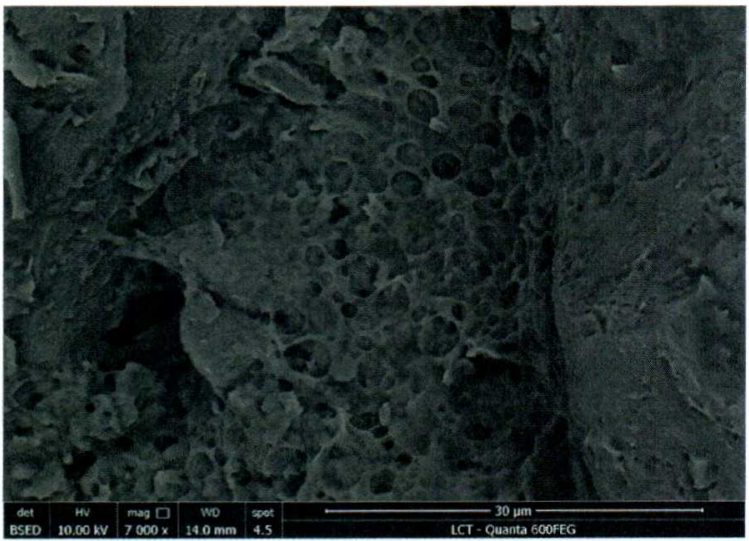

Figura 10.101 - Marcas de bolhas em maior aumento - MEV Poli.

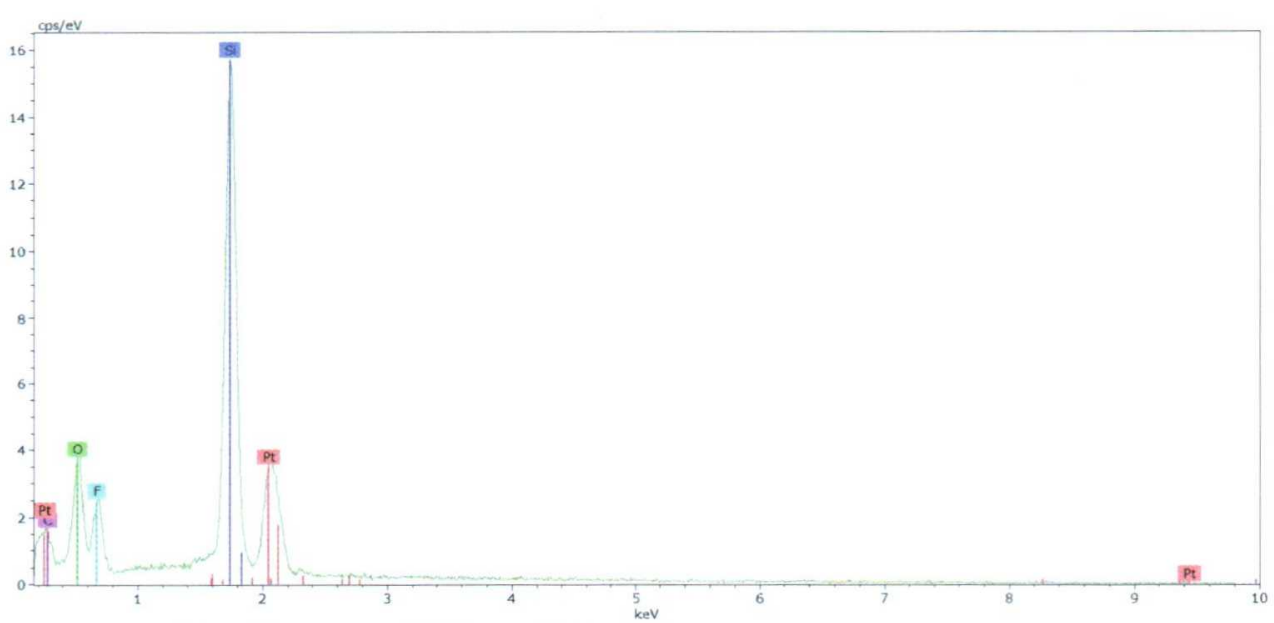

Figura 10.103 - Espectro EDS qualitativo da amostra tratada com AG - MEV Poli.

O MEV mostrou-se um instrumento adequado para observar a deposição dos produtos.

Quando foi aplicado o A, apareceram estruturas esferoidais formadas por cálcio, que puderam ser observadas em todas as amostras pré-tratadas com estes produtos. A proveniência deste elemento químico foi pesquisada por FRX e foi confirmada que advém do produto $\mathbf{A}$. Nas rochas tratadas com este produto, também 
foi encontrada a presença de carbono, formando agregados em forma de flores. O P conseguiu recobrir os grãos com uma camada, que parece ser de fosfato de magnésio. Nas amostras em que foi aplicado o AP, foi observada uma camada de aspecto alveolar recobrindo os grãos. $\mathrm{O} \mathrm{PCaOH}$ formou estruturas esferoidais de fosfato de magnésio, que recobrem, principalmente os poros e grãos menores. $O$ $\mathrm{CaOH}$ formou agregados em forma de bastonetes, salpicados sobre os grãos. O TW formou um filme espesso, que abre gretas de contração após sua secagem. Quando aplicado o A antes do TW, o produto pareceu fraturar menos. O 808 forma uma camada de aspecto áspero e o 630 forma um filme de aspecto reticulado. Quando aplicado o A, antes do 630 , ele forma um filme de aspecto amorfo. O AG cobre todos os grãos e forma uma camada com formas de contorno de bolhas.

\subsubsection{Porosimetria de mercúrio}

\section{- Universidade de Princeton}

Informa-se que o eixo y dos gráficos a seguir é sempre diferente, pois não houve a possibilidade de padronizá-lo. No eixo $x$, os poros maiores estão à esquerda $e$ os menores à direita.

A amostra fresca de grãos mais finos, possuem poros com distribuição bimodal em 700 e 8.000 nm (Figura 10.104). Nas amostras de grãos mais grossos, os poros apresentaram distribuição unimodal, com 10.000 nm de diâmetro (Figura 10.105). volume dos poros é de $0,06 \mathrm{~mL} / \mathrm{g}$ para as de grãos mais finos e de $0,08 \mathrm{~mL} / \mathrm{g}$ para amostras de grãos mais grossos. A porosidade para a rocha fresca de grãos predominantemente finos é de $14,1 \%$, e $17,1 \%$ para as que possuem camada de grãos mais grossos. 


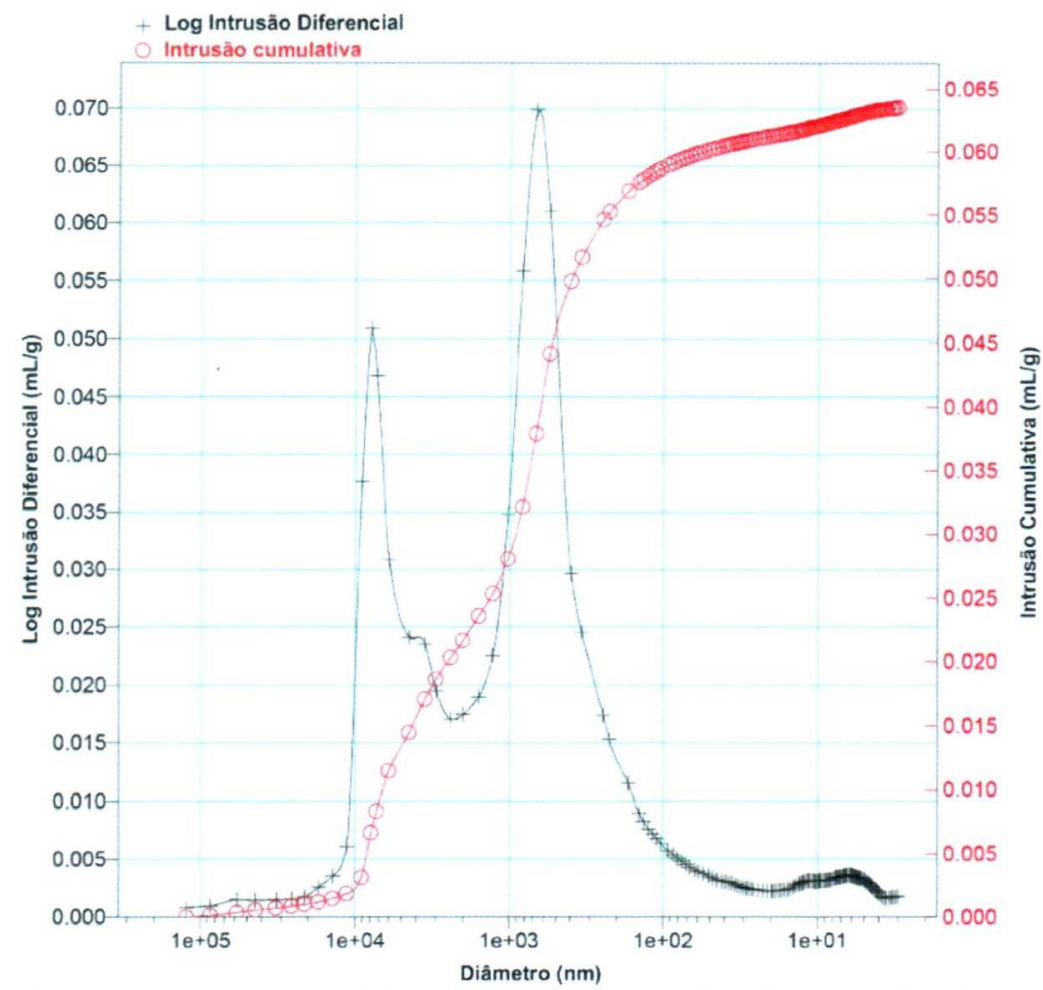

Figura 10.104 - Porosimetria de mercúrio em amostra de grãos finos do Arenito Itararé fresco.

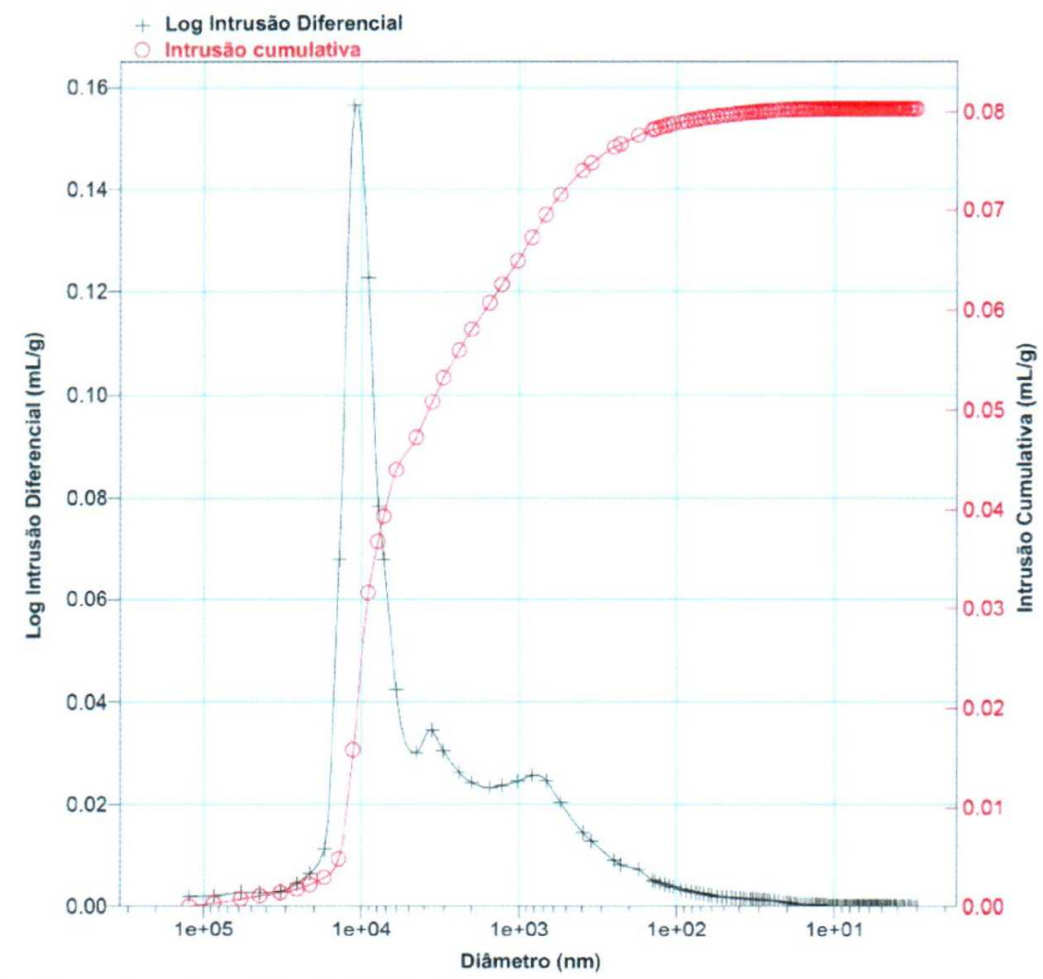

Figura 10.105 - Porosimetria de mercúrio em amostra de grãos grossos do Arenito Itararé fresco. 
O tratamento com A, reduziu acentuadamente os poros menores que $700 \mathrm{~nm}$ nas duas amostras testadas. Para a amostra de poros mais grossos, apareceram poros de $2.000 \mathrm{~nm}$ e os de $10.000 \mathrm{~nm}$ foram reduzidos para $9.000 \mathrm{~nm}$. A porosidade ficou em 15,1\% para as de grãos mais finos (Figura 10.106), e intrusão cumulativa de $0,07 \mathrm{~mL} / \mathrm{g}$. A porosidade ficou em 16,1\% para as de grãos mais grossos, e a intrusão cumulativa ficou em $0,07 \mathrm{~mL} / \mathrm{g}$ (Figura 10.107). Ambas as intrusões cumulativas ficaram mais altas do que as amostras frescas. Acredita-se que os surfactantes unam as camadas de argilominerais e isso possa causar este efeito.

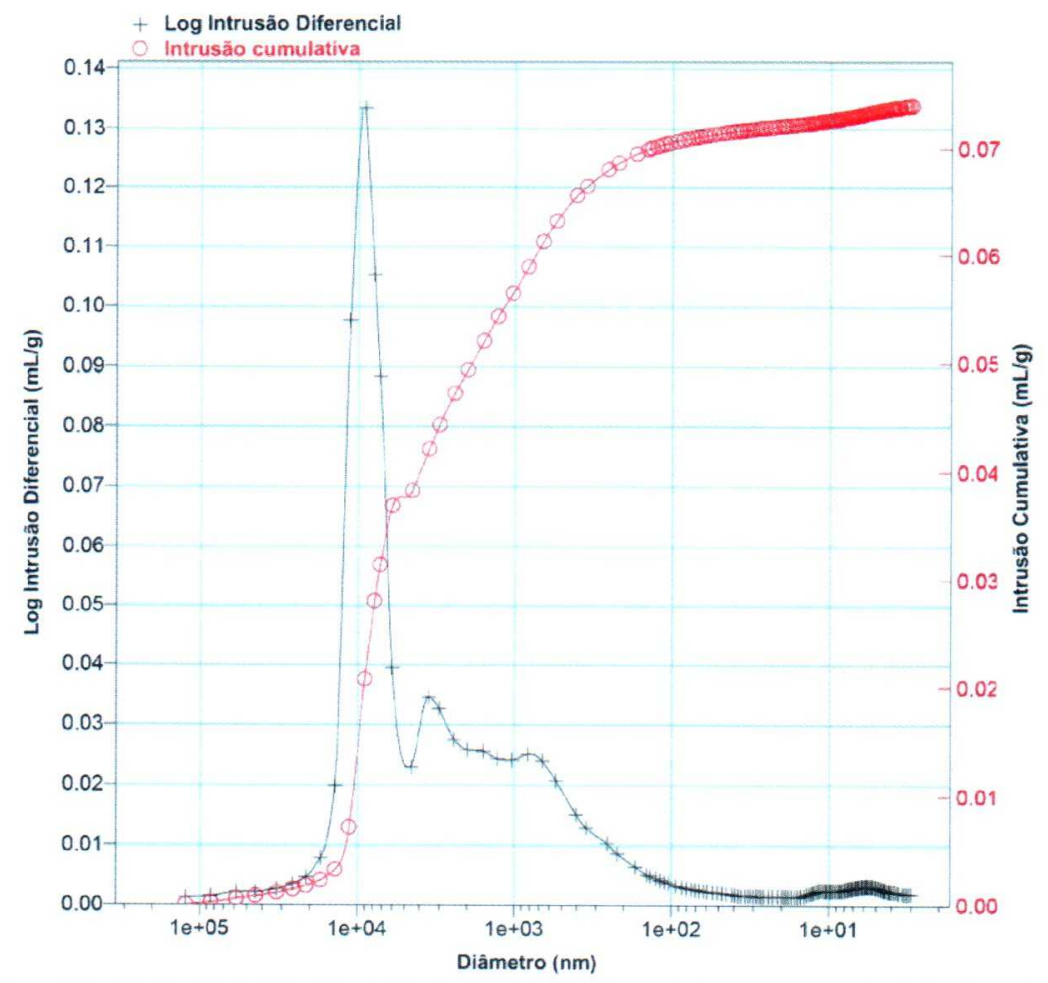

Figura 10.106 - Porosimetria de mercúrio para amostras de grãos mais finos do Arenito Itararé tratado com A. 


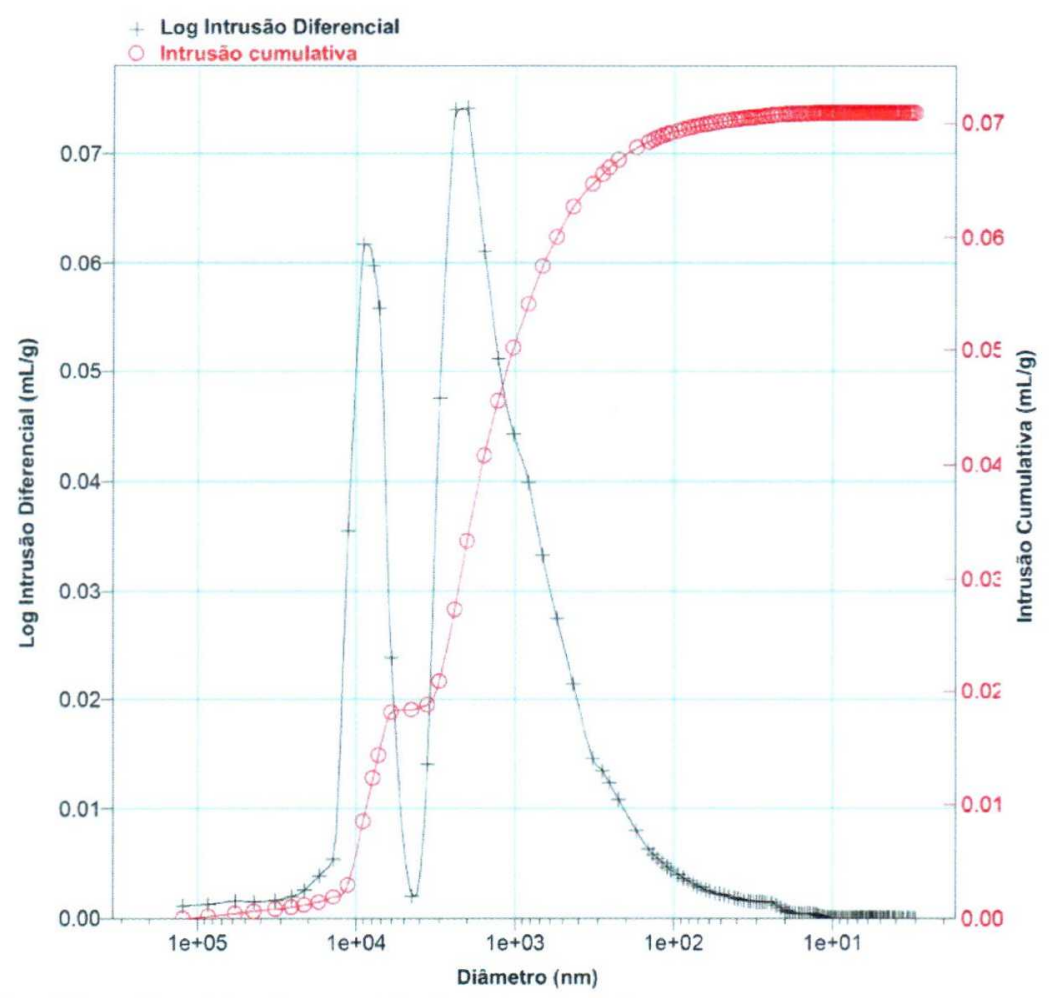

Figura 10.107 - Porosimetria de mercúrio para amostras de grãos mais grossos do Arenito Itararé tratado com A.

O P quase eliminou os poros de $8.000 \mathrm{~nm}$, mostrando pequenos picos nesta região e na região dos $3.000 \mathrm{~nm}$. Os de $700 \mathrm{~nm}$, permaneceram. $\mathrm{Na}$ amostra de grãos mais grossos, o pico dos poros de $10.000 \mathrm{~nm}$ foi deslocado para $5.000 \mathrm{~nm}$. A amostra que possui alguns grãos menores, apresentou porosidade de $14,4 \%$ (Figura 10.108). A intrusão cumulativa ficou bem próxima à da amostra fresca, mostrando $0,06 \mathrm{~mL} / \mathrm{g}$. $A$ porosidade das rochas de maior granulometria, ficou em 29,7\% (Figura 10.109). Este aumento da porosidade pode ser devido a uma característica daquela amostra, devido à falta de homogeneidade do Arenito Itararé ou devido ao aumento relativo residual dos poros médios. No entanto, a intrusão cumulativa aumentou, alcançando 0,15 $\mathrm{mL} / \mathrm{g}$, o que corrobora com o resultado da porosidade. 


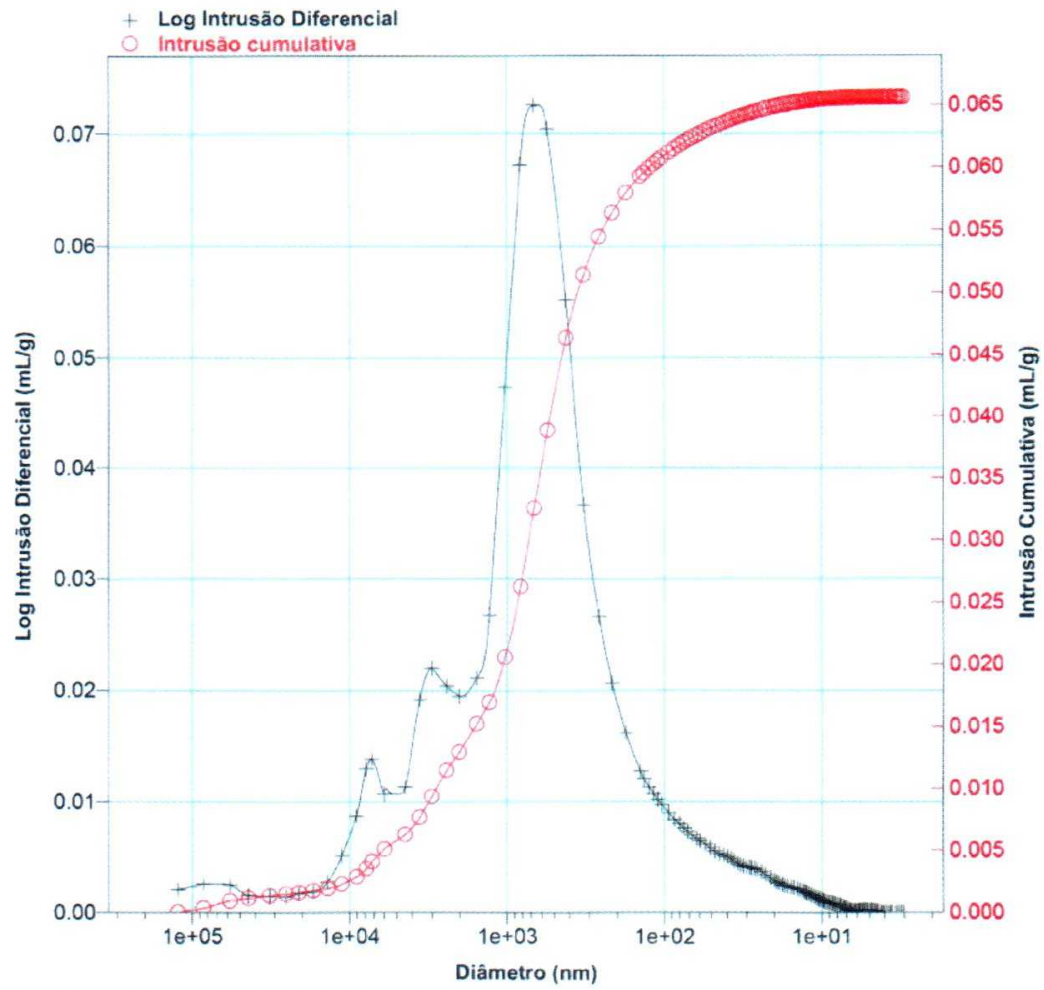

Figura 10.108 - Porosimetria de mercúrio em amostra do Arenito Itararé com grãos mais finos tratada com $\mathrm{P}$.

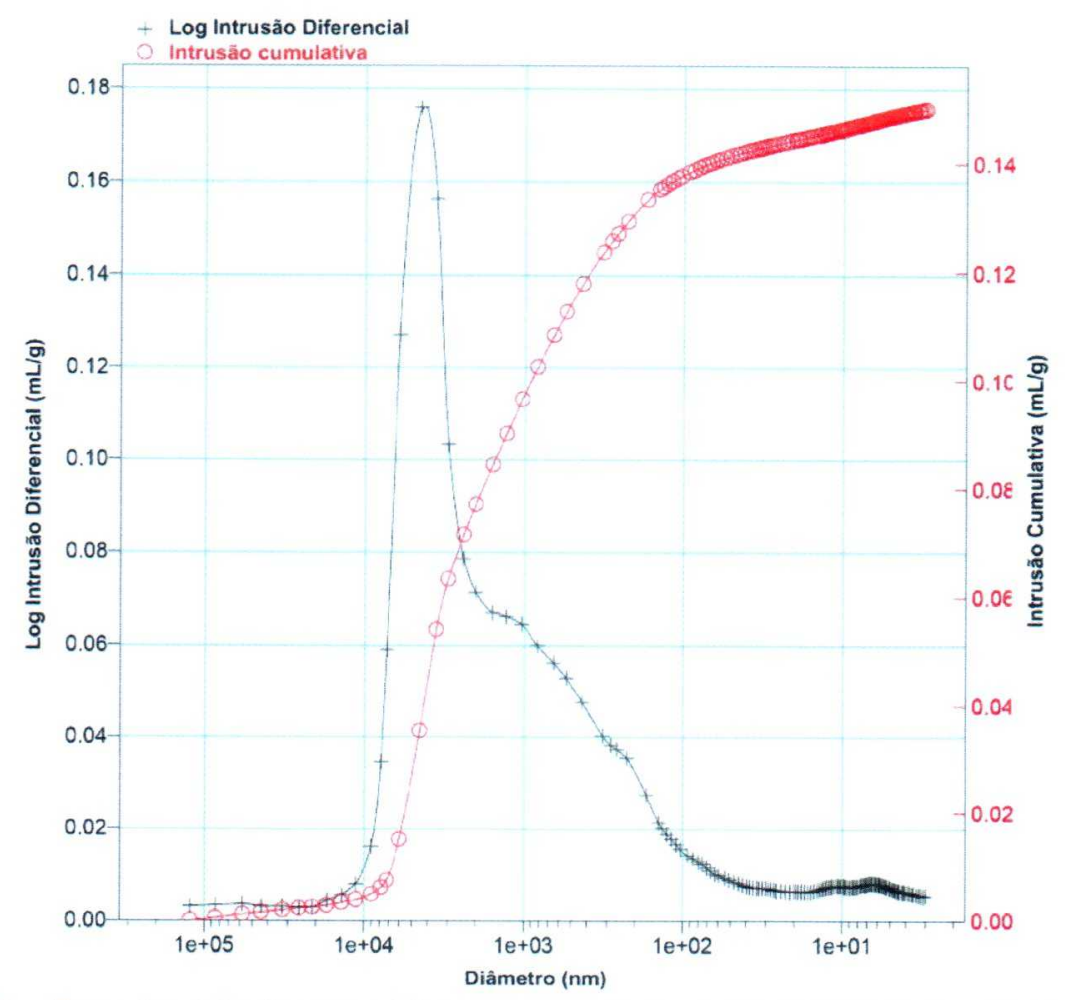

Figura 10.109 - Porosimetria de mercúrio em amostra do Arenito Itararé de grãos mais grossos tratado com $\mathrm{P}$. 
Quando o A foi aplicado antes do $\mathbf{P}$ nas amostras com grãos mais finos, a porosidade reduziu para $9,6 \%$ (Figura 10.110) e a intrusão cumulativa também diminuiu $(0,04 \mathrm{~mL} / \mathrm{g})$. De maneira geral, a distribuição dos poros não mudou muito, em ambas amostras. Nas amostras de grãos mais finos, manteve os picos de $700 \mathrm{e}$ $8.000 \mathrm{~nm}$, porém diminui a quantidade dos de $700 \mathrm{~nm}$. A porosidade da amostra de grãos mais grossos ficou em 17,0\% (Figura 10.111), bem semelhante à porosidade da rocha fresca e a intrusão cumulativa ficou em $0,08 \mathrm{~mL} / \mathrm{g}$; igual a encontrada em rocha fresca.

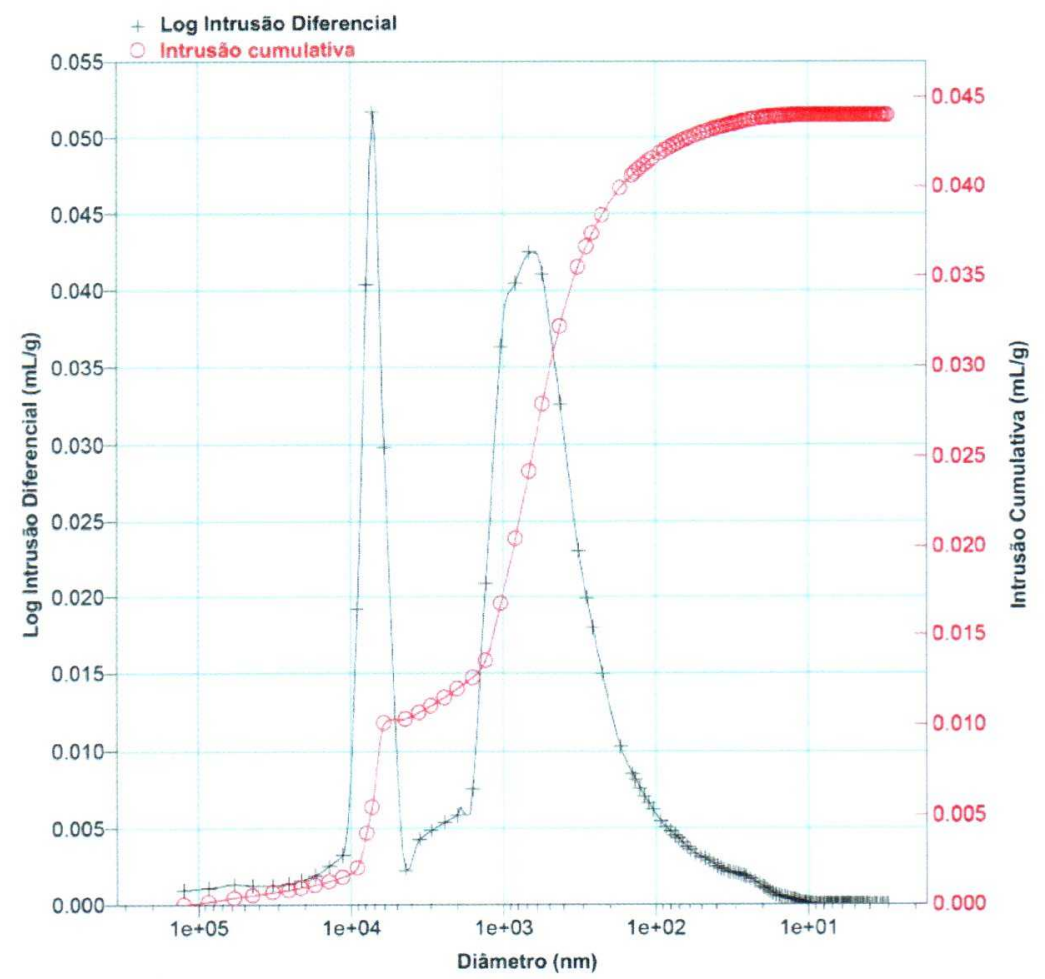

Figura 10.110 - Porosimetria de mercúrio em amostra do Arenito Itararé com grãos mais finos tratado com AP. 


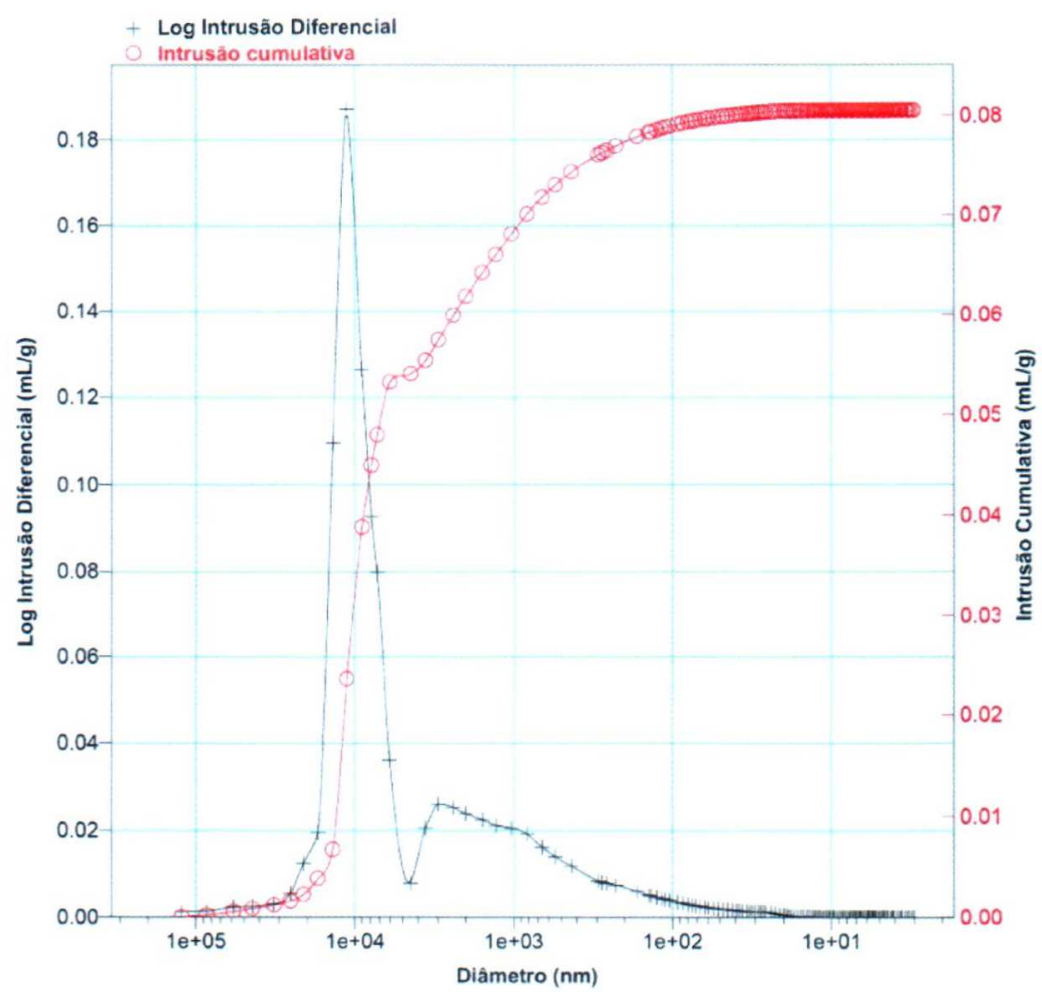

Figura 10.111 - Porosimetria de mercúrio em amostra de Arenito Itararé tratado com AP.

No tratamento com TC, a amostra de grãos mais finos apresentou porosidade de $13,1 \%$ e teve os poros de $8.000 \mathrm{~nm}$ eliminados, passando a uma distribuição unimodal. O pico dos poros de $700 \mathrm{~nm}$ foi deslocado e passou para $2.000 \mathrm{~nm}$. A intrusão cumulativa ficou em $0,05 \mathrm{~mL} / \mathrm{g}$ (Figura 10.112), bastante próxima da amostra fresca. A amostra de grãos maiores foi quase que totalmente preenchida pelo produto, pois a porosidade encontrada após o tratamento foi de 1,8\%. Este valor é muito baixo, sendo possível que tenha ocorrido algum problema analítico. A intrusão cumulativa apresentada foi de $0,06 \mathrm{~mL} / \mathrm{g}$ (Figura 10.113). A distribuição dos poros ficou em 8.000 $\mathrm{nm}$ e um pequeno pico em $2.500 \mathrm{~nm}$. 


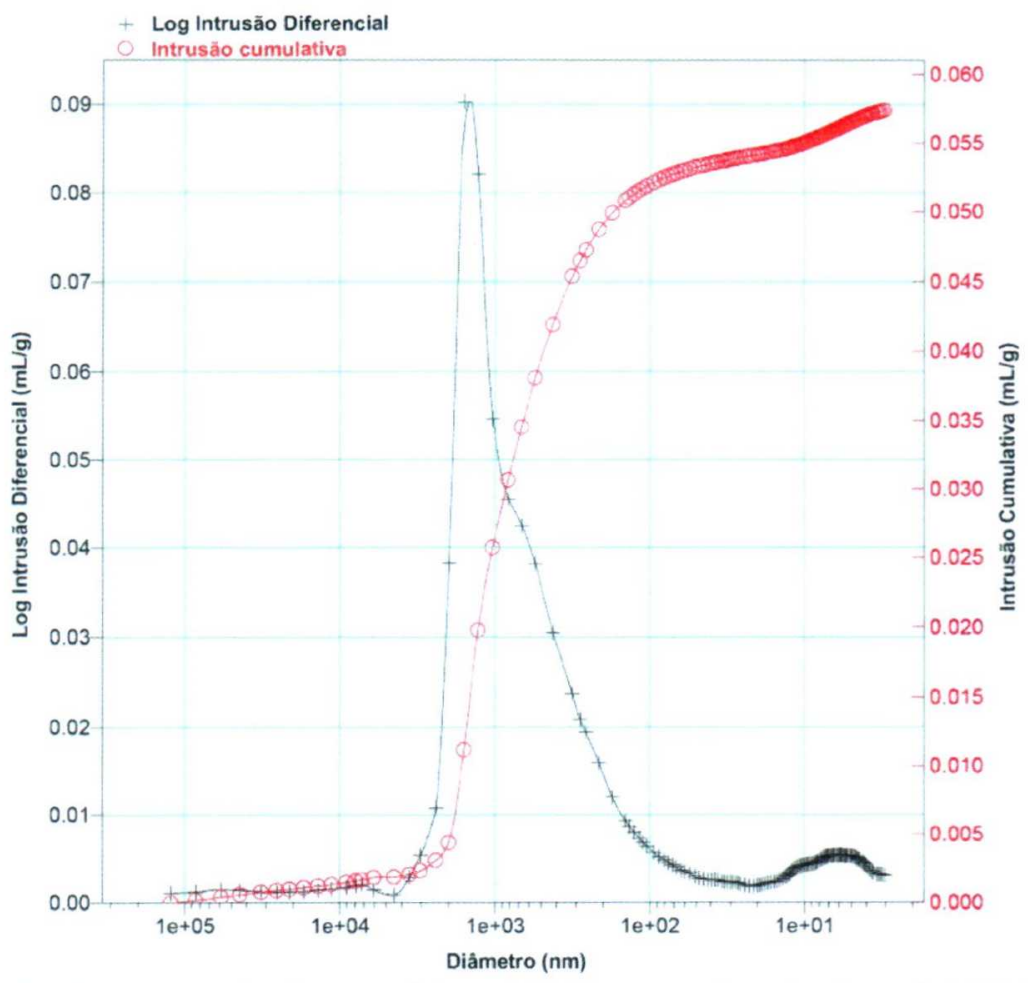

Figura 10.112 - Porosimetria de mercúrio em amostra do Arenito Itararé com grãos mais finos tratado com TC

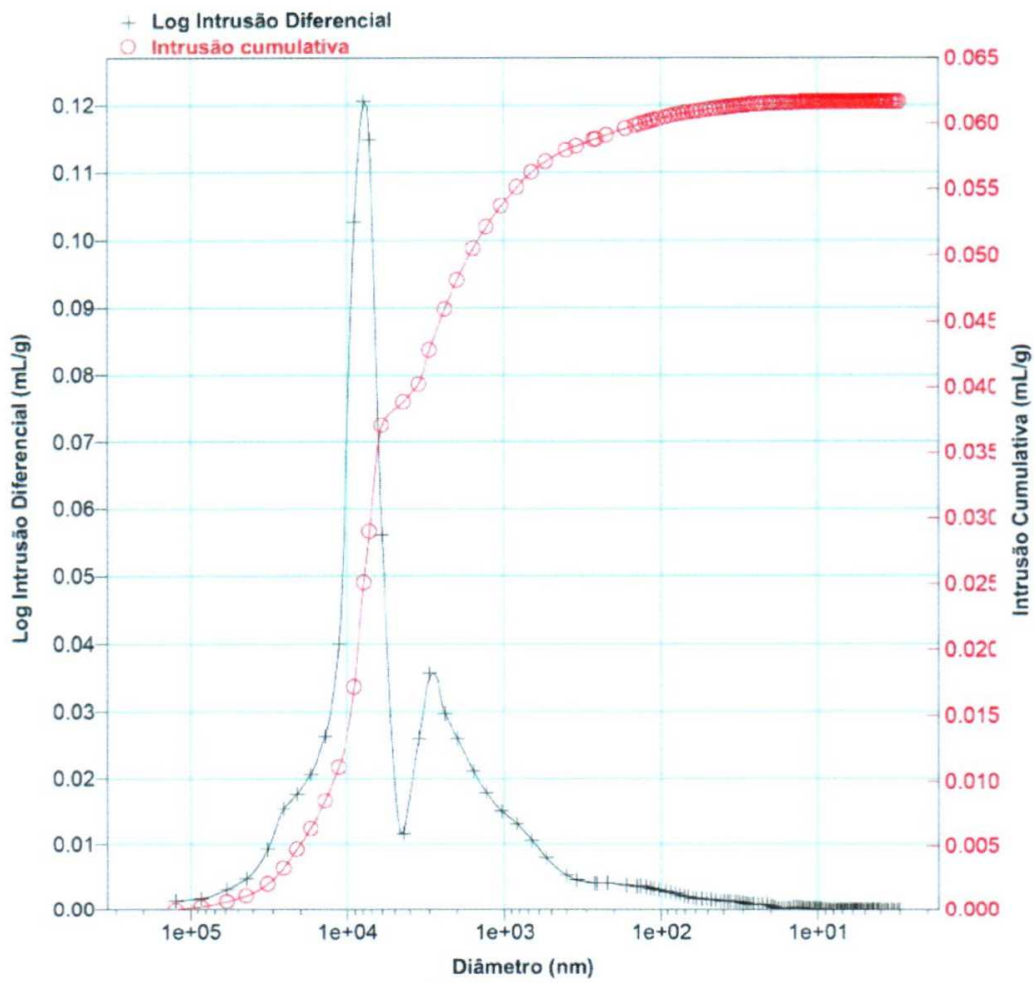

Figura 10.113 - Porosimetria de mercúrio em amostra do Arenito Itararé com grãos mais grossos tratado com TC. 
Quando aplicado o A antes do TC em amostra de grãos mais finos, surgiu um novo tamanho de poros: $1000 \mathrm{~nm}$. Provavelmente, pela cobertura das paredes dos poros, pelo produto. Os poros de $700 \mathrm{~nm}$ e de $8.000 \mathrm{~nm}$ foram eliminados. A porosidade foi de $10,8 \%$, e a intrusão cumulativa foi de $0,05 \mathrm{~mL} / \mathrm{g}$ (Figura 10.114). A porosidade foi de $14,5 \%$, para a amostra de grãos maiores e a intrusão cumulativa foi $0,06 \mathrm{~mL} / \mathrm{g}$ (Figura 10.115). Os poros de $10.000 \mathrm{~nm}$ diminuíram e surgiu um novo tamanho de poros: $5.000 \mathrm{~nm}$.

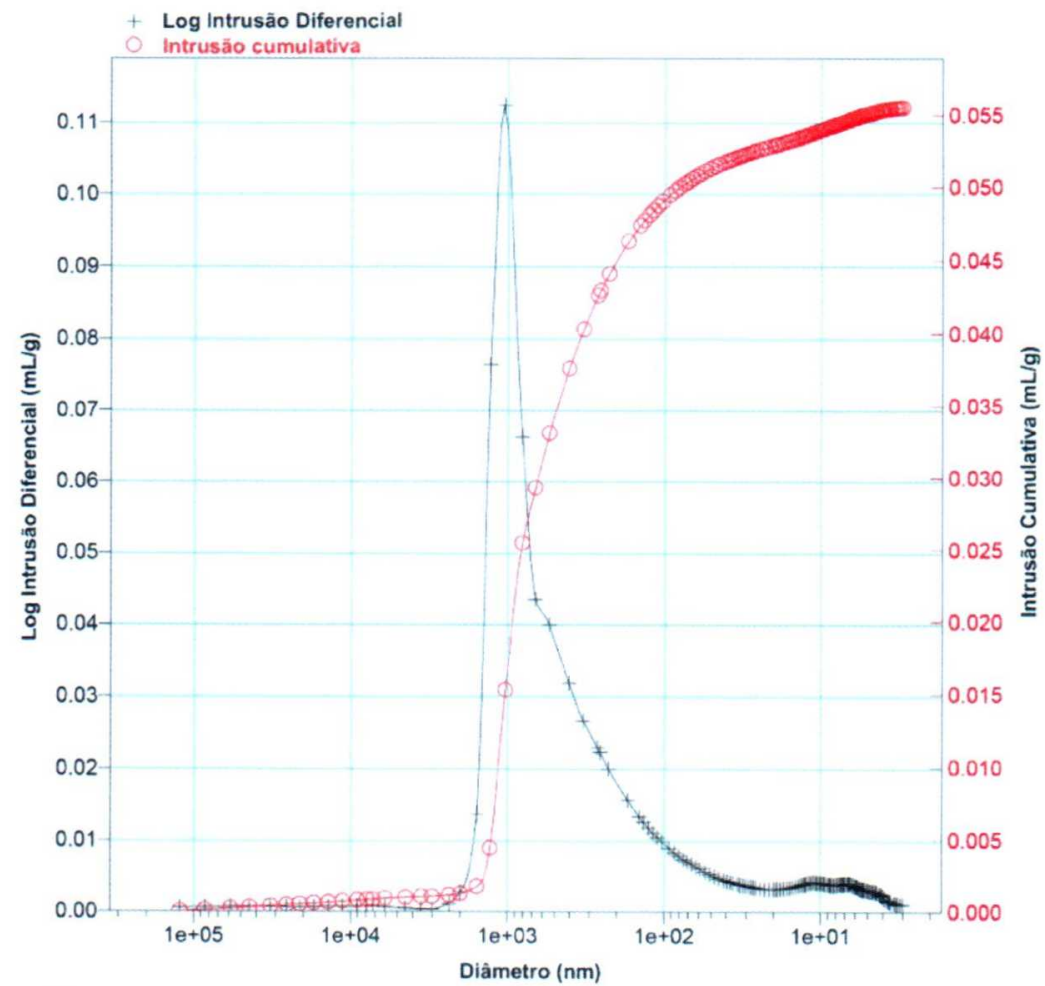

Figura 10.114 - Porosimetria de mercúrio de amostra do Arenito Itararé de grãos mais finos tratado com ATC. 


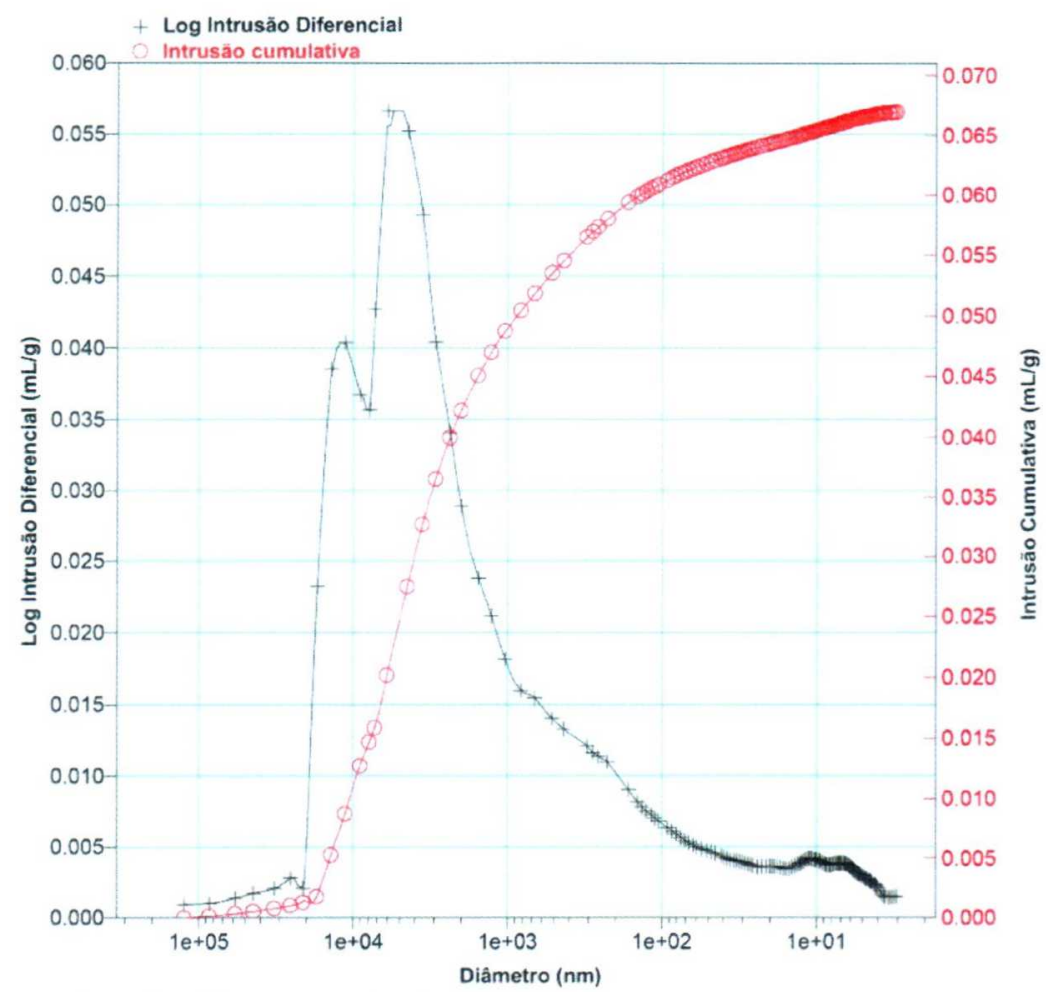

Figura 10.115 - Porosimetria de mercúrio de amostra de grãos mais grosseiros do Arenito Itararé tratado com ATC.

Observando-se a distribuição dos poros, AP foi o tratamento que menos a modificou. Essa conclusão converge com os valores de porosidade encontrados na rocha de grãos grossos, tratada. A diferença de porosidade de uma amostra para outra torna a avaliação da aplicação dos consolidantes bastante intrincada, dificultando a análise.

Observando-se a porosidade (Tabela 10.6), o A manteve os valores bastante próximos aos da rocha fresca, e $\mathbf{P}$ aumentou este parâmetro na amostra de grãos mais grossos.

De maneira geral, todo tratamento provoca alguma alteração na porosidade.

Tabela 10.6 - Porosidade total do Arenito Itararé fresco e tratado.

\begin{tabular}{lcc}
\hline Tratamento & $\begin{array}{c}\text { Porosidade }(\%)- \\
\text { poros grandes }\end{array}$ & $\begin{array}{c}\text { Porosidade }(\%)- \\
\text { poros pequenos }\end{array}$ \\
\hline Fresca & 17,1 & 14,1 \\
A & 16,1 & 15,1 \\
P & 29,7 & 14,4 \\
AP & 17,0 & 9,6 \\
TC & 1,8 & 13,1 \\
ATC & 14,5 & 10,8 \\
\hline
\end{tabular}




\section{- Universidade de São Carlos}

Os gráficos que serão mostrados a seguir, não tiveram seu eixo y padronizado, pois, para algumas amostras, os resultados foram muito maiores do que para outros. Isso faria com que a visualização dos gráficos com valores menores fosse bastante dificultada.

As amostras utilizadas para o ensaio de porosimetria de mercúrio, realizado no Brasil, não foram separadas em visualmente finas ou grossas. Portanto, os resultados não apresentarão esta divisão.

A amostra de Arenito Itararé fresca, submetida ao ensaio de porosimetria de mercúrio (Figura 10.116), mostrou distribuição trimodal com poros menores de $10 \mathrm{~nm}$, de $1.000 \mathrm{~nm}$ e $10.000 \mathrm{~nm}$. Sua porosidade total foi de $5,8 \%$ e sua intrusão cumulativa foi $0,02 \mathrm{~mL} / \mathrm{g}$. A porosidade e a intrusão cumulativa ficaram bem menores do que as das amostras frescas ensaiadas na Universidade de Princeton. Provavelmente, essa redução se deve a heterogeneidade do corpo rochoso do Arenito Itararé, já que a maioria das amostras seguiu este mesmo padrão de porosidade.

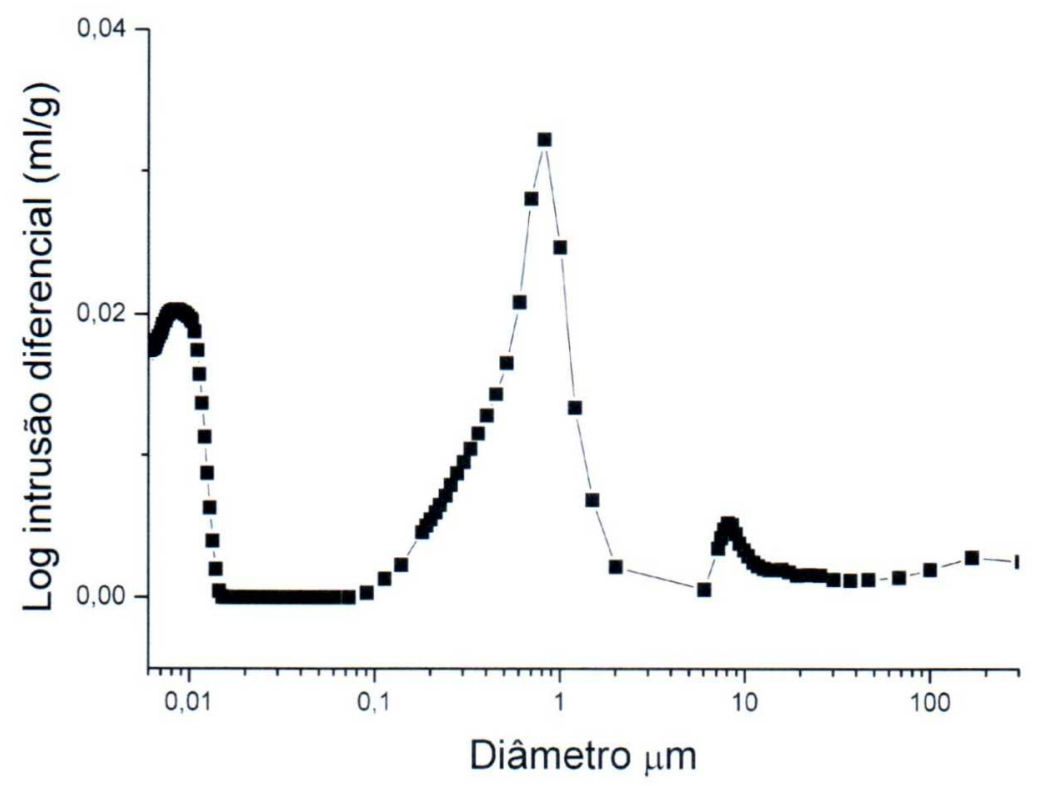

Figura 10.116 - Distribuição dos tamanhos dos poros da amostra de Arenito Itararé fresca.

A amostra tratada com A2 (Figura 10.117) apresentou aumento dos poros de $10.000 \mathrm{~nm}$ e leve diminuição na quantidade dos poros de $1.000 \mathrm{~nm}$ e menores que 10 $\mathrm{nm}$. A porosidade, provavelmente devido ao aumento dos poros de $10.000 \mathrm{~nm}$, ficou um pouco maior do que na rocha fresca $(6,5 \%)$. A intrusão cumulativa também foi um pouco maior do que na da amostra fresca $(0,03 \mathrm{~mL} / \mathrm{g})$. Este aumento também ocorreu nas amostras tratadas na Universidade de Princeton e mostradas anteriormente. 
Portanto, o produto age aumentando a porosidade da rocha, provavelmente devido ao deslizamento e rearranjo das placas de argilominerais.

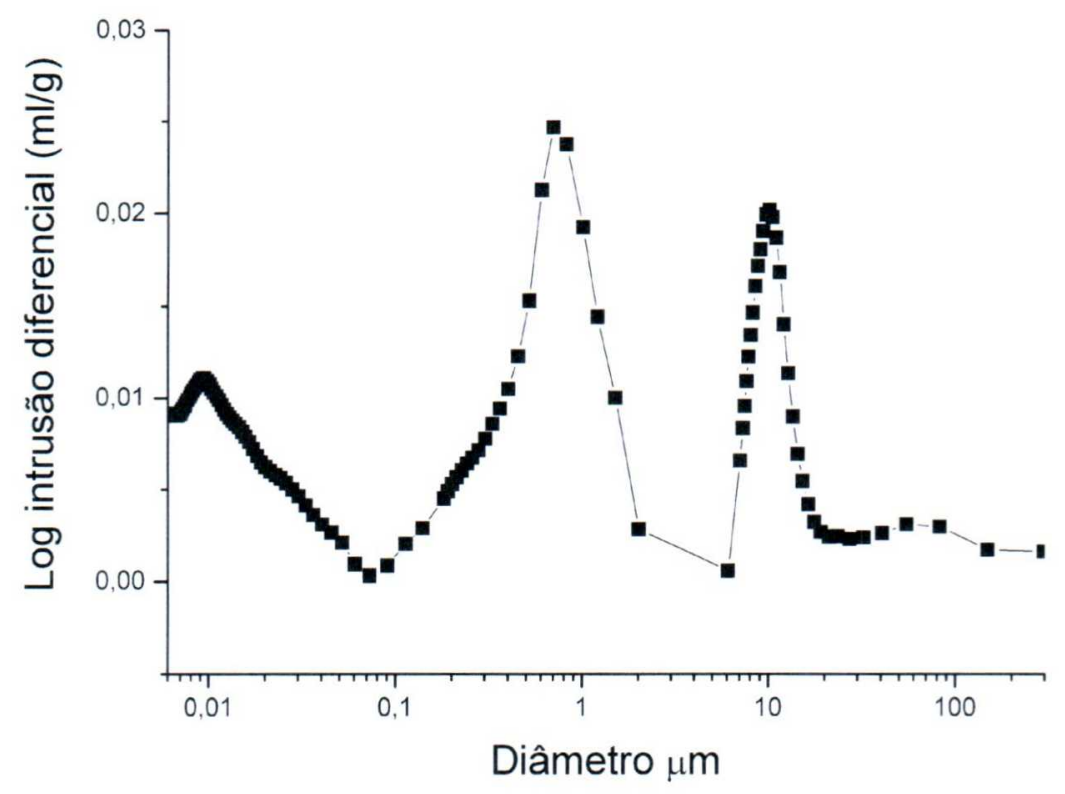

Figura 10.117 - Distribuição dos tamanhos dos poros da amostra de Arenito Itararé tratado com A2.

$\mathrm{Na}$ aplicação do A2 seguido pelo A3 (Figura 10.118), os poros de $10.000 \mathrm{~nm}$ e $10 \mathrm{~nm}$ foram, quase que totalmente, eliminados, permanecendo os de $1.000 \mathrm{~nm}$. Provavelmente, eles foram ocupados pelas estruturas em forma de flor, observadas anteriormente, ao MEV. A porosidade caiu para $4,2 \%$ e a intrusão cumulativa encontrada, foi de 0,02; também, menor do que a apresentada pela amostra fresca. 


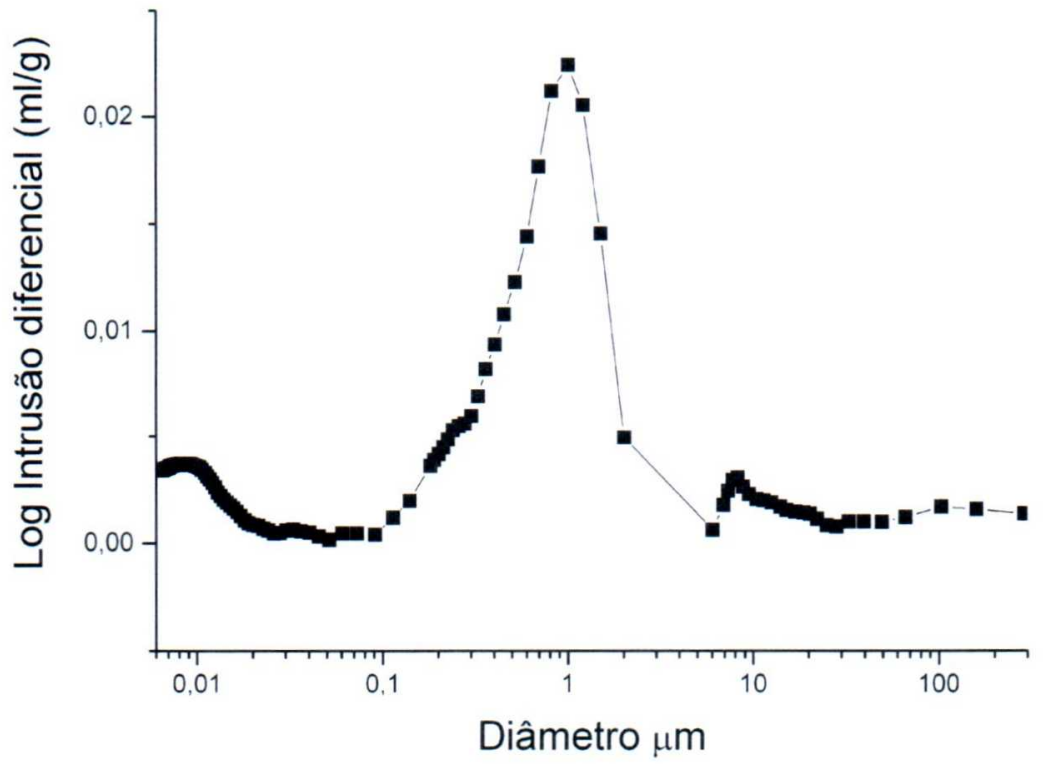

Figura 10.118 - Distribuição dos tamanhos dos poros de amostra de Arenito Itararé tratada com A23.

A amostra tratada com A2, seguida por A3 e seguida por A6 (A), apresentou os poros de $10 \mathrm{~nm}$ e $1.000 \mathrm{~nm}$, quase nulos (Figura 10.119). No entanto, a quantidade de poros de $10.000 \mathrm{~nm}$ aumentou consideravelmente. A porosidade ficou um pouco maior do que a da rocha tratada com A23 (4,6\%) mas, abaixo do que o valor encontrado na rocha fresca. A intrusão cumulativa apresentada foi de $0,02 \mathrm{~mL} / \mathrm{g}$; bastante próximo do valor apresentado pela rocha fresca.

Esses valores mostram que a exposição às cadeias maiores de carbono, auxilia na manutenção da porosidade inicial da rocha. Parece ser importante aplicar cadeias carbônicas maiores, consecutivamente, pois o A2 aumentou a porosidade inicial e facilitou a penetração dos A3 e A6. 


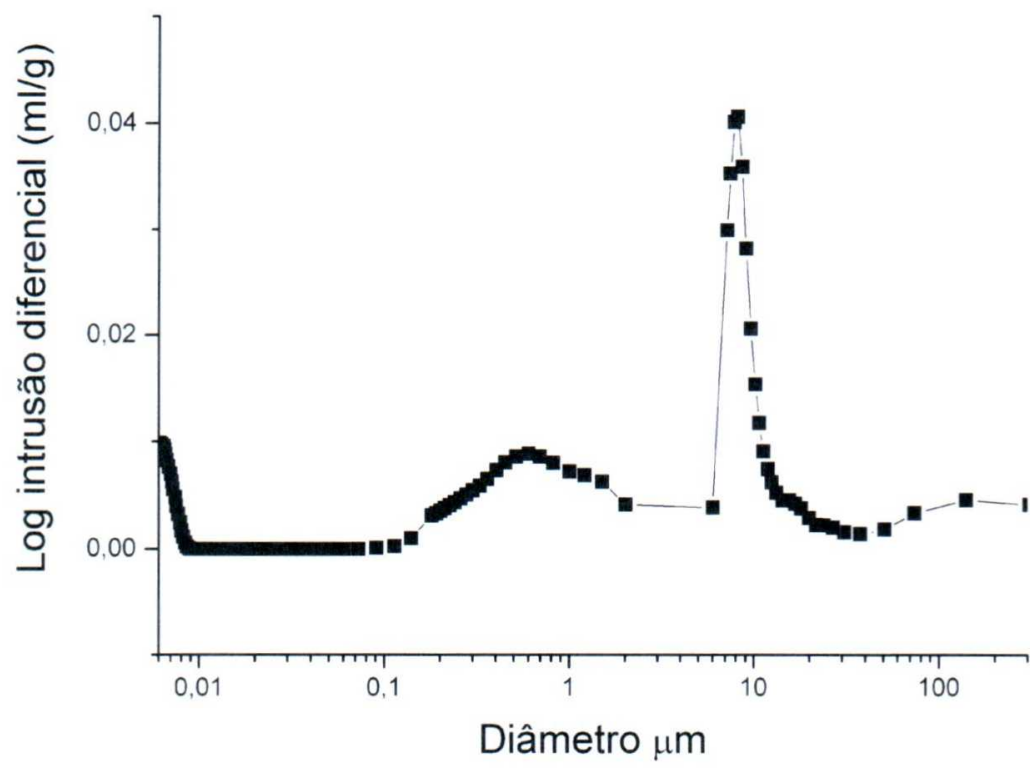

Figura 10.119 - Distribuição dos tamanhos dos poros de amostra de arenito Itararé tratada com A.

A amostra tratada com $\mathbf{P}$ apresentou sensível aumento dos poros menores que $10 \mathrm{~nm}$. No entanto, os poros de $1.000 \mathrm{~nm}$ e $10.000 \mathrm{~nm}$, foram eliminados (Figura 10.120). Possivelmente, o produto formado e observado ao MEV, anteriormente, também está presente nas paredes dos poros, diminuindo-os. A porosidade total aumentou para $36,4 \%$, devido ao aumento da quantidade de poros de $10.000 \mathrm{~nm}$ e a intrusão cumulativa foi de $0,17 \mathrm{~mL} / \mathrm{g}$. Tanto a porosidade, quanto a intrusão cumulativa ficaram bem mais altas do que as apresentadas pela amostra fresca. Uma outra amostra foi testada e os valores apresentados foram os mesmos. Isso mostra que os valores são devido a heterogeneidade da rocha e não um problema com o teste. 


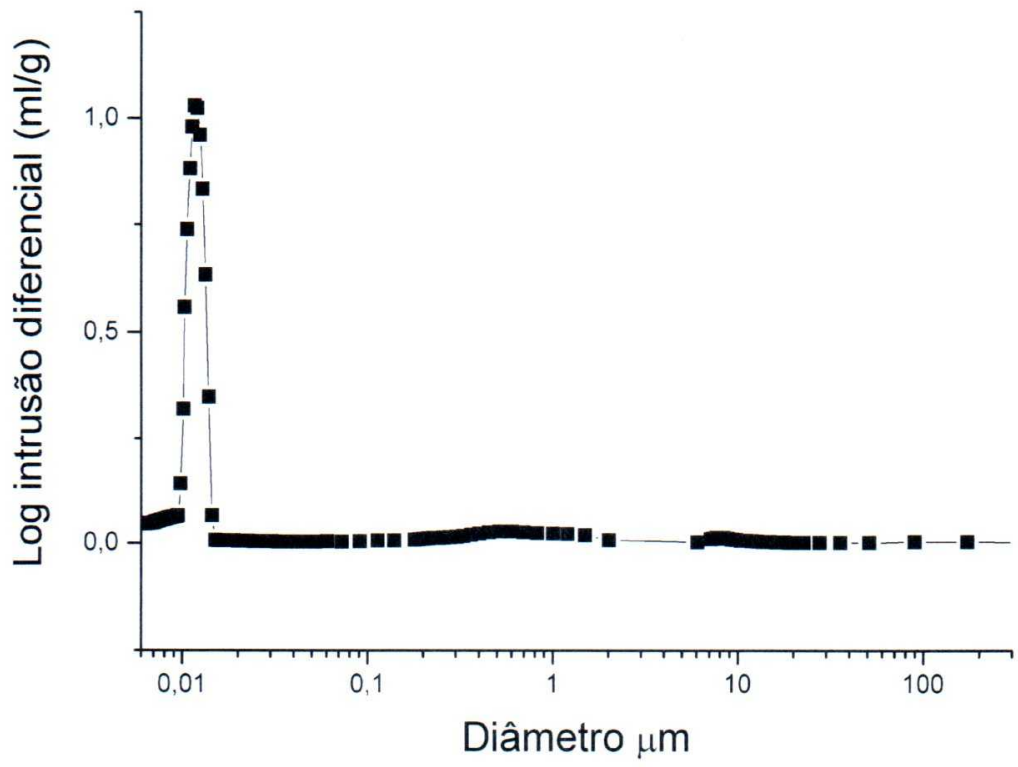

Figura 10.120 - Distribuição dos tamanhos dos poros da amostra de Arenito Itararé tratada com P.

Quando o $\mathrm{CaOH}$ (solução de hidróxido de cálcio) foi adicionado ao $\mathrm{P}(\mathrm{PCaOH})$, os poros menores que $10 \mathrm{~nm}$ foram eliminados, os poros de $1.000 \mathrm{~nm}$ foram diminuídos e os de $10.000 \mathrm{~nm}$ aumentaram (Figura 10.121). A porosidade ficou menor $(3,3 \%)$ do que a da rocha fresca. A intrusão cumulativa foi de $0,01 \mathrm{~mL} / \mathrm{g}$; metade da apresentada pela rocha fresca.

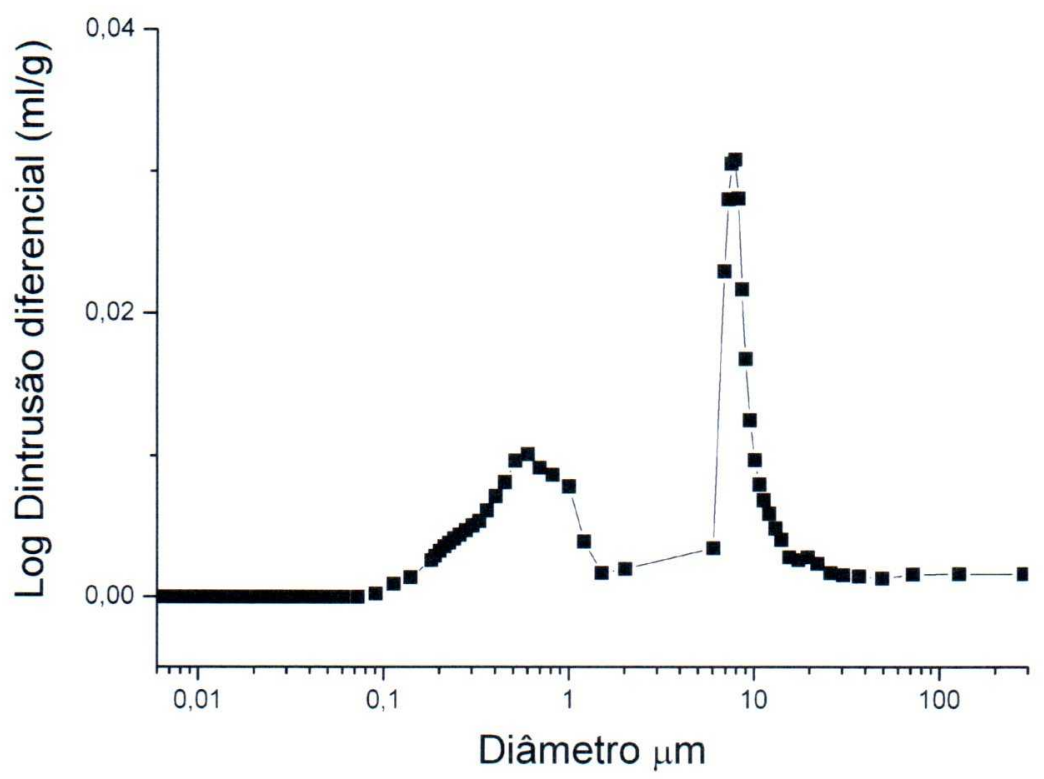

Figura 10.121 - Distribuição dos tamanhos dos poros da amostra de Arenito Itararé tratada com $\mathrm{PCaOH}$. 
As amostras tratadas por $\mathrm{CaOH}$ apresentaram os poros concentrados em 10 $\mathrm{nm}$ (Figura 10.122). A porosidade foi de $39,0 \%$ e a intrusão cumulativa foi de 0,18 $\mathrm{mL} / \mathrm{g}$; ambas bastante semelhantes à encontrada nas rochas tratadas com $\mathbf{P}$. Possivelmente trata-se da falta de homogeneidade do corpo rochoso, mais uma vez.

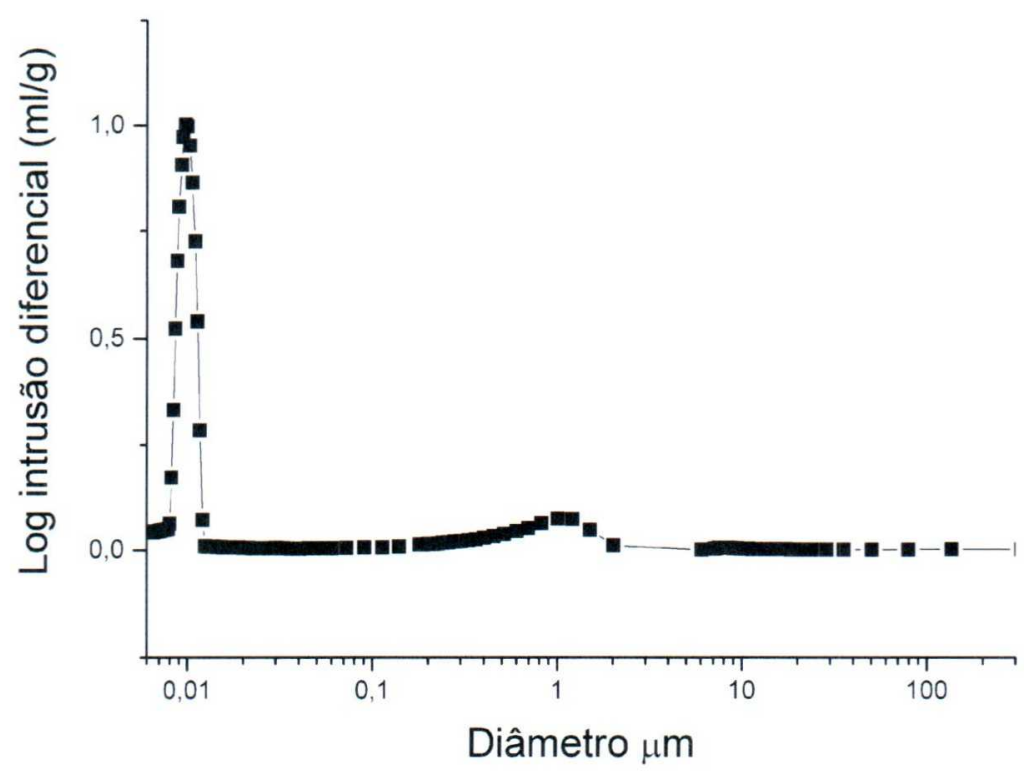

Figura 10.122 - Distribuição dos tamanhos dos poros da amostra de Arenito Itararé tratada com $\mathrm{CaOH}$.

Quando a amostra foi tratada com TW, os poros de $1.000 \mathrm{~nm}$ e $10.000 \mathrm{~nm}$ foram eliminados, e apareceram poros de $50 \mathrm{~nm}$ (Figura 10.123). A porosidade foi de $37,6 \%$ e a intrusão cumulativa foi de $0,15 \mathrm{~mL} / \mathrm{g}$; ambas, bem maiores do que as apresentadas ela rocha fresca. 


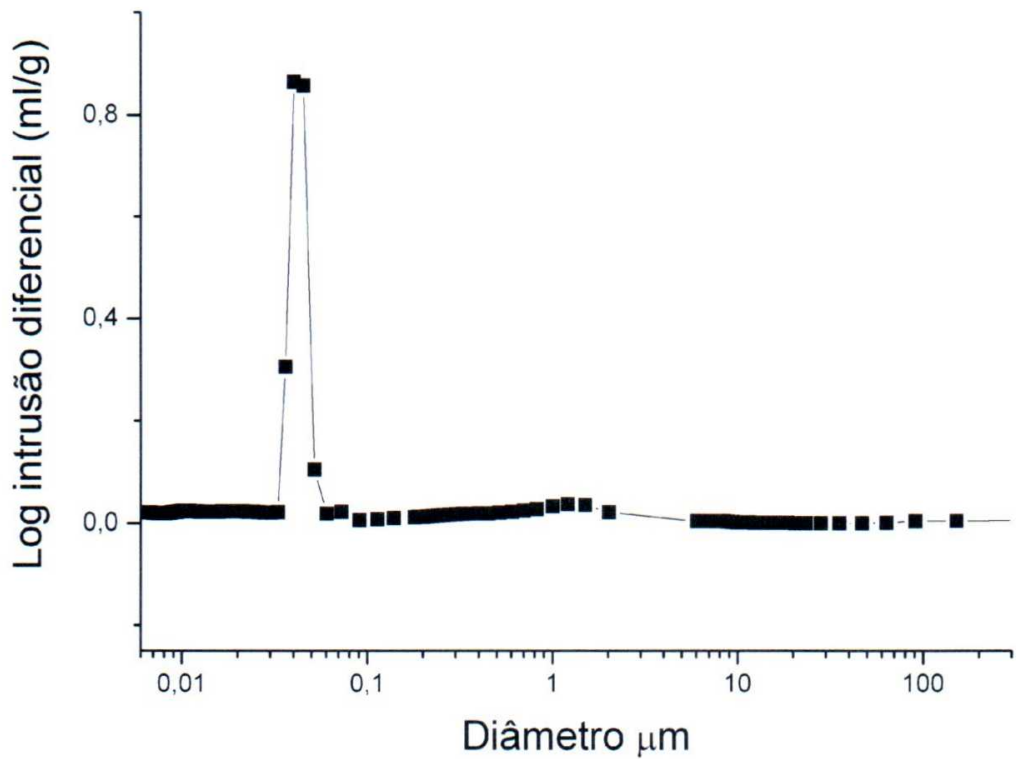

Figura 10.123 - Distribuição dos tamanhos dos poros de amostra de Arenito Itararé tratada com TW.

Quando foi aplicado o A antes do TW, os poros aumentaram, nos três picos observados em rocha fresca $(10,1.000$ e 10.000) (Figura 10.124). A porosidade e a intrusão cumulativa ficaram bem próximas a da rocha fresca $(6,1 \%$ e $0,03 \mathrm{~mL} / \mathrm{g}$, respectivamente). A amostra tratada com TW não apresentou porosidade semelhante a tratada com ATW. Portanto, os resultados não podem ser comparados.

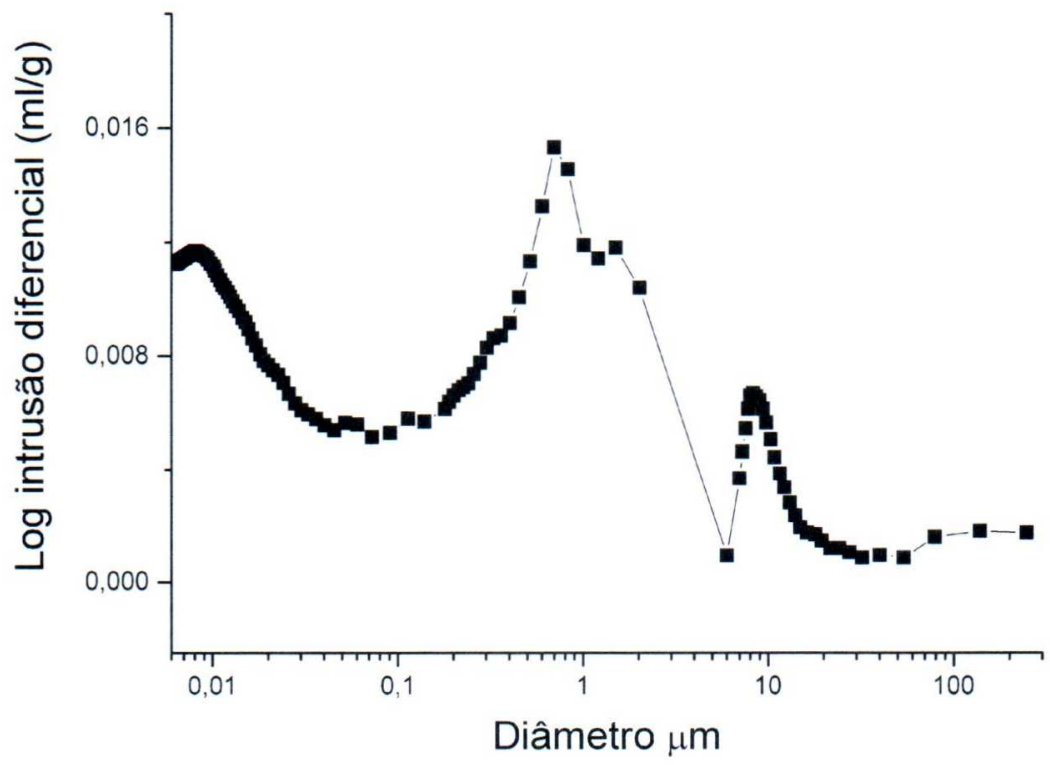

Figura 10.124 - Distribuição dos tamanhos dos poros de amostra de Arenito Itararé tratada com ATW. 
A amostra tratada com 808 apresentou os poros menores que $10 \mathrm{~nm}$, de 1.000 $\mathrm{nm}$ e $10.000 \mathrm{~nm}$ (Figura 10.125), como na rocha fresca, aumentando a quantidade de poros de $10.000 \mathrm{~nm}$. Tal fato, pode ser devido a uma diferença de porosidade da amostra, já que a porosidade do Arenito Itararé é acentuadamente heterogênea. A porosidade foi de $5,5 \%$ e a intrusão cumulativa foi de $0,02 \mathrm{~mL} / \mathrm{g}$; ambas bem semelhantes as da amostra fresca.

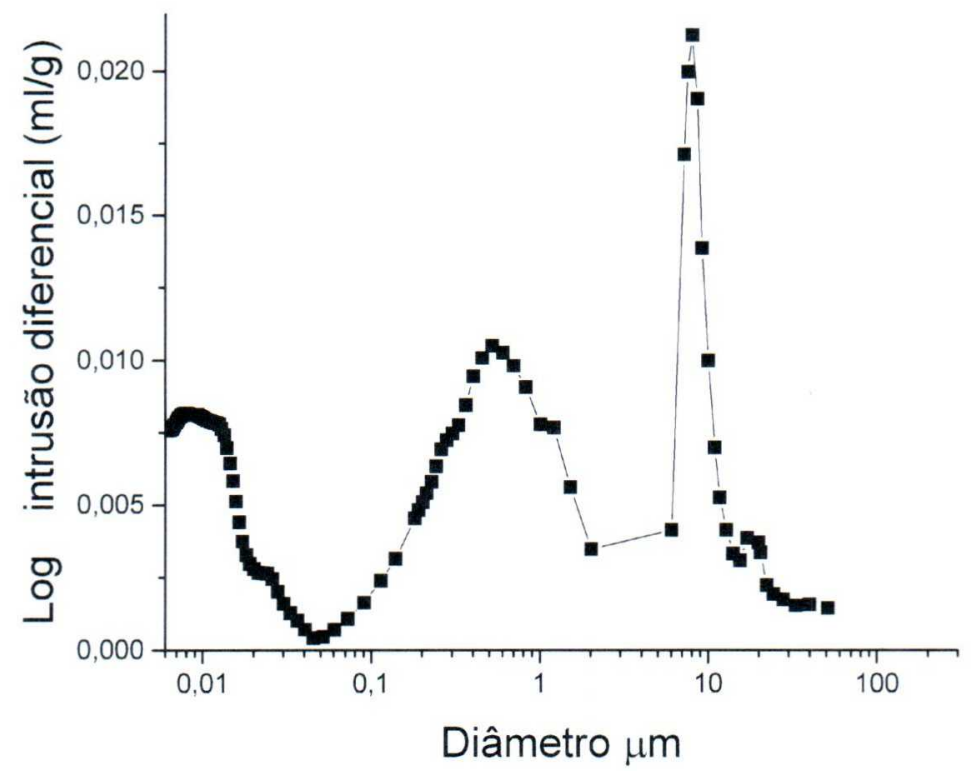

Figura 10.125 - Distribuição dos tamanhos dos poros de amostra de Arenito Itararé tratada com 808

As amostras tratadas com A808, apresentaram os poros menores que $10 \mathrm{~nm} e$ $1.000 \mathrm{~nm}$ diminuídos, quando comparados com a rocha fresca (Figura 10.126). A porosidade foi de $4,4 \%$ e a intrusão cumulativa foi de $0,02 \mathrm{~mL} / \mathrm{g}$; ambas, um pouco menores do que as apresentadas pela rocha fresca. Portanto, para o caso do 808, o pré-tratamento com A não foi benéfico. 


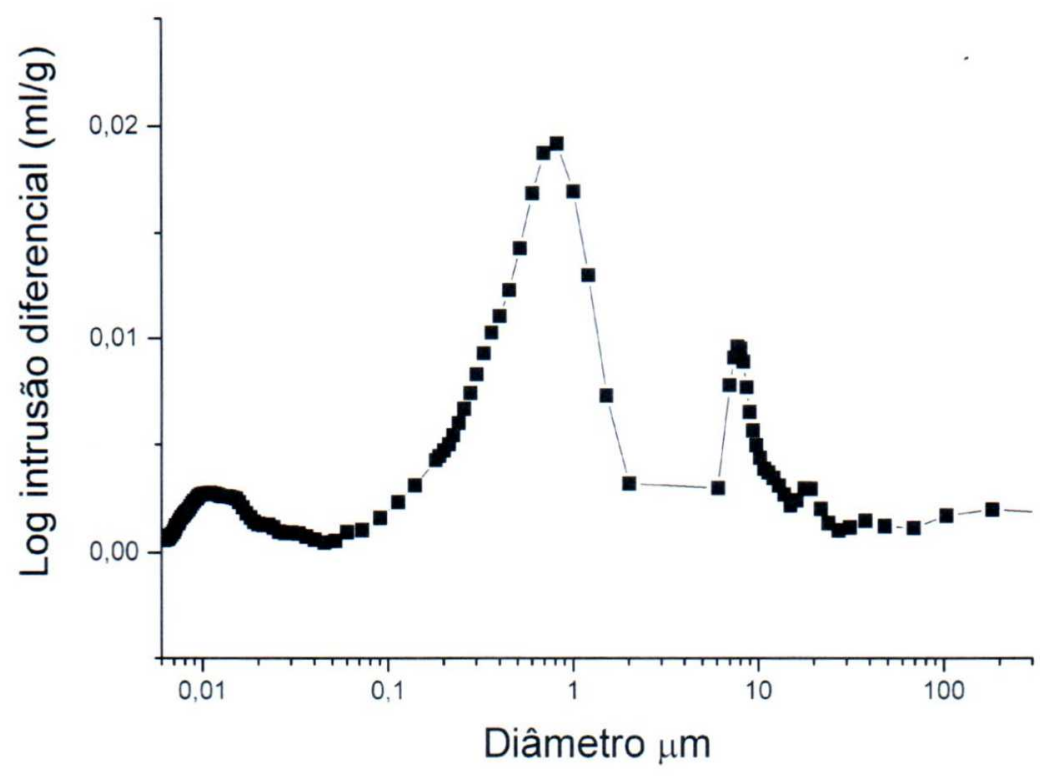

Figura 10.126 - Distribuição dos tamanhos dos poros de amostra de Arenito Itararé tratada com A808.

O 630 eliminou os poros menores que $10 \mathrm{~nm}$ e diminuiu os de 10.000 (Figura 10.127). Todavia, os poros de $1.000 \mathrm{~nm}$ foram aumentados. A porosidade total diminuiu para $4,1 \%$ e a intrusão cumulativa diminuiu para $0,02 \mathrm{~mL} / \mathrm{g}$.

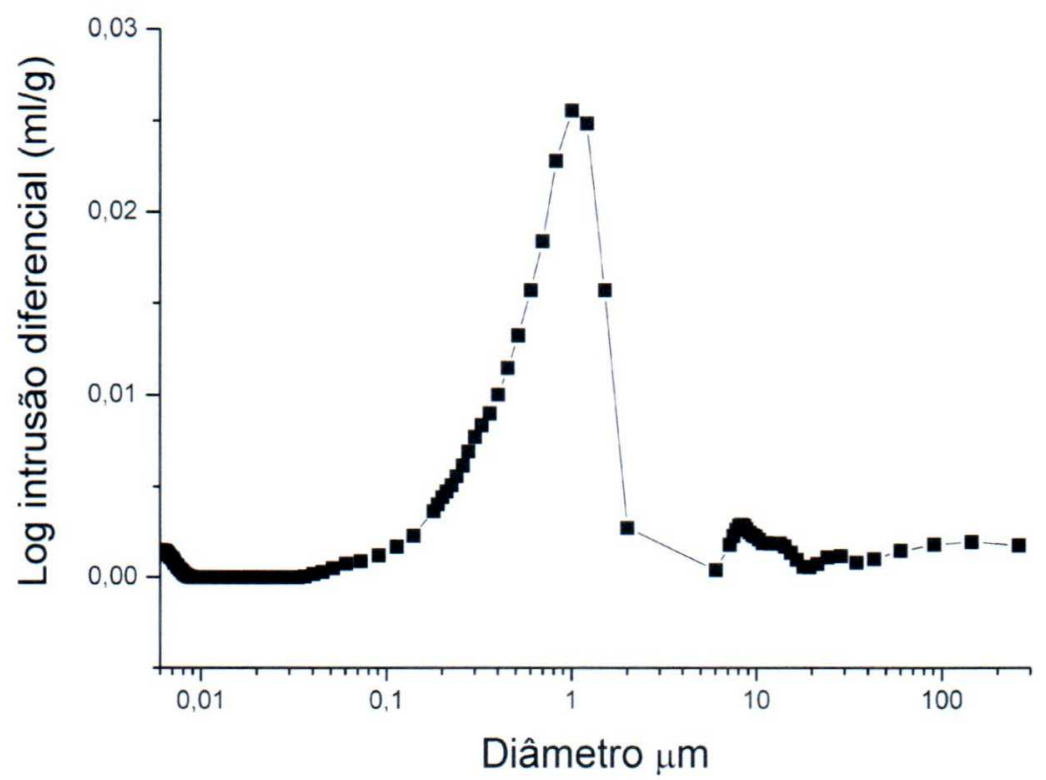

Figura 10.127 - Distribuição dos tamanhos dos poros de amostra de Arenito Itararé tratada com 630 . 
A amostra em que foi aplicado o AG, eliminou os poros menores que $10 \mathrm{~nm}$ (Figura 10.128), como observado ao MEV. Nota-se também o aumento dos poros de $10.000 \mathrm{~nm}$ e manutenção dos poros de $1.000 \mathrm{~nm}$. A porosidade ficou em 5,4\% e a intrusão cumulativa em $0,02 \mathrm{~mL} / \mathrm{g}$; ambas bem semelhantes aos valores apresentados pela rocha fresca.

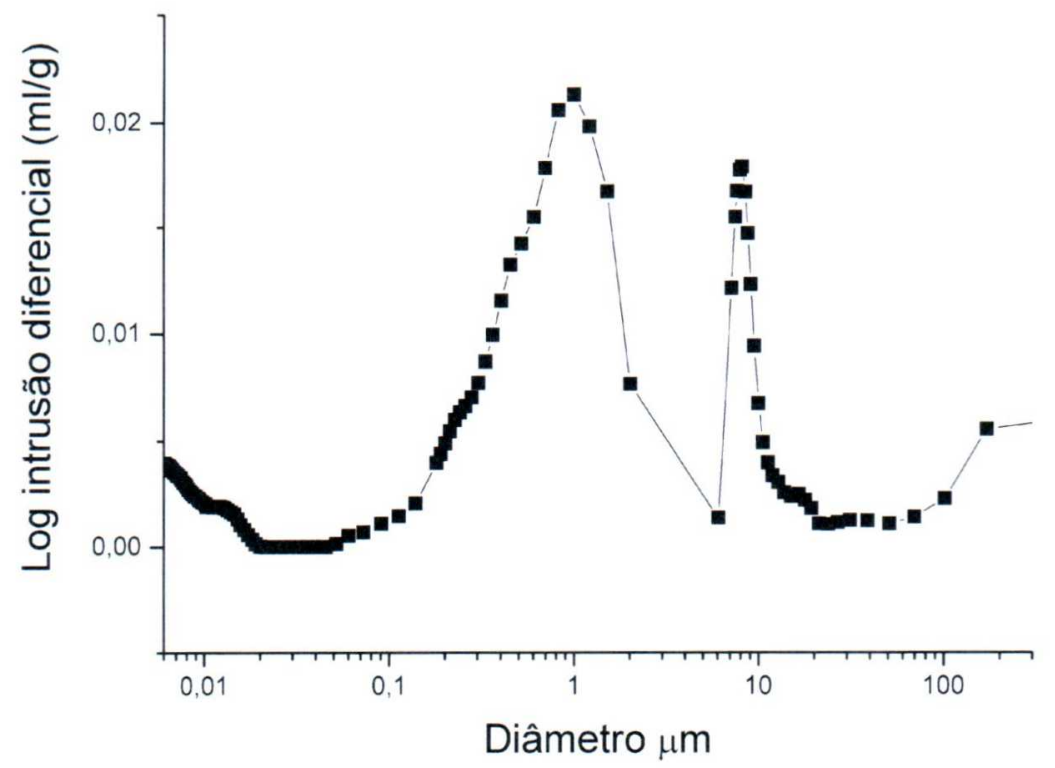

Figura 10.128 - Distribuição dos tamanhos dos poros de amostra de Arenito Itararé tratada com AG.

Todos os valores de porosidade e intrusão cumulativa encontram-se na Tabela 10.7

Com relação aos consolidantes $\mathrm{P}$ e $\mathrm{CaOH}$, devido ao fato da heterogeneidade da porosidade da rocha, não é possível verificar qual deles modificou menos a dinâmica dos poros. No entanto, se compararmos todas as rochas amostradas que apresentaram porosidade semelhante, não há muita diferença entre a porosidade delas. O TW apresentou apenas poros de $50 \mathrm{~nm}$.

O ATW mostrou distribuição de poros e porosidade bastante semelhante a da amostra fresca.

O A2, apesar de não ser um consolidante, quase não alterou a distribuição dos poros.

O hidrofugante que menos alterou a porosidade foi $\bigcirc 808$. $\bigcirc 630$ mudou bastante a distribuição dos poros. O AG não alterou muito a porosidade.

Com exceção ao $\mathrm{CaOH}$, os produtos não parecem ter alterado substancialmente a porosidade total. Mas, alguns, como citado acima, modificaram a distribuição dos poros. 
Tabela 10.7 - Valores de porosidade e intrusão cumulativa nos diversos tratamentos aplicados no Arenito Itararé.

\begin{tabular}{lccc}
\hline \multicolumn{1}{c}{ Tratamento } & Porosidade $(\%)$ & ${\text { Variação }(\%)^{*}}^{\text {Intrusão }}$ & $\begin{array}{c}\text { Indativa }(\mathrm{mL} / \mathrm{g}) \\
\text { cumula }\end{array}$ \\
\hline Fresca & 5,8 & - & 0,02 \\
A2 & 6,5 & 12 & 0,03 \\
A23 & 4,2 & -28 & 0,02 \\
A236 & 4,6 & -20 & 0,02 \\
P & 36,4 & 528 & 0,17 \\
PCaOH & 3,3 & -43 & 0,01 \\
CaOH & 39,0 & 572 & 0,18 \\
TW & 37,6 & 548 & 0,17 \\
ATW & 6,1 & 5 & 0,03 \\
808 & 5,5 & -5 & 0,02 \\
A808 & 4,4 & -24 & 0,02 \\
630 & 4,1 & -30 & 0,02 \\
AG & 5,4 & -7 & 0,02 \\
\hline
\end{tabular}

* Variação em comparação com a amostra fresca.

Comparando os dados encontrados na bibliografia e os obtidos nestes dois ensaios, verifica-se que os valores encontrados na Universidade de Princeton, estão mais próximos aos encontrados por Del Lama et al. (2008), que foi de $10 \%$ a $18 \%$. Os valores encontrados em amostra fresca, no ensaio na Universidade de São Carlos, são bem mais baixos do que os encontrados por estes autores.

\subsubsection{Saturação a vácuo}

O ensaio de saturação a vácuo, foi realizado na Universidade de Princeton.

A porosidade encontrada para o Arenito Itararé fresco, foi de $7,5 \%$.

Tanto o teste de saturação a vácuo, quanto o de porosimetria de mercúrio, determinam a porosidade da rocha. Se forem comparados os resultados obtidos em ambos os testes na Universidade de Princeton (14\% a $17 \%$ na porosimetria de mercúrio), nota-se que são diferentes. No ensaio de porosimetria de mercúrio realizado na Universidade de São Carlos, a porosidade da rocha fresca foi de 5,8\%, bem menor do que a encontrada na Universidade de Princeton, porém, mais próxima ao valor encontrado no teste de saturação a vácuo. Portanto, presume-se que há uma grande variação de porosidade, causada pela variação do corpo rochoso. 
A falta de correlação ocorre em outros experimentos utilizando máquinas diferentes, como mostram Pejon e Zuquete (2006), realizando outros ensaios, também notaram que não é possível comparar valores obtidos em máquinas diferentes.

\subsubsection{Resistência à flexão}

O teste não apresentou dados precisos, pois as amostras não puderam ser cortadas de modo adequado. Estas precisam ser longas, finas e lados perfeitamente paralelos.

Os resultados encontram-se reunidos no Anexo II.

\subsubsection{Ciclos de saturação e secagem}

\section{- Universidade de Princeton}

\section{- Espectrofotometria}

As medidas de espectrofotometria, nas amostras tratadas na Universidade de Princeton, foram realizadas no Laboratório de Métodos não Destrutivos, do Instituto de Geociências, da Universidade de São Paulo.

Infelizmente, não existem os dados de cor antes de serem tratadas, pois o equipamento para medir esta variável não estava disponível no laboratório de Princeton. Portanto, o valor da rocha fresca é a média de 45 medidas realizadas em rochas frescas.

Com relação ao parâmetro $\mathrm{L}$, a amostra consolidada com $\mathrm{P}$ mostrou o menor escurecimento e as tratadas com TC e ATC, os maiores. O pré-tratamento com A, também causou escurecimento (Figura 10.129).

$\mathrm{O}$ desvio padrão foi $\mathbf{A}=2,5, \mathbf{P}=2,4, \mathbf{T C}=1,3$ e $\mathbf{A T C}=1,4$. 


\section{Parâmetro L}

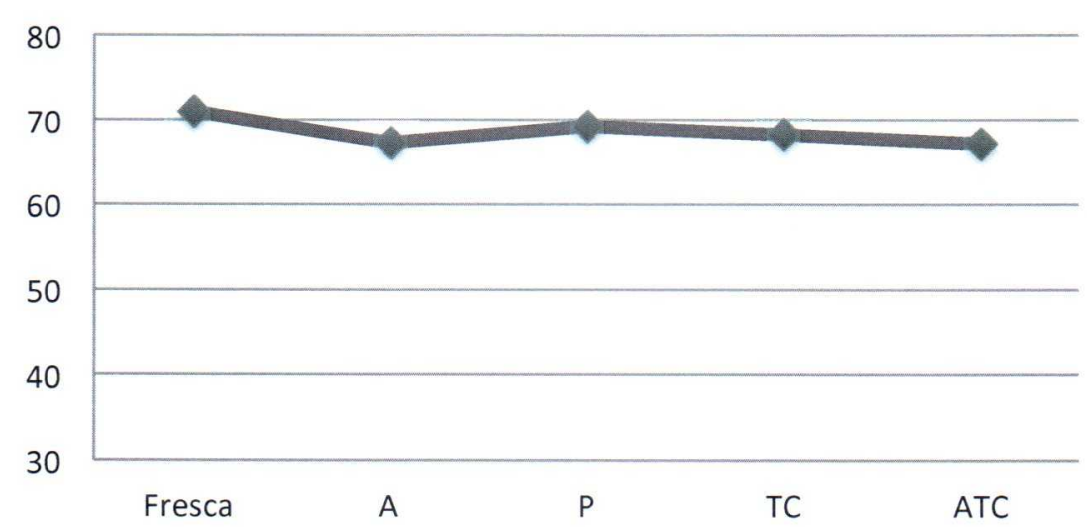

Figura 10.129 - Parâmetro L médio para amostras com diversos tratamentos realizados na Universidade de Princeton, comparado com o valor médio de amostras frescas.

Quando observado o parâmetro a* (Figura 10.130), os valores estão bem próximos ao valor médio da amostra fresca. O desvio padrão foi 0,6 para $P$, TC e ATC. Para A, o desvio padrão foi de 0,8.

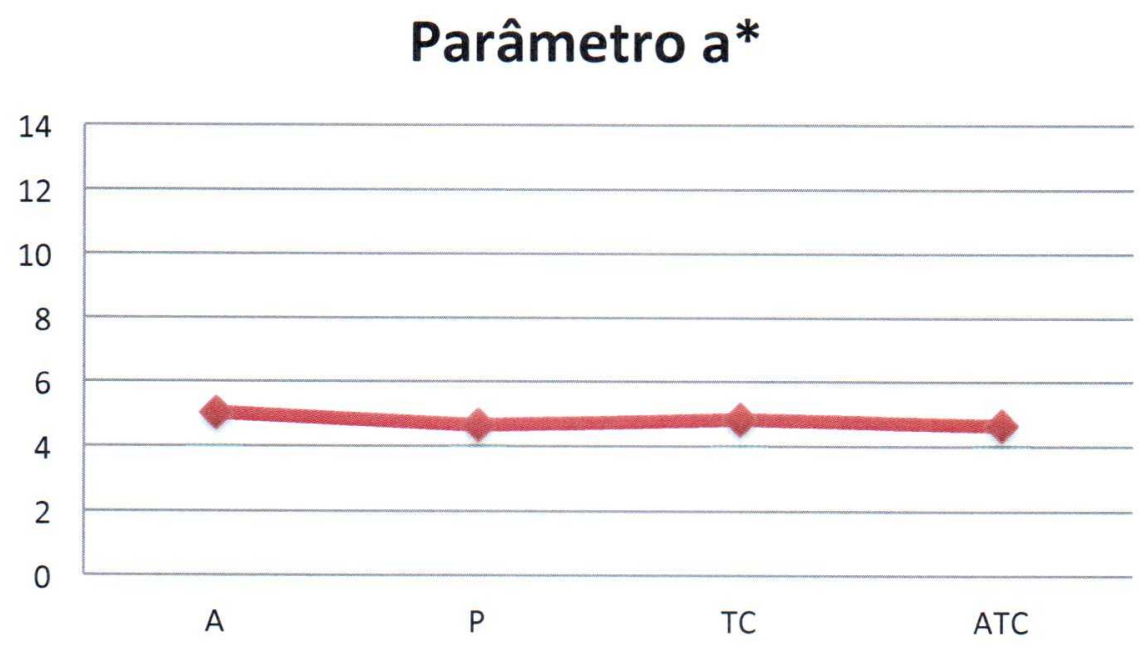

Figura 10.130 - Parâmetro $a^{*}$ médio para amostras tratadas na Universidade de Princeton, comparado com o valor médio de amostras frescas.

Observando o parâmetro b* (Figura 10.131), todas as amostras apresentaram valores mais baixos que os encontrados na amostra fresca. O consolidante que mais alterou este parâmetro, foi o ATC e os que menos alteraram foram A, P e TC. Mas, os valores dos três produtos, estão bem próximos.

O desvio padrão foi $\mathbf{A}=2,0, \mathbf{P}=1,8, \mathrm{TC}=0,9$ e $\mathbf{A T C}=0,5$. 


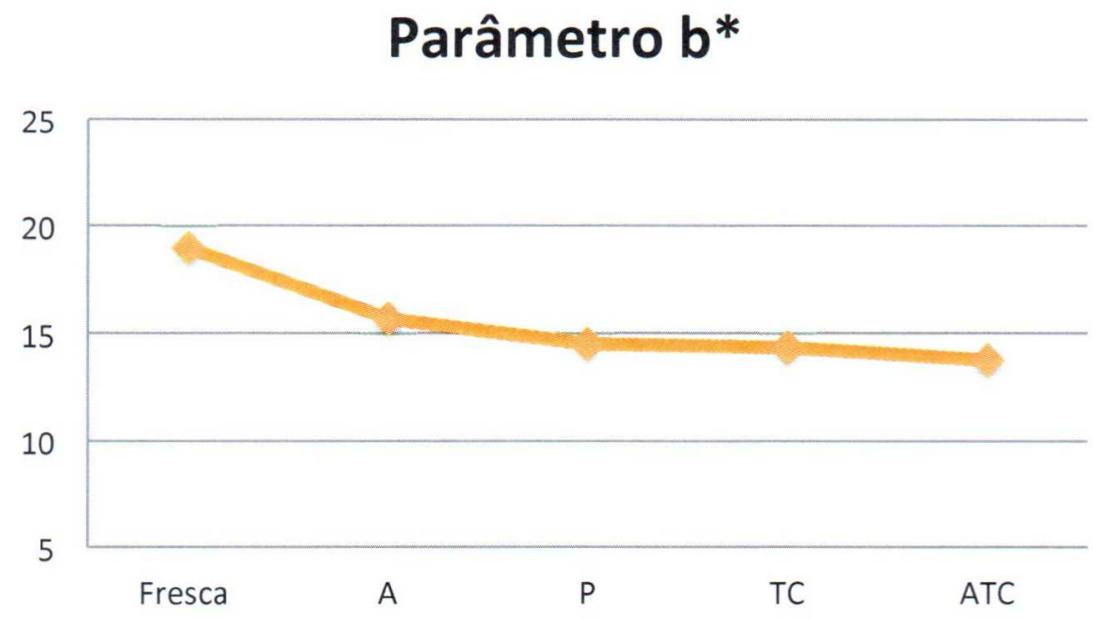

Figura 10.131 - Parâmetro b* médio das amostras tratadas na Universidade de Princeton em comparação com amostra fresca.

Portanto, os produtos que menos alteraram a coloração, considerando os três parâmetros, foi o $\mathbf{P}$.

\section{- Velocidade de ondas ultrassônicas}

As amostras frescas, após os ciclos de saturação e secagem, apresentaram uma queda média de $6,5 \%$ na velocidade de ondas ultrassônicas. As amostras tratadas com ATC apresentaram um decréscimo médio de 13,5\%, TC 9,4\%, A 7,9\% e P $7,8 \%$. No entanto, se olharmos para os valores da velocidade (Tabela 10.8), todos eles são mais altos do que os valores apresentados pela amostra fresca, mesmo após a redução pela deterioração. O mais alto de todos é o valor apresentado pelas amostras tratadas com ATC, seguido pelas tratadas com TC, A e P. As amostras tratadas com AP não foram ensaiadas pois mostraram maus resultados no ensaio de capilaridade, devido à reatividade dos produtos. 
Tabela 10.8 - Velocidade de ondas ultrassônicas em amostras antes e após o teste de ciclos de saturação em água e secagem.

\begin{tabular}{|c|c|c|c|c|}
\hline Tratamento & $\begin{array}{c}\text { Velocidade } \\
\text { saturado antes } \\
\text { do teste }(\mathrm{km} / \mathrm{s})\end{array}$ & Média & $\begin{array}{l}\text { Velocidade } \\
\text { saturado } \\
\text { depois do } \\
\text { teste }(\mathrm{km} / \mathrm{s}) \\
\end{array}$ & Média \\
\hline \multirow[t]{2}{*}{ Fresca } & $\begin{array}{l}2,5 \\
2,7\end{array}$ & 2,7 & $\begin{array}{l}2,4 \\
2,5\end{array}$ & \multirow[t]{2}{*}{2,5} \\
\hline & 2,9 & & 2,7 & \\
\hline A & $\begin{array}{l}3,1 \\
3,2\end{array}$ & 3,1 & $\begin{array}{l}2,6 \\
2,7\end{array}$ & 2,6 \\
\hline \multirow{5}{*}{ TC } & $\begin{array}{l}3,7 \\
3,8\end{array}$ & \multirow{5}{*}{3,3} & $\begin{array}{l}3,2 \\
3,2\end{array}$ & \multirow{5}{*}{3,0} \\
\hline & 3,6 & & 3,2 & \\
\hline & 3,1 & & 2,8 & \\
\hline & 3,1 & & 2,8 & \\
\hline & 3,1 & & 2,8 & \\
\hline \multirow{5}{*}{ ATC } & $\begin{array}{l}3,6 \\
3,7\end{array}$ & \multirow{5}{*}{3,6} & $\begin{array}{l}3,3 \\
3,3\end{array}$ & \multirow{5}{*}{3,1} \\
\hline & 3,6 & & 3,2 & \\
\hline & 3,4 & & 3,1 & \\
\hline & 3,4 & & 3,0 & \\
\hline & 3,3 & & 2,9 & \\
\hline \multirow{5}{*}{$\mathbf{P}$} & $\begin{array}{l}2,9 \\
3,1\end{array}$ & \multirow{5}{*}{2,9} & $\begin{array}{l}2,6 \\
2,6\end{array}$ & \multirow{5}{*}{2,6} \\
\hline & 3,1 & & 2,6 & \\
\hline & 3,1 & & 2,5 & \\
\hline & 3,1 & & 2,6 & \\
\hline & 3,2 & & 2,7 & \\
\hline
\end{tabular}

\section{- Universidade de São Paulo}

\section{- Espectrofotometria}

Observando a variação do parâmetro L (Figura 10.132) nas amostras fresca, aquecida, tratada e após os ciclos de saturação e secagem, pode-se dizer que todos os procedimentos, de um modo geral, levam ao escurecimento da rocha. Os tratamentos que menos alteram a luminosidade são, em ordem decrescente: $\mathbf{P}, \mathbf{C a O H}$, $\mathrm{PCaOH}, \mathrm{AP}$ e A. Os que mais escureceram a rocha são: ATW e AG. 


\section{Parâmetro L}

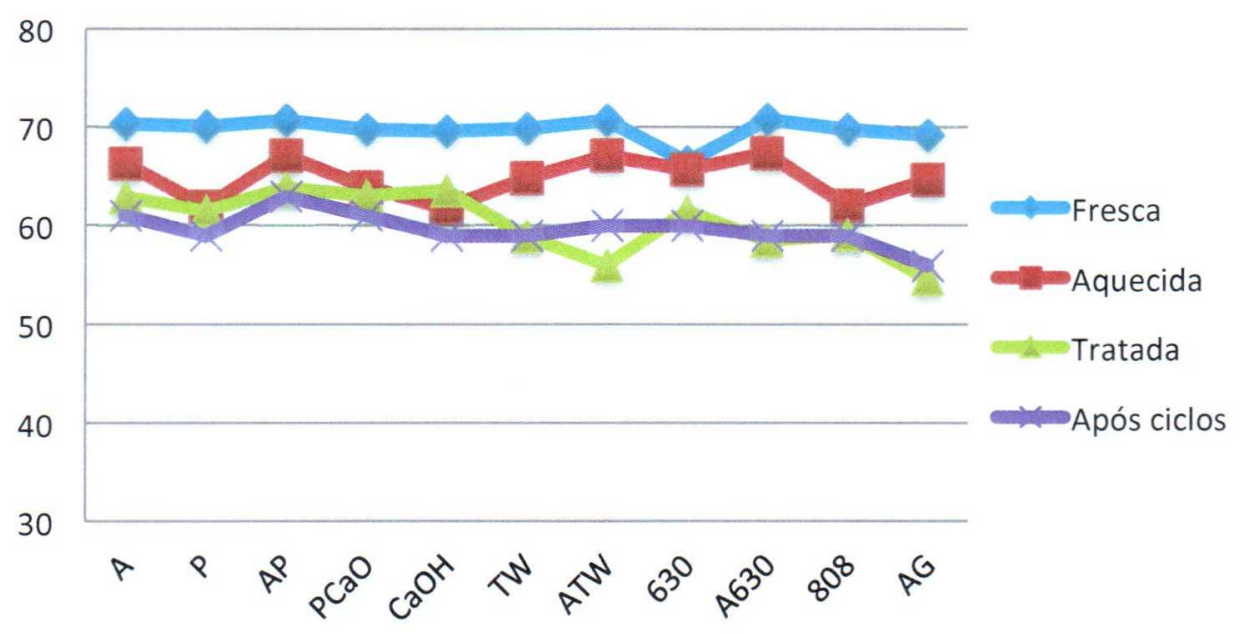

Figura 10.132 - Valores médios do parâmetro L para amostras frescas, aquecidas, tratadas e após os ciclos de saturação e secagem.

Observando-se o parâmetro a* (Figura 10.133), o aquecimento e o tratamento tendem a avermelhar e manter esse avermelhamento. Os ciclos de saturação e secagem, tendem a diminuir essa coloração provocada pelo aquecimento.

Os tratamentos que tendem a aproximar essa tonalidade da cor original da rocha, são todos os que passaram pelo pré-tratamento com $\mathbf{A}$.

Após os ciclos, os tratamentos que estavam com o parâmetro $a^{*}$ mais próximo da rocha fresca foram AP, PCaOH, 630 e ATW.

\section{Parâmetro a*}

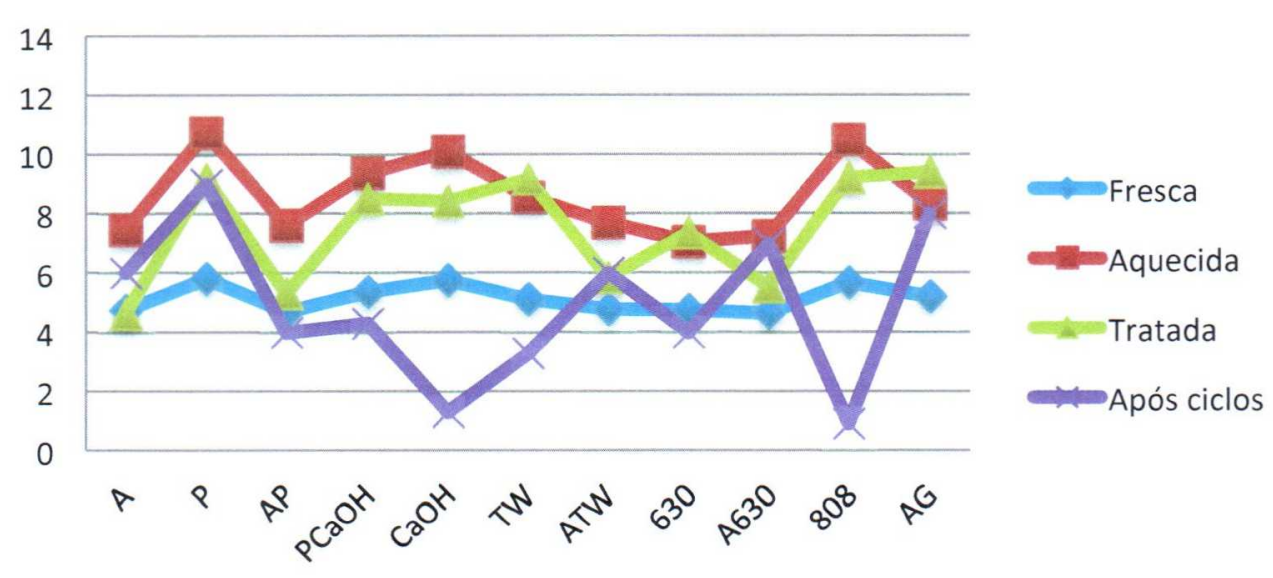

Figura 10.133 - Parâmetro a* médio para amostras frescas, aquecidas, tratadas e após os ciclos de saturação e secagem. 
Com relação ao parâmetro b* (Figura 10.134), a própria rocha fresca possui valor alto de desvio padrão (Tabela 10.9). Com exceção aos tratamentos com $\mathbf{C a O H}$, 630, AG e A, todos os outros mostraram valores bastante próximos a rocha fresca, em todas as etapas (aquecimento, tratamento e ciclos).

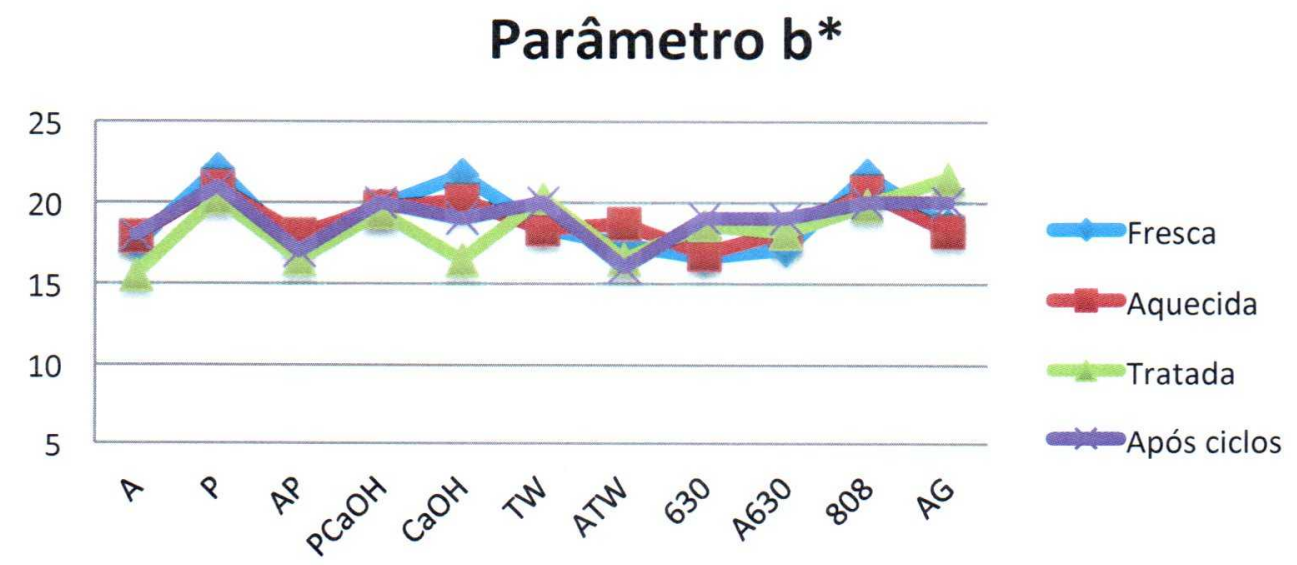

Figura 10.134 - Parâmetro b* médio para amostras frescas, aquecidas, tratadas e após os ciclos de saturação e secagem.

Tabela 10.9 - Valores de $L, a^{*}, b^{*}$ e desvio padrão para as rochas fresca e tratadas.

\begin{tabular}{llccccc}
\hline Tratamento & $\mathbf{L}$ & $\begin{array}{c}\text { Desvio } \\
\text { padrão }\end{array}$ & $\mathbf{a}^{*}$ & $\begin{array}{c}\text { Desvio } \\
\text { padrão }\end{array}$ & $\mathbf{b}^{*}$ & $\begin{array}{c}\text { Desvio } \\
\text { padrão }\end{array}$ \\
\hline Fresca & 70 & 1,5 & 5 & 0,8 & 17 & 3,5 \\
Aquecidas & 66 & 3,5 & 7 & 1,1 & 19 & 2,4 \\
A & 63 & 3,9 & 5 & 1,5 & 16 & 1,5 \\
P & 62 & 1,0 & 9 & 1,1 & 20 & 0,8 \\
AP & 64 & 3,7 & 5 & 1,4 & 16 & 1,7 \\
PCaOH & 63 & 4,3 & 8 & 1,9 & 19 & 2,2 \\
CaOH & 64 & 1,7 & 8 & 1,0 & 16 & 1,3 \\
TW & 59 & 3,4 & 9 & 2,5 & 20 & 2,2 \\
ATW & 56 & 4,7 & 6 & 1,7 & 17 & 1,5 \\
$\mathbf{6 3 0}$ & 61 & 2,8 & 7 & 2,1 & 19 & 1,9 \\
A630 & 58 & 2,9 & 6 & 1,7 & 18 & 1,3 \\
$\mathbf{8 0 8}$ & 59 & 1,0 & 9 & 0,8 & 20 & 0,6 \\
AG & 55 & 3,7 & 9 & 2,0 & 22 & 1,8 \\
\hline
\end{tabular}

Portanto, os tratamentos consolidantes que menos modificaram a cor, utilizando todos os parâmetros, foram $\mathrm{AP}$ e $\mathrm{PCaOH}$. O tratamento com $\mathrm{A}$ também não 
modificou muito a cor, porém, não é um consolidante. O hidrofugante que menos alterou a cor foi o 630 .

\section{- Velocidade de ondas ultrassônicas}

As amostras utilizadas para os ciclos de saturação e secagem, foram aquecidas para simular o intemperismo natural. Esta técnica mostrou-se bastante eficiente para diminuir a velocidade das ondas ultrassônicas (Figura 10.135).

\section{Ciclos de saturação e secagem}

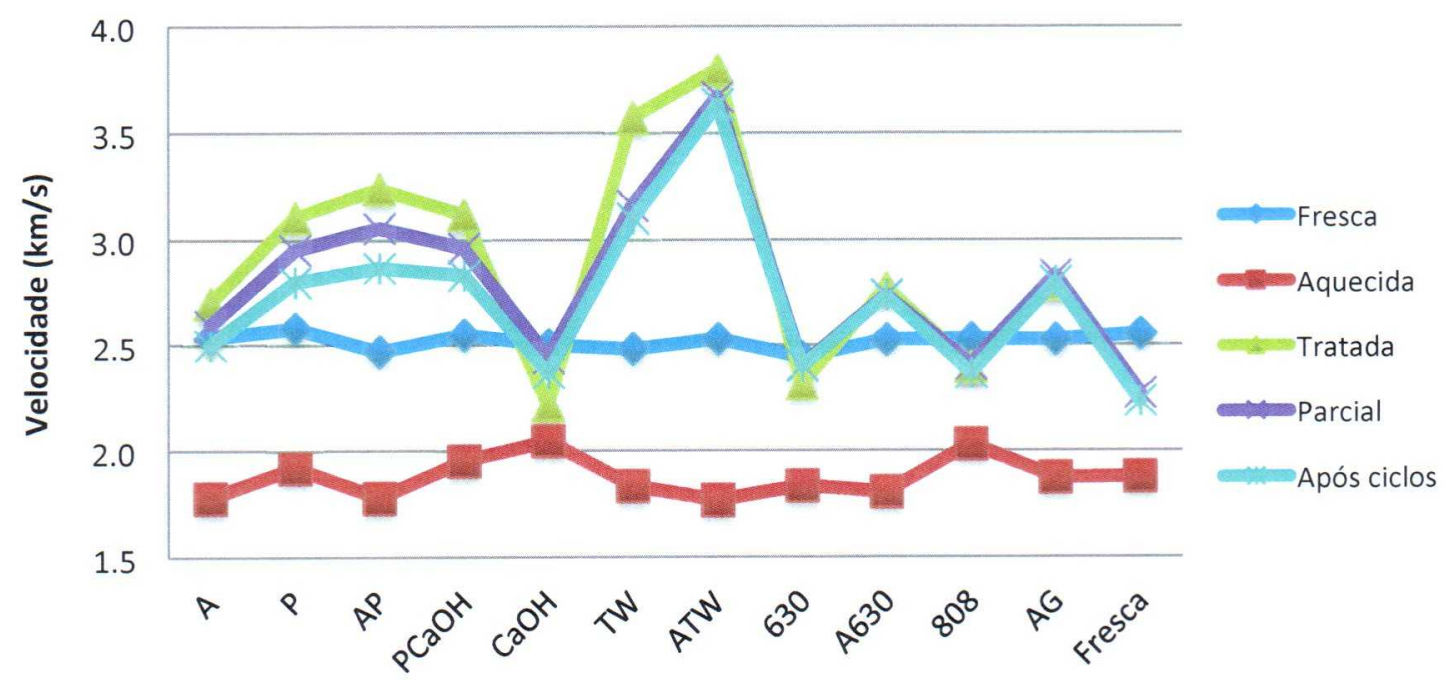

Figura 10.135 - Velocidade de ondas ultrassônicas de amostras frescas, aquecidas, tratadas, parcial e total dos ciclos de saturação e secagem.

Quanto à consolidação, os produtos que mais aumentaram a velocidade de ondas ultrassônicas foram, em ordem decrescente: ATW, TW, AP, P e PCaOH.

Os hidrofugantes, protetor de superfície e pré-tratamentos, também aumentaram a velocidade das ondas ultrassônicas nas amostras artificialmente intemperizadas. Em ordem decrescente de aumento de velocidade, tem-se: A630, A, AG, 630, 808 e CaOH. O 808 é vendido pelo fabricante como hidrofugante e consolidante. No entanto, não aumentou a velocidade de ondas ultrassônicas e, portanto, não consolidou.

Após os ciclos de saturação e secagem, os consolidantes que melhor mantiveram sua ação, ou seja, apresentaram a menor variação na velocidade das ondas ultrassônicas, em ordem decrescente, foram: ATW, PCaOH, P, AP e TW.

Os outros produtos, que melhor se comportaram frente à deterioração da água, em ordem decrescente, foram: 630, AG, A630 e 808, e A. Nota-se que o A aumentou 
a resistência à água do 630 e o AG não sofreu nenhuma alteração após os ciclos de saturação e secagem.

A resistência do A à lavagem, mostra que o produto se deposita por troca catiônica e não por outros processos como complexação dos grupos amina.

$\mathrm{O} \mathrm{CaOH}$ mostrou aumento da velocidade após os ciclos de intemperismo, mostrando, que se utilizado para uma rocha que ele consiga consolidar, como mármore, calcarenito ou outras rochas calcíticas, deve ser bastante resistente à deterioração por água.

Para melhor visualização, todos os valores médios obtidos na rocha fresca, aquecida, tratada e alterada por saturação e secagem, encontram-se reunidos na Tabela 10.10 .

Tabela 10.10 - Valores de ondas ultrassônicas do ensaio de saturação e secagem.

\begin{tabular}{lcccccc}
\hline Tratamento & $\begin{array}{c}\text { Velocidade } \\
\text { fresca } \\
(\mathbf{k m} / \mathbf{s})\end{array}$ & $\begin{array}{c}\text { Velocidade } \\
\text { aquecida } \\
(\mathbf{k m} / \mathbf{s})\end{array}$ & $\begin{array}{c}\text { Velocidade } \\
\text { tratada } \\
(\mathbf{k m} / \mathbf{s})\end{array}$ & $\begin{array}{c}\text { Variação } \\
(\%)\end{array}$ & $\begin{array}{c}\text { Velocidade } \\
\text { após } \\
\text { ciclos } \\
(\mathbf{k m} / \mathbf{s})\end{array}$ & $\begin{array}{c}\text { Variação } \\
(\%)\end{array}$ \\
\hline Fresca & 2,6 & 1,9 & - & - & 2,2 & 19 \\
A & 2,5 & 1,8 & 2,7 & 52 & 2,5 & -7 \\
P & 2,6 & 1,9 & 3,1 & 62 & 2,8 & -10 \\
AP & 2,5 & 1,8 & 3,2 & 82 & 2,9 & -12 \\
PCaOH & 2,5 & 2,0 & 3,1 & 60 & 2,8 & -9 \\
CaOH & 2,5 & 2,0 & 2,2 & 8 & 2,4 & 7 \\
TW & 2,5 & 1,8 & 3,6 & 94 & 3,1 & -13 \\
ATW & 2,5 & 1,8 & 3,8 & 115 & 3,6 & -4 \\
630 & 2,4 & 1,8 & 2,3 & 26 & 2,4 & 4 \\
A630 & 2,5 & 1,8 & 2,8 & 54 & 2,7 & -1 \\
808 & 2,5 & 2,0 & 2,4 & 18 & 2,4 & -1 \\
AG & 2,5 & 1,9 & 2,8 & 49 & 2,8 & 0 \\
\hline
\end{tabular}

Portanto, os tratamentos mais resistentes à deterioração por água são, em ordem decrescente: ATW, PCaOH, P e AP.

O módulo dinâmico também sofreu alterações durante os procedimentos, tratamentos e ciclos, como pode ser observado na Tabela 10.11. O aquecimento diminuiu o módulo dinâmico em $44 \%$, na média. O pré-tratamento, com $\mathrm{A}$ antes do TW e do 630 , fez com que o módulo dinâmico fosse maior do que quando a rocha não foi pré-tratada. A adição da solução de $\mathrm{CaOH}$ ao $\mathrm{P}$ também faz com que o módulo dinâmico seja maior do que quando o P é aplicado sozinho. 
Os maiores módulos após o tratamento foram, em ordem decrescente: ATW, TW, $\mathrm{PCaOH}$ e $\mathrm{P}$.

As amostras tratadas com a solução de $\mathrm{CaOH}$ tiveram sua velocidade aumentada após o teste, pois houve a carbonatação do produto.

O 630, que é apenas um hidrofugante, quando aplicado após o pré-tratamento com A, exerceu efeito inesperado sobre a rocha, aumentando o módulo dinâmico.

Tabela 10.11 - Módulo dinâmico médio nas amostras fresca, aquecida, tratada e após os ciclos de saturação e secagem.

\begin{tabular}{lccccccc}
\hline Tratamento & $\begin{array}{c}\text { Densidade } \\
\left(\mathbf{g} / \mathbf{c m}^{\mathbf{3}}\right)\end{array}$ & Fresca & Aquecida & Tratada & $\begin{array}{c}\text { Variação } \\
(\%)\end{array}$ & $\begin{array}{c}\text { Após } \\
\text { ciclos }\end{array}$ & $\begin{array}{c}\text { Variação } \\
(\%)\end{array}$ \\
\hline Fresca & 2119 & 14,1 & 7,7 & - & - & 11,0 & 43 \\
A & 2098 & 13,5 & 6,7 & 15,3 & 130 & 13,5 & -12 \\
P & 2124 & 14,2 & 7,8 & 20,5 & 162 & 17,0 & -17 \\
AP & 2116 & 14,1 & 8,3 & 21,1 & 155 & 17,3 & -18 \\
PCaOH & 2163 & 13,0 & 6,7 & 22,3 & 232 & 17,3 & -22 \\
$\mathbf{C a O H}$ & 2147 & 13,4 & 9,0 & 10,6 & 17 & 12,0 & 13 \\
TW & 2106 & 13,0 & 7,1 & 26,9 & 277 & 20,2 & -25 \\
ATW & 2104 & 13,5 & 6,6 & 30,4 & 359 & 27,9 & -8 \\
$\mathbf{6 3 0}$ & 2126 & 12,8 & 7,2 & 11,5 & 59 & 12,4 & 8 \\
A630 & 2087 & 13,4 & 6,8 & 16,1 & 136 & 15,4 & -4 \\
$\mathbf{8 0 8}$ & 2160 & 13,9 & 9,0 & 12,5 & 39 & 12,1 & -3 \\
AG & 2083 & 13,5 & 7,4 & 16,5 & 122 & 16,5 & 0 \\
\hline
\end{tabular}

\subsubsection{Profundidade de Penetração}

Das técnicas utilizadas para avaliar a profundidade de penetração, é possivel notar que, de uma maneira geral, o spray apresentou maior profundidade de penetração que o pincel (Figura 10.136). Já as polpas, sejam de celulose, bentonita ou estopa, apresentaram grande diferença de profundidade de penetração em relação aos outros métodos, sendo o mais eficiente deles.

Quanto aos pré-consolidantes, a maior penetração ocorreu com a aplicação do A2, seguido do A3.

Quando observado as três formas de preparação do $\mathbf{P}$, a que alcançou maior profundidade foi o P sozinho. Para este produto o pré-tratamento dificultou a penetração do consolidante. 
No caso do TW, a aplicação do consolidante não parece ter melhorado e nem piorado a penetração. A bentonita foi a técnica que conseguiu levar o produto em maior profundidade, na amostra pré-tratada com $\mathbf{A}$.

Para o 808, o A só diminuiu a penetração para a técnica da polpa. As técnicas do pincel e do spray não tiveram grandes diferenças com a aplicação do $\mathbf{A}$.

Os produtos que menos penetraram foram $\mathrm{AP}, \mathrm{PCaOH}, \mathrm{TW}$ e A808. Os que mais penetraram foram o A e o $\mathbf{P}$.

\section{Profundidade de penetração}

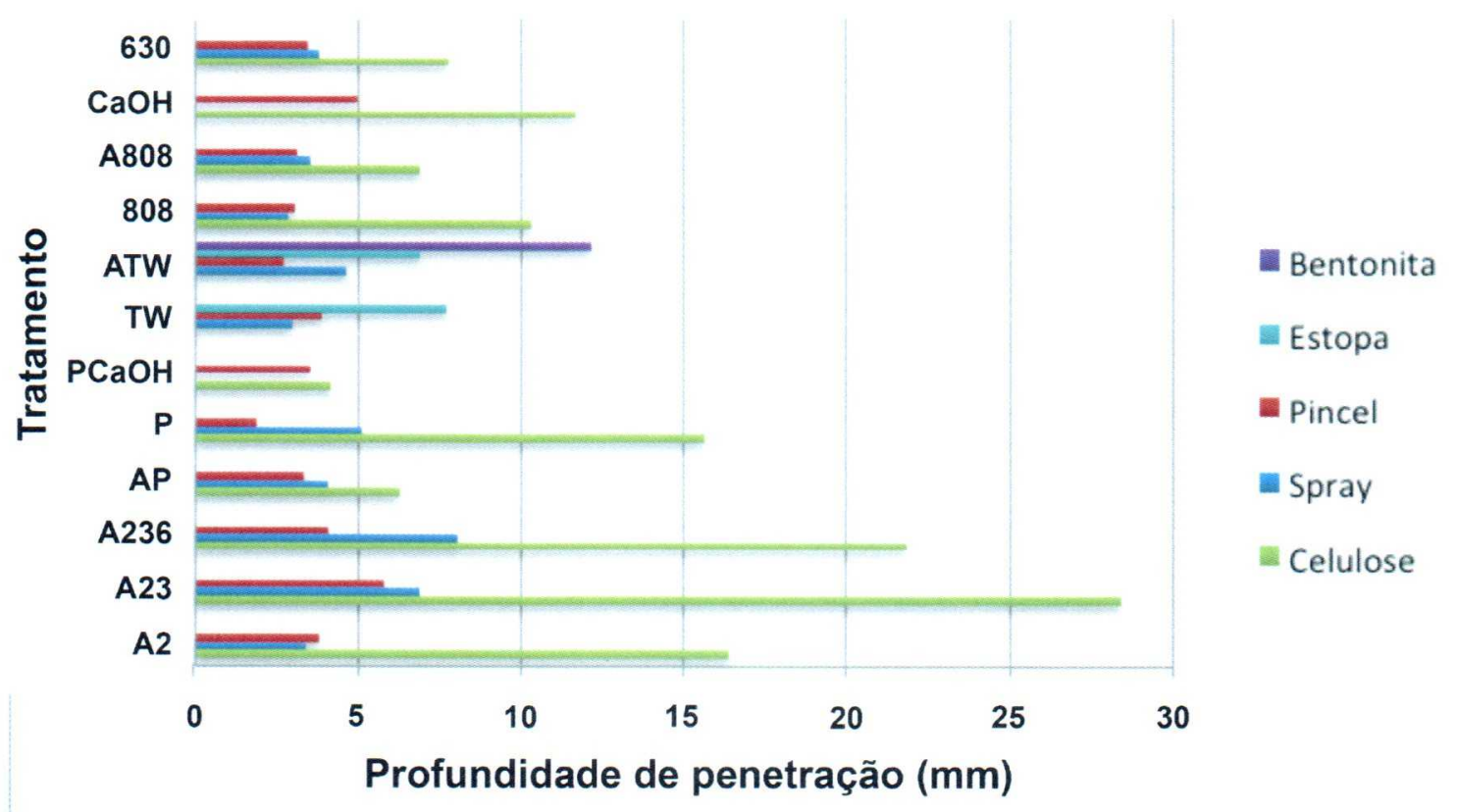

Figura 10.136 - Comparação entre os valores encontrados no teste de profundidade de penetração, com as diferentes técnicas.

Os valores exatos dos resultados encontram-se na Tabela 10.12. 
Tabela 10.12 - Valores do teste de profundidade de penetração (mm).

\begin{tabular}{lccccc}
\hline \multicolumn{1}{r}{ Tratamento } & Spray & Pincel & Polpa & Bentonita & Estopa \\
\hline A2 & 3,4 & 3,8 & 16,4 & - & - \\
A23 & 6,9 & 5,8 & 28,4 & - & - \\
A236 & 8,1 & 4,1 & 21,8 & - & - \\
AP & 4,1 & 3,3 & 6,3 & - & - \\
P & 5,2 & 1,9 & 15,6 & - & - \\
PCaOH & - & 3,5 & 4,2 & - & - \\
TW & 3,0 & 3,9 & - & - & 7,7 \\
ATW & 4,6 & 2,7 & - & 12,2 & 6,9 \\
808 & 2,9 & 3,1 & 10,3 & - & - \\
A808 & 3,6 & 3,1 & 6,9 & - & - \\
CaOH & - & 5,0 & 11,7 & - & - \\
630 & 3,8 & 3,5 & 7,8 & - & - \\
\hline
\end{tabular}

10.1.15. Alteração acelerada por $\mathrm{SO}_{2}$

- Espectrofotometria

As amostras que apresentaram menor variação de luminosidade (parâmetro $L$ ) após o tratamento (Figura 10.137), quando comparados aos valores obtidos quando as amostras estavam frescas, foram:

- ATW (0\%) e A808 (0\%);

- A $(1,5 \%)$ e P $(-1,5 \%)$;

- $\mathrm{CaOH}(3 \%)$;

$-630(-4,5 \%)$;

- $808(-6 \%)$;

- $\mathrm{PCaOH}(-7,5 \%)$;

- TW $(-7,6 \%)$;

- AP (-12,1\%).

Após a alteração com $\mathrm{SO}_{2}$, a alteração da luminosidade, foi:

- A808 (0\%);

$-630(-1,5)$ e $808(-1,5)$;

- P, AP e PCaOH (3\%);

- A $(3,1 \%)$ e ATW $(-3,1)$;

- TW $(-7,6)$;

- $\mathrm{CaOH}(9 \%)$. 
Portanto, as amostras que apresentaram menor variação de luminosidade após o tratamento e do intemperismo acelerado foram A, P, A808 e ATW. As duas últimas mostram que a aplicação do $\mathbf{A}$ antes do produto de tratamento, auxiliou na manutenção da cor, em relação ao parâmetro de luminosidade.

Todos os valores médios encontrados, com o desvio padrão e a variação em relação a amostra fresca, são mostrados na Tabela 10.13 .

\section{Parâmetro L}

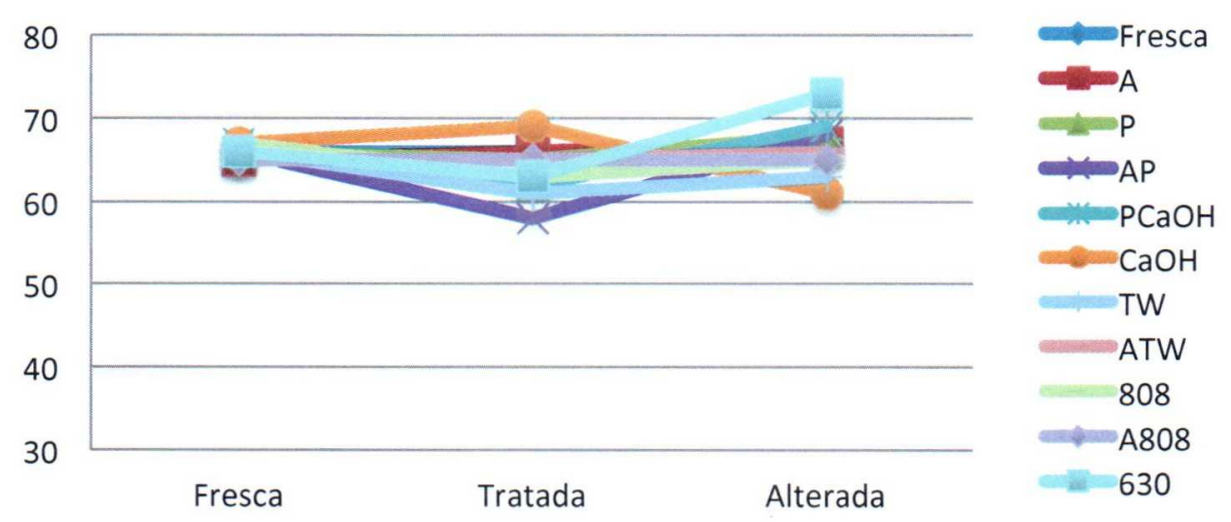

Figura 10.137 - Variação do parâmetro L médio em rocha fresca, tratada e alterada com $\mathrm{SO}_{2}$. 
Tabela 10.13 - Média e desvio padrão do parâmetro L para amostras frescas, tratadas e alteradas.

\begin{tabular}{|c|c|c|c|c|}
\hline \multicolumn{2}{|c|}{ Tratamento } & Média & Desvio padrão & Variação $(\%)^{*}$ \\
\hline \multirow{3}{*}{ Fresca } & Fresca & 67 & 2.1 & - \\
\hline & Tratada & - & - & - \\
\hline & Alterada & 67 & 1,9 & 0 \\
\hline \multirow{3}{*}{ A } & Fresca & 64 & 1,9 & - \\
\hline & Tratada & 66 & 2,2 & 1,5 \\
\hline & Alterada & 67 & 1,6 & 3,1 \\
\hline \multirow{3}{*}{ P } & Fresca & 65 & 2,8 & \\
\hline & Tratada & 65 & 1,7 & $-1,5$ \\
\hline & Alterada & 68 & 1,3 & 3.0 \\
\hline \multirow{3}{*}{ AP } & Fresca & 64 & 1,4 & \\
\hline & Tratada & 58 & 2,6 & -12.1 \\
\hline & Alterada & 68 & 1,2 & 3.0 \\
\hline \multirow{3}{*}{$\mathrm{PCaOH}$} & Fresca & 68 & 2.3 & - \\
\hline & Tratada & 62 & 3,3 & $-7,5$ \\
\hline & Alterada & 69 & 2,0 & 3,0 \\
\hline \multirow{3}{*}{$\mathrm{CaOH}$} & Fresca & 68 & 2,6 & \\
\hline & Tratada & 69 & 3,8 & 3,0 \\
\hline & Alterada & 73 & 1,6 & 9,0 \\
\hline \multirow{3}{*}{ TW } & Fresca & 66 & 3,0 & - \\
\hline & Tratada & 61 & 3,9 & $-7,6$ \\
\hline & Alterada & 61 & 4,2 & $-7,6$ \\
\hline \multirow{3}{*}{ ATW } & Fresca & 65 & 1.3 & - \\
\hline & Tratada & 65 & 2,5 & 0 \\
\hline & Alterada & 63 & 1,0 & $-3,1$ \\
\hline \multirow{3}{*}{808} & Fresca & 67 & 1,4 & - \\
\hline & Tratada & 63 & 2,4 & -6 \\
\hline & Alterada & 66 & 1,6 & $-1,5$ \\
\hline \multirow{3}{*}{ A808 } & Fresca & 65 & 1,7 & - \\
\hline & Tratada & 65 & 2,1 & 0 \\
\hline & Alterada & 65 & 1,7 & 0 \\
\hline \multirow{3}{*}{630} & Fresca & 66 & 1,5 & \\
\hline & Tratada & 63 & 2,1 & $-4,5$ \\
\hline & Alterada & 65 & 2,6 & $-1,5$ \\
\hline
\end{tabular}

* Comparação com a média da rocha fresca.

Quando observados os valores do parâmetro a* (vermelho - positivos e verde - negativos) (Figura 10.138), nota-se que os produtos que mais se aproximam dos valores exibidos pela rocha fresca são AP, 630 e 808 e os que estão mais distantes são TW, CaOH, ATW e A808.

Observando a Tabela 10.14, pode-se verificar, mais detalhadamente, que os produtos que menos mudaram a cor em relação ao parâmetro $\mathbf{a}^{*}$, após o tratamento, foram:

- $\mathrm{PCaOH}(-3,5 \%)$;

- AP $(5,8 \%)$;

- A808 (-7,1\%);

$-630(-8,2 \%)$;

- $808(10,2 \%)$;

- P (14,3\%); 
- $\mathrm{CaOH}(-18,4 \%)$;

- A $(-21,4 \%)$;

- ATW (-23,4\%);

- TW $(26,4 \%)$.

Os produtos que menos alteraram a cor em relação ao parâmetro $a^{*}$ após a alteração acelerada com $\mathrm{SO}_{2}$, foram:

- $630(4,1 \%)$;

- ATW (4,3\%);

- $\operatorname{TW}(5,7 \%)$

- AP (-11,5\%);

- A808 (-11,9\%);

- P $(12,2 \%$ e $808(-12,2 \%)$;

- PCaOH (-12,3\%);

- A (-28,6\%);

- $\mathrm{CaOH}(-44,9 \%)$.

Considerando a cor da rocha fresca, após o tratamento e após a alteração acelerada, os quatro produtos que menos modificaram a cor, foram AP, 630, A808 e P.

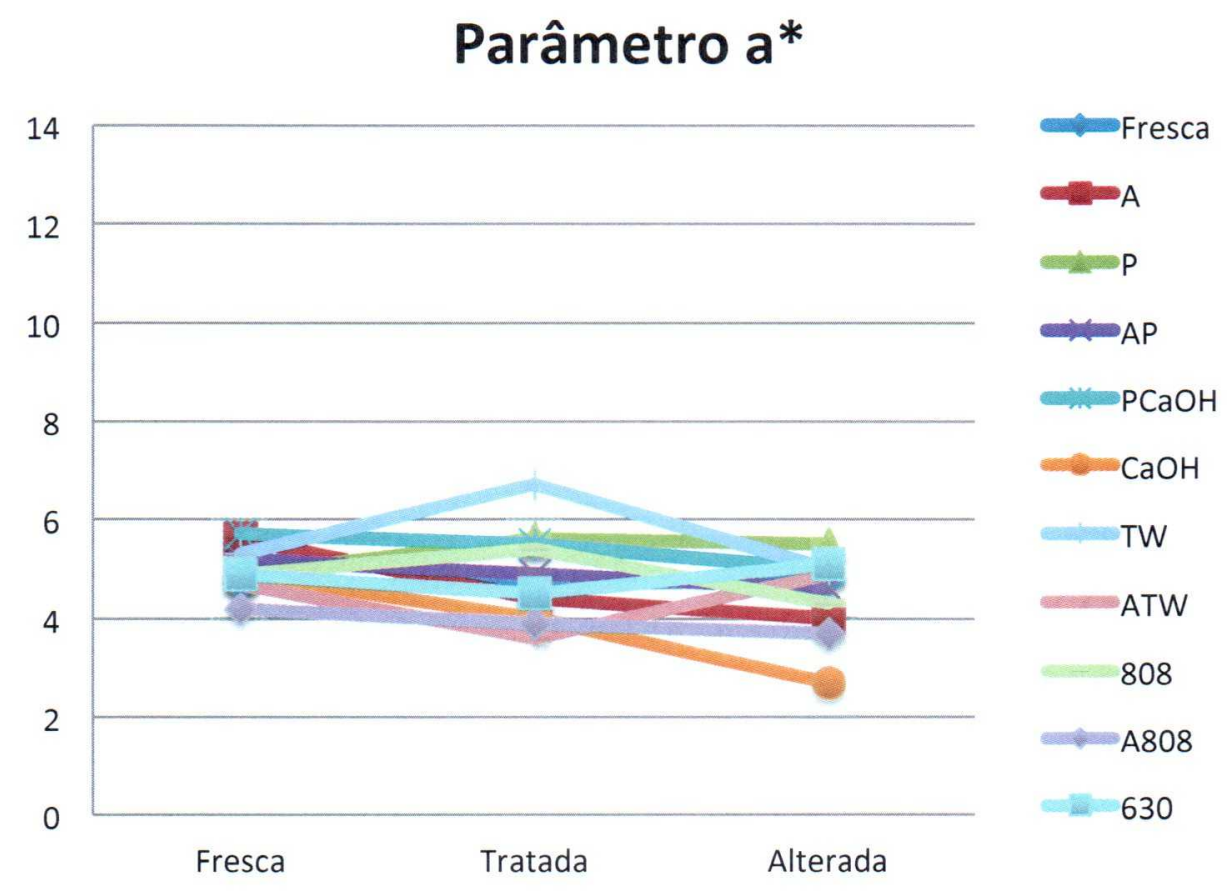

Figura 10.138 - Variação do parâmetro a* médio em rocha fresca, tratada e alterada com $\mathrm{SO}_{2}$. 
Tabela 10.14 - Média e desvio padrão do parâmetro a* para amostras frescas, tratadas e alteradas.

\begin{tabular}{|c|c|c|c|c|}
\hline Tratamento & & Média & Desvio padrão & Variação $(\%)^{\star}$ \\
\hline \multirow{3}{*}{ Fresca } & Fresca & 5 & 0,4 & - \\
\hline & Tratada & - & - & - \\
\hline & Alterada & 4,8 & 0,5 & -4 \\
\hline \multirow{3}{*}{ A } & Fresca & 5,6 & 0,4 & - \\
\hline & Tratada & 4,4 & 0,3 & $-21,4$ \\
\hline & Alterada & 4,0 & 0,4 & $-28,6$ \\
\hline \multirow{3}{*}{$\mathbf{P}$} & Fresca & 4,9 & 0,9 & - \\
\hline & Tratada & 5,6 & 0,4 & 14,3 \\
\hline & Alterada & 5,5 & 0,7 & 12,2 \\
\hline \multirow{3}{*}{ AP } & Fresca & 5,2 & 0,4 & - \\
\hline & Tratada & 4,9 & 0,4 & $-5,8$ \\
\hline & Alterada & 4,6 & 0,3 & $-11,5$ \\
\hline \multirow{3}{*}{$\mathrm{PCaOH}$} & Fresca & 5,7 & 0,7 & - \\
\hline & Tratada & 5,5 & 1,0 & $-3,5$ \\
\hline & Alterada & 5,0 & 0,6 & $-12,3$ \\
\hline \multirow{3}{*}{$\mathrm{CaOH}$} & Fresca & 4,9 & 0,6 & - \\
\hline & Tratada & 4,0 & 0,9 & $-18,4$ \\
\hline & Alterada & 2,7 & 0,5 & $-44,9$ \\
\hline \multirow{3}{*}{ TW } & Fresca & 5,3 & 0,8 & - \\
\hline & Tratada & 6,7 & 1,0 & 26,4 \\
\hline & Alterada & 5,0 & 0,7 & 5,7 \\
\hline \multirow{3}{*}{ ATW } & Fresca & 4,7 & 0,3 & - \\
\hline & Tratada & 3,6 & 0,7 & $-23,4$ \\
\hline & Alterada & 4,9 & 0,4 & 4,3 \\
\hline \multirow{3}{*}{808} & Fresca & 4,9 & 0,6 & - \\
\hline & Tratada & 5,4 & 1,0 & 10,2 \\
\hline & Alterada & 4,3 & 0,6 & $-12,2$ \\
\hline \multirow{3}{*}{ A808 } & Fresca & 4,2 & 0,4 & - \\
\hline & Tratada & 3,9 & 0,5 & $-7,1$ \\
\hline & Alterada & 3,7 & 0,4 & $-11,9$ \\
\hline \multirow{3}{*}{630} & Fresca & 4,9 & 0,5 & - \\
\hline & Tratada & 4,0 & 0,9 & $-8,2$ \\
\hline & Alterada & 5,1 & 0,7 & 4,1 \\
\hline
\end{tabular}

* Comparação com a média da rocha fresca.

Quando observado o parâmetro b* (amarelo - positivos e azul - negativos), o produto que apresentou o comportamento mais discrepante, tanto após o tratamento, quanto após a alteração acelerada foi a solução de $\mathrm{CaOH}$ (Figura 10.139). Os dois produtos que mais alteraram a cor após a aplicação foram ATW e TW. No entanto, após a alteração acelerada, voltaram a apresentar valores mais próximos da rocha fresca. De maneira geral, todos os outros produtos apresentaram valores bem próximos aos da rocha fresca. Todos os valores médios encontrados, o desvio padrão 
e a variação, comparativamente com a rocha fresca, são apresentados na Tabela 10.15 .

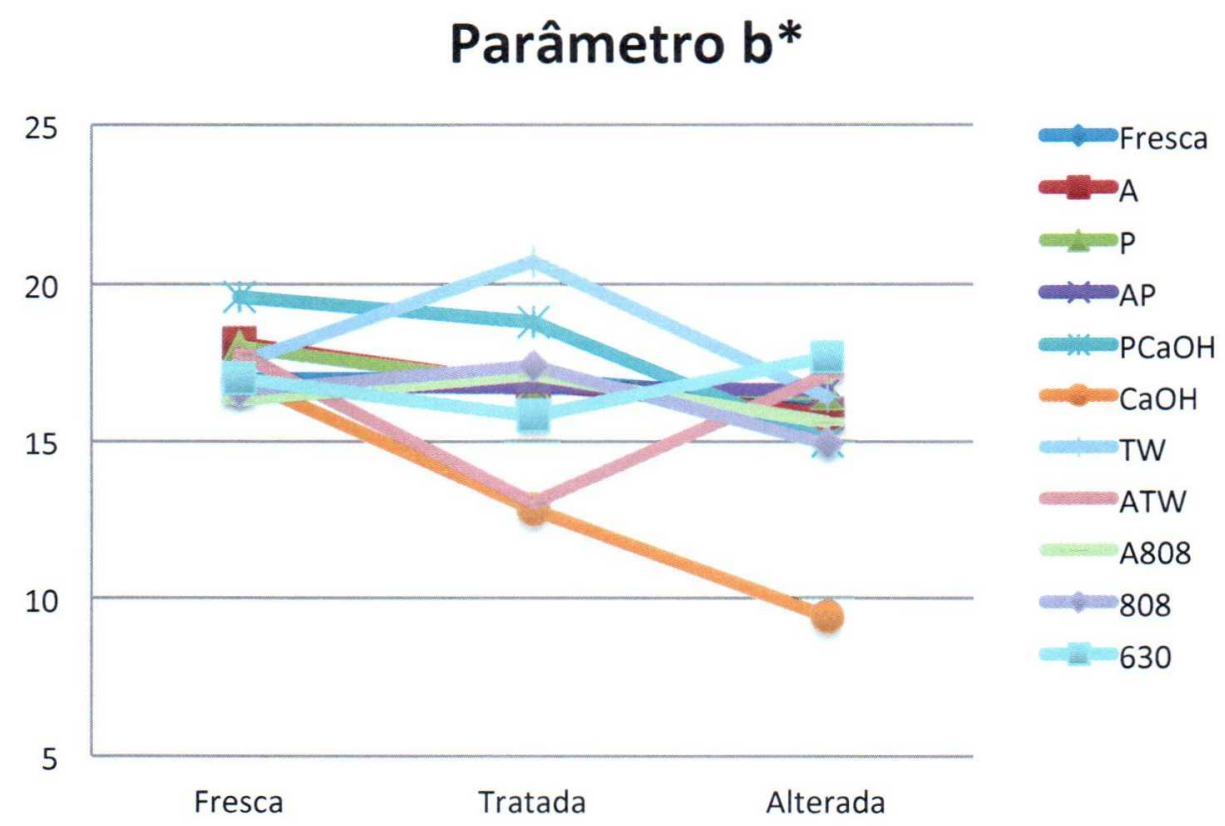

Figura 10.139 - Variação do parâmetro b* médio em rocha fresca, tratada e alterada com $\mathrm{SO}_{2}$.

Alguns produtos não modificaram muito a cor quando aplicados nas amostras. No entanto, acabaram modificando-as bastante após a alteração acelerada. Outros ainda, modificaram a cor quando aplicados, mas, após a alteração, apresentaram coloração bem próxima a da rocha fresca.

De forma geral, levando em consideração os três parâmetros colorimétricos, os produtos que menos alteraram a cor após a alteração acelerada, em ordem crescente foram:

- AP;

- A808 e 630;

- 808;

- P, PCaOH e TW;

$-\mathrm{A}$;

- ATW;

- $\mathrm{CaOH}$ 
Tabela 10.15 - Média e desvio padrão do parâmetro b* para amostras frescas, tratadas e alteradas.

\begin{tabular}{|c|c|c|c|c|}
\hline Tratamento & & Média & Desvio padrão & Variação $(\%)^{*}$ \\
\hline \multirow{3}{*}{ Fresca } & Fresca & 17 & 1,9 & - \\
\hline & Tratada & - & - & - \\
\hline & Alterada & 16,3 & 0,9 & $-4,1$ \\
\hline \multirow{3}{*}{ A } & Fresca & 18,1 & 1,4 & - \\
\hline & Tratada & 16,8 & 1,1 & $-7,2$ \\
\hline & Alterada & 15,9 & 1,2 & $-12,1$ \\
\hline \multirow{3}{*}{$P$} & Fresca & 18,0 & 2,4 & - \\
\hline & Tratada & 16,8 & 1,2 & $-6,7$ \\
\hline & Alterada & 16,5 & 0,9 & $-8,3$ \\
\hline \multirow{3}{*}{ AP } & Fresca & 16,8 & 0,8 & - \\
\hline & Tratada & 16,7 & 0,8 & $-0,6$ \\
\hline & Alterada & 16,6 & 0,9 & $-1,2$ \\
\hline \multirow{3}{*}{$\mathrm{PCaOH}$} & Fresca & 19,6 & 1,9 & - \\
\hline & Tratada & 18,8 & 3,0 & $-4,1$ \\
\hline & Alterada & 15,0 & 1,1 & -23.5 \\
\hline \multirow{3}{*}{$\mathrm{CaOH}$} & Fresca & 17,0 & 1,9 & - \\
\hline & Tratada & 12,8 & 3,0 & $-24,7$ \\
\hline & Alterada & 9,4 & 1,7 & $-44,7$ \\
\hline \multirow{3}{*}{ TW } & Fresca & 17,5 & 2,0 & - \\
\hline & Tratada & 20,7 & 2,0 & 18,3 \\
\hline & Alterada & 16,4 & 1,1 & $-6,3$ \\
\hline \multirow{3}{*}{ ATW } & Fresca & 17,8 & 1,2 & - \\
\hline & Tratada & 13 & 1,6 & $-27,0$ \\
\hline & Alterada & 17,1 & 0,9 & $-3,9$ \\
\hline \multirow{3}{*}{808} & Fresca & 16,6 & 1,2 & - \\
\hline & Tratada & 17,4 & 2,6 & 4,8 \\
\hline & Alterada & 14,9 & 1,5 & $-10,2$ \\
\hline \multirow{3}{*}{ A808 } & Fresca & 16,3 & 1,6 & - \\
\hline & Tratada & 17,1 & 2,0 & 4,9 \\
\hline & Alterada & 15,6 & 1,6 & $-4,3$ \\
\hline \multirow{3}{*}{630} & Fresca & 17,0 & 1,7 & - \\
\hline & Tratada & 15,8 & 2,3 & $-7,1$ \\
\hline & Alterada & 17,7 & 1,3 & 4,1 \\
\hline
\end{tabular}

* Comparação com a média da rocha fresca.

\section{- Velocidade de ondas ultrassônicas}

As amostras que foram submetidas ao ensaio de intemperismo acelerado por $\mathrm{SO}_{2}$ tiveram suas velocidades medidas quando frescas, após o tratamento e após 15 ciclos na câmara intempérica de $\mathrm{SO}_{2}$.

A velocidade de ondas ultrassônicas das amostras tratadas (Figura 10.140), foi maior do que a encontrada nas amostras frescas, em todos os casos, exceto nas 
amostras tratadas com $\mathrm{CaOH}$ e com 630, mostrando que eles não aumentam a coesão entre os grãos da rocha.

O A, 808 e A808, que não são consolidantes, elevaram levemente a velocidade das ondas ultrassônicas.

Entre os consolidantes, os que mais elevaram o valor da velocidade foram, em ordem decrescente: ATW, TW, AP, PCaOH e P

O ensaio de intemperismo acelerado deveria diminuir a velocidade de ondas ultrassônicas. No entanto, ele a aumentou em todos os casos, inclusive na rocha fresca. O aumento da velocidade dá-se pela deposição de sulfato nos poros e fissuras das amostras, como já observado por Frascá (2003b).

\section{Intemperismo acelerado - $\mathrm{SO}_{2}$}

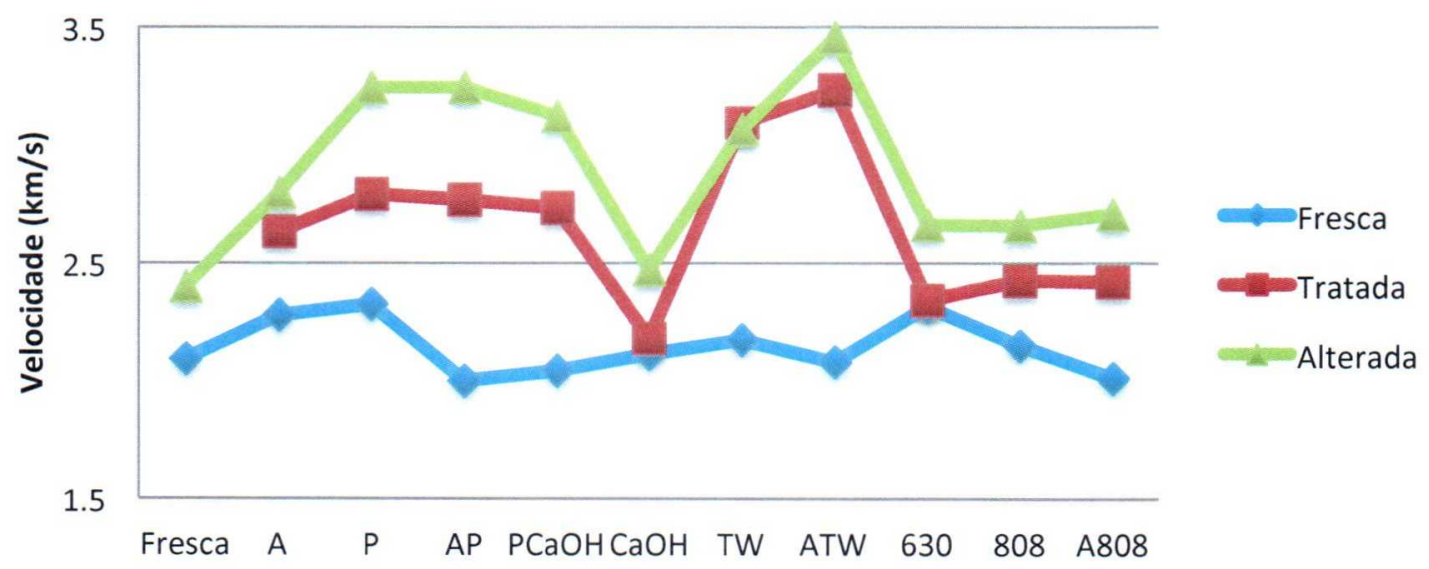

Figura 10.140 - Velocidade média de ondas ultrassônicas em amostras frescas, tratadas e alteradas pelo intemperismo acelerado em câmara de $\mathrm{SO}_{2}$.

$\mathrm{Na}$ Tabela 10.16, pode-se observar a velocidade de ondas ultrassônicas na amostra fresca, tratada e após o ensaio, além da variação em relação à rocha fresca. Observando o módulo dinâmico (Tabela 10.17), é possível verificar que este parâmetro também aumentou após o ensaio. $\mathrm{O}$ aumento tanto da velocidade quanto do módulo dinâmico se deve ao preenchimento de poros e fissuras pelo gipso (Gobbi et al. 1998, Grossi e Murray 1999) formado da reação entre feldspatos e o SO (Frascá $^{2}$ 2003b). Apenas $\mathbf{P}$, ATW e TW mostraram redução deste parâmetro.

Se comparamos os resultados, apenas das amostras frescas e tratadas, neste ensaio e no ensaio dos ciclos de umedecimento e secagem, verifica-se que os resultados foram praticamente os mesmos. É veificada apenas uma pequena mudança entre as amostras tratadas com $\mathrm{P}$ e $\mathrm{PCaOH}$, pois para o caso da amostras aquecidas, $\mathrm{P}$ funcionou tão bem quanto $\circ \mathrm{PCaOH}$. Outra pequena alteração foi entre 
- 630 e o 808, que no caso das aquecidas, o primeiro se mostrou um pouco mais eficiente que o segundo. No caso das amostras tratadas sem aquecimento prévio, o 630 não alterou significativamente o valor da velocidade de ondas ultrassônicas.

Tabela 10.16 - Velocidade de ondas ultrassônicas em amostra fresca, tratada e alterada por

\begin{tabular}{cccccc}
\hline Tratamento & $\begin{array}{c}\text { Fresca } \\
(\mathbf{k m} / \mathbf{s})\end{array}$ & $\begin{array}{c}\text { Tratada } \\
(\mathbf{k m} / \mathbf{s})\end{array}$ & $\begin{array}{c}\mathrm{SO}_{2} . \\
(\%)\end{array}$ & $\begin{array}{c}\text { Após ensaioa } \\
(\mathbf{k m} / \mathbf{s})\end{array}$ & $\begin{array}{c}\text { Variação } \\
(\%)\end{array}$ \\
\hline Fresca & 2,1 & - & - & 2,4 & 15 \\
A & 2,3 & 2,6 & 16 & 2,8 & 23 \\
P & 2,3 & 2,8 & 20 & 3,2 & 40 \\
AP & 2,0 & 2,8 & 39 & 3,2 & 62 \\
PCaOH & 2,0 & 2,7 & 34 & 3,1 & 53 \\
CaOH & 2,1 & 2,2 & 3 & 2,5 & 17 \\
TW & 2,2 & 3,1 & 43 & 3,1 & 41 \\
ATW & 2,1 & 3,2 & 56 & 3,5 & 66 \\
630 & 2,3 & 2,3 & 1 & 2,7 & 15 \\
808 & 2,1 & 2,4 & 13 & 2,7 & 24 \\
A808 & 2,0 & 2,4 & 20 & 2,7 & 35 \\
\hline
\end{tabular}

Tabela 10.17 - Módulo dinâmico médio e variação para amostras frescas, tratadas e submetidas ao ensaio de intemperismo acelerado por $\mathrm{SO}_{2}$.

\begin{tabular}{lcccccc}
\hline Tratamento & $\begin{array}{c}\text { Densidade } \\
\left(\mathbf{g} / \mathbf{c m}^{3}\right)\end{array}$ & Fresca & Tratada & $\begin{array}{c}\text { Variação } \\
(\%)\end{array}$ & $\begin{array}{c}\text { Após } \\
\text { ensaio }\end{array}$ & $\begin{array}{c}\text { Variação } \\
(\%)\end{array}$ \\
\hline Fresca & 2007 & 10,8 & - & - & 12,1 & 21 \\
A & 2063 & 10,8 & 14,3 & 33 & 16,2 & 13 \\
P & 2060 & 11,4 & 16,1 & 41 & 10,1 & -37 \\
AP & 2056 & 8,2 & 15,8 & 92 & 24,5 & 55 \\
PCaOH & 2085 & 8,7 & 15,6 & 79 & 21,7 & 39 \\
CaOH & 2055 & 9,3 & 9,8 & 5 & 21,8 & 122 \\
TW & 2086 & 9,9 & 20,0 & 103 & 19,6 & -2 \\
ATW & 2050 & 8,9 & 21,4 & 140 & 14,7 & -31 \\
$\mathbf{6 3 0}$ & 2083 & 11,2 & 11,4 & 2 & 12,6 & 11 \\
$\mathbf{8 0 8}$ & 2073 & 9,6 & 12,2 & 27 & 20,3 & 66 \\
A808 & 2069 & 5,4 & 8,2 & 51 & 14,8 & 80 \\
\hline
\end{tabular}

Assim, a velocidade de ondas ultrassônicas não é um bom ensaio para acompanhar a alteração acelerada por $\mathrm{SO}_{2}$. 


\subsection{Arenito Missões}

Todos os testes ensaiados no Arenito Missões foram realizados na Universidade de Princeton.

\subsubsection{Petrografia}

Observando o Arenito Missões em amostra de mão, verifica-se coloração avermelhada com estratificações constituídas por minerais mais escuros. Os grãos não variam muito de tamanho.

Analisando as sessões delgadas, verifica-se que seus grãos são bem selecionados (Figura 10.141), com formatos arredondados a subangulosos, de 0,1 a $0,4 \mathrm{~mm}$, predominando $0,2 \mathrm{~mm}$ (Figura 10.142). Ele é composto basicamente por quartzo, cimentado por calcedônia. Apresenta, localmente, óxido de ferro e minerais pesados como granada, epidoto e estaurolita.

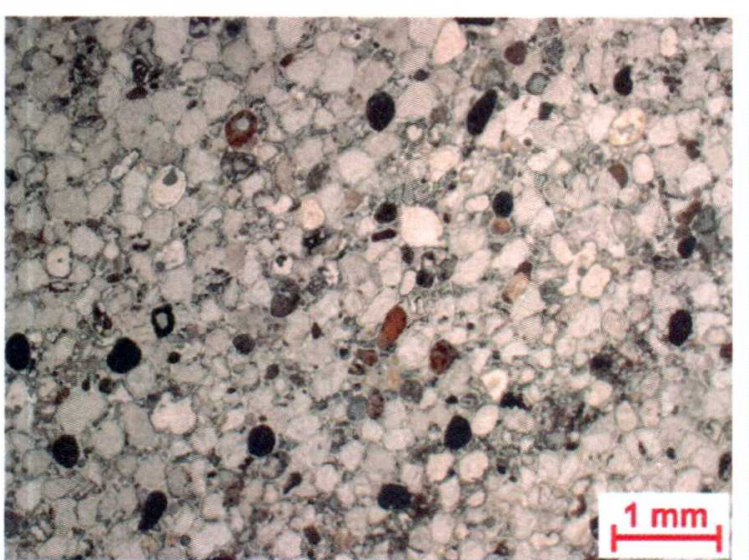

Figura 10.141 - Visão geral do Arenito Missões.

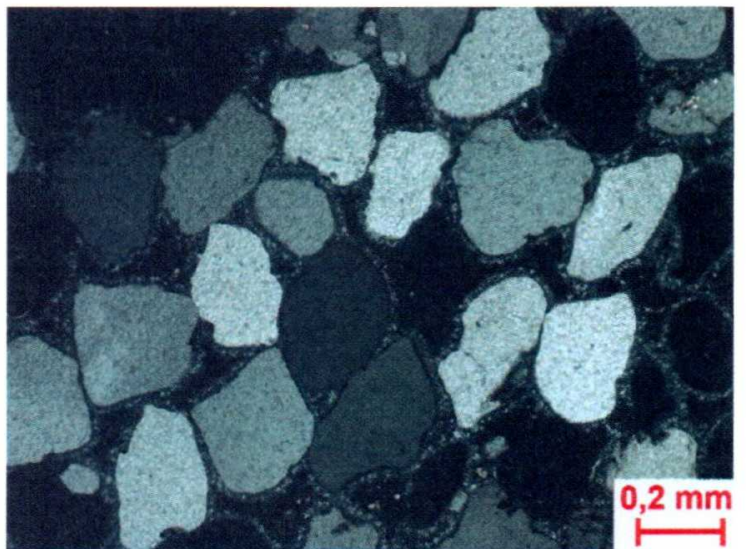

Figura 10.142 - Arenito missões - nicóis cruzados

\subsubsection{Espectrofotometria}

Ao comparar os dados de luminosidade (Figura 10.143) entre as amostras tratadas e frescas do Arenito Missões é possível verificar que as amostras tratadas com ATC apresentaram leve escurecimento. Para os outros produtos, não houve grande mudança neste parâmetro.

O desvio padrão foi: fresca $=4,1, \mathbf{A}=4,0, \mathbf{P}=3,3, \mathbf{A P}=3,2, \mathbf{T C}=2,6$ e $\mathbf{A T C}=$ 4,4 . 


\section{Parâmetro L}

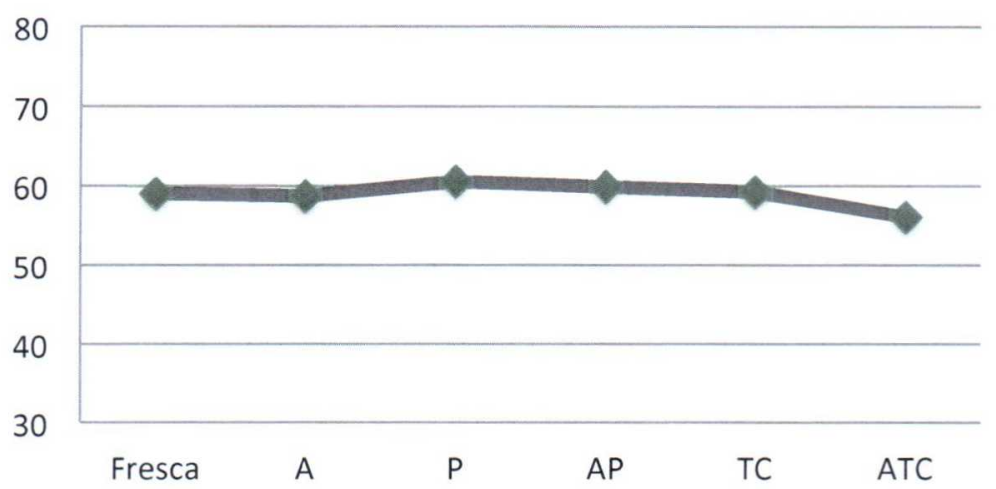

Figura 10.143 - Parâmetro L médio, para as amostras do Arenito Missões com diversos tratamentos.

Ao observar o parâmetro a* (Figura 10.144), nota-se uma pequena variação na tonalidade vermelhada nos diferentes tratamentos, mas não há nenhuma mudança acentuada.

Os desvios padrão foram: fresca $=1,4, \mathbf{A}=0,9, \mathrm{P}=1,1, \mathrm{AP}=0,8, \mathrm{TC}=0,8 \mathrm{e}$ ATC $=0,8$.

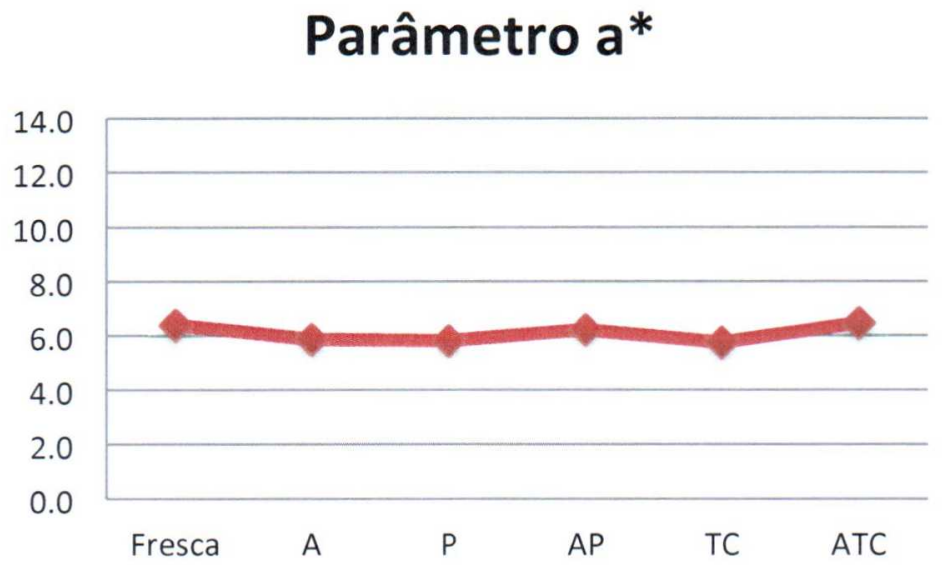

Figura 10.144 - Parâmetro $a^{*}$ das amostras do Arenito Missões tratadas com diversos produtos.

Com relação ao parâmetro $\mathbf{b}^{*}$ (Figura 10.145), o tratamento que menos modificou a cor foi AP e o que mais modificou foi A. A aplicação do A antes do TC, auxiliou a manutenção da cor original. De forma geral, nenhum dos produtos apresentou variação substancial neste parâmetro. 


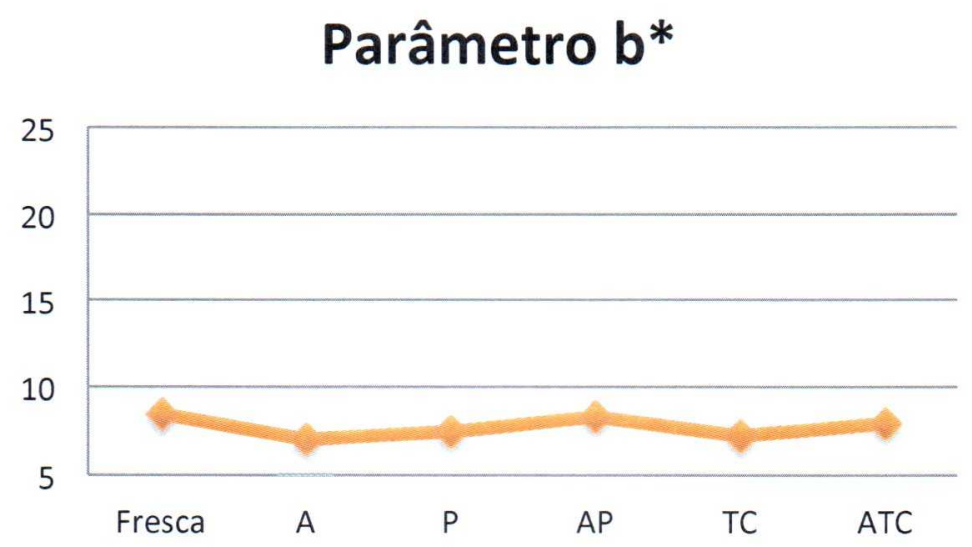

Figura 10.145 - Parâmetro b* para o Arenito Missões com aplicação de pré-consolidantes e consolidantes.

Portanto, AP é o produto que menos modifica os três parâmetros.

\subsubsection{Capilaridade}

\section{- Fresca}

Nas amostras sem tratamento, a capilaridade média encontrada ensaiada com fluxo perpendicular ao acamamento foi $0,0027 \mathrm{~g} / \mathrm{cm}^{2} \cdot \mathrm{s}$, para o paralelo 0,0019 $\mathrm{g} / \mathrm{cm}^{2} \cdot \mathrm{s}$. Esses resultados contrariaram a expectativa pois, quando as camadas estão orientadas verticalmente, espera-se que a água ascenda mais rápido. No entanto, tal fato pode ser relativo à diferença de porosidade entre as amostras, pois a amostra 1 , que foi testada na direção de fluxo perpendicular, absorveu mais água do que as outras amostras, sugerindo que possui poros maiores e interconectados. Para verificar alguns resultados que pareciam inconsistentes, as amostras 3 e 7 foram repetidas. $A$ amostra 3, mostrou melhor resultado no segundo teste (3-2) mas, mesmo assim, o resultado é bastante diferente das amostras ensaiadas com o acamamento posicionado verticalmente. A amostra 7 apresentou o mesmo resultado em ambos os testes (Figura 10.146). 


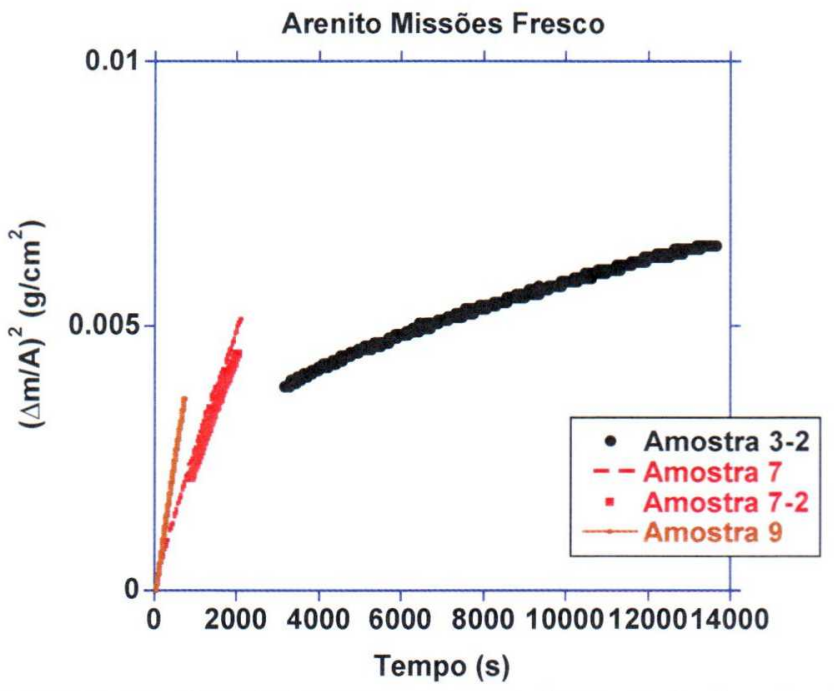

Figura 10.146 - Teste de capilaridade em amostras frescas do Arenito Missões. Amostra 3-2 com fluxo perpendicular e amostras 7, 7-2 e 9 com fluxo paralelo.

$-P$

Os resultados encontrados com a aplicação do $\mathrm{P}$, mostraram que a porosidade diminuiu muito. A amostra ensaiada com fluxo perpendicular ao acamamento, apresentou valor de $0,0009 \mathrm{~g} / \mathrm{cm}^{2} \cdot \mathrm{s}$, que é muito baixo. A amostra com fluxo paralelo, apresentou o valor de $0,0013 \mathrm{~g} / \mathrm{cm}^{2} \cdot \mathrm{s}$ (Figura 10.147). Portanto este produto não é recomendado para esta rocha pois obstrui muito os poros.

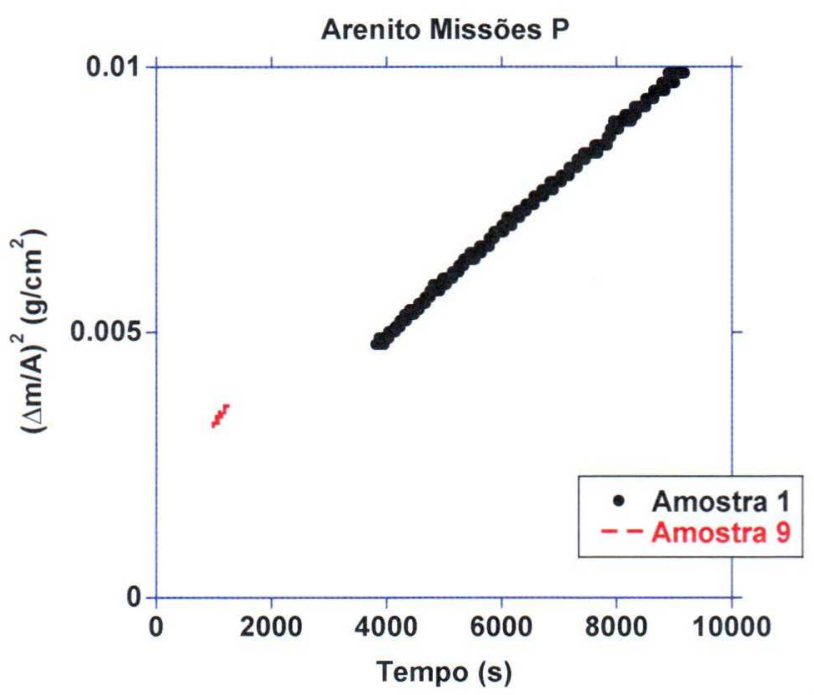

Figura 10.147 - Teste de capilaridade no Arenito Missões tratado com P. Amostra 1 com fluxo perpendicular e amostra $9 \mathrm{com}$ fluxo paralelo. 


\section{- AP}

Quando foi aplicado o pré-consolidante A antes do $\mathbf{P}$, a rocha mostrou o valor de $0,0024 \mathrm{~g} / \mathrm{cm}^{2} \cdot s$ (próximo a rocha fresca) para o fluxo perpendicular e de 0,014 $\mathrm{g} / \mathrm{cm}^{2} \cdot \mathrm{s}$ (maior que na rocha fresca) para o fluxo paralelo (Figura 10.148). Portanto o pré-consolidante não permitiu que o $\mathbf{P}$ ocluísse os poros.

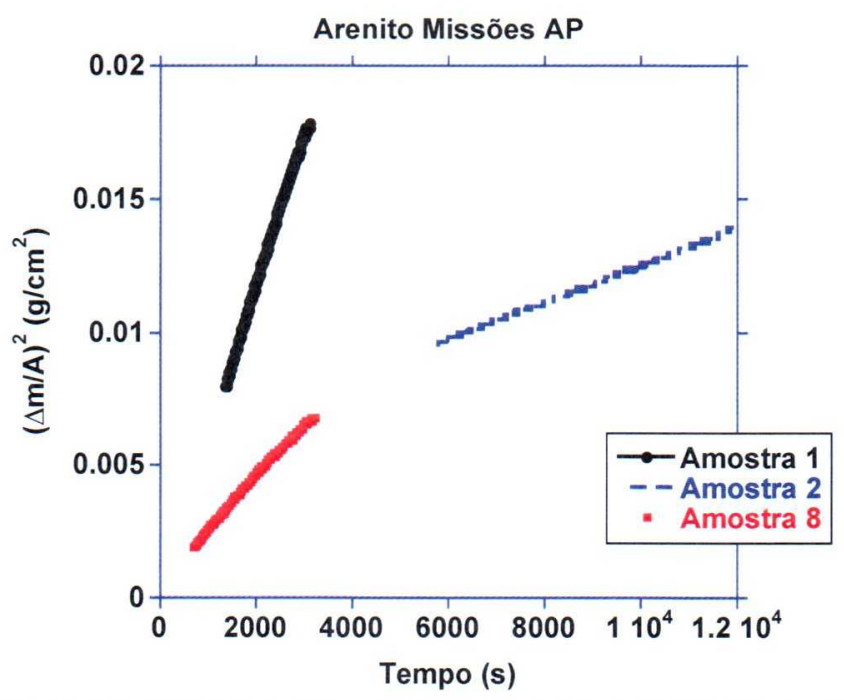

Figura 10.148 - Teste de capilaridade em amostras do Arenito Missões tratadas com AP Amostra 1 e $2 \mathrm{com}$ fluxo perpendicular e amostra $8 \mathrm{com}$ fluxo paralelo.

- TC

A média encontrada para as rochas com fluxo perpendicular ao acamamento é de $0,0022 \mathrm{~g} / \mathrm{cm}^{2} \cdot \mathrm{min}^{1 / 2}$ e para o fluxo paralelo é de $0,0010 \mathrm{~g} / \mathrm{cm}^{2} \cdot \mathrm{s}$ (Figura 10.149). A capilaridade foi levemente reduzida no fluxo perpendicular, mas reduziu pela metade no paralelo. 


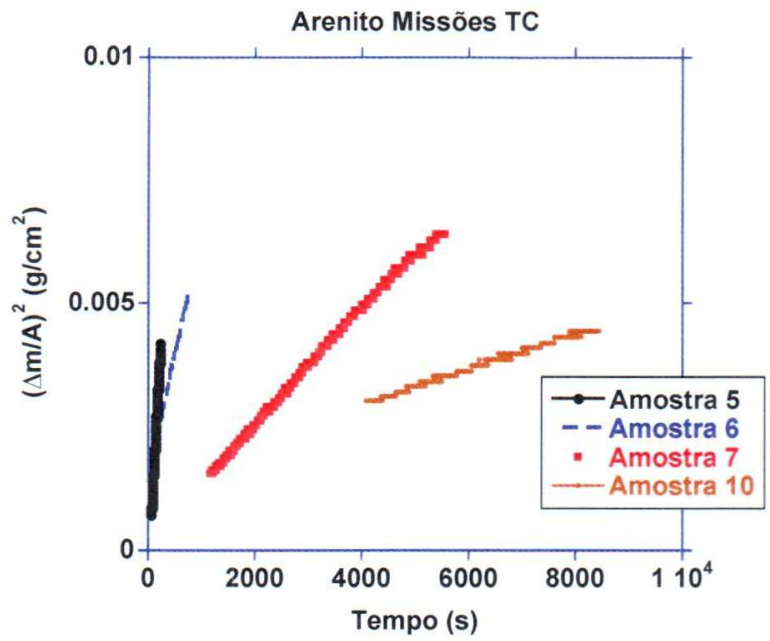

Figura 10.149 - Teste de capilaridade em no Arenito Missões tratado com TC. Amostras 5 e 6 com fluxo perpendicular e amostras 7 e 10, paralelo.

\section{- ATC}

As amostras com fluxo perpendicular ao acamamento apresentaram capilaridade de $0,0013 \mathrm{~g} / \mathrm{cm}^{2} \cdot \mathrm{s}$ e as com fluxo paralelo ao acamamento, média de $0,0018 \mathrm{~g} / \mathrm{cm}^{2} \cdot \mathrm{s}$ (Figura 10.150). A amostra 12 demorou mais para absorver a água.

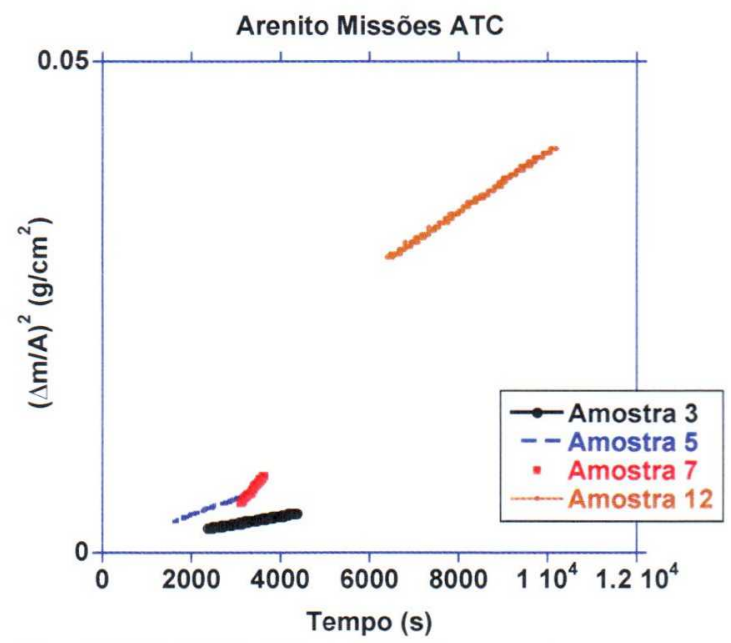

Figura 10.150 - Teste de capilaridade em amostras do Arenito Missões tratado com ATC. Amostras 3 e $5 \mathrm{com}$ fluxo perpendicular e amostra 7 e 12, paralelo.

Todos os resultados dos experimentos de capilaridade encontram-se reunidos na Tabela 10.18. 
Tabela 10.18 - Valores de capilaridade para o Arenito Missões tratado.

\begin{tabular}{llcc}
\hline Tratamento & Direção de fluxo & $\begin{array}{c}\text { Capilaridade } \\
\left(\mathbf{g} / \mathbf{c m}^{2} \cdot \mathbf{s}\right)\end{array}$ & $\begin{array}{c}\text { Variação média } \\
(\%)^{*}\end{array}$ \\
\hline \multirow{2}{*}{ Fresca } & Perpendicular & $0,0027^{* *}$ & - \\
\hline \multirow{2}{*}{ P } & Paralelo & $0,0019^{* *}$ & - \\
\hline \multirow{2}{*}{ AP } & Perpendicular & 0,0009 & $-66,7$ \\
& Paralelo & 0,0013 & $-31,6$ \\
\hline \multirow{2}{*}{ TC } & Perpendicular & 0,0024 & $-11,1$ \\
& Paralelo & 0,0014 & $-26,3$ \\
\hline \multirow{2}{*}{ ATC } & Perpendicular & 0,0022 & $-18,5$ \\
& Paralelo & 0,0010 & $-47,4$ \\
\hline
\end{tabular}

* variação em relação à amostra fresca.

** média.

A menor variação foi encontrada nas amostras em que foi aplicado AP. Observando os resultados, é possível verificar que o TC não é tão eficiente, já que fecha os poros, principalmente quando ensaiado com fluxo paralelo. O P é a última opção para esta rocha.

\subsubsection{Ultrassom}

\section{- Amostra fresca e seca}

Os valores médios encontrados em amostra fresca seca foram de $4,1 \mathrm{~km} / \mathrm{s}$ para medidas perpendiculares ao acamamento e $4,4 \mathrm{~km} / \mathrm{s}$ para medidas paralelas. 0 desvio padrão foi de 0,15 e 0,09, respectivamente. O módulo de elasticidade dinâmico médio foi de 37,8 GPa para medidas realizadas perpendicularmente e 43,7 GPa para medidas feitas paralelamente ao acamamento.

\section{$-\mathrm{A}$}

Nas amostras em que foi aplicado o pré-consolidante $\mathbf{A}$, a velocidade encontrada foi de $4,0 \mathrm{~km} / \mathrm{s}$ para o acamamento perpendicular e $4,1 \mathrm{~km} / \mathrm{s}$ para 0 acamamento paralelo. Em relação à amostra fresca, a variação média da velocidade foi de $-0,2 \%$ e $-7,0 \%$, respectivamente. O módulo de elasticidade teve uma diminuição de $-0,4 \%$ para as rochas com acamamento horizontal e $-13,5 \%$ para o vertical. 


\section{$-P$}

Quando aplicado apenas o P nas amostras, os resultados encontrados foram de $4,4 \mathrm{~km} / \mathrm{s}$ para o acamamento horizontal e $4,5 \mathrm{~km} / \mathrm{s}$ para o acamamento vertical, o que significa um aumento de $7,3 \%$ para o horizontal e um aumento de $1,5 \%$ para 0 vertical. O módulo dinâmico diminuiu $-1,3 \%$ para o primeiro e aumentou $3 \%$ para 0 segundo.

\section{- AP}

Nas amostras em que foi aplicado o $\mathbf{A}$ antes do $\mathbf{P}$ foi encontrada um aumento de $7,3 \%$ para a direção horizontal $(4,4 \mathrm{~km} / \mathrm{s})$ e aumento de $10,0 \%$ para o vertical $(4,8$ $\mathrm{km} / \mathrm{s}$ ). O módulo de elasticidade aumentou 10,3\% para o horizontal (41,7 GPa) e aumentou $20,9 \%$ para o vertical $(48,4 \mathrm{GPa})$.

\section{- TC}

Após a aplicação do TC, a velocidade apresentou aumento de $4,5 \%$ para o horizontal $(4,2 \mathrm{~km} / \mathrm{s})$ e $10,2 \%$ para o vertical $(5,0 \mathrm{~km} / \mathrm{s})$. O módulo de elasticidade sofreu um aumento de $9,2 \%(38,2 \mathrm{GPa})$ e de $21,4 \%$ (54 GPa), respectivamente.

\section{- ATC}

Com a aplicação do pré-consolidante A antes do TC, foi encontrado um aumento de $13,8 \%$ para o horizontal $(4,7 \mathrm{~km} / \mathrm{s})$ e aumento de $16,7 \%$ para o vertical ( 5 $\mathrm{km} / \mathrm{s}$ ). Em relação ao módulo de elasticidade, o aumento foi de 29,5\% (46,5 GPa) e $36,1 \%(54,1 \mathrm{GPa})$, respectivamente.

Na Tabela 10.19 encontram-se compilados todos os resultados com o teste de velocidade de ondas ultrassônicas. 
Tabela 10.19 - Velocidade ultrassônica no Arenito Missões após consolidação.

\begin{tabular}{llcccc}
\hline Tratamento & $\begin{array}{c}\text { Medida } \mathbf{x} \\
\text { acamamento }\end{array}$ & $\begin{array}{c}\text { Velocidade } \\
(\mathbf{k m} / \mathbf{s})\end{array}$ & $\begin{array}{c}\text { Variação } \\
(\%)\end{array}$ & $\mathbf{E}_{\text {din }}(\mathrm{GPa})$ & $\begin{array}{c}\text { Variação } \\
(\%)\end{array}$ \\
\hline \multirow{2}{*}{ Fresca } & Perpendicular & $4,1^{*}$ & - & $37,8^{*}$ & - \\
\hline \multirow{2}{*}{ A } & Paralelo & $4,4^{*}$ & - & $43,7^{*}$ & - \\
\hline \multirow{2}{*}{ P } & Perpendicular & $4,0^{*}$ & $-0,2^{*}$ & $36,2^{*}$ & $-0,4^{*}$ \\
& Paralelo & $4,1^{*}$ & $-7,0^{*}$ & $37,0^{*}$ & $-13,5^{*}$ \\
\hline \multirow{2}{*}{ AP } & Perpendicular & 4,4 & 7,3 & 41,4 & $-1,3$ \\
& Paralelo & 4,5 & 1,5 & 44,5 & 3,0 \\
\hline \multirow{2}{*}{ TC } & Perpendicular & 4,4 & 7,3 & 41,7 & 10,3 \\
& Paralelo & 4,8 & 10,0 & 48,4 & 20,9 \\
\hline \multirow{2}{*}{ ATC } & Perpendicular & 4,2 & 4,5 & 38,2 & 9,2 \\
\hline
\end{tabular}

*Média

\subsubsection{Teste de expansibilidade}

Os resultados do teste de expansibilidade não apresentaram resultados congruentes, portanto estes não serão considerados para esta pesquisa. No entanto, para fins ilustrativos, todos os resultados encontram-se reunidos no Anexo II.

\subsubsection{Porosimetria de mercúrio}

As rochas frescas apresentaram variação entre as amostras. A amostra 10 (Figura 10.151) apresentou poros com distribuição polimodal, com poros de diâmetro de 5,100 e $7.000 \mathrm{~nm}$, intrusão cumulativa de $0,04 \mathrm{~mL} / \mathrm{g}$ e porosidade de $9,8 \%$, enquanto a amostra 12 (Figura 10.152) apresentou poros com diâmetro de 5, 100 , $1.000,3.000 \mathrm{~nm}$, intrusão cumulativa de $0,05 \mathrm{ml} / \mathrm{g}$ e porosidade de $11,3 \%$. 


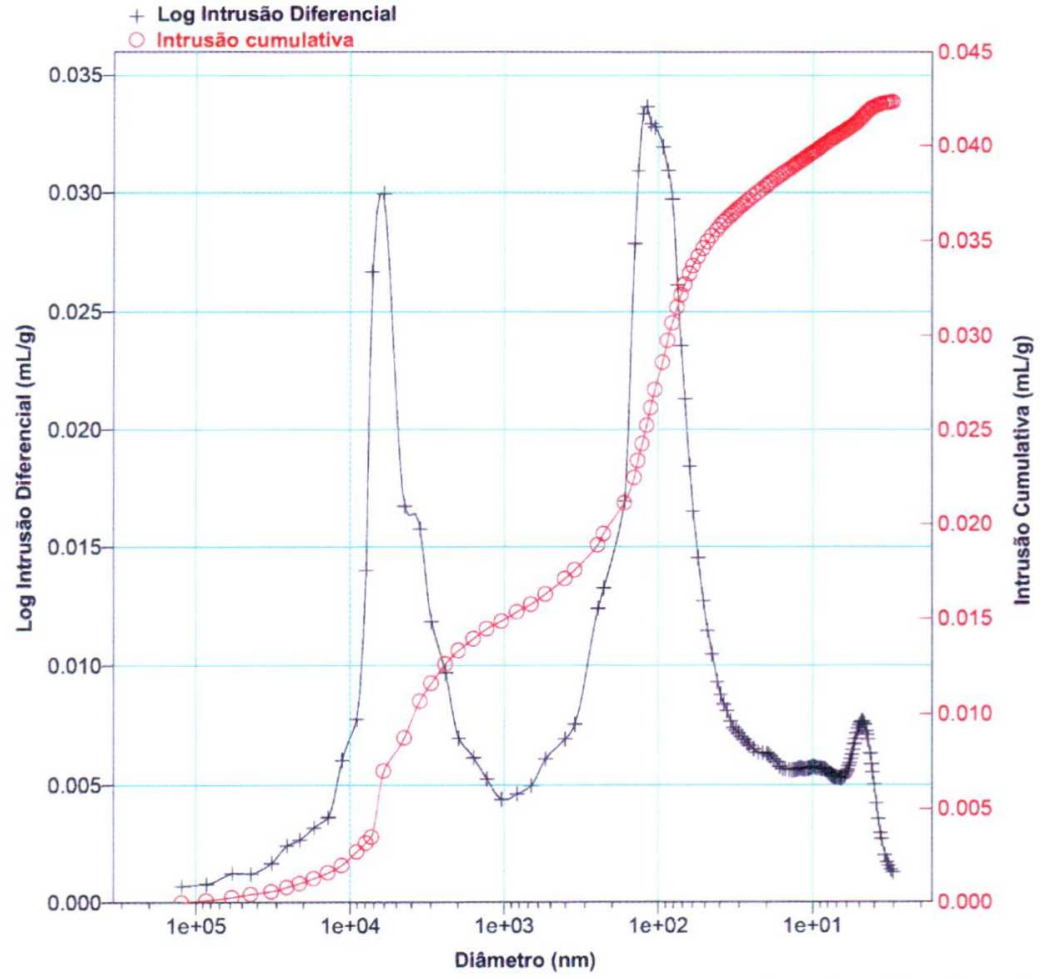

Figura 10.151 - Porosimetria de mercúrio em amostra do Arenito Missões fresco.

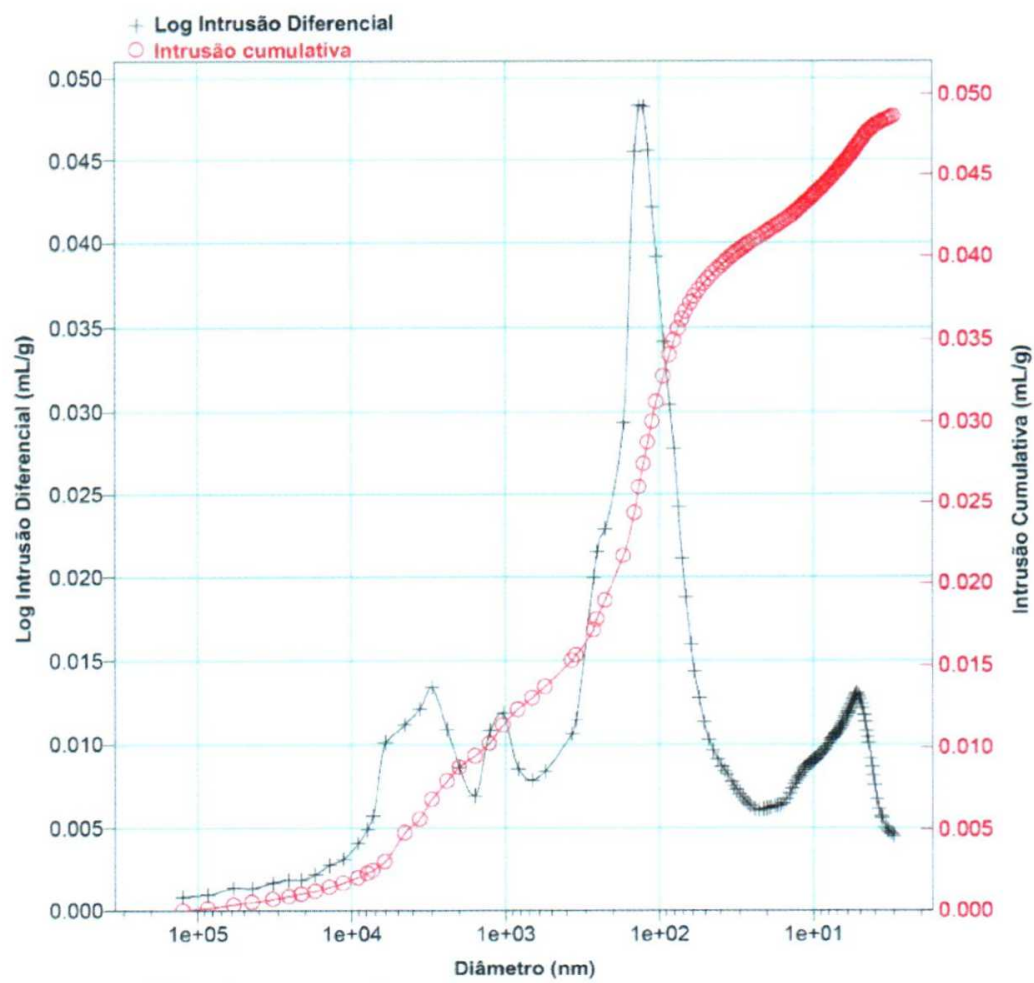

Figura 10.152 - Porosimetria de mercúrio no Arenito Missões fresco.

Quando aplicado apenas o P (Figura 10.153), a porosidade aumentou (24,7\%) e a intrusão cumulativa subiu significativamente $(0,13 \mathrm{~mL} / \mathrm{g})$. O mesmo ocorreu na 
amostra do Arenito Itararé tratado apenas com $\mathbf{P}$. Então, de alguma maneira, o P faz com que a intrusão cumulativa e os poros aumentem. Os poros apresentaram diâmetro de $5,100,3.000$ e $10.000 \mathrm{~nm}$.

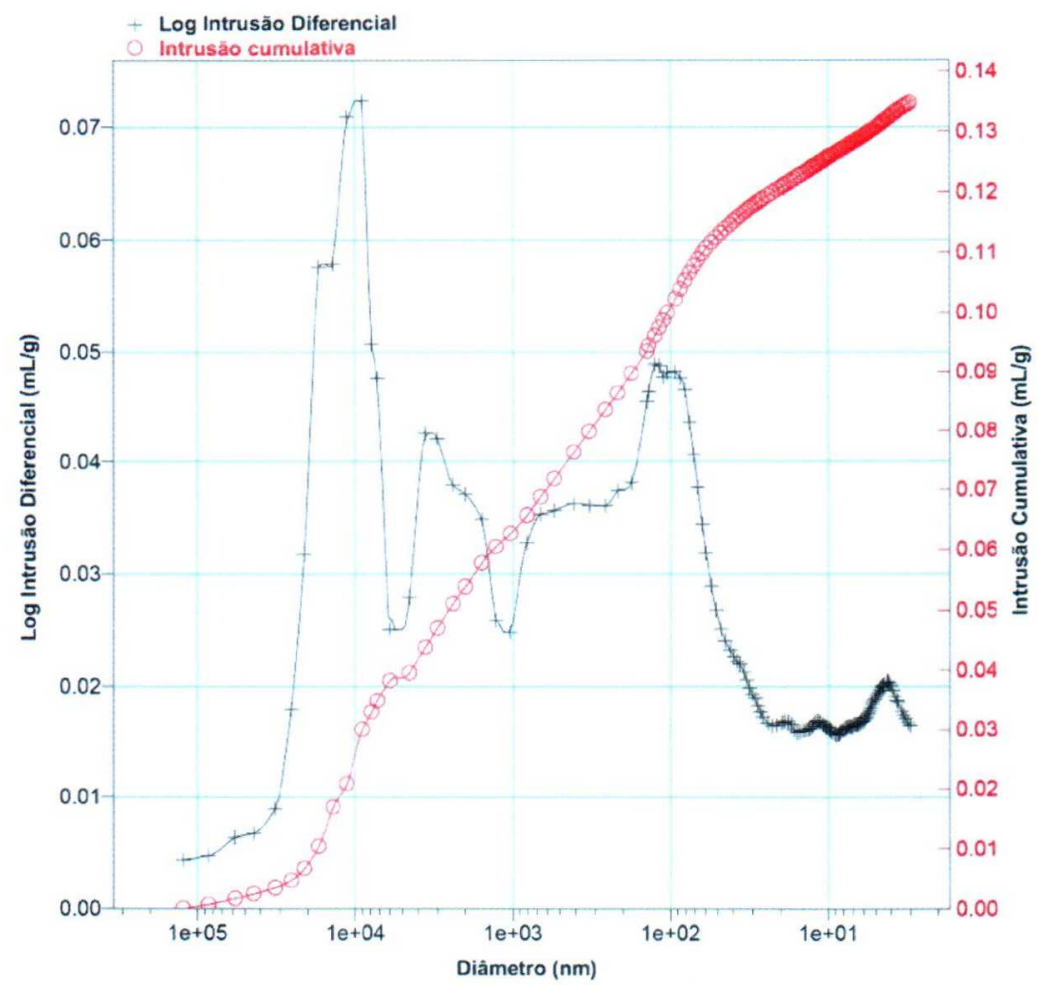

Figura 10.153 - Porosimetria de mercúrio no Arenito Missões tratado com P.

As amostras tratadas com AP (Figura 10.154) ficou bem próxima dos resultados apresentados pela amostra 10 fresca. A intrusão cumulativa foi de 0,06 $\mathrm{mL} / \mathrm{g}$. O aumento da intrusão cumulativa da amostra tratada com AP é devido à distribuição dos poros foi de 5, 100, 3.000 e 20.000 nm. Este último, é um tamanho de poro que não foi encontrado nas duas amostras frescas testadas. A porosidade ficou em $14,4 \%$.

As amostras que foram tratadas apenas com o TC (Figura 10.155), tiveram seus poros de $5 \mathrm{~nm}$ eliminados. Os poros de 100, 1000 e $3.000 \mathrm{~nm}$ aparecem todos juntos num único pico com base alargada. Os poros de 20.000 foram mantidos. $A$ porosidade apresentou valor bem próximo ao da amostra 12 fresca, 12,6\%. A intrusão cumulativa ficou em $0,05 \mathrm{~mL} / \mathrm{g}$. Todavia, quando aplicado após a pré-consolidação com A, os poros de $100 \mathrm{~nm}$ não foram totalmente preenchidos. Acredita-se que o motivo seja a reatividade entre o $\mathrm{A}$ e o TC impediu que que os poros pequenos fossem preenchidos (Figura 10.156). 


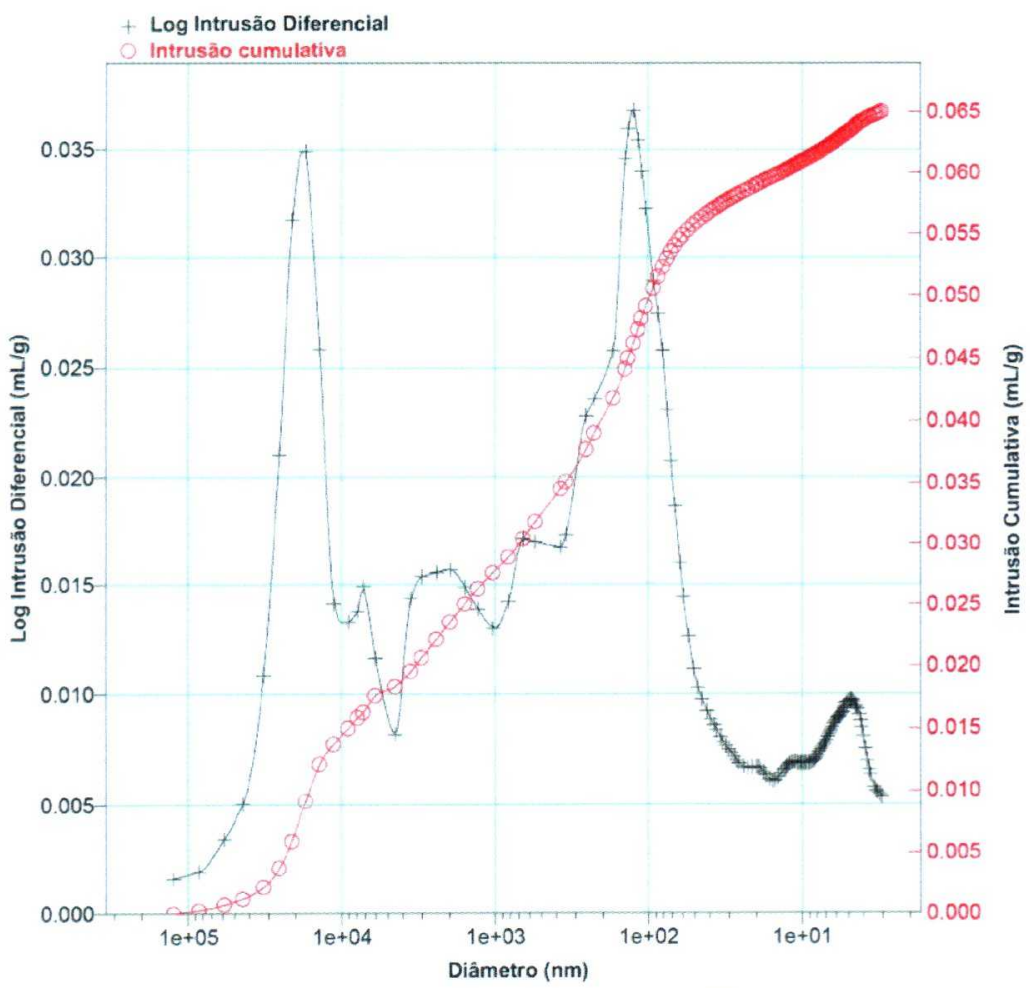

Figura 10.154 - Porosimetria de mercúrio no Arenito Missões tratado com AP.

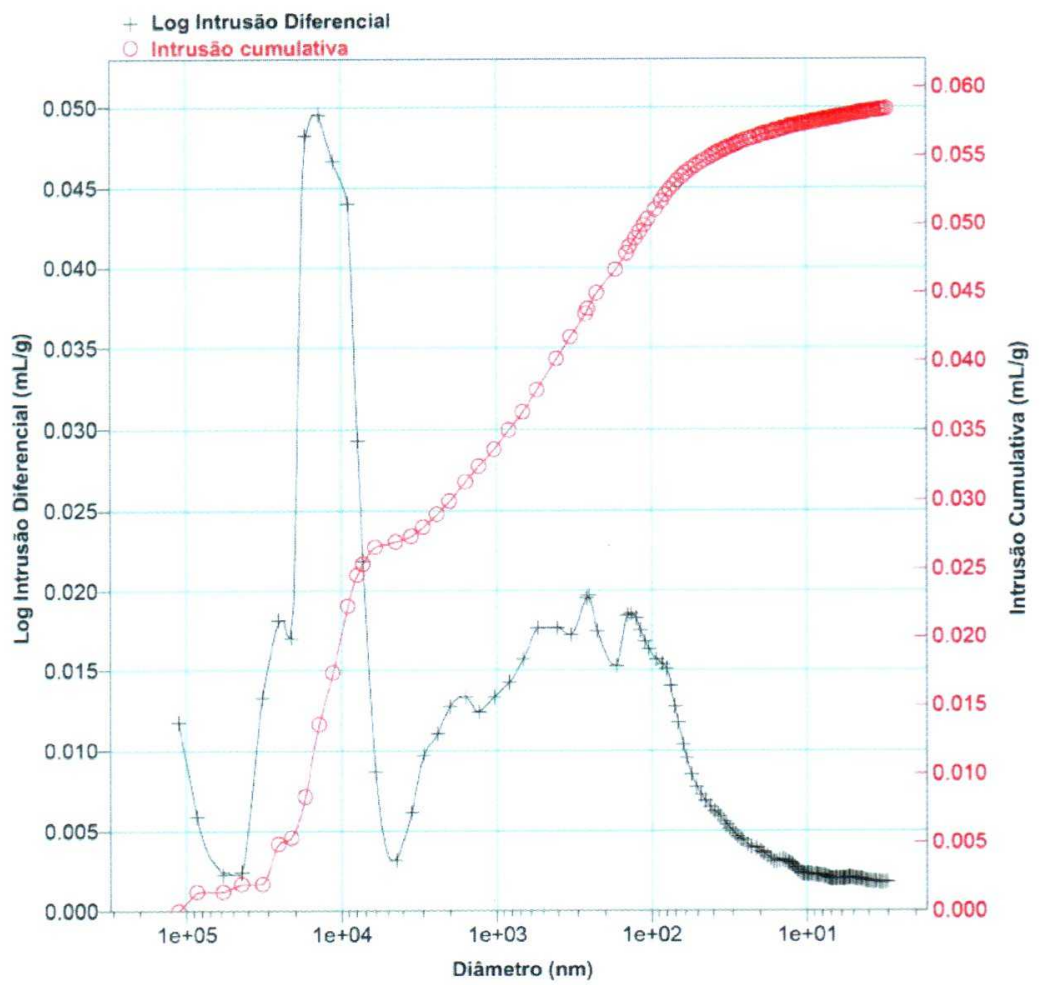

Figura 10.155 - Porosimetria de mercúrio no Arenito Missões tratado com TC.

A distribuição dos poros da amostra tratada com ATC foi de 90 e $20.000 \mathrm{~nm}$. (Figura 10.156). A intrusão cumulativa coi de e $0,05 \mathrm{~mL} / \mathrm{g}$. A porosidade ficou em $11,2 \%$. 


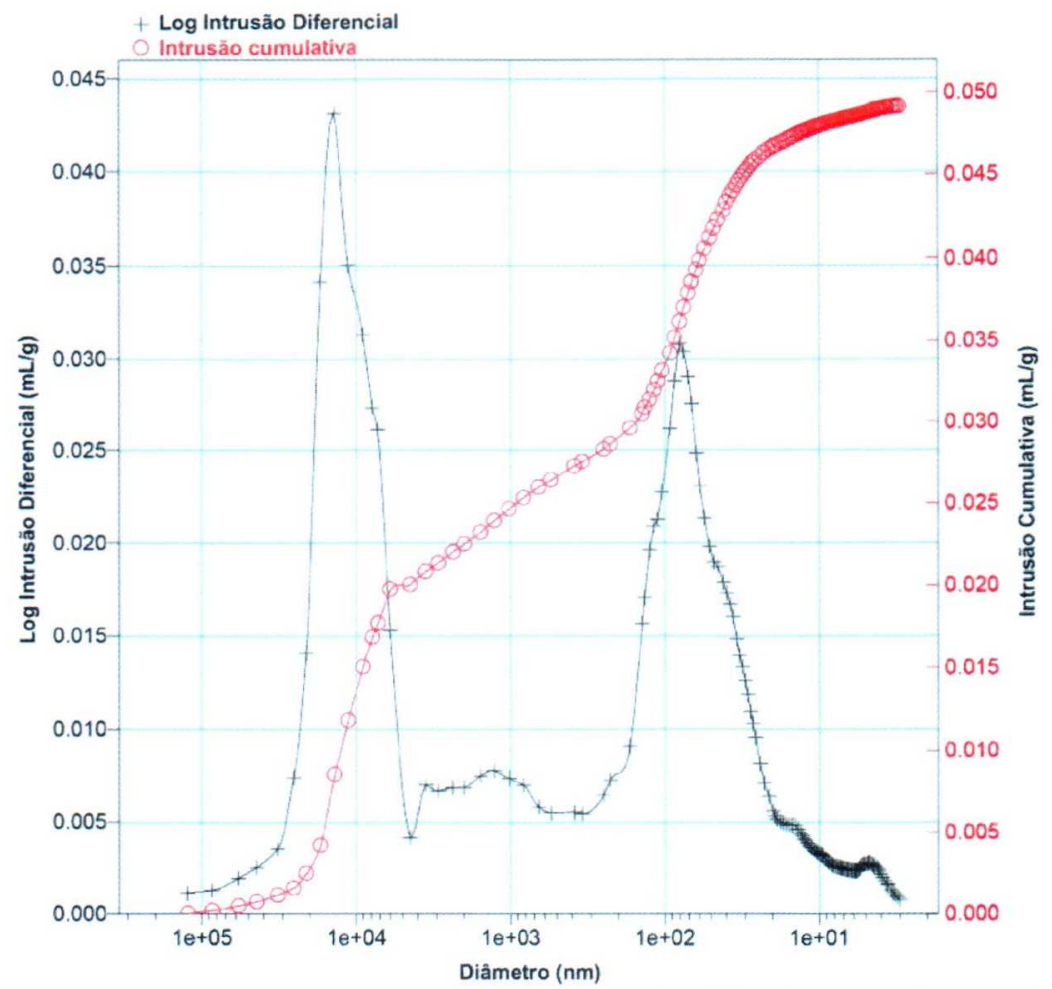

Figura 10.156 - Porosimetria de mercúrio no Arenito Missões tratado com ATC.

De modo geral, a porosidade total não foi muito afetada pelos produtos. O TC, quando aplicado sozinho, eliminou os poros pequenos. Talvez se for utilizada uma maior diluição do produto, a sua viscosidade seja diminuida e os poros pequenos não sejam preenchidos. Esta hipótese deve ser testada. O P, quando aplicado sozinho, aumentou bastante a porosidade e a intrusão cumulativa. Ele pode ser um bom produto, no entanto, o aumento da porosidade precisa ser melhor compreendido. AP é o produto que menos altera a distribuição dos poros.

\subsubsection{Saturação a vácuo}

O resultado para o Arenito Missões foi de $5,2 \%$ de porosidade, que não é condizente com os valores encontrados na porosimetria de mercúrio. Como são métodos muito diferentes, os resultados, muitas vezes, não são comparáveis.

\subsubsection{Resistência à flexão}

O teste não apresentou dados precisos pois as amostras não puderam ser cortadas de modo adequado, pois precisam ser longas, finas e lados perfeitamente 
paralelos. Portanto, estes dados foram descartados. No entanto, todos os valores encontrados estão no Anexo II. 


\section{Discussão}

O Arenito Itararé, utilizado na fachada frontal do Teatro Municipal, apresenta características mineralógicas que levam à sua deterioração. Esta é uma rocha que possui argilominerais expansivos e seus grãos, em várias áreas do corpo rochoso, possuem baixa coesão. Esta é uma rocha que não deveria ser utilizada em fachadas ou locais expostos às intempéries. Contudo, quando o Teatro foi construído, não havia conhecimento e equipamentos que a caracterizassem.

$\mathrm{Na}$ caracterização da rocha por difratometria de raios $\mathrm{X}$, verificou-se a existência de argilominerais expansivos do grupo das esmectitas, responsáveis pela alta velocidade de deterioração observada no teatro.

Os resultados de três campanhas de espectrofotometria, realizadas na fachada do Teatro Municipal de São Paulo, não mostraram grandes diferenças de um ano para outro. Contudo, mostram que a rocha da fachada está mais avermelhada, menos amarela e mais escura do que a rocha fresca. Seria necessário acompanhar esses dados por mais tempo para conseguir verificar alguma tendência.

O aquecimento das amostras para simular o intemperismo diminuiu a velocidade das ondas ultrassônicas. Contudo, modificou a cor e a porosidade. A modificação da cor provavelmente é devida a presença dos minerais de ferro presentes no Arenito Itararé. A porosidade diminui, provavelmente pela recristalização dos argilominerais. Essas mudanças não conferem com os parâmetros encontrados na rocha intemperizada naturalmente. Portanto, esse método não é ideal para simular o intemperismo de uma forma global para o Arenito Itararé. Mas, o aquecimento não interferiu na ação dos consolidantes, pois a ordem do aumento de coesão permaneceu quase a mesma, em comparação com os valores encontrados nas amostras tratadas para o intemperismo acelerado por $\mathrm{SO}_{2}$, que não foram aquecidas antes do tratamento. É verificada apenas uma pequena mudança entre as amostras tratadas com $\mathrm{P}$ e $\mathrm{PCaOH}$ pois, para o caso da amostras aquecidas, o $\mathbf{P}$ funcionou tão bem quanto $\circ \mathrm{PCaOH}$. Outra pequena alteração foi entre $\circ 630$ e $\circ 808$, que no caso das aquecidas, o primeiro se mostrou um pouco mais eficiente que o segundo. No caso das amostras tratadas sem aquecimento prévio, o 630 não alterou significativamente o valor da velocidade de ondas ultrassônicas.

No ensaio de capilaridade, das amostras tratadas e avaliadas na Universidade de Princeton, o TC diminuiu este parâmetro. Os produtos que melhor se apresentaram foram A, seguido por P, AP e ATC com proporção semelhante. No ensaio de capilaridade, realizado na Universidade de São Paulo, os produtos que não alteraram a capilaridade foram: TW, $\mathrm{CaOH}$ e P. Dos hidrofugantes, o 808 foi o que menos 
alterou este parâmetro. No entanto, foram diferenças muito sutis e devido à variabilidade dos dados, não permite que este método indique o melhor tratamento.

Com relação à quantidade de água absorvida (tubo de Karsten - ensaio realizado no Brasil), os produtos que menos modificaram este parâmetro foram $P, A P$ e $\mathrm{PCaOH}$, sendo que o $\mathrm{P}$ foi que mais o modificou e $\circ \mathrm{PCaOH}$, o que menos o alterou. O A aumentou a quantidade de água absorvida, provavelmente devido ao deslizamento e rearranjo das camadas de argilominerais.

Considerando-se os resultados obtidos com o tubo de Karsten e com o ensaio de capilaridade, os dois convergem para que P, TW e ATW sejam os tratamentos mais indicados.

No MEV, notou-se que alguns produtos conseguem cobrir todos os grãos como AG, 808, 630, TW e P. A amostra tratada com A, mostrou a formação estruturas em forma de flor, formadas por carbono e estruturas esferoidais formadas por cálcio. A amostra tratada por $\mathbf{P}$, mostrou consolidação dos grãos menores como os argilominerais, por uma camada formada, provavelmente, por fosfato de magnésio. As amostras tratadas com AP mostraram as estruturas esferoidais características do A e uma camada de aspecto alveolar, pela deposição do produto. Desta vez, não foi observado o fosfato de magnésio. O $\mathrm{PCaOH}$ apresentou estruturas esferoidais formadas por fósforo, cobrindo os grãos menores e poros. Houve, novamente, a formação do fosfato de magnésio. A amostra tratada com $\mathrm{CaOH}$, apresentou estruturas em forma de bastonetes, salpicadas por toda a superfície dos grãos. Em alguns grãos, foi observada a formação de uma camada de aspecto irregular. O TW mostrou-se quase que totalmente polimerizado e com rachaduras tanto na espessura total do gel, quanto apenas superficiais. Formou uma camada sobre os grãos com aspecto de "pele de sapo". O tratamento com ATW mostrou as estruturas esferoidais características do $\mathrm{A}$ e gretas de contração um pouco menores do que as encontradas no tratamento com apenas TW. Foi detectada a presença de carbono, podendo indicar que o A retarda a polimerização do TW. Na amostra tratada com 630 foi observada uma camada de aspecto folicular, o qual apresentou carbono, que denota uma polimerização incompleta. Nas amostras tratadas com A630 foi observada a formação de uma camada amorfa sobre os grãos. Não se observou as estruturas esferoidais características do A, mas pode-se verificar a presença de grande quantidade de cálcio. Na observação da amostra tratada com 808, observou-se uma camada irregular recobrindo os grãos, de modo que não foi possível determinar visualmente quais eram os minerais subjacentes. $O$ tratamento com $A G$ formou uma camada com aspecto de bolhas secas. 
No ensaio de porosimetria de mercúrio, realizado na Universidade de Princeton, o produto que menos alterou o tamanho e distribuição dos poros foi o AP, por manter a distribuição dos poros bem próxima a da amostra fresca. $O$ tratamento com A diminuiu os poros de $700 \mathrm{~nm}$ e aumentou os de $10.000 \mathrm{~nm}$ (amostra de grãos mais finos). Para a de grãos mais grossos, apareceram poros de $2.000 \mathrm{~nm}$ e mantiveram-se os de $10.000 \mathrm{~nm}$. Nas amostras de grãos mais finos em que foi aplicado $\mathbf{P}$, os poros de $8.000 \mathrm{~nm}$ foram eliminados e na de grãos mais grossos, os de $10.000 \mathrm{~nm}$ apresentaram sua quantidade aumentada. Nas amostras de grãos finos tratadas com AP, os poros de $700 \mathrm{~nm}$ foram mantidos e os de 8.000 foram levemente diminuídos. Na de grãos grossos, os poros de $10.000 \mathrm{~nm}$ foram mantidos. Nas amostras de grãos finos tratadas com TC, os poros de $8.000 \mathrm{~nm}$ foram eliminados e na de grãos grossos, apareceram poros de $2.000 \mathrm{~nm}$ e os de $10.000 \mathrm{~nm}$ foram reduzidos para $9.000 \mathrm{~nm}$. Na amostra de grãos finos tratada com ATC, aparecem apenas poros de $1.000 \mathrm{~nm}$. Os outros foram eliminados. Na de grãos grossos, apareceram poros de $5.000 \mathrm{~nm}$ e os de $10.000 \mathrm{~nm}$ apresentaram sua quantidade diminuída. No mesmo ensaio, realizado na Universidade de São Carlos, a porosidade da rocha fresca foi bem menor do que a encontrada em Princeton e o diâmetro dos poros encontrados foi de $10 \mathrm{~nm}, 1.000 \mathrm{~nm}$ e $10.000 \mathrm{~nm}$. O consolidante que menos alterou a quantidade e distribuição dos poros foi o ATW, aumentando levemente a quantidade destes três tamanhos de poros. O hidrofugante que menos alterou este parâmetro foi o 808 , seguido pelo AG. O PCaOH eliminou os de $10 \mathrm{~nm}$, diminuiu os de $1.000 \mathrm{~nm}$ e aumentou os de $10.000 \mathrm{~nm}$. O CaOH diminuiu a porosidade pela eliminação dos poros de 1.000 e $10.000 \mathrm{~nm}$. P, TW e ATW apresentaram porosidade muito maior, devido à heterogeneidade da rocha, e não puderam ser avaliadas. Contudo, não houve muita variação entre eles. O aumento de porosidade das amostras tratadas com $\mathbf{P}$, foi observado nas duas rochas testadas em Princeton e nos ensaios realizados no Brasil.

Nos ciclos de saturação e secagem, realizados em Princeton, os produtos que mais aumentaram a coesão entre os grãos, antes da realização do ensaio, foram AP e ATC, tanto com o primeiro, quanto com o segundo procedimento. O A foi o que mais aumentou a velocidade. Todavia, ele não é um consolidante. TC e P são os terceiro e quarto consolidantes que melhor funcionaram. Na fase de resistência à água, todos os produtos aplicados apresentaram boa resistência à deterioração por água, sendo que ATC, foi levemente melhor, seguido por TC e P. Vale salientar que o AP não foi ensaiado devido aos seus maus resultados no ensaio de capilaridade. O produto que menos alterou a cor foi o $\mathbf{P}$, seguido por TC e ATC. 
No mesmo teste, realizado no Brasil, e com produtos aqui disponíveis, os que apresentaram maior aumento de coesão, foram, em ordem decrescente: ATW, TW, AP e P. Os que menos deterioraram após os ciclos, foram: ATW, PCaOH, P, AP e TW. Portanto, o ATW foi o melhor produto neste teste, e a aplicação do préconsolidante influenciou muito no aumento de coesão e na resistência à deterioração por água. Um resultado surpreendente foi que o $\mathbf{A 8 0 8}$, que é um hidrofugante, e não possui ação consolidante, conseguiu aumentar o valor da velocidade de ondas ultrassônicas na mesma proporção que o $\mathrm{P}$, mostrando aumento de coesão entre os grãos. Quanto à cor, todos os consolidantes apresentaram boa performance, com exceção ao TW e ATW, que escurecem visivelmente a superfície. Este escurecimento permanece, mesmo após os ciclos. Dos hidrofugantes, o 630 apresentou a melhor performance e menor alteração de cor. O pequeno aumento da velocidade dos produtos hidrofugantes e protetor de superfície prova que houve o depósito de produto.

Para o ensaio de profundidade de penetração, a técnica que conseguiu levar o produto mais profundamente foi a polpa. O spray e o pincel variaram sua performance em virtude do produto utilizado. Mas, de forma geral, o spray funcionou melhor que o pincel. Os produtos que penetraram mais profundamente foram os pré-consolidantes, seguidos pelo $\mathrm{P}$ e ATW. No caso do ATW, a pré-consolidação auxiliou o TW a atingir maiores profundidades. No caso dos hidrofugantes, o que mais penetrou com a polpa foi o 808. Contudo o que mais penetrou com o pincel e com o spray foi o 630 .

No ensaio de alteração acelerada por $\mathrm{SO}_{2}$, a velocidade de ondas ultrassônicas, que deveria diminuir após o ensaio, aumentou. Não se sabe ao certo qual foi a causa, pois, o aumento da velocidade foi observado em todas as amostras, tanto nas frescas, quanto nas tratadas. Uma hipótese é a deposição de sulfato nos poros e fissuras da amostra. Quanto à alteração da cor, alguns produtos alteraram a cor da rocha quando aplicados. Outros, modificaram este parâmetro após o contato da rocha com a névoa de $\mathrm{SO}_{2}$. O consolidante que menos alterou a cor após o ensaio foi o AP, seguido por $\mathrm{PCaOH}, \mathrm{P}$ e TW. Os três últimos mostraram-se, tecnicamente, com a mesma performance.

Dos produtos utilizados na Universidade de Princeton no Arenito Itararé, os que melhor funcionaram foram AP e ATC, atentando-se para a total secagem do préconsolidante antes da aplicação do consolidante, para evitar a reatividade entre os produtos.

Dentre os produtos testados utilizados no Brasil e aplicados no Arenito Itararé, considerando que os parâmetros mais importantes são aumento de coesão e manutenção da porosidade original, o produto que melhor funcionou, foi o AP. Vale 
ressaltar que a aplicação do $\mathbf{P}$ realizada no Brasil foi distinta da realizada em Princeton. Esta alteração no método de aplicação levou a melhores resultados. No entanto, o grande aumento da porosidade deve ser estudado com mais profundidade para compreender como o consolidante está agindo.

Para o Arenito Missões, o melhor tratamento foi AP, seguido pelo ATC. TC sozinho, não foi uma boa opção, pois obstruiu os poros. No entanto, outras diluições podem ser testadas. 


\section{Conclusões}

Conclui-se que a aplicação dos DAAs (A) tanto na Universidade de Princeton $(A 2+A 3)$, quanto na Universidade de São Paulo $(A 2+A 3+A 6)$ foi benéfica, pois os produtos apresentam a manutenção da capilaridade. Independente do número de átomos de carbono, todos os DAAs aumentaram a quantidade de água absorvida com o ensaio do tubo de Karsten. Este fato, deve-se, provavelmente, ao deslizamento e rearranjo das camadas de argilominerais. Isto mostra que o pré-tratamento facilita a penetração dos produtos. Quanto ao tamanho e distribuição dos poros, tanto na porosimetria de mercúrio realizada na Universidade de Princeton, quanto no mesmo ensaio realizado na Universidade de São Carlos, ele reduziu levemente a porosidade e modificou um pouco a distribuição dos poros. Apresentou boa manutenção da cor do Arenito Itararé e baixa velocidade de deterioração por água (Universidade de São Paulo). No entanto, para alguns produtos, ele não melhorou o desemprenho do consolidante, como será mostrado a seguir.

A aplicação do fosfato de amônio dibásico (P), mostrou ação inovadora, com a formação de fosfato de magnésio. Resultado este, divergente ao de Sassoni et al. (2011), que utilizou o mesmo produto em arenitos calcários e quartizíticos e observou a formação de fosfato de cálcio. O P é um produto com grande potencial pois, apresentou a maior resistência ao ataque por água e boa manutenção da cor original. No entanto, apesar de manter a capilaridade, aumentou a porosidade tanto na porosimetria de mercúrio realizada na Universidade de Princeton, quanto na ensaiada na Universidade de São Carlos. Este aumento da porosidade deve ser estudado e melhor compreendido. Por este fato, este produto não está sendo aqui recomendado mas, estudos mais aprofundados devem ser realizados para entender a formação do fosfato de magnésio. Ao utilizar o mesmo produto, Sassoni et al. (2013) encontraram resultado diferente, obtendo pequena diminuição da porosidade.

O DAAs (A2 + A3 + A6) + fosfato de amônio dibásico (AP) foi o produto que melhor se comportou no Arenito Itararé, pois manteve capilaridade, apesar de reduzir levemente a porosidade e modificar a distribuição dos poros. No entanto, não houve eliminação dos poros pequenos, um fator que leva ao aumento da velocidade da deterioração da rocha e desplacamento de grandes superfícies. Diminuiu um pouco a quantidade de água absorvida no tubo de Karsten. Apresentou boa manutenção da cor original da rocha, após sua aplicação. Quando utilizado o pré-tratamento, não pôde ser observada a formação de fosfato de magnésio. 
O Conservare $\mathrm{OH} 100$ (TC) não é um produto recomendado para esta rocha, pois diminuiu a capilaridade, que é um parâmetro importantíssimo para que a restauração não resulte em resultados ruins. Diminuiu também a porosidade $e$ eliminou os poros pequenos.

A aplicação dos DAAs (A2 + A3) + Conservare OH 100 (ATC) mostrou que esta sequência de tratamento não é indicada para o Arenito Itararé, pois apesar de manter a capilaridade, reduziu a porosidade pela eliminação dos poros grandes e pequenos e mostrou rápida deterioração frente ao intemperismo por água.

O Silres BS OH 100 (TW) não é indicado pois, apesar de manter capilaridade, apresentou gretas de contração, o que diminui a proteção e coesão do produto. Também escureceu visivelmente a rocha.

O DAAs (A2 + A3 + A6) + Silres BS OH 100 (ATW) não é indicado para o Arenito Itararé, pois aumentou a porosidade, apresentou gretas de contração, apesar de menores do que quando o gel foi aplicado sozinho e escureceu visivelmente a rocha.

Os resultados da aplicação da solução de hidróxido de cálcio $(\mathrm{CaOH})$ mostraram que este produto não é indicado, pois aumentou a quantidade de água absorvida e não apresentou cobertura dos grãos, mostrando que o produto é ineficiente para a consolidação do Arenito Itararé.

O fosfato de amônio dibásico + solução de hidróxido de cálcio ( $\mathrm{PCaOH})$ foi o produto que menos alterou a absorção de água com uso do tubo de Karsten. Apresentou sensivel redução da porosidade. Quase não alterou a coloração original da rocha. Foi observado ao MEV a formação de fosfato de magnésio. Esta mistura não é indicada, pois a adição de $\mathrm{CaOH}$ não trouxe nenhum benefício à ação do $P$.

O Protectosil WS 808 (808) foi o hidrofugante que manteve os valores de capilaridade e de porosidade mais próximos aos da rocha fresca. Quase não alterou a cor original da rocha. Observando as amostras tratadas ao MEV, verifica-se a formação de um filme, de forma que os minerais subjacentes não podem ser identificados visualmente. Dos hidrofugantes testados, este foi o que apresentou melhor comportamento, principalmente devido à manutenção da porosidade de distribuição dos poros.

O DAAs (A3 + A3 + A6) + Protectosil WS 808 (A808) diminuiu a porosidade e devido a este fato, esta sequência de produtos não é indicada.

O Protectosil WS 630 (630) não é indicado para o Arenito Itararé, pois diminuiu a porosidade pela eliminação dos poros pequenos, apesar de apresentar boa manutenção da cor e ótima resistência ao ataque por água. 
O Antigraffiti (AG) quase não alterou a porosidade, mas eliminou os poros pequenos, dificultando a troca de água em forma de vapor entre a rocha e o meio circundante.

Portanto, para o Arenito Itararé, o melhor tratamento dentre os estudados, foi o AP.

Este é um trabalho experimental, e não deve ser utilizado como parâmetro para a consolidação e proteção de outras rochas. Cada rocha, mesmo que pertença ao mesmo grupo, como sedimentar, metamórfica ou ígnea, possui características distintas como mineralogia, porosidade, orientação dos grãos, que faz com que um mesmo produto, apresente resultados diferentes em cada uma delas. Neste trabalho, foi observado, devido à grande variação de porosidade e granulometria do Arenito Itararé, que os produtos se comportam de forma diferente em amostras coletadas em pontos distintos.

Este trabalho pode servir como um guia dos procedimentos utilizados para a caracterização rochosa e avaliação do comportamento de consolidantes em rochas. Contudo, cada rocha exibirá resultados diferentes mesmo quando aplicado um mesmo produto. 


\section{Referências bibliográficas}

Almeida F. F. M. 1980. Síntese sobre a tectônica da Bacia do Paraná. In: $3^{\circ}$. Simp Reg Geol., Curtiba. PR, $1-20$.

Amoroso G. G., Fassina V. 1985. Stone decay and Conservation: Atmospheric Pollution, Cleaning, Consolidation and Protecting. Bulletin of the Association for Preservation Technology, 17 (3/4): $84-86$.

Apps C. A. C. P. 2011. Avaliação da variabilidade de técnica de ensaio do tubo de Karsten na medição da permeabilidade à água líquida em revestimentos de ladrilhos cerâmicos e argamassas. Dissertação de Mestrado, Instituto Superior Técnico - Universidade Técnica de Lisboa, 156 p.

Arnold L. 1978. The preservations of stone by impregnation os silanes. Newsletter of the Council for Places Workship, 24: 345 - 347.

Associação Brasileira de Normas Técnicas NBR 8096: 1983. Material metálico revestido e não-revestido - Corrosão por exposição ao dióxido de enxofre Método de ensaio. Rio de Janeiro, $3 \mathrm{p}$.

Associação Brasileira de Normas Técnicas NBR 6490: 1985. Reconhecimento e amostragem para fins de caracterização de ocorrência de rochas. Rio de Janeiro, $4 \mathrm{p}$.

Associação Brasileira de Normas Técnicas NBR 15012: 2013. Rochas para revestimento de edificações Terminologia. Rio de Janeiro, 10 p.

Associação Brasileira de Normas Técnicas NBR 9779: 2012. Argamassa e concreto endurecidos - Determinação da absorção de água por capilaridade. Rio de Janeiro, $7 \mathrm{p}$.

ASTM International. C119: 2014. Standard Terminology Relating to Dimension Stone. West Conshohocken, PA, 7 p. 
Bocardi L. B., Fernandes L. A., Rostirolla S. P. Appi C. J. 2006. Diagênese dos arenitos do Grupo Itararé, permocabonífero, Bacia do Paraná. Revista Brasileira de Geociências, São Paulo, 36 (7): 221 - 231

Borsoi G., Veiga R., Santos Silva A. 2012. Consolidação de argamassas históricas de revestimento com produtos compatíveis; avaliação da eficácia. In: $4^{\circ}$ Congresso Nacional sobre Argamassas e Etics; APFAC 2012, Coimbra, Portugal.

Brady N. C., Weil R. R. 2012. Elementos da Natureza e Propriedades dos Solos. Tradução: Lepsch I. F. Bookman, p. 716.

Brandão I. L. 1993. Teatro municipal de São Paulo: grandes momentos. São Paulo: DBA Artes Gráficas, $120 \mathrm{pp}$

Brandi C. 1963. Teoria da Restauração. Tradução: Kühl B. M. Ateliê Editorial, Cotia, 2008, $261 \mathrm{pp}$

British Standard BS EN 1925: 1999. Natural stone test methods - Determination of water absorption coeficiente by capillarity. Bruxelas, $10 \mathrm{p}$.

British Standard BS EN 12524: 2000. Building materials and products. Hygrothermal properties. Tabulates design values, $4 \mathrm{p}$.

CETESB 2013. Relatório anual. Diretoria de Engenharia e Qualidade Ambiental, Departamento de Qualidade Ambiental, Divisão de Qualidade do ar. 53 p. Disponivel em http://www.cetesb.sp.gov.br/userfiles/file/ar/operacaoinverno/relatorio-op-inverno-2013.pdf. Acessado em 23 de janeiro de 2015.

Choay F. 2001. A alegoria do patrimônio. São Paulo: Estação Liberdade, 304 p.

Concremat 2010. Arquivos dos processos realizados no restauro do Theatro Municipal. Fornecido por Fernanda Lapo.

CPRM - Companhia de Pesquisa de Recursos Minerais 1999. São Paulo: Programa Levantamentos Geológicos Básicos do Brasil, Projeto Integração Geológico- 
metalogenética. Folha SF - $23-Y-C$. Folha Rio de Janeiro, carta geológica, escala 1:250.000.

Cunha C. dos R. 2006. Alois Riegl e "O Culto Moderno dos Monumentos". Revista CPC, São Paulo,2(1): 6-16.

Davino A. 1975. Geologia da serra de Araçoiaba, Estado de São Paulo, Boltim IGUSP, 6: $129-144$.

Delgado Rodrigues J., Costa D. 1996. Assessment of the harmfulness of consolidants in granites. In: Delgado Rodrigues J., Costa D. (eds.). Conservation of Granitic Rocks. Laboratório Nacional de Engenharia Civil, p. 71 - 78.

Del Lama E. A., Szabó G. A. J., Dehira L. K., Kihara Y. 2008. Impacto do Intemperismo no Arenito de Revestimento do Teatro Municipal de São Paulo. Geologia USP, Série Científica, 8: 75 - 86. Disponível em http://geologiausp.igc.usp.br/geologiausp/sc1/art.php?artigo=703. Acessado em 27 de setembro de 2012.

Del Lama E. A., Dehira L. K., Reys, A. C. 2009. Visão geológica dos monumentos da cidade de São Paulo. Revista Brasileira de Geociências, 39 (3): 409 - 420. Disponível no endereço: http://www.sbgeo.org.br/pub_sbg/rbg/vol39_down/3903/11163.pdf.

Del Lama E. A., Bacci D. D. L. C.,Martins L., Garcia M. G. M., Dehira L. K. 2015. Urban geotourism and the old centre of São Paulo city, Brazil. Geoheritage, 7: 147 164. DOI 10.1007/S12371-014-0119-7.

DIN 52615: 1987. Testing of thermal insulating materials; determination of water vapour (moisture) permeability of construction and insulating materials. Deustches Institut für Normung, Berlim.

Dvořák M. 1916. Catecismo da Preservação de Monumentos. Trad.: Valéria Alves Esteves Lima. Artes \& Ofícios, 2008, 124 pp.

Folha de São Paulo, Caderno Cotidiano, 12 de junho de 2008. Acessado em 01 de dezembro de 2011. 
Folha de São Paulo, Caderno llustrada, 17 de fevereiro de 2010. Acessado em 01 de dezembro de 2011.

Franzoni E., Sassoni E., Pigino B., Scherer G. W., Naidu S. 2013 Artificial weathering of stone by heating. Journal of Cultural Heritage, 14: e85 - e93.

Franzoni E., Sassoni E., Graziani G. 2014. Brushing, poultice or immersion? The role of the application technique on the performance of a novel hydroxyapatitebased consolidating treatment for limestone. Journal of Cultural Heritage, 16 (2): $173-184$.

Frascá M. H. B. O. 2003a. Deteriorações e a questão do uso e da durabilidade de rochas ornamentais e para revestimento. In: Villas Bôas R. C., Calvo B., Peiter C. C. (eds.). Iberoeka en Mármoles y Granitos, p. $111-132$.

Frascá M. H. B. O. 2003b. Estudos experimentais de alteração acelerada em rochas graníticas para revestimento. Tese de Doutorado, Instituto de Geociências, Universidade de São Paulo, 227 p.

Gimenez A. M. S., Del Lama E. A. 2014. Comportamento de ondas ultrassônicas no Granito Mauá para a conservação do Monumento às Bandeiras. Geologia USP - Série Científica, Revista do Instituto de Geociências USP, 14 (3): 47 - 60. Disponivel no endereço: http://ppegeo.igc.usp.br/pdf/guspsc/v14n3/04.pdf

Ginell W. S., Kumar R., Doehne E. 1995. Conservation studies on limestone from the Maya site at Xunantunich, Belize. In: Material Issues in Art and Archaeology IV: Symposium Held May 16-21, 1994, Cancun, Mexico. Edited by J. R. Druzik, J. L. Galvan Madrid, I. C. Freestone and G. S. Wheeler, The Getty Conservation Institute, Los Angeles, CA, p. $813-821$.

Gobbi G., Zappia G., Sabbioni C. 1998. Sulphite quantification on damaged srones and mortar. Atmospheric Environment, 32 (4): 783 - 789.

Goldich S. S. 1938. A study in rock-weathering. Journal of Geology, 46: 17-58. 
Graziani G., Sassoni E., Franzoni E. 2015. Consolidation of porous carbonate stones by an innovative phosphate treatment: mechanical strengthening and physical microestructural compatibility in comparison with TEOS-based treatments. Heritage Science 3 (1): $6 \mathrm{p}$.

Grossi C., Murray M. 1999. Characteristics of carbonate building stones that influence the dry deposition of acidic gases. Constructions and Building Materials, 1: 101 -108 .

Grossi D. 2013. Análise do estado de conservação do Monumento a Ramos de Azevedo com utilização de métodos não destrutivos. Dissertação de Mestrado, Instituto de Geociências, 138 p.

Gusmão Filho J. A. 2008. Solos - Da Formação Geológica Ao Uso Na Engenharia. UFPE, $198 \mathrm{p}$.

Honsinger D., Sasse H. R. 1991. Alteration of Microstructure and Moisture Characteritics of Stone Materials due to Impregnation. In: Baker J. M., Nixon P. J., Majumdar A. J., Da Vies H. (eds.) Durability of Building Materials and Components. E.\& F. N. Spon, Chapman and Hall, p. $213-224$.

Instituto do Patrimônio Histórico e Artístico Nacional. 1995. Cartas Patrimoniais. IPHAN, Brasília, 344p.

IPT (Instituto de Pesquisas Tecnológicas do Estado de São Paulo). 1990. Catálogo de Rochas Ornamentais do Estado de São Paulo. Coordenadores: Caruso L.G., Braga T. O., Frascá, M. H. O. São Paulo, Instituto de Pesquisas Tecnológicas, $122 \mathrm{pp}$.

Jiménez González I., Scherer G. W. 2004. Effect of swelling inhibitors on the swelling and stress relaxation of clay-bearing stones. Environmental Geology, 46: 364 377.

Jiménez González I., Scherer G. W. 2006. Evaluating the potential damage to stones from wetting and drying cycles. In: Konsta-Gdoutos M. S. (ed.). Measuring, Monitoring and Modeling Concrete Properties, Springer, Londres p. 685 - 693. 
Kahraman S. 2002. The effects of fracture roughness on $P$-wave velocity. Engineering Geology, 63: $347-350$.

Kersten M. S. de A. 2000. Os rituais de tombamento e a escrita da história: bens tombados no Paraná entre 1938-1990. UFPR, Curitiba, 300 pp.

Kühl B. M. 2000. Viollet-le-Duc e o verbete da restauração. In: Restauração. Ateliê Editorial, Cotia, p. 9-24.

Kühl B. M. 2002. Os Restauradores e o Pensamento de Camillo Boito sobre a restauração. In: Os Restauradores. Ateliê Editorial, Cotia, p. 9-28.

Kupchella C. E., Hyland M. C. 1992. Environmental science: living with the system of nature, $3^{\mathrm{a}}$ ed. Prentice-Hall, New Jersey, $656 \mathrm{pp}$.

Lima E. F. W., Maleque M. R. 2007. Espaço e cidade. 7 Letras, Rio de Janeiro, 183 p.

Mannheimer W. A. 2002. Microscopia dos materiais. E-papers serviços editoriais, Rio de Janeiro, $221 \mathrm{p}$.

Martini A. 2010. Theatro Municipal de São Paulo, 26 de outubro. Disponível em: http://asimplicidadedascoisas.wordpress.com/2010/10/26/theatro-municipal-desao-paulo/. Acessado em 01/12/2011.

Medeiros H. F. M., Andrade J. J. O., Helene P. 2011. Durabilidade e Vida Útil das Estruturas de Concreto. In: Concreto: Ciência e Tecnologia. IBRACON, 1: 773 808.

Meneses, U. T. B. 1992. O patrimônio cultural entre o público e o privado. In: O Direito à Memória: patrimônio histórico e cidadania. São Paulo, DPH, 189 - 194 p.

Método Engenharia. 1991. Obras de reforma e restauro. $2^{\text {a }}$ fase. Dez 90 - set 91. (Relatório disponível no Departamento de Patrimônio Histórico da Prefeitura Municipal de São Paulo).

Milani E. J. 2004. Magmatismo Toleítico na Bacia do Paraná. In: Neto V. M., Bartorelli A., Dal Ré Carneiro C., Brito-Neves B. B. Geologia do Continente Sul- 
Americano: Evolução da obra de Fernando Flávio Marques de Almeida, Beca, São Paulo, p. $245-279$.

Montanheiro T. J. 1999. Prospecção e caracterização de pozolanas na Bacia do Paraná, estado de São Paulo. Instituto de Geociências, Universidade de São Paulo, Tese de doutorado, $226 \mathrm{p}$.

Morenghi C. L. 2007. Arcabouço estratigráfico e potencial de armazenamento em arenitos permocarboníferos do Grupo Itararé na Região do Alto estrutural de Pitanga, centro-leste do estado de São Paulo. Dissertação de Mestrado, Instituto de Geociências, Universidade de São Paulo, 105 p.

Murta J. F. 2015. Consolidação de materiais pétreos em obras de interesse cultural por meio do processo sol gel híbrido. Escola de Arquitetura, Universidade Federal de Minas Gerais, Dissertação de Mestrado, 180 p.

Naidu S., Chun L., Scherer G. W. 2015. Hydroxyapatite-based consolidant and the acceleration of hydrolysis of silicate-based consolidants. Journal of Cultural Heritage, 16 (1): $94-101$.

Neves P. C. P. 2011. Introdução à mineralogia prática. ULBRA, 380 p.

Neville A. 2001. Consideration of durability of concrete structures: past, present and future. Materials and Structures, 34 (2): 114 - 118.

Nora P. 1993. Entre história e memória: a problemática dos lugares. Revista Projeto História, 10: 7-28.

Oliveira E. C., Pessoa E. C., Fontaneta G. T., Soares L. C. R.; Boggiani P. C. 2005. Pesquisa Geológica no morro de Araçoiaba, Capacitação e Treinamento Geológico dos Monitores da Floresta Nacional de Ipanema, Município de Iperó, SP. Pró Reitoria de Cultura e Extensão Universitária/ USP, 37 p.

Papida S., Murphy W. 2000. The use of sound velocity determination for the nondestructive estimation of physical and microbial weathering of limestone and dolomites. International Congresso $n$ Deterioration and Conservations of Stone, 9. Proceedings, Elsevier, Veneza, p. $609-617$. 
Pejon O. J., Zuquete L.V. 2006. Effects of strain on the swelling pressure of mudrocks. International Journal of Rock Mechanics \& Mining Sciencies, 43: 817 - 825.

Pensavento S. J. 2002. Memória, história e cidade: lugares no tempo, momentos no espaço. Revista ArtCultura, Uberlândia, 4 (4): 9 - 17.

Petri S., Souza P. A. 1993. Síntese dos conhecimentos e novas concepções sobre a bioestratigrafia do subgrupo Itararé, bacia do Paraná, Brasil._Revista do Instituto Geológico, 2 (14): 7 - 18.

Pinheiro M. L. B. 2008. John Ruskin e as Sete Lâmpadas da Arquitetura - Algumas repercussões no Brasil. In: Ruskin J. A Lâmpada da Memória, p. 9 - 48.

Pollak M. 1989. Memória, esquecimento e silêncio. Estudos Históricos, Rio de Janeiro, $3(2): 3-15$.

Poupeleer A. S. 2007. Transport and crystallization of dissolved salts in cracked porous building materials. Tese de doutorado. Katholike Universiteit Leuven, Faculteit Toegepaste Wetenschappen, 299 p.

Prata J. M. 2009. Patrimônio cultural e cidade: práticas de preservação em São Paulo. Tese de Doutorado, Faculdade de Arquitetura e Urbanismo, Universidade de São Paulo, 182 p.

Price C. A. 2006. Consolidation. In: Henry A. (ed.) Stone conservation: principles and practice. Donhead publishing, United Kingdon, p. $101-125$.

Rocha-Campos A. C., Santos P. R. 1981. The Itararé subgroup, Aquidauana group and San Gregório formation, Paraná basin, southeastern South America.In: Hambrey M.J., Harland M.J. (Org.). Earth's Pre-Pleistocene glacial records. Cambridge University Press, New York, p. $842-852$.

Rodrigues N. M. 2012. Ensaios não destrutivos em monumentos pétreos paulistanos. Monografia de Trabalho de Formatura, Instituto de Geociências, Universidade de São Paulo, 47 p. 
Ruskin J. 1849. A Lâmpada da Memória. Trad: Pinheiro M. L. B.Atelie Editorial, 2008, $88 p$.

Sacramento L. 2010. Restauração do Teatro Municipal chega a reta final. Portal R7, publicado em 05/11/2010. Disponivel em: http://noticias.r7.com/saopaulo/noticias/restauracao-do-teatro-municipal-de-sao-paulo-chega-a-reta-final20101105.html. Acessado em 01 de dezembro de 2011.

Salvetti R. A. P. 2005. Sistemas deposicionais e paleogeografia do subgrupo Itararé (neopaleozóico da Bacia do Paraná), na região entre Itu e Indaiatuba, SP. Dissertação de Mestrado, Instituto de Geociências, Universidade de São Paulo, $110 p$.

Santos M. C. 2007. Propostas de Reformulação da Visita Monitorada e Criação de Material de Apoio Trilíngue ao Turista para o Theatro Municipal de São Paulo História. Revista eletrônica UNISANTOS. Disponivel em: http://www. unisantos. br/pos/revistapatrimonio/artigos.php?cod=90. Acessado em 25 de outubro de 2012.

Santos A. Theatro Municipal vira modelo de restauração, Cimento Itambé, 20 julho de 2011. Disponivel em: http://www.cimentoitambe.com.br/massacinzenta/theatro-municipal-de-sao-paulo-vira-modelo-de-restauracao/. Acessado em 01 de dezembro de 2011.

Sassoni E., Naidu S., Scherer G. W. 2011. The use of hydroxyapatite as a new inorganic consolidant for damaged carbonate stones. Journal of cultural heritage, 12 (4): $346-355$.

Sassoni E., Franzoni E., Scherer G. W., Naidu S. 2012. Consolidation of a porous limestone by means of a new treatment based on hydroxyapatite. In:12th International Congresso $\mathrm{n}$ the Deterioration and Conservation of Stone Columbia University, New York, p. $10-19$.

Sassoni E., Franzoni E., Pigino B., Scherer G. W., Naidu S. 2013. Consolidation of calcareous and siliceous sandstones by hidroxiapatite: Comparison with a TEOS-based consolidant. Journal of Cultural Heritage, 14 (3): e103 - e108. 
Sattler L., Snethlage R. 1988. Durability of stone consolidation treatments with silicic acid ester.In:Marinos, Paul G.; Koukis, George C.Engineering geology of ancient works, monuments and historical sites: preservation and protection.Balkema A. A., Rotterdam, 2: 953 - 956.

Scartezini L. M. B., Juca T. R., Teixeira F., Antonelli G., Cascudo O., Carshek H. 2002. Influência do preparo da base na aderência e na permeabilidade à água dos revestimentos de argamassa. Revista Ambiente Construído, 2: 85 - 92.

Scherer G. W., Jiménez González I. 2005. Characterization of swelling in clay- bearing stone. In: Turkington A. V. (ed.) Stone Decay in the Architectural Environment. The Geological Society of America, SP 390,. $51-61$.

Scherer G. W., Jiménez González I. 2006. Evaluating the potencial damage to stones from wetting and drying cycles. In. Konsta-Gdoutos M. S. (ed.) Measuring, Monitorins ans Modeling Concrete properties: An International Symposium dedicated to Professor Surendra P. Shah, Northwester University, USA, 685 693.

Scherer G. W., Jiménez González I. 2008. Swelling clays nd salt crystallization: Damage mechanisms and the role of consolidants. In: Delgado Rodrigues J. E Mimoso J. M. (Eds.). Stone Consolidations in Cultural Heritage: Research and Practice; Proceedings of the International Symposium, Lisboa: LNEC Laboratório Nacional de Engenharia Civil, p. 29 - 40.

Scherer G. W., Wheeler G. S. 2009. Silicate Consolidants for Stone. Key Engineering Materials, 391: $1-25$.

Searls C. L., Thomasen S. E. 1991. Deterioration Mechanisms in Sandstone. In: Baker J. M., Nixon P. J., Majumdar A. J., Da Vies H. (eds.) Durability of Building Materials and Components. E.\&F. N. Spon, Chapman and Hall, p. 87 - 95.

Secretaria Municipal de Cultura de São Paulo. Disponível em: http://www.prefeitura.sp.gov.br/cidade/secretarias/cultura/theatromunicipal/corp os_artisticos/index.php?p=1035. Acessado em 06 de Dezembro de 2011. 
Severo, R. 1911. O theatro municipal de São Paulo. São Paulo. Officinas de Pocai \& Weiss, $40 \mathrm{p}$.

Sitte C. 1992. Construção da Cidade para Princípios Artísticos. Ática Editora, 240 p.

Snethlage R., Sterflinger K. 2011. Stone Conservation. In: Sigesmund S., Snethlage R. (eds.) Stone in architecture. Springer, Londres, p. $411-434$.

Soares A. de A. 2010. Formas de alteração e avaliação da degradação dos granitos da cantaria de Igreja de Santa Rita, Paraty-RJ. Trabalho de conclusão de curso, Instituto de Geociências, Universidade Federal do Rio de Janeiro, 64 p.

Souza D. A. 2012. Determinação de tensões residuais em materiais metálicos por meio de ensaio de dureza. Dissertação de mestrado, Universidade Federal de São João Del-Rei, 114 p.

Stern A. G., Riccomini C., Fambrini G. L., Chamani M. A. C. 2006. Roteiro geológico pelos edifícios e monumentos históricos do centro da cidade de São Paulo. Revista Brasileira de Geociências, 36: 704 - 711.

Toledo M. C. M., Oliveira S. M. B., Melfi A. J. 2009 Da rocha ao solo: intemperismo e pedogênese. In: Teixeira W., Fairchild T. R., Toledo M. C. M., Taioli F. (Org.). Decifrando a Terra. Companhia Editora Nacional, São Paulo, p. $210-239$.

Tucker M. E. 2014. Rochas Sedimentares: guia geológico de campo. Bookman, Porto Alegre, $324 \mathrm{p}$.

Viollet-le-Duc E. E. 1854. Restauração. Trad.: Beatriz Mugayar Kuhl. Ateliê Editorial, Cotia, 2000, $76 \mathrm{p}$.

Wangler T., Wylykanowitz A. K., Scherer G. W. 2006. Controlling stress from swelling clay. In: Konsta- Gdoutos M. S. (ed.), Mesuring, Monitoring and Modeling Concrete Properties. Springer, The Netherlands p. $703-708$.

Wangler T., Scherer G. W. 2008. Clay swelling mechanism in clay-bearing sandstones. Environmental Geology, 56: 529 - 534. 
Wangler T., Scherer G. W. 2009. Clay swelling inhibition mechanism of a,wdiaminoalkanes in Portland Brownstone. Journal of Materials Research, 24 (5): $1646-1652$.

Wangler T., Wylykanovitz A. K., Scherer G. W. 2006. Controlling stress from swelling clay. In: Konsta-Gdoutos M. S. (Ed.). Measuring, Monitoring and Modeling Concrete Properties. Springer, Londres, p. $703-708$.

Wheeler G. 2005. Alkoxisilanes and the Consolidation of Stone. The Getty Institute,196 p.

Winkler E. M. 1997. Stone in architecture: properties, durability. $3^{a}$ ed. Springer-Verlag, Berlin, 313p. 


\section{ANEXO}

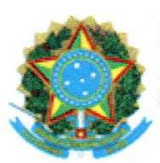

Ministério do Meio Ambiente - MMA

Instituto Chico Mendes de Conservação da Biodiversidade - ICMBio

Sistema de Autorização e Informação em Biodiversidade - SISBIO

\section{Autorização para atividades com finalidade científica}

Número: $38002-1$

Data da Emissão: 25/02/2013 10:17

Data para Revalidação*: 27/03/2014

* De acordo com o art. 33 da IN 154/2009, esta autorização tem prazo de validade equivalente ao previsto no cronograma de atividades do projeto, mas deverá ser revalidada anualmente mediante a apresentação do relatório de atividades a ser enviado por meio do Sisbio no prazo de até 30 dias a contar da data do aniversário de sua emissão.

Dados do titular

\begin{tabular}{|l|l|l|}
\hline Nome: Danielle Grossi & CPF: 287.765.578-47 \\
\hline Titulo do Projeto: Avaliação da aplicação de consolidantes no Arenito Itararé, constituinte da fachada do Teatro Municipal de São Paulo \\
\hline Nome da Instituição: Instituto de Geociências da USP & CNPJ: 63.025.530/0007-08 \\
\hline
\end{tabular}

Cronograma de atividades

\begin{tabular}{|l|ll|l|l|}
\hline$\#$ & Descrição da atividade & Inicio (mês/ano) & Fim (mês/ano) \\
\hline 1 & Coleta de amostras do Arenito Itararé & $04 / 2013$ & $06 / 2017$ \\
\hline
\end{tabular}

Observações e ressalvas

1 As atividades de campo exercidas por pessoa natural ou jurídica estrangeira, em todo o território nacional, que impliquem o deslocamento de recursos humanos $\theta$

materiais, tendo por objeto coletar dados, materiais, especimes biológicos e minerais, peças integrantes da cultura nativa e cultura popular, presente e passada

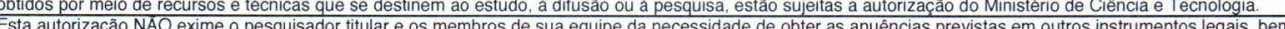

como do consentimento do responsável pela área, pública ou privada, onde será realizada a atividade, inclusive do órgão gestor de terra indigena (FUNAl), da

unidade de conservação estadual, distrital ou municipal, ou do proprietário, arrendatário, posseiro ou morador de área dentro dos limites de unidade de conservaçăo

federal cujo processo de regularização fundiária encontra-se em curso.

Este documento somente poderá ser utilizado para os fins previstos na Instrução Normativa IBAMA $n^{\circ}$ 154/2007 ou na Instrução Normativa ICMBio $n^{\circ}$ 10/2010, no que especifica esta Autorização, não podendo ser utilizado para fins comerciais, industriais ou esportivos. O material biológico coletado deverá ser utilizado para atividades cientificas ou didaticas no âmbito do ensino superior.

O titular de licença ou autorização e os membros da sua equipe deverão optar por métodos de coleta e instrumentos de captura direcionados, sempre que possivel. ao grupo taxonômico de interesse, evitando a morte ou dano significativo a outros grupos; e empregar estorço de coleta ou captura que não comprometa a viabilidade de populaçōes do grupo taxonomico de interesse em condiçâo in siltu

Otitular de autorização ou de licença permanente, assim como os membros de sua equipe, quando da violação da legislação vigente, ou quando da inadequação.

omissão ou talsa descrição de informações relevantes que subsidiaram a expedição do ato, poderá, mediante decisão motivada, ter a autorização ou licença

suspensa ou revogada pelo ICMBio e o material biológico coletado apreendido nos termos da legislação brasileira em vigor.

- Este docrmo território nacional, na plataforma continental e na zona econômica exclusiva, ou ao conhecimento tradicional associado ao patrimônio genético, para fins de pesquisa científica, Em caso de pesquisa em UNIDADE DE CONSERVAÇAO, o pesquisador titular desta autorizaçăo deverá contactar a administração da unidade a fim de CONFIRMAR AS DATAS das expediçōes, as condicōes para realização das coletas e de uso da intra-estrutura da unidade.

Outras ressalvas

1. A coleta de arenitos só poderá ocorrer na Zona de Uso Especial da Flona, próxima ao Viveiro

2. A pesquisadora deverá informar com antecedencia o periodo de trabalho de campo, bem como relacionar o(s) nome(s) das pessoas

3. A pesquisadora deverá comparecer à Unidade de Conservação para tomar conhecimento das normas da UC.

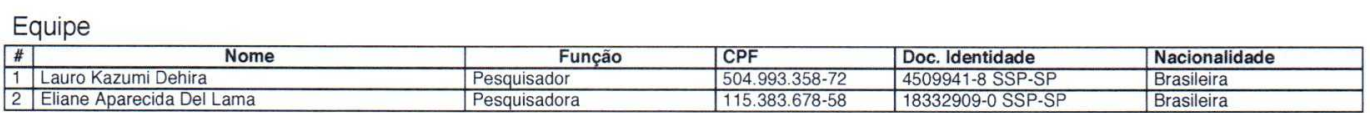

Locais onde as atividades de campo serão executadas

\begin{tabular}{|l|l|l|l|l|}
\hline$\#$ & Municipio & UF & Descricăo do local & Tipo \\
\hline 1 & & SP & FLORESTA NACIONAL DE IPANEMA & UC Federal \\
\hline
\end{tabular}

Este documento (Autorização para atividades com finalidade cientifica) foi expedido com base na Instrução Normativa n¹54/2007. Através do código de autenticação abaixo, qualquer cidadão poderá verificar a autenticidade ou regularidade deste documento, por meio da página do Sisbio/ICMBio na Internet (www.icmbio.gov. br/sisbio).

Código de autenticação: 21439696 
Ministério do Meio Ambiente - MMA

Instituto Chico Mendes de Conservação da Biodiversidade - ICMBio

Sistema de Autorização e Informação em Biodiversidade - SISBIO

\section{Autorização para atividades com finalidade científica}

\begin{tabular}{|c|c|c|}
\hline Número: 38002-3 & Data da Emissão: 12/01/2015 18:44 & Data para Revalidação*: 11/02/2016 \\
\hline "De acordo com o art. 28 da IN 03/2014, esta autorizaçăo tem prazo de validade equivalente ao previsto no cronograma de atividades do projeto, \\
mas deverá ser revalidada anualmente mediante a apresentação do relatório de atividades a ser enviado por meio do Sisbio no prazo de até 30 dias
\end{tabular}
a contar da data do aniversário de sua emissão.

Dados do titular

\begin{tabular}{|l|l|}
\hline Nome: Danielle Grossi & \multicolumn{1}{l|}{ CPF: 287.765.578-47 } \\
\hline Titulo do Projeto: Avaliação da aplicação de consolidantes no Arenito Itararé, constituinte da fachada do Teatro Municipal de São Paulo \\
\hline Nome da Instituição: Instituto de Geociências da USP & CNPJ: 63.025.530/0007-08 \\
\hline
\end{tabular}

Cronograma de atividades

\begin{tabular}{|l|ll|l|l|}
\hline$\#$ & Descrição da atividade & Inicio (més/ano) & Fim (més/ano) \\
\hline 1 & Coleta de amostras do Arenito Itararé & $04 / 2013$ & $06 / 2017$ \\
\hline
\end{tabular}

Observações e ressalvas

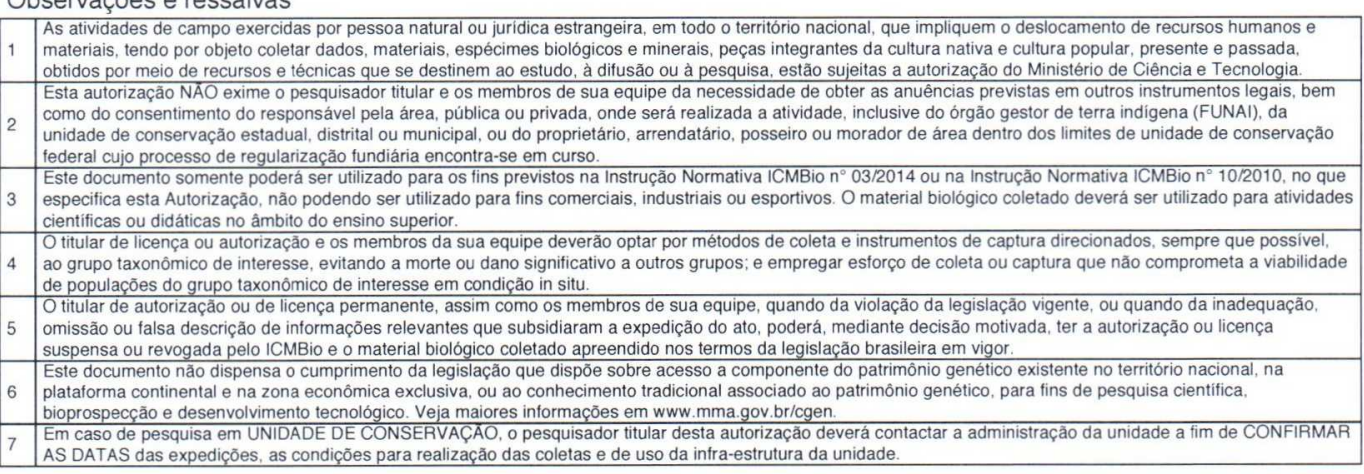

Outras ressalvas

1. A coleta de arenitos só poderá ocorrer na Zona de Uso Especial da Flona, próxima ao Viveiro

2. A pesquisadora deverá informar com antecedência o período de trabalho de campo, bem como relacionar o(s) nome(s) das pessoas incumbidas do trabalho de campo (corte de rochas):

A pesquisadora deverá comparecer à Unidade de Conservação para tomar conhecimento das normas da UC.

Equipe

Equipe
\begin{tabular}{|l|l|l|l|l|l|}
\hline$\#$ & \multicolumn{1}{|c|}{ Nome } & Funçäo & CPF & Doc. Identidade & Nacionalidade \\
\hline 1 & ALEXANDER MARTIN SILVEIRA GIMENEZ & Pesquisador & $214.929 .078-20$ & Vo25006-0 CPGIDIREX-SP & Estrangeira \\
\hline 2 & Lauro Kazumi Dehira & Pesquisador & $504.993 .358-72$ & $4509941-8$ SSP-SP & Brasileira \\
\hline 3 & Eliane Aparecida Del Lama & Pesquisadora & $115.383 .678-58$ & $18332909-0$ SSP-SP & Brasileira \\
\hline
\end{tabular}

Locais onde as atividades de campo serão executadas

\begin{tabular}{|l|l|l|l|l|}
\hline$\#$ & Municipio & UF & Descriç̃ão do local & Tipo \\
\hline 1 & SP & FLORESTA NACIONAL DE IPANEMA & UC Federal \\
\hline
\end{tabular}

Este documento (Autorização para atividades com finalidade científica) foi expedido com base na Instrução Normativa n 03/2014. Através do código de autenticação abaixo, qualquer cidadão poderá verificar a autenticidade ou regularidade deste documento, por meio da página do Sisbio/lCMBio na Internet (www.icmbio gov.br/sisbio)

Código de autenticação: 52973489 


\section{ANEXO II}

\section{- Arenito Itararé}

- Resultados do experimento de ultrassom no Arenito Itararé

Tabela A1 - Velocidade de ondas ultrassônicas no Arenito Itararé fresco.

\begin{tabular}{|c|c|c|c|c|c|c|c|}
\hline $\begin{array}{l}\text { Número } \\
\text { da } \\
\text { amostra }\end{array}$ & $\begin{array}{l}\text { Direção do } \\
\text { fluxo }\end{array}$ & $\begin{array}{c}\text { Velocidade } \\
\text { no eixo } X \\
(\mathrm{~km} / \mathrm{s})\end{array}$ & $\begin{array}{c}\text { Velocidade } \\
\text { no eixo y } \\
(\mathrm{km} / \mathrm{s})\end{array}$ & $\begin{array}{c}\text { Velocidade } \\
\text { no eixo z } \\
(\mathrm{km} / \mathrm{s})\end{array}$ & $\begin{array}{l}E_{\operatorname{din}} \mathrm{X} \\
(\mathrm{GPa})\end{array}$ & $\begin{array}{l}E_{\text {din }} y \\
(\mathrm{GPa})\end{array}$ & $\begin{array}{l}E_{\text {dinz }} \\
(\mathrm{GPa})\end{array}$ \\
\hline 1 & Paralelo & 2,9 & 3,0 & 2,7 & 18,50 & 19,13 & 15,98 \\
\hline 2 & Paralelo & 3,1 & 3,0 & 2,8 & 17,78 & 17,34 & 14,69 \\
\hline 3 & Paralelo & 2,8 & 2,7 & 2,6 & 17,60 & 16,48 & 14,64 \\
\hline 4 & Paralelo & 3,0 & 3,0 & 2,7 & 18,79 & 19,12 & 15,53 \\
\hline 5 & Paralelo & 3,5 & 3,3 & 2,9 & 26,72 & 24,83 & 19,30 \\
\hline 6 & Paralelo & 3,1 & 3,1 & 2,7 & 20,68 & 20,39 & 15,83 \\
\hline 7 & Perpendicular & 2,8 & 3,3 & 3,0 & 16,08 & 22,74 & 19,22 \\
\hline 8 & Perpendicular & 2,3 & 2,6 & 2,4 & 11,65 & 14,37 & 12,09 \\
\hline 9 & Perpendicular & 2,8 & 2,8 & 2,6 & 17,45 & 18,23 & 15,47 \\
\hline 10 & Perpendicular & 2,9 & 3,3 & 3,2 & 17,74 & 22,76 & 21,34 \\
\hline 11 & Perpendicular & 2,5 & 2,8 & 2,4 & 13,68 & 16,67 & 12,23 \\
\hline 12 & Perpendicular & 2,2 & 2,4 & 1,9 & 10,07 & 12,16 & 7,81 \\
\hline
\end{tabular}

$E_{\text {din }}=$ módulo dinâmico de elasticidade. 
- Resultados do teste de capilaridade no Arenito Itararé

Tabela A2 -Capilaridade no Arenito Itararé fresco e tratado.

\begin{tabular}{|c|c|c|c|c|}
\hline Tratamento & Direção de fluxo & $\begin{array}{l}\text { Número } \\
\text { amostra }\end{array}$ & $\begin{array}{c}\text { Capilaridade } \\
\left(\mathrm{g} / \mathrm{cm}^{2} \cdot \mathrm{s}\right)\end{array}$ & $\begin{array}{c}\text { Média } \\
\left(\mathrm{g} / \mathrm{cm}^{2} \cdot \mathrm{s}\right)\end{array}$ \\
\hline \multirow{9}{*}{ Fresca } & Perpendicular & 2 & 0,0057 & \multirow{4}{*}{0,0038} \\
\hline & Perpendicular & $2-2$ & 0,0043 & \\
\hline & Perpendicular & 5 & 0,00002 & \\
\hline & Perpendicular & $5-2$ & 0,0026 & \\
\hline & Perpendicular & $5-3$ & 0,0025 & \multirow{5}{*}{0,0043} \\
\hline & Paralelo & 10 & 0,0043 & \\
\hline & Paralelo & $10-2$ & 0,0039 & \\
\hline & Paralelo & 11 & 0,0050 & \\
\hline & Paralelo & $11-2$ & 0,0040 & \\
\hline \multirow{4}{*}{ A } & Perpendicular & 4 & 0,0050 & \multirow{2}{*}{0,0060} \\
\hline & Perpendicular & 6 & 0,0069 & \\
\hline & Paralelo & 11 & 0,0042 & \multirow{2}{*}{0,0051} \\
\hline & Paralelo & 12 & 0,0060 & \\
\hline \multirow{2}{*}{$P$} & Perpendicular & 2 & 0,0027 & 0,0027 \\
\hline & Paralelo & 11 & 0,0053 & 0,0053 \\
\hline \multirow{5}{*}{$A P$} & Perpendicular & 1 & - & \multirow{5}{*}{0,0004} \\
\hline & Perpendicular & 2 & 0,0004 & \\
\hline & Perpendicular & 8 & - & \\
\hline & Perpendicular & 9 & - & \\
\hline & Perpendicular & 11 & - & \\
\hline \multirow{4}{*}{ TC } & Perpendicular & 5 & 0,0017 & \multirow{2}{*}{0,0022} \\
\hline & Perpendicular & 7 & 0,0027 & \\
\hline & Paralelo & 10 & 0,0039 & \multirow{2}{*}{0,0077} \\
\hline & Paralelo & 10 & 0,0115 & \\
\hline \multirow{4}{*}{ ATC } & Perpendicular & 3 & 0,0024 & \multirow{2}{*}{0,0019} \\
\hline & Perpendicular & 5 & 0,0014 & \\
\hline & Paralelo & 7 & 0,0043 & \multirow{2}{*}{0,0055} \\
\hline & Paralelo & 10 & 0,0067 & \\
\hline
\end{tabular}


- Resultados do ensaio de expansibilidade no Arenito Itararé

Tabela A3 - Resultados do teste de expansibilidade no Arenito Itararé direção do acamamento: horizontal.

\begin{tabular}{|c|c|c|c|}
\hline Tratamento & Amostra $\mathrm{n}^{\circ}$ & Tensão de expansão & $\begin{array}{c}\text { Média } \\
\left(\mathrm{g} / \mathrm{cm}^{2} \cdot \mathrm{min}^{1 / 2}\right)\end{array}$ \\
\hline \multirow{4}{*}{ Fresca } & 1 & $-4,65 \times 10^{-5}$ & \multirow{4}{*}{$6,30 \times 10^{-5}$} \\
\hline & 2 & $-9,93 \times 10^{-4}$ & \\
\hline & 3 & $7,38 \times 10^{-4}$ & \\
\hline & 4 & $6,95 \times 10^{-4}$ & \\
\hline \multirow{5}{*}{ A } & $\begin{array}{c}4 \\
4-2\end{array}$ & $\begin{array}{l}2,92 \times 10^{-4} \\
-2,09 \times 10^{-4}\end{array}$ & \multirow{5}{*}{$-8,94 \times 10^{-5}$} \\
\hline & $4-3$ & $-2,44 \times 10^{-4}$ & \\
\hline & 6 & $-1,26 \times 10^{-4}$ & \\
\hline & $6-2$ & $-1,96 \times 10^{-4}$ & \\
\hline & $6-3$ & $-5,30 \times 10^{-5}$ & \\
\hline$P$ & 3 & $2,01 \times 10^{-4}$ & $2,01 \times 10^{-4}$ \\
\hline$\overline{A P}$ & $\begin{array}{l}1 \\
2\end{array}$ & $\begin{array}{l}8,35 \times 10^{-5} \\
1,16 \times 10^{-4}\end{array}$ & $9,98 \times 10^{-5}$ \\
\hline TC & 5 & $1,75 \times 10^{-4}$ & $1,75 \times 10^{-4}$ \\
\hline \multirow{2}{*}{$\overline{\text { ATC }}$} & 3 & $7,11 \times 10^{-5}$ & \multirow{2}{*}{$3,79 \times 10^{-5}$} \\
\hline & 5 & $8,28 \times 10^{-6}$ & \\
\hline AP 2 & 2 & $-3,10 \times 10^{-5}$ & $-3,10 \times 10^{-5}$ \\
\hline AP 2E & $\begin{array}{l}2 \\
4\end{array}$ & $\begin{array}{c}-8,96 \times 10^{-5} \\
4,09 \times 10^{-4}\end{array}$ & $1,60 \times 10^{-4}$ \\
\hline ATC 2 & $\begin{array}{l}2 \\
4\end{array}$ & $\begin{array}{c}-2,22 \times 10^{-5} \\
5,98 \times 10^{-5}\end{array}$ & $1,88 \times 10^{-5}$ \\
\hline ATC 2E & $\begin{array}{l}5 \\
6\end{array}$ & $\begin{array}{r}3,07 \times 10^{-5} \\
-3,03 \times 10^{-5}\end{array}$ & $1,84 \times 10^{-7}$ \\
\hline
\end{tabular}


- Resultados da resistência à flexão no Arenito Itararé

Tabela A4 - Valores obtidos no teste de resistência à flexão.

\begin{tabular}{lcc}
\hline Tratamento & $\begin{array}{c}\text { Módulo elástico seco } \\
(\mathrm{GPa})\end{array}$ & $\begin{array}{c}\text { Módulo elástico } \\
\text { saturado }(\mathrm{GPa})\end{array}$ \\
\hline Fresca & 1,67 & 2,16 \\
Fresca & 1,33 & 0,29 \\
Fresca & 1,34 & 0,47 \\
Fresca & 1,64 & 1,21 \\
TC & 0,86 & 1,16 \\
TC & 1,44 & 2,20 \\
A & 0,65 & 0,70 \\
A & 1,93 & 1,32 \\
P & 1,71 & 0,47 \\
P & 0,92 & 1,02 \\
ATC & 2,52 & 2,52 \\
ATC & 1,69 & 1,31 \\
\hline
\end{tabular}

- Resultados da Difração de Raios X no Arenito Itararé.

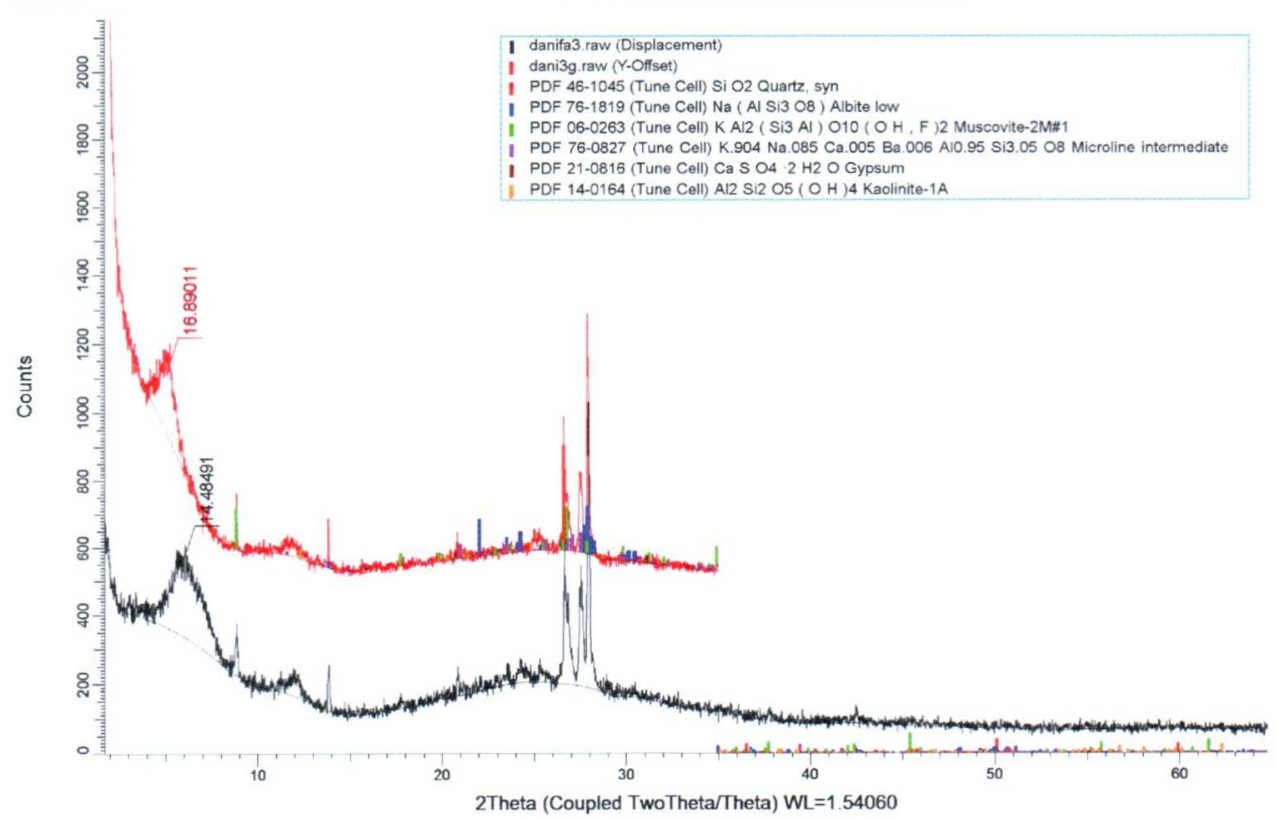

Figura A1 - Difração de Raios X na fração argila - com (vermelho) e sem glicolagem (preto). 


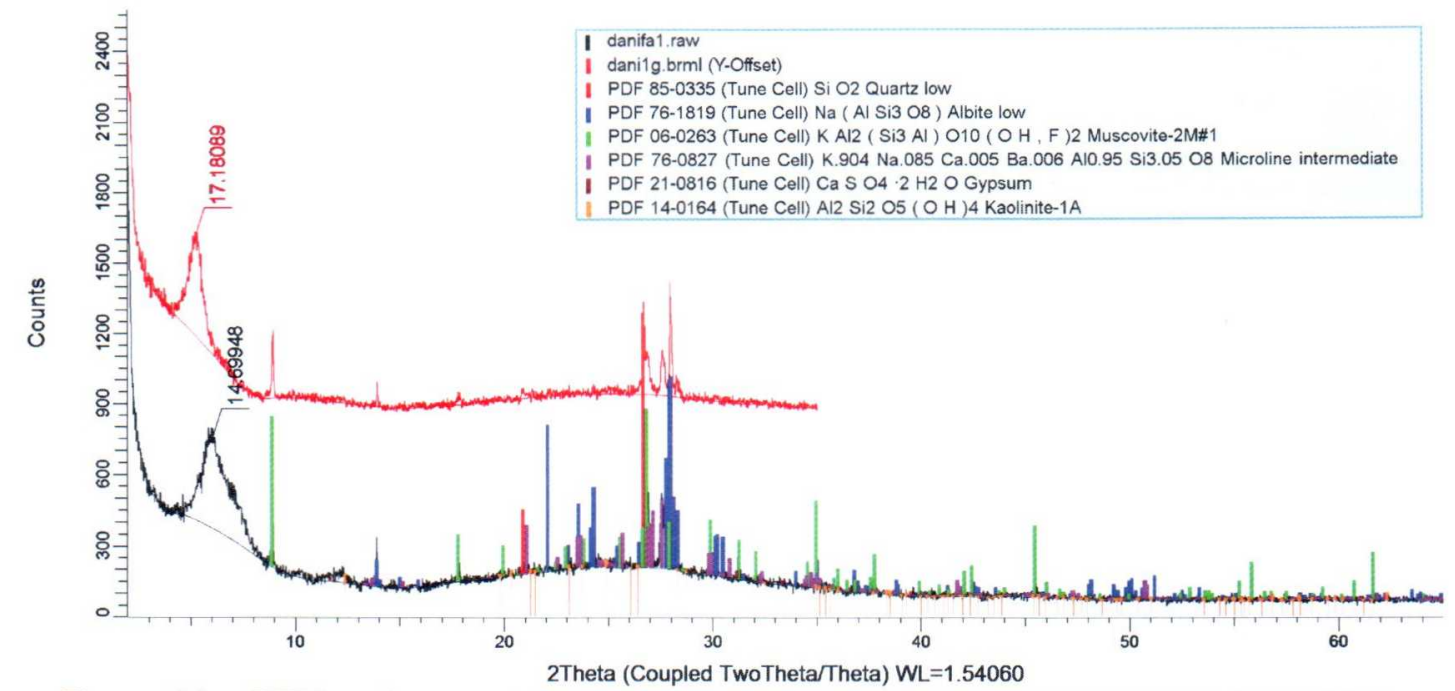

Figura A2 - DRX na fração argila sem glicolagem (preto) e com glicolagem (vermelho).

\section{- Arenito Missões}

- Resultados do experimento de ultrassom no Arenito Missões

Tabela A5 - Velocidade no arenito Missões fresco nos diferentes eixos.

\begin{tabular}{|c|c|c|c|c|c|c|c|}
\hline $\begin{array}{c}\mathrm{N}^{0} \mathrm{da} \\
\text { amostra }\end{array}$ & $\begin{array}{c}\text { Direção do } \\
\text { acamamento } \\
\text { da amostra * }\end{array}$ & $\begin{array}{c}\text { Velocidade } \\
\text { no eixo } X \\
(\mathrm{~km} / \mathrm{s})\end{array}$ & $\begin{array}{c}\text { Velocidade } \\
\text { no eixo y } \\
(\mathrm{km} / \mathrm{s})\end{array}$ & $\begin{array}{c}\text { Velocidade } \\
\text { no eixo z } \\
(\mathrm{km} / \mathrm{s})\end{array}$ & $\begin{array}{c}E_{\mathrm{din}} \mathrm{X} \\
(\mathrm{GPa})\end{array}$ & $\begin{array}{c}E_{\text {din }} y \\
(\mathrm{GPa})\end{array}$ & $\begin{array}{c}E_{\text {din } z} \\
(\mathrm{GPa})\end{array}$ \\
\hline 1 & Perpendicular & 5,0 & 5,0 & 4,4 & 56,35 & 55,16 & 42,85 \\
\hline 2 & Perpendicular & 5,0 & 5,0 & 4,4 & 54,56 & 55,40 & 42,64 \\
\hline 3 & Perpendicular & 5,2 & 5,2 & 4,5 & 60,63 & 59,47 & 44,32 \\
\hline 4 & Perpendicular & 5,1 & 5,1 & 4,4 & 57,39 & 57,91 & 41,97 \\
\hline 5 & Perpendicular & 5,1 & 5,0 & 4,4 & 57,36 & 55,96 & 43,52 \\
\hline 6 & Perpendicular & 5,2 & 5,1 & 4,6 & 61,99 & 60,48 & 47,97 \\
\hline 7 & Paralelo & 4,7 & 5,2 & 5,1 & 49,72 & 61,54 & 58,15 \\
\hline 8 & Paralelo & 4,8 & 5,4 & 5,0 & 51,64 & 65,22 & 56,77 \\
\hline 9 & Paralelo & 4,9 & 5,2 & 4,8 & 54,43 & 60,85 & 52,04 \\
\hline 10 & Paralelo & 4,9 & 5,5 & 5,2 & 53,27 & 67,62 & 60,97 \\
\hline 11 & Paralelo & 5,0 & 5,5 & 5,5 & 55,05 & 68,49 & 67,68 \\
\hline 12 & Paralelo & 5,0 & 5,4 & 5,3 & 55,63 & 66,11 & 63,70 \\
\hline
\end{tabular}

${ }^{*}$ Com relação ao lado de menor tamanho.

$\mathrm{E}_{\text {din }}=$ módulo dinâmico de elasticidade. 
- Resultados do experimento de capilaridade no Arenito Missões

Tabela A6 - Valores de capilaridade no Arenito Missões.

\begin{tabular}{|c|c|c|c|c|}
\hline Tratamento & $\begin{array}{l}\text { Direção do } \\
\text { fluxo }\end{array}$ & $\begin{array}{l}\text { Número } \\
\text { amostra }\end{array}$ & $\begin{array}{c}\text { Capilaridade } \\
\left(\mathrm{g} / \mathrm{cm}^{2} \cdot \mathrm{s}\right)\end{array}$ & $\begin{array}{c}\text { Média } \\
\left(\mathrm{g} / \mathrm{cm}^{2} \cdot \mathrm{s}\right)\end{array}$ \\
\hline $\begin{array}{l}\text { Fresca } \\
\text { Fresca }\end{array}$ & $\begin{array}{l}\text { Perpendicular } \\
\text { Perpendicular }\end{array}$ & $\begin{array}{l}1-2 \\
3-2\end{array}$ & $\begin{array}{l}0,0037 \\
0,0050\end{array}$ & \multirow{5}{*}{0,0027} \\
\hline Fresca & Paralelo & 7 & 0,0016 & \\
\hline Fresca & Paralelo & $7-2$ & 0,0014 & \\
\hline Fresca & Paralelo & 9 & 0,0023 & \\
\hline Fresca & Paralelo & $9-2$ & 0,0020 & \\
\hline$P$ & Perpendicular & 1 & 0,0010 & 0,0010 \\
\hline $\begin{array}{l}\text { AP } \\
\text { AP }\end{array}$ & $\begin{array}{l}\text { Perpendicular } \\
\text { Perpendicular }\end{array}$ & $\begin{array}{l}1 \\
2\end{array}$ & $\begin{array}{l}0,0024 \\
0,0008\end{array}$ & \multirow[t]{2}{*}{0,0015} \\
\hline AP & Paralelo & 8 & 0,0014 & \\
\hline $\begin{array}{l}\text { TC } \\
\text { TC }\end{array}$ & $\begin{array}{l}\text { Perpendicular } \\
\text { Perpendicular }\end{array}$ & $\begin{array}{l}5 \\
6\end{array}$ & $\begin{array}{l}0,0046 \\
0,0022\end{array}$ & \multirow{3}{*}{0,0021} \\
\hline $\mathrm{TC}$ & Paralelo & 7 & 0,0010 & \\
\hline TC & Paralelo & 10 & 0,0006 & \\
\hline $\begin{array}{l}\text { ATC } \\
\text { ATC }\end{array}$ & $\begin{array}{l}\text { Perpendicular } \\
\text { Perpendicular }\end{array}$ & $\begin{array}{l}3 \\
5\end{array}$ & $\begin{array}{l}0.0009 \\
0.0013\end{array}$ & \multirow{3}{*}{0,0016} \\
\hline ATC & Paralelo & 7 & 0.0023 & \\
\hline ATC & Paralelo & 12 & 0.0018 & \\
\hline
\end{tabular}

- Resultados do experimento de expansibilidade no Arenito Missões

Tabela A7 - Resultados da expansibilidade no Arenito Missões direção do acamamento: horizontal.

\begin{tabular}{lcc}
\hline Tratamento & Amostra $^{\circ}$ & $\begin{array}{l}\text { Tensão de } \\
\text { expansão }\end{array}$ \\
\hline Fresca & 1 & $-2,14 \times 10^{-4}$ \\
P & 1 & $6,48 \times 10^{-4}$ \\
AP & 2 & $5,70 \times 10^{-4}$ \\
TC & 5 & $1,91 \times 10^{-4}$ \\
ATC & 5 & $2,75 \times 10-4$ \\
\hline
\end{tabular}


- Resultados do experimento de resistência à flexão no Arenito Missões.

Tabela A8 - Valores obtidos no teste de resistência à flexão.

\begin{tabular}{lcc}
\hline Tratamento & $\begin{array}{c}\text { Módulo elástico seco } \\
(\mathrm{GPa})\end{array}$ & $\begin{array}{c}\text { Módulo elástico } \\
\text { saturado }(\mathrm{GPa})\end{array}$ \\
\hline Fresca & 1,37 & 2,08 \\
TC & 3,46 & 2,10 \\
A & 1,48 & 2,24 \\
A & 1,01 & 2,42 \\
P & 0,94 & 1,25 \\
P & 0,85 & 1,01 \\
ATC & 0,50 & 1,83 \\
ATC & 1,99 & 2,19 \\
\hline
\end{tabular}

DOACEO Pós-grad.
08ta: $28 / 03 / 17$ 
